WSRC-TR-2004-00049

Revision 0

KEY WORDS:

Saltstone Disposal Facility

Performance Assessment

Closure Cap

\title{
SALTSTONE DISPOSAL FACILITY \\ MECHANICALLY STABILIZED EARTH VAULT \\ CLOSURE CAP DEGRADATION: \\ SENSITIVITY ANALYSIS (U)
}

FEBRUARY 12, 2004

PREPARED BY:

Mark A. Phifer

Westinghouse Savannah River Company LLC

Westinghouse Savannah River Company LLC

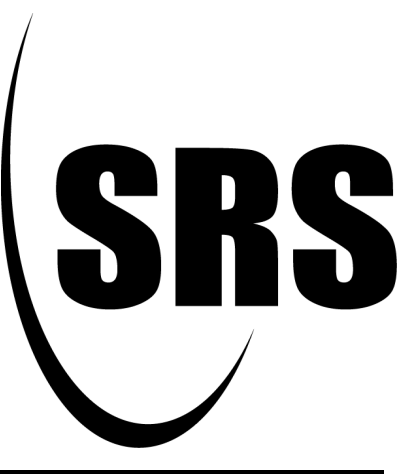

Savannah River Site

Aiken, SC 29808

Prepared for the U.S. Department of Energy under Contract No. DE-AC09-96SR18500 
This document was prepared in conjunction with work accomplished under Contract No. DE-AC09-96SR18500 with the U. S. Department of Energy.

\section{DISCLAIMER}

This report was prepared as an account of work sponsored by an agency of the United States Government. Neither the United States Government nor any agency thereof, nor any of their employees, makes any warranty, express or implied, or assumes any legal liability or responsibility for the accuracy, completeness, or usefulness of any information, apparatus, product or process disclosed, or represents that its use would not infringe privately owned rights. Reference herein to any specific commercial product, process or service by trade name, trademark, manufacturer, or otherwise does not necessarily constitute or imply its endorsement, recommendation, or favoring by the United States Government or any agency thereof. The views and opinions of authors expressed herein do not necessarily state or reflect those of the United States Government or any agency thereof.

This report has been reproduced directly from the best available copy.

Available for sale to the public, in paper, from: U.S. Department of Commerce, National Technical Information Service, 5285 Port Royal Road, Springfield, VA 22161, phone: (800) 553-6847, fax: (703) 605-6900

email: orders@ntis.fedworld.gov

online ordering: http://www.ntis.gov/help/index.asp

Available electronically at http://www.osti.gov/bridge

Available for a processing fee to U.S. Department of Energy and its contractors, in paper, from: U.S. Department of Energy, Office of Scientific and Technical Information, P.O. Box 62, Oak Ridge, TN 37831-0062,

phone: (865)576-8401,

fax: (865)576-5728

email: $\underline{\text { reports@ adonis.osti.gov }}$ 
WSRC-TR-2004-00049

Revision 0

KEY WORDS:

Saltstone Disposal Facility

Performance Assessment

Closure Cap

\section{SALTSTONE DISPOSAL FACILITY \\ MECHANICALLY STABILIZED EARTH VAULT \\ CLOSURE CAP DEGRADATION: \\ SENSITIVITY ANALYSIS (U)}

FEBRUARY 12, 2004

PREPARED BY:

Mark A. Phifer

Westinghouse Savannah River Company LLC

Westinghouse Savannah River Company LLC

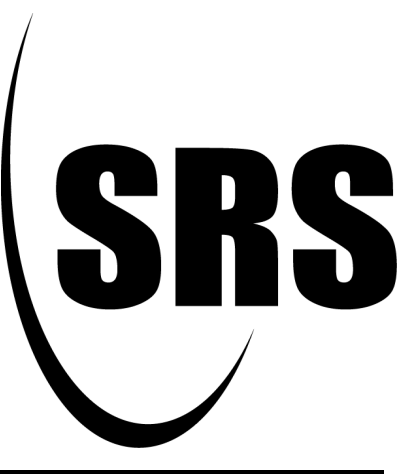

Savannah River Site

Aiken, SC 29808

Prepared for the U.S. Department of Energy under Contract No. DE-AC09-96SR18500 
THIS PAGE INTENTIONALLY LEFT BLANK 


\section{THIS PAGE INTENTIONALLY LEFT BLANK}

Rev. 0 


\section{TABLE OF CONTENTS}

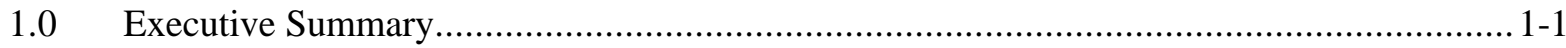

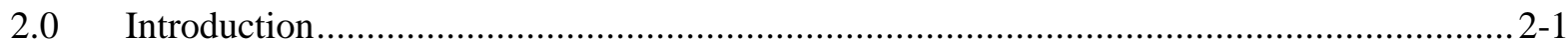

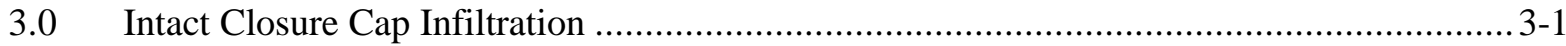

3.1 Intact SDF GCL Closure Cap Footprint, Configuration, and Properties ............................ 3-1

3.2 Help Model and Generic Input Data............................................................................. 3-3

3.3 Intact Closure Cap Curve Number Input Parameter Values ............................................. 3-4

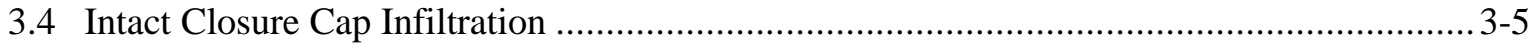

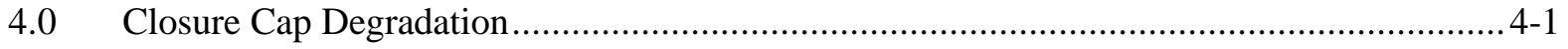

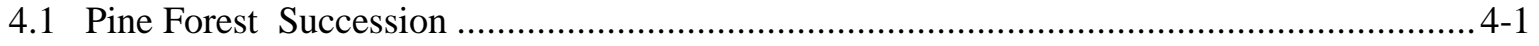

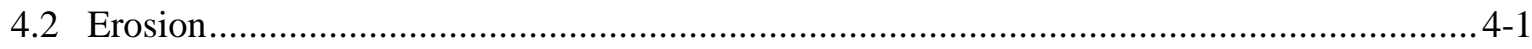

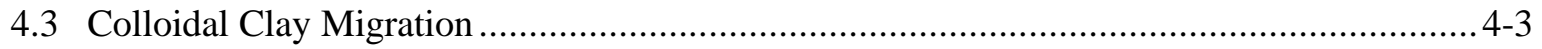

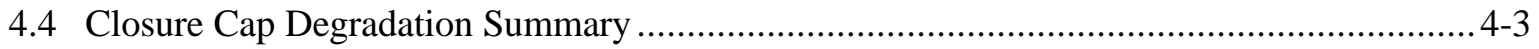

5.0 Closure Cap Infiltration for Lower Bounding Scenario (Continuous Bamboo Cover) .......... 5-1

5.1 LBS Degraded Layer Properties over Time............................................................... 5-1

5.1.1 LBS Middle Backfill and Upper Drainage Layer ...................................................5-1

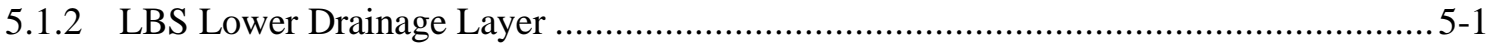

5.1.3 LBS Summary Material Properties over Time …..................................................... 5-2

5.2 LBS Degraded Closure Cap Infiltration over Time ....................................................... 5-2

5.3 LBS Infiltration after Complete Closure Cap Degradation.............................................5-3

6.0 Closure Cap Infiltration for Upper Bounding Scenario

(Institutional Control To Farm To Pine Forest) …....................................................... 6-1

6.1 UBS Degraded Layer Properties over Time …........................................................... 6-1

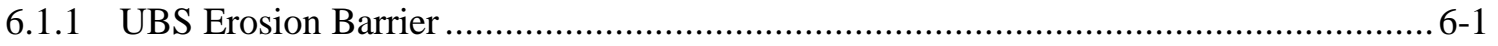

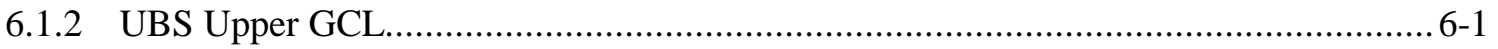

6.1.3 UBS Middle Backfill and Upper Drainage Layer..................................................... 6-2

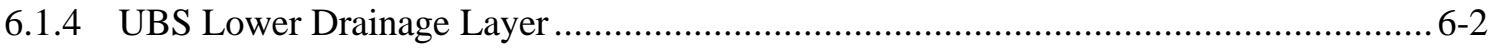

6.1.5 UBS Summary Material Properties over Time ........................................................ 6-3

6.2 UBS Degraded Closure Cap Infiltration over Time .................................................... 6-4

6.3 UBS Infiltration after Complete Closure Cap Degradation ......................................... 6-5

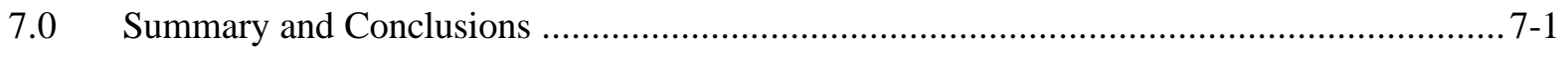

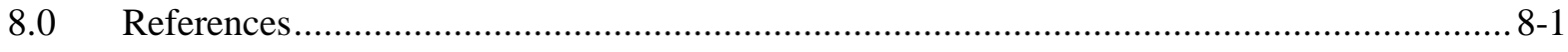

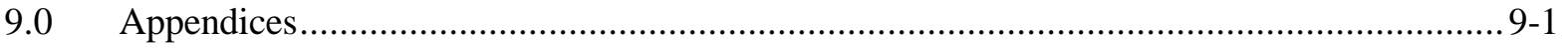




\section{LIST OF FIGURES}

Figure 2.0-1. Saltstone Disposal Facility Closure Cap (Phifer and Nelson 2003)...................... 2-2

Figure 2.0-2. Saltstone Disposal Facility MSE Vault (Phifer 2003)........................................ 2-2

Figure 3.1-1. MSE Vault Layout (Phifer 2003)............................................................... 3-1

Figure 3.1-2. Closure Cap Footprint and Drainage System (Detail A) (Phifer 2003) ................. 3-2

Figure 3.1-3. MSE Vault and Closure Cap Cross-Section (Section A-A) (Phifer 2003) ............... 3-2

Figure 7.0-1. Base Case, Lower Bounding, and Upper Bounding Infiltration over Time ............. 7-3

Figure 7.0-2. Lower Drainage Layer Saturated Hydraulic Conductivity for the Base Case, Lower Bounding, and Upper Bounding Scenarios over Time............................. 7-4 


\section{LIST OF TABLES}

Table 3.1-1. Intact SDF MSE Vault Closure Cap Configuration and Properties (Phifer and Nelson 2003) ..................................................................................... 3-3

Table 3.2-1. Generic Input Parameter Values - Area and Initial Moisture................................ 3-4

Table 3.3-1. Curve Number (CN) Input Parameter Values for Intact Closure Cap.................... 3-5

Table 4.2-1. $\quad$ USLE Parameter Values................................................................................. 4-2

Table 4.4-1. $\quad$ Lower Bounding Scenario Closure Cap Layer Degradation Assumptions (modified from Phifer and Nelson 2003) ............................................................ 4-4

Table 4.4-2. Upper Bounding Scenario Closure Cap Layer Degradation Assumptions (modified from Phifer and Nelson 2003) ......................................................... 4-5

Table 5.1-1. Lower Bounding Scenario Material Property Summary Results .......................... 5-2

Table 5.2-1. $\quad$ Lower Bounding Sensitivity Values ............................................................ 5-3

Table 6.1-1. $\quad$ Upper Bounding Scenario Material Property Summary Results ........................... 6-3

Table 6.2-1. $\quad$ Upper Bounding Sensitivity Values .................................................................. 6-5

Table 7.0-1. Base Case, Lower Bounding, and Upper Bounding Infiltration over Time ............. 7-3

Table 7.0-2. Lower Drainage Layer Saturated Hydraulic Conductivity for the Base Case, Lower Bounding, and Upper Bounding Scenarios over Time. 


\section{LIST OF APPENDICES}

Appendix A Augusta Synthetic Precipitation Modified with SRS Specific Average Monthly Precipitation Data over 100 Years (file name: Zprec.d4) A-1

Appendix B Augusta Synthetic Temperature Modified with SRS Specific Average Monthly Temperature Data over 100 Years (file name: Ztemp.d7)

Appendix C Augusta Synthetic Solar Radiation Data over 100 Years

(file name: Zsolar.d13)

Appendix D Augusta Evapotranspiration Data (file name: Zevap.d11)

Appendix E Intact SDF MSE Vault Closure Cap (0 Years): HELP Model Input

Data and Output File (output file name: ZMSEIout.OUT)

Appendix F SDF MSE Vault Closure Cap Degraded Property Value Calculations

for Lower Bounding Scenario (i.e. Continuous Bamboo Cover) F-1

Appendix G Lower Bounding Scenario Degraded SDF MSE Vault Closure Cap (100 Years): HELP Model Input Data and Output File (output file name: ZLBS1out.OUT) G-1

Appendix H Lower Bounding Scenario Degraded SDF MSE Vault Closure Cap (300 Years): HELP Model Input Data and Output File (output file name: ZLBS2out.OUT) H-1

Appendix I Lower Bounding Scenario Degraded SDF MSE Vault Closure Cap (550 Years): HELP Model Input Data and Output File (output file name: ZLBS3out.OUT) I-1

Appendix J Lower Bounding Scenario Degraded SDF MSE Vault Closure Cap (1,000 Years): HELP Model Input Data and Output File (output file name: ZLBS4out.OUT) $\mathrm{J}-1$

Appendix K Lower Bounding Scenario Degraded SDF MSE Vault Closure Cap (1,800 Years): HELP Model Input Data and Output File (output file name: ZLBS5out.OUT) K-1

Appendix L Lower Bounding Scenario Degraded SDF MSE Vault Closure Cap (3,400 Years): HELP Model Input Data and Output File (output file name: ZLBS6out.OUT) L-1

Appendix M Lower Bounding Scenario Degraded SDF MSE Vault Closure Cap (5,600 Years): HELP Model Input Data and Output File (output file name: ZLBS7out.OUT) 


\section{LIST OF APPENDICES (continued)}

Appendix N Lower Bounding Scenario Degraded SDF MSE Vault Closure Cap (10,000 Years): HELP Model Input Data and Output File (output file name: ZLBS8out.OUT) $\mathrm{N}-1$

Appendix O SDF MSE Vault Closure Cap Degraded Property Value Calculations for Upper Bounding Scenario (i.e. Institutional Control to Farm to Pine Forest) O-1

Appendix P Upper Bounding Scenario Degraded SDF MSE Vault Closure Cap (100 Years): HELP Model Input Data and Output File (output file name: ZUBSD1ou.OUT) P-1

Appendix Q Upper Bounding Scenario Degraded SDF MSE Vault Closure Cap (154 Years): HELP Model Input Data and Output File (output file name: ZUBSD2ou.OUT)

Appendix R Upper Bounding Scenario Degraded SDF MSE Vault Closure Cap (300 Years): HELP Model Input Data and Output File (output file name: ZUBSD3ou.OUT) $\mathrm{R}-1$

Appendix S Upper Bounding Scenario Degraded SDF MSE Vault Closure Cap (550 Years): HELP Model Input Data and Output File (output file name: ZUBSD4ou.OUT)

Appendix T Upper Bounding Scenario Degraded SDF MSE Vault Closure Cap (602 Years): HELP Model Input Data and Output File (output file name: ZUBSD5ou.OUT) $\mathrm{T}-1$

Appendix U Upper Bounding Scenario Degraded SDF MSE Vault Closure Cap (802 Years): HELP Model Input Data and Output File (output file name: ZUBSD6ou.OUT) U-1

Appendix V Upper Bounding Scenario Degraded SDF MSE Vault Closure Cap (1,000 Years): HELP Model Input Data and Output File (output file name: ZUBSD7ou.OUT) $\mathrm{V}-1$

Appendix W Upper Bounding Scenario Degraded SDF MSE Vault Closure Cap (1,800 Years): HELP Model Input Data and Output File (output file name: ZUBSD8ou.OUT) W-1

Appendix X Upper Bounding Scenario Degraded SDF MSE Vault Closure Cap (3,400 Years): HELP Model Input Data and Output File (output file name: ZUBSD9ou.OUT) $\mathrm{X}-1$ 


\section{LIST OF APPENDICES (continued)}

Appendix Y Upper Bounding Scenario Degraded SDF MSE Vault Closure Cap (5,600 Years): HELP Model Input Data and Output File (output file name: ZUBSD10o.OUT) ........................................................ Y-1

Appendix Z Upper Bounding Scenario Degraded SDF MSE Vault Closure Cap (10,000 Years): HELP Model Input Data and Output File (output file name: ZUBSD11o.OUT) 


\section{LIST OF ACRONYMS AND ABBREVIATIONS}

\section{ACRONYMS}

\begin{tabular}{|c|c|}
\hline CLSM & Controlled Low Strength Material \\
\hline $\mathrm{CN}$ & Curve Number \\
\hline $\mathrm{FC}$ & field capacity \\
\hline FML & flexible membrane liner \\
\hline GCL & geosynthetic clay liner \\
\hline GSE & GSE Lining Technology, Inc. \\
\hline HELP & Hydrologic Evaluation of Landfill Performance \\
\hline LBS & Lower Bounding Scenario \\
\hline MMES & Martin Marietta Energy Systems, Inc. \\
\hline MSE & Mechanically Stabilized Earth \\
\hline PA & Performance Assessment \\
\hline PORFLOW & Software for multiphase fluid flow, heat and mass transport in fractured porous media \\
\hline SCS & Soil Conservation Service \\
\hline SDF & Saltstone Disposal Facility \\
\hline SRS & Savannah River Site \\
\hline UBS & Upper Bounding Scenario \\
\hline U.S. & United States \\
\hline USCS & Unified Soil Classification System \\
\hline USLE & Universal Soil Loss Equation \\
\hline USDA & United States Department of Agriculture \\
\hline USEPA & United States Environmental Protection Agency \\
\hline WP & wilting point \\
\hline WSRC & Westinghouse Savannah River Company \\
\hline
\end{tabular}




\section{LIST OF ACRONYMS AND ABBREVIATIONS (continued)}

\section{ABBREVIATIONS}

\begin{tabular}{|c|c|}
\hline A & Area \\
\hline A & Universal Soil Loss Equation soil loss \\
\hline $\mathrm{C}$ & Universal Soil Loss Equation vegetative cover factor \\
\hline $\mathrm{cm}$ & centimeter \\
\hline $\mathrm{cm}^{2}$ & square centimeter \\
\hline $\mathrm{cm}^{3}$ & cubic centimeter \\
\hline $\mathrm{d}$ & thickness or depth \\
\hline $\mathrm{F}$ & fraction \\
\hline $\mathrm{ft}$ & feet \\
\hline $\mathrm{ft}^{2}$ & square feet \\
\hline $\mathrm{ft}^{3}$ & cubic feet \\
\hline $\mathrm{ft}-\mathrm{msl}$ & feet above mean sea level \\
\hline $\mathrm{g}$ & gram \\
\hline I & infiltration \\
\hline in & inch \\
\hline Instal. & installation \\
\hline $\mathrm{K}$ & saturated hydraulic conductivity \\
\hline $\mathrm{K}$ & Universal Soil Loss Equation soil erodibility factor \\
\hline $\mathrm{L}$ & liter \\
\hline lbs & pounds \\
\hline LS & Universal Soil Loss Equation slope length and steepness factor \\
\hline $\mathrm{m}^{3}$ & cubic meter \\
\hline $\mathrm{mg}$ & milligram \\
\hline mil & thousandth of an inch \\
\hline $\mathrm{mph}$ & miles per hour \\
\hline $\mathrm{n}$ & porosity \\
\hline $\mathrm{N}$ & no \\
\hline No. & number \\
\hline $\mathrm{P}$ & Universal Soil Loss Equation erosion control practice factor \\
\hline $\mathrm{R}$ & Universal Soil Loss Equation rainfall erosion index \\
\hline
\end{tabular}




\section{LIST OF ACRONYMS AND ABBREVIATIONS (continued)}

\section{ABBREVIATIONS (continued)}

$\begin{array}{ll}\text { Recirc. } & \text { Recirculation } \\ \text { s } & \text { second } \\ \text { Sat. Hyd. Cond. } & \text { saturated hydraulic conductivity } \\ \text { sec } & \text { second } \\ \text { STD. } & \text { Standard } \\ \text { T } & \text { time } \\ \text { VEG. } & \text { Vegetative } \\ \text { V } & \text { volume } \\ \text { Vol } & \text { volume } \\ \text { Y } & \text { yes } \\ \text { yr } & \text { year } \\ \rho_{\mathrm{b}} & \text { bulk density } \\ \rho_{\mathrm{p}} & \text { particle density } \\ \text { ‘ } & \text { foot } \\ \text { “ } & \text { inch } \\ \% & \text { percent } \\ \# & \text { number } \\ / & \text { per } \\ \sim & \text { approximately }\end{array}$




\section{THIS PAGE INTENTIONALLY LEFT BLANK}

Rev. 0 


\subsection{EXECUTIVE SUMMARY}

As part of the current Saltstone Disposal Facility (SDF) Performance Assessment (PA) revision, Mechanically Stabilized Earth (MSE) vault closure cap degradation mechanisms and their impact upon infiltration through the MSE vault closure cap were evaluated for the base case land use scenario (i.e. institutional control to pine forest). The degradation mechanisms evaluated included pine forest succession, erosion, and colloidal clay migration (Phifer 2003). Infiltration through the upper hydraulic barrier layer of the closure cap as determined by this evaluation will be utilized as the infiltration input to subsequent PORFLOW vadose zone contaminant transport modeling, which will also be performed as part of the PA revision.

Additionally as part of the PA revision, a sensitivity analysis has been performed and documented herein, to bound the previous base case land use scenario results. The same degradation mechanisms utilized for the base case, as appropriate, have been utilized in the sensitivity analysis. The bounding sensitivity analysis includes the following two MSE vault, closure cap, land use scenarios:

- Continuous bamboo cover (this scenario bounds the lower end of infiltration), and

- Institutional control to farm to pine forest (this scenario bounds the upper end of infiltration).

The estimated infiltration through the upper GCL for the lower bounding, base case, and upper bounding scenarios at year 1000 were $1.75,12.04$, and 19.46 inches/year, respectively. The maximum infiltration estimated through the upper GCL within the first 10,000 years infiltration for the lower bounding, base case, and upper bounding scenarios were 6.46 inches/year at year 3,400, 14.09 inches/year at year 10,000, and 21.42 inches/year at year 3,400, respectively. The estimated infiltration through the upper GCL at complete degradation of the closure cap for the lower bounding, base case, and upper bounding scenarios were 4.75 inches/year at year 280,000, 18.12 inches/year at year 280,000 , and 18.60 at approximately year 38,250 .

Based upon the results of this sensitivity analysis, it was estimated that the pine forest succession, degradation mechanism results in the greatest increase in infiltration at approximately 13.5 inches/year. It was estimated that colloidal clay migration into the drainage layer results in an infiltration increase of approximately 6 inches/year. Finally it was estimated that erosion results in the least infiltration increase of the degradation mechanisms at approximately 1 inch/year. Based upon this, it is evident that elimination of the pine forest succession, degradation mechanism would do the most to minimize increases in the infiltration over time.

In addition to infiltration over time, the saturated hydraulic conductivity of the lower drainage layer over time is an important parameter. It is estimated that the lower drainage layer completely silts-in (i.e. has a saturated hydraulic conductivity of $0.0001 \mathrm{~cm} / \mathrm{s}$ ) in year 26,000 for the lower bounding scenario, in year 12,000 for the base case scenario, and in year 8,300 for the upper bounding scenario. 


\section{THIS PAGE INTENTIONALLY LEFT BLANK}

Rev. 0 


\subsection{INTRODUCTION}

As part of the current Saltstone Disposal Facility (SDF) Performance Assessment (PA) revision, the closure cap configuration was reevaluated and closure cap degradation mechanisms and their impact upon infiltration through the closure cap were evaluated for the base case land use scenario (i.e. institutional control to pine forest). This land use scenario assumes a 100 -year institutional control period following final SDF closure during which the closure cap is maintained. At the end of institutional control, it is assumed that a pine forest succeeds the cap's original bamboo cover (Phifer and Nelson 2003).

The revised closure cap configuration is presented in Figure 2.0-1 (Phifer and Nelson 2003). The degradation mechanisms evaluated for this closure cap included pine forest succession, erosion, and colloidal clay migration. These degradation mechanisms resulted in changes in the hydraulic properties of the closure cap layers and resulting increases in infiltration through the closure cap over time. The primary changes caused by the degradation mechanisms that result in increased infiltration are the formation of holes in the upper geosynthetic clay liner (GCL) by pine forest succession and the reduction in the saturated hydraulic conductivity of the drainage layers due to colloidal clay migration into the layers. Erosion can also result in significant increases in infiltration if it causes the removal of soil layers, which provide water storage for the promotion of evapotranspiration.

The infiltration results for the existing SDF concrete vaults (i.e. vaults 1 and 4) and for the proposed Mechanically Stabilized Earth (MSE) vaults were documented within Phifer and Nelson (2003) and Phifer (2003), respectively. The existing SDF vaults (i.e. vaults 1 and 4) are above grade, roofed, reinforced concrete vaults. The proposed MSE vault configuration is presented in Figure 2.0-2 (Phifer 2003). Infiltration through the upper hydraulic barrier layer of the closure cap as determined by these evaluations will be utilized as the infiltration input to subsequent PORFLOW vadose zone contaminant transport modeling, which will also be performed as part of the PA revision.

Additionally as part of the PA revision, a sensitivity analysis has been performed and documented herein, to bound the previous results for the MSE vault, closure cap, base case land use scenario (i.e. institutional control to pine forest). The bounding sensitivity analysis includes the following two MSE vault, closure cap, land use scenarios:

- Continuous bamboo cover, and

- Institutional control to farm to pine forest.

The continuous bamboo cover land use scenario assumes that bamboo, which is shallow-rooted, is the climax species for the closure cap (i.e. pine trees will not encroach upon the bamboo). This scenario results in the least amount of infiltration through the upper hydraulic barrier layer (i.e. lower bounding scenario). The institutional control to farm to pine forest, land use scenario assumes a 100year institutional control period following final SDF closure during which the closure cap is maintained. At the end of institutional control, it is assumed that the cap's original bamboo cover is removed and that corn is grown until the closure cap layers above the erosion barrier are completely eroded. After the layers above the erosion barrier are gone, it is assumed that a pine forest succeeds corn farming. This scenario results in the greatest amount of infiltration through the upper hydraulic barrier layer (i.e. upper bounding scenario). The same degradation mechanisms, as appropriate, have been evaluated for both the lower and upper bounding scenarios. 


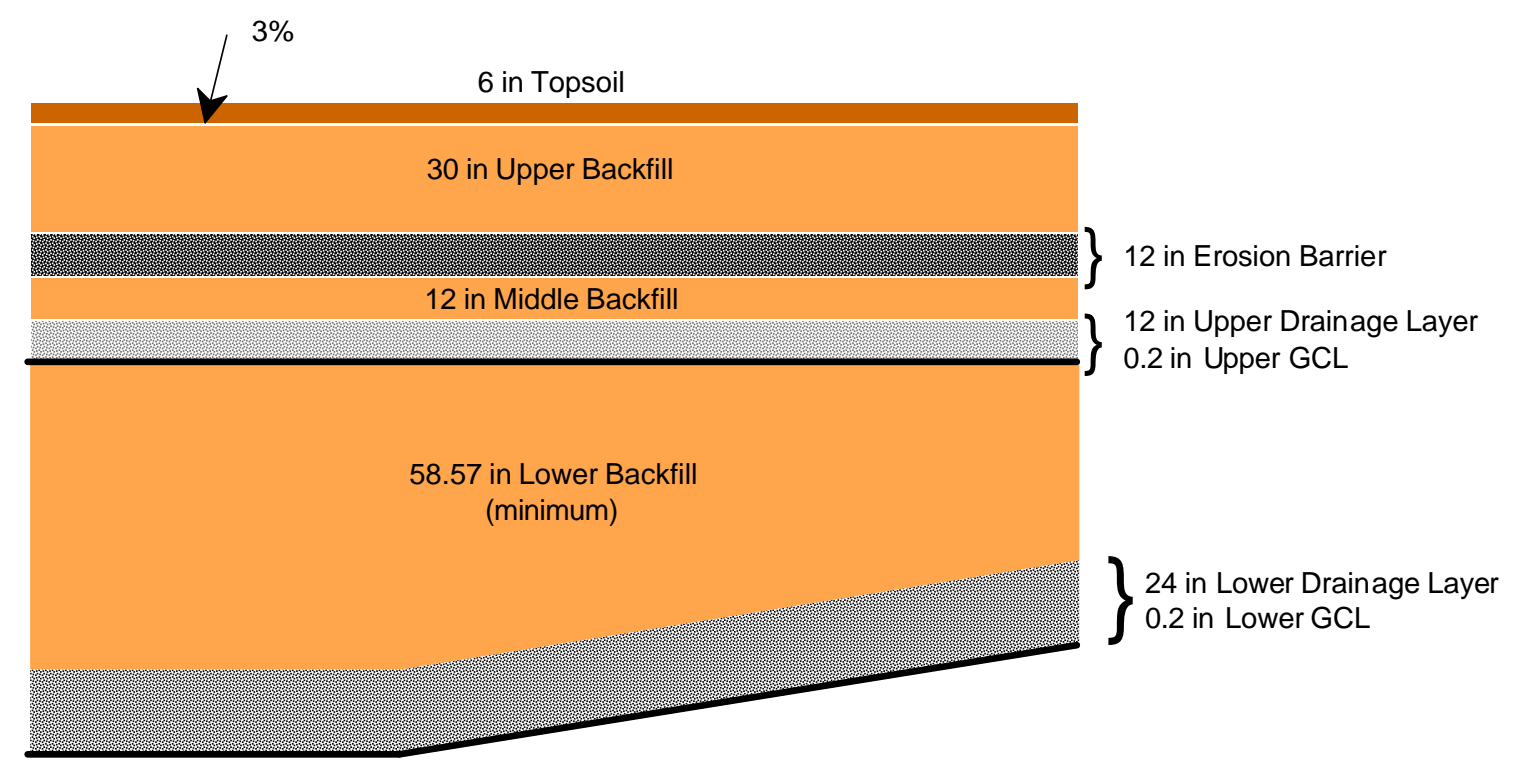

Figure 2.0-1. Saltstone Disposal Facility Closure Cap (Phifer and Nelson 2003)

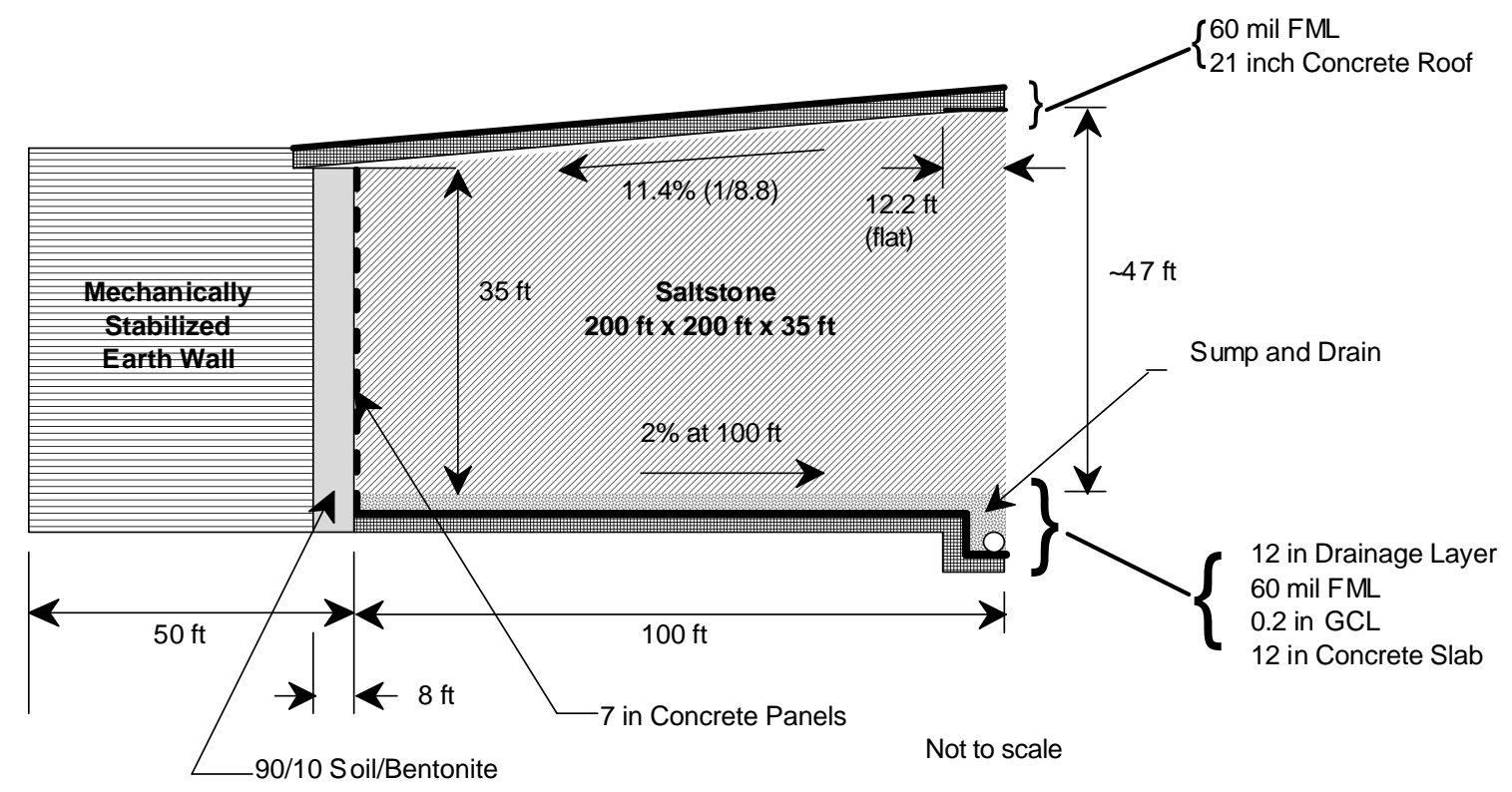

Figure 2.0-2. Saltstone Disposal Facility MSE Vault (Phifer 2003) 


\subsection{INTACT CLOSURE CAP INFILTRATION}

\subsection{Intact SDF GCL Closure Cap Footprint, Configuration, and Properties}

The MSE vault layout (Figure 3.1-1) and the closure cap footprint and drainage system configuration (Figure 3.1-2) developed by Phifer (2003) has been utilized for the sensitivity analysis presented herein. Figure 3.1-3 presents the MSE vault and closure cap cross-section as previously described in Section 2.0. The assumption has been made that the lower GCL only covers the MSE vault roof whereas the upper GCL is continuous over the entire closure cap footprint presented in Figure 3.1-2. Table 3.1-1 presents the intact SDF MSE Vault closure cap configuration and soil properties as developed by Phifer and Nelson (2003).

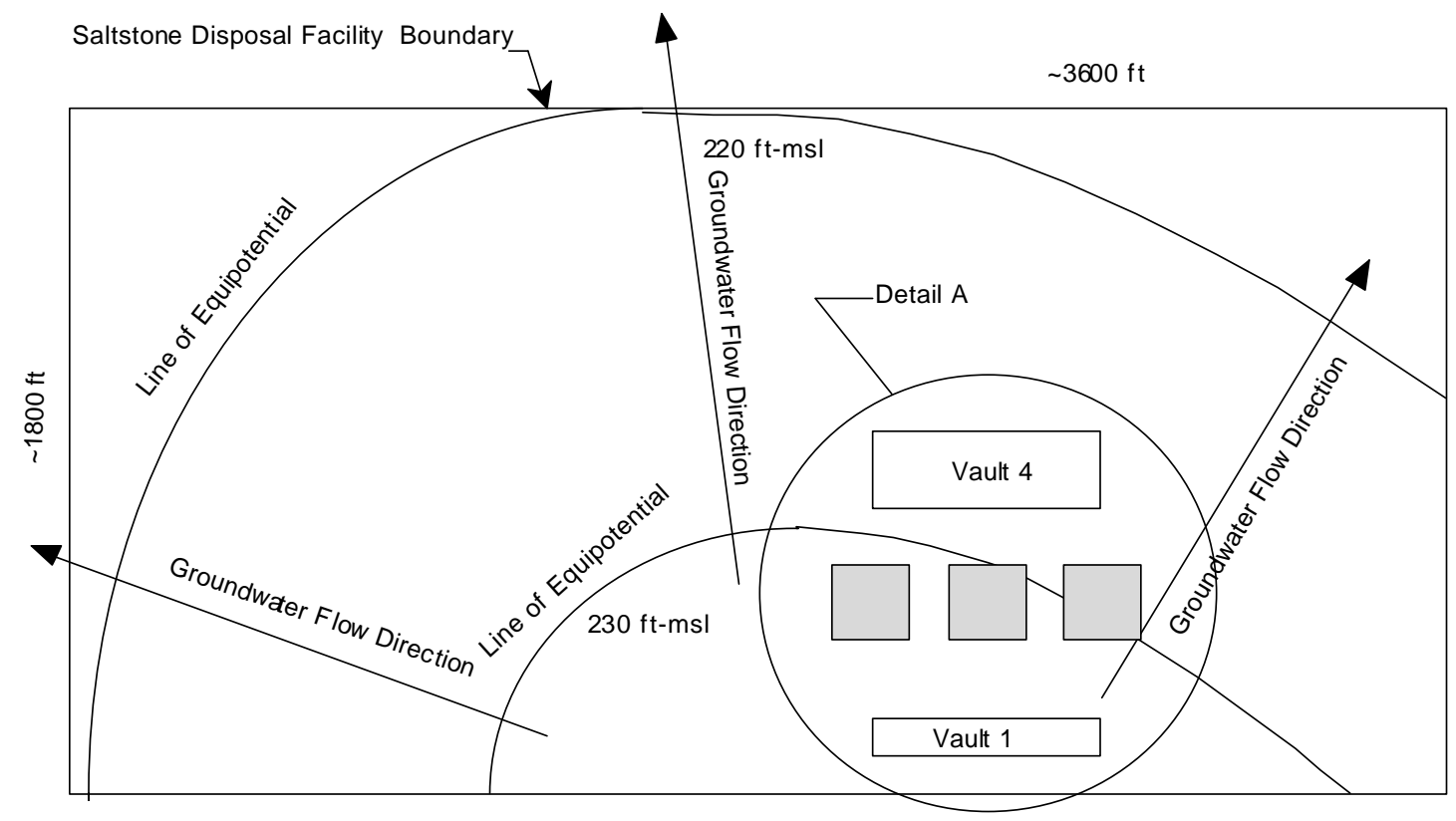

Figure 3.1-1. MSE Vault Layout (Phifer 2003) 


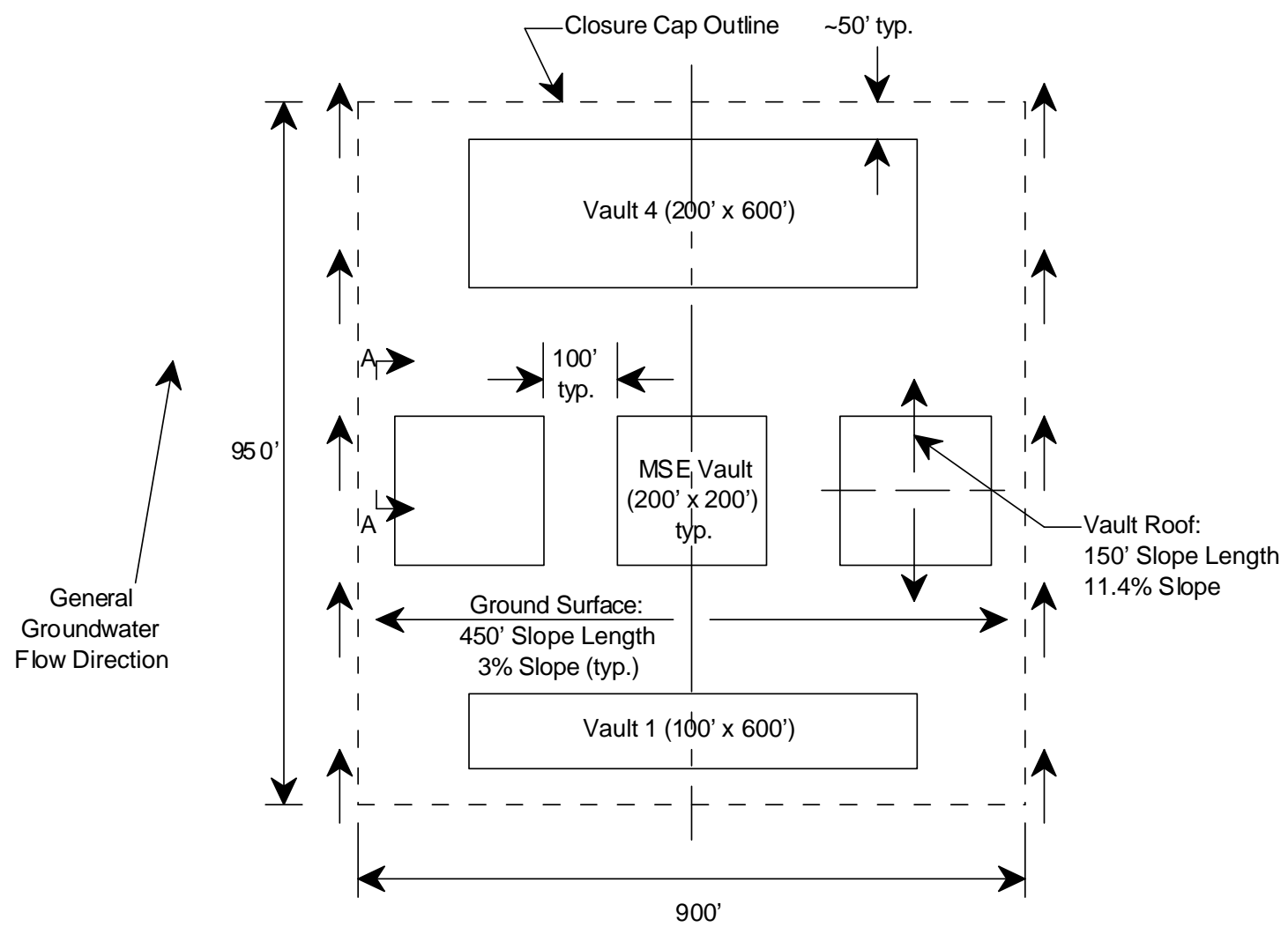

Figure 3.1-2. Closure Cap Footprint and Drainage System (Detail A) (Phifer 2003)

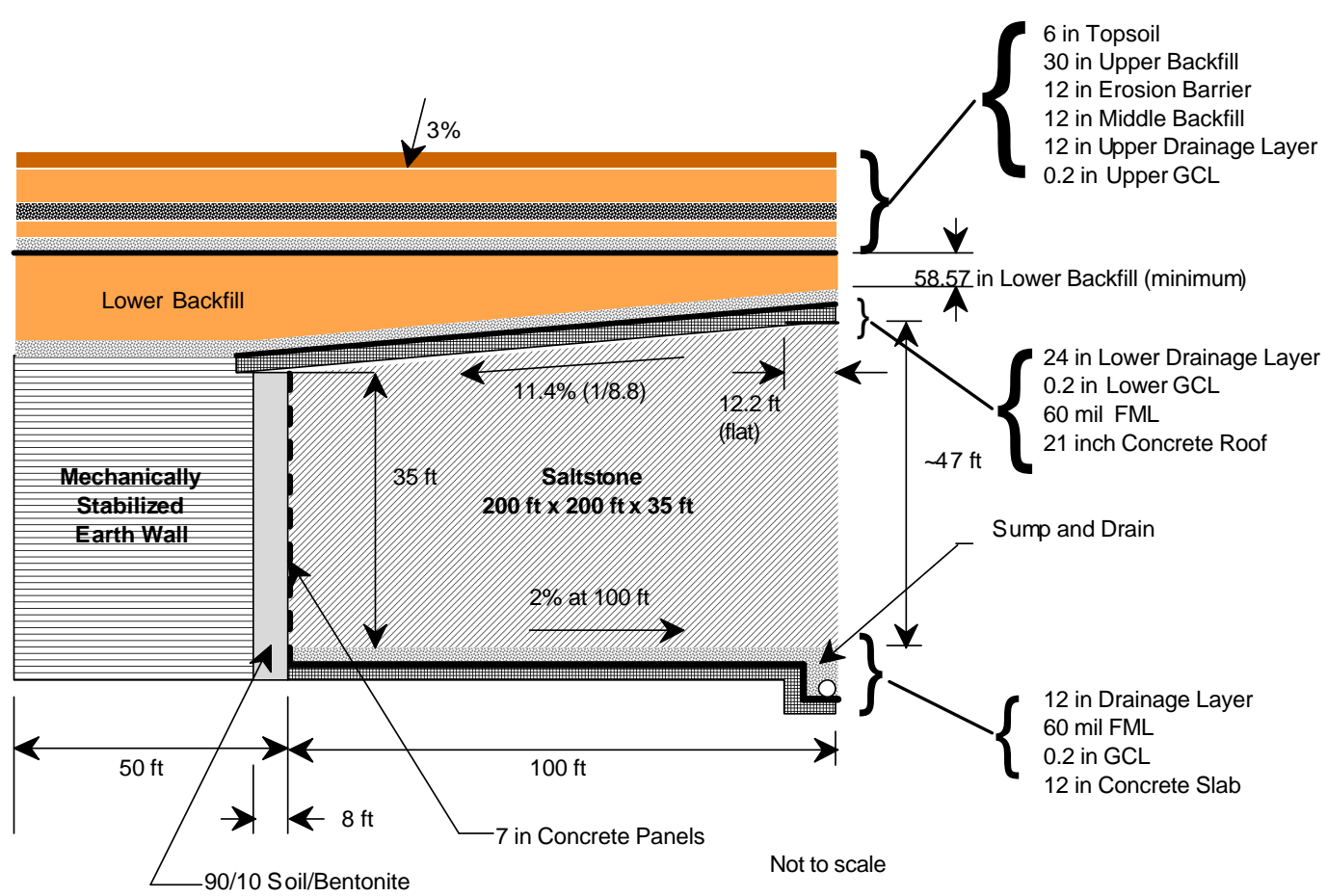

Figure 3.1-3. MSE Vault and Closure Cap Cross-Section (Section A-A) (Phifer 2003) 
Table 3.1-1. Intact SDF MSE Vault Closure Cap Configuration and Properties (Phifer and Nelson 2003)

\begin{tabular}{|c|c|c|c|c|c|}
\hline Layer & $\begin{array}{c}\text { Thickness } \\
\text { (inches) }\end{array}$ & $\begin{array}{c}\text { Saturated } \\
\text { Hydraulic } \\
\text { Conductivity } \\
(\mathrm{cm} / \mathrm{sec})\end{array}$ & $\begin{array}{c}\text { Total } \\
\text { Porosity } \\
\text { (Vol/Vol) }\end{array}$ & $\begin{array}{c}\text { Field } \\
\text { Capacity } \\
\text { (Vol/Vol) }\end{array}$ & $\begin{array}{l}\text { Wilting Point } \\
\text { (Vol/Vol) }\end{array}$ \\
\hline Topsoil $^{1}$ & 6 & $1.00 \mathrm{E}-03$ & 0.4 & 0.11 & 0.058 \\
\hline Upper Backfill $^{1}$ & 30 & $1.00 \mathrm{E}-04$ & 0.37 & 0.24 & 0.136 \\
\hline Erosion Barrier ${ }^{2}$ & 12 & $3.97 \mathrm{E}-04$ & 0.06 & 0.056 & 0.052 \\
\hline$\underset{1}{\text { Middle Backfill }}$ & 12 & $1.00 \mathrm{E}-04$ & 0.37 & 0.24 & 0.136 \\
\hline $\begin{array}{l}\text { Geotextile Filter } \\
\text { Fabric }^{3}\end{array}$ & - & - & - & - & - \\
\hline $\begin{array}{l}\text { Upper Drainage } \\
\text { Layer }{ }^{1}\end{array}$ & 12 & $1.00 \mathrm{E}-01$ & 0.38 & 0.08 & 0.013 \\
\hline Upper GCL & $0.2^{4}$ & $5.00 \mathrm{E}-09^{5}$ & $0.75^{6}$ & $0.747^{6}$ & $0.40^{6}$ \\
\hline Lower Backfill $^{1}$ & $\begin{array}{l}58.57 \\
\text { (minimum) }\end{array}$ & $1.00 \mathrm{E}-04$ & 0.37 & 0.24 & 0.136 \\
\hline $\begin{array}{l}\text { Geotextile Filter } \\
\text { Fabric }{ }^{5}\end{array}$ & - & - & - & - & - \\
\hline $\begin{array}{l}\text { Lower Drainage } \\
\text { Layer }^{1}\end{array}$ & 24 & $1.00 \mathrm{E}-01$ & 0.38 & 0.08 & 0.013 \\
\hline Lower GCL & $0.2^{4}$ & $5.00 \mathrm{E}-09^{5}$ & $0.75^{6}$ & $0.747^{6}$ & $0.40^{6}$ \\
\hline
\end{tabular}

WSRC 2002

${ }^{2}$ Phifer and Nelson 2003; The erosion barrier is assumed to consist of a one foot thick layer of 2-inch to 6-inch granite stone whose voids are filled with a Controlled Low Strength Material (CLSM) or flowable fill.

${ }^{3}$ It is assumed that a geotextile filter fabric will be placed above the drainage layers to minimize the infiltration of fines from the overlying layers into the drainage layer. However it is not necessary to include the filter fabric in the HELP models.

${ }^{4}$ USEPA 2001

${ }^{5}$ GSE 2002

${ }^{6}$ USEPA 1994a and USEPA 1994b

\subsection{HELP Model and Generic Input Data}

The Hydrologic Evaluation of Landfill Performance (HELP) model has been utilized to conduct the evaluation of the impact of closure cap degradation upon infiltration for each bounding sensitivity land use scenario (see Section 2.0) for the MSE vault closure cap (see Section 3.1). The HELP model is a quasi-two-dimensional water balance model designed to conduct landfill water balance analyses. The model requires the input of weather, soil, and design data. It provides estimates of runoff, evapotranspiration, lateral drainage, vertical percolation (infiltration), hydraulic head, and water storage for the evaluation of various landfill designs. Personnel at the U.S. Army Engineer Waterways Experiment Station in Vicksburg, Mississippi developed the HELP model, under an interagency agreement with the U.S. Environmental Protection Agency (USEPA). HELP model 
version 3.07, issued on November 1, 1997, is the latest version of the model available from the Waterways Experiment Station (USEPA 1994a and USEPA 1994b).

The HELP model requires the input of evapotranspiration, precipitation, temperature, and solar radiation data. Phifer and Nelson (2003) developed the weather data utilized to conduct this evaluation. The HELP model weather data input files, which were utilized for all HELP model runs, are provided in the following appendices:

- Appendix A, Augusta Synthetic Precipitation Modified with SRS Specific Average Monthly Precipitation Data over 100 Years (file name: Zprec.d4),

- Appendix B, Augusta Synthetic Temperature Modified with SRS Specific Average Monthly Temperature Data over 100 Years (file name: Ztemp.d7),

- Appendix C, Augusta Synthetic Solar Radiation Data over 100 Years (file name: Zsolar.d13), and

- Appendix D, Augusta Evapotranspiration Data (file name: Zevap.d11).

Table 3.2-1 provides a listing of generic input parameters (i.e., HELP model query) and the associated values selected. Use of selected fixed values for these HELP model queries provides compatibility between the different HELP model runs. The landfill area is based upon the Figure 3.1-2 length (950 feet) and width (900 feet), which results in a surface area of 760,000 feet squared or 19.63 acres. It has been assumed that the final covers are appropriately sloped so that 100 percent of the covers allow runoff to occur (i.e., there are no depressions). A yes response has been provided to the HELP model query, which asks, "Do you want to specify initial moisture storage? (Y/N)." The amount of water or snow on the surface of the covers was assumed to be zero as the initial model condition.

Table 3.2-1. Generic Input Parameter Values - Area and Initial Moisture

\begin{tabular}{|l|l|}
\hline \multicolumn{1}{|c|}{ Input Parameter (HELP Model Query) } & \multicolumn{1}{c|}{ Generic Input Parameter Value } \\
\hline Landfill area & 19.63 acres \\
\hline Percent of area where runoff is possible & $100 \%$ \\
\hline Do you want to specify initial moisture storage? (Y/N) & $\mathrm{Y}$ \\
\hline Amount of water or snow on surface & 0 in. \\
\hline
\end{tabular}

As stated the initial moisture storage has been specified for all soil layers. While the initial moisture storage is not a fixed value for all runs, a fixed method of selecting the initial moisture storage value has been utilized for consistency. The initial, soil moisture storage value has been selected as follows:

- The initial moisture storage of soil layers designated as either a vertical percolation layer or a lateral drainage layer was set at the field capacity of the soil.

- The initial moisture storage of soil layers designated as a barrier soil liner was set at the porosity of the soil.

\subsection{Intact Closure Cap Curve Number Input Parameter Values}

The Soil Conservation Service (SCS) runoff curve number $(\mathrm{CN})$ is another required HELP model input parameter. The HELP model provides three options to specify the $\mathrm{CN}$. The option that produces a HELP model computed curve number, based on surface slope and slope length, soil texture of the top layer, and vegetation, was utilized for the intact closure cap. Table 3.3-1 provides the input values of surface slope and slope length, soil texture of the top layer, and vegetation that were utilized to produce the HELP model computed curve number. The 3 percent slope is that specified for the top surface of the Saltstone final cover within the Saltstone closure plan (Cook et al. 2000). The 450-foot 
slope length is based upon Figure 3.1-2. The soil texture, selected as an input for calculation of the $\mathrm{CN}$, is a loamy fine sand per the United States Department of Agriculture (USDA) and a silty sand per Unified Soil Classification System (USCS). This soil texture closely represents the typical vegetative soil layers utilized at the Savannah River Site (SRS). The corresponding number in the HELP default soil texture list is 5. Based upon these input parameter values the HELP model computed a $\mathrm{CN}$ of 54.4 for the intact closure cap case.

Table 3.3-1. Curve Number (CN) Input Parameter Values for Intact Closure Cap

\begin{tabular}{|l|l|}
\hline \multicolumn{1}{|c|}{ CN Input Parameter (HELP Model Query) } & \multicolumn{1}{c|}{ CN Input Parameter Value } \\
\hline Slope & $3 \%$ \\
\hline Slope length & $450 \mathrm{ft}$ \\
\hline Soil Texture & 5 (HELP model default soil texture) \\
\hline Vegetation & 4 (i.e., a good stand of grass) \\
\hline HELP Model Computed Curve Number & 54.4 \\
\hline
\end{tabular}

\subsection{Intact Closure Cap Infiltration}

HELP modeling of the Table 3.1-1 intact SDF MSE vault closure cap configuration has been performed utilizing the Section 3.2 input data. As documented in Phifer and Nelson (2003), the HELP model does not need to include the vault in order to obtain an appropriate infiltration through the upper GCL. Therefore the vault has not been included in any of the HELP modeling presented herein. Based upon this modeling the infiltration through the upper GCL has been estimated to be 0.36 inches per year for intact conditions. The following appendix provides the detailed HELP model, input data and output file for the intact condition:

- Appendix E, Intact SDF MSE Vault Closure Cap (0 Years): HELP Model Input Data and Output File (output file name: ZMSEIout.OUT) 


\section{THIS PAGE INTENTIONALLY LEFT BLANK}

Rev. 0 


\subsection{CLOSURE CAP DEGRADATION}

The following two primary closure cap degradation mechanisms have been assumed to significantly impact the infiltration through the MSE vault closure cap over time for the continuous bamboo cover land use scenario (i.e. lower bounding scenario):

- Erosion

- Colloidal clay migration

The pine forest succession, degradation mechanism is not applicable to the continuous bamboo cover land use scenario.

The following three primary closure cap degradation mechanisms have been assumed to significantly impact the infiltration through the MSE vault closure cap over time for the institutional control to farm to pine forest land use scenario (i.e. upper bounding scenario):

- Pine forest succession

- Erosion

- Colloidal clay migration

Phifer and Nelson (2003) discussed each of these degradation mechanisms in detail.

\subsection{Pine Forest Succession}

Pine forest succession is only a degradation mechanism for the upper bounding scenario as outlined above. Corn is a shallow-rooted, single harvest per year farm crop in the vicinity of SRS. For the upper bounding scenario, it is assumed that pine trees succeed corn farming after erosion exposes the erosion barrier. Pine trees are the most deeply rooted naturally occurring plants at SRS. (MMES 1992; Cook et al. 2000). The following assumptions, which were made relative to pine forest succession by Phifer and Nelson (2003), have also been utilized for this evaluation as appropriate:

- 200 years after the end of farming it is assumed that the entire cap is dominated by pine.

- Complete turnover of the 400 mature trees per acre occurs every 100 years (in a staggered manner).

- There are 400 mature trees per acre with 4 roots to 6 feet and 1 root to 12 feet. The roots are 3 inches in diameter at a depth of 1 foot and 0.25 inches in diameter at either 6 or 12 feet, whichever is applicable.

\subsection{Erosion}

The topsoil and upper backfill layers, which are located above the erosion barrier, are subject to erosion. For the lower bounding scenario erosion is assumed to occur with a bamboo vegetative cover only. For the upper bounding scenario erosion is assumed to occur with a bamboo vegetative cover for the first 100 years followed by erosion with corn cover until both the topsoil and upper backfill layers are completely eroded. The projected erosion rate for both the topsoil and upper backfill layers has been determined utilizing the Universal Soil Loss Equation for both bamboo and corn vegetative covers. The Universal Soil Loss Equation (USLE) is expressed as: 
$A=R \times K \times L S \times C \times P$

where

$$
\begin{aligned}
& \mathrm{A}=\text { soil loss (tons/acre/year) } \\
& \mathrm{R}=\text { rainfall erosion index }(100 \mathrm{ft} \cdot \mathrm{ton} / \mathrm{acre} \text { per in/hr) } \\
& \mathrm{K}=\text { soil erodibility factor, tons/acre per unit of } \mathrm{R} \\
& \mathrm{LS}=\text { slope length and steepness factor, dimensionless } \\
& \mathrm{C}=\text { vegetative cover factor, dimensionless } \\
& \mathrm{P}=\text { erosion control practice factor, dimensionless }
\end{aligned}
$$

Table 4.2-1 presents the USLE parameter values utilized and the source of the values for both the topsoil and backfill cover with bamboo and corn.

Table 4.2-1. USLE Parameter Values

\begin{tabular}{|l|l|l|}
\hline \multicolumn{1}{|c|}{ USLE Parameter } & \multicolumn{1}{|c|}{ Value Utilized } & \multicolumn{1}{c|}{ Source } \\
\hline R for SRS location & 260 & Horton and Wilhite 1978 \\
\hline K for topsoil & 0.28 & $\begin{array}{l}\text { Phifer and Nelson 2003 and } \\
\text { Goldman et al. 1986 Figure 5.6 }\end{array}$ \\
\hline K for backfill & 0.20 & $\begin{array}{l}\text { Phifer and Nelson 2003 and } \\
\text { Goldman et al. 1986 Figure 5.6 }\end{array}$ \\
\hline $\begin{array}{l}\text { LS for 450-foot 3\% slope } \\
\text { (see Figure 3.1-2) }\end{array}$ & 0.45 & Goldman et al. 1986 Table 5.5 \\
\hline C for bamboo & 0.001 & Horton and Wilhite 1978 \\
\hline C for corn & 0.54 & Horton and Wilhite 1978 \\
\hline P for no supporting practices & 1 & Not applicable \\
\hline
\end{tabular}

${ }^{1}$ Assumed to be the same as a natural successional forest.

Based upon the Universal Soil Loss Equation and the Table 4.2-1 parameter values the following soil losses were estimated:

- Topsoil with bamboo has an estimated soil loss of 0.0328 tons/acre/year $(A=260 \times 0.28 \times 0.45 \times 0.001 \times 1)$. Based upon the dry bulk density the estimated soil loss can be converted to a loss in terms of depth of loss per year. From Jones and Phifer (2002), the dry bulk density of topsoil was taken as $90 \mathrm{lbs} / \mathrm{ft}^{3}$. Topsoil with bamboo has an estimated depth of soil loss of approximately 2.0E-04 inches/year.

$$
\left(\text { Loss }=\frac{0.0328 \text { tons } / \text { acre } / \text { year } \times 2000 \mathrm{lbs} / \text { ton } \times 12 \text { inches } / \text { foot }}{43560 \mathrm{ft}^{2} / \text { acre } \times 90 \mathrm{lbs} / \mathrm{ft}^{3}}\right) .
$$

- Topsoil with corn has an estimated soil loss of 17.69 tons/acre/year $(A=260 \times 0.28 \times 0.45 \times 0.54 \times 1)$. Based upon the dry bulk density the estimated soil loss can be converted to a loss in terms of depth of loss per year. From Jones and Phifer (2002), the dry 
bulk density of topsoil was taken as $90 \mathrm{lbs} / \mathrm{ft}^{3}$. Topsoil with corn has an estimated depth of soil loss of approximately 0.11 inches/year.

$$
\left(\text { Loss }=\frac{17.69 \text { tons } / \text { acre } / \text { year } \times 2000 \mathrm{lbs} / \text { ton } \times 12 \text { inches } / \text { foot }}{43560 \mathrm{ft}^{2} / \text { acre } \times 90 \mathrm{lbs} / \mathrm{ft}^{3}}\right) .
$$

- Backfill with bamboo has an estimated soil loss of 0.0234 tons/acre/year ( $A=260 \times 0.20 \times 0.45 \times 0.001 \times 1)$. Based upon the dry bulk density the estimated soil loss can be converted to a loss in terms of depth of loss per year. From Jones and Phifer (2002), the dry bulk density of backfill was taken as $104 \mathrm{lbs} / \mathrm{ft}^{3}$. Backfill with bamboo has an estimated depth of soil loss of approximately 1.2E-04 inches/year.

$$
\left(\text { Loss }=\frac{0.0234 \text { tons } / \text { acre } / \text { year } \times 2000 \mathrm{lbs} / \text { ton } \times 12 \text { inches } / \text { foot }}{43560 \mathrm{ft}^{2} / \text { acre } \times 104 \mathrm{lbs} / \mathrm{ft}^{3}}\right) .
$$

- Backfill with corn has an estimated soil loss of 12.64 tons/acre/year ( $A=260 \times 0.20 \times 0.45 \times 0.54 \times 1$ ). Based upon the dry bulk density the estimated soil loss can be converted to a loss in terms of depth of loss per year. From Jones and Phifer (2002), the dry bulk density of backfill was taken as $104 \mathrm{lbs} / \mathrm{ft}^{3}$. Backfill with corn has an estimated depth of soil loss of approximately 0.067 inches/year.

$$
\left(\text { Loss }=\frac{12.64 \text { tons } / \text { acre } / \text { year } \times 2000 \mathrm{lbs} / \text { ton } \times 12 \text { inches } / \text { foot }}{43560 \mathrm{ft}^{2} / \text { acre } \times 104 \mathrm{lbs} / \mathrm{ft}^{3}}\right) .
$$

\subsection{Colloidal Clay Migration}

It is assumed that colloidal clay migrates from overlying backfill layers and accumulates in the drainage layers reducing the saturated hydraulic conductivity of the drainage layers over time. As previously documented in Phifer and Nelson (2003), it will be assumed that water flux driven colloidal clay migration at a concentration of $63 \mathrm{mg} / \mathrm{L}$ occurs from overlying backfill layers to the drainage layers. It will be further assumed that the colloidal clay accumulates in the drainage layer from the bottom up filling the void space of the drainage layer with clay at a density of $1.1 \mathrm{~g} / \mathrm{cm}^{3}$ (Hillel 1982).

\subsection{Closure Cap Degradation Summary}

Based upon the erosion and colloidal clay migration degradation mechanisms, degradation assumptions for each closure cap layer has been made as outlined in Table 4.4-1 for the lower bounding scenario (i.e. continuous bamboo cover). Based upon the pine forest succession, erosion, and colloidal clay migration degradation mechanisms, degradation assumptions for each closure cap layer has been made as outlined and in Table 4.4-2 for the upper bounding scenario (i.e. institutional control to farm to pine forest). These degradation scenarios form the basis for modifying the thickness and hydraulic properties of each layer over time. This information has been utilized in Section 5.0 to determine infiltration though the upper GCL over time. 
Table 4.4-1. Lower Bounding Scenario Closure Cap Layer Degradation Assumptions (modified from Phifer and Nelson 2003)

\begin{tabular}{|l|l|}
\hline Layer & Degradation Assumption \\
\hline Vegetation & Bamboo covers the closure cap continuously \\
\hline Topsoil & Topsoil erosion occurs at 2.0E-04 inches per year with bamboo. \\
\hline Upper Backfill & $\begin{array}{l}\text { Backfill erosion occurs at 1.2E-04 inches per year with bamboo, after the } \\
\text { topsoil layer has been depleted. }\end{array}$ \\
\hline Erosion Control & $\begin{array}{l}\text { None. Bamboo roots are assumed to have no impact upon the erosion control } \\
\text { barrier. }\end{array}$ \\
\hline Middle Backfill & $\begin{array}{l}\text { Colloidal clay migration from the 1-foot-thick middle backfill to the } \\
\text { underlying 1-foot-thick upper drainage layer causes the saturated hydraulic } \\
\text { conductivity to increase over time. }\end{array}$ \\
\hline Geotextile Filter & $\begin{array}{l}\text { For purposes of colloidal clay migration into the underlying drainage layer the } \\
\text { geotextile filter fabric is assumed to be ineffective over the time period under } \\
\text { consideration. }\end{array}$ \\
\hline $\begin{array}{l}\text { Upper Drainage } \\
\text { Layer }\end{array}$ & $\begin{array}{l}\text { Colloidal clay migration from the overlying 1-foot-thick backfill into the 1- } \\
\text { foot-thick upper drainage layer causes the saturated hydraulic conductivity to } \\
\text { decrease over time. }\end{array}$ \\
\hline Upper GCL & $\begin{array}{l}\text { None. Bamboo roots are assumed to have no impact upon the upper GCL, } \\
\text { since the upper GCL is located at a depth beyond the penetration of bamboo } \\
\text { roots. }\end{array}$ \\
\hline Lower Backfill & $\begin{array}{l}\text { None. While it is assumed that colloidal clay migration from this layer to the } \\
\text { underlying lower drainage layer occurs, it is also assumed that the thickness of } \\
\text { the lower backfill layer (minimum 5-foot) relative to the lower drainage layer } \\
\text { (2-foot) prevents the quantity of clay loss necessary to change the hydraulic } \\
\text { properties of the lower backfill. }\end{array}$ \\
\hline $\begin{array}{l}\text { Geotextile Filter } \\
\text { Fabric }\end{array}$ & $\begin{array}{l}\text { For purposes of colloidal clay migration into the underlying drainage layer the } \\
\text { geotextile filter fabric is assumed to be ineffective over the time period under } \\
\text { consideration. }\end{array}$ \\
\hline $\begin{array}{l}\text { Colloidal clay migration from the overlying minimum 5-foot-thick lower } \\
\text { backfill into the 1-foot-thick lower drainage layer reduces its saturated } \\
\text { hydraulic conductivity over time. }\end{array}$ \\
$\begin{array}{l}\text { None. Bamboo roots are assumed to have no impact upon the lower GCL, } \\
\text { since the lower GCL is located at a depth beyond the penetration of bamboo } \\
\text { roots. }\end{array}$ \\
\hline Layer
\end{tabular}


Table 4.4-2. Upper Bounding Scenario Closure Cap Layer Degradation Assumptions (modified from Phifer and Nelson 2003)

\begin{tabular}{|c|c|}
\hline Layer & Degradation Assumption \\
\hline Vegetation & $\begin{array}{l}\text { Bamboo is maintained during the } 100 \text {-year institutional control period, corn is } \\
\text { grown until the erosion barrier is exposed, pine trees begin to encroach after } \\
\text { farming has ceased, and a pine forest covers the cap } 200 \text { years after farming } \\
\text { has ceased. }\end{array}$ \\
\hline Topsoil & $\begin{array}{l}\text { Topsoil erosion occurs at } 2.0 \mathrm{E}-04 \text { inches per year with bamboo and } 0.11 \\
\text { inches per year with corn. }\end{array}$ \\
\hline Upper Backfill & $\begin{array}{l}\text { Backfill erosion occurs at } 1.2 \mathrm{E}-04 \text { inches per year with bamboo and } 0.067 \\
\text { inches per year with corn, after the topsoil layer has been depleted. }\end{array}$ \\
\hline $\begin{array}{l}\text { Erosion Control } \\
\text { Barrier }\end{array}$ & $\begin{array}{l}\text { Maintenance and farm practices during institutional control and corn farming } \\
\text { prevent degradation of the erosion control barrier. Subsequent to corn farming } \\
\text { after complete erosion of the topsoil and upper backfill, pine forest succession } \\
\text { will result in root penetration through the erosion control barrier. This does not } \\
\text { impact its ability to function as an erosion barrier. It will be assumed that root } \\
\text { penetration breaks up the flowable fill and separates it from the granite stone. } \\
\text { After the root decomposes it will be assumed that segregation of the granite } \\
\text { stone and broken up flowable fill occurs, resulting in the flowable fill at the } \\
\text { bottom of the hole and the granite stone at the top. }\end{array}$ \\
\hline Middle Backfill & $\begin{array}{l}\text { Colloidal clay migration from the } 1 \text {-foot-thick middle backfill to the } \\
\text { underlying } 1 \text {-foot-thick upper drainage layer causes the saturated hydraulic } \\
\text { conductivity to increase over time. }\end{array}$ \\
\hline $\begin{array}{l}\text { Geotextile Filter } \\
\text { Fabric }\end{array}$ & $\begin{array}{l}\text { For purposes of colloidal clay migration into the underlying drainage layer the } \\
\text { geotextile filter fabric is assumed to be ineffective over the time period under } \\
\text { consideration. }\end{array}$ \\
\hline $\begin{array}{l}\text { Upper Drainage } \\
\text { Layer }\end{array}$ & $\begin{array}{l}\text { Colloidal clay migration from the overlying } 1 \text {-foot-thick backfill into the } 1 \text { - } \\
\text { foot-thick upper drainage layer causes the saturated hydraulic conductivity to } \\
\text { decrease over time. }\end{array}$ \\
\hline Upper GCL & $\begin{array}{l}\text { Maintenance during institutional control period and farming practices prevent } \\
\text { degradation of the upper GCL. Subsequent to the institutional control period } \\
\text { and corn farming after all of the topsoil and upper backfill have been } \\
\text { completely eroded, pine forest succession will result in root penetration } \\
\text { through the GCL. This allows the overlying drainage layer to fill the holes } \\
\text { after the roots decompose. }\end{array}$ \\
\hline Lower Backfill & $\begin{array}{l}\text { None. While it is assumed that colloidal clay migration from this layer to the } \\
\text { underlying lower drainage layer occurs, it is also assumed that the thickness of } \\
\text { the lower backfill layer (minimum 5-foot) relative to the lower drainage layer } \\
\text { (2-foot) prevents the quantity of clay loss necessary to change the hydraulic } \\
\text { properties of the lower backfill. }\end{array}$ \\
\hline $\begin{array}{l}\text { Geotextile Filter } \\
\text { Fabric }\end{array}$ & $\begin{array}{l}\text { For purposes of colloidal clay migration into the underlying drainage layer the } \\
\text { geotextile filter fabric is assumed to be ineffective over the time period under } \\
\text { consideration. }\end{array}$ \\
\hline $\begin{array}{l}\text { Lower Drainage } \\
\text { Layer }\end{array}$ & $\begin{array}{l}\text { Colloidal clay migration from the overlying minimum } 5 \text {-foot-thick lower } \\
\text { backfill into the } 1 \text {-foot-thick lower drainage layer reduces its saturated } \\
\text { hydraulic conductivity over time. }\end{array}$ \\
\hline Lower GCL & $\begin{array}{l}\text { None. Pine tree roots do not penetration to a sufficient enough depth to impact } \\
\text { this layer. Additionally the underlying concrete vault roof along with the GCL } \\
\text { produces a hard layer and continuous water saturation within and above these } \\
\text { layers so that root elongation is stopped. }\end{array}$ \\
\hline
\end{tabular}




\section{THIS PAGE INTENTIONALLY LEFT BLANK}

Rev. 0 


\subsection{CLOSURE CAP INFILTRATION FOR LOWER BOUNDING SCENARIO (CONTINUOUS BAMBOO COVER)}

\subsection{LBS Degraded Layer Properties over Time}

The SDF GCL closure cap initial (0 year) intact layer thickness and hydraulic property values from top to bottom are provided in Table 3.1-1. The degradation assumptions for each layer of the lower bounding scenario are provided in Table 4.4-1. Based upon the Table 4.4-1 degradation assumptions, the Table 3.3-1 initial SDF closure cap layer thickness and hydraulic property values have been modified to account for degradation at 100, 300, 550, 1,000, 1,800, 3,400, 5,600 and 10,000 years after closure of the SDF. The following discussions provide additional detail associated with determination of the degraded properties for the middle backfill, upper drainage layer, and lower drainage layer as originally presented by Phifer and Nelson (2003).

\subsubsection{LBS Middle Backfill and Upper Drainage Layer}

It is assumed that water flux driven colloidal-clay migration from the 1-foot-thick middle backfill to the underlying 1-foot-thick upper drainage layer causes the middle backfill saturated hydraulic conductivity to increase over time and that of the upper drainage layer to decrease over time. It has been assumed that clay migration occurs out of the backfill into the drainage layer with the water flux containing $63 \mathrm{mg} / \mathrm{L}$ of colloidal clay. Since both layers are of the same thickness and the middle backfill layer has limited clay content, it has been assumed that half the clay content of the backfill will migrate into the drainage layer. At which point the two layers essentially become the same material and material property changes cease. Based upon this it will be assumed that the endpoint saturated hydraulic conductivity of the layers will become that of the log mid-point between the initial backfill and upper drainage layer conditions. It will also be assumed that the endpoint porosity, field capacity, and wilting point will become the arithmetic average of the backfill and upper drainage layer. The hydraulic properties at times prior to the endpoint have been proportioned between that of the endpoint properties and the initial properties based upon the fraction of clay that has migrated out of the backfill.

\subsubsection{LBS Lower Drainage Layer}

It is assumed that colloidal clay migration from the minimum 5-foot-thick overlying backfill into the 2 -foot-thick lower drainage layer is driven by the water flux through the upper GCL. This water flux driven clay migration enters into the lower drainage layer and fills the lower drainage layer from the bottom up. This reduces the saturated hydraulic conductivity of the clay-filled portion from 1.0E-01 to $1.0 \mathrm{E}-04 \mathrm{~cm} / \mathrm{s}$ (i.e. to the saturated hydraulic conductivity of the overlying backfill), while the conductivity of the clean portion remains at $1.0 \mathrm{E}-01 \mathrm{~cm} / \mathrm{s}$. As the thickness of the lower drainage layer filled with clay increases, the equivalent hydraulic conductivity of the entire layer decreases. The equivalent horizontal hydraulic conductivity for this layer has been determined from the following equation (Freeze and Cherry 1979):

$$
K_{h}=\sum_{i=1}^{n} \frac{K_{i} d_{i}}{d}
$$

where

$$
\begin{aligned}
& \mathrm{K}_{\mathrm{h}}=\text { equivalent horizontal saturated hydraulic conductivity, } \\
& \mathrm{K}_{\mathrm{i}}=\text { horizontal saturated hydraulic conductivity of } \mathrm{i}^{\text {th }} \text { layer, } \\
& \mathrm{d}_{\mathrm{i}}=\text { thickness of } \mathrm{i}^{\text {th }} \text { layer, }
\end{aligned}
$$




$$
\mathrm{d}=\text { total thickness }
$$

This is different from that assumed for the upper drainage layer, since the lower drainage layer has significantly more backfill overlying it.

\subsubsection{LBS Summary Material Properties over Time}

The lower bounding scenario calculations associated with determination of the layer thicknesses and hydraulic property values over time are provided in Appendix F. Table 5.1-1 provides the primary Appendix F, material property results (thickness and saturated hydraulic conductivity), for layers which change with time and were utilized in subsequent HELP modeling. The porosity, field capacity, and wilting points are not provided in Table 5.1-1. Values for these parameters are provided in Appendix F.

Table 5.1-1. Lower Bounding Scenario Material Property Summary Results

\begin{tabular}{|l|l|l|l|l|}
\hline Year & \multicolumn{1}{|c|}{$\begin{array}{c}\text { Topsoil Layer } \\
\text { Thickness } \\
\text { (inches) }\end{array}$} & $\begin{array}{c}\text { Middle Backfill } \\
\text { Layer Saturated } \\
\text { Hydraulic } \\
\text { Conductivity } \\
(\mathrm{cm} / \mathrm{s})\end{array}$ & $\begin{array}{c}\text { Upper Drainage } \\
\text { Layer Saturated } \\
\text { Hydraulic } \\
\text { Conductivity } \\
(\mathrm{cm} / \mathrm{s})\end{array}$ & $\begin{array}{c}\text { Lower Drainage } \\
\text { Layer Saturated } \\
\text { Hydraulic } \\
\text { Conductivity } \\
(\mathrm{cm} / \mathrm{s})\end{array}$ \\
\hline 0 & 6 & $1.00 \mathrm{E}-04$ & $1.00 \mathrm{E}-01$ & $1.00 \mathrm{E}-01$ \\
\hline 100 & 5.980 & $1.20 \mathrm{E}-04$ & $8.60 \mathrm{E}-02$ & $1.00 \mathrm{E}-01$ \\
\hline 300 & 5.940 & $1.60 \mathrm{E}-04$ & $6.30 \mathrm{E}-02$ & $9.98 \mathrm{E}-02$ \\
\hline 550 & 5.890 & $2.30 \mathrm{E}-04$ & $4.30 \mathrm{E}-02$ & $9.89 \mathrm{E}-02$ \\
\hline 1,000 & 5.800 & $4.60 \mathrm{E}-04$ & $2.10 \mathrm{E}-02$ & $9.61 \mathrm{E}-02$ \\
\hline 1,800 & 5.640 & $1.60 \mathrm{E}-03$ & $6.30 \mathrm{E}-03$ & $8.96 \mathrm{E}-02$ \\
\hline 3,400 & 5.320 & $3.20 \mathrm{E}-03$ & $3.20 \mathrm{E}-03$ & $7.56 \mathrm{E}-02$ \\
\hline 5,600 & 4.880 & $3.20 \mathrm{E}-03$ & $3.20 \mathrm{E}-03$ & $5.62 \mathrm{E}-02$ \\
\hline 10,000 & 4.0 & $3.20 \mathrm{E}-03$ & $3.20 \mathrm{E}-03$ & $1.74 \mathrm{E}-02$ \\
\hline
\end{tabular}

\subsection{LBS Degraded Closure Cap Infiltration over Time}

Table 5.1-1 and Appendix F data were utilized as input to the HELP model (USEPA 1994a and USEPA 1994b) in order to determine infiltration through the upper GCL for the lower bounding scenario at each degraded time step. The following appendices provide the detailed HELP model, input data and output files for each time step:

- Appendix G, Lower Bounding Scenario Degraded SDF MSE Vault Closure Cap (100 Years): HELP Model Input Data and Output File (output file name: ZLBS1out.OUT)

- Appendix H, Lower Bounding Scenario Degraded SDF MSE Vault Closure Cap (300 Years): HELP Model Input Data and Output File (output file name: ZLBS2out.OUT)

- Appendix I, Lower Bounding Scenario Degraded SDF MSE Vault Closure Cap (550 Years): HELP Model Input Data and Output File (output file name: ZLBS3out.OUT)

- Appendix J, Lower Bounding Scenario Degraded SDF MSE Vault Closure Cap (1,000 Years): HELP Model Input Data and Output File (output file name: ZLBS4out.OUT)

- Appendix K, Lower Bounding Scenario Degraded SDF MSE Vault Closure Cap (1,800 Years): HELP Model Input Data and Output File (output file name: ZLBS5out.OUT) 
- Appendix L, Lower Bounding Scenario Degraded SDF MSE Vault Closure Cap (3,400 Years): HELP Model Input Data and Output File (output file name: ZLBS6out.OUT)

- Appendix M, Lower Bounding Scenario Degraded SDF MSE Vault Closure Cap (5,600 Years): HELP Model Input Data and Output File (output file name: ZLBS7out.OUT)

- Appendix N, Lower Bounding Scenario Degraded SDF MSE Vault Closure Cap (10,000 Years): HELP Model Input Data and Output File (output file name: ZLBS8out.OUT)

The following outputs from this evaluation are lower bounding sensitivity values, which will be utilized within the Performance Assessment:

- Infiltration through the upper GCL

- Saturated hydraulic conductivity of the 2-foot-thick lower Drainage Layer

Table 5.2-1 provides a summary of these parameter values.

Table 5.2-1. Lower Bounding Sensitivity Values

\begin{tabular}{|l|l|l|}
\hline \multicolumn{1}{|c|}{ Year } & \multicolumn{1}{|c|}{$\begin{array}{c}\text { Infiltration through Upper GCL } \\
\text { (in/yr) }\end{array}$} & \multicolumn{1}{c|}{$\begin{array}{c}\text { Lower Drainage Layer Saturated } \\
\text { Hydraulic Conductivity } \\
(\mathrm{cm} / \mathrm{s})\end{array}$} \\
\hline 0 & 0.36 & $1.00 \mathrm{E}-01$ \\
\hline 100 & 0.41 & $1.00 \mathrm{E}-01$ \\
\hline 300 & 0.55 & $9.99 \mathrm{E}-02$ \\
\hline 550 & 0.80 & $9.98 \mathrm{E}-02$ \\
\hline 1,000 & 1.75 & $9.94 \mathrm{E}-02$ \\
\hline 1,800 & 5.05 & $9.77 \mathrm{E}-02$ \\
\hline 3,400 & 6.46 & $9.20 \mathrm{E}-02$ \\
\hline 5,600 & 6.44 & $8.30 \mathrm{E}-02$ \\
\hline 10,000 & 6.40 & $6.53 \mathrm{E}-02$ \\
\hline 26,250 & ND & $\begin{array}{l}1.00 \mathrm{E}-04 \\
\text { (year lower drainage layer completely } \\
\text { silts in) }\end{array}$ \\
\hline 280,000 & $\begin{array}{l}4.75 \\
\text { (infiltration at complete degradation of } \\
\text { the closure cap) }\end{array}$ & $\begin{array}{l}1.00 \mathrm{E}-04 \\
\end{array}$ \\
\hline
\end{tabular}

$\mathrm{ND}=$ not determined

\subsection{LBS Infiltration After Complete Closure Cap Degradation}

The infiltration through the upper GCL at complete closure cap degradation for the lower bounding scenario and the associated time of occurrence have been determined based upon the following:

- Complete closure cap degradation occurs when both the topsoil and upper backfill have eroded away.

- As outlined in Appendix F, it is assumed that the material properties of the middle backfill and upper drainage layer become the same at year 2246 and remain constant thereafter. Therefore the middle backfill and upper drainage layer material properties will be taken as those determined at year 2246. 
- As previously demonstrated in Appendix F, the material properties of the lower drainage layer do not impact infiltration through the upper GCL. Completely silted in conditions will be assumed for the lower drainage layer for determination of this infiltration.

Appendix F provides the material property calculations based upon the above assumptions and the detailed HELP model input data and output file associated with this infiltration through the upper GCL. This infiltration through the upper GCL was determined to be 4.75 inches/year in year 280,000. This infiltration has been included in Table 5.2-1 for comparison purposes.

In addition, the time that the lower drainage layer completely silts in and assumes the properties of the overlying backfill has been estimated to occur in the year 26,250 (see Appendix F). This has also been included in Table 5.2-1. 


\subsection{CLOSURE CAP INFILTRATION FOR UPPER BOUNDING SCENARIO (INSTITUTIONAL CONTROL TO FARM TO PINE FOREST)}

\subsection{UBS Degraded Layer Properties over Time}

The SDF GCL closure cap initial (0 year) intact layer thickness and hydraulic property values from top to bottom are provided in Table 3.1-1. The degradation assumptions for each layer are provided in Table 4.4-2. Based upon the Table 4.4-2 degradation assumptions, the Table 3.3-1 initial SDF closure cap layer thickness and hydraulic property values have been modified to account for degradation at $100,154,300,550,602,802,1,000,1,800,3,400,5,600$ and 10,000 years after closure of the SDF. The following discussions provide additional detail associated with determination of the degraded properties for the erosion barrier, upper GCL, middle backfill, upper drainage layer, and lower drainage layer as originally presented by Phifer and Nelson (2003).

\subsubsection{UBS Erosion Barrier}

As outlined in Phifer and Nelson 2003, the erosion barrier is assumed to consist of a one foot thick layer of 2-inch to 6-inch granite stone whose voids are filled with a Controlled Low Strength Material (CLSM) or flowable fill. Under the upper bounding scenario maintenance during the institutional control period and farming practices during corn farming prevent degradation of the erosion control barrier. Subsequent to the institutional control period and corn farming, pine forest succession will result in root penetration through the erosion control barrier. This does not impact its ability to function as an erosion barrier. For this scenario pine forest succession occurs after all of the topsoil and upper backfill have been completely eroded, therefore the upper backfill is not available to fill holes in the erosion barrier after the roots decompose. However it will be assumed that root penetration breaks up the flowable fill and separates it from the granite stone. After the root decomposes it will be assumed that segregation of the granite stone and broken up flowable fill occurs, resulting in the flowable fill at the bottom of the hole and the granite stone at the top. For the purposes of this calculation the properties of the broken up flowable fill will be ignored. Therefore will assume that the degraded barrier consists of intact erosion barrier with holes filled with the granite stone. The equivalent hydraulic properties of the overall erosion barrier change as the area of holes filled with separated and segregated granite stone and broken up flowable fill increases with time. The equivalent hydraulic properties have been estimated over time by area proportioning the properties between that of the intact erosion barrier and infiltrating backfill.

\subsubsection{UBS Upper GCL}

Under the upper bounding scenario maintenance during the institutional control period and farming practices during corn farming prevent degradation of the upper GCL. Subsequent to the institutional control period and corn farming after all of the topsoil and upper backfill have been completely eroded, pine forest succession will result in root penetration through the GCL. This allows the overlying drainage layer to fill the holes after the roots decompose. The holes in the GCL essentially act as direct conduits from the upper drainage layer to the lower backfill layer. When saturated conditions occur in the drainage layer after major precipitation events, cones of depression are created around the holes in the GCL with a radius of influence much greater than the radius of the hole. This means that a small area of GCL holes can greatly reduce the lateral flow of water in the drainage layer and increase the vertical flow into the lower backfill. Due to the significant influence of holes in the GCL to the quantity of infiltration, the use of equivalent hydraulic properties is not appropriate, since it does not consider the radius of influence associated with holes. Therefore, within the HELP model the degraded GCL has been modeled as a geomembrane liner with leakage through holes when appropriate. The HELP model considers both water flux through intact portions of the geomembrane using an "equivalent geomembrane hydraulic conductivity" and water flux through holes in the 
geomembrane. The HELP model does not assign a porosity, field capacity, or wilting point to geomembranes, however this is not considered essential to the GCL, since it is assumed that the GCL will remain fully saturated and it is below the depth where evapotranspiration is assumed to occur. The HELP model allows the input of up to 999,999 one square centimeter installation defects for a geomembrane liner. Therefore the calculated area of holes created by root penetration has been converted into an equivalent number of one square centimeter installation defects for input to the HELP model when appropriate. Excellent contact is assumed between the GCL and underlying backfill layer as a HELP model input, since the GCL is put in dry and swells into the surrounding soil as it hydrates. As outlined in Phifer (2003) a GCL with randomly spaced holes equivalent to approximately 0.3 percent (i.e. 120,000 installation defects) of the GCL area results in an infiltration equivalent to that produced without the GCL. Therefore for cases where the equivalent number of installation defects exceeds 999,999, the GCL has been assigned as a barrier soil liner with the same material properties as the overlying upper drainage layer.

\subsubsection{UBS Middle Backfill and Upper Drainage Layer}

It is assumed that water flux driven colloidal-clay migration from the 1-foot-thick middle backfill to the underlying 1-foot-thick upper drainage layer causes the middle backfill saturated hydraulic conductivity to increase over time and that of the upper drainage layer to decrease over time. It has been assumed that clay migration occurs out of the backfill into the drainage layer with the water flux containing $63 \mathrm{mg} / \mathrm{L}$ of colloidal clay. Since both layers are of the same thickness and the middle backfill layer has limited clay content, it has been assumed that half the clay content of the backfill will migrate into the drainage layer. At which point the two layers essentially become the same material and material property changes cease. Based upon this it will be assumed that the endpoint saturated hydraulic conductivity of the layers will become that of the log mid-point between the initial backfill and upper drainage layer conditions. It will also be assumed that the endpoint porosity, field capacity, and wilting point will become the arithmetic average of the backfill and upper drainage layer. The hydraulic properties at times prior to the endpoint have been proportioned between that of the endpoint properties and the initial properties based upon the fraction of clay that has migrated out of the backfill.

\subsubsection{UBS Lower Drainage Layer}

It is assumed that colloidal clay migration from the minimum 5-foot-thick overlying backfill into the 2 -foot-thick lower drainage layer is driven by the water flux through the upper GCL. This water flux driven clay migration enters into the lower drainage layer and fills the lower drainage layer from the bottom up. This reduces the saturated hydraulic conductivity of the clay-filled portion from $1.0 \mathrm{E}-01$ to $1.0 \mathrm{E}-04 \mathrm{~cm} / \mathrm{s}$ (i.e. to the saturated hydraulic conductivity of the overlying backfill), while the conductivity of the clean portion remains at $1.0 \mathrm{E}-01 \mathrm{~cm} / \mathrm{s}$. As the thickness of the lower drainage layer filled with clay increases, the equivalent hydraulic conductivity of the entire layer decreases. The equivalent horizontal hydraulic conductivity for this layer has been determined from the following equation (Freeze and Cherry 1979):

$$
K_{h}=\sum_{i=1}^{n} \frac{K_{i} d_{i}}{d}
$$

where

$$
\begin{aligned}
& \mathrm{K}_{\mathrm{h}}=\text { equivalent horizontal saturated hydraulic conductivity, } \\
& \mathrm{K}_{\mathrm{i}}=\text { horizontal saturated hydraulic conductivity of } i^{\text {th }} \text { layer, } \\
& \mathrm{d}_{\mathrm{i}}=\text { thickness of } \mathrm{i}^{\text {th }} \text { layer, }
\end{aligned}
$$




$$
\mathrm{d}=\text { total thickness }
$$

This is different from that assumed for the upper drainage layer, since the lower drainage layer has significantly more backfill overlying it.

\subsubsection{UBS Summary Material Properties over Time}

The upper bounding scenario calculations associated with determination of the layer thicknesses and hydraulic property values over time are provided in Appendix O. Table 6.1-1 provides the primary Appendix $\mathrm{O}$, material property results (thickness, saturated hydraulic conductivity, and holes in the upper GCL), for layers which change with time and were utilized in subsequent HELP modeling. The porosity, field capacity, and wilting points are not provided in Table 6.1-1. Values for these parameters are provided in Appendix O. By year 10,000 all closure cap layers except the erosion barrier have reached their assumed degradation endpoint.

Table 6.1-1. Upper Bounding Scenario Material Property Summary Results

\begin{tabular}{|c|c|c|c|c|}
\hline Year & Vegetation & $\begin{array}{l}\text { Topsoil Layer } \\
\text { Thickness } \\
\text { (inches) }\end{array}$ & $\begin{array}{l}\text { Upper Backfill Layer } \\
\text { Thickness (inches) }\end{array}$ & $\begin{array}{c}\text { Erosion Barrier } \\
\text { Saturated Hydraulic } \\
\text { Conductivity } \\
(\mathrm{cm} / \mathrm{s})\end{array}$ \\
\hline 0 & Bamboo & 6 & 30 & $3.97 \mathrm{E}-04$ \\
\hline 100 & Bamboo & 5.980 & 30 & $3.97 \mathrm{E}-04$ \\
\hline 154 & Corn & 0 & 30 & $3.97 \mathrm{E}-04$ \\
\hline 300 & Corn & 0 & 20.2 & $3.97 \mathrm{E}-04$ \\
\hline 550 & Corn & 0 & 3.5 & $3.97 \mathrm{E}-04$ \\
\hline 602 & Corn & 0 & 0 & $3.97 \mathrm{E}-04$ \\
\hline 802 & Pine Forest & 0 & 0 & $1.2 \mathrm{E}-03$ \\
\hline 1,000 & Pine Forest & 0 & 0 & $2.8 \mathrm{E}-03$ \\
\hline 1,800 & Pine Forest & 0 & 0 & $9.1 \mathrm{E}-03$ \\
\hline 3,400 & Pine Forest & 0 & 0 & $2.2 \mathrm{E}-02$ \\
\hline 5,600 & Pine Forest & 0 & 0 & $3.9 \mathrm{E}-02$ \\
\hline 10,000 & Pine Forest & 0 & 0 & $7.5 \mathrm{E}-02$ \\
\hline Year & $\begin{array}{c}\text { Middle Backfill } \\
\text { Layer Saturated } \\
\text { Hydraulic } \\
\text { Conductivity } \\
(\mathrm{cm} / \mathrm{s}) \\
\end{array}$ & $\begin{array}{l}\text { Upper Drainage } \\
\text { Layer Saturated } \\
\text { Hydraulic } \\
\text { Conductivity } \\
(\mathrm{cm} / \mathrm{s}) \\
\end{array}$ & $\begin{array}{c}\text { Saturated Hydraulic } \\
\text { Conductivity }(\mathrm{cm} / \mathrm{s}) / \text { One } \\
\text { Square Centimeter Holes in } \\
\text { Upper GCL }{ }^{1} \\
\text { (\#/acre) } \\
\end{array}$ & $\begin{array}{l}\text { Lower Drainage } \\
\text { Layer Saturated } \\
\text { Hydraulic } \\
\text { Conductivity } \\
(\mathrm{cm} / \mathrm{s})\end{array}$ \\
\hline 0 & $1.00 \mathrm{E}-04$ & $1.00 \mathrm{E}-01$ & $5.00 \mathrm{E}-09 / 0$ & $1.00 \mathrm{E}-01$ \\
\hline 100 & $1.20 \mathrm{E}-04$ & $8.20 \mathrm{E}-02$ & 5.00E-09 / 0 & $1.00 \mathrm{E}-01$ \\
\hline 154 & $1.40 \mathrm{E}-04$ & $7.40 \mathrm{E}-02$ & 5.00E-09 / 0 & $1.00 \mathrm{E}-01$ \\
\hline 300 & $1.80 \mathrm{E}-04$ & $5.60 \mathrm{E}-02$ & $5.00 \mathrm{E}-09 / 0$ & $9.99 \mathrm{E}-02$ \\
\hline 550 & $2.90 \mathrm{E}-04$ & $3.40 \mathrm{E}-02$ & $5.00 \mathrm{E}-09 / 0$ & $9.98 \mathrm{E}-02$ \\
\hline 602 & $3.20 \mathrm{E}-04$ & $3.10 \mathrm{E}-02$ & $5.00 \mathrm{E}-09 / 0$ & $9.97 \mathrm{E}-02$ \\
\hline 802 & $4.70 \mathrm{E}-04$ & $2.10 \mathrm{E}-02$ & $5.00 \mathrm{E}-09 / 40,877$ & $9.86 \mathrm{E}-02$ \\
\hline 1,000 & $6.90 \mathrm{E}-04$ & $1.40 \mathrm{E}-02$ & $5.00 \mathrm{E}-09 / 121,703$ & $9.64 \mathrm{E}-02$ \\
\hline 1,800 & $3.20 \mathrm{E}-03$ & $3.20 \mathrm{E}-03$ & $5.00 \mathrm{E}-09 / 448,722$ & $8.62 \mathrm{E}-02$ \\
\hline 3,400 & $3.20 \mathrm{E}-03$ & $3.20 \mathrm{E}-03$ & $3.20 \mathrm{E}-03 / 0$ & $6.47 \mathrm{E}-02$ \\
\hline 5,600 & $3.20 \mathrm{E}-03$ & $3.20 \mathrm{E}-03$ & $3.20 \mathrm{E}-03 / 0$ & $3.54 \mathrm{E}-02$ \\
\hline 10,000 & $3.20 \mathrm{E}-03$ & $3.20 \mathrm{E}-03$ & $3.20 \mathrm{E}-03 / 0$ & $1.00 \mathrm{E}-04$ \\
\hline
\end{tabular}


${ }^{1}$ Number of HELP model installation defects

\subsection{UBS Degraded Closure Cap Infiltration over Time}

Table 6.1-1 and Appendix O data were utilized as input to the HELP model (USEPA 1994a and USEPA 1994b) in order to determine infiltration through the upper GCL for the upper bounding scenario at each degraded time step. The following appendices provide the detailed HELP model, input data and output files for each time step:

- Appendix P, Upper Bounding Scenario Degraded SDF MSE Vault Closure Cap (100 Years): HELP Model Input Data and Output File (output file name: ZUBSD1ou.OUT)

- Appendix Q, Upper Bounding Scenario Degraded SDF MSE Vault Closure Cap (154 Years): HELP Model Input Data and Output File (output file name: ZUBSD2ou.OUT)

- Appendix R, Upper Bounding Scenario Degraded SDF MSE Vault Closure Cap (300 Years): HELP Model Input Data and Output File (output file name: ZUBSD3ou.OUT)

- Appendix S, Upper Bounding Scenario Degraded SDF MSE Vault Closure Cap (550 Years): HELP Model Input Data and Output File (output file name: ZUBSD4ou.OUT)

- Appendix T, Upper Bounding Scenario Degraded SDF MSE Vault Closure Cap (602 Years): HELP Model Input Data and Output File (output file name: ZUBSD5ou.OUT)

- Appendix U, Upper Bounding Scenario Degraded SDF MSE Vault Closure Cap (802 Years): HELP Model Input Data and Output File (output file name: ZUBSD6ou.OUT)

- Appendix V, Upper Bounding Scenario Degraded SDF MSE Vault Closure Cap (1,000 Years): HELP Model Input Data and Output File (output file name: ZUBSD7ou.OUT)

- Appendix W, Upper Bounding Scenario Degraded SDF MSE Vault Closure Cap (1,800 Years): HELP Model Input Data and Output File (output file name: ZUBSD8ou.OUT)

- Appendix X, Upper Bounding Scenario Degraded SDF MSE Vault Closure Cap (3,400 Years): HELP Model Input Data and Output File (output file name: ZUBSD9ou.OUT)

- Appendix Y, Upper Bounding Scenario Degraded SDF MSE Vault Closure Cap (5,600 Years): HELP Model Input Data and Output File (output file name: ZUBSD10o.OUT)

- $\quad$ Appendix Z, Upper Bounding Scenario Degraded SDF MSE Vault Closure Cap (10,000 Years): HELP Model Input Data and Output File (output file name: ZUBSD11o.OUT)

The following outputs from this evaluation are upper bounding sensitivity values, which will be utilized within the Performance Assessment:

- Infiltration through the upper GCL

- Saturated hydraulic conductivity of the 2-foot-thick lower Drainage Layer

Table 6.2-1 provides a summary of these parameter values. 
Table 6.2-1. Upper Bounding Sensitivity Values

\begin{tabular}{|l|l|l|}
\hline Year & $\begin{array}{l}\text { Infiltration through Upper GCL } \\
\text { (in/yr) }\end{array}$ & $\begin{array}{l}\text { Lower Drainage Layer Saturated } \\
\text { Hydraulic Conductivity } \\
\text { (cm/s) }\end{array}$ \\
\hline 0 & 0.36 & $1.00 \mathrm{E}-01$ \\
\hline 100 & 0.43 & $1.00 \mathrm{E}-01$ \\
\hline 154 & 0.42 & $1.00 \mathrm{E}-01$ \\
\hline 300 & 0.56 & $9.99 \mathrm{E}-02$ \\
\hline 550 & 1.22 & $9.98 \mathrm{E}-02$ \\
\hline 602 & 1.37 & $9.97 \mathrm{E}-02$ \\
\hline 802 & 16.12 & $9.86 \mathrm{E}-02$ \\
\hline 1,000 & 19.46 & $9.64 \mathrm{E}-02$ \\
\hline 1,800 & 21.32 & $8.62 \mathrm{E}-02$ \\
\hline 3,400 & 21.42 & $6.47 \mathrm{E}-02$ \\
\hline 5,600 & 21.13 & $3.54 \mathrm{E}-02$ \\
\hline 8,303 & ND & $\begin{array}{l}1.00 \mathrm{E}-04 \\
\text { (year lower drainage layer completely } \\
\text { silts in) }\end{array}$ \\
\hline 10,000 & 20.05 & $1.00 \mathrm{E}-04$ \\
\hline 38,254 & $\begin{array}{l}18.60 \\
\text { (infiltration at complete degradation of } \\
\text { the closure cap) }\end{array}$ & $\begin{array}{l}1.00 \mathrm{E}-04 \\
\end{array}$ \\
\hline
\end{tabular}

$\mathrm{ND}=$ not determined

\subsection{UBS Infiltration after Complete Closure Cap Degradation}

The infiltration through the upper GCL at complete closure cap degradation for the upper bounding scenario and the associated time of occurrence have been determined based upon the following:

- As outlined in Section 6.1.5 at year 10,000 all layers except the erosion barrier have reached their assumed degradation endpoint. Therefore the properties of all layers except the erosion barrier will be assigned their year 10,000 values.

- As outlined in Table 4.4-2 complete degradation of the erosion barrier is assumed to result in separation and segregation of the granite stone and flowable fill with the granite stone located on top of the broken up flowable fill. As previous done for the purposes of this calculation the properties of the broken up flowable fill will be ignored. Therefore the properties of the completely degraded erosion barrier are those of the granite stone.

Appendix $O$ provides the material property calculations based upon the above assumptions and the detailed HELP model input data and output file associated with infiltration at complete closure cap degradation through the upper GCL. This infiltration at complete closure cap degradation through the upper GCL was determined to be 18.6 inches/year in year 38,254. This worse case infiltration has been included in Table 6.2-1 for comparison purposes.

In addition, the time that the lower drainage layer completely silts in and assumes the properties of the overlying backfill has been estimated to occur in the year 8,303 (see Appendix O). This has also been included in Table 6.2-1 as input to the PA sensitivity analysis. 


\section{THIS PAGE INTENTIONALLY LEFT BLANK}

Rev. 0 


\subsection{SUMMARY AND CONCLUSIONS}

Within Phifer (2003) closure cap degradation mechanisms and their impact upon infiltration through the closure cap developed in Phifer and Nelson (2003) have been evaluated for the proposed Mechanically Stabilized Earth (MSE) vaults developed in Winship (2003) for the base case land use scenario (i.e. institutional control to pine forest). This land use scenario is considered to be the most likely scenario. It assumes a 100-year institutional control period following final SDF closure during which the closure cap is maintained. At the end of institutional control, it is assumed that a pine forest succeeds the cap's original bamboo cover. The impact of pine forest succession, erosion, and colloidal clay migration as degradation mechanisms on the infiltration through the MSE vault closure cap has been evaluated. The primary changes caused by the degradation mechanisms that result in increased infiltration are the formation of holes in the upper geosynthetic clay liner (GCL) by pine forest succession and the reduction in the saturated hydraulic conductivity of the drainage layers due to colloidal clay migration into the layers. Holes due to root penetration at approximately 0.3 percent of the GCL area resulted in an infiltration rate as though the GCL were not there at all. A very small area of holes essentially controlled the hydraulic performance of the GCL.

As documented within this report a sensitivity analysis has been performed to bound the previous results for the MSE vault, closure cap, base case land use scenario (i.e. institutional control to pine forest) documented within Phifer 2003. The bounding sensitivity analysis includes the following two MSE vault, closure cap, land use scenarios:

- Continuous bamboo cover, and

- Institutional control to farm to pine forest.

The continuous bamboo cover land use scenario assumes that bamboo, which is shallow-rooted, is the climax species for the closure cap (i.e. pine trees will not encroach upon the bamboo). This scenario results in the least amount of infiltration through the upper hydraulic barrier layer (i.e. lower bounding scenario). The institutional control to farm to pine forest, land use scenario assumes a 100year institutional control period following final Saltstone Disposal Facility (SDF) closure during which the closure cap is maintained. At the end of institutional control, it is assumed that the cap's original bamboo cover is removed and that corn is grown until the closure cap layers above the erosion barrier are completely eroded. After the layers above the erosion barrier are gone, it is assumed that a pine forest succeeds corn farming. This scenario results in the greatest amount of infiltration through the upper hydraulic barrier layer (i.e. upper bounding scenario). The same degradation mechanisms utilized for the base case scenario (Phifer 2003), as appropriate, have been evaluated for both the lower and upper bounding scenarios.

Table 7.0-1 and Figure 7.0-1 provide the infiltration over time for the base case scenario (i.e. institutional control to pine forest), the lower bounding scenario (i.e. continuous bamboo cover), and the upper bounding scenario (i.e. institutional control to farm to pine forest). The estimated infiltration through the upper GCL for the lower bounding, base case, and upper bounding scenarios at year 1000 were $1.75,12.04$, and 19.46 inches/year, respectively. The maximum infiltration estimated through the upper GCL within the first 10,000 years infiltration for the lower bounding, base case, and upper bounding scenarios were 6.46 inches/year at year 3,400, 14.09 inches/year at year 10,000, and 21.42 inches/year at year 3,400, respectively. The estimated infiltration through the upper GCL at complete degradation of the closure cap for the lower bounding, base case, and upper bounding scenarios were 4.75 inches/year at year 280,000, 18.12 inches/year at year 280,000, and 18.60 at approximately year 38,250 .

Within the first 10,000 years the primary reason(s) for the estimated infiltration increases over time for each scenario are as follows: 
- The primary reason for the lower bounding scenario (i.e. continuous bamboo cover) estimated infiltration increase through the upper GCL over time is the assumed reduction in the saturated hydraulic conductivity of the upper drainage layer due to colloidal clay migration into the layer. This silting in results in an infiltration increase from 0.36 inches/year to a maximum of 6.46 inches/year within the first 10,000 years.

- The primary reasons for the base case land use scenario (i.e. institutional control to pine forest) estimated infiltration increase through the upper GCL over time, in order of importance, are the formation of holes in the upper GCL by pine forest succession and the reduction in the saturated hydraulic conductivity of the upper drainage layer due to colloidal clay migration into the layer. These primary degradation mechanisms result in an infiltration increase from 0.36 inches/year to a maximum of 14.09 inches/year within the first 10,000 years.

- The primary reasons for the upper bounding scenario (i.e. institutional control to farm to pine forest) estimated infiltration increase through the upper GCL over time, in order of importance, are the formation of holes in the upper GCL by pine forest succession, the reduction in the saturated hydraulic conductivity of the upper drainage layer due to colloidal clay migration into the layer, the increase in the saturated hydraulic conductivity of the erosion barrier due to pine forest succession, and the erosion of the topsoil and upper backfill. These primary degradation mechanisms result in an infiltration increase from 0.36 inches/year to a maximum of 21.42 inches/year within the first 10,000 years.

Based upon the above results the following can be deduced concerning the impact of the closure cap degradation mechanisms (i.e. pine forest succession, erosion, and colloidal clay migration) on infiltration through the upper GCL:

- It is estimated that pine forest succession results in the greatest increase in infiltration through the upper GCL. An approximately 13.5-inches/year increase can be attributed to pine forest succession. It is estimated that pine forest succession produces a 7.5-inches/year increase due to the formation of holes in the upper GCL and a 6-inches/year increase due to the degradation of the erosion barrier.

- It is estimated that the reduction in the saturated hydraulic conductivity of the upper drainage layer due to colloidal clay migration into the layer results in an approximately 6 inches/year increase in infiltration through the upper GCL.

- It is estimated that erosion of the topsoil and upper backfill results in an approximately 1inch/year increase in infiltration through the upper GCL.

Based upon this it is evident that elimination of the pine forest succession, degradation mechanism would do the most to minimize increases in the infiltration through the upper GCL over time.

In addition to infiltration over time, the saturated hydraulic conductivity of the lower drainage layer over time is an important parameter. Table 7.0-2 and Figure 7.0-2 provide the saturated hydraulic conductivity of the lower drainage layer over time for each of the scenarios. The saturated hydraulic conductivity of the lower drainage layer is assumed to reduce over time from $0.1 \mathrm{~cm} / \mathrm{s}$ to $0.0001 \mathrm{~cm} / \mathrm{s}$ over time due to colloidal clay migration into the layer. It is estimated that the lower drainage layer completely silts-in (i.e. has a saturated hydraulic conductivity of $0.0001 \mathrm{~cm} / \mathrm{s}$ ) in year 26,000 for the lower bounding scenario, in year 12,000 for the base case scenario, and in year 8,300 for the upper bounding scenario. 
Table 7.0-1. Base Case, Lower Bounding, and Upper Bounding Infiltration over Time

\begin{tabular}{|c|c|c|c|c|c|}
\hline \multicolumn{2}{|c|}{ Lower Bounding Scenario } & \multicolumn{2}{|c|}{ Base Case Scenario } & \multicolumn{2}{|c|}{ Upper Bounding Scenario } \\
\hline Year & $\begin{array}{l}\text { Infiltration }{ }^{1} \\
\text { (in/yr) }\end{array}$ & Year & $\begin{array}{c}\text { Infiltration }^{1} \\
\text { (in/yr) }\end{array}$ & Year & $\begin{array}{c}\text { Infiltration } \\
\text { (in/yr) }\end{array}$ \\
\hline 0 & 0.36 & 0 & 0.36 & 0 & 0.36 \\
\hline 100 & 0.41 & 100 & 0.41 & 100 & 0.43 \\
\hline 300 & 0.55 & 300 & 3.05 & 154 & 0.42 \\
\hline 550 & 0.80 & 550 & 7.90 & 300 & 0.56 \\
\hline 1,000 & 1.75 & 1,000 & 12.04 & 550 & 1.22 \\
\hline 1,800 & 5.05 & 1,800 & 13.76 & 602 & 1.37 \\
\hline 3,400 & 6.46 & 3,400 & 14.03 & 802 & 16.12 \\
\hline 5,600 & 6.44 & 5,600 & 14.08 & 1,000 & 19.46 \\
\hline 10,000 & 6.40 & 10,000 & 14.09 & 1,800 & 21.32 \\
\hline $280,000^{3}$ & 4.75 & $96,667^{2}$ & 14.10 & 3,400 & 21.42 \\
\hline & & $280,000^{3}$ & 18.12 & 5,600 & 21.13 \\
\hline & & & & 10,000 & 20.05 \\
\hline & & & & $38,254^{3}$ & 18.60 \\
\hline
\end{tabular}

${ }^{1}$ Infiltration through upper GCL

${ }^{2}$ The year 96,667 is not a calculated value; it is an assumed value. It is assumed that infiltration remains at 14.10 inches/year until the upper backfill erodes to the assumed evapotranspiration zone depth of 22 inches in year 96,667. At that point it is assumed that infiltration increases linearly from 14.10 inches/year to the year 280,000 infiltration of 18.12 inches/year.

${ }^{3}$ Infiltration at complete degradation of the closure cap

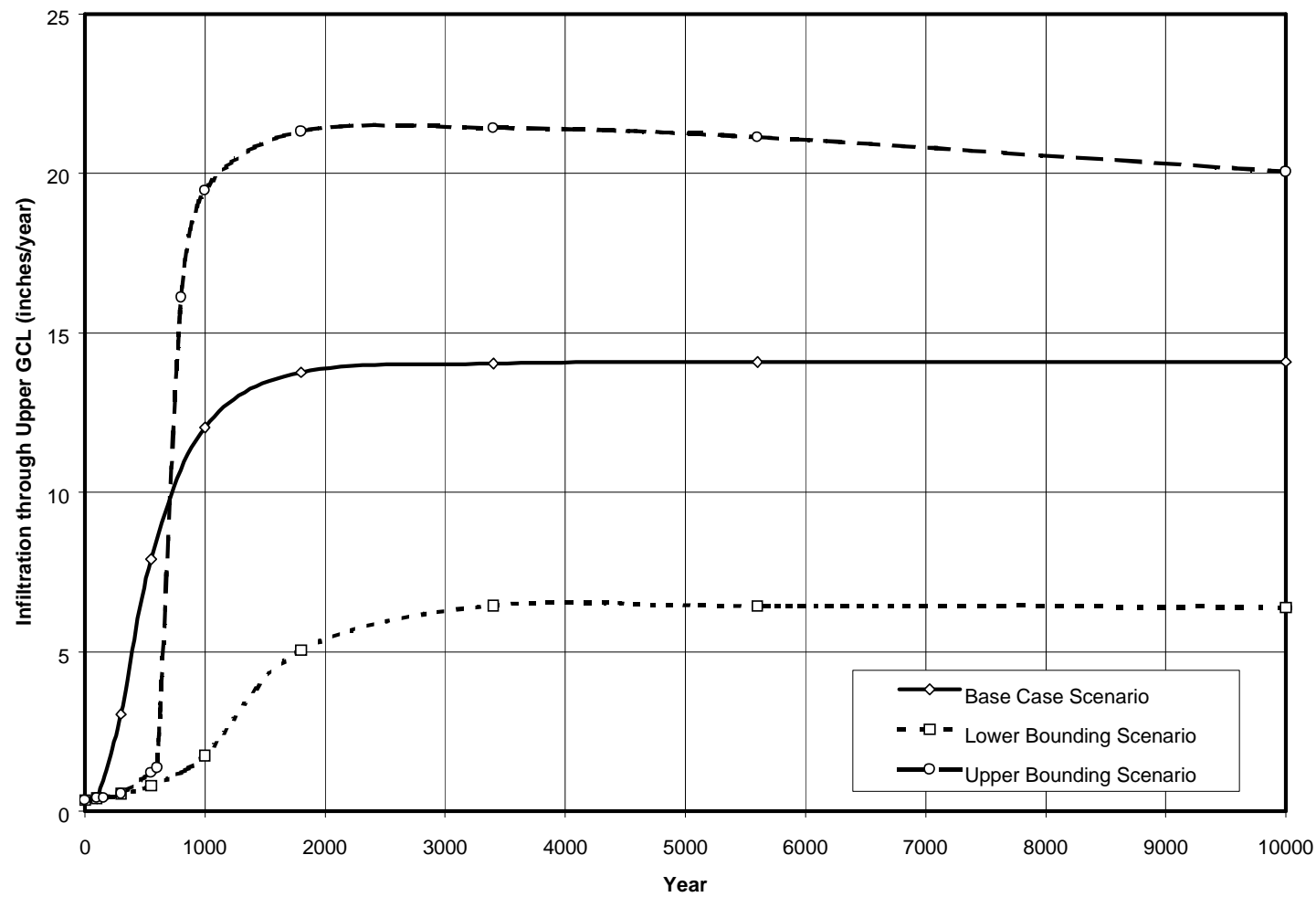

Figure 7.0-1. Base Case, Lower Bounding, and Upper Bounding Infiltration over Time 
Table 7.0-2. Lower Drainage Layer Saturated Hydraulic Conductivity for the Base Case, Lower Bounding, and Upper Bounding Scenarios over Time

\begin{tabular}{|c|c|c|c|c|c|}
\hline \multicolumn{2}{|c|}{ Lower Bounding Scenario } & \multicolumn{2}{|c|}{ Base Case Scenario } & \multicolumn{2}{|c|}{ Upper Bounding Scenario } \\
\hline Year & $\begin{array}{c}\mathrm{K}_{\mathrm{s}}^{\mathrm{I}} \\
(\mathrm{cm} / \mathrm{s})\end{array}$ & Year & $\begin{array}{c}\mathrm{K}_{\mathrm{s}}{ }^{\mathrm{C}} \\
(\mathrm{cm} / \mathrm{s})\end{array}$ & Year & $\begin{array}{c}\mathrm{K}_{\mathrm{s}}{ }^{\mathrm{C}} \\
(\mathrm{cm} / \mathrm{s})\end{array}$ \\
\hline 0 & $1.00 \mathrm{E}-01$ & 0 & $1.00 \mathrm{E}-01$ & 0 & $1.00 \mathrm{E}-01$ \\
\hline 100 & $1.00 \mathrm{E}-01$ & 100 & $1.00 \mathrm{E}-01$ & 100 & $1.00 \mathrm{E}-01$ \\
\hline 300 & $9.99 \mathrm{E}-02$ & 300 & $9.98 \mathrm{E}-02$ & 154 & $1.00 \mathrm{E}-01$ \\
\hline 550 & $9.98 \mathrm{E}-02$ & 550 & 9.89E-02 & 300 & 9.99E-02 \\
\hline 1,000 & $9.94 \mathrm{E}-02$ & 1,000 & $9.61 \mathrm{E}-02$ & 550 & $9.98 \mathrm{E}-02$ \\
\hline 1,800 & $9.77 \mathrm{E}-02$ & 1,800 & $8.96 \mathrm{E}-02$ & 602 & $9.97 \mathrm{E}-02$ \\
\hline 3,400 & $9.20 \mathrm{E}-02$ & 3,400 & $7.56 \mathrm{E}-02$ & 802 & $9.86 \mathrm{E}-02$ \\
\hline 5,600 & $8.30 \mathrm{E}-02$ & 5,600 & $5.62 \mathrm{E}-02$ & 1,000 & 9.64E-02 \\
\hline 10,000 & $6.53 \mathrm{E}-02$ & 10,000 & $1.74 \mathrm{E}-02$ & 1,800 & $8.62 \mathrm{E}-02$ \\
\hline $26,250^{2}$ & $1.00 \mathrm{E}-04$ & $11,953^{2}$ & $1.00 \mathrm{E}-04$ & 3,400 & $6.47 \mathrm{E}-02$ \\
\hline & & & & 5,600 & $3.54 \mathrm{E}-02$ \\
\hline & & & & $8,303^{2}$ & $1.00 \mathrm{E}-04$ \\
\hline
\end{tabular}

${ }^{1}$ Lower drainage layer saturated hydraulic conductivity

${ }^{2}$ This is the year that the lower drainage layer is assumed to completely silt in and the saturated hydraulic conductivity is assumed to remain at $1.00 \mathrm{E}-04 \mathrm{~cm} / \mathrm{s}$ thereafter.

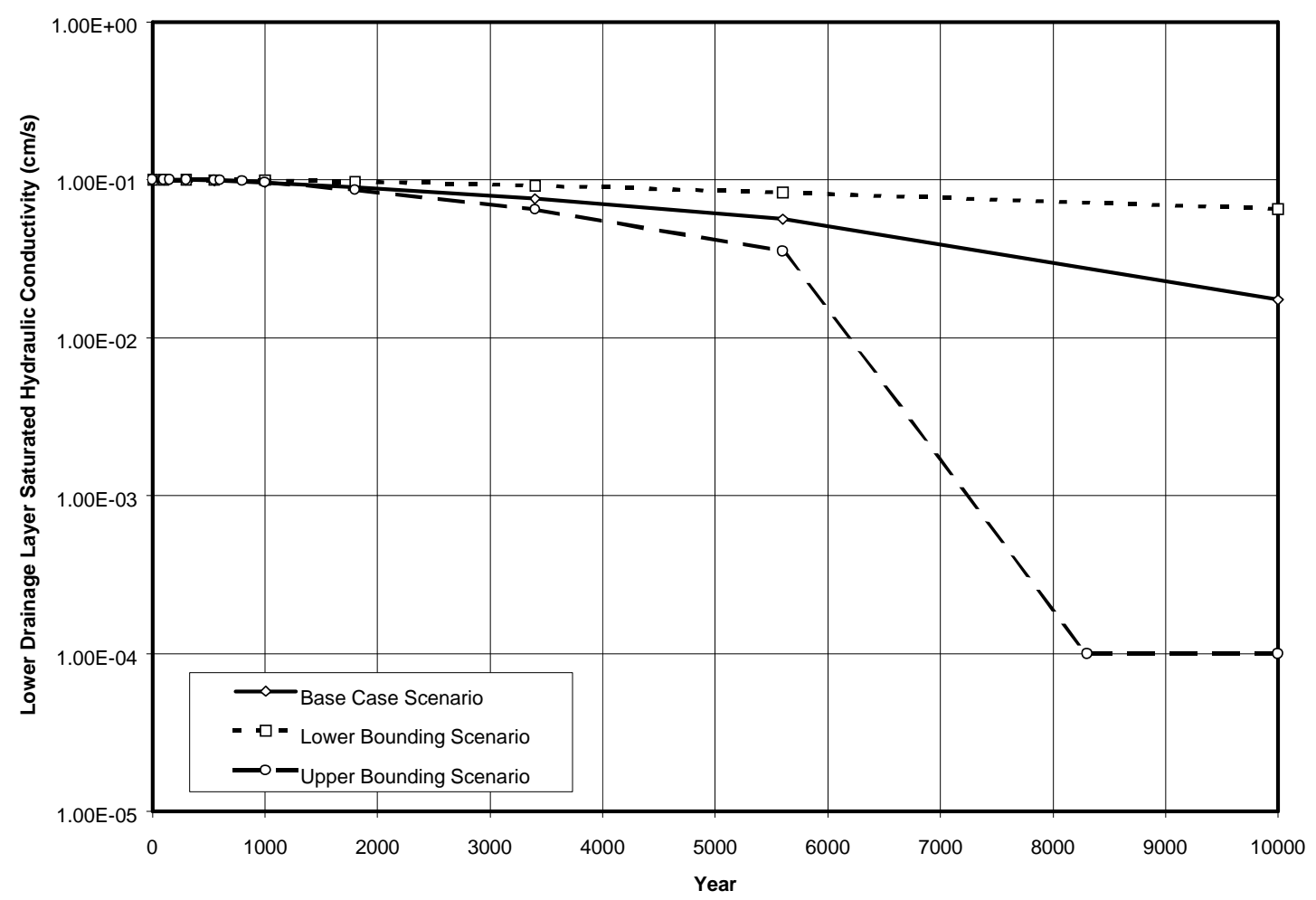

Figure 7.0-2. Lower Drainage Layer Saturated Hydraulic Conductivity for the Base Case, Lower Bounding, and Upper Bounding Scenarios over Time 


\subsection{REFERENCES}

Cook, J. R., Wilhite, E. L., and Young, K. E. 2000. Closure Plan for the Z-Area Saltstone Disposal Facility $(U)$, Rev. 0, WSRC-RP-2000-00426, Westinghouse Savannah River Company, Aiken, South Carolina. September 29, 2000.

Freeze, R. A. and Cherry, J. A. 1979. Groundwater, Prentice-Hall, Inc., Englewood Cliffs, New Jersey.

Goldman, S. J., Jackson, K., and Bursztynsky, T. A. 1986. Erosion and Sediment Control Handbook, McGraw-Hill Publishing Company, New York.

GSE (GSE Lining Technology, Inc.). 2002. Web site:

http://www.gseworld.com/findproducts.htm

Hillel, D. 1982. Introduction to Soil Physics, Academic Press, Inc., San Diego, California.

Horton, J. H. and Wilhite, E. L. 1978. Estimated Erosion Rate at the SRP Burial Ground, DP-1493, E. I. du Pont de Nemours and Company, Aiken, South Carolina. April 1978.

Jones, W. E. and Phifer, M. A. 2002. Corrosion and Potential Subsidence Scenarios for Buried B-25 Waste Containers, WSRC-TR-2002-00354, Westinghouse Savannah River Company, Aiken, South Carolina. September 2002.

MMES (Martin Marietta Energy Systems, Inc., EG\&G Idaho, Inc., Westinghouse Hanford company, and Westinghouse Savannah River Company). 1992. Radiological Performance Assessment for the Z-Area Saltstone Disposal Facility (U), Rev. 0, WSRC-RP-92-1360, Westinghouse Savannah River Company, Aiken, South Carolina. December 18, 1992.

Phifer, M. A. and Nelson, E. A. 2003. Saltstone Disposal Facility Closure Cap Configuration and Degradation Base Case: Institutional Control to Pine Forest Scenario (U), Rev. 0, WSRC-TR-200300436, Westinghouse Savannah River Company, Aiken, South Carolina. September 22, 2003.

Phifer, M. A. 2003. Saltstone Disposal Facility Mechanically Stabilized Earth Vault Closure Cap Configuration and Degradation Base Case: Institutional Control to Pine Forest Scenario (U), Rev. 0, WSRC-TR-2003-00523, Westinghouse Savannah River Company, Aiken, South Carolina. December $18,2003$.

USEPA (U.S. Environmental Protection Agency). 1994a. The Hydrologic Evaluation of Landfill Performance (HELP) Model User's Guide for Version 3, EPA/600/R-94/168a, Office of Research and Development, United States Environmental Protection Agency, Washington, DC. September 1994.

USEPA (U.S. Environmental Protection Agency). 1994b. The Hydrologic Evaluation of Landfill Performance (HELP) Engineering Documentation for Version 3, EPA/600/R-94/168b, Office of Research and Development, United States Environmental Protection Agency, Washington, DC. September 1994.

USEPA (U.S. Environmental Protection Agency). 2001. Geosynthetic Clay Liners Used in Municipal Solid Waste Landfills, EPA 530-F-97-002, Solid Waste and Emergency Response, United States Environmental Protection Agency, Washington, DC. December 2001.

Winship, G. 2003. Closure Business Unit Saltstone Vault Study (U), Revision 0, G-ADS-Z-00001, Westinghouse Savannah River Company, Aiken, South Carolina, July 30, 2003. 
WSRC (Westinghouse Savannah River Company). 2002. Saltstone Landfill Design Equivalency Demonstration (U), Rev. 0, WSRC-TR-2002-00236, Westinghouse Savannah River Company, Aiken, South Carolina. August 30, 2002. 


\subsection{APPENDICES}

Appendix A Augusta Synthetic Precipitation Modified with SRS Specific Average Monthly Precipitation Data over 100 Years (file name: Zprec.d4) A-1

Appendix B Augusta Synthetic Temperature Modified with SRS Specific Average Monthly Temperature Data over 100 Years (file name: Ztemp.d7) B-1

Appendix C Augusta Synthetic Solar Radiation Data over 100 Years (file name: Zsolar.d13)

Appendix D Augusta Evapotranspiration Data (file name: Zevap.d11) D-1

Appendix E Intact SDF MSE Vault Closure Cap (0 Years): HELP Model Input Data and Output File (output file name: ZMSEIout.OUT)

Appendix F SDF MSE Vault Closure Cap Degraded Property Value Calculations for Lower Bounding Scenario (i.e. Continuous Bamboo Cover) F-1

Appendix G Lower Bounding Scenario Degraded SDF MSE Vault Closure Cap (100 Years): HELP Model Input Data and Output File (output file name: ZLBS1out.OUT) G-1

Appendix H Lower Bounding Scenario Degraded SDF MSE Vault Closure Cap (300 Years): HELP Model Input Data and Output File (output file name: ZLBS2out.OUT) H-1

Appendix I Lower Bounding Scenario Degraded SDF MSE Vault Closure Cap (550 Years): HELP Model Input Data and Output File (output file name: ZLBS3out.OUT) I-1

Appendix J Lower Bounding Scenario Degraded SDF MSE Vault Closure Cap (1,000 Years): HELP Model Input Data and Output File (output file name: ZLBS4out.OUT) $\mathrm{J}-1$

Appendix K Lower Bounding Scenario Degraded SDF MSE Vault Closure Cap (1,800 Years): HELP Model Input Data and Output File (output file name: ZLBS5out.OUT) K-1

Appendix L Lower Bounding Scenario Degraded SDF MSE Vault Closure Cap (3,400 Years): HELP Model Input Data and Output File (output file name: ZLBS6out.OUT) L-1

Appendix M Lower Bounding Scenario Degraded SDF MSE Vault Closure Cap (5,600 Years): HELP Model Input Data and Output File (output file name: ZLBS7out.OUT) 
Appendix N Lower Bounding Scenario Degraded SDF MSE Vault Closure

Cap (10,000 Years): HELP Model Input Data and Output File (output file name: ZLBS8out.OUT)

Appendix O SDF MSE Vault Closure Cap Degraded Property Value Calculations

for Upper Bounding Scenario (i.e. Institutional Control to Farm to

Pine Forest)

Appendix P Upper Bounding Scenario Degraded SDF MSE Vault Closure

Cap (100 Years): HELP Model Input Data and Output File

(output file name: ZUBSD1ou.OUT)

Appendix Q Upper Bounding Scenario Degraded SDF MSE Vault Closure

Cap (154 Years): HELP Model Input Data and Output File (output file name: ZUBSD2ou.OUT)

Appendix R Upper Bounding Scenario Degraded SDF MSE Vault Closure

Cap (300 Years): HELP Model Input Data and Output File (output file name: ZUBSD3ou.OUT)

Appendix S Upper Bounding Scenario Degraded SDF MSE Vault Closure Cap (550 Years): HELP Model Input Data and Output File (output file name: ZUBSD4ou.OUT)

Appendix T Upper Bounding Scenario Degraded SDF MSE Vault Closure Cap (602 Years): HELP Model Input Data and Output File (output file name: ZUBSD5ou.OUT) $\mathrm{T}-1$

Appendix U Upper Bounding Scenario Degraded SDF MSE Vault Closure Cap (802 Years): HELP Model Input Data and Output File (output file name: ZUBSD6ou.OUT) U-1

Appendix V Upper Bounding Scenario Degraded SDF MSE Vault Closure Cap (1,000 Years): HELP Model Input Data and Output File (output file name: ZUBSD7ou.OUT) $\mathrm{V}-1$

Appendix W Upper Bounding Scenario Degraded SDF MSE Vault Closure Cap (1,800 Years): HELP Model Input Data and Output File (output file name: ZUBSD8ou.OUT) W-1

Appendix X Upper Bounding Scenario Degraded SDF MSE Vault Closure Cap (3,400 Years): HELP Model Input Data and Output File (output file name: ZUBSD9ou.OUT) $\mathrm{X}-1$

Appendix Y Upper Bounding Scenario Degraded SDF MSE Vault Closure Cap (5,600 Years): HELP Model Input Data and Output File 
(output file name: ZUBSD10o.OUT) .................................................... Y-1

Appendix Z Upper Bounding Scenario Degraded SDF MSE Vault Closure Cap (10,000 Years): HELP Model Input Data and Output File (output file name: ZUBSD11o.OUT) 


\section{THIS PAGE INTENTIONALLY LEFT BLANK}

Rev. 0 
Appendix A, Augusta Synthetic Precipitation Modified with SRS Specific Average Monthly Precipitation Data over 100 Years (file name: Zprec.d4)

This appendix is in CD format due to its size. Available upon request. 


\section{THIS PAGE INTENTIONALLY LEFT BLANK}

Rev. 0 
Appendix B, Augusta Synthetic Temperature Modified with SRS Specific Average Monthly Temperature Data over 100 Years (file name: Ztemp.d7)

This appendix is in CD format due to its size. Available upon request. 


\section{THIS PAGE INTENTIONALLY LEFT BLANK}

Rev. 0 
Appendix C, Augusta Synthetic Solar Radiation Data over 100 Years (file name: Zsolar.d13)

This appendix is in CD format due to its size. Available upon request. 


\section{THIS PAGE INTENTIONALLY LEFT BLANK}

Rev. 0 
Appendix D, Augusta Evapotranspiration Data (file name: Zevap.d11)

1

AUGUSTA GEORGIA

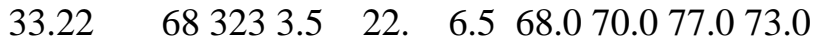


THIS PAGE INTENTIONALLY LEFT BLANK 
Appendix E, Intact SDF MSE Vault Closure Cap (0 Years): HELP Model Input Data and Output File (output file name: ZMSEIout.OUT)

Input Data:

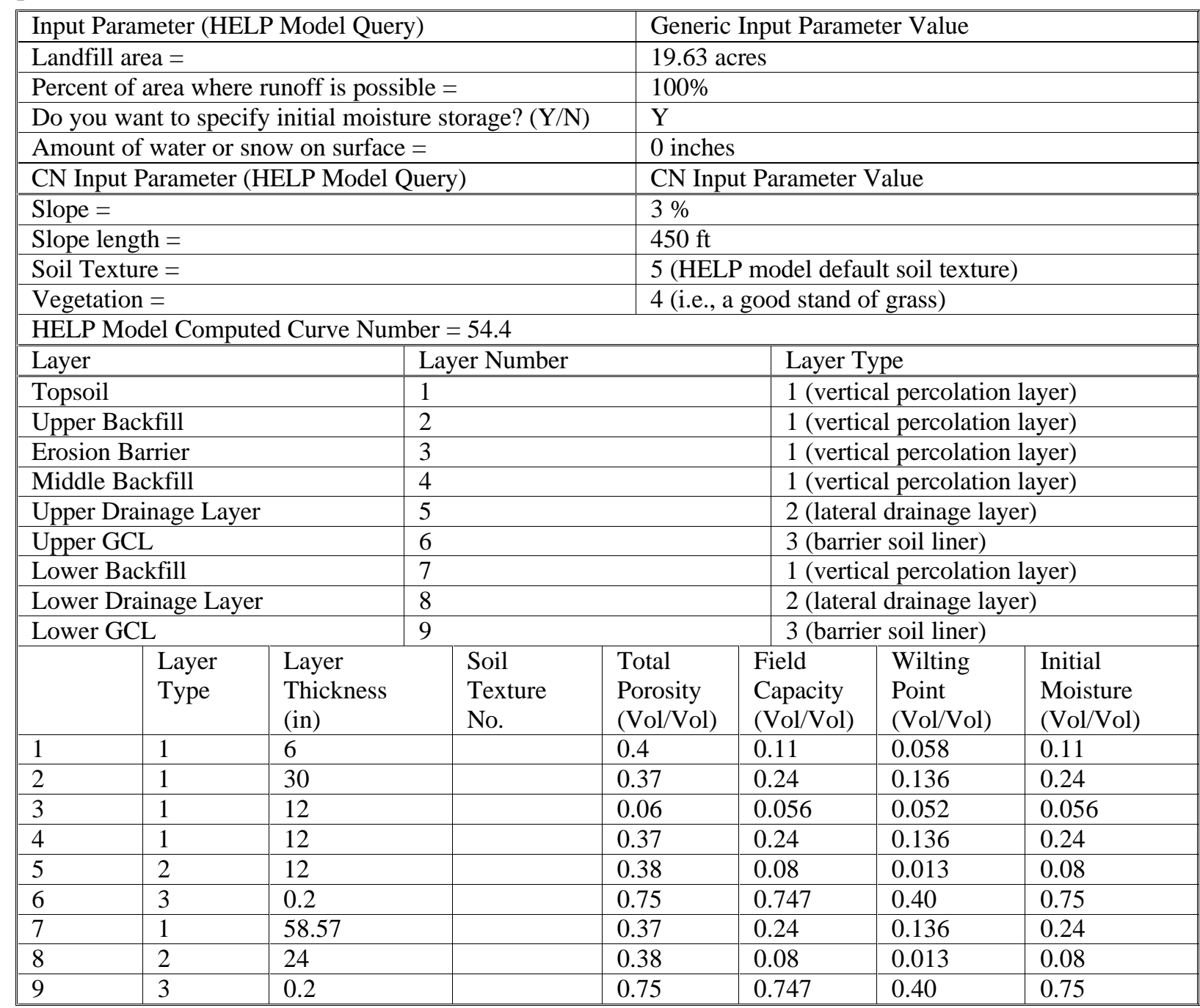

The lack of values in the table for particular parameters in particular layers denotes that no HELP model input was required for that parameter in that layer. No data are missing from the table. 
Input Data (continued):

\begin{tabular}{|c|c|c|c|c|c|c|c|c|c|}
\hline & $\begin{array}{l}\text { Layer } \\
\text { Type }\end{array}$ & $\begin{array}{l}\text { Sat. Hyd. } \\
\text { Conductivity * } \\
(\mathrm{cm} / \mathrm{sec})\end{array}$ & \multicolumn{2}{|c|}{$\begin{array}{l}\text { Drainage } \\
\text { Length } \\
(\mathrm{ft}) \\
\end{array}$} & $\begin{array}{l}\text { Drain } \\
\text { Slope } \\
(\%)\end{array}$ & $\begin{array}{l}\text { Leachate } \\
\text { Recirc. } \\
(\%) \\
\end{array}$ & \multicolumn{2}{|c|}{$\begin{array}{l}\text { Recirc. to } \\
\text { Layer } \\
(\#)\end{array}$} & $\begin{array}{l}\text { Subsurface } \\
\text { Inflow } \\
\text { (in/yr) }\end{array}$ \\
\hline 1 & 1 & $1.00 \mathrm{E}-03$ & & & & & & & \\
\hline 2 & 1 & $1.00 \mathrm{E}-04$ & & & & & & & \\
\hline 3 & 1 & $3.97 \mathrm{E}-04$ & & & & & & & \\
\hline 4 & 1 & $1.00 \mathrm{E}-04$ & & & & & & & \\
\hline 5 & 2 & $1.00 \mathrm{E}-01$ & 450 & & 3 & & & & \\
\hline 6 & 3 & $5.00 \mathrm{E}-09$ & & & & & & & \\
\hline 7 & 1 & $1.00 \mathrm{E}-04$ & & & & & & & \\
\hline 8 & 2 & $1.00 \mathrm{E}-01$ & 150 & & 11.4 & & & & \\
\hline \multirow[t]{2}{*}{9} & 3 & $5.00 \mathrm{E}-09$ & & & & & & \\
\hline & $\begin{array}{l}\text { Layer } \\
\text { Type }\end{array}$ & \multicolumn{2}{|l|}{$\begin{array}{l}\text { Geomembrane } \\
\text { Pinhole Density } \\
\text { (\#/acre) }\end{array}$} & \multicolumn{2}{|c|}{$\begin{array}{l}\text { Geomembrane } \\
\text { Instal. Defects } \\
(\# / \text { acre })\end{array}$} & \multicolumn{2}{|c|}{$\begin{array}{l}\text { Geomembrane } \\
\text { Placement Quality }\end{array}$} & \multicolumn{2}{|c|}{$\begin{array}{l}\text { Geotextile } \\
\text { Transmissivity } \\
\left(\mathrm{cm}^{2} / \mathrm{sec}\right)\end{array}$} \\
\hline 1 & 1 & & & & & & & & \\
\hline 2 & 1 & & & & & & & & \\
\hline 3 & 1 & & & & & & & & \\
\hline 4 & 1 & & & & & & & & \\
\hline 5 & 2 & & & & & & & & \\
\hline 6 & 3 & & & & & & & & \\
\hline 7 & 1 & & & & & & & & \\
\hline 8 & 2 & & & & & & & & \\
\hline 9 & 3 & & & & & & & & \\
\hline
\end{tabular}

The lack of values in the table for particular parameters in particular layers denotes that no HELP model input was required for that parameter in that layer. No data are missing from the table.

* The HELP model output often produces an increased number of significant digits for the Effective Saturated Hydraulic Conductivity over that of the actual input 


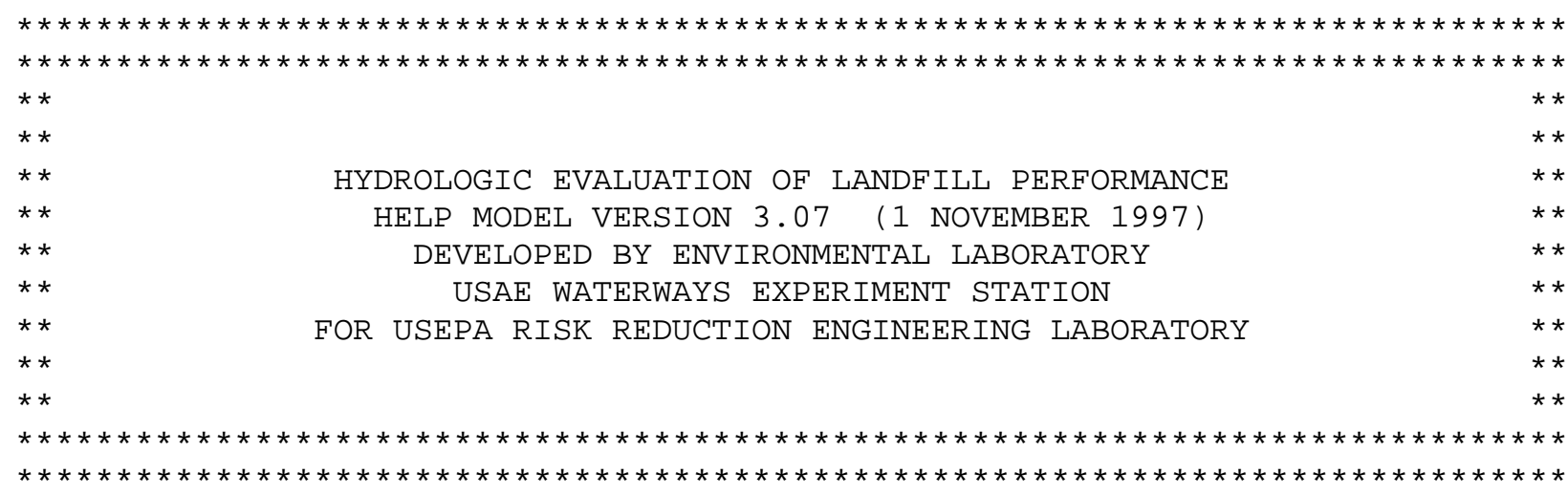
PRECIPITATION DATA FILE:
D : \HELP 3\Hweather ZZPREC.D4
TEMPERATURE DATA FILE:
D: \HELP $3 \backslash$ Hweather $\backslash Z T E M P$. D 7
SOLAR RADIATION DATA FILE: D: \HELP3\Hweather \ZSOLAR.D13

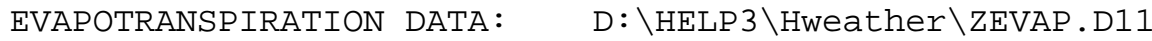
SOIL AND DESIGN DATA FILE: D:\HELP3\Hsdfmse ZMSEI.D10
OUTPUT DATA FILE:
D : \HELP $3 \backslash$ Hsdfmse ZMSEIout.OUT

TIME: $14: 56 \quad$ DATE: $11 / 13 / 2003$

TITLE: Intact SDF MSE Vault Closure Cap - 0 years

NOTE: INITIAL MOISTURE CONTENT OF THE LAYERS AND SNOW WATER WERE SPECIFIED BY THE USER.

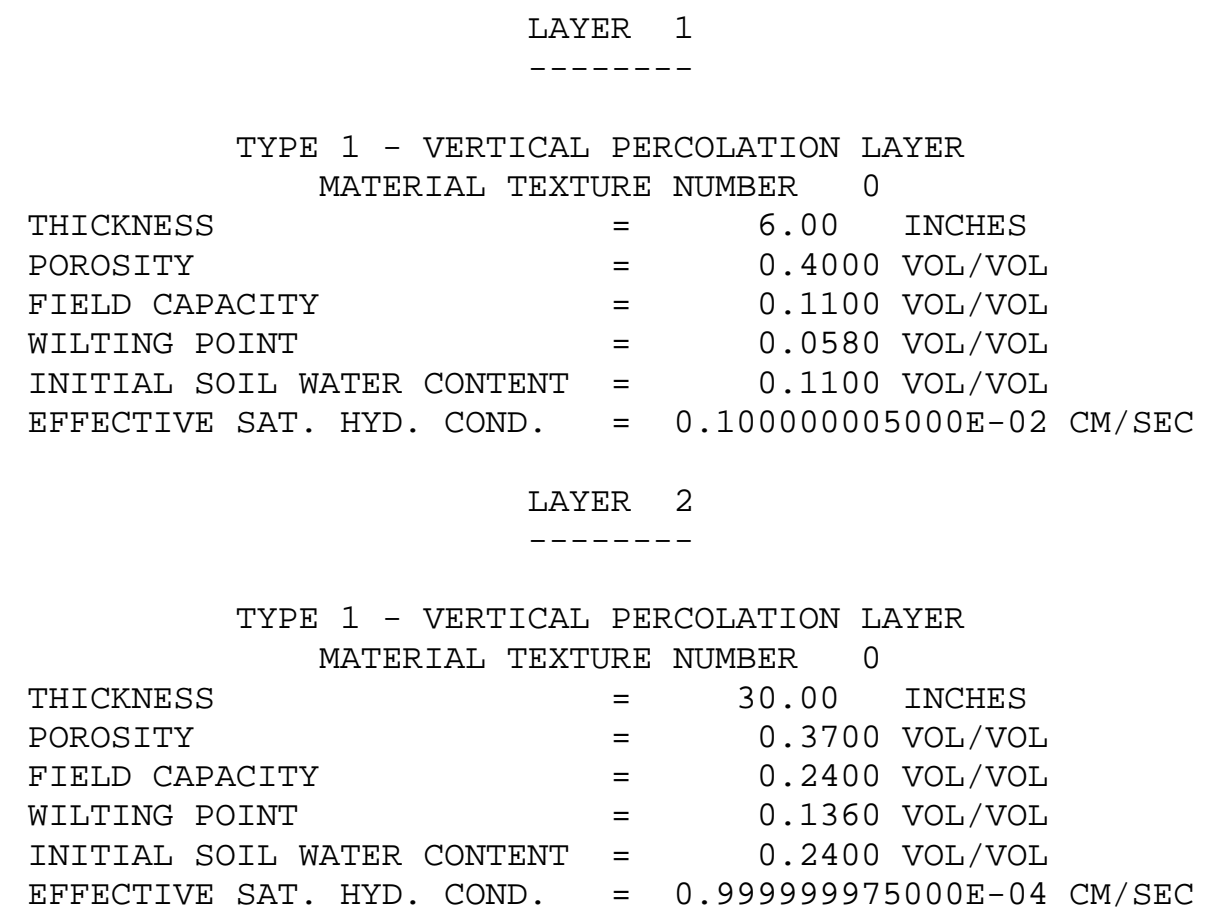

Rev. 0 
LAYER 3

--------

TYPE 1 - VERTICAL PERCOLATION LAYER MATERIAL TEXTURE NUMBER 0

$\begin{array}{llrl}\text { THICKNESS } & = & 12.00 & \text { INCHES } \\ \text { POROSITY } & = & 0.0600 \mathrm{VOL} / \mathrm{VOL} \\ \text { FIELD CAPACITY } & = & 0.0560 \mathrm{VOL} / \mathrm{VOL} \\ \text { WILTING POINT } & = & 0.0520 \mathrm{VOL} / \mathrm{VOL} \\ \text { INITIAL SOIL WATER CONTENT } & = & 0.0560 \mathrm{VOL} / \mathrm{VOL} \\ \text { EFFECTIVE SAT. HYD. COND. } & =0.39699999600 \mathrm{E}-03 \mathrm{CM} / \mathrm{SEC}\end{array}$

LAYER 4

TYPE 1 - VERTICAL PERCOLATION LAYER MATERIAL TEXTURE NUMBER 0

$\begin{array}{llrl}\text { THICKNESS } & = & 12.00 \mathrm{INCHES} \\ \text { POROSITY } & = & 0.3700 \mathrm{VOL} / \mathrm{VOL} \\ \text { FIELD CAPACITY } & = & 0.2400 \mathrm{VOL} / \mathrm{VOL} \\ \text { WILTING POINT } & = & 0.1360 \mathrm{VOL} / \mathrm{VOL} \\ \text { INITIAL SOIL WATER CONTENT } & = & 0.2400 \mathrm{VOL} / \mathrm{VOL} \\ \text { EFFECTIVE SAT. HYD. COND. } & =0.999999975000 \mathrm{E}-04 \mathrm{CM} / \mathrm{SEC}\end{array}$
LAYER 5

$--------$

TYPE 2 - LATERAL DRAINAGE LAYER MATERIAL TEXTURE NUMBER 0

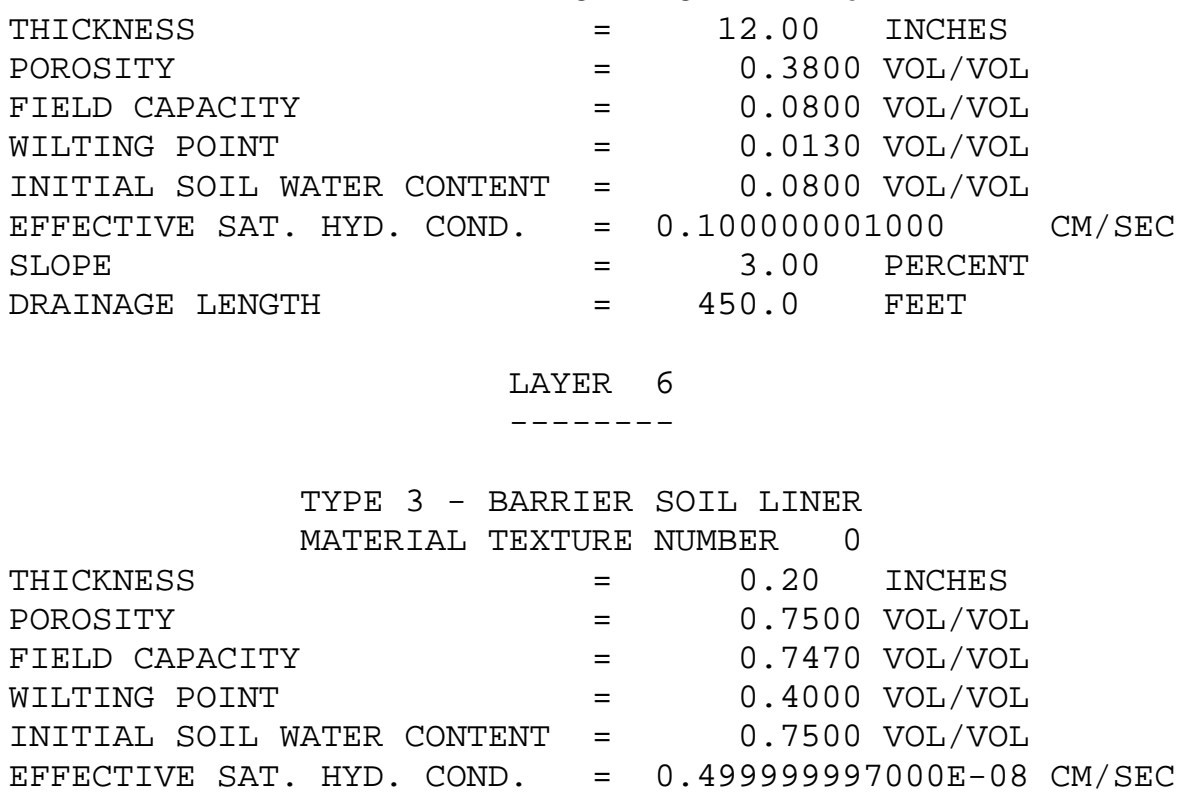


LAYER 7

$--------$

TYPE 1 - VERTICAL PERCOLATION LAYER

MATERIAL TEXTURE NUMBER 0

$\begin{array}{llrl}\text { THICKNESS } & = & 58.57 & \text { INCHES } \\ \text { POROSITY } & = & 0.3700 \mathrm{VOL} / \mathrm{VOL} \\ \text { FIELD CAPACITY } & = & 0.2400 \mathrm{VOL} / \mathrm{VOL} \\ \text { WILTING POINT } & = & 0.1360 \mathrm{VOL} / \mathrm{VOL} \\ \text { INITIAL SOIL WATER CONTENT } & = & 0.2400 \mathrm{VOL} / \mathrm{VOL} \\ \text { EFFECTIVE SAT. HYD. COND. } & =0.999999975000 \mathrm{E}-04 \mathrm{CM} / \mathrm{SEC}\end{array}$

LAYER 8

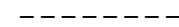

TYPE 2 - LATERAL DRAINAGE LAYER

$\begin{array}{llrl}\text { THICKNESS } & = & 24.00 & \text { INCHES } \\ \text { POROSITY } & = & 0.3800 \mathrm{VOL} / \mathrm{VOL} \\ \text { FIELD CAPACITY } & = & 0.0800 \mathrm{VOL} / \mathrm{VOL} \\ \text { WILTING POINT } & = & 0.0130 \mathrm{VOL} / \mathrm{VOL} \\ \text { INITIAL SOIL WATER CONTENT } & = & 0.0800 \mathrm{VOL} / \mathrm{VOL} \\ \text { EFFECTIVE SAT. HYD. COND. } & = & 0.10000001000 & \mathrm{CM} / \mathrm{SEC} \\ \text { SLOPE } & = & 11.40 \mathrm{PERCENT} & \\ \text { DRAINAGE LENGTH } & = & 150.0 & \mathrm{FEET}\end{array}$

LAYER 9

--------

TYPE 3 - BARRIER SOIL LINER

MATERIAL TEXTURE NUMBER 0

$\begin{array}{llrl}\text { THICKNESS } & = & 0.20 & \text { INCHES } \\ \text { POROSITY } & = & 0.7500 \mathrm{VOL} / \mathrm{VOL} \\ \text { FIELD CAPACITY } & = & 0.7470 \mathrm{VOL} / \mathrm{VOL} \\ \text { WILTING POINT } & = & 0.4000 \mathrm{VOL} / \mathrm{VOL} \\ \text { INITIAL SOIL WATER CONTENT } & = & 0.7500 \mathrm{VOL} / \mathrm{VOL} \\ \text { EFFECTIVE SAT. HYD. COND. } & =0.499999997000 \mathrm{E}-08 \mathrm{CM} / \mathrm{SEC}\end{array}$

GENERAL DESIGN AND EVAPORATIVE ZONE DATA

NOTE: SCS RUNOFF CURVE NUMBER WAS COMPUTED FROM DEFAULT SOIL DATA BASE USING SOIL TEXTURE \# 5 WITH A GOOD STAND OF GRASS, A SURFACE SLOPE OF 3.\% AND A SLOPE LENGTH OF 450. FEET.

SCS RUNOFF CURVE NUMBER

FRACTION OF AREA ALLOWING RUNOFF

AREA PROJECTED ON HORIZONTAL PLANE

EVAPORATIVE ZONE DEPTH

INITIAL WATER IN EVAPORATIVE ZONE

UPPER LIMIT OF EVAPORATIVE STORAGE

LOWER LIMIT OF EVAPORATIVE STORAGE

INITIAL SNOW WATER

INITIAL WATER IN LAYER MATERIALS

TOTAL INITIAL WATER

TOTAL SUBSURFACE INFLOW

$\begin{array}{lcl}= & 54.40 & \\ = & 100.0 & \text { PERCENT } \\ = & 19.630 & \text { ACRES } \\ = & 22.0 & \text { INCHES } \\ = & 4.500 & \text { INCHES } \\ = & 8.320 & \text { INCHES } \\ = & 2.524 & \text { INCHES } \\ = & 0.000 & \text { INCHES } \\ = & 28.649 & \text { INCHES } \\ = & 28.649 & \text { INCHES } \\ = & 0.00 & \text { INCHES /YEAR }\end{array}$

Rev. 0 


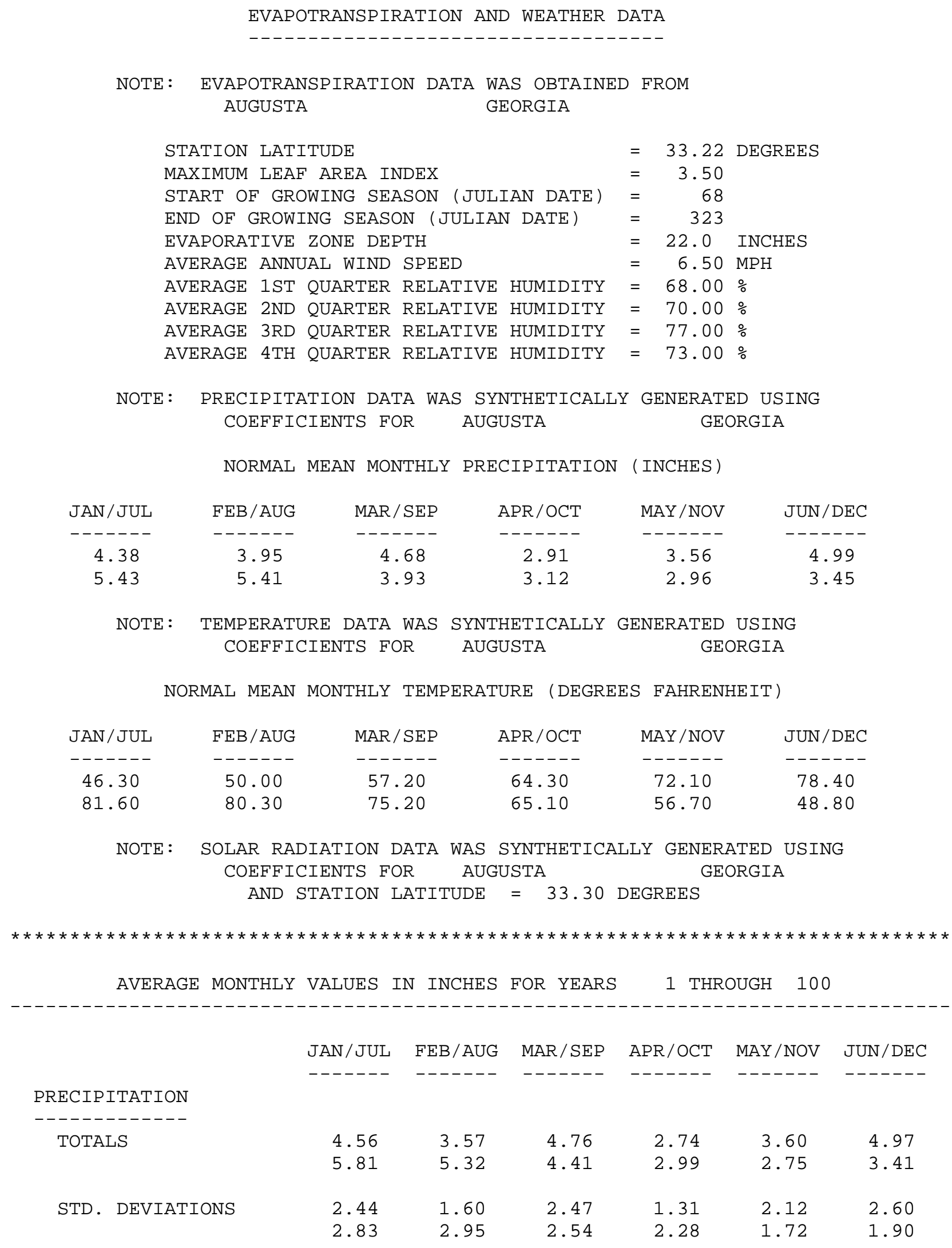

Rev. 0 
RUNOFF

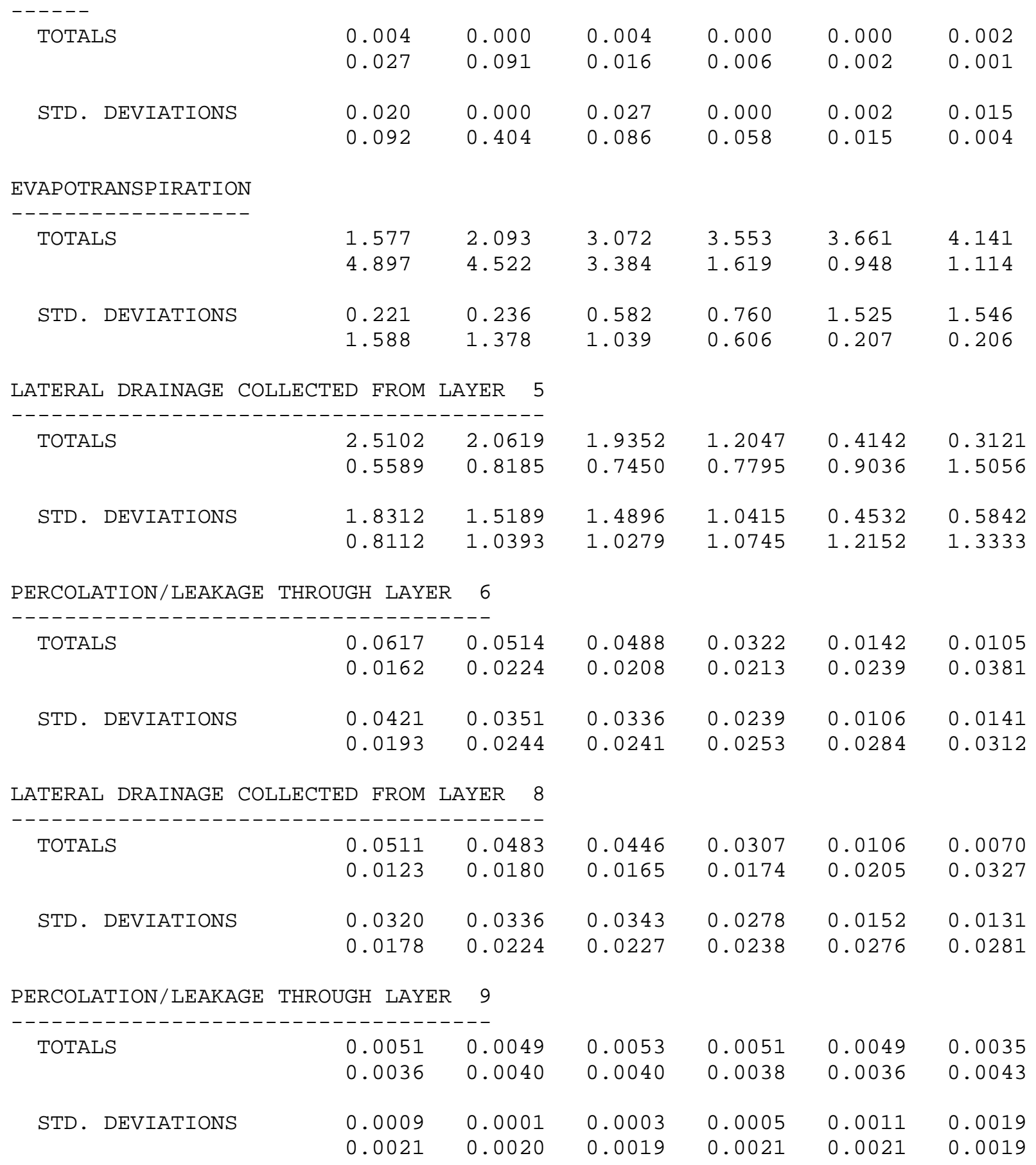


AVERAgES OF MONTHLY AVERAgED DAILY HEADS (INCHES)

DAILY AVERAGE HEAD ON TOP OF LAYER 6

\begin{tabular}{|c|c|c|c|c|c|c|}
\hline \multirow[t]{2}{*}{ AVERAGES } & 2.1516 & 1.9398 & 1.6538 & 1.0666 & 0.3539 & 0.2755 \\
\hline & 0.4775 & 0.6992 & 0.6594 & 0.6660 & 0.7977 & 1.2862 \\
\hline \multirow[t]{2}{*}{ STD. DEVIATIONS } & 1.5865 & 1.4607 & 1.2739 & 0.9329 & 0.3872 & 0.5157 \\
\hline & 0.6930 & 0.8878 & 0.9127 & 0.9179 & 1.0727 & 1.1390 \\
\hline
\end{tabular}

DAILY AVERAGE HEAD ON TOP OF LAYER 9

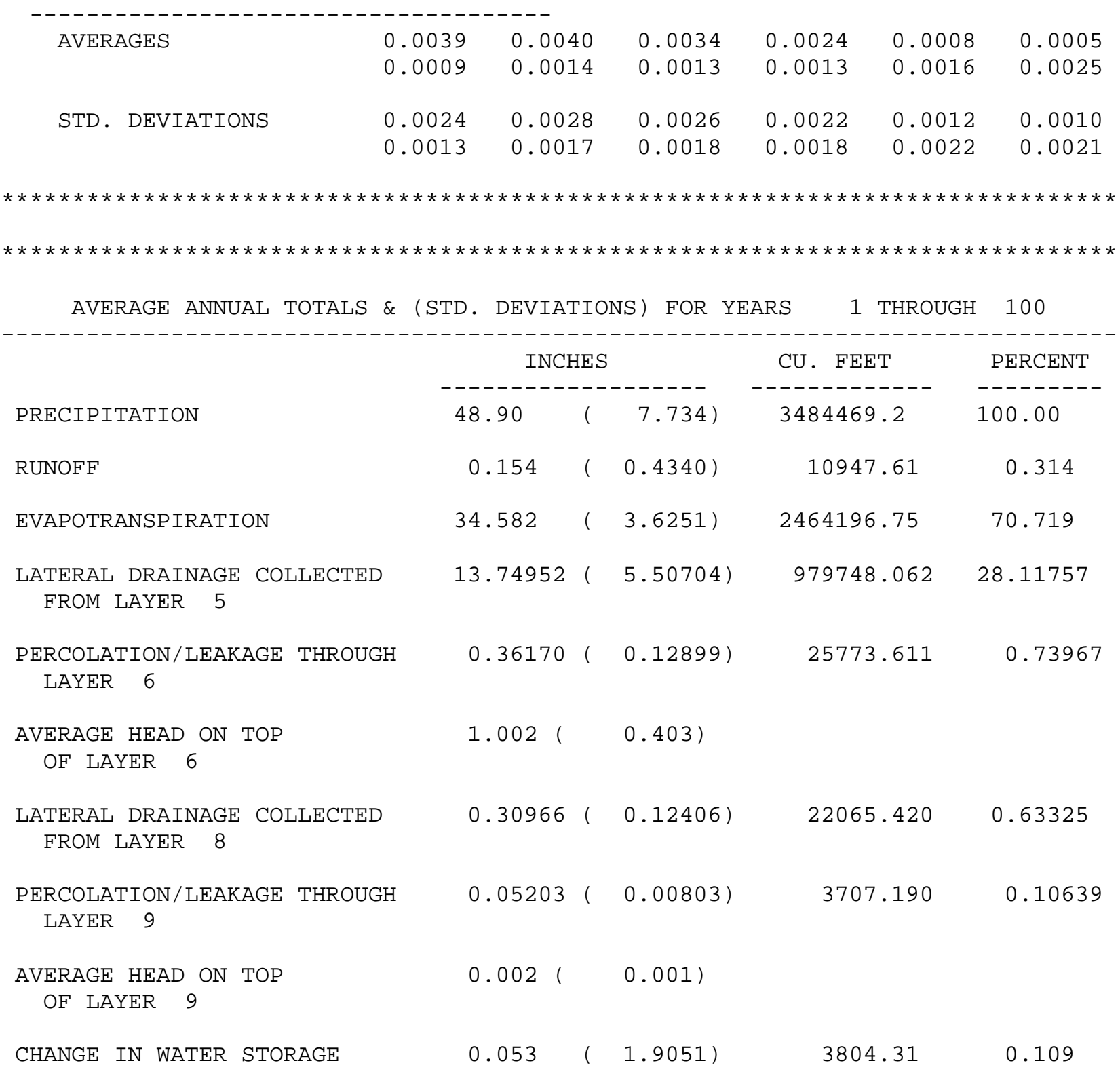




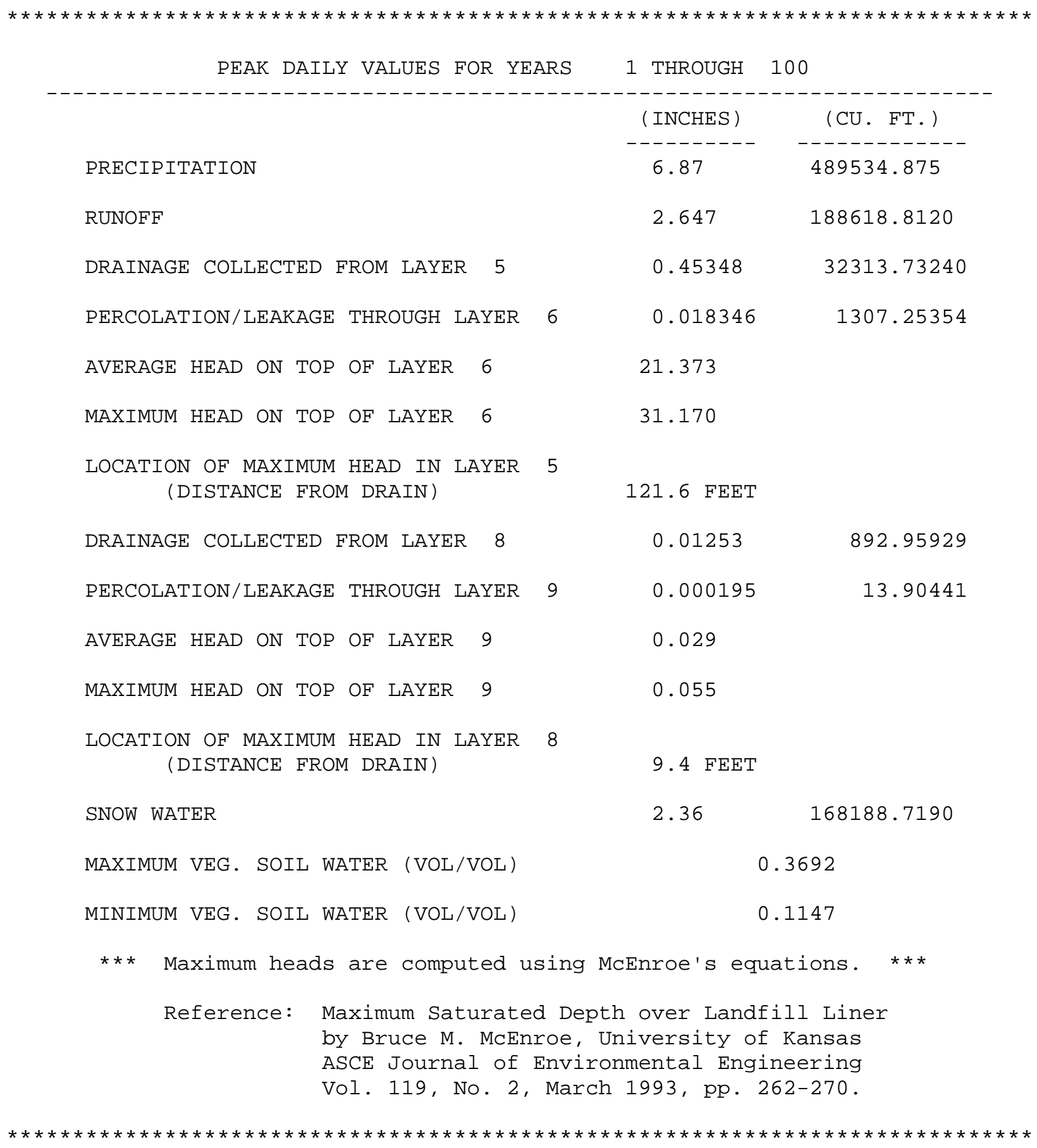

Rev. 0 


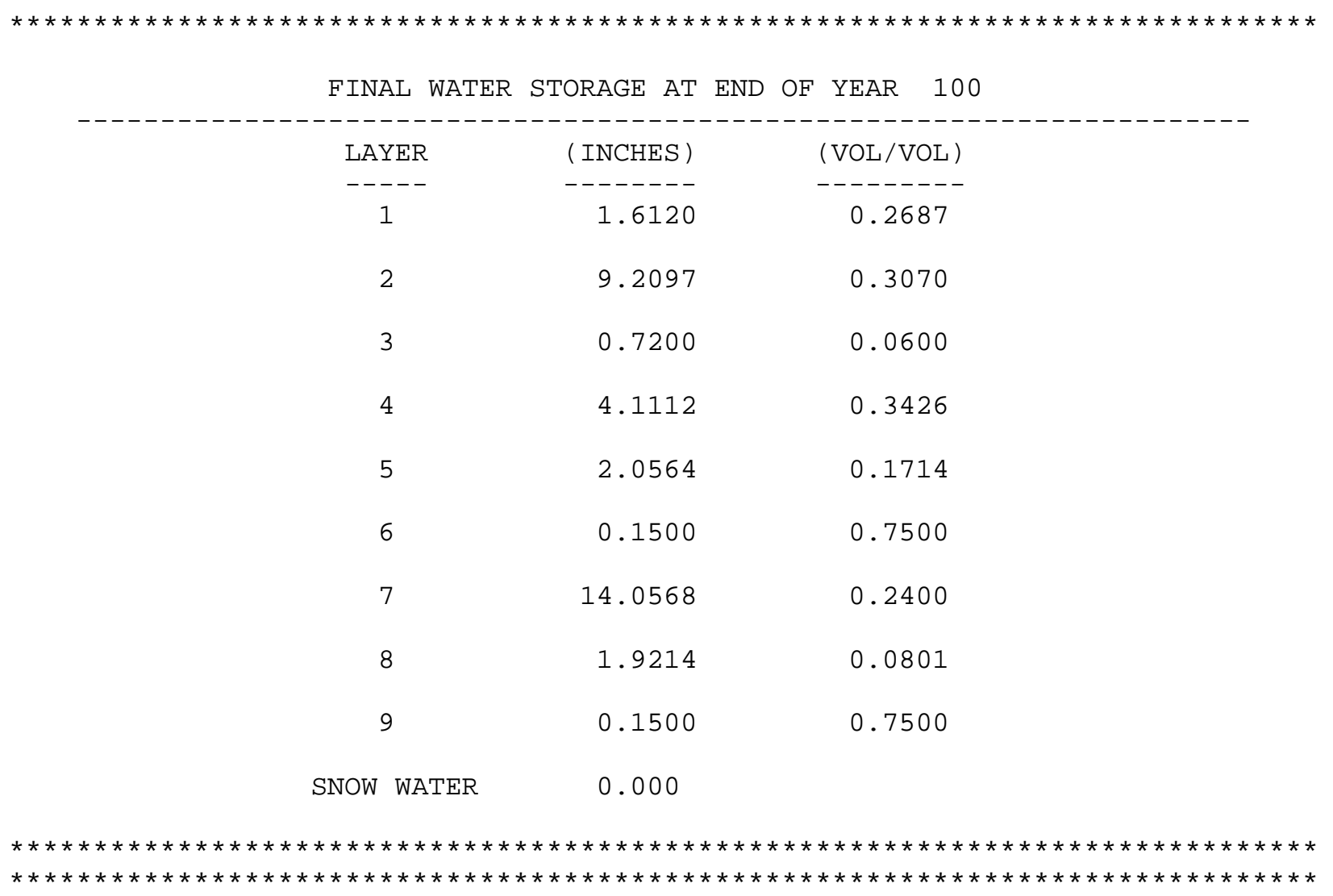




\section{Appendix F, SDF MSE Vault Closure Cap Degraded Property Value Calculations for Lower Bounding Scenario (i.e. Continuous Bamboo Cover)}

The MSE vault closure cap initial (0 year) layer thickness and hydraulic property values from top to bottom are provided in Table 3.1-1. The degradation scenarios for each layer are provided in Table 4.4-1. Based upon the Table 4.4-1 degradation scenarios, the Table 3.1-1 initial SDF closure cap layer thickness and hydraulic property values have been modified to account for degradation at 100, 300, 550, 1,000, 1,800, $3,400,5,600$ and 10,000 years after closure of the SDF.

\section{Topsoil and Upper Backfill Layer Thickness:}

From Section 4.2 the soil loss in terms of depth of loss per year for the topsoil and upper backfill for a bamboo cover was estimated to be 2.0E-04 inches/year and 1.2E-04 inches/year, respectively.

Topsoil Thickness over Time Calculation:

\begin{tabular}{|l|l|}
\hline Year & Thickness \\
\hline 0 & $6 "-(0$ years $\times 2.0 \mathrm{E}-04$ inches/year $)=6 "$ \\
\hline 100 & $6 "-(100$ years $\times 2.0 \mathrm{E}-04$ inches/year $)=5.980 "$ \\
\hline 300 & $6 "-(300$ years $\times 2.0 \mathrm{E}-04$ inches/year $)=5.940 "$ \\
\hline 550 & $6 "-(550$ years $\times 2.0 \mathrm{E}-04$ inches/year $)=5.890 "$ \\
\hline 1,000 & $6 "-(1000$ years $\times 2.0 \mathrm{E}-04$ inches/year $)=5.800 "$ \\
\hline 1,800 & $6 "-(1800$ years $\times 2.0 \mathrm{E}-04$ inches/year $)=5.640 "$ \\
\hline 3,400 & $6 "-(3400$ years $\times 2.0 \mathrm{E}-04$ inches/year $)=5.320 "$ \\
\hline 5,600 & $6 "-(5600$ years $\times 2.0 \mathrm{E}-04$ inches/year $)=4.880 "$ \\
\hline 10,000 & $6 "-(10000$ years $\times 2.0 \mathrm{E}-04$ inches/year $)=4.0 "$ \\
\hline
\end{tabular}

Since the topsoil does not completely erode away within the 10,000 years of interest, no reduction in the upper backfill layer occurs within this time frame.

\section{Ground Surface Soil Texture:}

The soil texture of the ground surface will change over time due to erosion of the topsoil and upper backfill layers. Soil texture is utilized in the HELP model to determine the SCS Curve Number $(\mathrm{CN})$ and subsequent runoff from the closure cap. The default HELP model ground surface soil textures will be assigned based upon an equivalence between the saturated hydraulic conductivity of the material assumed to be at the ground surface and that of the default HELP model ground surface soil textures.

Default HELP Model Ground Surface Soil Textures:

\begin{tabular}{|l|l|l|l|}
\hline Ground Surface Material & $\begin{array}{l}\text { Ground Surface Material K } \\
(\mathrm{cm} / \mathrm{s})\end{array}$ & HELP Soil Texture & $\begin{array}{l}\text { HELP Soil Texture K } \\
(\mathrm{cm} / \mathrm{s})\end{array}$ \\
\hline Topsoil & $1.0 \mathrm{E}-3$ & 5 & $1.0 \mathrm{E}-3$ \\
\hline Backfill & $1.0 \mathrm{E}-4$ & 10 & $1.2 \mathrm{E}-4$ \\
\hline Erosion Barrier & $3.97 \mathrm{E}-4$ & 8 & $3.7 \mathrm{E}-4$ \\
\hline
\end{tabular}

Middle Backfill Layer and Upper Drainage Layer Hydraulic Properties:

It is assumed that colloidal clay migration from the 1-foot-thick middle backfill to the underlying 1-footthick upper drainage layer causes the middle backfill saturated hydraulic conductivity to increase over time and that of the upper drainage layer to decrease over time.

Determine mass of clay to fill upper drainage layer void volume (0.38):

Assume clay bulk density is $1.1 \mathrm{~g} / \mathrm{cm}^{3}$

Look at a $1-\mathrm{ft}^{2}$ area of the 1 -foot-thick upper drainage layer (i.e. $1 \mathrm{ft}^{3}$ )

Void volume $=0.38 \times 1 \mathrm{ft}^{3}=0.38 \mathrm{ft}^{3}$ 
Clay mass per $\mathrm{ft}^{3}=1.1 \mathrm{~g} / \mathrm{cm}^{3} \times 0.38 \mathrm{ft}^{3} \times 2.831685 \mathrm{E}-02 \mathrm{~m}^{3} / \mathrm{ft}^{3} \times 1,000,000 \mathrm{~cm}^{3} / \mathrm{m}^{3}=11,836.3 \mathrm{~g}$

Determine available clay mass in the middle backfill layer:

Assume that the middle backfill layer consists of $20 \%$ clay and $80 \%$ sand with a dry bulk density of 104$\mathrm{lbs} / \mathrm{ft}^{3}$.

Clay mass $=104 \mathrm{lbs} / \mathrm{ft}^{3} \times 0.20 \times 453.59 \mathrm{~g} / \mathrm{lbs}=9,434.7 \mathrm{~g} / \mathrm{ft}^{3}$

There is not enough clay in the middle backfill layer to fill the upper drainage layer. Therefore it will be assumed that half the clay content of the middle backfill migrates into the upper drainage layer, at which point the two layers essentially become the same material and material property changes cease. Based upon this it will be assumed that the endpoint saturated hydraulic conductivity of the layers will become that of the log mid-point between the initial backfill and upper drainage layer conditions. It will also be assumed that the endpoint porosity, field capacity, and wilting point will become the arithmetic average of the backfill and upper drainage layer.

Endpoint hydraulic properties:

Intact hydraulic properties:

\begin{tabular}{|l|l|l|}
\hline Hydraulic Parameter & Middle Backfill & Upper Drainage Layer \\
\hline K & $1.0 \mathrm{E}-04 \mathrm{~cm} / \mathrm{s}$ & $1.0 \mathrm{E}-01 \mathrm{~cm} / \mathrm{s}$ \\
\hline $\mathrm{n}$ & 0.37 & 0.38 \\
\hline FC & 0.24 & 0.08 \\
\hline WP & 0.136 & 0.013 \\
\hline
\end{tabular}

Endpoint saturated hydraulic conductivity:

Middle backfill: $\mathrm{K}_{\mathrm{MB}}=0.0001 ; \log \mathrm{K}_{\mathrm{MB}}=-4$

Upper drainage layer: $\mathrm{K}_{\mathrm{UDL}}=0.1 ; \log \mathrm{K}_{\mathrm{UDL}}=-1$

Log mid-point: $\quad \frac{\log K_{M B}+\log K_{U D L}}{2}=\frac{-1+(-4)}{2}=-2.5$

$\mathrm{K}_{\mathrm{E}}=10^{-2.5}=3.2 \mathrm{E}-03 \mathrm{~cm} / \mathrm{s}$

Endpoint n, FC, and WP:

$$
\begin{aligned}
& \mathrm{n}=(0.37+0.38) / 2=0.375 \\
& \mathrm{FC}=(0.24+0.08) / 2=0.16 \\
& \mathrm{WP}=(0.136+0.013) / 2=0.0745
\end{aligned}
$$

It will be assumed that the clay migrates out of the middle backfill into the upper drainage layer with the water flux containing $63 \mathrm{mg} / \mathrm{L}$ of colloidal clay. It will also be assumed that the time to achieve the endpoint conditions will be based upon the estimated water flux into the upper drainage layer and migration of half the clay content of the middle backfill layer (i.e. $9,434.7 \mathrm{~g} / \mathrm{ft}^{3} \div 2=4717.4 \mathrm{~g} / \mathrm{ft}^{3}$ ).

Determine flux of water into the upper drainage layer:

Section 3.3 intact SDF closure cap Modeling determined the following average annual flux of water into the upper drainage layer (see Appendix E):

Precipitation $=48.90$ inches $/$ year

Runoff $=0.154$ inches/year

Evapotranspiration $=34.582$ inches $/$ year

Flux of water into upper drainage layer $=$ Precipitation $-($ Runoff + Evapotranspiration $)$ 
Flux of water into upper drainage layer $=48.90 \mathrm{in} / \mathrm{yr}-(0.154 \mathrm{in} / \mathrm{yr}+34.582 \mathrm{in} / \mathrm{yr})$

Flux of water into upper drainage layer $=14.164 \mathrm{in} / \mathrm{yr}$

Based upon Phifer 2003 this flux of water ( 14.2 inches/year) is satisfactory for the determination of the timing to achieve the endpoint conditions for the middle backfill and upper drainage layer.

Determine yearly clay migration into the upper drainage layer:

Flux into upper drainage layer $=14.2 \mathrm{in} / \mathrm{yr}$

Colloidal clay concentration $=63 \mathrm{mg} / \mathrm{L}$

Flux through a $1 \mathrm{ft}^{2}$ area $=14.2 \mathrm{in} / \mathrm{yr} \times \mathrm{ft} / 12 \mathrm{in} \times 1 \mathrm{ft}^{2}=1.18 \mathrm{ft}^{2} / \mathrm{yr}$

Clay flux $=1.18 \mathrm{ft}^{2} / \mathrm{yr} \times 63 \mathrm{mg} / \mathrm{L} \times 2.831685 \mathrm{E}-02 \mathrm{~m}^{3} / \mathrm{ft}^{3} \times 1000 \mathrm{~L} / \mathrm{m}^{3}=2,105 \mathrm{mg} / \mathrm{yr}=2.1 \mathrm{~g} / \mathrm{yr}$

Determine time it takes for the $4717.4 \mathrm{~g}$ of clay to migrate from the middle backfill layer to the upper drainage layer:

Time $=4717.4 \mathrm{~g} \div 2.1 \mathrm{~g} / \mathrm{yr}=2,246$ years

Determine middle backfill and upper drainage layer hydraulic property variation with time:

It will be assumed that the $\mathrm{K}$ of the middle backfill layer is increasing log linearly with time from 1.0E-04 $\mathrm{cm} / \mathrm{s}$ to $3.2 \mathrm{E}-03 \mathrm{~cm} / \mathrm{s}$, until year 2,246 at which time the $\mathrm{K}$ becomes static. Conversely it will be assumed that the $\mathrm{K}$ of the upper drainage layer is decreasing $\log$ linearly with time from $1.0 \mathrm{E}-01 \mathrm{~cm} / \mathrm{s}$ to $3.2 \mathrm{E}-03 \mathrm{~cm} / \mathrm{s}$, until year 2,246 at which time the K becomes static. Porosity (n), FC, and WP will be assumed to behave similarly but in an arithmetic linear manner.

Initial and End State hydraulic properties:

\begin{tabular}{|l|l|l|l|}
\hline Hydraulic Parameter & Initial Middle Backfill & $\begin{array}{l}\text { Initial Upper Drainage } \\
\text { Layer }\end{array}$ & End State at 2,246 years \\
\hline $\mathrm{K}$ & $1.0 \mathrm{E}-04 \mathrm{~cm} / \mathrm{s}$ & $1.0 \mathrm{E}-01 \mathrm{~cm} / \mathrm{s}$ & $3.2 \mathrm{E}-03 \mathrm{~cm} / \mathrm{s}$ \\
\hline $\mathrm{n}$ & 0.37 & 0.38 & 0.375 \\
\hline $\mathrm{FC}$ & 0.24 & 0.08 & 0.16 \\
\hline $\mathrm{WP}$ & 0.136 & 0.013 & 0.0745 \\
\hline
\end{tabular}

Determine fraction change for each year:

\begin{tabular}{|l|l|}
\hline Year & Fraction \\
\hline 0 & $0 \div 2246=0$ \\
\hline 100 & $100 \div 2246=0.0445$ \\
\hline 300 & $300 \div 2246=0.1336$ \\
\hline 550 & $550 \div 2246=0.2449$ \\
\hline 1,000 & $1000 \div 2246=0.4452$ \\
\hline 1,800 & $1800 \div 2246=0.8014$ \\
\hline 3,400 & 1.0 \\
\hline 5,600 & 1.0 \\
\hline 10,000 & 1.0 \\
\hline
\end{tabular}


Determine variation in $\mathrm{K}, \mathrm{n}, \mathrm{FC}$, and WP with time in the middle backfill:

\begin{tabular}{|l|l|l|l|l|l|}
\hline Year & Fraction, $\mathrm{F}$ & $\mathrm{K}^{1}(\mathrm{~cm} / \mathrm{s})$ & $\mathrm{n}^{2}$ & $\mathrm{FC}^{3}$ & $\mathrm{WP}^{4}$ \\
\hline 0 & 0 & 0.0001 & 0.37 & 0.24 & 0.136 \\
\hline 100 & 0.0445 & 0.00012 & 0.37 & 0.236 & 0.133 \\
\hline 300 & 0.1336 & 0.00016 & 0.371 & 0.229 & 0.128 \\
\hline 550 & 0.2449 & 0.00023 & 0.371 & 0.220 & 0.121 \\
\hline 1,000 & 0.4452 & 0.00046 & 0.372 & 0.204 & 0.109 \\
\hline 1,800 & 0.8014 & 0.0016 & 0.374 & 0.176 & 0.0867 \\
\hline 3,400 & 1.0 & 0.0032 & 0.375 & 0.16 & 0.0745 \\
\hline 5,600 & 1.0 & 0.0032 & 0.375 & 0.16 & 0.0745 \\
\hline 10,000 & 1.0 & 0.0032 & 0.375 & 0.16 & 0.0745 \\
\hline
\end{tabular}

${ }^{1} K=10^{[-4+((-2.5-(-4)) F)]}=10^{(-4+1.5 F)}$

${ }^{2} \mathrm{n}=0.37+(0.375-0.37) \mathrm{F}$

${ }^{3} \mathrm{FC}=0.24-(0.24-0.16) \mathrm{F}$

${ }^{4} \mathrm{WP}=0.136-(0.136-0.0745) \mathrm{F}$

Determine variation in $\mathrm{K}, \mathrm{n}, \mathrm{FC}$, and WP with time in the upper drainage layer:

\begin{tabular}{|l|l|l|l|l|l|}
\hline Year & Fraction, $\mathrm{F}$ & $\mathrm{K}^{1}(\mathrm{~cm} / \mathrm{s})$ & $\mathrm{n}^{2}$ & $\mathrm{FC}^{3}$ & $\mathrm{WP}^{4}$ \\
\hline 0 & 0 & 0.1 & 0.38 & 0.08 & 0.013 \\
\hline 100 & 0.0445 & 0.086 & 0.38 & 0.084 & 0.016 \\
\hline 300 & 0.1336 & 0.063 & 0.379 & 0.089 & 0.021 \\
\hline 550 & 0.2449 & 0.043 & 0.379 & 0.10 & 0.028 \\
\hline 1,000 & 0.4452 & 0.021 & 0.378 & 0.116 & 0.040 \\
\hline 1,800 & 0.8014 & 0.0063 & 0.376 & 0.144 & 0.062 \\
\hline 3,400 & 1.0 & 0.0032 & 0.375 & 0.16 & 0.0745 \\
\hline 5,600 & 1.0 & 0.0032 & 0.375 & 0.16 & 0.0745 \\
\hline 10,000 & 1.0 & 0.0032 & 0.375 & 0.16 & 0.0745 \\
\hline
\end{tabular}

${ }^{1} K=10^{[-1+((-2.5-(-1)) F)]}=10^{(-1-1.5 F)}$

${ }^{2} \mathrm{n}=0.38-(0.38-0.375) \mathrm{F}$

${ }^{3} \mathrm{FC}=0.08+(0.16-0.08) \mathrm{F}$

${ }^{4} \mathrm{WP}=0.013+(0.0745-0.013) \mathrm{F}$

\section{Lower Drainage Layer Hydraulic Properties:}

It is assumed that colloidal clay migration from the overlying backfill is driven by the water flux through the upper GCL. This water flux driven clay migration enters into the 2 -foot thick lower drainage layer and fills the lower drainage layer from the bottom up. This reduces the saturated hydraulic conductivity of the clay filled portion from $1.0 \mathrm{E}-01$ to $1.0 \mathrm{E}-04 \mathrm{~cm} / \mathrm{s}$ (i.e. the saturated hydraulic conductivity of the overlying backfill layer). As the thickness of the lower drainage layer filled with clay increases the overall hydraulic conductivity of the layer decreases. This is different from that assumed for the upper drainage layer since the lower drainage layer has significantly more backfill overlying it. The HELP model was run for each year with all of the previously degraded properties (see above) without degradation of the lower drainage layer in order to determine the infiltration through the upper GCL. The results are as follows: 


\begin{tabular}{|l|l|}
\hline Year & Infiltration through upper GCL (inches/year) \\
\hline 0 & 0.36170 \\
\hline 100 & 0.41335 \\
\hline 300 & 0.55102 \\
\hline 550 & 0.80275 \\
\hline 1,000 & 1.75224 \\
\hline 1,800 & 5.05125 \\
\hline 3,400 & 6.45544 \\
\hline 5,600 & 6.44166 \\
\hline 10,000 & 6.39636 \\
\hline
\end{tabular}

It is assumed that there is a linear increase in the infiltration over time between data points.

Determine cumulative volume of water through the lower drainage layer over time:

\begin{tabular}{|l|l|l|l|l|}
\hline Year & $\begin{array}{l}\text { Infiltration through } \\
\text { upper GCL } \\
\text { (inches/year) }\end{array}$ & $\begin{array}{l}\text { Time Step } \\
\text { Infiltration } \\
\text { (inches) }\end{array}$ & $\begin{array}{l}\text { Cumulative } \\
\text { Infiltration } \\
\text { (inches) }\end{array}$ & $\begin{array}{l}\text { Cumulative Volume } \\
\text { over one } \mathrm{ft}^{2} \mathrm{area}^{3} \\
\left.\mathrm{ft}^{3}\right)\end{array}$ \\
\hline 0 & 0.36170 & 0 & 0 & 0 \\
\hline 100 & 0.41335 & 38.75 & 38.75 & 3.23 \\
\hline 300 & 0.55102 & 96.44 & 135.19 & 11.26 \\
\hline 550 & 0.80227 & 169.16 & 304.35 & 25.36 \\
\hline 1,000 & 1.75224 & 574.87 & 879.22 & 73.27 \\
\hline 1,800 & 5.05125 & $2,721.40$ & $3,600.62$ & 300.05 \\
\hline 3,400 & 6.45544 & $9,205.32$ & $12,805.94$ & $1,067.16$ \\
\hline 5,600 & 6.44166 & $14,186.81$ & $26,992.75$ & $2,249.4$ \\
\hline 10,000 & 6.39636 & $28,243.62$ & $55,236.37$ & $4,603.03$ \\
\hline
\end{tabular}

${ }^{1}$ Time Step Infiltration $=\left[I_{1} \times\left(T_{2}-T_{1}\right)\right]+\left[1 / 2 \times\left(I_{2}-I_{1}\right)\left(T_{2}-T_{1}\right)\right]$, where $\mathrm{I}=$ infiltration at time 1 or 2 ; $\mathrm{T}=$ time at time 1 or 2

${ }^{2}$ Cumulative Infiltration $=$ Previous Cumulative Infiltration + Time Step Infiltration at current time step

${ }^{3}$ Cumulative Volume over one $\mathrm{ft}^{2}$ area $=($ Cumulative Infiltration $\div 12 \mathrm{in} / \mathrm{ft}) \times 1 \mathrm{ft}^{2}$

Determine mass of clay to fill lower drainage layer void volume (0.38):

Assume clay bulk density is $1.1 \mathrm{~g} / \mathrm{cm}^{3}$

Look at a 1- $\mathrm{ft}^{2}$ area of the 2-foot-thick upper drainage layer (i.e. $2 \mathrm{ft}^{3}$ )

Void volume $=0.38 \times 2 \mathrm{ft}^{3}=0.76 \mathrm{ft}^{3}$

Clay mass per $\mathrm{ft}^{3}=1.1 \mathrm{~g} / \mathrm{cm}^{3} \times 0.76 \mathrm{ft}^{3} \times 2.831685 \mathrm{E}-02 \mathrm{~m}^{3} / \mathrm{ft}^{3} \times 1,000,000 \mathrm{~cm}^{3} / \mathrm{m}^{3}=23,672.9 \mathrm{~g}$

Determine total flux of water into the lower drainage layer required to completely fill it with clay:

It will be assumed that the clay migrates out of the lower backfill into the lower drainage layer with the water flux containing $63 \mathrm{mg} / \mathrm{L}$ of colloidal clay.

$$
V=\frac{23,672.9 \mathrm{~g} \times 1000 \mathrm{mg} / \mathrm{g}}{63 \mathrm{mg} / \mathrm{L} \times 28.31685 \mathrm{~L} / \mathrm{ft}^{3}}=13,269.8 \mathrm{ft}^{3}
$$


Determine the mass of clay that has migrated into the lower drainage layer at the end of each time step:

\begin{tabular}{|l|l|}
\hline Year & Mass of clay into lower drainage layer \\
\hline 0 & 0 \\
\hline 100 & $3.23 \mathrm{ft}^{3} \times 63 \mathrm{mg} / \mathrm{L} \times 28.31685 \mathrm{~L} / \mathrm{ft}^{3} \times \mathrm{g} / 1000 \mathrm{mg}=5.76 \mathrm{~g}$ \\
\hline 300 & $11.26 \mathrm{ft}^{3} \times 63 \mathrm{mg} / \mathrm{L} \times 28.31685 \mathrm{~L} / \mathrm{ft}^{3} \times \mathrm{g} / 1000 \mathrm{mg}=20.09 \mathrm{~g}$ \\
\hline 550 & $25.36 \mathrm{ft}^{3} \times 63 \mathrm{mg} / \mathrm{L} \times 28.31685 \mathrm{~L} / \mathrm{ft}^{3} \times \mathrm{g} / 1000 \mathrm{mg}=45.24 \mathrm{~g}$ \\
\hline 1,000 & $73.27 \mathrm{ft}^{3} \times 63 \mathrm{mg} / \mathrm{L} \times 28.31685 \mathrm{~L} / \mathrm{ft}^{3} \times \mathrm{g} / 1000 \mathrm{mg}=130.71 \mathrm{~g}$ \\
\hline 1,800 & $300.05 \mathrm{ft}^{3} \times 63 \mathrm{mg} / \mathrm{L} \times 28.31685 \mathrm{~L} / \mathrm{ft}^{3} \times \mathrm{g} / 1000 \mathrm{mg}=535.28 \mathrm{~g}$ \\
\hline 3,400 & $1,067.16 \mathrm{ft}^{3} \times 63 \mathrm{mg} / \mathrm{L} \times 28.31685 \mathrm{~L} / \mathrm{ft}^{3} \times \mathrm{g} / 1000 \mathrm{mg}=1,903.77 \mathrm{~g}$ \\
\hline 5,600 & $2,249.4 \mathrm{ft}^{3} \times 63 \mathrm{mg} / \mathrm{L} \times 28.31685 \mathrm{~L} / \mathrm{ft}^{3} \times \mathrm{g} / 1000 \mathrm{mg}=4,012.84 \mathrm{~g}$ \\
\hline 10,000 & $4,603.03 \mathrm{ft}^{3} \times 63 \mathrm{mg} / \mathrm{L} \times 28.31685 \mathrm{~L} / \mathrm{ft}^{3} \times \mathrm{g} / 1000 \mathrm{mg}=8,211.63 \mathrm{~g}$ \\
\hline
\end{tabular}

Determine the fraction of the lower drainage layer filled at the end of each time step:

\begin{tabular}{|l|l|}
\hline Year & Fraction of the lower drainage layer filled \\
\hline 0 & 0 \\
\hline 100 & $5.76 \mathrm{~g} \div 23,672.9 \mathrm{~g}=0.000243$ \\
\hline 300 & $20.09 \mathrm{~g} \div 23,672.9 \mathrm{~g}=0.000849$ \\
\hline 550 & $45.24 \mathrm{~g} \div 23,672.9 \mathrm{~g}=0.00191$ \\
\hline 1,000 & $130.71 \mathrm{~g} \div 23,672.9 \mathrm{~g}=0.00552$ \\
\hline 1,800 & $535.28 \mathrm{~g} \div 23,672.9 \mathrm{~g}=0.0226$ \\
\hline 3,400 & $1,903.77 \mathrm{~g} \div 23,672.9 \mathrm{~g}=0.0804$ \\
\hline 5,600 & $4,012.84 \mathrm{~g} \div 23,672.9 \mathrm{~g}=0.170$ \\
\hline 10,000 & $8,211.63 \mathrm{~g} \div 23,672.9 \mathrm{~g}=0.347$ \\
\hline
\end{tabular}

The following are the hydraulic properties of the clean and clay filled portion of the lower drainage layer:

\begin{tabular}{|l|l|l|l|l|}
\hline Material & $\begin{array}{l}\text { Saturated Hydraulic } \\
\text { Conductivity }(\mathrm{cm} / \mathrm{s})\end{array}$ & Porosity & Field Capacity & Wilting Point \\
\hline Clean & $1.0 \mathrm{E}-01$ & 0.38 & 0.08 & 0.013 \\
\hline Clay filled & $1.0 \mathrm{E}-04$ & 0.22 (see below) & 0.21 (see below) & 0.20 (see below) \\
\hline
\end{tabular}

Determine the porosity of the clay filled portion of the lower drainage layer:

Porosity of the clay:

Assumed clay bulk density, $\rho_{\mathrm{b}}=1.1 \mathrm{~g} / \mathrm{cm}^{2}$

Assumed clay particle density, $\rho_{\mathrm{p}}=2.6 \mathrm{~g} / \mathrm{cm}^{2}$

Resulting clay porosity, $n=1-\frac{\rho_{b}}{\rho_{p}}=1-\frac{1.1 \mathrm{~g} / \mathrm{cm}^{2}}{2.6 \mathrm{~g} / \mathrm{cm}^{2}}=0.58$

Porosity of the clay filled portion $=$ Porosity of clean portion $\times$ porosity of clay

Porosity of the clay filled portion $=0.38 \times 0.58=0.22$

Determine the field capacity and wilting point of the clay filled portion of the lower drainage layer:

Will assume that the field capacity and wilting point of the clay fill portion has the same ratio versus its porosity of 0.22 as the equivalent ratio for kaolin clay.

From WSRC 2002 the following kaolin properties are found: $\mathrm{n}=0.56 ; \mathrm{FC}=0.55 ; \mathrm{WP}=0.50$

$$
\begin{aligned}
& \mathrm{FC}=0.22 \times(0.55 \div 0.56) \approx 0.21 \\
& \mathrm{WP}=0.22 \times(0.50 \div 0.56) \approx 0.20
\end{aligned}
$$

Determine the equivalent horizontal hydraulic conductivity of the lower drainage layer over time: 
The equivalent horizontal hydraulic conductivity for horizontal flow in a series of horizontal layers with different saturated hydraulic conductivities can be determined from the following equation (Freeze and Cherry 1979):

$$
K_{h}=\sum_{i=1}^{n} \frac{K_{i} d_{i}}{d}, \text { where } \mathrm{K}_{\mathrm{h}}=\text { equivalent horizontal saturated hydraulic conductivity, } \mathrm{K}_{\mathrm{i}}=\text { horizontal }
$$
saturated hydraulic conductivity of $i^{\text {th }}$ layer, $d_{i}=$ thickness of $i^{\text {th }}$ layer, $d=$ total thickness

The fraction, $\mathrm{F}$, equals $d_{i} / d$ for the clay filled portion and $d_{i} / d$ for the clean drainage layer material equals $(1-\mathrm{F})$, making the equation:

$$
K_{h}=\left(K_{\text {filled }} \times F\right)+\left[K_{\text {clean }} \times(1-F)\right]
$$

\begin{tabular}{|l|l|}
\hline Year & Equivalent $\mathrm{K}(\mathrm{cm} / \mathrm{s})$ \\
\hline 0 & 0.1 \\
\hline 100 & $(0.0001 \times 0.000243)+[0.1 \times(1-0.000243)]=0.1$ \\
\hline 300 & $(0.0001 \times 0.000849)+[0.1 \times(1-0.000849)]=0.0999$ \\
\hline 550 & $(0.0001 \times 0.00191)+[0.1 \times(1-0.00191)]=0.0998$ \\
\hline 1,000 & $(0.0001 \times 0.00552)+[0.1 \times(1-0.00552)]=0.0994$ \\
\hline 1,800 & $(0.0001 \times 0.0226)+[0.1 \times(1-0.0226)]=0.0977$ \\
\hline 3,400 & $(0.0001 \times 0.170)+[0.1 \times(1-0.170)]=0.0830$ \\
\hline 5,600 & $(0.0001 \times 0.347)+[0.1 \times(1-0.347)]=0.0653$ \\
\hline 10,000 & \\
\hline
\end{tabular}

Determine the equivalent $\mathrm{n}, \mathrm{FC}$, and WP for the lower drainage layer over time:

In an analogous manner to that for $\mathrm{K}$, the equivalent $\mathrm{n}, \mathrm{FC}$, and WP can be determined based upon the fraction filled as follows:

$$
\begin{aligned}
& n=\left(n_{\text {filled }} \times F\right)+\left[n_{\text {clean }} \times(1-F)\right] \\
& F C=\left(F C_{\text {filled }} \times F\right)+\left[F C_{\text {clean }} \times(1-F)\right] \\
& W P=\left(W P_{\text {filled }} \times F\right)+\left[W P_{\text {clean }} \times(1-F)\right]
\end{aligned}
$$

\begin{tabular}{|l|l|}
\hline Year & Equivalent $\mathrm{n}$ \\
\hline 0 & $(0.22 \times 0)+[0.38 \times(1-0)]=0.38$ \\
\hline 100 & $(0.22 \times 0.000243)+[0.38 \times(1-0.000243)]=0.38$ \\
\hline 300 & $(0.22 \times 0.000849)+[0.38 \times(1-0.000849)]=0.38$ \\
\hline 550 & $(0.22 \times 0.00191)+[0.38 \times(1-0.00191)]=0.38$ \\
\hline 1,000 & $(0.22 \times 0.00552)+[0.38 \times(1-0.00552)]=0.379$ \\
\hline 1,800 & $(0.22 \times 0.0226)+[0.38 \times(1-0.0226)]=0.376$ \\
\hline 3,400 & $(0.22 \times 0.0804)+[0.38 \times(1-0.0804)]=0.367$ \\
\hline 5,600 & $(0.22 \times 0.170)+[0.38 \times(1-0.170)]=0.353$ \\
\hline 10,000 & $(0.22 \times 0.347)+[0.38 \times(1-0.347)]=0.324$ \\
\hline
\end{tabular}




\begin{tabular}{|l|l|}
\hline Year & Equivalent FC \\
\hline 0 & $(0.21 \times 0)+[0.08 \times(1-0)]=0.08$ \\
\hline 100 & $(0.21 \times 0.000243)+[0.08 \times(1-0.000243)]=0.08$ \\
\hline 300 & $(0.21 \times 0.000849)+[0.08 \times(1-0.000849)]=0.0801$ \\
\hline 550 & $(0.21 \times 0.00191)+[0.08 \times(1-0.00191)]=0.0802$ \\
\hline 1,000 & $(0.21 \times 0.00552)+[0.08 \times(1-0.00552)]=0.0807$ \\
\hline 1,800 & $(0.21 \times 0.0226)+[0.08 \times(1-0.0226)]=0.0829$ \\
\hline 3,400 & $(0.21 \times 0.0804)+[0.08 \times(1-0.0804)]=0.0904$ \\
\hline 5,600 & $(0.21 \times 0.170)+[0.08 \times(1-0.170)]=0.102$ \\
\hline 10,000 & $(0.21 \times 0.347)+[0.08 \times(1-0.347)]=0.125$ \\
\hline
\end{tabular}

\begin{tabular}{|l|l|}
\hline Year & Equivalent WP \\
\hline 0 & $(0.20 \times 0)+[0.013 \times(1-0)]=0.013$ \\
\hline 100 & $(0.20 \times 0.000243)+[0.013 \times(1-0.000243)]=0.013$ \\
\hline 300 & $(0.20 \times 0.000849)+[0.013 \times(1-0.000849)]=0.0132$ \\
\hline 550 & $(0.20 \times 0.00191)+[0.013 \times(1-0.00191)]=0.0134$ \\
\hline 1,000 & $(0.20 \times 0.00552)+[0.013 \times(1-0.00552)]=0.0140$ \\
\hline 1,800 & $(0.20 \times 0.0226)+[0.013 \times(1-0.0226)]=0.0172$ \\
\hline 3,400 & $(0.20 \times 0.0804)+[0.013 \times(1-0.0804)]=0.0280$ \\
\hline 5,600 & $(0.20 \times 0.170)+[0.013 \times(1-0.170)]=0.0448$ \\
\hline 10,000 & $(0.20 \times 0.347)+[0.013 \times(1-0.347)]=0.0779$ \\
\hline
\end{tabular}

Summary Lower Drainage Layer Hydraulic Properties with Time:

\begin{tabular}{|l|l|l|l|l|}
\hline Year & $\mathrm{K}(\mathrm{cm} / \mathrm{s})$ & $\mathrm{n}$ & $\mathrm{FC}$ & WP \\
\hline 0 & 0.1 & 0.38 & 0.08 & 0.013 \\
\hline 100 & 0.1 & 0.38 & 0.08 & 0.013 \\
\hline 300 & 0.0999 & 0.38 & 0.0801 & 0.0132 \\
\hline 550 & 0.0998 & 0.38 & 0.0802 & 0.0134 \\
\hline 1,000 & 0.0994 & 0.379 & 0.0807 & 0.0140 \\
\hline 1,800 & 0.0977 & 0.376 & 0.0829 & 0.0172 \\
\hline 3,400 & 0.0920 & 0.367 & 0.0904 & 0.0280 \\
\hline 5,600 & 0.0830 & 0.353 & 0.102 & 0.0448 \\
\hline 10,000 & 0.0653 & 0.324 & 0.125 & 0.0779 \\
\hline
\end{tabular}

The HELP model was rerun for each time step with all of the degraded properties (see above) including that of the lower drainage layer. Infiltration through the upper GCL did not change with the addition of the degraded lower drainage layer properties. Therefore the above estimated lower drainage layer hydraulic properties over time are verified.

\section{Infiltration through the Upper GCL after Topsoil and Upper Backfill Eroded}

The infiltration through the upper GCL at complete closure cap degradation for the lower bounding scenario and the associated time of occurrence have been determined based upon the following:

- Complete closure cap degradation occurs when both the topsoil and upper backfill have eroded away.

- As outlined previously, it is assumed that the material properties of the middle backfill and upper drainage layer become the same at year 2,246 and remain constant thereafter. Therefore the middle backfill and upper drainage layer material properties will be taken as those determined at year 2,246.

- As previously demonstrated, the material properties of the lower drainage layer do not impact infiltration through the upper GCL. Completely silted in conditions will be assumed for the lower drainage layer for determination of this infiltration. 
From Section 4.2 the soil loss in terms of depth of loss per year for the topsoil and upper backfill was estimated to be 2.0E-04 inches/year and 1.2E-04 inches/year, respectively.

Determine time required to completely erode the topsoil:

$$
6 " \div 2.0 \text { E-04 inches/year }=30,000 \text { years }
$$

Determine time required to completely erode the upper backfill:

$$
30 ” \div 1.2 \mathrm{E}-04 \text { inches/year }=250,000 \text { years }
$$

Total time required to completely erode both the topsoil and upper backfill:

$$
30,000 \text { years }+250,000 \text { years }=280,000 \text { years }
$$

Based upon the above the following are the input properties utilized for the topsoil, upper backfill, middle backfill, upper drainage layer, and lower drainage layer for determination of the year 280,000 infiltration through the upper GCL.

Summary Hydraulic Properties for determination of the infiltration through the upper GCL at 280,000 years:

\begin{tabular}{|l|l|l|l|l|l|}
\hline Layer & $\begin{array}{l}\text { Thickness } \\
\text { (inches) }\end{array}$ & $\mathrm{K}(\mathrm{cm} / \mathrm{s})$ & $\mathrm{n}$ & FC & WP \\
\hline Topsoil & 0 & NA & NA & NA & NA \\
\hline Upper Backfill & 0 & NA & NA & NA & NA \\
\hline Middle Backfill & 12 & $3.2 \mathrm{E}-03$ & 0.375 & 0.16 & 0.0745 \\
\hline $\begin{array}{l}\text { Upper Drainage } \\
\text { Layer }\end{array}$ & 12 & $3.2 \mathrm{E}-03$ & 0.375 & 0.16 & 0.0745 \\
\hline $\begin{array}{l}\text { Lower Drainage } \\
\text { Layer }\end{array}$ & 24 & $1.0 \mathrm{E}-04$ & 0.37 & 0.24 & 0.136 \\
\hline
\end{tabular}

$\mathrm{NA}=$ not applicable

At 280,000 years the topsoil and upper backfill are completely eroded and the erosion barrier is at the ground surface. As outlined previously default HELP model soil texture number 8 is assumed to be equivalent to the erosion barrier based upon the saturated hydraulic conductivities. This HELP model soil texture will be used to determine the $\mathrm{CN}$ number for determination of runoff.

The above parameter values were utilized as HELP model input to determine the infiltration through the upper GCL at 280,000 years, when both the topsoil and upper backfill are completely eroded. The detailed HELP model input data and output file associated with this infiltration at year 280,000 are provided at the end of this appendix. The infiltration through the upper GCL at year 280,000 was determined to be 4.75118 inches/year.

\section{Year that Lower Drainage Layer Completely Silts In}

After year 10,000 it will be assumed that the infiltration through the upper GCL is 6.4 inches per year (i.e. maximum infiltration through the upper GCL). From previous calculations above:

- It takes a total of $13,269.8 \mathrm{ft}^{3}$ of infiltrating water to completely silt in the lower drainage layer

- Through year 10,000 the infiltrating water volume was $4,603.04 \mathrm{ft}^{3}$

Determine water volume remaining after year 10,000 to completely silt in the lower drainage layer:

$$
\mathrm{V}=13,269.8 \mathrm{ft}^{3}-4,603.04 \mathrm{ft}^{3}=8,666.76 \mathrm{ft}^{3}
$$

Determine length of time to obtain this volume at 6.4 inches per year over a $1-\mathrm{ft}^{2}$ area:

$$
\text { Time }=8,666.76 \mathrm{ft}^{3} \div\left(6.4 \mathrm{in} / \mathrm{yr} \times 12 \mathrm{ft} / \mathrm{in} \times 1-\mathrm{ft}^{2}\right)=16,250 \text { years }
$$


Determine time to completely silt in the lower drainage layer:

$$
\text { Time }=10,000 \text { years }+16,250 \text { years }=26,250 \text { years }
$$


Lower Bounding Scenario Degraded SDF MSE Vault Closure Cap (280,000 years): HELP Model Input Data and Output File (output file name: ZLBSWout.OUT)

\section{Input Data:}

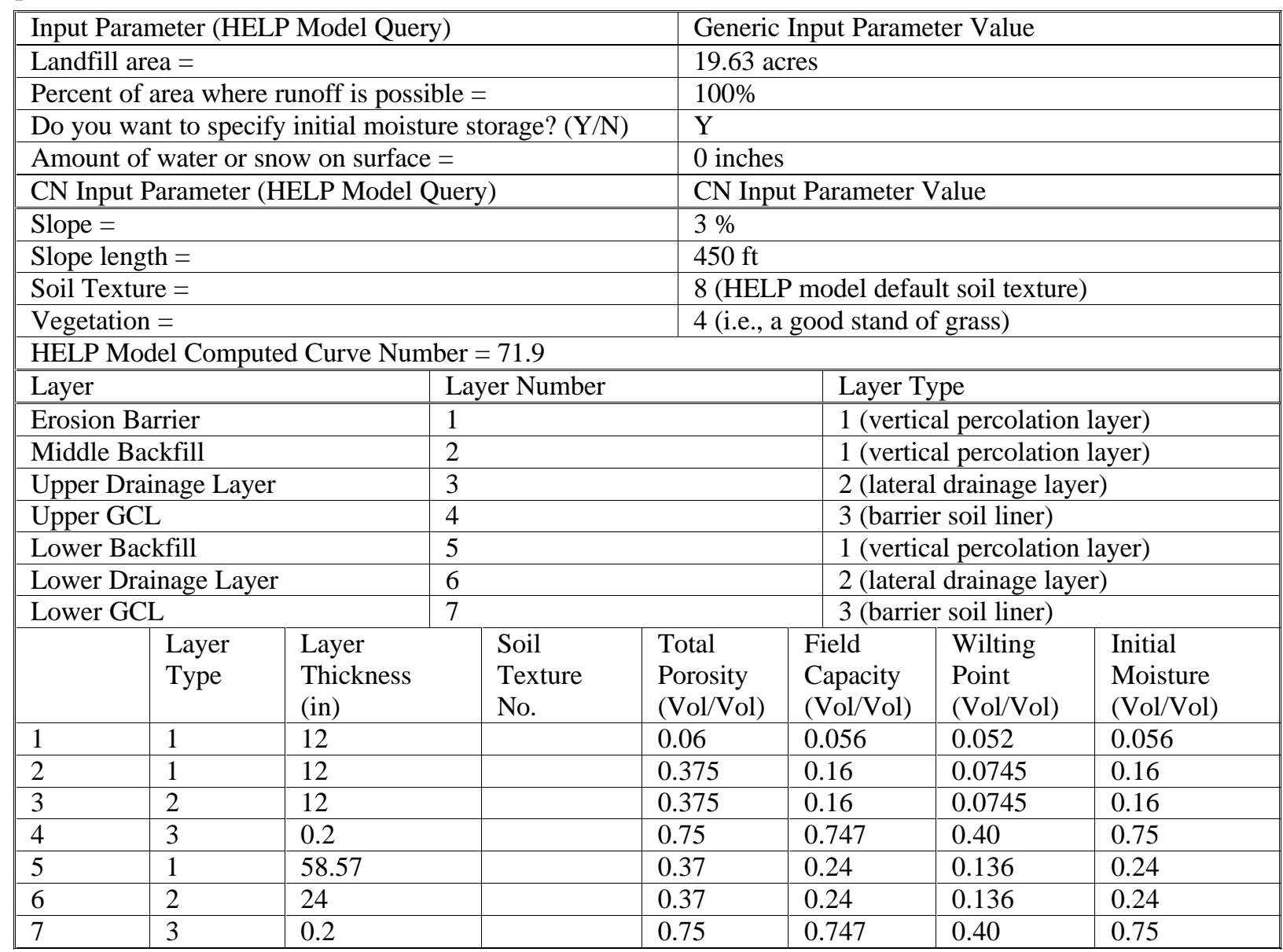

The lack of values in the table for particular parameters in particular layers denotes that no HELP model input was required for that parameter in that layer. No data are missing from the table. 
Input Data (continued):

\begin{tabular}{|c|c|c|c|c|c|c|c|c|c|}
\hline & $\begin{array}{l}\text { Layer } \\
\text { Type }\end{array}$ & $\begin{array}{l}\text { Sat. Hyd. } \\
\text { Conductivity * } \\
(\mathrm{cm} / \mathrm{sec})\end{array}$ & \multicolumn{2}{|c|}{$\begin{array}{l}\text { Drainage } \\
\text { Length } \\
(\mathrm{ft}) \\
\end{array}$} & $\begin{array}{l}\text { Drain } \\
\text { Slope } \\
(\%)\end{array}$ & $\begin{array}{l}\text { Leachate } \\
\text { Recirc. } \\
(\%)\end{array}$ & \multicolumn{2}{|c|}{$\begin{array}{l}\text { Recirc. to } \\
\text { Layer } \\
(\#)\end{array}$} & $\begin{array}{l}\text { Subsurface } \\
\text { Inflow } \\
\text { (in/yr) }\end{array}$ \\
\hline 1 & 1 & 3.97E-04 & & & & & & & \\
\hline 2 & 1 & $3.20 \mathrm{E}-03$ & & & & & & & \\
\hline 3 & 2 & $3.20 \mathrm{E}-03$ & 450 & & 3 & & & & \\
\hline 4 & 3 & $5.00 \mathrm{E}-09$ & & & & & & & \\
\hline 5 & 1 & $1.00 \mathrm{E}-04$ & & & & & & & \\
\hline 6 & 2 & $1.00 \mathrm{E}-04$ & 150 & & 11.4 & & & & \\
\hline 7 & 3 & $5.00 \mathrm{E}-09$ & & & & & & & \\
\hline & $\begin{array}{l}\text { Layer } \\
\text { Type }\end{array}$ & \multicolumn{2}{|l|}{$\begin{array}{l}\text { Geomembrane } \\
\text { Pinhole Density } \\
\text { (\#/acre) }\end{array}$} & $\begin{array}{l}\mathrm{Ge} \\
\mathrm{Ins} \\
(\# / \mathrm{c}\end{array}$ & $\begin{array}{l}\text { mbrane } \\
\text { Defects }\end{array}$ & \multicolumn{2}{|c|}{$\begin{array}{l}\text { Geomembrane } \\
\text { Placement Quality }\end{array}$} & \multicolumn{2}{|c|}{$\begin{array}{l}\text { Geotextile } \\
\text { Transmissivity } \\
\left(\mathrm{cm}^{2} / \mathrm{sec}\right)\end{array}$} \\
\hline 1 & 1 & & & & & & & & \\
\hline 2 & 1 & & & & & & & & \\
\hline 3 & 2 & & & & & & & & \\
\hline 4 & 3 & & & & & & & & \\
\hline 5 & 1 & & & & & & & & \\
\hline 6 & 2 & & & & & & & & \\
\hline 7 & 3 & & & & & & & & \\
\hline
\end{tabular}

The lack of values in the table for particular parameters in particular layers denotes that no HELP model input was required for that parameter in that layer. No data are missing from the table.

* The HELP model output often produces an increased number of significant digits for the Effective Saturated Hydraulic Conductivity over that of the actual input 


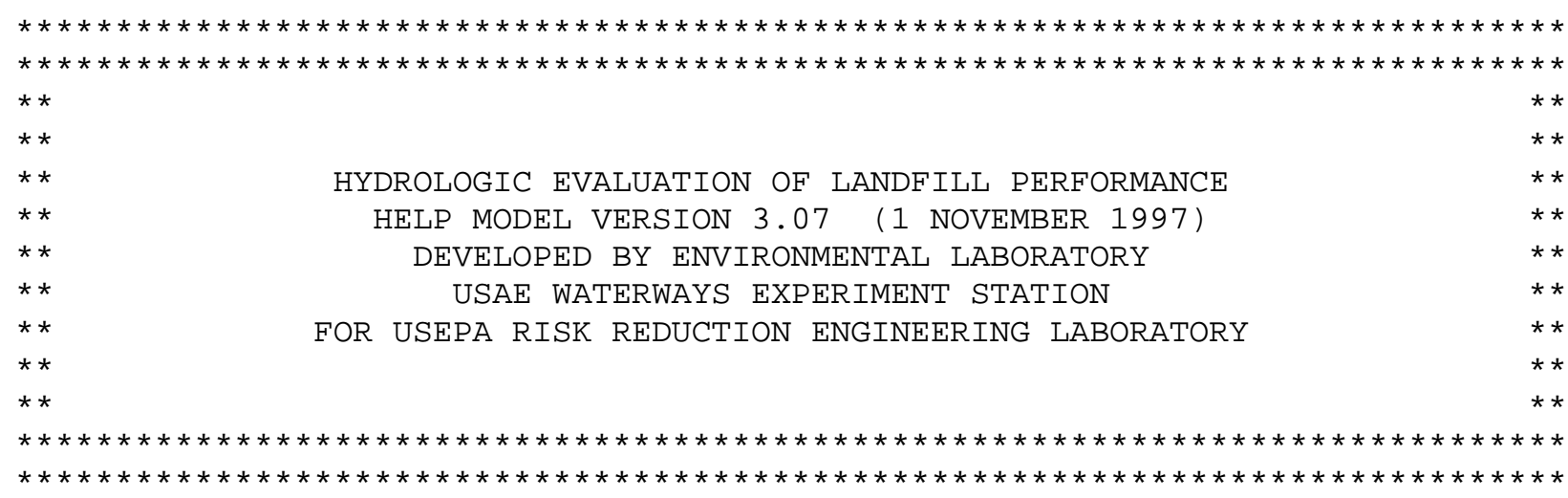

\begin{tabular}{|c|c|}
\hline PRECIPITATION DATA FILE: & $\mathrm{D}: \backslash$ HELP $3 \backslash$ Hweather $\backslash Z$ \\
\hline TEMPERATURE DATA FILE: & D : \HELP $3 \backslash$ Hweather $\backslash \mathrm{ZTEMP}$. D 7 \\
\hline SOLAR RADIATION DATA FILE: & D : \HELP $3 \backslash$ Hweather $\backslash$ ZSOLAR.D13 \\
\hline EVAPOTRANSPIRATION DATA: & D : \HELP $3 \backslash$ Hweat her $\backslash$ ZEVAP . D11 \\
\hline SOIL AND DESIGN DATA FILE: & D : \HELP $3 \backslash$ Hsdfmse $\backslash$ ZLBSW . D10 \\
\hline UTPUT DATA FILE: & $\mathrm{D}: \backslash$ HELP $3 \backslash$ Hsdfmse $\backslash Z L B S W o u$ \\
\hline
\end{tabular}

TIME : $13: 28 \quad$ DATE $: \quad 1 / 14 / 2004$

TITLE: LBS Degraded MSE Vault Closure Cap - 280,000 years

NOTE: INITIAL MOISTURE CONTENT OF THE LAYERS AND SNOW WATER WERE SPECIFIED BY THE USER.

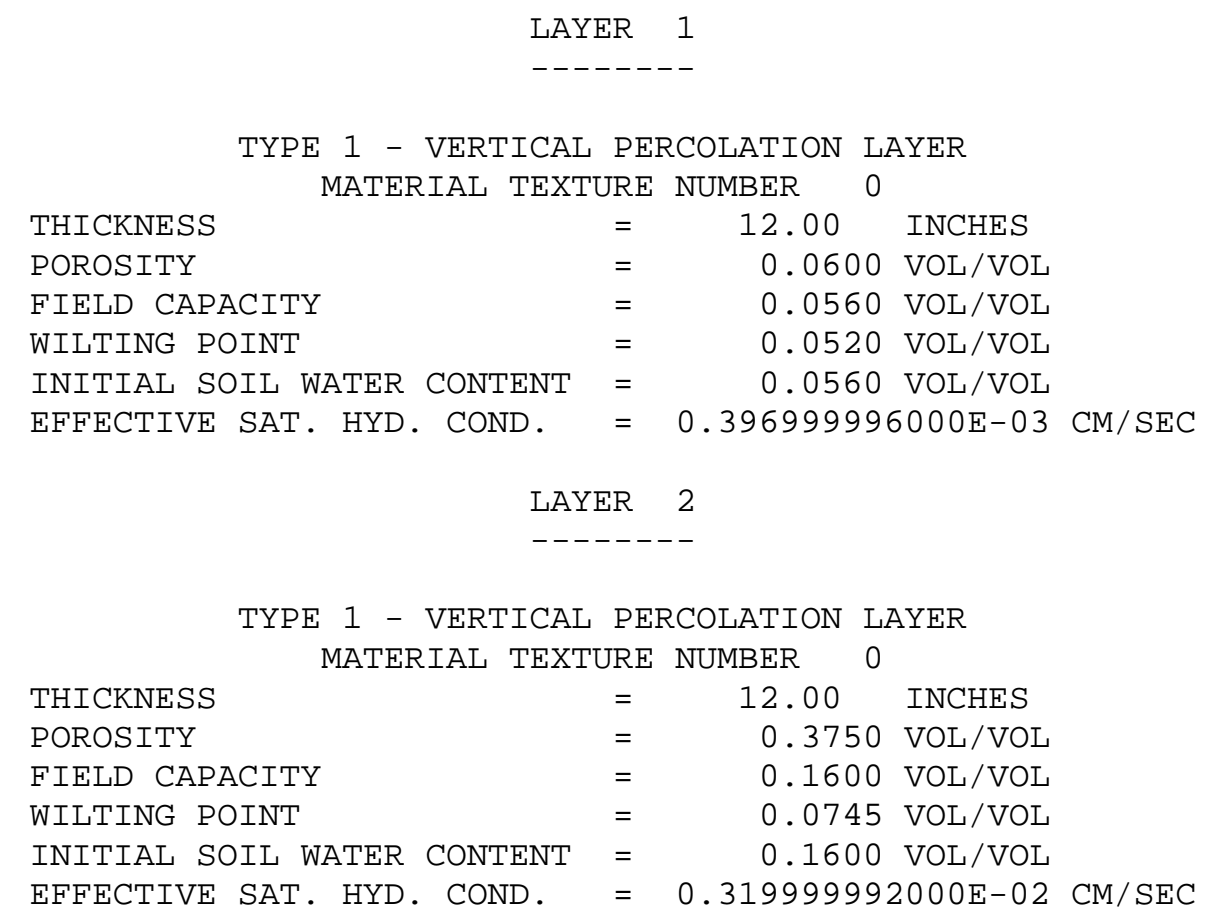

Rev. 0 
LAYER 3

--------

TYPE 2 - LATERAL DRAINAGE LAYER

MATERIAL TEXTURE NUMBER 0

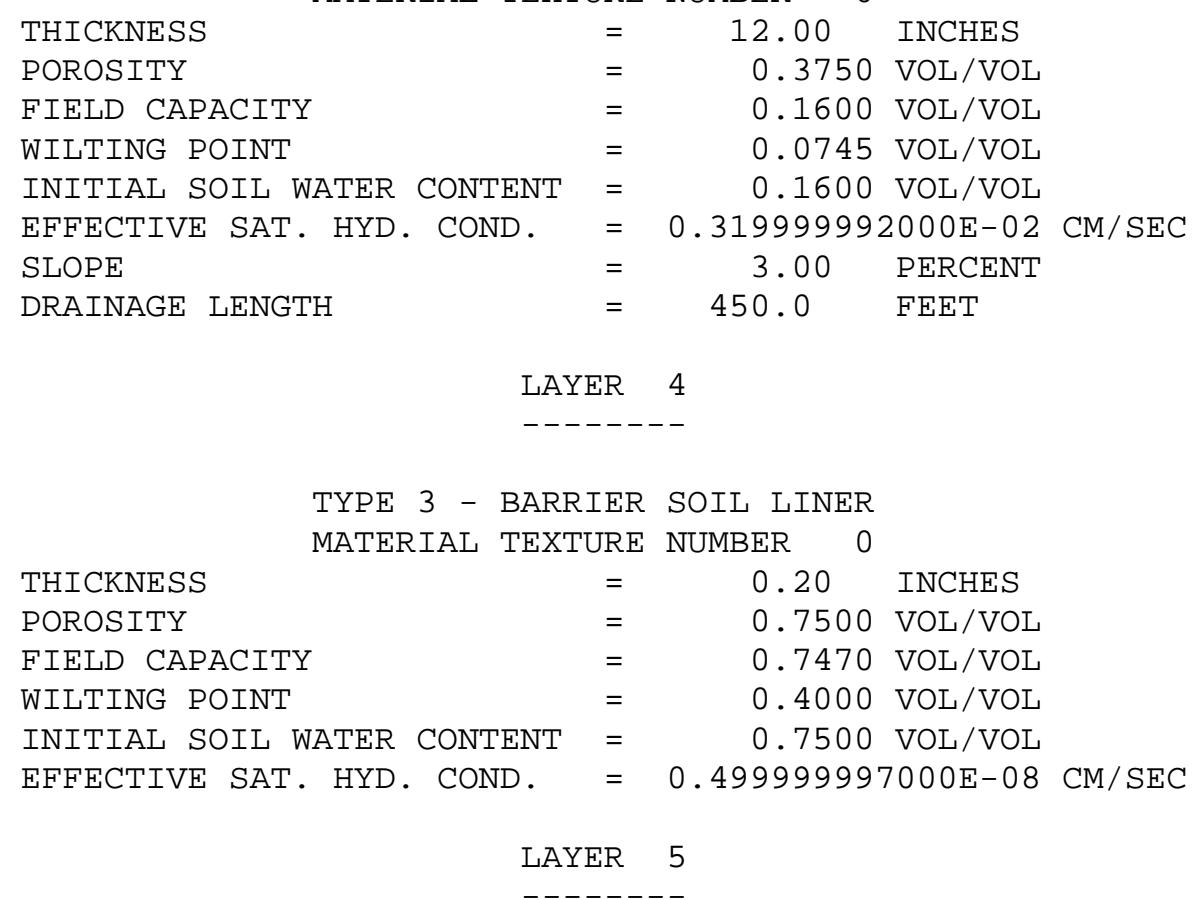

TYPE 1 - VERTICAL PERCOLATION LAYER MATERIAL TEXTURE NUMBER 0

$\begin{array}{llrl}\text { THICKNESS } & = & 58.57 \mathrm{INCHES} \\ \text { POROSITY } & = & 0.3700 \mathrm{VOL} / \mathrm{VOL} \\ \text { FIELD CAPACITY } & = & 0.2400 \mathrm{VOL} / \mathrm{VOL} \\ \text { WILTING POINT } & = & 0.1360 \mathrm{VOL} / \mathrm{VOL} \\ \text { INITIAL SOIL WATER CONTENT } & = & 0.2400 \mathrm{VOL} / \mathrm{VOL} \\ \text { EFFECTIVE SAT. HYD. COND. } & =0.999999975000 \mathrm{E}-04 \mathrm{CM} / \mathrm{SEC}\end{array}$

LAYER 6

$--------$

TYPE 2 - LATERAL DRAINAGE LAYER

MATERIAL TEXTURE NUMBER 0

THICKNESS

POROSITY

$=24.00 \quad$ INCHES

FIELD CAPACITY

$=0.3700 \mathrm{VOL} / \mathrm{VOL}$

WILTING POINT $=0.1360 \mathrm{VOL} / \mathrm{VOL}$

INITIAL SOIL WATER CONTENT $=0.2400 \mathrm{VOL} / \mathrm{VOL}$

EFFECTIVE SAT. HYD. COND. $=0.999999975000 \mathrm{E}-04 \mathrm{CM} / \mathrm{SEC}$

SLOPE

$=\quad 11.40 \quad$ PERCENT

DRAINAGE LENGTH

$=\quad 150.0 \quad \mathrm{FEET}$ 
LAYER 7

$--------$

TYPE 3 - BARRIER SOIL LINER

MATERIAL TEXTURE NUMBER 0

$\begin{array}{llll}\text { THICKNESS } & = & 0.20 \mathrm{INCHES} \\ \text { POROSITY } & = & 0.7500 \mathrm{VOL} / \mathrm{VOL} \\ \text { FIELD CAPACITY } & = & 0.7470 \mathrm{VOL} / \mathrm{VOL} \\ \text { WILTING POINT } & = & 0.4000 \mathrm{VOL} / \mathrm{VOL} \\ \text { INITIAL SOIL WATER CONTENT } & = & 0.7500 \mathrm{VOL} / \mathrm{VOL} \\ \text { EFFECTIVE SAT. HYD. COND. } & =0.499999997000 \mathrm{E}-08 \mathrm{CM} / \mathrm{SEC}\end{array}$

GENERAL DESIGN AND EVAPORATIVE ZONE DATA

NOTE: SCS RUNOFF CURVE NUMBER WAS COMPUTED FROM DEFAULT SOIL DATA BASE USING SOIL TEXTURE \# 8 WITH A GOOD STAND OF GRASS, A SURFACE SLOPE OF 3.\% AND A SLOPE LENGTH OF 450. FEET.

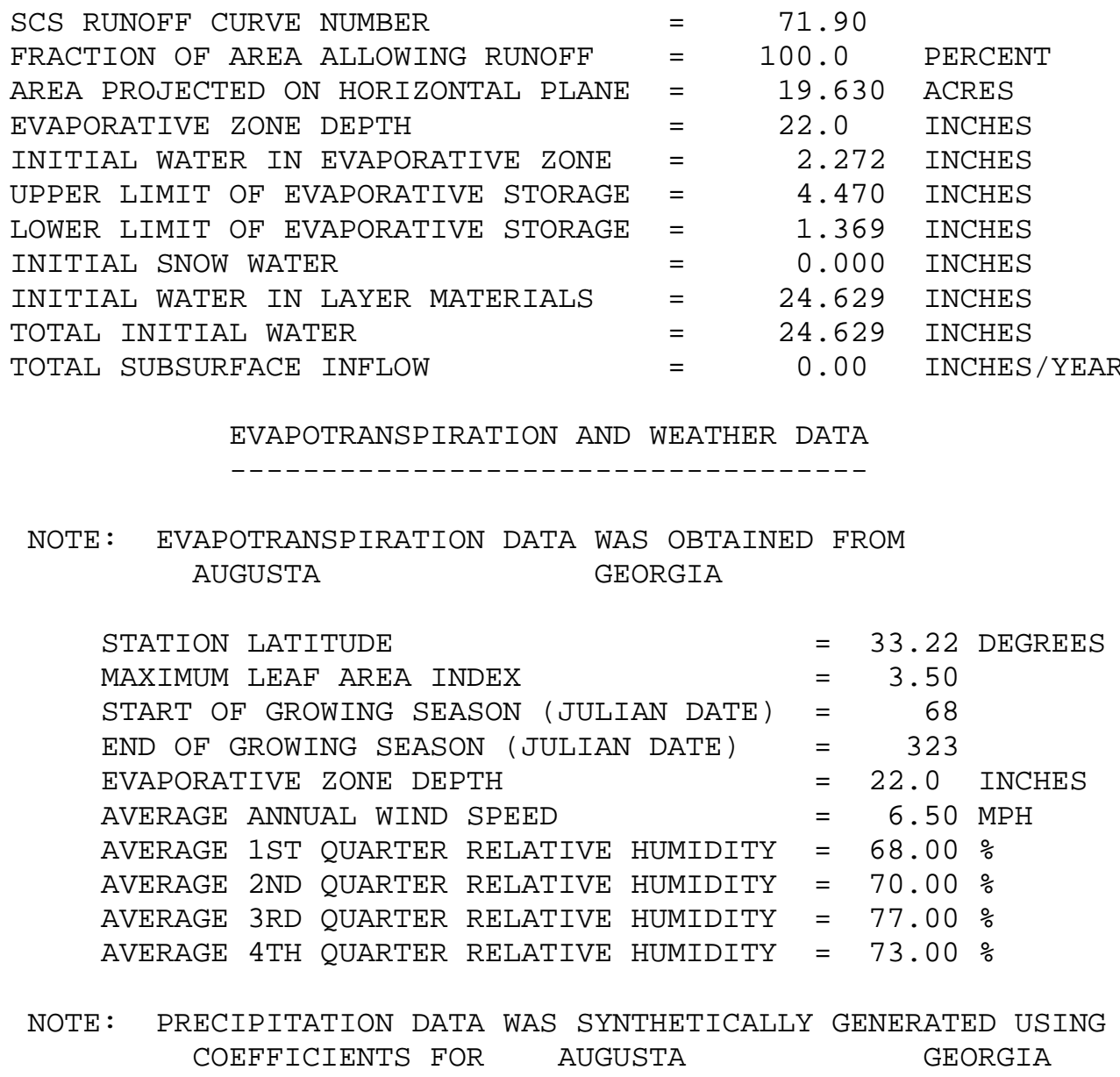


NORMAL MEAN MONTHLY PRECIPITATION (INCHES)

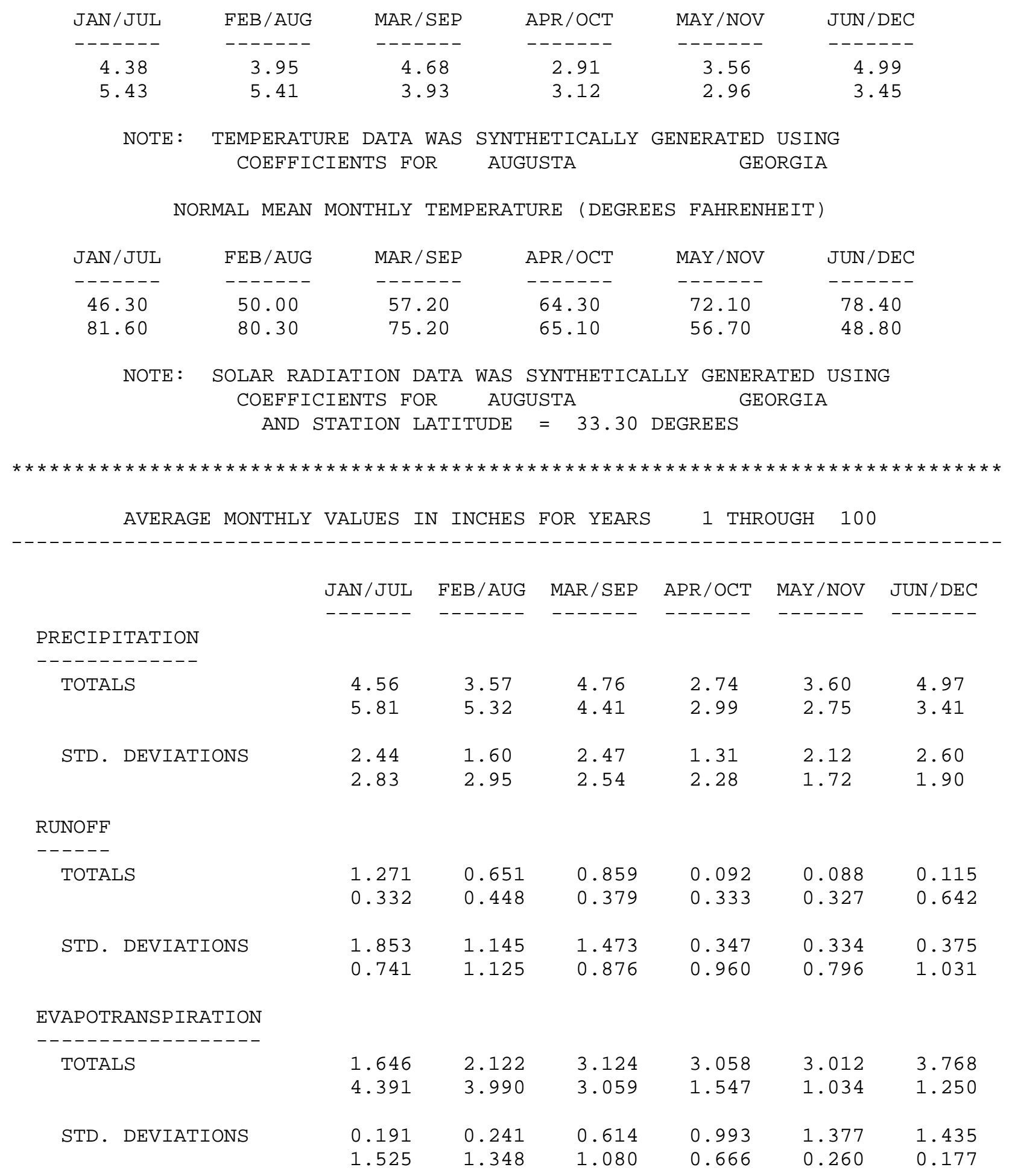


LATERAL DRAINAGE COLLECTED FROM LAYER 3

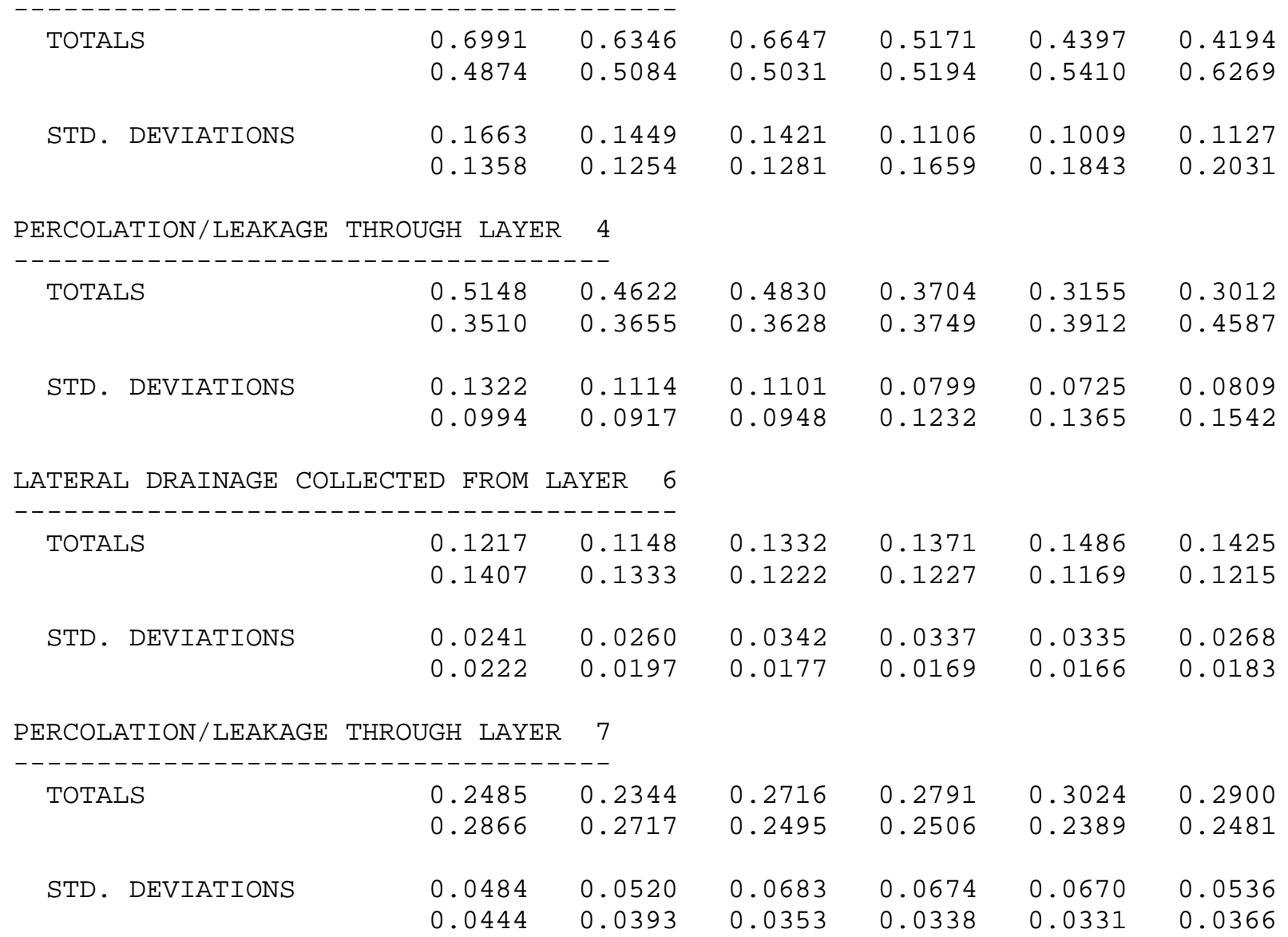

DAILY AVERAGE HEAD ON TOP OF LAYER 4

$\begin{array}{lllllll}\text { AVERAGES } & 19.3304 & 19.0270 & 18.1211 & 14.3182 & 11.7689 & 11.6082 \\ & 13.1135 & 13.6633 & 14.0202 & 14.0219 & 15.1354 & 17.2001 \\ & & & & & & \\ \text { STD. DEVIATIONS } & 5.0087 & 4.5875 & 4.1763 & 3.1330 & 2.7496 & 3.1696 \\ & 3.7718 & 3.4770 & 3.7177 & 4.6718 & 5.3506 & 5.8492\end{array}$

DAILY AVERAGE HEAD ON TOP OF LAYER 7

$\begin{array}{lrrrrrr}\text { AVERAGES } & 9.2267 & 9.5590 & 10.1047 & 10.7419 & 11.2712 & 11.1683 \\ & 10.6730 & 10.1073 & 9.5791 & 9.3045 & 9.1634 & 9.2125 \\ & & & & & & \\ \text { STD. DEVIATIONS } & 1.8269 & 2.1831 & 2.5920 & 2.6422 & 2.5414 & 2.1011 \\ & 1.6843 & 1.4907 & 1.3838 & 1.2808 & 1.2976 & 1.3878\end{array}$




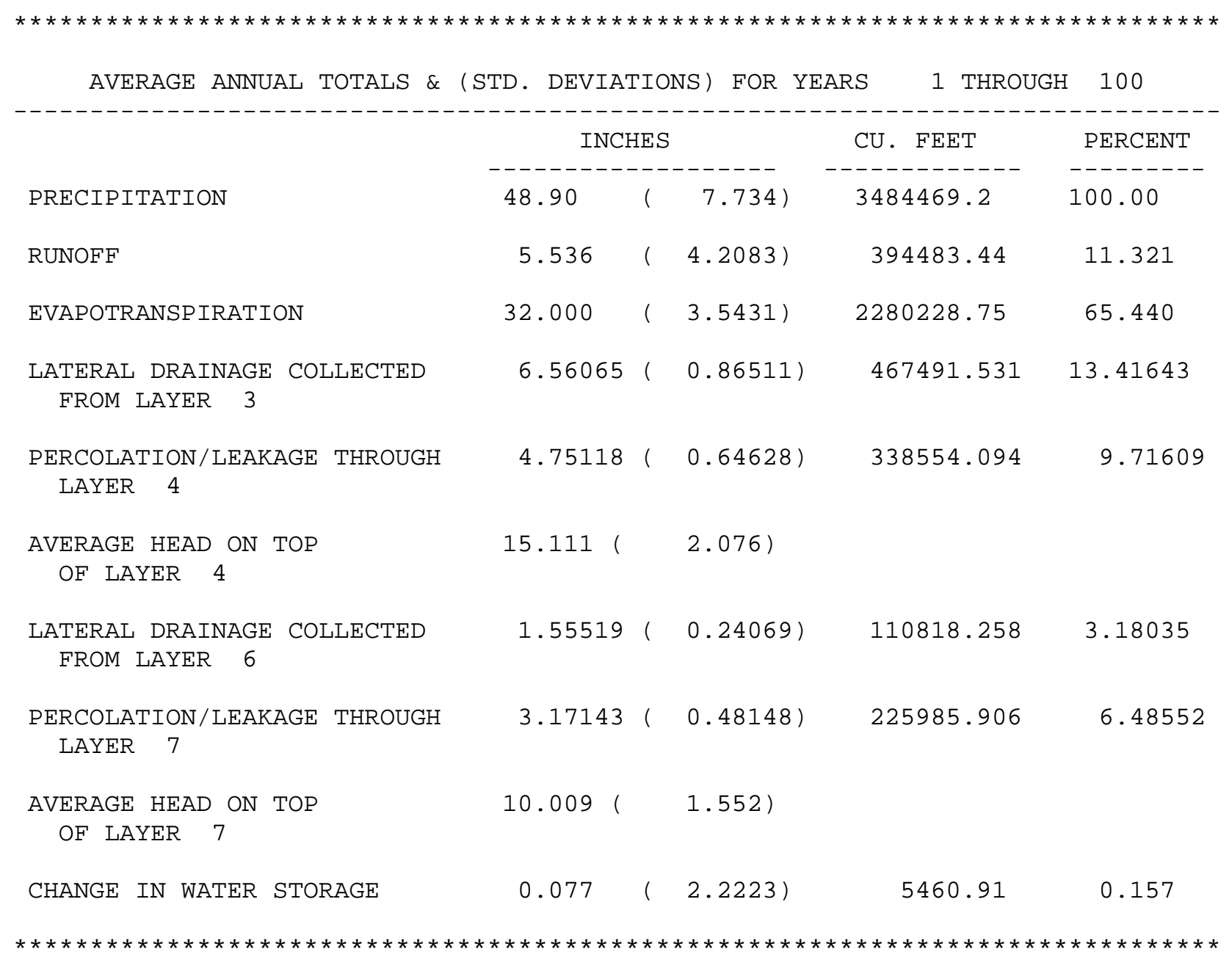




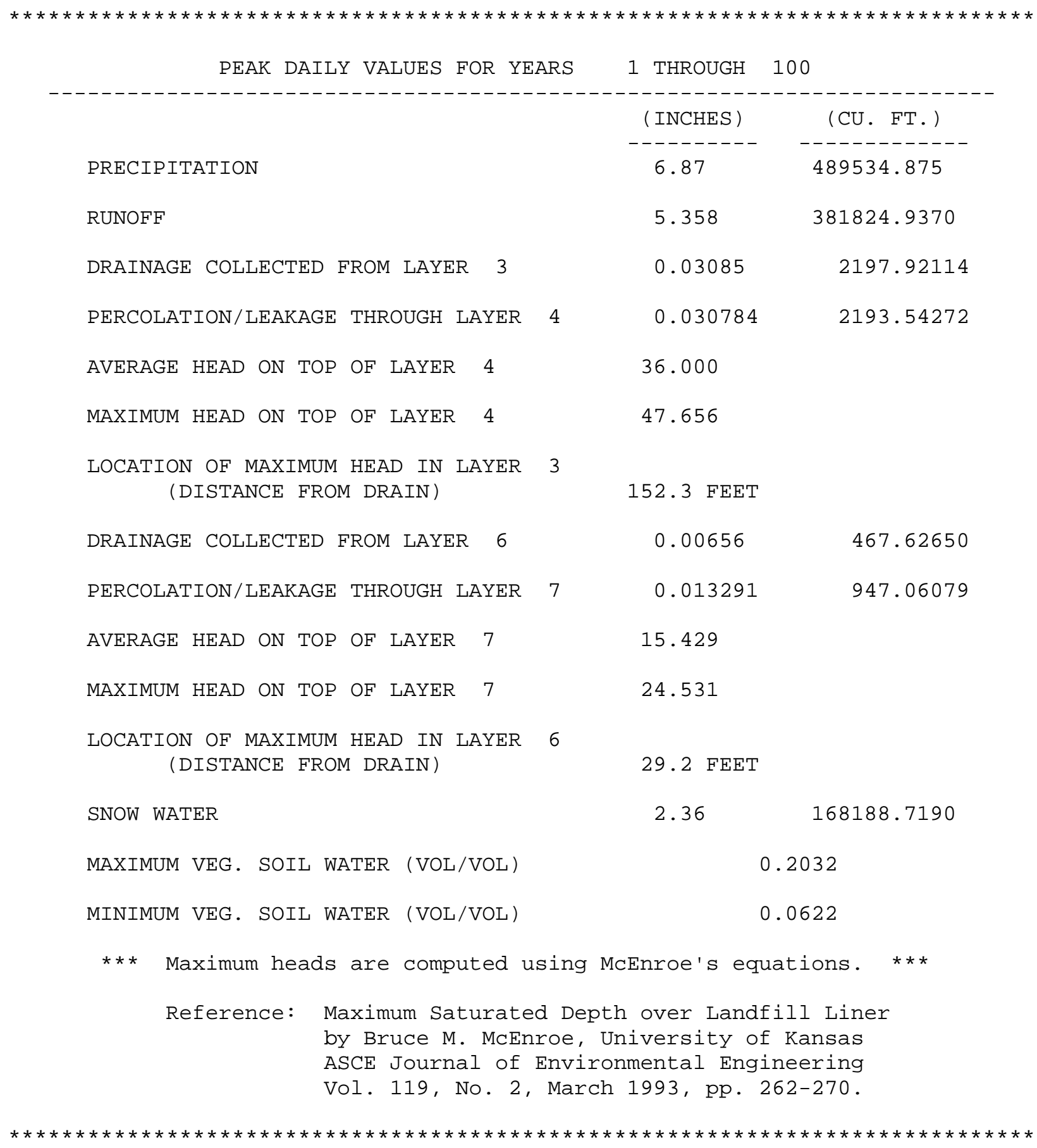

Rev. 0 


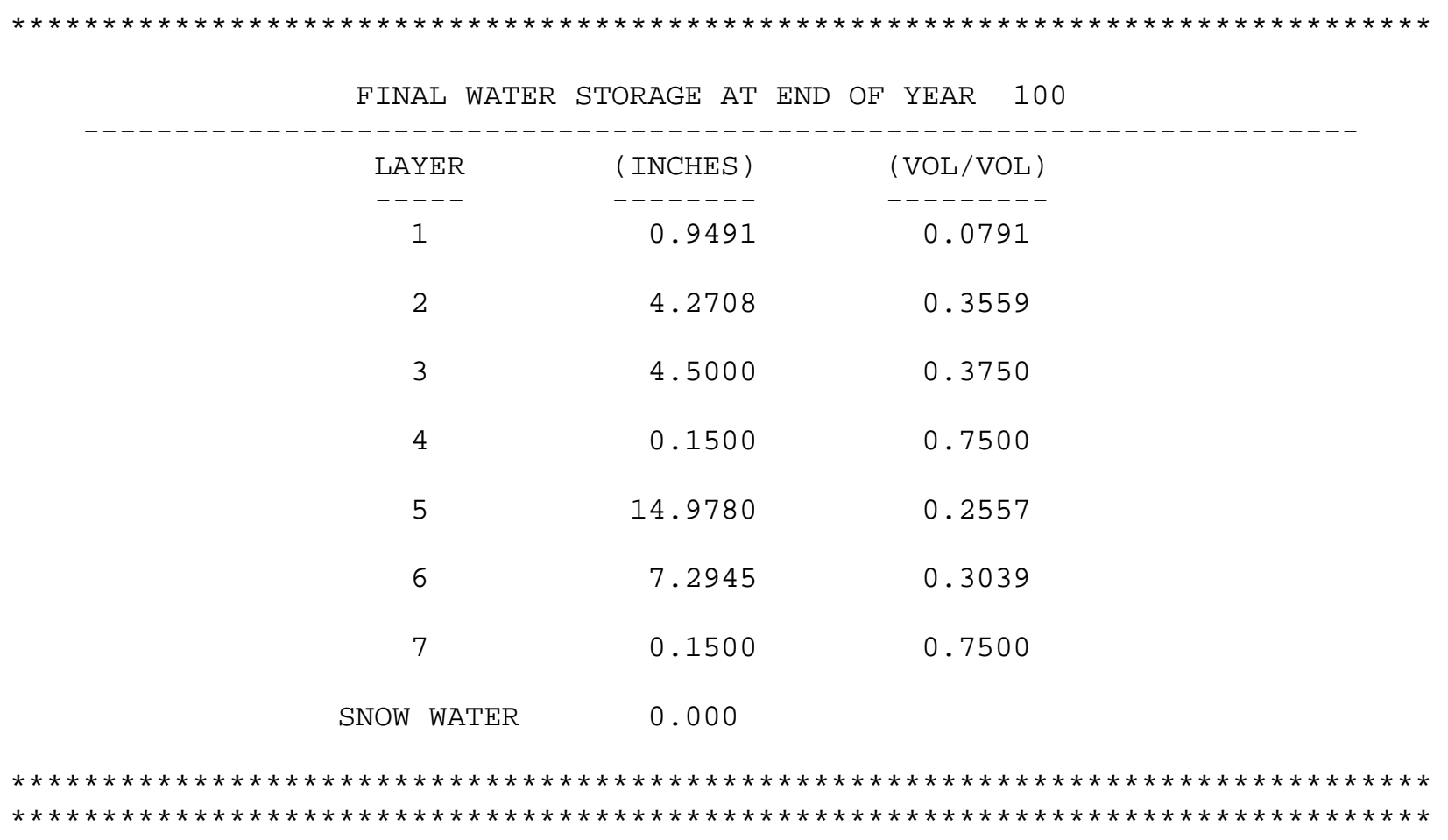


Appendix G, Lower Bounding Scenario Degraded SDF MSE Vault Closure Cap (100 Years): HELP Model Input Data and Output File (output file name: ZLBS1out.OUT)

\section{Input Data:}

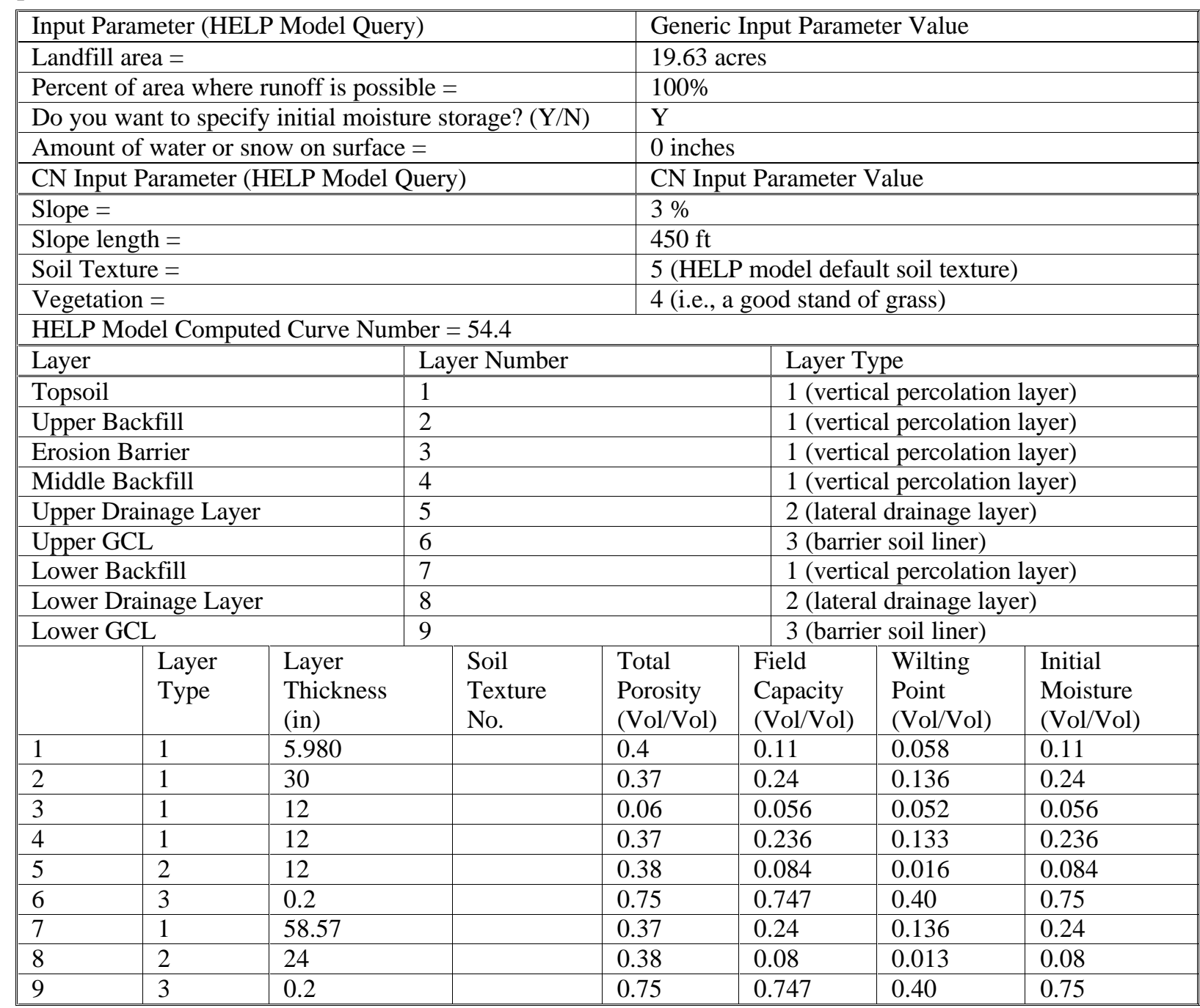

The lack of values in the table for particular parameters in particular layers denotes that no HELP model input was required for that parameter in that layer. No data are missing from the table. 
Input Data (continued):

\begin{tabular}{|c|c|c|c|c|c|c|c|c|c|}
\hline & $\begin{array}{l}\text { Layer } \\
\text { Type }\end{array}$ & $\begin{array}{l}\text { Sat. Hyd. } \\
\text { Conductivity * } \\
(\mathrm{cm} / \mathrm{sec})\end{array}$ & \multicolumn{2}{|c|}{$\begin{array}{l}\text { Drainage } \\
\text { Length } \\
(\mathrm{ft})\end{array}$} & $\begin{array}{l}\text { Drain } \\
\text { Slope } \\
(\%)\end{array}$ & $\begin{array}{l}\text { Leachate } \\
\text { Recirc. } \\
(\%) \\
\end{array}$ & \multicolumn{2}{|c|}{$\begin{array}{l}\text { Recirc. to } \\
\text { Layer } \\
(\#)\end{array}$} & $\begin{array}{l}\text { Subsurface } \\
\text { Inflow } \\
\text { (in/yr) }\end{array}$ \\
\hline 1 & 1 & $1.00 \mathrm{E}-03$ & & & & & & & \\
\hline 2 & 1 & $1.00 \mathrm{E}-04$ & & & & & & & \\
\hline 3 & 1 & $3.97 \mathrm{E}-04$ & & & & & & & \\
\hline 4 & 1 & $1.20 \mathrm{E}-04$ & & & & & & & \\
\hline 5 & 2 & $8.60 \mathrm{E}-02$ & 450 & & 3 & & & & \\
\hline 6 & 3 & $5.00 \mathrm{E}-09$ & & & & & & & \\
\hline 7 & 1 & $1.00 \mathrm{E}-04$ & & & & & & & \\
\hline 8 & 2 & $1.00 \mathrm{E}-01$ & 150 & & 11.4 & & & & \\
\hline \multirow[t]{2}{*}{9} & 3 & $5.00 \mathrm{E}-09$ & & & & & & \\
\hline & $\begin{array}{l}\text { Layer } \\
\text { Type }\end{array}$ & \multicolumn{2}{|l|}{$\begin{array}{l}\text { Geomembrane } \\
\text { Pinhole Density } \\
\text { (\#/acre) }\end{array}$} & \multicolumn{2}{|c|}{$\begin{array}{l}\text { Geomembrane } \\
\text { Instal. Defects } \\
(\# / \text { acre })\end{array}$} & \multicolumn{2}{|c|}{$\begin{array}{l}\text { Geomembrane } \\
\text { Placement Quality }\end{array}$} & \multicolumn{2}{|c|}{$\begin{array}{l}\text { Geotextile } \\
\text { Transmissivity } \\
\left(\mathrm{cm}^{2} / \mathrm{sec}\right)\end{array}$} \\
\hline 1 & 1 & & & & & & & & \\
\hline 2 & 1 & & & & & & & & \\
\hline 3 & 1 & & & & & & & & \\
\hline 4 & 1 & & & & & & & & \\
\hline 5 & 2 & & & & & & & & \\
\hline 6 & 3 & & & & & & & & \\
\hline 7 & 1 & & & & & & & & \\
\hline 8 & 2 & & & & & & & & \\
\hline 9 & 3 & & & & & & & & \\
\hline
\end{tabular}

The lack of values in the table for particular parameters in particular layers denotes that no HELP model input was required for that parameter in that layer. No data are missing from the table.

* The HELP model output often produces an increased number of significant digits for the Effective Saturated Hydraulic Conductivity over that of the actual input 


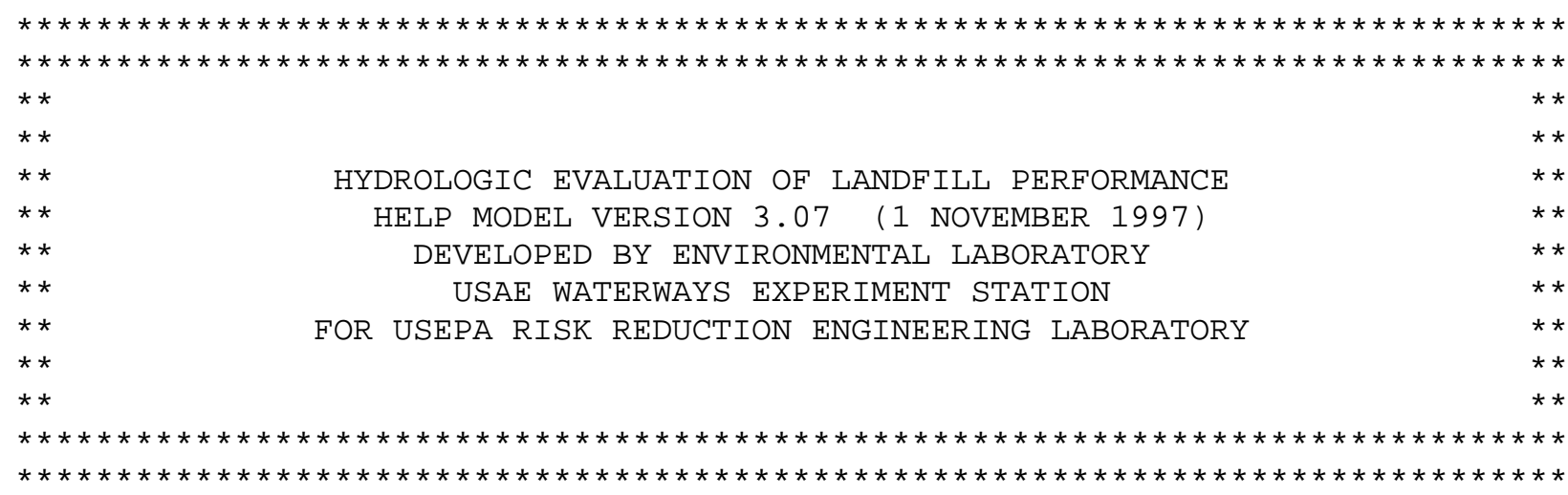
PRECIPITATION DATA FILE:
D: \HELP 3 \Hweather $\backslash$ ZPREC.D4
TEMPERATURE DATA FILE:
D: \HELP $3 \backslash$ Hweather $\backslash$ ZTEMP.D7
SOLAR RADIATION DATA FILE: D: \HELP3\Hweather $\backslash$ ZSOLAR.D13
EVAPOTRANSPIRATION DATA: D: \HELP3\Hweather $\backslash$ ZEVAP.D11
SOIL AND DESIGN DATA FILE: D: \HELP3\Hsdfmse \ZLBS1.D10
OUTPUT DATA FILE:
D: \HELP $3 \backslash$ Hsdfmse $\backslash Z L B S 1$ out.OUT

TIME: $\quad 9: 10 \quad$ DATE $: \quad 12 / 11 / 2003$

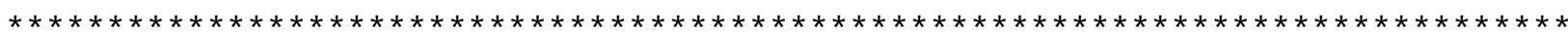

TITLE: LBS Degraded MSE Vault Closure Cap - 100 Years

NOTE: INITIAL MOISTURE CONTENT OF THE LAYERS AND SNOW WATER WERE SPECIFIED BY THE USER.

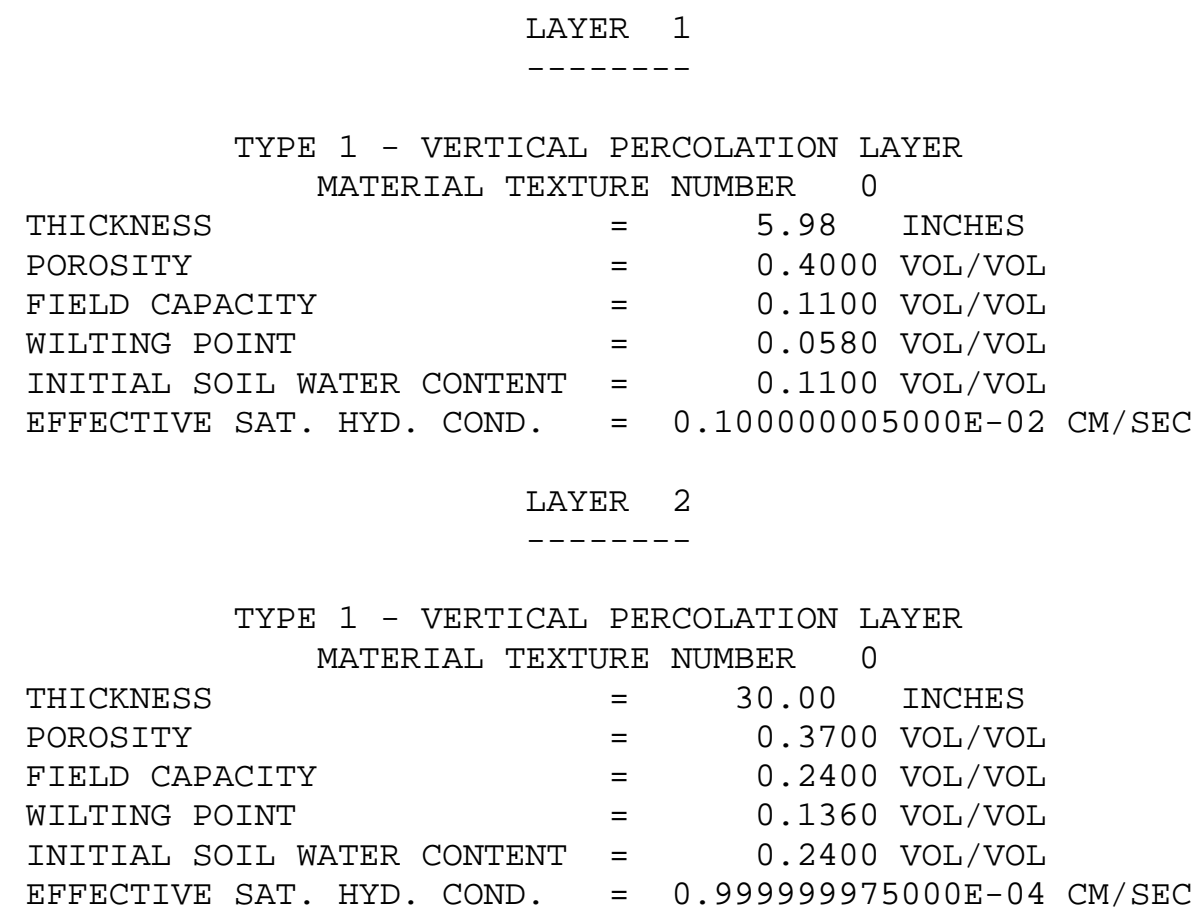

Rev. 0 
LAYER 3

--------

TYPE 1 - VERTICAL PERCOLATION LAYER

MATERIAL TEXTURE NUMBER 0

$\begin{array}{llrl}\text { THICKNESS } & = & 12.00 \mathrm{INCHES} \\ \text { POROSITY } & = & 0.0600 \mathrm{VOL} / \mathrm{VOL} \\ \text { FIELD CAPACITY } & = & 0.0560 \mathrm{VOL} / \mathrm{VOL} \\ \text { WILTING POINT } & = & 0.0520 \mathrm{VOL} / \mathrm{VOL} \\ \text { INITIAL SOIL WATER CONTENT } & = & 0.0560 \mathrm{VOL} / \mathrm{VOL} \\ \text { EFFECTIVE SAT. HYD. COND. } & =0.396999996000 \mathrm{E}-03 \mathrm{CM} / \mathrm{SEC}\end{array}$

LAYER 4

TYPE 1 - VERTICAL PERCOLATION LAYER MATERIAL TEXTURE NUMBER 0

$\begin{array}{llrl}\text { THICKNESS } & = & 12.00 & \text { INCHES } \\ \text { POROSITY } & = & 0.3700 \mathrm{VOL} / \mathrm{VOL} \\ \text { FIELD CAPACITY } & = & 0.2360 \mathrm{VOL} / \mathrm{VOL} \\ \text { WILTING POINT } & = & 0.1330 \mathrm{VOL} / \mathrm{VOL} \\ \text { INITIAL SOIL WATER CONTENT } & = & 0.2360 \mathrm{VOL} / \mathrm{VOL} \\ \text { EFFECTIVE SAT. HYD. COND. } & =0.11999999000 \mathrm{E}-03 \mathrm{CM} / \mathrm{SEC}\end{array}$

LAYER 5

$--------$

TYPE 2 - LATERAL DRAINAGE LAYER MATERIAL TEXTURE NUMBER 0

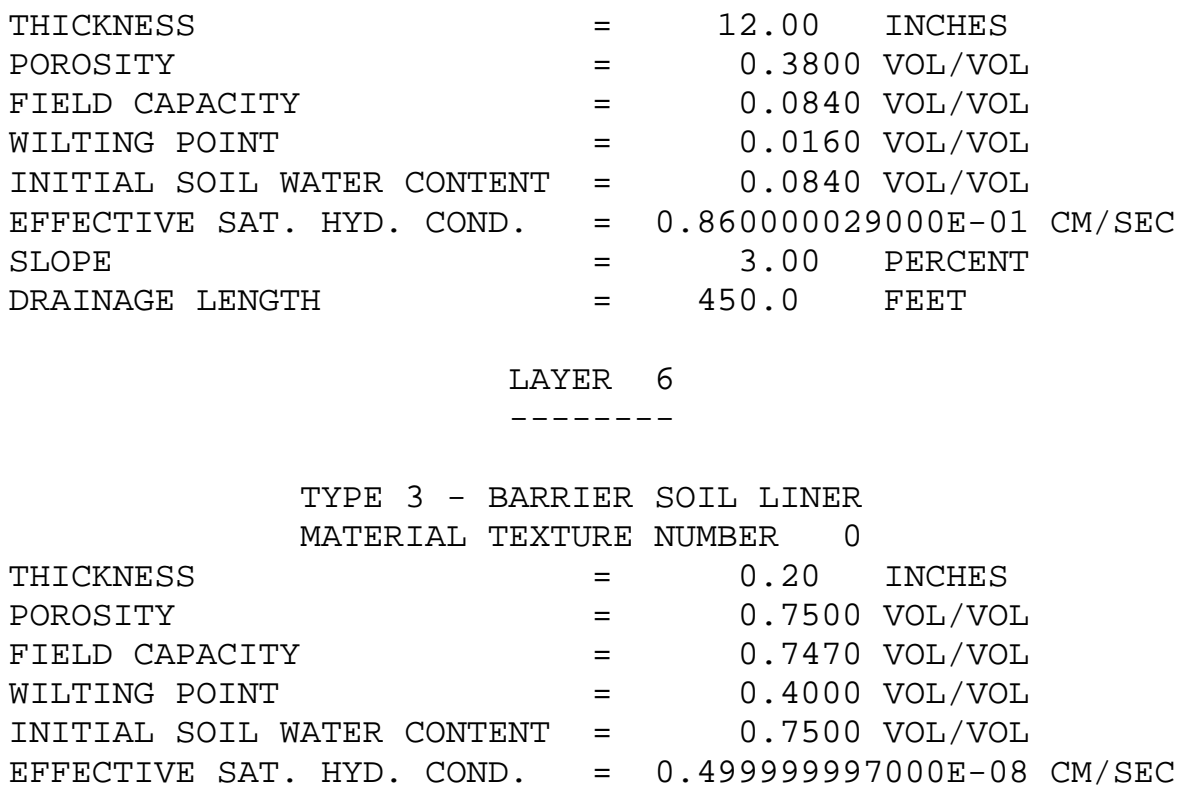


LAYER 7

$--------$

TYPE 1 - VERTICAL PERCOLATION LAYER

MATERIAL TEXTURE NUMBER 0

$\begin{array}{llrl}\text { THICKNESS } & = & 58.57 & \text { INCHES } \\ \text { POROSITY } & = & 0.3700 \mathrm{VOL} / \mathrm{VOL} \\ \text { FIELD CAPACITY } & = & 0.2400 \mathrm{VOL} / \mathrm{VOL} \\ \text { WILTING POINT } & = & 0.1360 \mathrm{VOL} / \mathrm{VOL} \\ \text { INITIAL SOIL WATER CONTENT } & = & 0.2400 \mathrm{VOL} / \mathrm{VOL} \\ \text { EFFECTIVE SAT. HYD. COND. } & =0.999999975000 \mathrm{E}-04 \mathrm{CM} / \mathrm{SEC}\end{array}$

LAYER 8

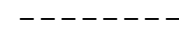

TYPE 2 - LATERAL DRAINAGE LAYER

$\begin{array}{llrl}\text { THICKNESS } & = & 24.00 & \text { INCHES } \\ \text { POROSITY } & = & 0.3800 \mathrm{VOL} / \mathrm{VOL} \\ \text { FIELD CAPACITY } & = & 0.0800 \mathrm{VOL} / \mathrm{VOL} \\ \text { WILTING POINT } & = & 0.0130 \mathrm{VOL} / \mathrm{VOL} \\ \text { INITIAL SOIL WATER CONTENT } & = & 0.0800 \mathrm{VOL} / \mathrm{VOL} \\ \text { EFFECTIVE SAT. HYD. COND. } & = & 0.10000001000 & \mathrm{CM} / \mathrm{SEC} \\ \text { SLOPE } & = & 11.40 \mathrm{PERCENT} & \\ \text { DRAINAGE LENGTH } & = & 150.0 & \mathrm{FEET}\end{array}$

LAYER 9

TYPE 3 - BARRIER SOIL LINER

MATERIAL TEXTURE NUMBER 0

$\begin{array}{llll}\text { THICKNESS } & = & 0.20 & \text { INCHES } \\ \text { POROSITY } & = & 0.7500 \mathrm{VOL} / \mathrm{VOL} \\ \text { FIELD CAPACITY } & = & 0.7470 \mathrm{VOL} / \mathrm{VOL} \\ \text { WILTING POINT } & = & 0.4000 \mathrm{VOL} / \mathrm{VOL} \\ \text { INITIAL SOIL WATER CONTENT } & = & 0.7500 \mathrm{VOL} / \mathrm{VOL} \\ \text { EFFECTIVE SAT. HYD. COND. } & =0.499999997000 \mathrm{E}-08 \mathrm{CM} / \mathrm{SEC}\end{array}$

GENERAL DESIGN AND EVAPORATIVE ZONE DATA

NOTE: SCS RUNOFF CURVE NUMBER WAS COMPUTED FROM DEFAULT SOIL DATA BASE USING SOIL TEXTURE \# 5 WITH A GOOD STAND OF GRASS, A SURFACE SLOPE OF 3.\% AND A SLOPE LENGTH OF 450. FEET.

SCS RUNOFF CURVE NUMBER

FRACTION OF AREA ALLOWING RUNOFF

AREA PROJECTED ON HORIZONTAL PLANE

EVAPORATIVE ZONE DEPTH

INITIAL WATER IN EVAPORATIVE ZONE

UPPER LIMIT OF EVAPORATIVE STORAGE

LOWER LIMIT OF EVAPORATIVE STORAGE

INITIAL SNOW WATER

INITIAL WATER IN LAYER MATERIALS

TOTAL INITIAL WATER

TOTAL SUBSURFACE INFLOW

$\begin{array}{lcl}= & 54.40 & \\ = & 100.0 & \text { PERCENT } \\ = & 19.630 & \text { ACRES } \\ = & 22.0 & \text { INCHES } \\ = & 4.503 & \text { INCHES } \\ = & 8.319 & \text { INCHES } \\ = & 2.526 & \text { INCHES } \\ = & 0.000 & \text { INCHES } \\ = & 28.647 & \text { INCHES } \\ = & 28.647 & \text { INCHES } \\ = & 0.00 & \text { INCHES /YEAR }\end{array}$

Rev. 0 


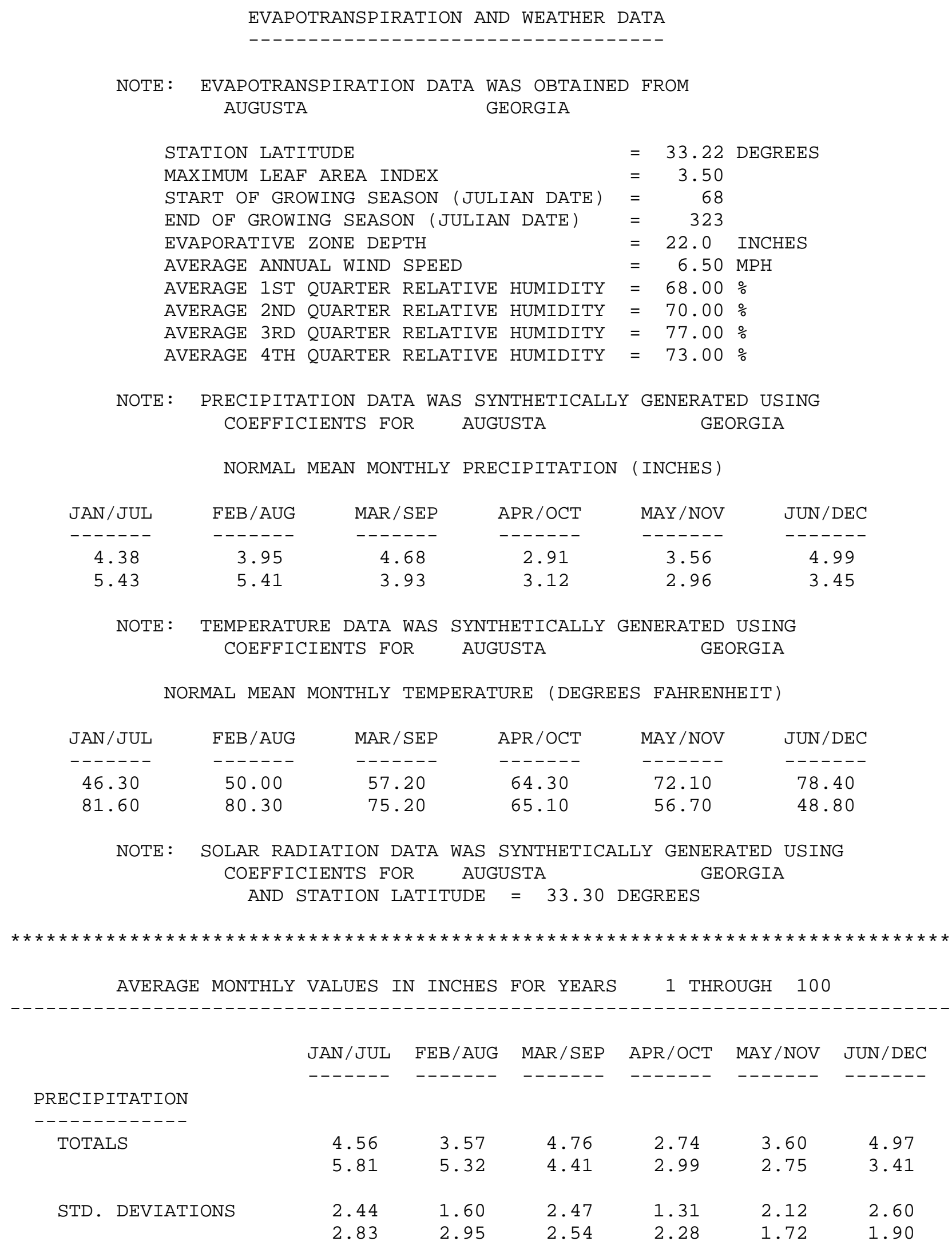

Rev. 0 
RUNOFF

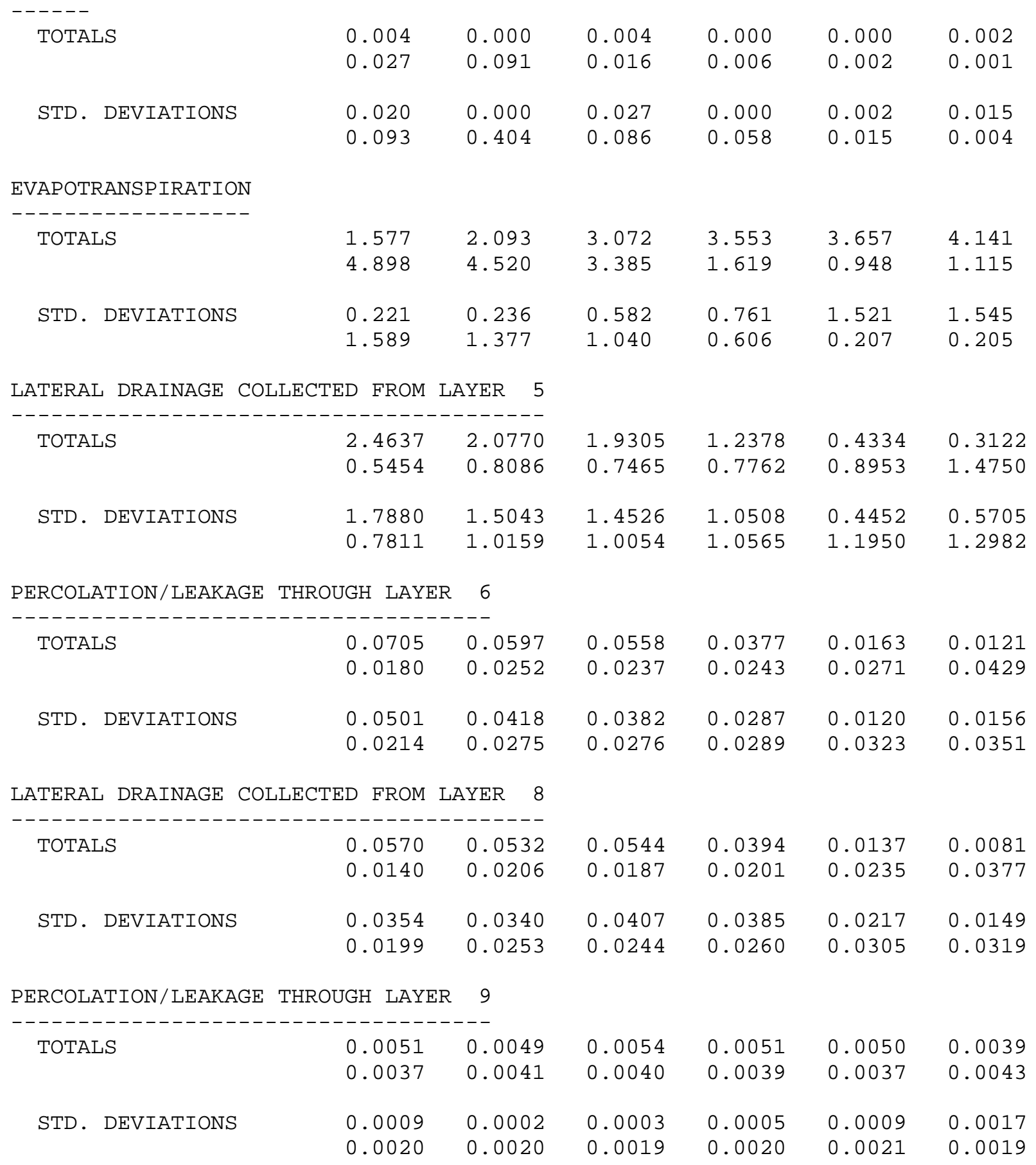


AVERAGES OF MONTHLY AVERAGED DAILY HEADS (INCHES)

DAILY AVERAGE HEAD ON TOP OF LAYER 6

$\begin{array}{lllllll}\text { AVERAGES } & 2.4840 & 2.2841 & 1.9194 & 1.2805 & 0.4305 & 0.3204 \\ & 0.5418 & 0.8032 & 0.7723 & 0.7744 & 0.9190 & 1.4652 \\ & & & & & & \\ & 1.8885 & 1.7392 & 1.4460 & 1.1237 & 0.4423 & 0.5856 \\ \text { STD. DEVIATIONS } & 0.7759 & 1.0092 & 1.0497 & 1.0610 & 1.2266 & 1.2896\end{array}$

DAILY AVERAGE HEAD ON TOP OF LAYER 9

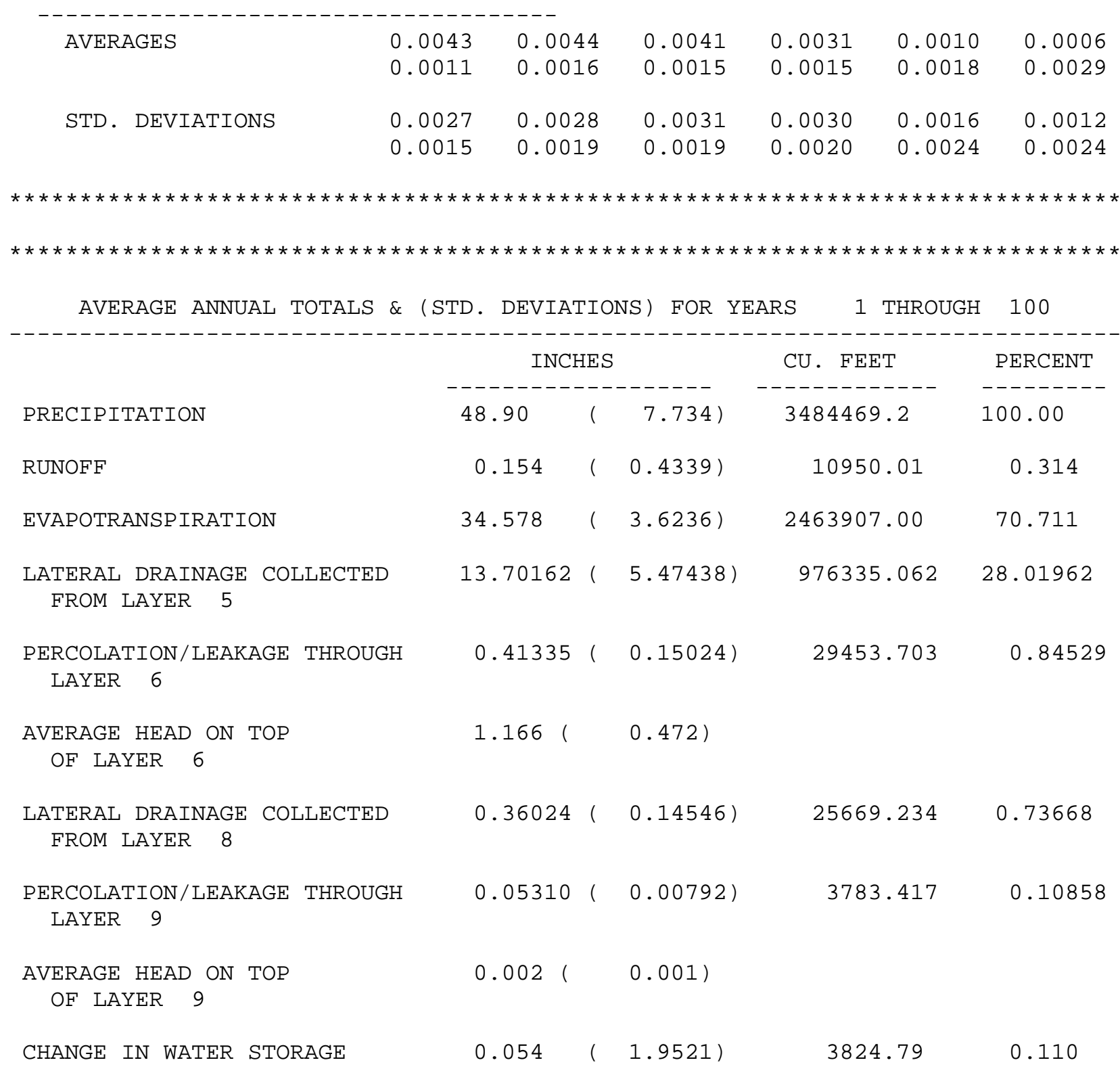




\begin{tabular}{|c|c|c|c|}
\hline \multicolumn{2}{|c|}{ PEAK DAILY VALUES FOR YEARS } & \multicolumn{2}{|l|}{1 THRO } \\
\hline & ( INCHES) & (CU. FT.) \\
\hline \multicolumn{2}{|l|}{ PRECIPITATION } & 6.87 & 489534.875 \\
\hline \multicolumn{2}{|l|}{ RUNOFF } & 2.648 & 188654.3750 \\
\hline \multicolumn{2}{|c|}{ DRAINAGE COLLECTED FROM LAYER 5} & 0.39526 & 28164.91210 \\
\hline \multicolumn{2}{|c|}{ PERCOLATION/LEAKAGE THROUGH LAYER 6} & 0.032853 & 2341.00708 \\
\hline \multicolumn{3}{|c|}{ AVERAGE HEAD ON TOP OF LAYER $6 \quad 38.433$} & \\
\hline \multicolumn{3}{|c|}{ MAXIMUM HEAD ON TOP OF LAYER $6 \quad 50.445$} & \\
\hline \multicolumn{4}{|c|}{$\begin{array}{l}\text { LOCATION OF MAXIMUM HEAD IN LAYER } 5 \\
\text { (DISTANCE FROM DRAIN) }\end{array}$} \\
\hline \multicolumn{2}{|c|}{ DRAINAGE COLLECTED FROM LAYER 8} & 0.01464 & 1042.84534 \\
\hline \multicolumn{2}{|c|}{ PERCOLATION/LEAKAGE THROUGH LAYER 9} & 0.000199 & 14.20408 \\
\hline \multicolumn{2}{|c|}{ AVERAGE HEAD ON TOP OF LAYER 9} & 0.034 & \\
\hline \multicolumn{2}{|c|}{ MAXIMUM HEAD ON TOP OF LAYER 9} & 0.071 & \\
\hline \multicolumn{4}{|c|}{$\begin{array}{l}\text { LOCATION OF MAXIMUM HEAD IN LAYER } 8 \\
\text { (DISTANCE FROM DRAIN) }\end{array}$} \\
\hline \multicolumn{2}{|l|}{ SNOW WATER } & 2.36 & 168188.7190 \\
\hline \multicolumn{2}{|c|}{ MAXIMUM VEG. SOIL WATER (VOL/VOL) } & \multicolumn{2}{|c|}{0.3691} \\
\hline \multicolumn{2}{|c|}{ MINIMUM VEG. SOIL WATER (VOL/VOL) } & \multicolumn{2}{|c|}{0.1148} \\
\hline \multirow[t]{2}{*}{ laximum heads } & s are computed using & McEnroe's equ & tions. \\
\hline & $\begin{array}{l}\text { Maximum Saturated De } \\
\text { by Bruce M. McEnroe, } \\
\text { ASCE Journal of Envi } \\
\text { Vol. 119, No. 2, Mar }\end{array}$ & $\begin{array}{l}\text { pth over Landf } \\
\text { University of } \\
\text { ronmental Engi } \\
\text { ch 1993, pp. } 2\end{array}$ & $\begin{array}{l}11 \text { Liner } \\
\text { Kansas } \\
\text { eering } \\
2-270\end{array}$ \\
\hline
\end{tabular}

Rev. 0 


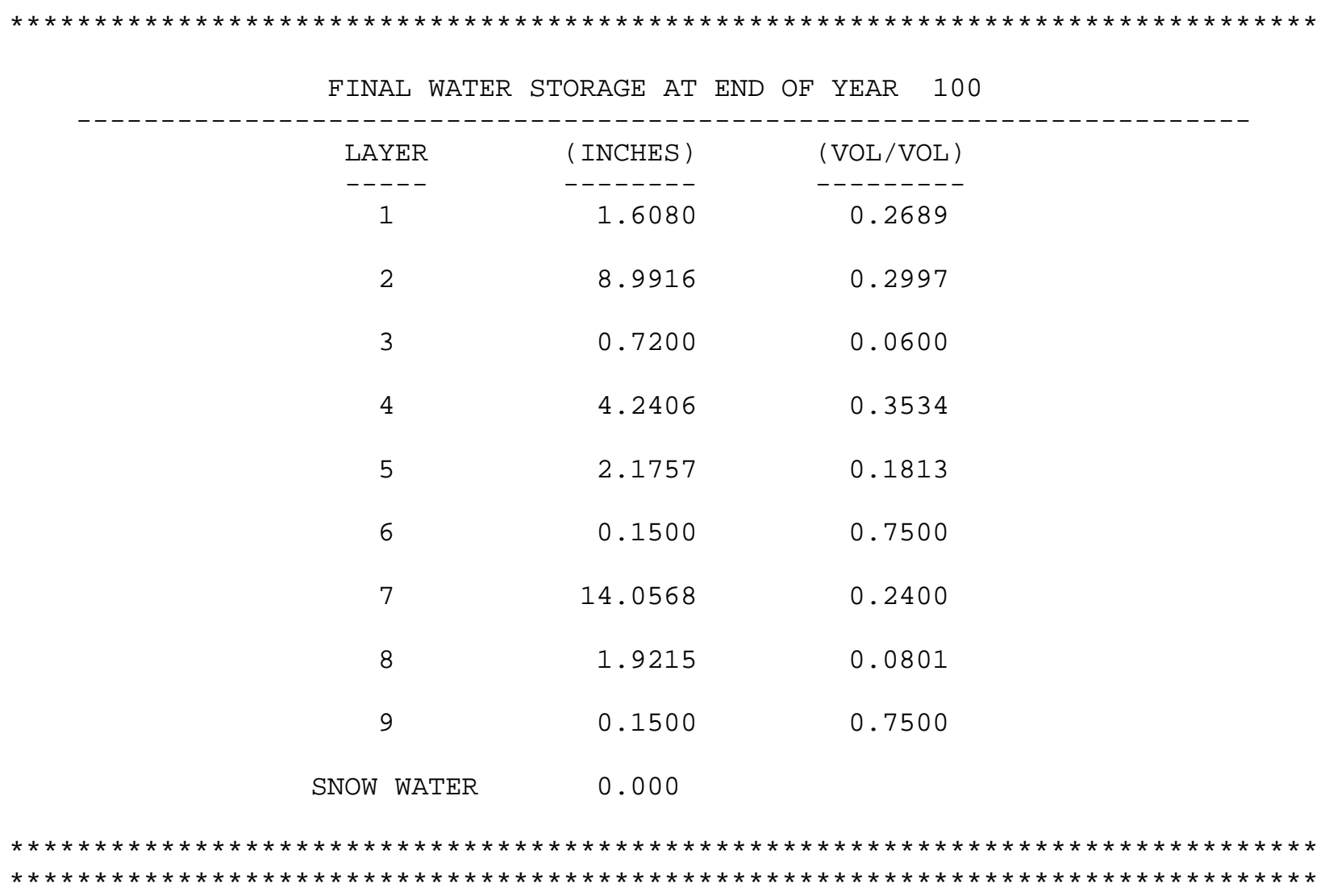


Appendix H, Lower Bounding Scenario Degraded SDF MSE Vault Closure Cap (300 Years): HELP Model Input Data and Output File (output file name: ZLBS2out.OUT)

\section{Input Data:}

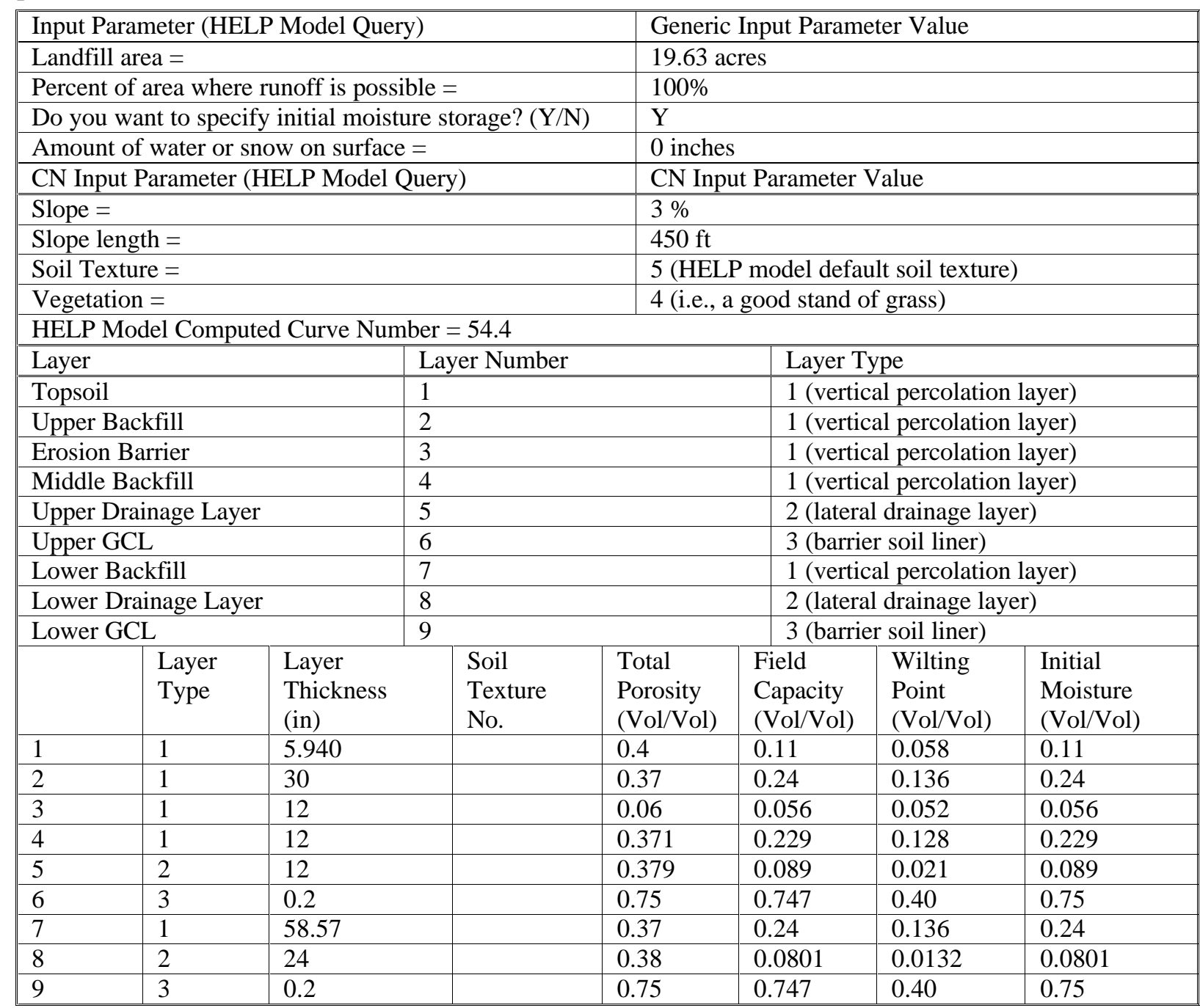

The lack of values in the table for particular parameters in particular layers denotes that no HELP model input was required for that parameter in that layer. No data are missing from the table. 
Input Data (continued):

\begin{tabular}{|c|c|c|c|c|c|c|c|c|c|}
\hline & $\begin{array}{l}\text { Layer } \\
\text { Type }\end{array}$ & $\begin{array}{l}\text { Sat. Hyd. } \\
\text { Conductivity * } \\
(\mathrm{cm} / \mathrm{sec})\end{array}$ & \multicolumn{2}{|c|}{$\begin{array}{l}\text { Drainage } \\
\text { Length } \\
(\mathrm{ft}) \\
\end{array}$} & $\begin{array}{l}\text { Drain } \\
\text { Slope } \\
(\%)\end{array}$ & $\begin{array}{l}\text { Leachate } \\
\text { Recirc. } \\
(\%) \\
\end{array}$ & \multicolumn{2}{|c|}{$\begin{array}{l}\text { Recirc. to } \\
\text { Layer } \\
(\#)\end{array}$} & $\begin{array}{l}\text { Subsurface } \\
\text { Inflow } \\
\text { (in/yr) }\end{array}$ \\
\hline 1 & 1 & $1.00 \mathrm{E}-03$ & & & & & & & \\
\hline 2 & 1 & $1.00 \mathrm{E}-04$ & & & & & & & \\
\hline 3 & 1 & $3.97 \mathrm{E}-04$ & & & & & & & \\
\hline 4 & 1 & $1.60 \mathrm{E}-04$ & & & & & & & \\
\hline 5 & 2 & $6.30 \mathrm{E}-02$ & 450 & & 3 & & & & \\
\hline 6 & 3 & $5.00 \mathrm{E}-09$ & & & & & & & \\
\hline 7 & 1 & $1.00 \mathrm{E}-04$ & & & & & & & \\
\hline 8 & 2 & 9.99E-02 & 150 & & 11.4 & & & & \\
\hline \multirow[t]{2}{*}{9} & 3 & $5.00 \mathrm{E}-09$ & & & & & & \\
\hline & $\begin{array}{l}\text { Layer } \\
\text { Type }\end{array}$ & \multicolumn{2}{|l|}{$\begin{array}{l}\text { Geomembrane } \\
\text { Pinhole Density } \\
\text { (\#/acre) }\end{array}$} & \multicolumn{2}{|c|}{$\begin{array}{l}\text { Geomembrane } \\
\text { Instal. Defects } \\
(\# / \text { acre })\end{array}$} & \multicolumn{2}{|c|}{$\begin{array}{l}\text { Geomembrane } \\
\text { Placement Quality }\end{array}$} & \multicolumn{2}{|c|}{$\begin{array}{l}\text { Geotextile } \\
\text { Transmissivity } \\
\left(\mathrm{cm}^{2} / \mathrm{sec}\right)\end{array}$} \\
\hline 1 & 1 & & & & & & & & \\
\hline 2 & 1 & & & & & & & & \\
\hline 3 & 1 & & & & & & & & \\
\hline 4 & 1 & & & & & & & & \\
\hline 5 & 2 & & & & & & & & \\
\hline 6 & 3 & & & & & & & & \\
\hline 7 & 1 & & & & & & & & \\
\hline 8 & 2 & & & & & & & & \\
\hline 9 & 3 & & & & & & & & \\
\hline
\end{tabular}

The lack of values in the table for particular parameters in particular layers denotes that no HELP model input was required for that parameter in that layer. No data are missing from the table.

* The HELP model output often produces an increased number of significant digits for the Effective Saturated Hydraulic Conductivity over that of the actual input 


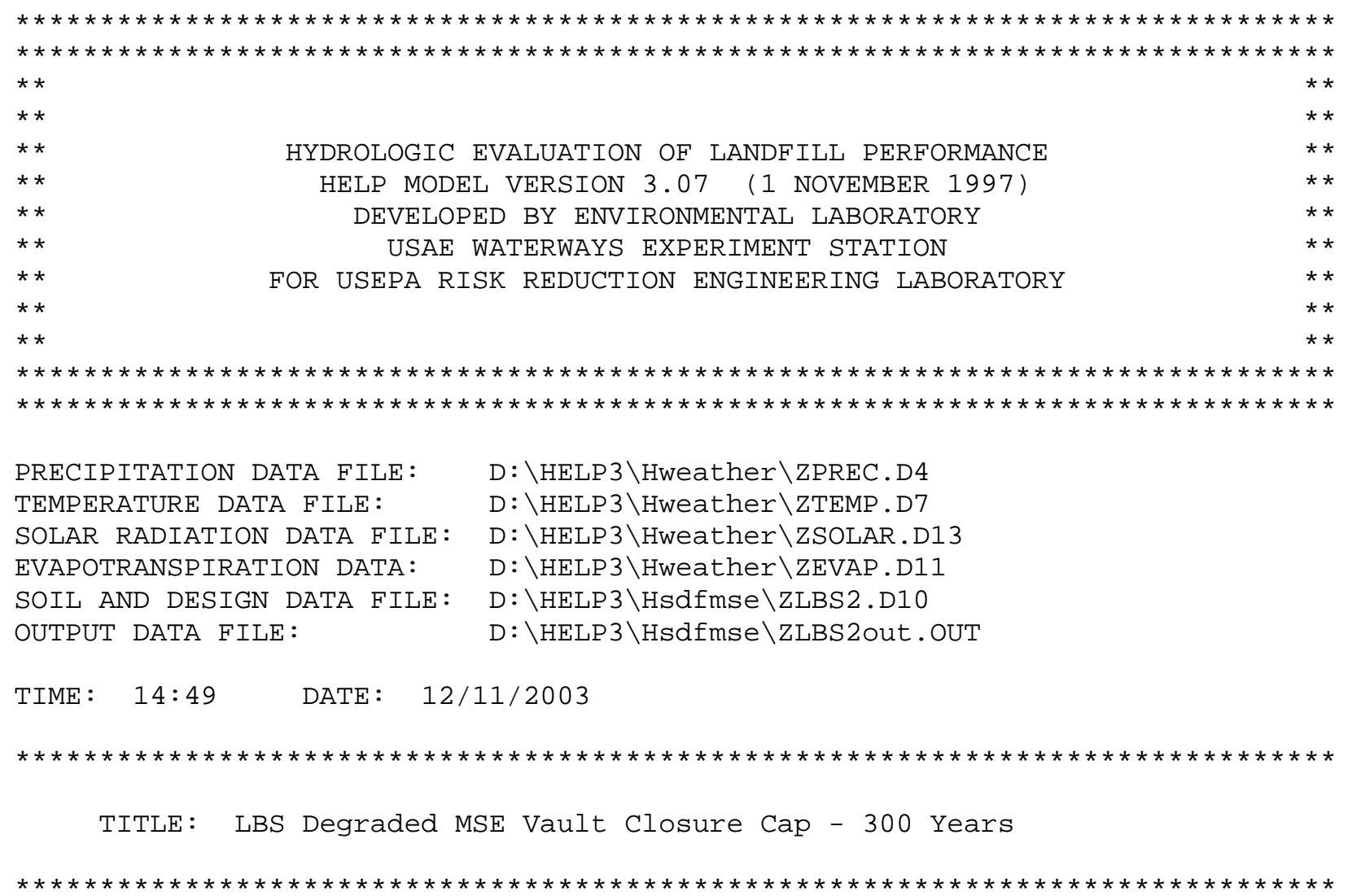

NOTE: INITIAL MOISTURE CONTENT OF THE LAYERS AND SNOW WATER WERE SPECIFIED BY THE USER.

\begin{tabular}{|c|c|c|c|c|}
\hline \multicolumn{5}{|c|}{ LAYER 1} \\
\hline \multicolumn{5}{|c|}{ TYPE 1 - VERTICAL PERCOLATION LAYER } \\
\hline THICKNESS & $=$ & 5.94 & INCHES & \\
\hline POROSITY & $=$ & 0.4000 & VOL/VOL & \\
\hline FIELD CAPACITY & $=$ & 0.1100 & VOL/VOL & \\
\hline WILTING POINT & $=$ & 0.0580 & VOL/VOL & \\
\hline INITIAL SOIL WATER CONTENT & $=$ & 0.1100 & VOL/VOL & \\
\hline EFFECTIVE SAT. HYD. COND. & $=$ & 0.10000000 & $5000 \mathrm{E}-02$ & $\mathrm{CM} / \mathrm{SEC}$ \\
\hline \multicolumn{5}{|c|}{ LAYER 2} \\
\hline $\begin{array}{r}\text { TYPE } 1 \text { - VERTICA } \\
\text { MATERIAL TEX }\end{array}$ & $\begin{array}{l}\text { PEF } \\
\mathrm{URE}\end{array}$ & $\begin{array}{cc}\text { RCOLATION } & \mathrm{L} \\
\text { NUMBER } & 0\end{array}$ & AYER & \\
\hline THICKNESS & $=$ & 30.00 & INCHES & \\
\hline POROSITY & $=$ & 0.3700 & VOL/VOL & \\
\hline FIELD CAPACITY & $=$ & 0.2400 & VOL/VOL & \\
\hline WILTING POINT & $=$ & 0.1360 & VOL/VOL & \\
\hline INITIAL SOIL WATER CONTENT & $=$ & 0.2400 & VOL/VOL & \\
\hline EFFECTIVE SAT. HYD. COND. & $=$ & 0.99999997 & $5000 \mathrm{E}-04$ & \\
\hline
\end{tabular}

Rev. 0 
LAYER 3

--------

TYPE 1 - VERTICAL PERCOLATION LAYER

MATERIAL TEXTURE NUMBER 0

$\begin{array}{llrl}\text { THICKNESS } & = & 12.00 \mathrm{INCHES} \\ \text { POROSITY } & = & 0.0600 \mathrm{VOL} / \mathrm{VOL} \\ \text { FIELD CAPACITY } & = & 0.0560 \mathrm{VOL} / \mathrm{VOL} \\ \text { WILTING POINT } & = & 0.0520 \mathrm{VOL} / \mathrm{VOL} \\ \text { INITIAL SOIL WATER CONTENT } & = & 0.0560 \mathrm{VOL} / \mathrm{VOL} \\ \text { EFFECTIVE SAT. HYD. COND. } & =0.396999996000 \mathrm{E}-03 \mathrm{CM} / \mathrm{SEC}\end{array}$

LAYER 4

TYPE 1 - VERTICAL PERCOLATION LAYER MATERIAL TEXTURE NUMBER 0

$\begin{array}{llrl}\text { THICKNESS } & = & 12.00 & \text { INCHES } \\ \text { POROSITY } & = & 0.3710 \mathrm{VOL} / \mathrm{VOL} \\ \text { FIELD CAPACITY } & = & 0.2290 \mathrm{VOL} / \mathrm{VOL} \\ \text { WILTING POINT } & = & 0.1280 \mathrm{VOL} / \mathrm{VOL} \\ \text { INITIAL SOIL WATER CONTENT } & = & 0.2290 \mathrm{VOL} / \mathrm{VOL} \\ \text { EFFECTIVE SAT. HYD. COND. } & =0.15999999000 \mathrm{E}-03 \mathrm{CM} / \mathrm{SEC}\end{array}$

LAYER 5

$--------$

TYPE 2 - LATERAL DRAINAGE LAYER MATERIAL TEXTURE NUMBER 0

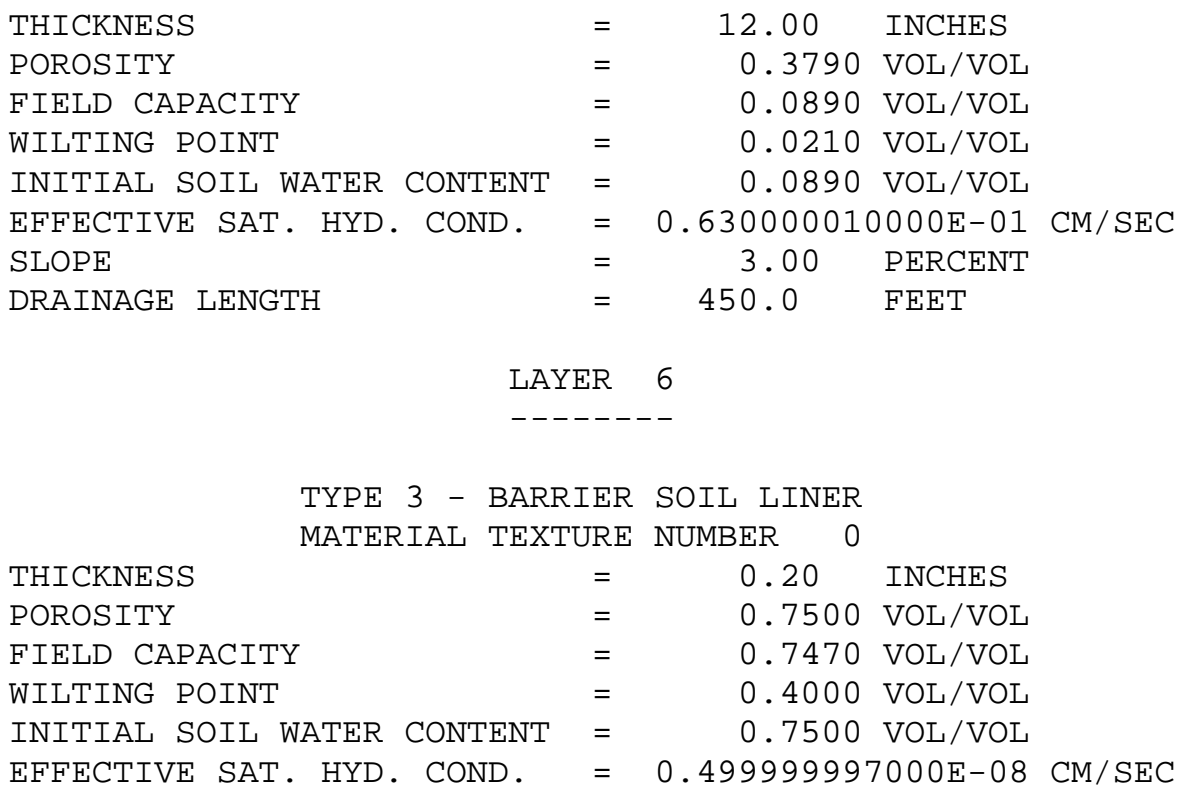

Rev. 0 
LAYER 7

$--------$

TYPE 1 - VERTICAL PERCOLATION LAYER

MATERIAL TEXTURE NUMBER 0

$\begin{array}{llrl}\text { THICKNESS } & = & 58.57 & \text { INCHES } \\ \text { POROSITY } & = & 0.3700 \mathrm{VOL} / \mathrm{VOL} \\ \text { FIELD CAPACITY } & = & 0.2400 \mathrm{VOL} / \mathrm{VOL} \\ \text { WILTING POINT } & = & 0.1360 \mathrm{VOL} / \mathrm{VOL} \\ \text { INITIAL SOIL WATER CONTENT } & = & 0.2400 \mathrm{VOL} / \mathrm{VOL} \\ \text { EFFECTIVE SAT. HYD. COND. } & =0.999999975000 \mathrm{E}-04 \mathrm{CM} / \mathrm{SEC}\end{array}$

LAYER 8

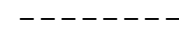

TYPE 2 - LATERAL DRAINAGE LAYER

$\begin{array}{llrl}\text { THICKNESS } & = & 24.00 & \text { INCHES } \\ \text { POROSITY } & = & 0.3800 \mathrm{VOL} / \mathrm{VOL} \\ \text { FIELD CAPACITY } & = & 0.0801 \mathrm{VOL} / \mathrm{VOL} \\ \text { WILTING POINT } & = & 0.0132 \mathrm{VOL} / \mathrm{VOL} \\ \text { INITIAL SOIL WATER CONTENT } & = & 0.0801 \mathrm{VOL} / \mathrm{VOL} \\ \text { EFFECTIVE SAT. HYD. COND. } & = & 0.99899998000 \mathrm{E}-01 \mathrm{CM} / \mathrm{SEC} \\ \text { SLOPE } & = & 11.40 \mathrm{PERCENT} \\ \text { DRAINAGE LENGTH } & = & 150.0 \mathrm{FEET}\end{array}$

LAYER 9

$--------$

TYPE 3 - BARRIER SOIL LINER

MATERIAL TEXTURE NUMBER 0

$\begin{array}{llll}\text { THICKNESS } & = & 0.20 & \text { INCHES } \\ \text { POROSITY } & = & 0.7500 \mathrm{VOL} / \mathrm{VOL} \\ \text { FIELD CAPACITY } & = & 0.7470 \mathrm{VOL} / \mathrm{VOL} \\ \text { WILTING POINT } & = & 0.4000 \mathrm{VOL} / \mathrm{VOL} \\ \text { INITIAL SOIL WATER CONTENT } & = & 0.7500 \mathrm{VOL} / \mathrm{VOL} \\ \text { EFFECTIVE SAT. HYD. COND. } & =0.499999997000 \mathrm{E}-08 \mathrm{CM} / \mathrm{SEC}\end{array}$

GENERAL DESIGN AND EVAPORATIVE ZONE DATA

NOTE: SCS RUNOFF CURVE NUMBER WAS COMPUTED FROM DEFAULT SOIL DATA BASE USING SOIL TEXTURE \# 5 WITH A GOOD STAND OF GRASS, A SURFACE SLOPE OF 3.\% AND A SLOPE LENGTH OF 450. FEET.

SCS RUNOFF CURVE NUMBER

FRACTION OF AREA ALLOWING RUNOFF

AREA PROJECTED ON HORIZONTAL PLANE

EVAPORATIVE ZONE DEPTH

INITIAL WATER IN EVAPORATIVE ZONE

UPPER LIMIT OF EVAPORATIVE STORAGE

LOWER LIMIT OF EVAPORATIVE STORAGE

INITIAL SNOW WATER

INITIAL WATER IN LAYER MATERIALS

TOTAL INITIAL WATER

TOTAL SUBSURFACE INFLOW

$\begin{array}{lcl}= & 54.40 & \\ = & 100.0 & \text { PERCENT } \\ = & 19.630 & \text { ACRES } \\ = & 22.0 & \text { INCHES } \\ = & 4.508 & \text { INCHES } \\ = & 8.318 & \text { INCHES } \\ = & 2.529 & \text { INCHES } \\ = & 0.000 & \text { INCHES } \\ = & 28.621 & \text { INCHES } \\ = & 28.621 & \text { INCHES } \\ = & 0.00 & \text { INCHES /YEAR }\end{array}$

Rev. 0 


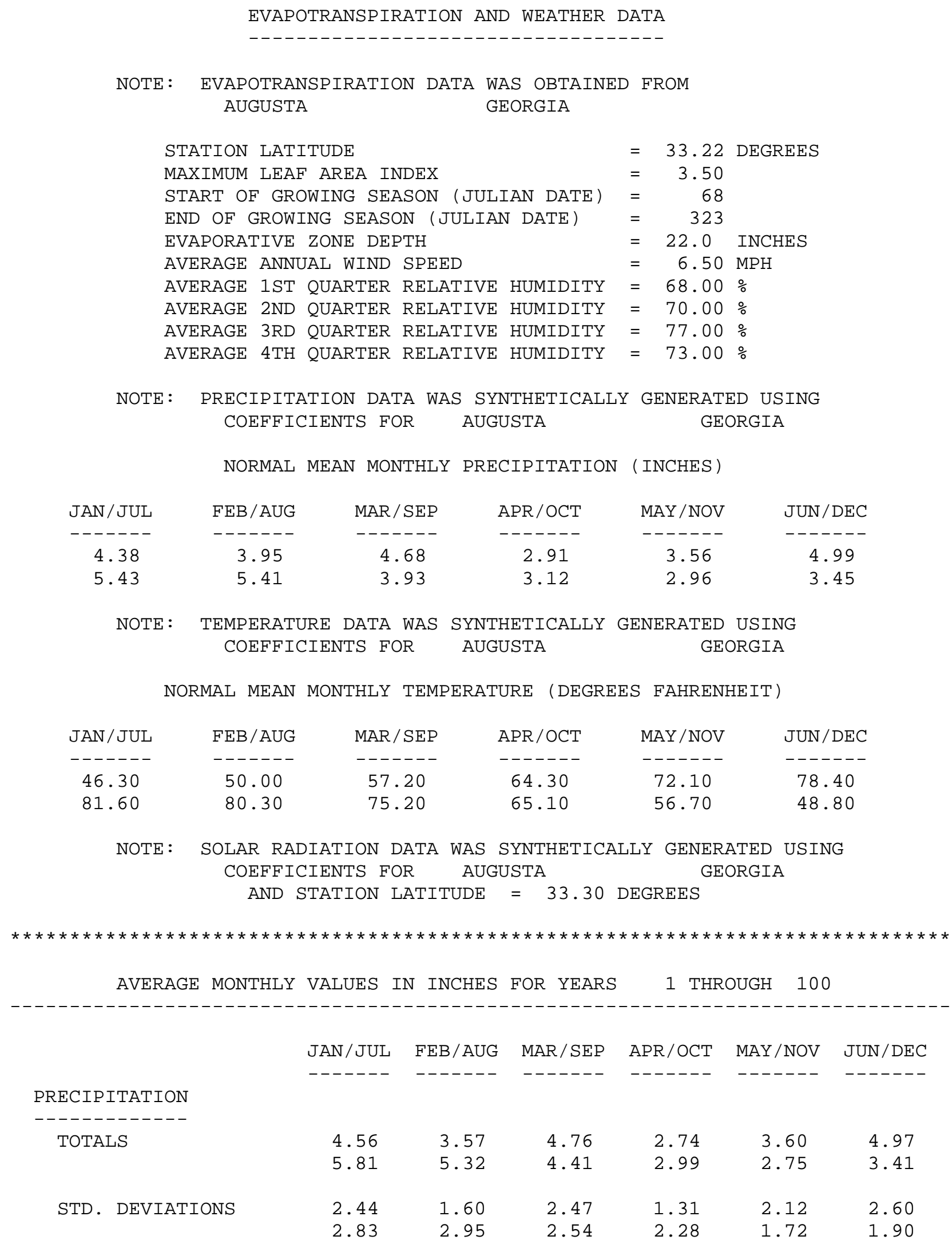

Rev. 0 
RUNOFF

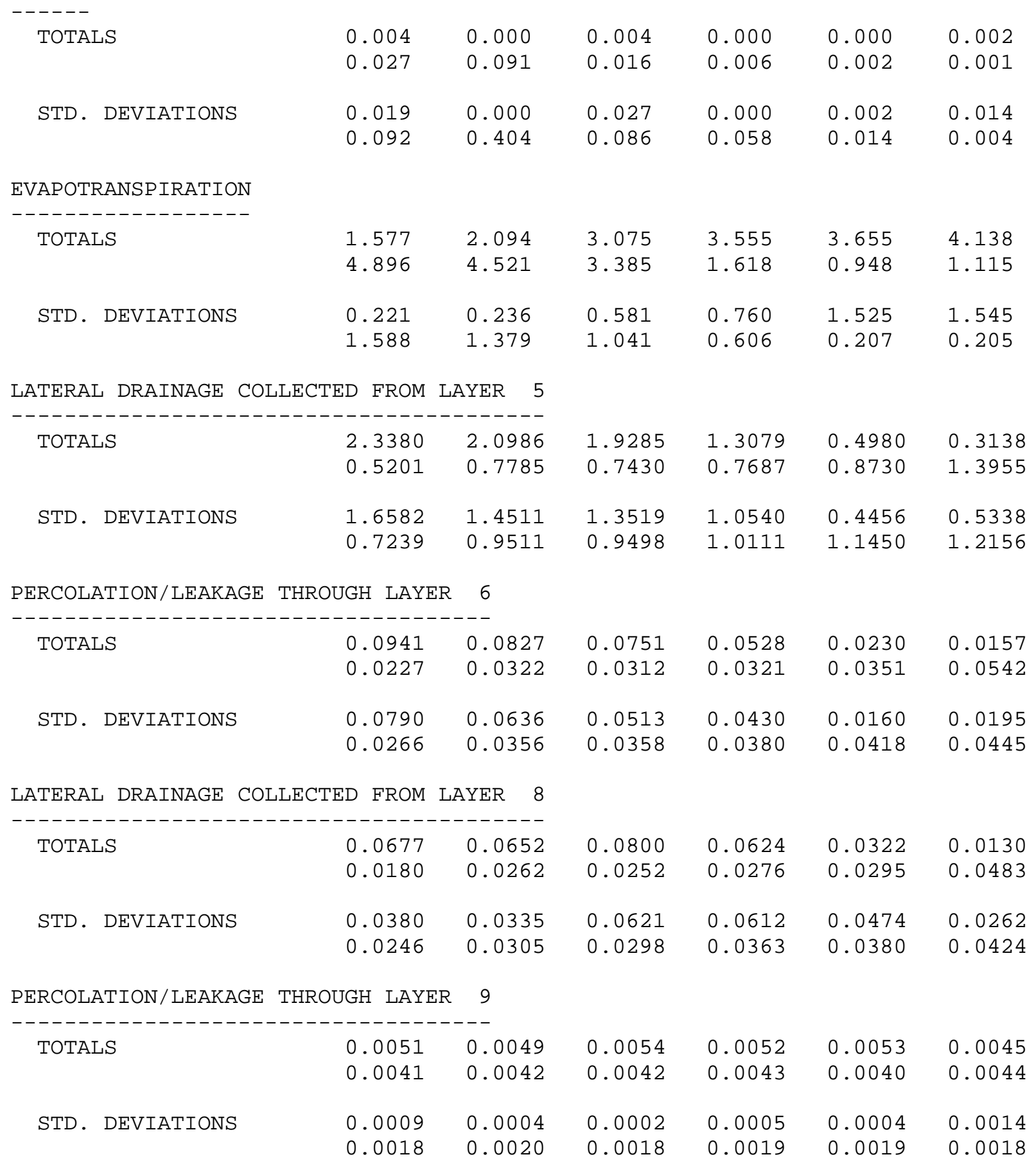


AVERAGES OF MONTHLY AVERAGED DAILY HEADS (INCHES)

DAILY AVERAGE HEAD ON TOP OF LAYER 6

\begin{tabular}{|c|c|c|c|c|c|c|}
\hline AVERAGES & $\begin{array}{l}3.3788 \\
0.7053\end{array}$ & $\begin{array}{l}3.2382 \\
1.0640\end{array}$ & $\begin{array}{l}2.6511 \\
1.0578\end{array}$ & $\begin{array}{l}1.8731 \\
1.0550\end{array}$ & $\begin{array}{l}0.6753 \\
1.2232\end{array}$ & $\begin{array}{l}0.4396 \\
1.8923\end{array}$ \\
\hline STD. DEVIATIONS & $\begin{array}{l}2.9857 \\
0.9816\end{array}$ & $\begin{array}{l}2.6532 \\
1.3175\end{array}$ & $\begin{array}{l}1.9439 \\
1.3750\end{array}$ & $\begin{array}{l}1.6851 \\
1.4131\end{array}$ & $\begin{array}{l}0.6042 \\
1.6044\end{array}$ & $\begin{array}{l}0.7480 \\
1.6483\end{array}$ \\
\hline
\end{tabular}

DAILY AVERAGE HEAD ON TOP OF LAYER 9

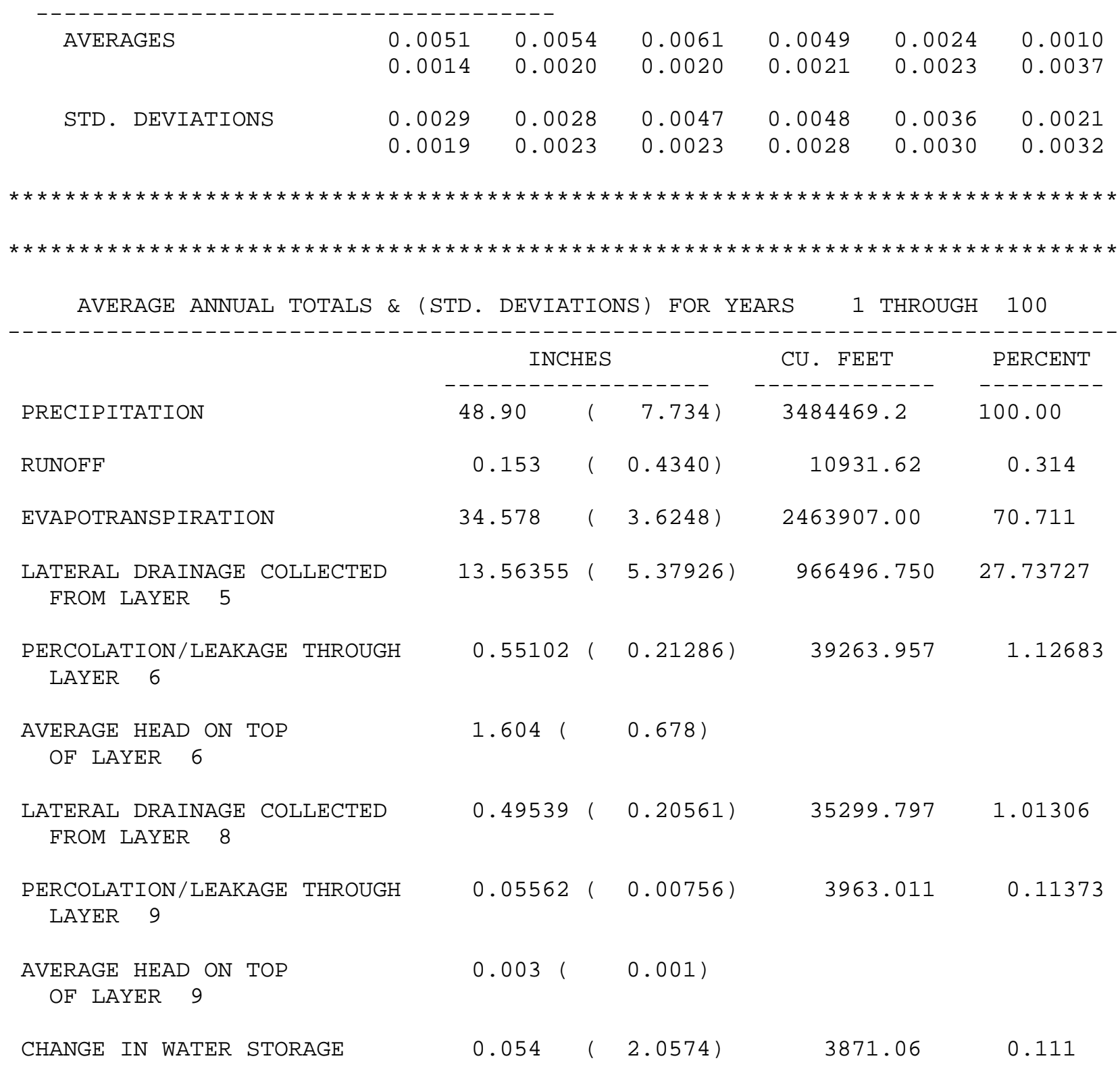




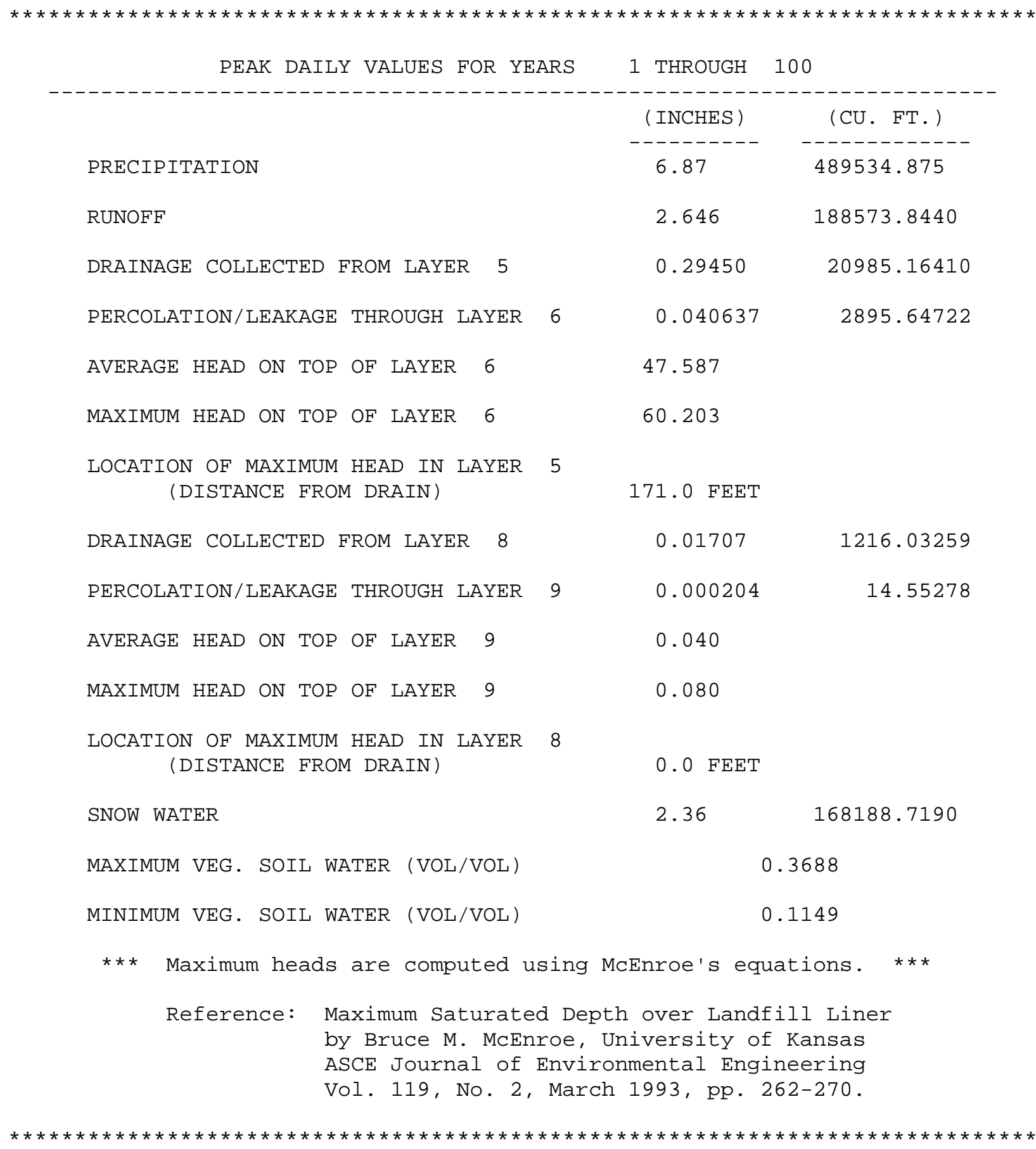

Rev. 0 


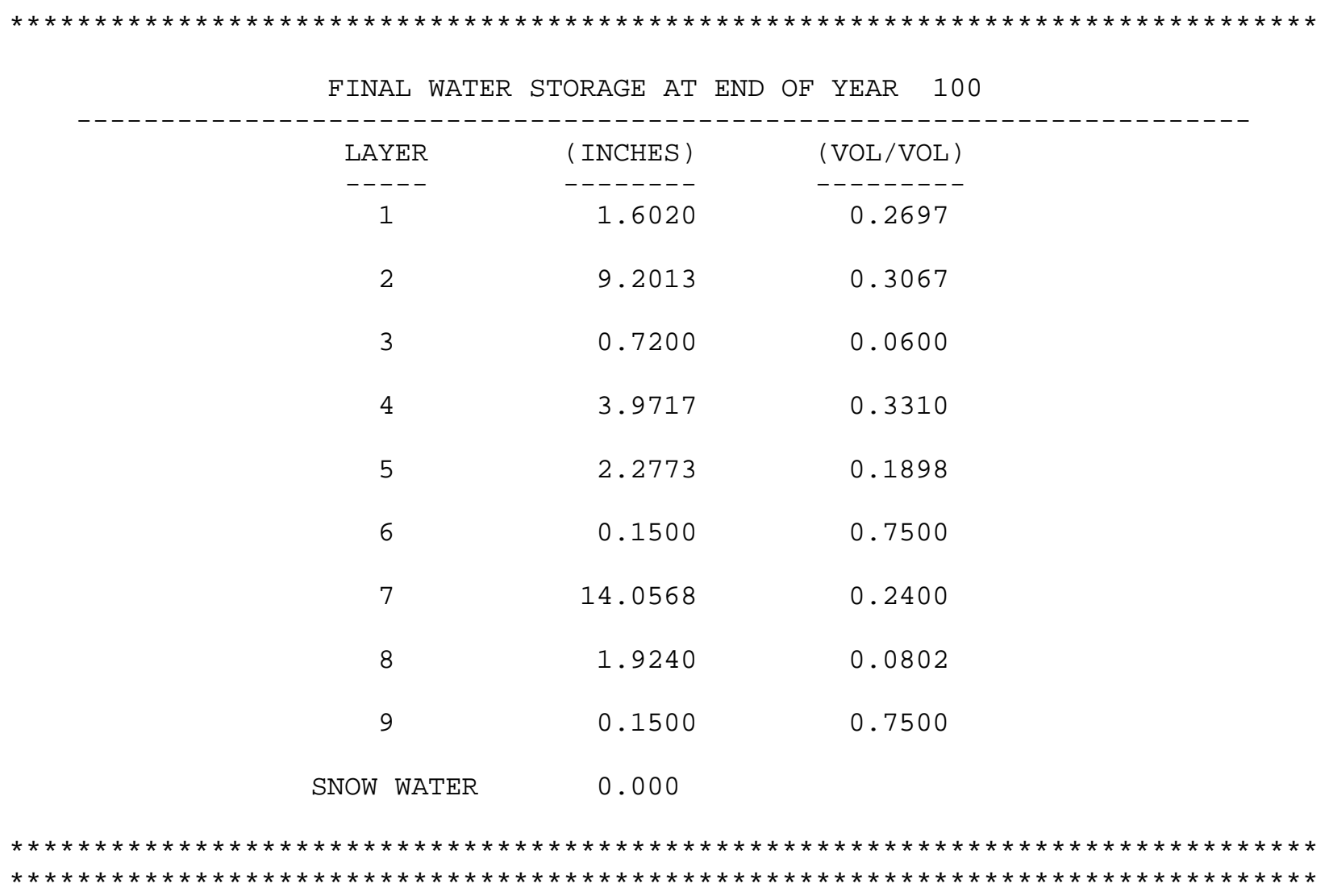


Appendix I, Lower Bounding Scenario Degraded SDF MSE Vault Closure Cap (550 Years): HELP Model Input Data and Output File (output file name: ZLBS3out.OUT)

\section{Input Data:}

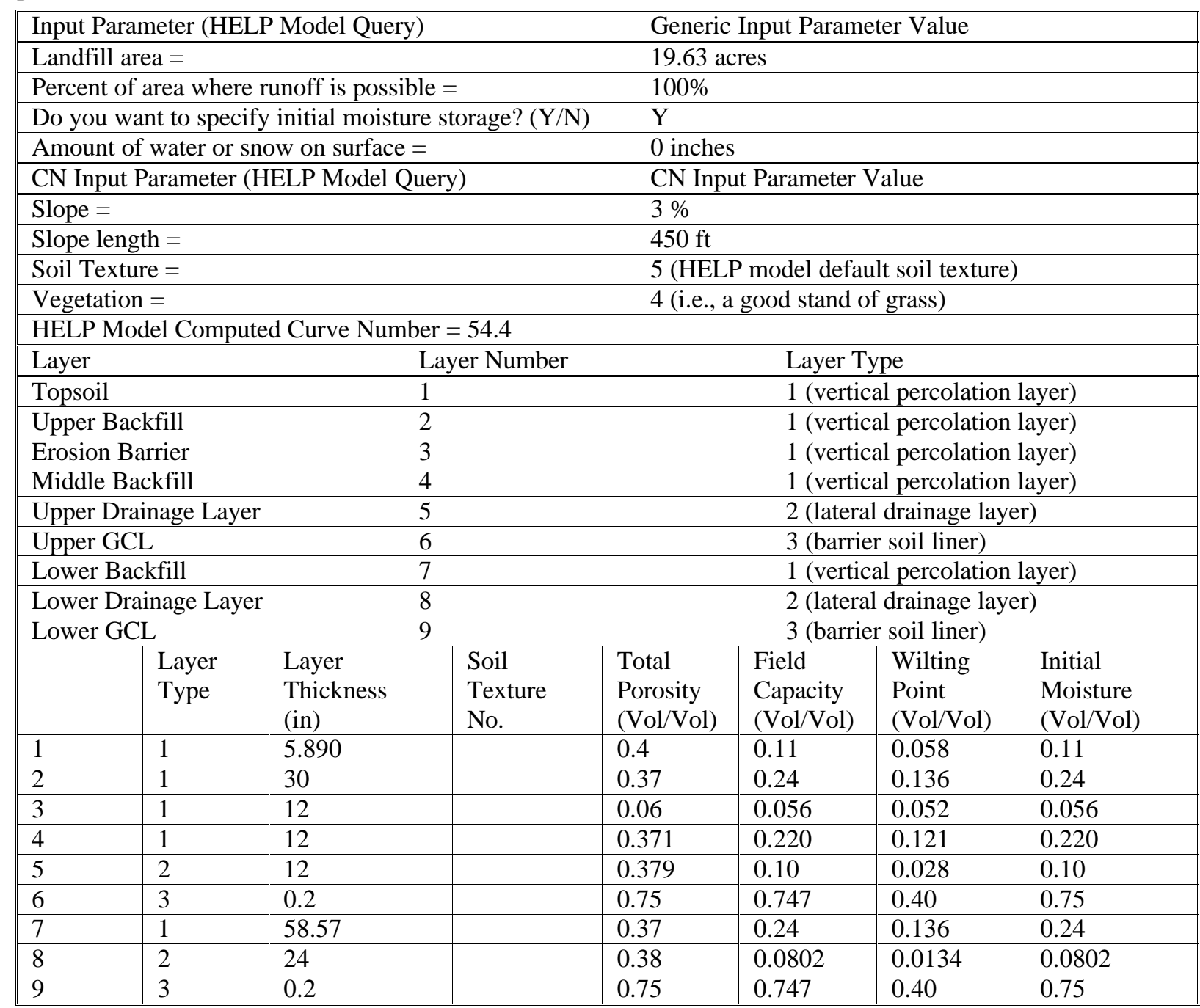

The lack of values in the table for particular parameters in particular layers denotes that no HELP model input was required for that parameter in that layer. No data are missing from the table. 
Input Data (continued):

\begin{tabular}{|c|c|c|c|c|c|c|c|c|c|}
\hline & $\begin{array}{l}\text { Layer } \\
\text { Type }\end{array}$ & $\begin{array}{l}\text { Sat. Hyd. } \\
\text { Conductivity * } \\
(\mathrm{cm} / \mathrm{sec})\end{array}$ & \multicolumn{2}{|c|}{$\begin{array}{l}\text { Drainage } \\
\text { Length } \\
(\mathrm{ft}) \\
\end{array}$} & $\begin{array}{l}\text { Drain } \\
\text { Slope } \\
(\%)\end{array}$ & $\begin{array}{l}\text { Leachate } \\
\text { Recirc. } \\
(\%) \\
\end{array}$ & \multicolumn{2}{|c|}{$\begin{array}{l}\text { Recirc. to } \\
\text { Layer } \\
(\#)\end{array}$} & $\begin{array}{l}\text { Subsurface } \\
\text { Inflow } \\
\text { (in/yr) }\end{array}$ \\
\hline 1 & 1 & $1.00 \mathrm{E}-03$ & & & & & & & \\
\hline 2 & 1 & $1.00 \mathrm{E}-04$ & & & & & & & \\
\hline 3 & 1 & $3.97 \mathrm{E}-04$ & & & & & & & \\
\hline 4 & 1 & $2.30 \mathrm{E}-04$ & & & & & & & \\
\hline 5 & 2 & $4.30 \mathrm{E}-02$ & 450 & & 3 & & & & \\
\hline 6 & 3 & $5.00 \mathrm{E}-09$ & & & & & & & \\
\hline 7 & 1 & $1.00 \mathrm{E}-04$ & & & & & & & \\
\hline 8 & 2 & $9.98 \mathrm{E}-02$ & 150 & & 11.4 & & & & \\
\hline \multirow[t]{2}{*}{9} & 3 & $5.00 \mathrm{E}-09$ & & & & & & \\
\hline & $\begin{array}{l}\text { Layer } \\
\text { Type }\end{array}$ & \multicolumn{2}{|l|}{$\begin{array}{l}\text { Geomembrane } \\
\text { Pinhole Density } \\
\text { (\#/acre) }\end{array}$} & \multicolumn{2}{|c|}{$\begin{array}{l}\text { Geomembrane } \\
\text { Instal. Defects } \\
(\# / \text { acre })\end{array}$} & \multicolumn{2}{|c|}{$\begin{array}{l}\text { Geomembrane } \\
\text { Placement Quality }\end{array}$} & \multicolumn{2}{|c|}{$\begin{array}{l}\text { Geotextile } \\
\text { Transmissivity } \\
\left(\mathrm{cm}^{2} / \mathrm{sec}\right)\end{array}$} \\
\hline 1 & 1 & & & & & & & & \\
\hline 2 & 1 & & & & & & & & \\
\hline 3 & 1 & & & & & & & & \\
\hline 4 & 1 & & & & & & & & \\
\hline 5 & 2 & & & & & & & & \\
\hline 6 & 3 & & & & & & & & \\
\hline 7 & 1 & & & & & & & & \\
\hline 8 & 2 & & & & & & & & \\
\hline 9 & 3 & & & & & & & & \\
\hline
\end{tabular}

The lack of values in the table for particular parameters in particular layers denotes that no HELP model input was required for that parameter in that layer. No data are missing from the table.

* The HELP model output often produces an increased number of significant digits for the Effective Saturated Hydraulic Conductivity over that of the actual input 


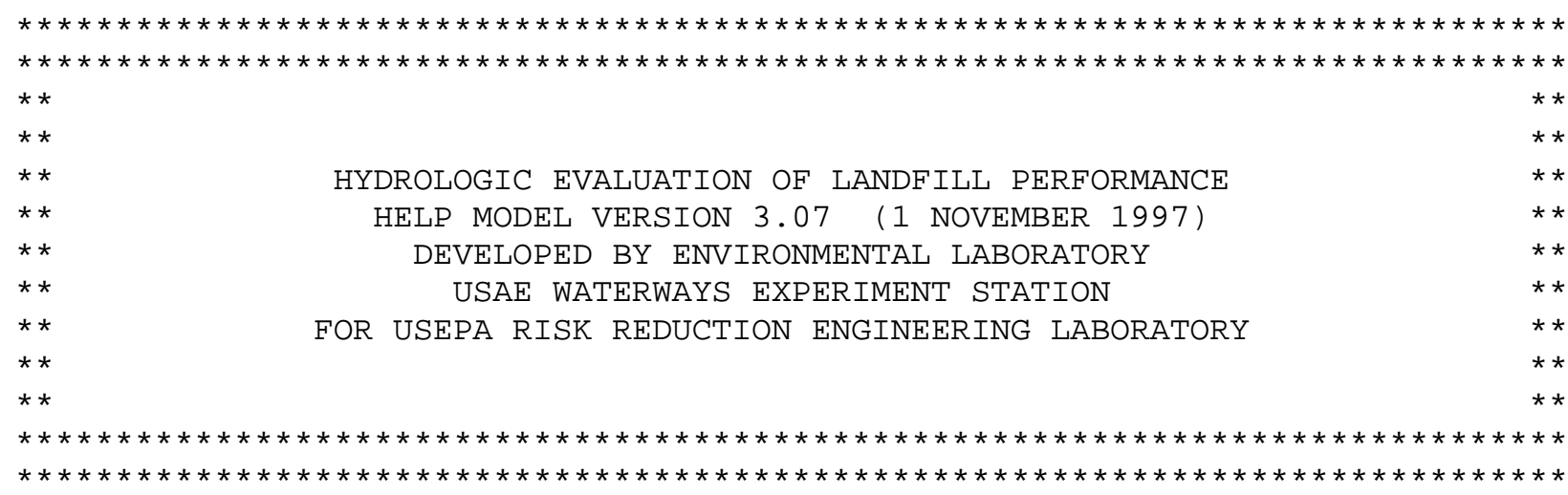

\begin{tabular}{|c|c|}
\hline PRECIPITATION DATA FILE: & $\mathrm{D}: \backslash$ HELP $3 \backslash$ Hweather $\backslash \mathrm{ZPREC} . \mathrm{D} 4$ \\
\hline TEMPERATURE DATA FILE: & D : \HELP $3 \backslash$ Hweather $\backslash \mathrm{ZTEMP}$. D 7 \\
\hline SOLAR RADIATION DATA FILE: & D : \HELP $3 \backslash$ Hweather $\backslash$ ZSOLAR.D13 \\
\hline EVAPOTRANSPIRATION DATA: & D : \HELP $3 \backslash$ Hweather $\backslash$ ZEVAP . D11 \\
\hline SOIL AND DESIGN DATA FILE: & D : \HELP $3 \backslash$ Hsdfmse $\backslash Z L B S 3 . D 10$ \\
\hline OUTPUT DATA FILE: & D : \HELP $3 \backslash$ Hsdfmse $\backslash$ ZLBS3out. OUT \\
\hline
\end{tabular}

TIME: $10: 5$ DATE: $2 / 11 / 2004$

TITLE: LBS Degraded MSE Vault Closure Cap - 550 Years

NOTE: INITIAL MOISTURE CONTENT OF THE LAYERS AND SNOW WATER WERE SPECIFIED BY THE USER.

\begin{tabular}{|c|c|c|c|c|}
\hline \multicolumn{5}{|c|}{$\begin{array}{ll}\text { LAYER } & 1 \\
-------\end{array}$} \\
\hline \multicolumn{4}{|c|}{ TYPE 1 - VERTICAL PERCOLATION LAYER } & \\
\hline THICKNESS & $=$ & 5.89 & INCHES & \\
\hline POROSITY & $=$ & 0.4000 & VOL/VOL & \\
\hline FIELD CAPACITY & $=$ & 0.1100 & $\mathrm{VOL} / \mathrm{VOL}$ & \\
\hline WILTING POINT & $=$ & 0.0580 & VOL/VOL & \\
\hline INITIAL SOIL WATER CONTENT & $=$ & 0.1100 & VOL/VOL & \\
\hline EFFECTIVE SAT. HYD. COND. & $=$ & 0.100000005 & $5000 E-02$ & $\mathrm{CM} / \mathrm{SEC}$ \\
\hline \multicolumn{5}{|c|}{ LAYER 2} \\
\hline \multicolumn{5}{|c|}{ TYPE 1 - VERTICAL PERCOLATION LAYER } \\
\hline THICKNESS & $=$ & 30.00 & INCHES & \\
\hline POROSITY & $=$ & 0.3700 & VOL/VOL & \\
\hline FIELD CAPACITY & $=$ & 0.2400 & VOL/VOL & \\
\hline WILTING POINT & $=$ & 0.1360 & VOL/VOL & \\
\hline INITIAL SOIL WATER CONTENT & $=$ & 0.2400 & VOL/VOL & \\
\hline EFFECTIVE SAT. HYD. COND. & $=$ & 0.999999975 & $5000 E-04$ & $\mathrm{Cl}$ \\
\hline
\end{tabular}

Rev. 0 
LAYER 3

--------

TYPE 1 - VERTICAL PERCOLATION LAYER

MATERIAL TEXTURE NUMBER 0

$\begin{array}{llrl}\text { THICKNESS } & = & 12.00 \mathrm{INCHES} \\ \text { POROSITY } & = & 0.0600 \mathrm{VOL} / \mathrm{VOL} \\ \text { FIELD CAPACITY } & = & 0.0560 \mathrm{VOL} / \mathrm{VOL} \\ \text { WILTING POINT } & = & 0.0520 \mathrm{VOL} / \mathrm{VOL} \\ \text { INITIAL SOIL WATER CONTENT } & = & 0.0560 \mathrm{VOL} / \mathrm{VOL} \\ \text { EFFECTIVE SAT. HYD. COND. } & =0.396999996000 \mathrm{E}-03 \mathrm{CM} / \mathrm{SEC}\end{array}$

LAYER 4

TYPE 1 - VERTICAL PERCOLATION LAYER MATERIAL TEXTURE NUMBER 0

$\begin{array}{llrl}\text { THICKNESS } & = & 12.00 & \text { INCHES } \\ \text { POROSITY } & = & 0.3710 \mathrm{VOL} / \mathrm{VOL} \\ \text { FIELD CAPACITY } & = & 0.2200 \mathrm{VOL} / \mathrm{VOL} \\ \text { WILTING POINT } & = & 0.1210 \mathrm{VOL} / \mathrm{VOL} \\ \text { INITIAL SOIL WATER CONTENT } & = & 0.2200 \mathrm{VOL} / \mathrm{VOL} \\ \text { EFFECTIVE SAT. HYD. COND. } & =0.230000005000 \mathrm{E}-03 \mathrm{CM} / \mathrm{SEC} \\ & \\ \text { LAYER } & 5 & \end{array}$

TYPE 2 - LATERAL DRAINAGE LAYER MATERIAL TEXTURE NUMBER 0

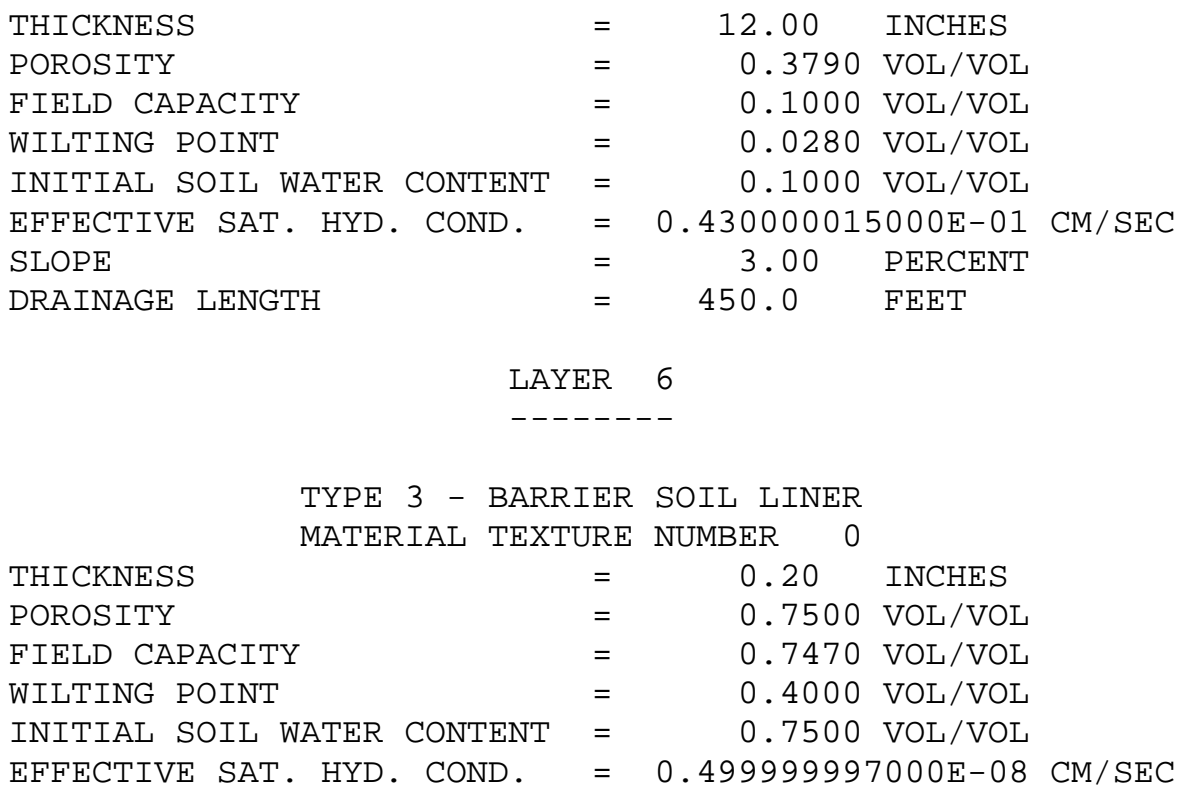

Rev. 0 
LAYER 7

$--------$

TYPE 1 - VERTICAL PERCOLATION LAYER

MATERIAL TEXTURE NUMBER 0

$\begin{array}{llrl}\text { THICKNESS } & = & 58.57 & \text { INCHES } \\ \text { POROSITY } & = & 0.3700 \mathrm{VOL} / \mathrm{VOL} \\ \text { FIELD CAPACITY } & = & 0.2400 \mathrm{VOL} / \mathrm{VOL} \\ \text { WILTING POINT } & = & 0.1360 \mathrm{VOL} / \mathrm{VOL} \\ \text { INITIAL SOIL WATER CONTENT } & = & 0.2400 \mathrm{VOL} / \mathrm{VOL} \\ \text { EFFECTIVE SAT. HYD. COND. } & =0.999999975000 \mathrm{E}-04 \mathrm{CM} / \mathrm{SEC}\end{array}$

LAYER 8

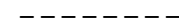

TYPE 2 - LATERAL DRAINAGE LAYER

$\begin{array}{llrl}\text { THICKNESS } & = & 24.00 & \text { INCHES } \\ \text { POROSITY } & = & 0.3800 \mathrm{VOL} / \mathrm{VOL} \\ \text { FIELD CAPACITY } & = & 0.0802 \mathrm{VOL} / \mathrm{VOL} \\ \text { WILTING POINT } & = & 0.0134 \mathrm{VOL} / \mathrm{VOL} \\ \text { INITIAL SOIL WATER CONTENT } & = & 0.0802 \mathrm{VOL} / \mathrm{VOL} \\ \text { EFFECTIVE SAT. HYD. COND. } & = & 0.997999981000 \mathrm{E}-01 \mathrm{CM} / \mathrm{SEC} \\ \text { SLOPE } & = & 11.40 \mathrm{PERCENT} \\ \text { DRAINAGE LENGTH } & = & 150.0 \mathrm{FEET}\end{array}$

LAYER 9

--------

TYPE 3 - BARRIER SOIL LINER

MATERIAL TEXTURE NUMBER 0

$\begin{array}{llrl}\text { THICKNESS } & = & 0.20 & \text { INCHES } \\ \text { POROSITY } & = & 0.7500 \mathrm{VOL} / \mathrm{VOL} \\ \text { FIELD CAPACITY } & = & 0.7470 \mathrm{VOL} / \mathrm{VOL} \\ \text { WILTING POINT } & = & 0.4000 \mathrm{VOL} / \mathrm{VOL} \\ \text { INITIAL SOIL WATER CONTENT } & = & 0.7500 \mathrm{VOL} / \mathrm{VOL} \\ \text { EFFECTIVE SAT. HYD. COND. } & =0.499999997000 \mathrm{E}-08 \mathrm{CM} / \mathrm{SEC}\end{array}$

GENERAL DESIGN AND EVAPORATIVE ZONE DATA

NOTE: SCS RUNOFF CURVE NUMBER WAS COMPUTED FROM DEFAULT SOIL DATA BASE USING SOIL TEXTURE \# 5 WITH A GOOD STAND OF GRASS, A SURFACE SLOPE OF 3.\% AND A SLOPE LENGTH OF 450. FEET.

SCS RUNOFF CURVE NUMBER

FRACTION OF AREA ALLOWING RUNOFF

AREA PROJECTED ON HORIZONTAL PLANE

EVAPORATIVE ZONE DEPTH

INITIAL WATER IN EVAPORATIVE ZONE

UPPER LIMIT OF EVAPORATIVE STORAGE

LOWER LIMIT OF EVAPORATIVE STORAGE

INITIAL SNOW WATER

INITIAL WATER IN LAYER MATERIALS

TOTAL INITIAL WATER

TOTAL SUBSURFACE INFLOW

$\begin{array}{lcl}= & 54.40 & \\ = & 100.0 & \text { PERCENT } \\ = & 19.630 & \text { ACRES } \\ = & 22.0 & \text { INCHES } \\ = & 4.514 & \text { INCHES } \\ = & 8.317 & \text { INCHES } \\ = & 2.533 & \text { INCHES } \\ = & 0.000 & \text { INCHES } \\ = & 28.642 & \text { INCHES } \\ = & 28.642 & \text { INCHES } \\ = & 0.00 & \text { INCHES /YEAR }\end{array}$

Rev. 0 


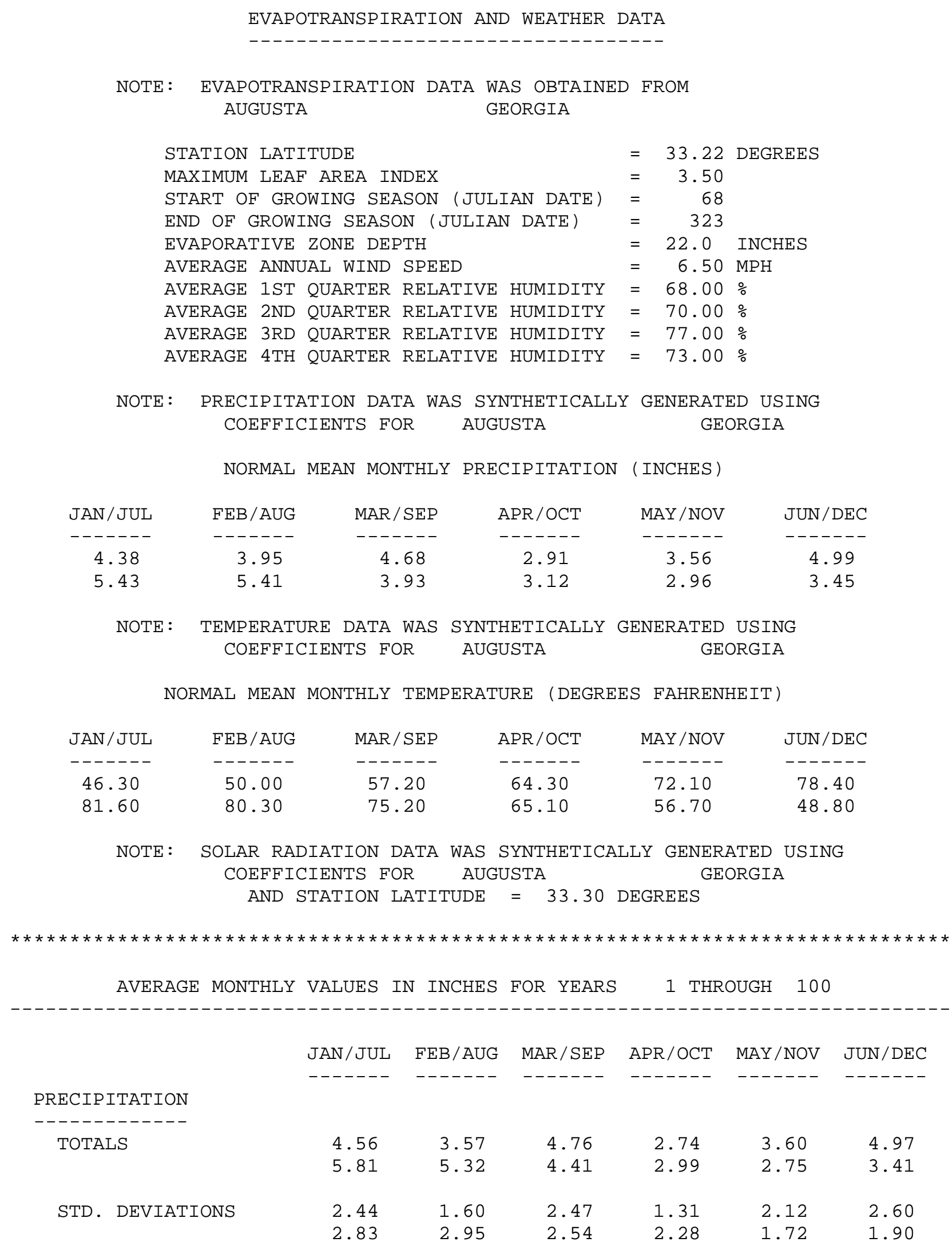

Rev. 0 


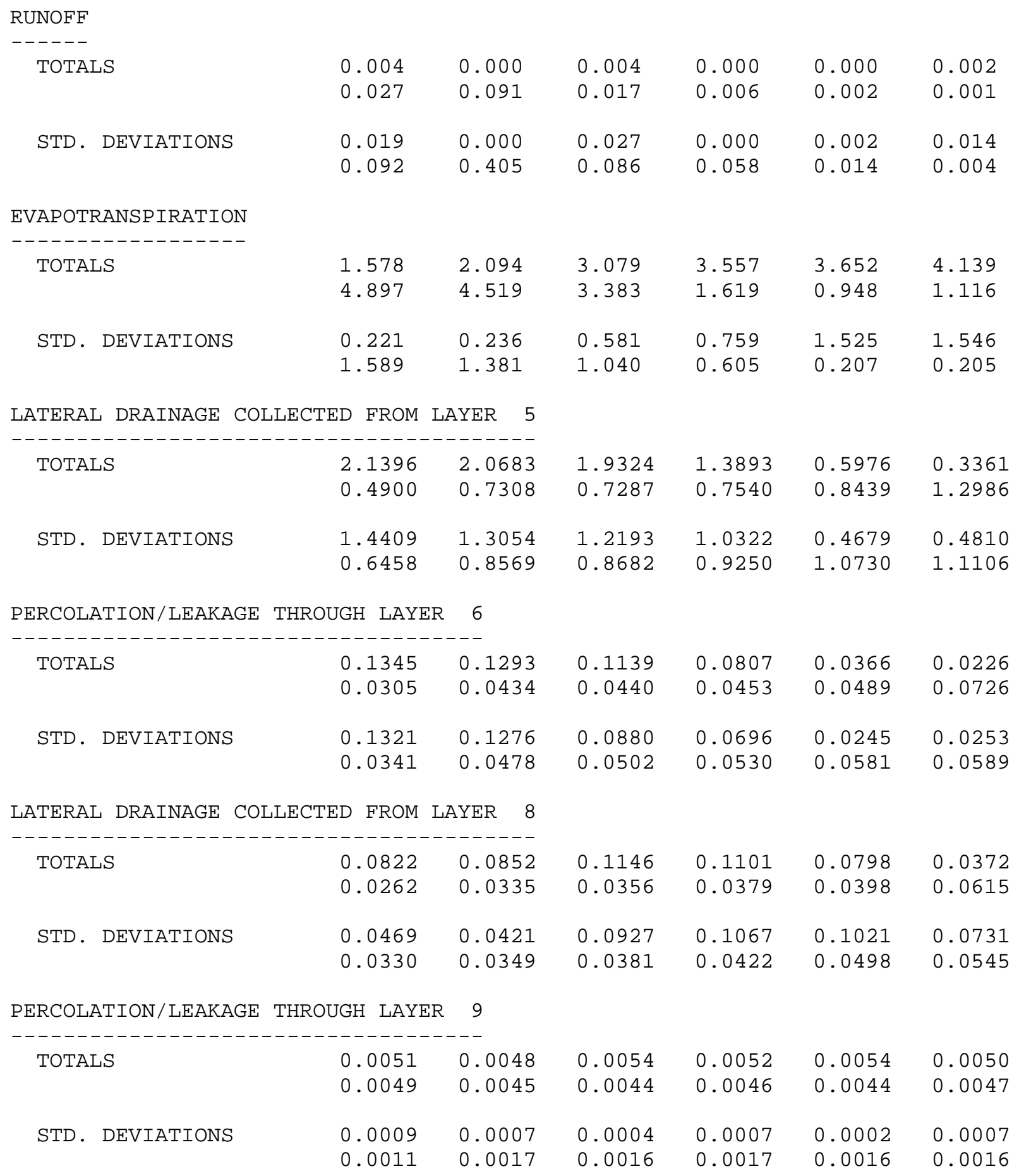


AVERAgES OF MONTHLY AVERAgED DAILY HEADS (INCHES)

DAILY AVERAGE HEAD ON TOP OF LAYER 6

\begin{tabular}{|c|c|c|c|c|c|c|}
\hline \multirow[t]{2}{*}{ AVERAGES } & 4.9100 & 5.1798 & 4.1221 & 2.9643 & 1.1873 & 0.6900 \\
\hline & 0.9734 & 1.4764 & 1.5521 & 1.5436 & 1.7459 & 2.5799 \\
\hline \multirow[t]{2}{*}{ STD. DEVIATIONS } & 5.0026 & 5.3145 & 3.3389 & 2.7254 & 0.9295 & 0.9875 \\
\hline & 1.2831 & 1.7908 & 1.9474 & 1.9914 & 2.2570 & 2.2064 \\
\hline
\end{tabular}

DAILY AVERAGE HEAD ON TOP OF LAYER 9

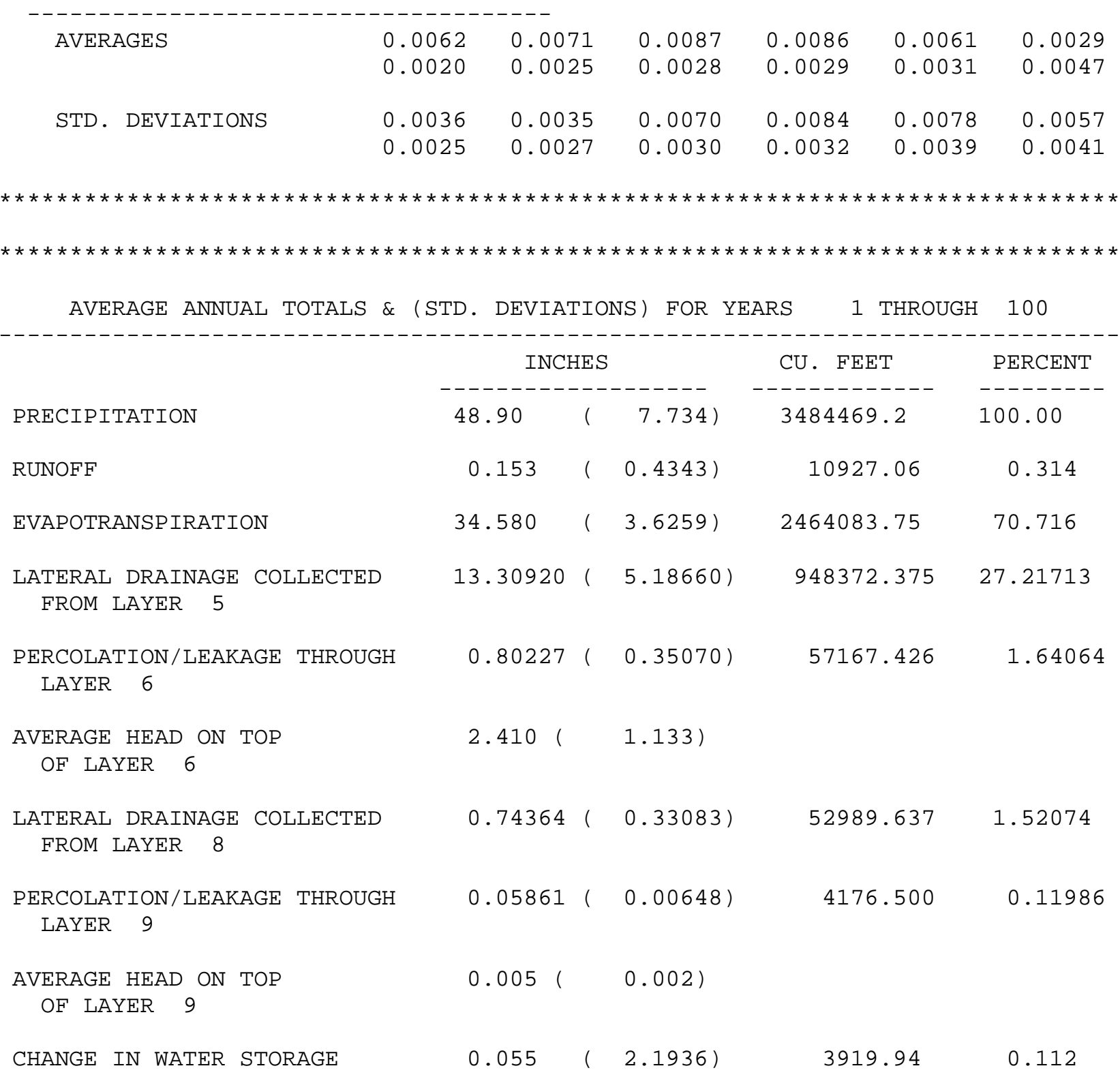




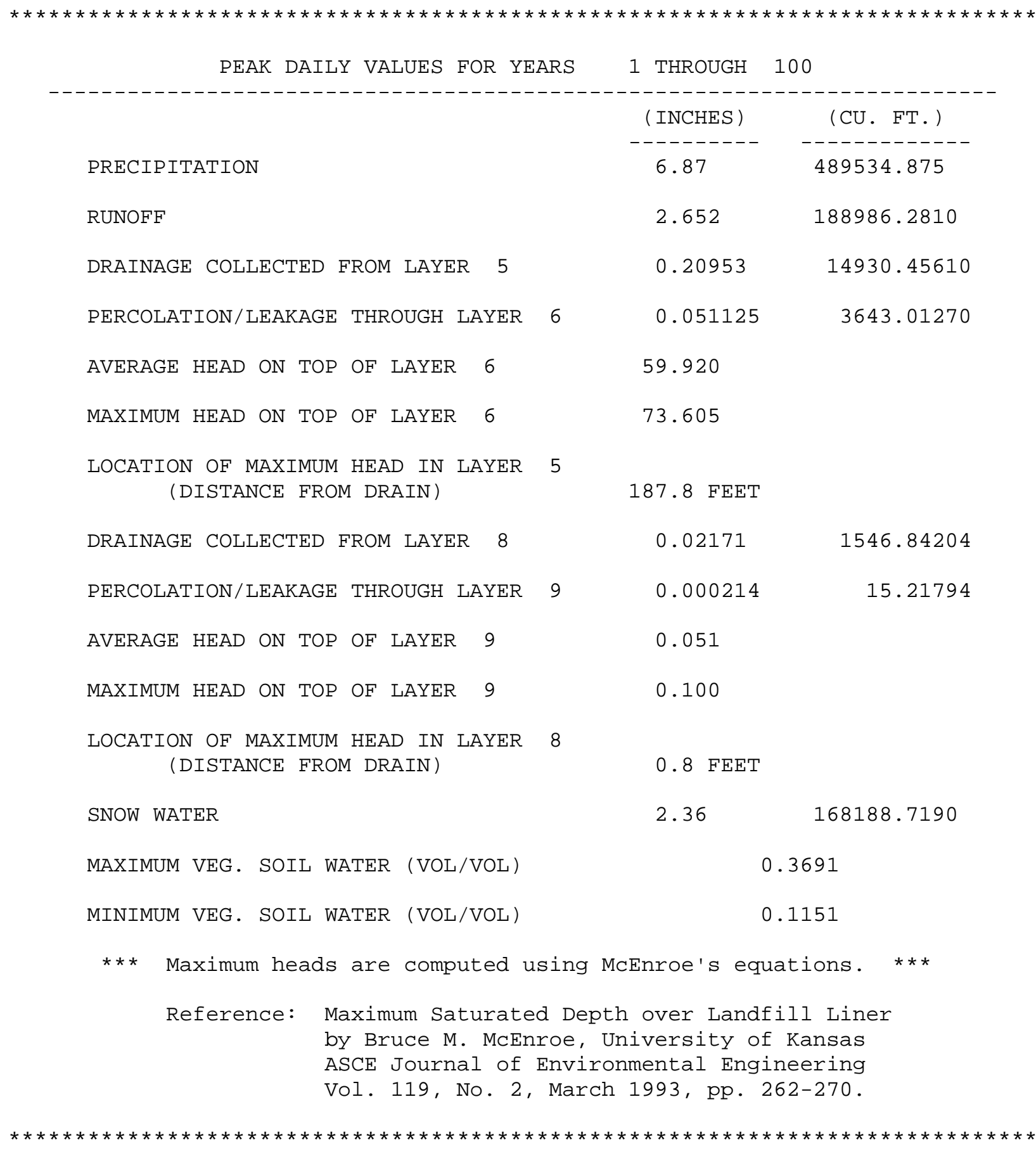

Rev. 0 


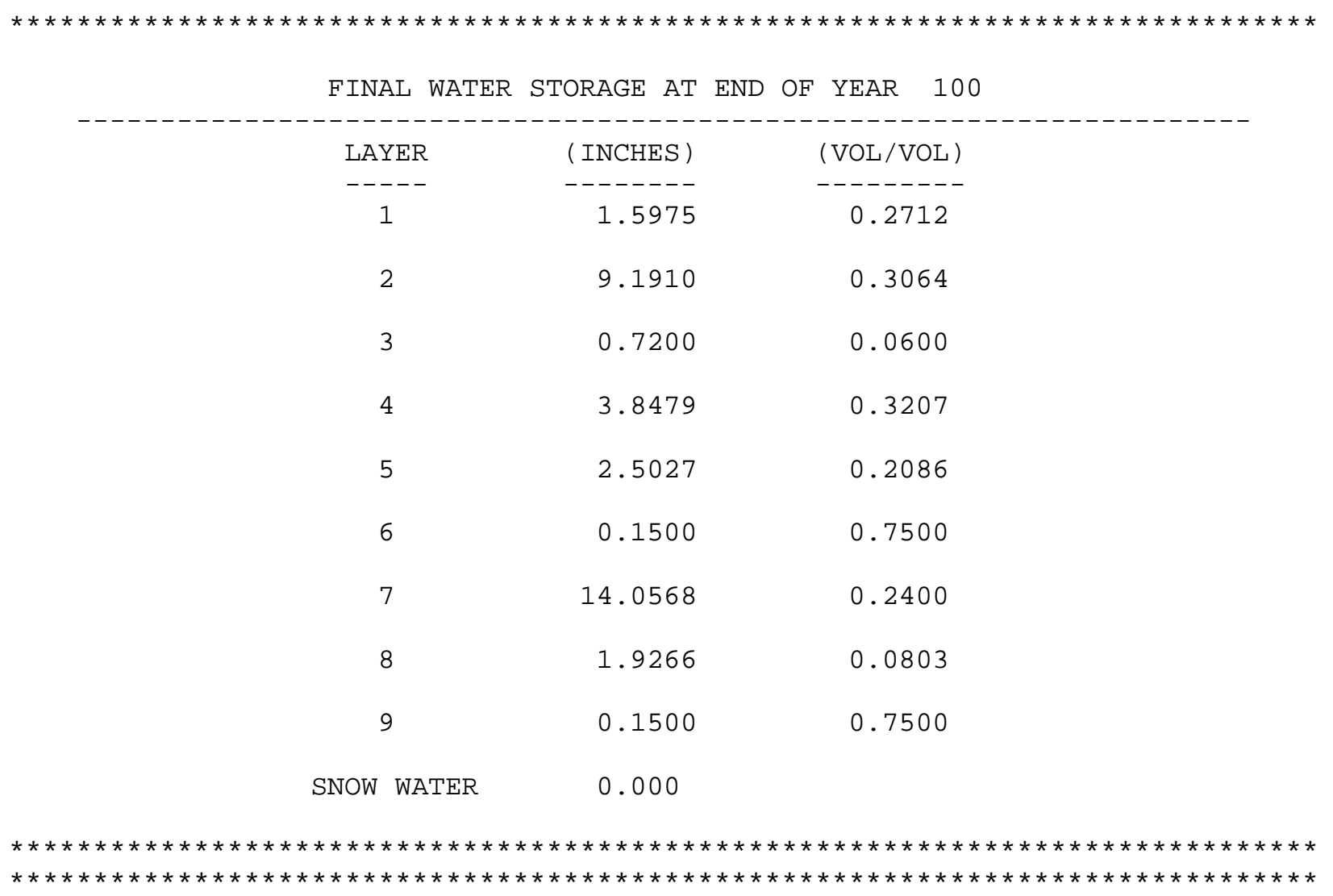


Appendix J, Lower Bounding Scenario Degraded SDF MSE Vault Closure Cap (1,000 Years): HELP Model Input Data and Output File (output file name: ZLBS4out.OUT)

\section{Input Data:}

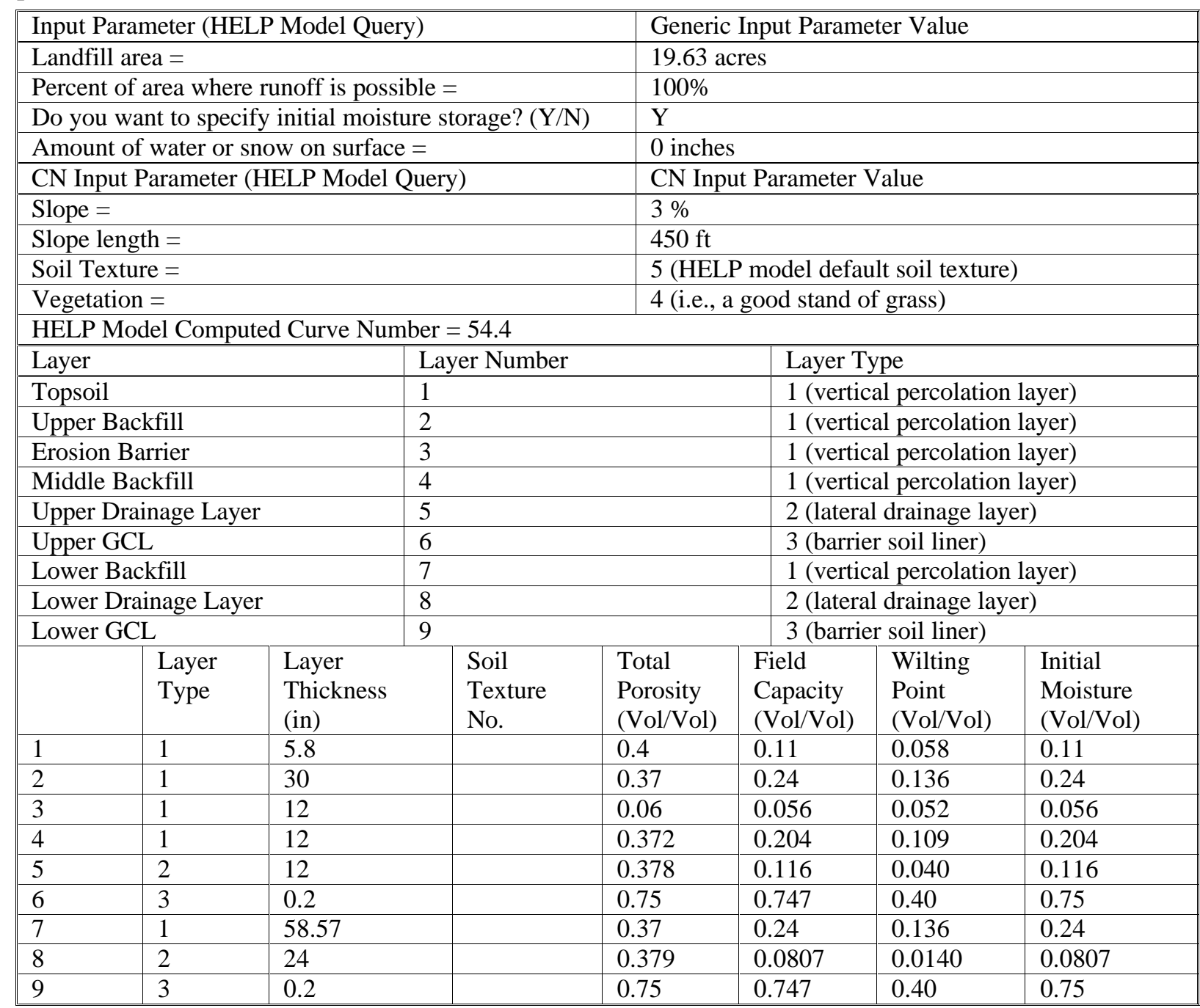

The lack of values in the table for particular parameters in particular layers denotes that no HELP model input was required for that parameter in that layer. No data are missing from the table. 
Input Data (continued):

\begin{tabular}{|c|c|c|c|c|c|c|c|c|c|}
\hline & $\begin{array}{l}\text { Layer } \\
\text { Type }\end{array}$ & $\begin{array}{l}\text { Sat. Hyd. } \\
\text { Conductivity * } \\
(\mathrm{cm} / \mathrm{sec})\end{array}$ & \multicolumn{2}{|c|}{$\begin{array}{l}\text { Drainage } \\
\text { Length } \\
(\mathrm{ft}) \\
\end{array}$} & $\begin{array}{l}\text { Drain } \\
\text { Slope } \\
(\%)\end{array}$ & $\begin{array}{l}\text { Leachate } \\
\text { Recirc. } \\
(\%) \\
\end{array}$ & \multicolumn{2}{|c|}{$\begin{array}{l}\text { Recirc. to } \\
\text { Layer } \\
(\#)\end{array}$} & $\begin{array}{l}\text { Subsurface } \\
\text { Inflow } \\
\text { (in/yr) }\end{array}$ \\
\hline 1 & 1 & $1.00 \mathrm{E}-03$ & & & & & & & \\
\hline 2 & 1 & $1.00 \mathrm{E}-04$ & & & & & & & \\
\hline 3 & 1 & $3.97 \mathrm{E}-04$ & & & & & & & \\
\hline 4 & 1 & $4.60 \mathrm{E}-04$ & & & & & & & \\
\hline 5 & 2 & $2.10 \mathrm{E}-02$ & 450 & & 3 & & & & \\
\hline 6 & 3 & $5.00 \mathrm{E}-09$ & & & & & & & \\
\hline 7 & 1 & $1.00 \mathrm{E}-04$ & & & & & & & \\
\hline 8 & 2 & 9.94E-02 & 150 & & 11.4 & & & & \\
\hline \multirow[t]{2}{*}{9} & 3 & $5.00 \mathrm{E}-09$ & & & & & & \\
\hline & $\begin{array}{l}\text { Layer } \\
\text { Type }\end{array}$ & \multicolumn{2}{|l|}{$\begin{array}{l}\text { Geomembrane } \\
\text { Pinhole Density } \\
\text { (\#/acre) }\end{array}$} & \multicolumn{2}{|c|}{$\begin{array}{l}\text { Geomembrane } \\
\text { Instal. Defects } \\
(\# / \text { acre })\end{array}$} & \multicolumn{2}{|c|}{$\begin{array}{l}\text { Geomembrane } \\
\text { Placement Quality }\end{array}$} & \multicolumn{2}{|c|}{$\begin{array}{l}\text { Geotextile } \\
\text { Transmissivity } \\
\left(\mathrm{cm}^{2} / \mathrm{sec}\right)\end{array}$} \\
\hline 1 & 1 & & & & & & & & \\
\hline 2 & 1 & & & & & & & & \\
\hline 3 & 1 & & & & & & & & \\
\hline 4 & 1 & & & & & & & & \\
\hline 5 & 2 & & & & & & & & \\
\hline 6 & 3 & & & & & & & & \\
\hline 7 & 1 & & & & & & & & \\
\hline 8 & 2 & & & & & & & & \\
\hline 9 & 3 & & & & & & & & \\
\hline
\end{tabular}

The lack of values in the table for particular parameters in particular layers denotes that no HELP model input was required for that parameter in that layer. No data are missing from the table.

* The HELP model output often produces an increased number of significant digits for the Effective Saturated Hydraulic Conductivity over that of the actual input 


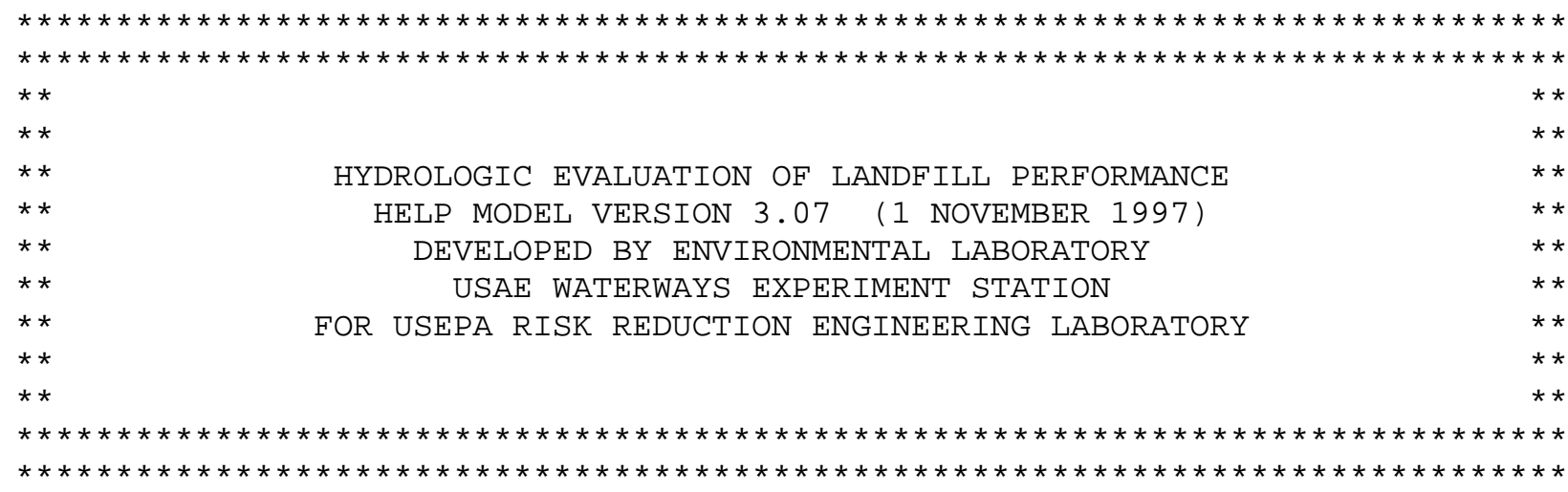

\begin{tabular}{|c|c|}
\hline PRECIPITATION DATA FILE: & $\mathrm{D}: \backslash$ HELP $3 \backslash$ Hweather $\backslash Z$ \\
\hline TEMPERATURE DATA FILE: & D : \HELP $3 \backslash$ Hweather $\backslash \mathrm{ZTEMP}$. D 7 \\
\hline SOLAR RADIATION DATA FILE: & D : \HELP $3 \backslash$ Hweather $\backslash$ ZSOLAR.D13 \\
\hline EVAPOTRANSPIRATION DATA: & D : \HELP $3 \backslash$ Hweat her $\backslash$ ZEVAP . D11 \\
\hline SOIL AND DESIGN DATA FILE: & $\mathrm{D}: \backslash$ HELP $3 \backslash$ Hsdfmse $\backslash$ ZLBS $4 . D 10$ \\
\hline UTPUT DATA FILE: & 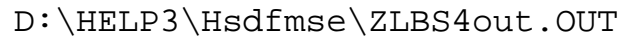 \\
\hline
\end{tabular}

TIME : $14: 55 \quad$ DATE $: \quad 12 / 11 / 2003$

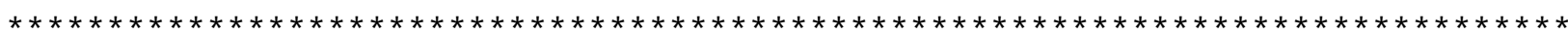
TITLE: LBS Degraded MSE Vault Closure Cap - 1,000 Years

NOTE: INITIAL MOISTURE CONTENT OF THE LAYERS AND SNOW WATER WERE SPECIFIED BY THE USER.

\begin{tabular}{|c|c|c|c|c|}
\hline \multicolumn{5}{|c|}{$\begin{array}{ll}\text { LAYER } & 1 \\
-------\end{array}$} \\
\hline \multicolumn{4}{|c|}{ TYPE 1 - VERTICAL PERCOLATION LAYER } & \\
\hline THICKNESS & $=$ & 5.80 & INCHES & \\
\hline POROSITY & $=$ & 0.4000 & VOL/VOL & \\
\hline FIELD CAPACITY & $=$ & 0.1100 & $\mathrm{VOL} / \mathrm{VOL}$ & \\
\hline WILTING POINT & $=$ & 0.0580 & VOL/VOL & \\
\hline INITIAL SOIL WATER CONTENT & $=$ & 0.1100 & VOL/VOL & \\
\hline EFFECTIVE SAT. HYD. COND. & $=$ & 0.100000005 & $5000 E-02$ & $\mathrm{CM} / \mathrm{SEC}$ \\
\hline \multicolumn{5}{|c|}{ LAYER 2} \\
\hline \multicolumn{5}{|c|}{ TYPE 1 - VERTICAL PERCOLATION LAYER } \\
\hline THICKNESS & $=$ & 30.00 & INCHES & \\
\hline POROSITY & $=$ & 0.3700 & VOL/VOL & \\
\hline FIELD CAPACITY & $=$ & 0.2400 & VOL/VOL & \\
\hline WILTING POINT & $=$ & 0.1360 & VOL/VOL & \\
\hline INITIAL SOIL WATER CONTENT & $=$ & 0.2400 & VOL/VOL & \\
\hline EFFECTIVE SAT. HYD. COND. & $=$ & 0.999999975 & $5000 E-04$ & $\mathrm{CM}$ \\
\hline
\end{tabular}

Rev. 0 
LAYER 3

$--------$

TYPE 1 - VERTICAL PERCOLATION LAYER

MATERIAL TEXTURE NUMBER 0

$\begin{array}{llrl}\text { THICKNESS } & = & 12.00 \mathrm{INCHES} \\ \text { POROSITY } & = & 0.0600 \mathrm{VOL} / \mathrm{VOL} \\ \text { FIELD CAPACITY } & = & 0.0560 \mathrm{VOL} / \mathrm{VOL} \\ \text { WILTING POINT } & = & 0.0520 \mathrm{VOL} / \mathrm{VOL} \\ \text { INITIAL SOIL WATER CONTENT } & = & 0.0560 \mathrm{VOL} / \mathrm{VOL} \\ \text { EFFECTIVE SAT. HYD. COND. } & =0.396999996000 \mathrm{E}-03 \mathrm{CM} / \mathrm{SEC}\end{array}$

LAYER 4

TYPE 1 - VERTICAL PERCOLATION LAYER MATERIAL TEXTURE NUMBER 0

$\begin{array}{llrl}\text { THICKNESS } & = & 12.00 & \text { INCHES } \\ \text { POROSITY } & = & 0.3720 \mathrm{VOL} / \mathrm{VOL} \\ \text { FIELD CAPACITY } & = & 0.2040 \mathrm{VOL} / \mathrm{VOL} \\ \text { WILTING POINT } & = & 0.1090 \mathrm{VOL} / \mathrm{VOL} \\ \text { INITIAL SOIL WATER CONTENT } & = & 0.2040 \mathrm{VOL} / \mathrm{VOL} \\ \text { EFFECTIVE SAT. HYD. COND. } & =0.460000010000 \mathrm{E}-03 \mathrm{CM} / \mathrm{SEC}\end{array}$

LAYER 5

$--------$

TYPE 2 - LATERAL DRAINAGE LAYER MATERIAL TEXTURE NUMBER 0

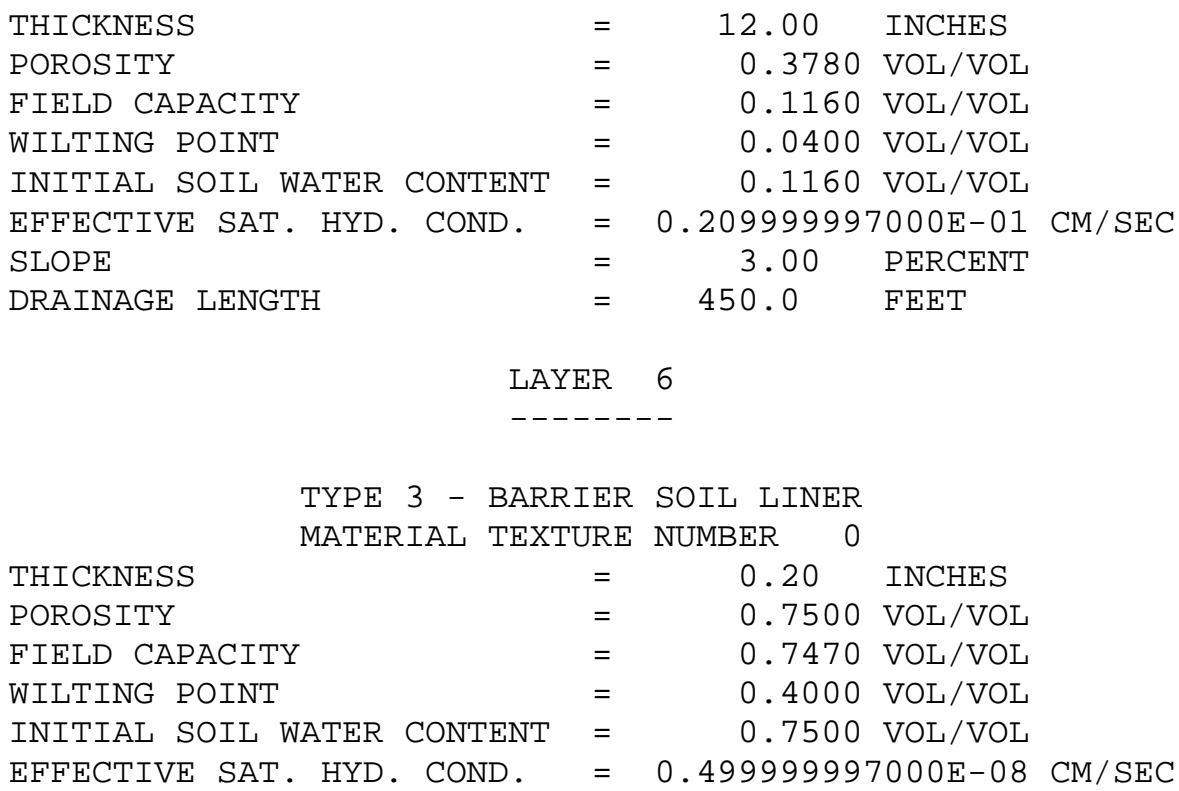

Rev. 0 
LAYER 7

$--------$

TYPE 1 - VERTICAL PERCOLATION LAYER

MATERIAL TEXTURE NUMBER 0

$\begin{array}{llrl}\text { THICKNESS } & = & 58.57 & \text { INCHES } \\ \text { POROSITY } & = & 0.3700 \mathrm{VOL} / \mathrm{VOL} \\ \text { FIELD CAPACITY } & = & 0.2400 \mathrm{VOL} / \mathrm{VOL} \\ \text { WILTING POINT } & = & 0.1360 \mathrm{VOL} / \mathrm{VOL} \\ \text { INITIAL SOIL WATER CONTENT } & = & 0.2400 \mathrm{VOL} / \mathrm{VOL} \\ \text { EFFECTIVE SAT. HYD. COND. } & =0.999999975000 \mathrm{E}-04 \mathrm{CM} / \mathrm{SEC}\end{array}$

LAYER 8

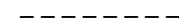

TYPE 2 - LATERAL DRAINAGE LAYER

$\begin{array}{llrl}\text { THICKNESS } & = & 24.00 & \text { INCHES } \\ \text { POROSITY } & = & 0.3790 \mathrm{VOL} / \mathrm{VOL} \\ \text { FIELD CAPACITY } & = & 0.0807 \mathrm{VOL} / \mathrm{VOL} \\ \text { WILTING POINT } & = & 0.0140 \mathrm{VOL} / \mathrm{VOL} \\ \text { INITIAL SOIL WATER CONTENT } & = & 0.0807 \mathrm{VOL} / \mathrm{VOL} \\ \text { EFFECTIVE SAT. HYD. COND. } & = & 0.993999988000 \mathrm{E}-01 \mathrm{CM} / \mathrm{SEC} \\ \text { SLOPE } & = & 11.40 \mathrm{PERCENT} \\ \text { DRAINAGE LENGTH } & = & 150.0 & \mathrm{FEET}\end{array}$

LAYER 9

TYPE 3 - BARRIER SOIL LINER

MATERIAL TEXTURE NUMBER 0

$\begin{array}{llrl}\text { THICKNESS } & = & 0.20 & \text { INCHES } \\ \text { POROSITY } & = & 0.7500 \mathrm{VOL} / \mathrm{VOL} \\ \text { FIELD CAPACITY } & = & 0.7470 \mathrm{VOL} / \mathrm{VOL} \\ \text { WILTING POINT } & = & 0.4000 \mathrm{VOL} / \mathrm{VOL} \\ \text { INITIAL SOIL WATER CONTENT } & = & 0.7500 \mathrm{VOL} / \mathrm{VOL} \\ \text { EFFECTIVE SAT. HYD. COND. } & =0.499999997000 \mathrm{E}-08 \mathrm{CM} / \mathrm{SEC}\end{array}$

GENERAL DESIGN AND EVAPORATIVE ZONE DATA

NOTE: SCS RUNOFF CURVE NUMBER WAS COMPUTED FROM DEFAULT SOIL DATA BASE USING SOIL TEXTURE \# 5 WITH A GOOD STAND OF GRASS, A SURFACE SLOPE OF 3.\% AND A SLOPE LENGTH OF 450. FEET.

SCS RUNOFF CURVE NUMBER

FRACTION OF AREA ALLOWING RUNOFF

AREA PROJECTED ON HORIZONTAL PLANE

EVAPORATIVE ZONE DEPTH

INITIAL WATER IN EVAPORATIVE ZONE

UPPER LIMIT OF EVAPORATIVE STORAGE

LOWER LIMIT OF EVAPORATIVE STORAGE

INITIAL SNOW WATER

INITIAL WATER IN LAYER MATERIALS

TOTAL INITIAL WATER

TOTAL SUBSURFACE INFLOW

$\begin{array}{lcl}= & 54.40 & \\ = & 100.0 & \text { PERCENT } \\ = & 19.630 & \text { ACRES } \\ = & 22.0 & \text { INCHES } \\ = & 4.526 & \text { INCHES } \\ = & 8.314 & \text { INCHES } \\ = & 2.540 & \text { INCHES } \\ = & 0.000 & \text { INCHES } \\ = & 28.644 & \text { INCHES } \\ = & 28.644 & \text { INCHES } \\ = & 0.00 & \text { INCHES /YEAR }\end{array}$

Rev. 0 


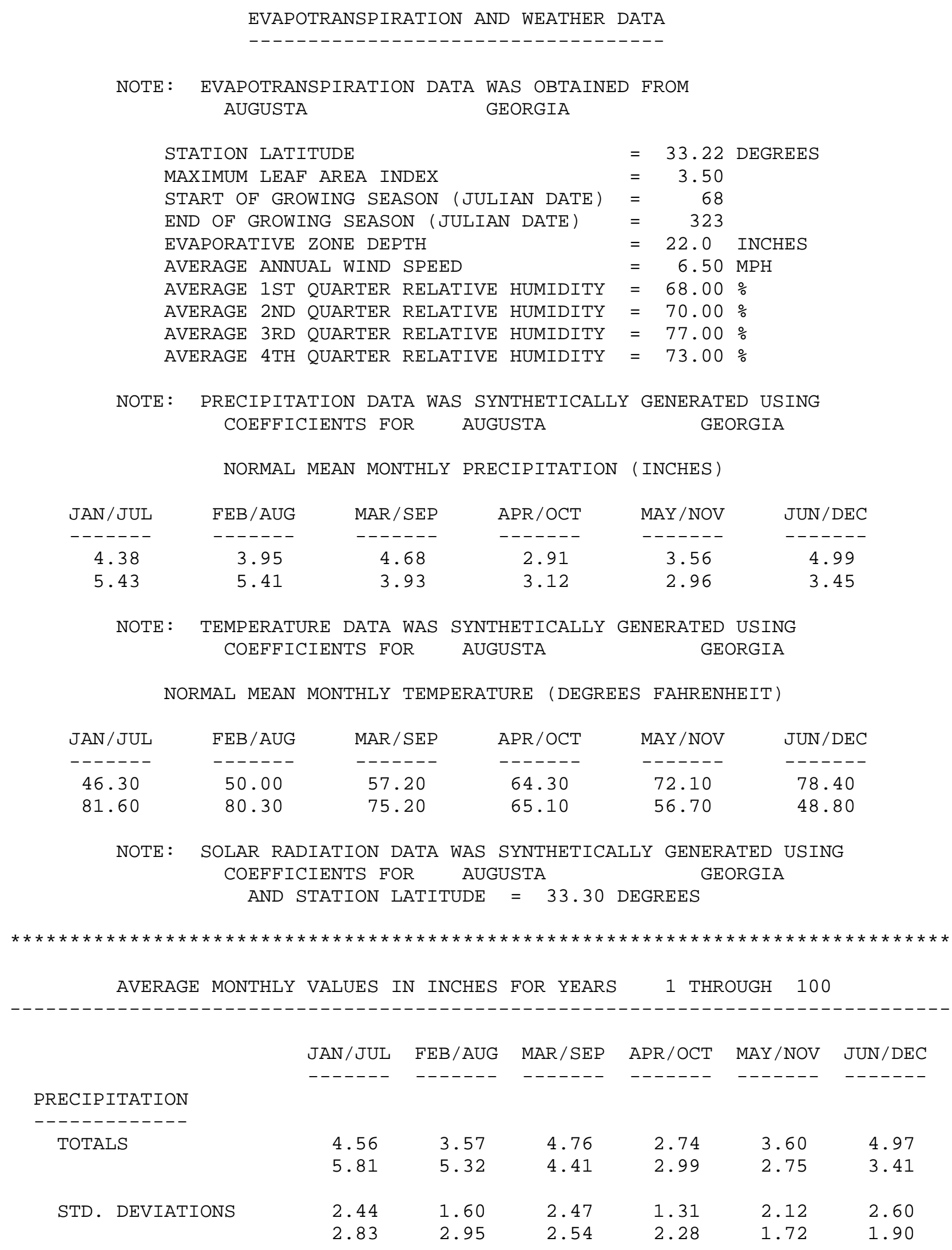

Rev. 0 
RUNOFF

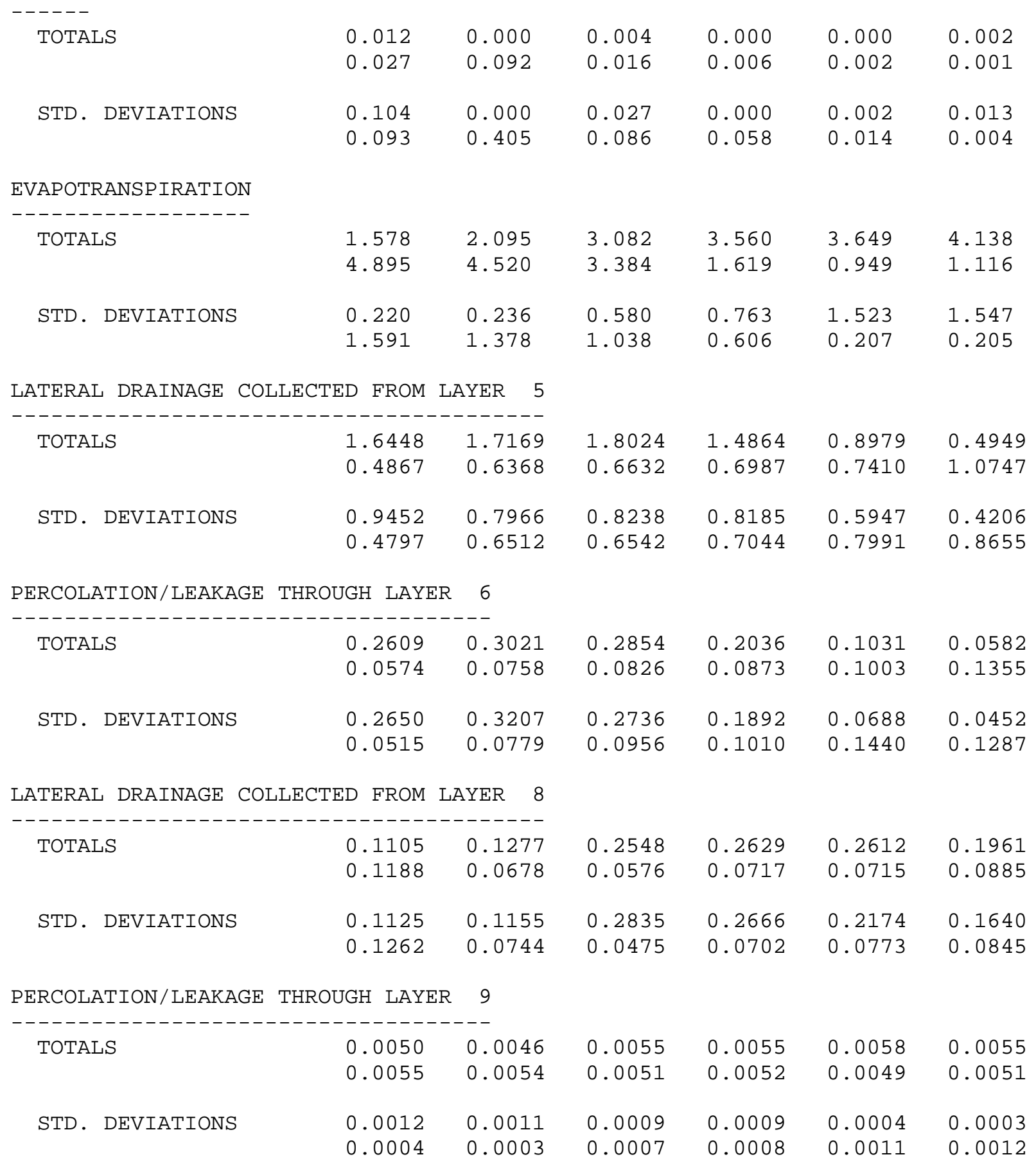


AVERAGES OF MONTHLY AVERAGED DAILY HEADS (INCHES)

DAILY AVERAGE HEAD ON TOP OF LAYER 6

$\begin{array}{lrrrrrr}\text { AVERAGES } & 9.6996 & 12.3618 & 10.6247 & 7.7825 & 3.7120 & 2.0811 \\ & 1.9798 & 2.6776 & 3.0434 & 3.1155 & 3.7426 & 4.9498 \\ \text { STD. DEVIATIONS } & 10.0502 & 13.3405 & 10.3789 & 7.4141 & 2.6101 & 1.7706 \\ & 1.9516 & 2.9533 & 3.7430 & 3.8267 & 5.6371 & 4.8722\end{array}$

DAILY AVERAGE HEAD ON TOP OF LAYER 9

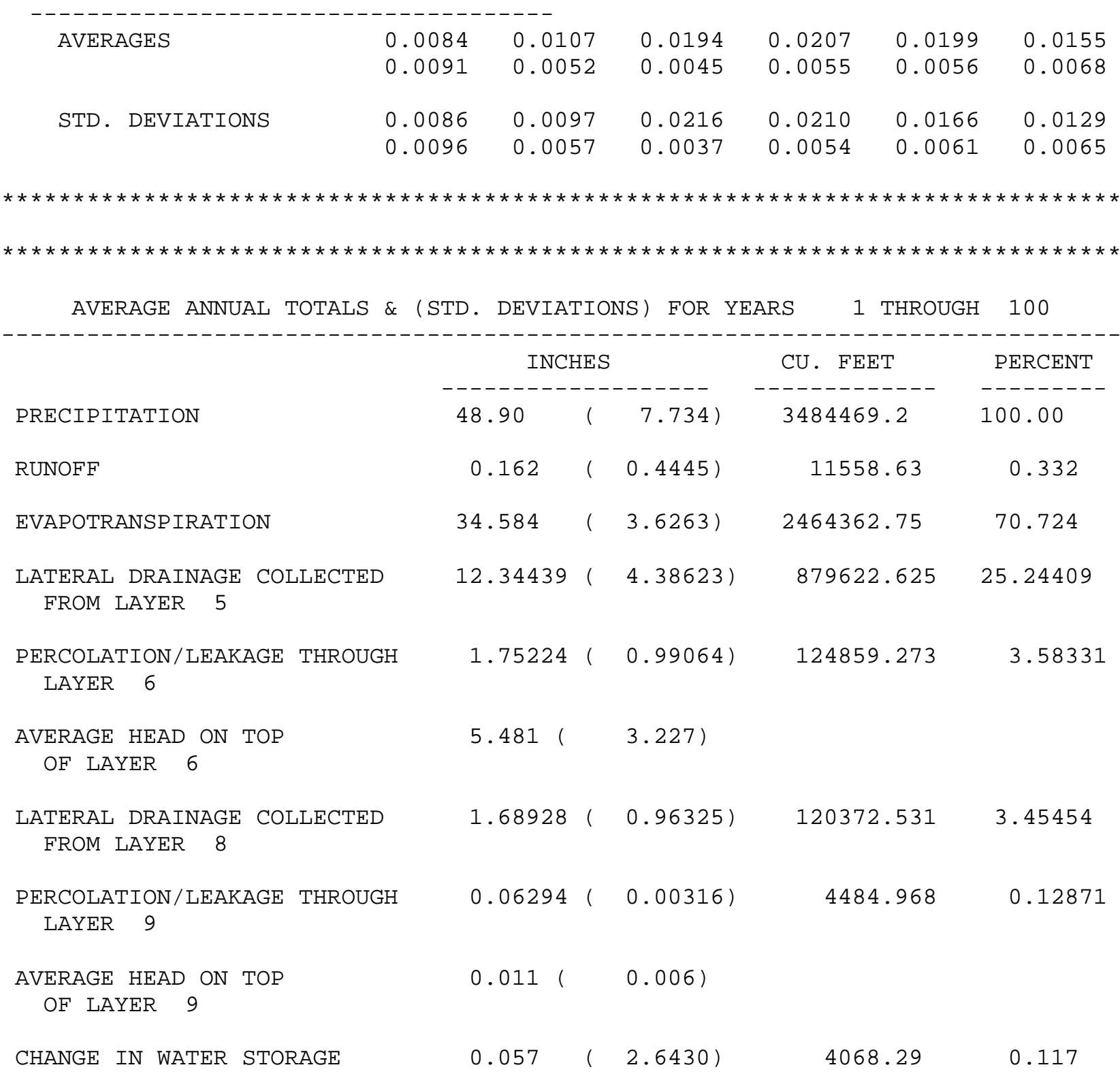




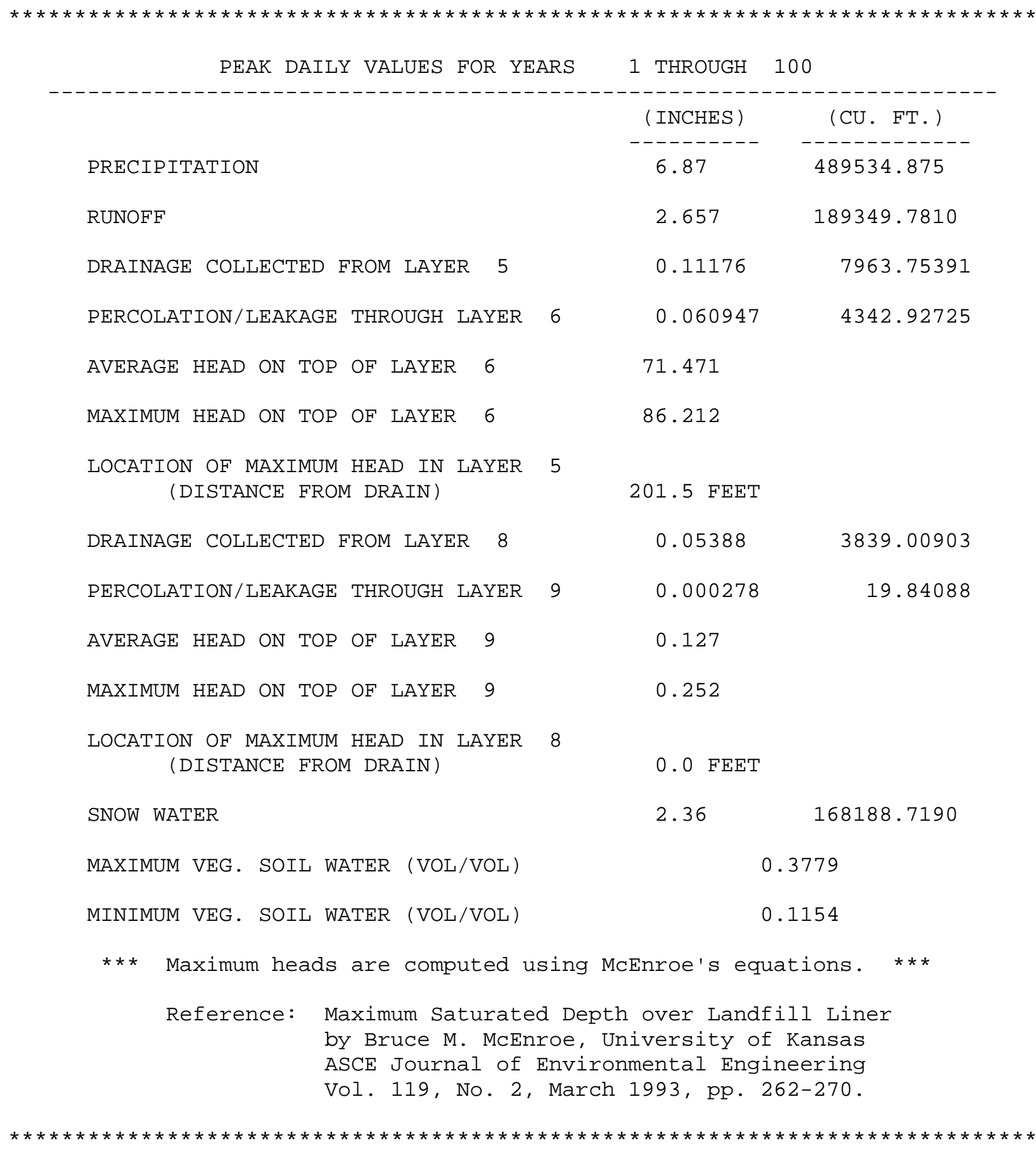

Rev. 0 


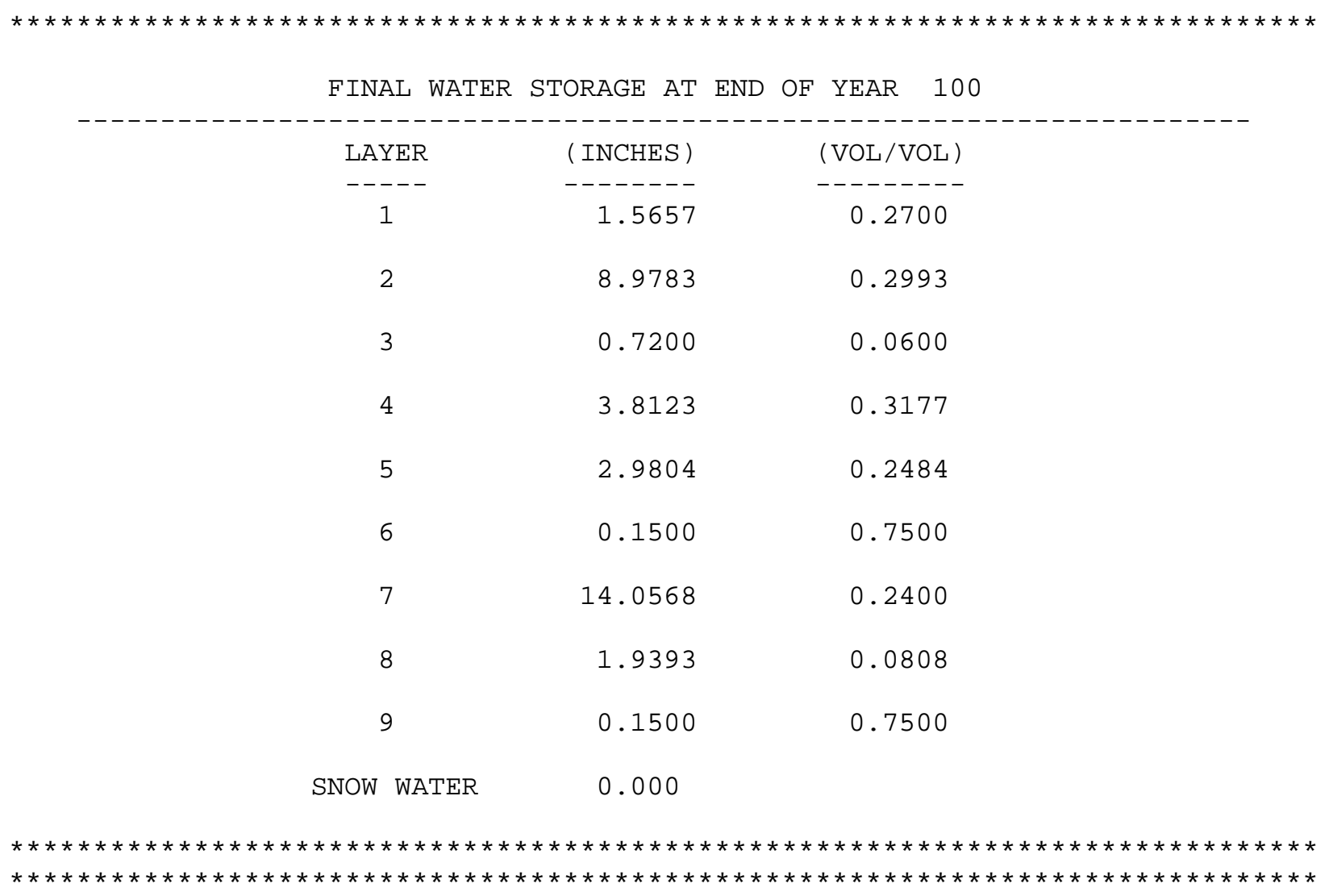


Appendix K, Lower Bounding Scenario Degraded SDF MSE Vault Closure Cap (1,800 Years): HELP Model Input Data and Output File (output file name: ZLBS5out.OUT)

\section{Input Data:}

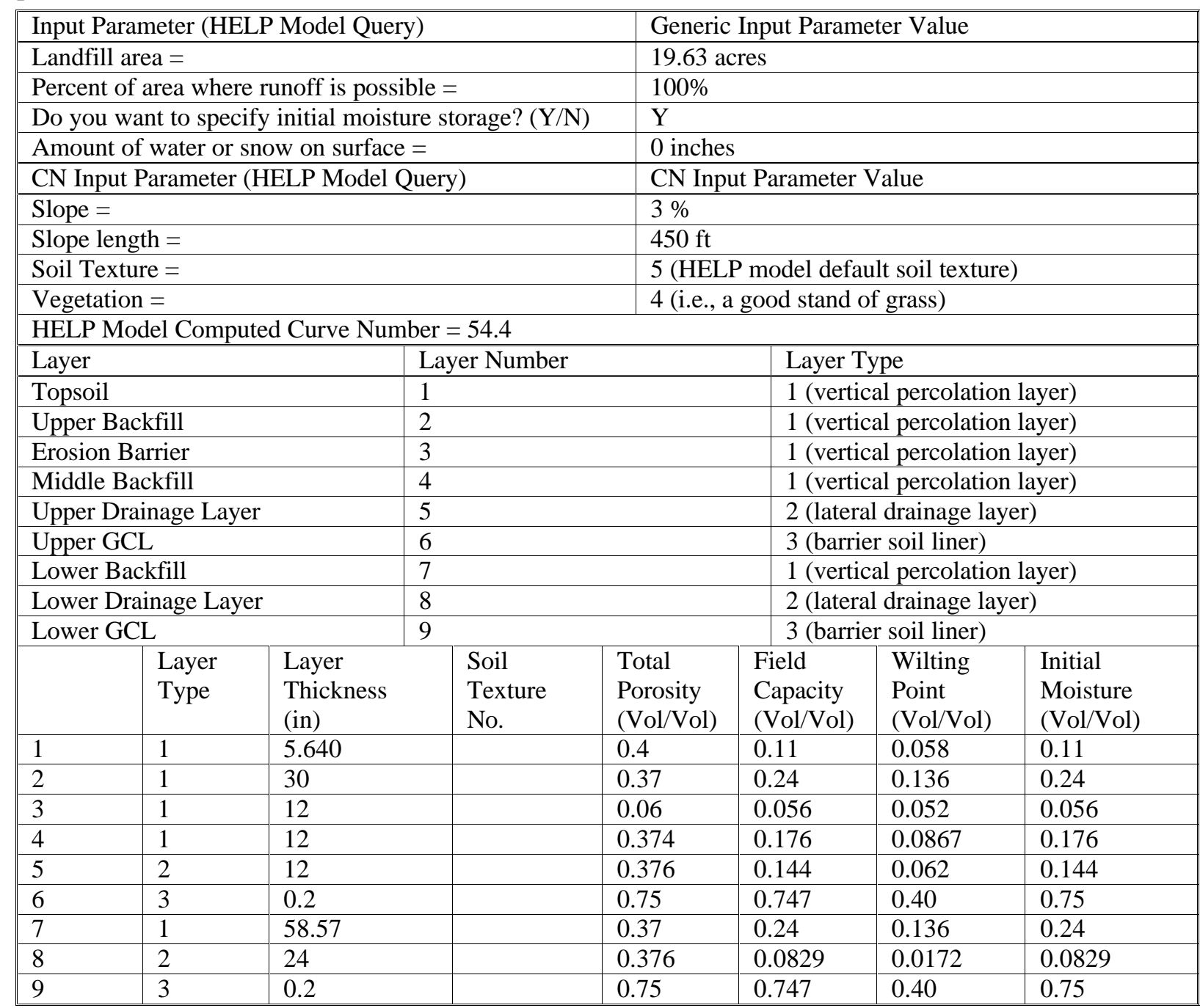

The lack of values in the table for particular parameters in particular layers denotes that no HELP model input was required for that parameter in that layer. No data are missing from the table. 
Input Data (continued):

\begin{tabular}{|c|c|c|c|c|c|c|c|c|c|}
\hline & $\begin{array}{l}\text { Layer } \\
\text { Type }\end{array}$ & $\begin{array}{l}\text { Sat. Hyd. } \\
\text { Conductivity * } \\
(\mathrm{cm} / \mathrm{sec})\end{array}$ & \multicolumn{2}{|c|}{$\begin{array}{l}\text { Drainage } \\
\text { Length } \\
(\mathrm{ft}) \\
\end{array}$} & $\begin{array}{l}\text { Drain } \\
\text { Slope } \\
(\%)\end{array}$ & $\begin{array}{l}\text { Leachate } \\
\text { Recirc. } \\
(\%) \\
\end{array}$ & \multicolumn{2}{|c|}{$\begin{array}{l}\text { Recirc. to } \\
\text { Layer } \\
(\#)\end{array}$} & $\begin{array}{l}\text { Subsurface } \\
\text { Inflow } \\
\text { (in/yr) }\end{array}$ \\
\hline 1 & 1 & $1.00 \mathrm{E}-03$ & & & & & & & \\
\hline 2 & 1 & $1.00 \mathrm{E}-04$ & & & & & & & \\
\hline 3 & 1 & $3.97 \mathrm{E}-04$ & & & & & & & \\
\hline 4 & 1 & $1.60 \mathrm{E}-03$ & & & & & & & \\
\hline 5 & 2 & $6.30 \mathrm{E}-03$ & 450 & & 3 & & & & \\
\hline 6 & 3 & $5.00 \mathrm{E}-09$ & & & & & & & \\
\hline 7 & 1 & $1.00 \mathrm{E}-04$ & & & & & & & \\
\hline 8 & 2 & $9.77 \mathrm{E}-02$ & 150 & & 11.4 & & & & \\
\hline \multirow[t]{2}{*}{9} & 3 & $5.00 \mathrm{E}-09$ & & & & & & \\
\hline & $\begin{array}{l}\text { Layer } \\
\text { Type }\end{array}$ & \multicolumn{2}{|l|}{$\begin{array}{l}\text { Geomembrane } \\
\text { Pinhole Density } \\
\text { (\#/acre) }\end{array}$} & \multicolumn{2}{|c|}{$\begin{array}{l}\text { Geomembrane } \\
\text { Instal. Defects } \\
(\# / \text { acre })\end{array}$} & \multicolumn{2}{|c|}{$\begin{array}{l}\text { Geomembrane } \\
\text { Placement Quality }\end{array}$} & \multicolumn{2}{|c|}{$\begin{array}{l}\text { Geotextile } \\
\text { Transmissivity } \\
\left(\mathrm{cm}^{2} / \mathrm{sec}\right)\end{array}$} \\
\hline 1 & 1 & & & & & & & & \\
\hline 2 & 1 & & & & & & & & \\
\hline 3 & 1 & & & & & & & & \\
\hline 4 & 1 & & & & & & & & \\
\hline 5 & 2 & & & & & & & & \\
\hline 6 & 3 & & & & & & & & \\
\hline 7 & 1 & & & & & & & & \\
\hline 8 & 2 & & & & & & & & \\
\hline 9 & 3 & & & & & & & & \\
\hline
\end{tabular}

The lack of values in the table for particular parameters in particular layers denotes that no HELP model input was required for that parameter in that layer. No data are missing from the table.

* The HELP model output often produces an increased number of significant digits for the Effective Saturated Hydraulic Conductivity over that of the actual input 


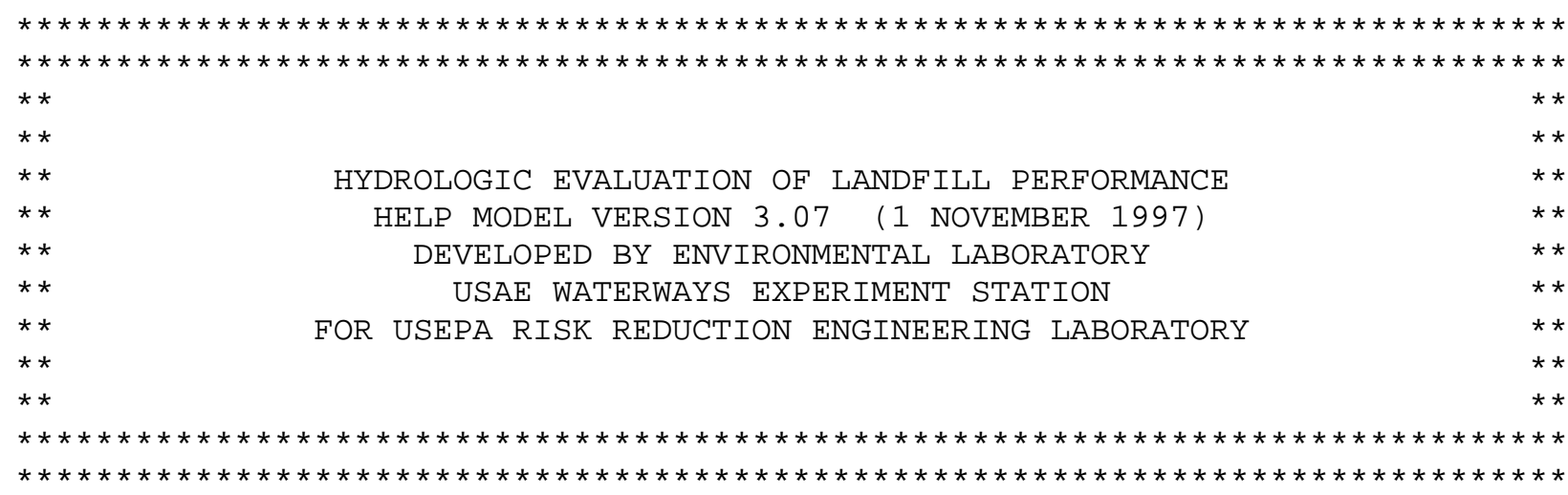
PRECIPITATION DATA FILE:
D: \HELP 3 \Hweather $\backslash$ ZPREC.D4
TEMPERATURE DATA FILE:
D: \HELP $3 \backslash$ Hweather $\backslash$ ZTEMP.D7
SOLAR RADIATION DATA FILE: D: \HELP3\Hweather $\backslash$ ZSOLAR.D13
EVAPOTRANSPIRATION DATA: D: \HELP3\Hweather $\backslash$ ZEVAP.D11
SOIL AND DESIGN DATA FILE: D: \HELP3\Hsdfmse \ZLBS5.D10
OUTPUT DATA FILE:
D: \HELP $3 \backslash$ Hsdfmse $\backslash Z L B S 5$ out.OUT

TIME: $14: 57 \quad$ DATE: $12 / 11 / 2003$

TITLE: LBS Degraded MSE Vault Closure Cap - 1,800 Years

NOTE: INITIAL MOISTURE CONTENT OF THE LAYERS AND SNOW WATER WERE SPECIFIED BY THE USER.

\begin{tabular}{|c|c|c|c|c|}
\hline \multicolumn{5}{|c|}{$\begin{array}{c}\text { TYPE } 1 \text { - VERTICAL PERCOLATION LAYER } \\
\text { MATERIAL TEXTURE NUMBER }\end{array}$} \\
\hline THICKNESS & $=$ & 5.64 & INCHES & \\
\hline POROSITY & $=$ & 0.4000 & VOL/VOI & \\
\hline FIELD CAPACITY & $=$ & 0.1100 & VOL/VOI & \\
\hline WILTING POINT & $=$ & 0.0580 & VOL/VOI & \\
\hline INITIAL SOIL WATER CONTENT & $=$ & 0.1100 & VOL/VOI & \\
\hline EFFECTIVE SAT. HYD. COND. & $=$ & 0.100000005 & $5000 \mathrm{E}-02$ & $\mathrm{CM} / \mathrm{SEC}$ \\
\hline \multicolumn{5}{|c|}{ LAYER 2} \\
\hline $\begin{array}{r}\text { TYPE } 1 \text { - VERTICAI } \\
\text { MATERIAL TEXT }\end{array}$ & & $\begin{array}{ll}\text { RCOLATION LA } \\
\text { NUMBER } & 0\end{array}$ & AYER & \\
\hline THICKNESS & $=$ & 30.00 & INCHES & \\
\hline POROSITY & $=$ & 0.3700 & VOL/VOI & \\
\hline FIELD CAPACITY & $=$ & 0.2400 & VOL/VOI & \\
\hline WILTING POINT & $=$ & 0.1360 & VOL/VOI & \\
\hline INITIAL SOIL WATER CONTENT & $=$ & 0.2400 & VOL/VOI & \\
\hline EFFECTIVE SAT. HYD. COND. & $=$ & 0.999999975 & $5000 \mathrm{E}-04$ & $\mathrm{C}$ \\
\hline
\end{tabular}

Rev. 0 
LAYER 3

--------

TYPE 1 - VERTICAL PERCOLATION LAYER

MATERIAL TEXTURE NUMBER 0

$\begin{array}{llrl}\text { THICKNESS } & = & 12.00 & \text { INCHES } \\ \text { POROSITY } & = & 0.0600 \mathrm{VOL} / \mathrm{VOL} \\ \text { FIELD CAPACITY } & = & 0.0560 \mathrm{VOL} / \mathrm{VOL} \\ \text { WILTING POINT } & = & 0.0520 \mathrm{VOL} / \mathrm{VOL} \\ \text { INITIAL SOIL WATER CONTENT } & = & 0.0560 \mathrm{VOL} / \mathrm{VOL} \\ \text { EFFECTIVE SAT. HYD. COND. } & =0.39699999600 \mathrm{E}-03 \mathrm{CM} / \mathrm{SEC}\end{array}$

LAYER 4

TYPE 1 - VERTICAL PERCOLATION LAYER MATERIAL TEXTURE NUMBER 0

$\begin{array}{llrl}\text { THICKNESS } & = & 12.00 & \text { INCHES } \\ \text { POROSITY } & = & 0.3740 \mathrm{VOL} / \mathrm{VOL} \\ \text { FIELD CAPACITY } & = & 0.1760 \mathrm{VOL} / \mathrm{VOL} \\ \text { WILTING POINT } & = & 0.0867 \mathrm{VOL} / \mathrm{VOL} \\ \text { INITIAL SOIL WATER CONTENT } & = & 0.1760 \mathrm{VOL} / \mathrm{VOL} \\ \text { EFFECTIVE SAT. HYD. COND. } & =0.159999996000 \mathrm{E}-02 \mathrm{CM} / \mathrm{SEC} \\ & \\ \text { LAYER } & 5 & \\ & & \end{array}$

TYPE 2 - LATERAL DRAINAGE LAYER MATERIAL TEXTURE NUMBER 0

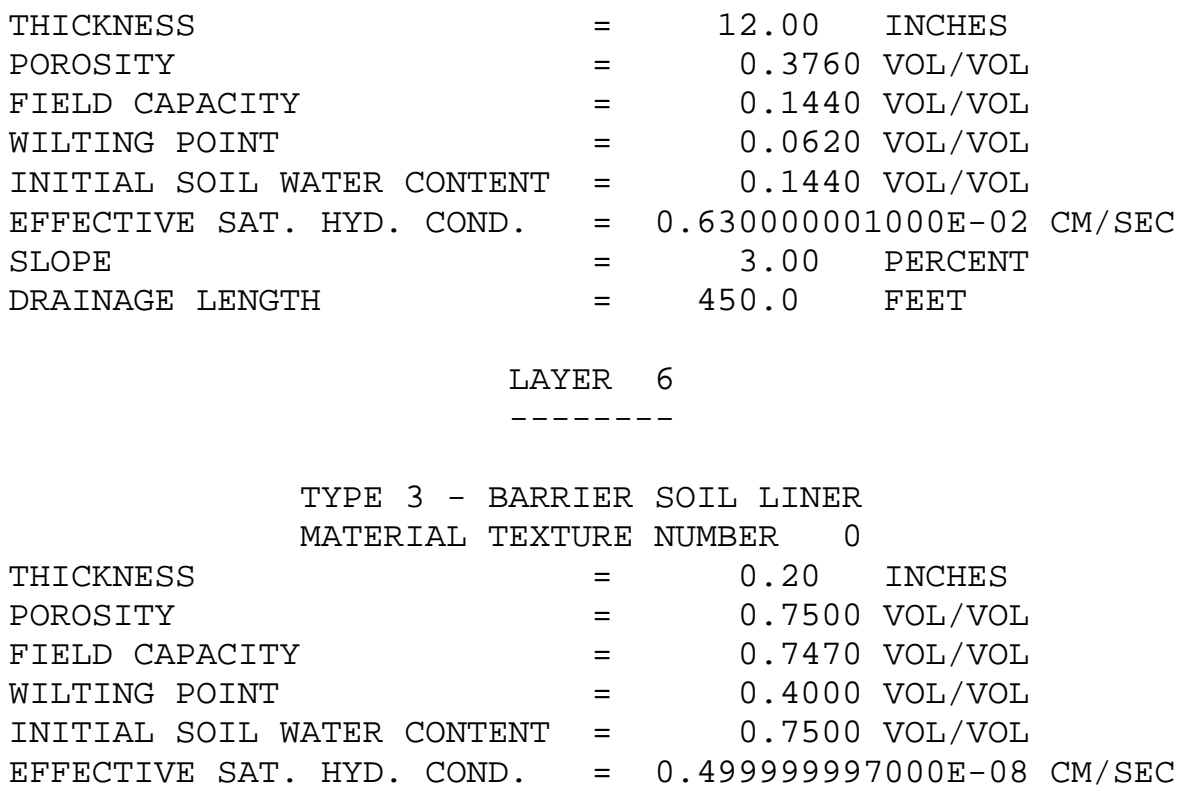


LAYER 7

$--------$

TYPE 1 - VERTICAL PERCOLATION LAYER

MATERIAL TEXTURE NUMBER 0

$\begin{array}{llrl}\text { THICKNESS } & = & 58.57 & \text { INCHES } \\ \text { POROSITY } & = & 0.3700 \mathrm{VOL} / \mathrm{VOL} \\ \text { FIELD CAPACITY } & = & 0.2400 \mathrm{VOL} / \mathrm{VOL} \\ \text { WILTING POINT } & = & 0.1360 \mathrm{VOL} / \mathrm{VOL} \\ \text { INITIAL SOIL WATER CONTENT } & = & 0.2400 \mathrm{VOL} / \mathrm{VOL} \\ \text { EFFECTIVE SAT. HYD. COND. } & =0.999999975000 \mathrm{E}-04 \mathrm{CM} / \mathrm{SEC}\end{array}$

LAYER 8

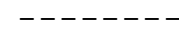

TYPE 2 - LATERAL DRAINAGE LAYER

$\begin{array}{llrl}\text { THICKNESS } & = & 24.00 & \text { INCHES } \\ \text { POROSITY } & = & 0.3760 \mathrm{VOL} / \mathrm{VOL} \\ \text { FIELD CAPACITY } & = & 0.0829 \mathrm{VOL} / \mathrm{VOL} \\ \text { WILTING POINT } & = & 0.0172 \mathrm{VOL} / \mathrm{VOL} \\ \text { INITIAL SOIL WATER CONTENT } & = & 0.0829 \mathrm{VOL} / \mathrm{VOL} \\ \text { EFFECTIVE SAT. HYD. COND. } & = & 0.97699999000 \mathrm{E}-01 \mathrm{CM} / \mathrm{SEC} \\ \text { SLOPE } & = & 11.40 \mathrm{PERCENT} \\ \text { DRAINAGE LENGTH } & = & 150.0 \mathrm{FEET}\end{array}$

LAYER 9

$--------$

TYPE 3 - BARRIER SOIL LINER

MATERIAL TEXTURE NUMBER 0

$\begin{array}{llll}\text { THICKNESS } & = & 0.20 & \text { INCHES } \\ \text { POROSITY } & = & 0.7500 \mathrm{VOL} / \mathrm{VOL} \\ \text { FIELD CAPACITY } & = & 0.7470 \mathrm{VOL} / \mathrm{VOL} \\ \text { WILTING POINT } & = & 0.4000 \mathrm{VOL} / \mathrm{VOL} \\ \text { INITIAL SOIL WATER CONTENT } & = & 0.7500 \mathrm{VOL} / \mathrm{VOL} \\ \text { EFFECTIVE SAT. HYD. COND. } & =0.499999997000 \mathrm{E}-08 \mathrm{CM} / \mathrm{SEC}\end{array}$

GENERAL DESIGN AND EVAPORATIVE ZONE DATA

NOTE: SCS RUNOFF CURVE NUMBER WAS COMPUTED FROM DEFAULT SOIL DATA BASE USING SOIL TEXTURE \# 5 WITH A GOOD STAND OF GRASS, A SURFACE SLOPE OF 3.\% AND A SLOPE LENGTH OF 450. FEET.

SCS RUNOFF CURVE NUMBER

FRACTION OF AREA ALLOWING RUNOFF

AREA PROJECTED ON HORIZONTAL PLANE

EVAPORATIVE ZONE DEPTH

INITIAL WATER IN EVAPORATIVE ZONE

UPPER LIMIT OF EVAPORATIVE STORAGE

LOWER LIMIT OF EVAPORATIVE STORAGE

INITIAL SNOW WATER

INITIAL WATER IN LAYER MATERIALS

TOTAL INITIAL WATER

TOTAL SUBSURFACE INFLOW

$\begin{array}{lcl}= & 54.40 & \\ = & 100.0 & \text { PERCENT } \\ = & 19.630 & \text { ACRES } \\ = & 22.0 & \text { INCHES } \\ = & 4.547 & \text { INCHES } \\ = & 8.309 & \text { INCHES } \\ = & 2.552 & \text { INCHES } \\ = & 0.000 & \text { INCHES } \\ = & 28.679 & \text { INCHES } \\ = & 28.679 & \text { INCHES } \\ = & 0.00 & \text { INCHES /YEAR }\end{array}$

Rev. 0 


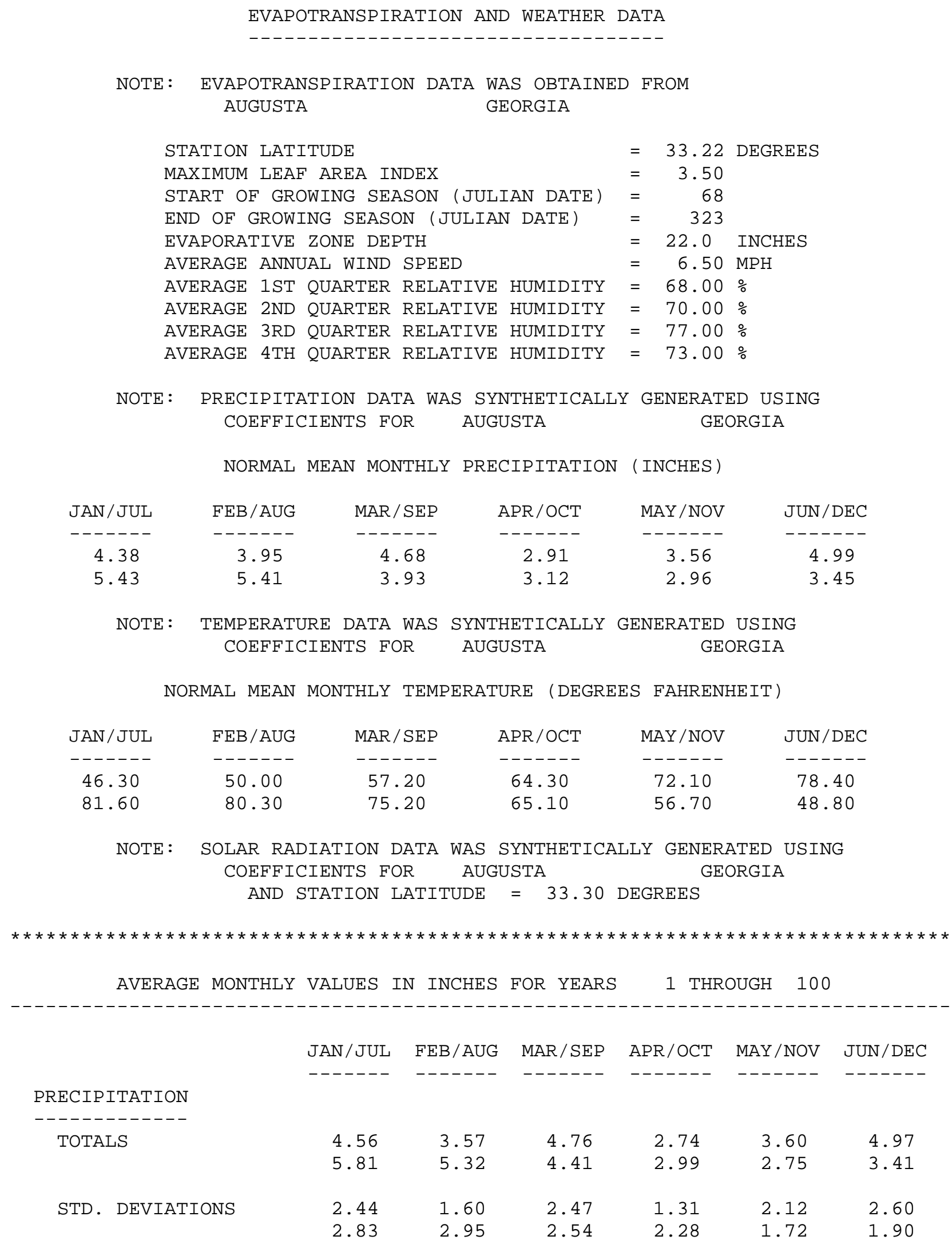

Rev. 0 
RUNOFF

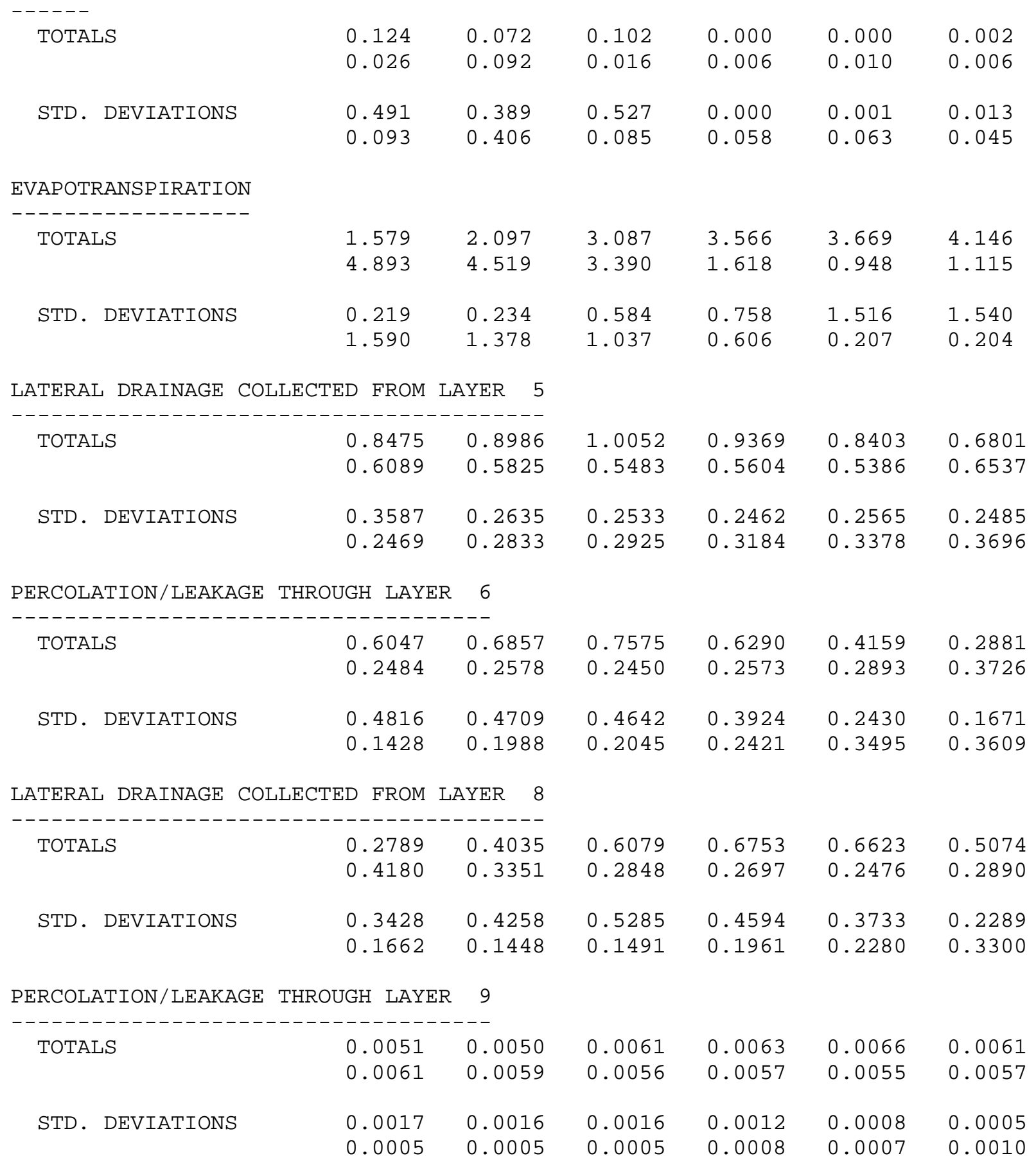


AVERAGES OF MONTHLY AVERAGED DAILY HEADS (INCHES)

DAILY AVERAGE HEAD ON TOP OF LAYER 6

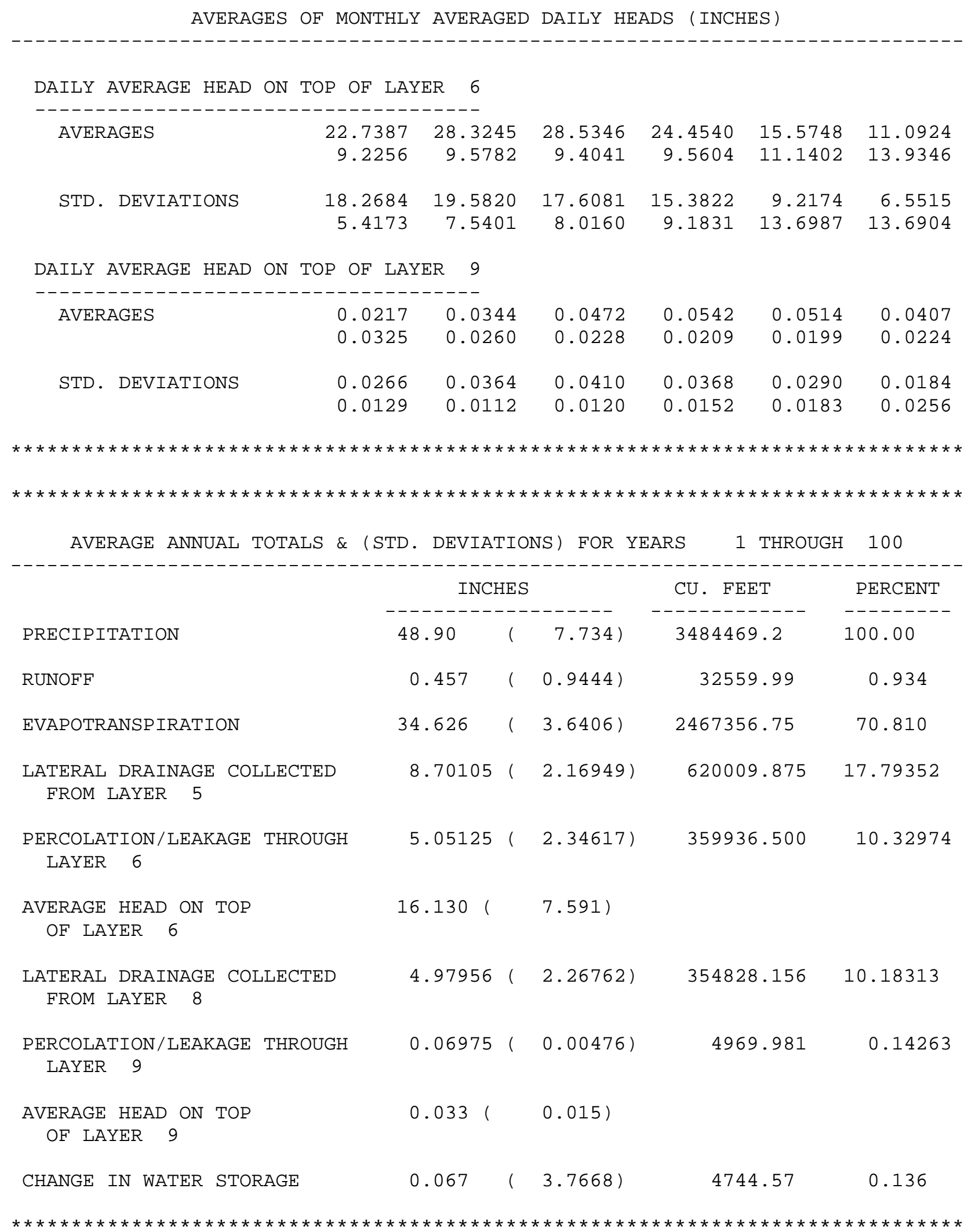$$
\star \star *
$$

Rev. 0 


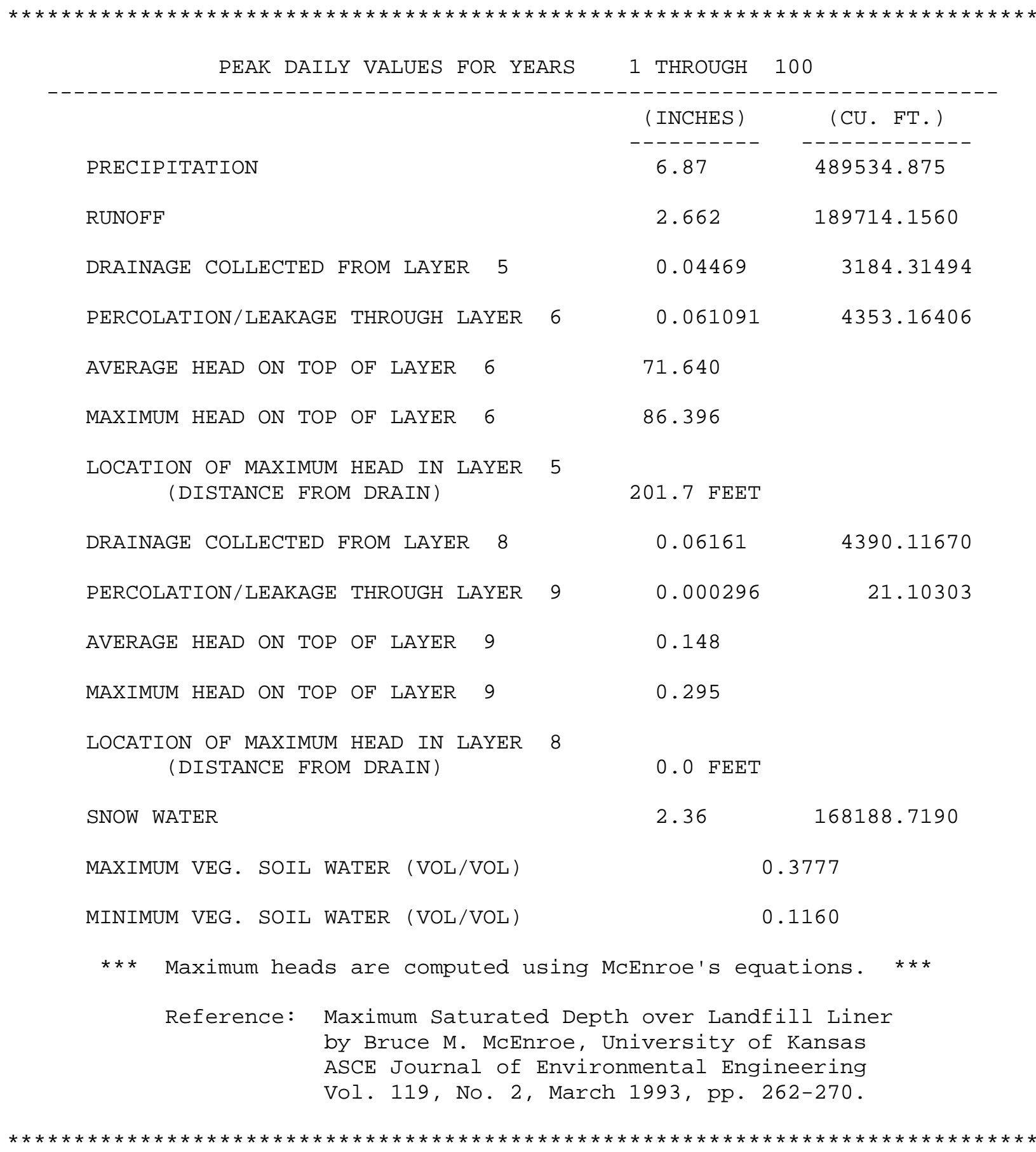

Rev. 0 


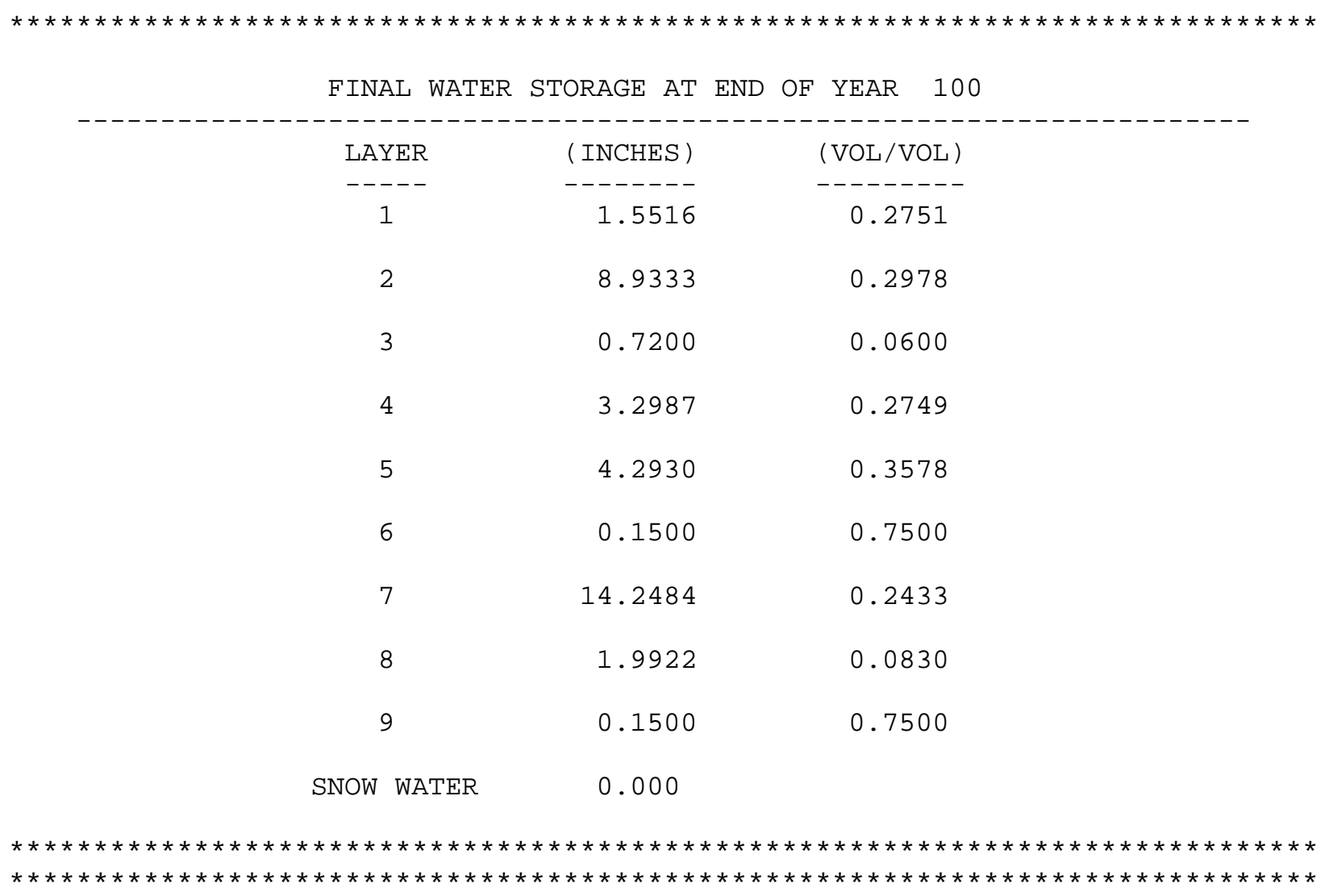


Appendix L, Lower Bounding Scenario Degraded SDF MSE Vault Closure Cap (3,400 Years): HELP Model Input Data and Output File (output file name: ZLBS6out.OUT)

\section{Input Data:}

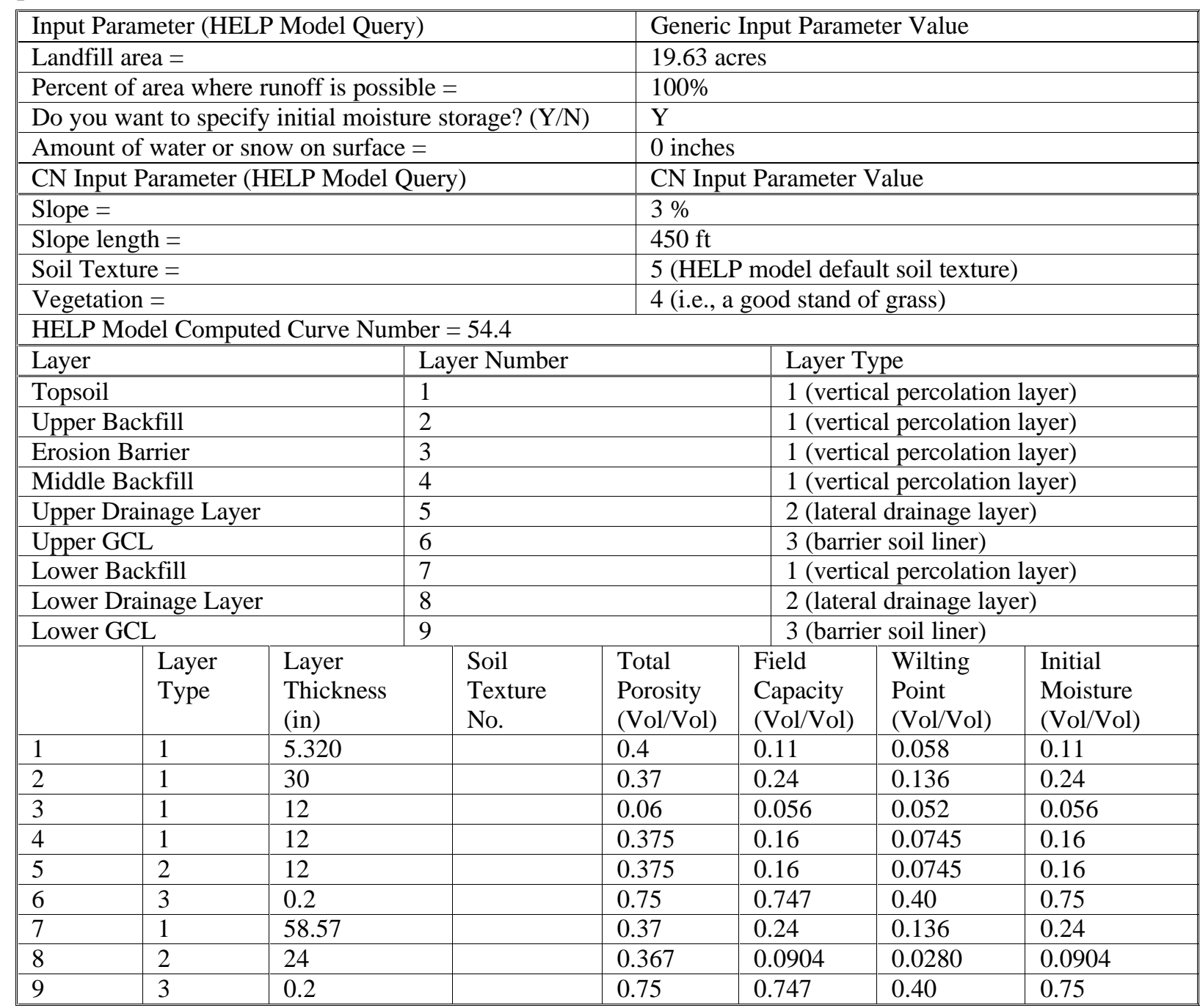

The lack of values in the table for particular parameters in particular layers denotes that no HELP model input was required for that parameter in that layer. No data are missing from the table. 
Input Data (continued):

\begin{tabular}{|c|c|c|c|c|c|c|c|c|c|}
\hline & $\begin{array}{l}\text { Layer } \\
\text { Type }\end{array}$ & $\begin{array}{l}\text { Sat. Hyd. } \\
\text { Conductivity * } \\
(\mathrm{cm} / \mathrm{sec})\end{array}$ & \multicolumn{2}{|c|}{$\begin{array}{l}\text { Drainage } \\
\text { Length } \\
(\mathrm{ft}) \\
\end{array}$} & $\begin{array}{l}\text { Drain } \\
\text { Slope } \\
(\%)\end{array}$ & $\begin{array}{l}\text { Leachate } \\
\text { Recirc. } \\
(\%) \\
\end{array}$ & \multicolumn{2}{|c|}{$\begin{array}{l}\text { Recirc. to } \\
\text { Layer } \\
(\#)\end{array}$} & $\begin{array}{l}\text { Subsurface } \\
\text { Inflow } \\
\text { (in/yr) }\end{array}$ \\
\hline 1 & 1 & $1.00 \mathrm{E}-03$ & & & & & & & \\
\hline 2 & 1 & $1.00 \mathrm{E}-04$ & & & & & & & \\
\hline 3 & 1 & $3.97 \mathrm{E}-04$ & & & & & & & \\
\hline 4 & 1 & $3.20 \mathrm{E}-03$ & & & & & & & \\
\hline 5 & 2 & $3.20 \mathrm{E}-03$ & 450 & & 3 & & & & \\
\hline 6 & 3 & $5.00 \mathrm{E}-09$ & & & & & & & \\
\hline 7 & 1 & $1.00 \mathrm{E}-04$ & & & & & & & \\
\hline 8 & 2 & $9.20 \mathrm{E}-02$ & 150 & & 11.4 & & & & \\
\hline \multirow[t]{2}{*}{9} & 3 & $5.00 \mathrm{E}-09$ & & & & & & \\
\hline & $\begin{array}{l}\text { Layer } \\
\text { Type }\end{array}$ & \multicolumn{2}{|l|}{$\begin{array}{l}\text { Geomembrane } \\
\text { Pinhole Density } \\
\text { (\#/acre) }\end{array}$} & \multicolumn{2}{|c|}{$\begin{array}{l}\text { Geomembrane } \\
\text { Instal. Defects } \\
(\# / \text { acre })\end{array}$} & \multicolumn{2}{|c|}{$\begin{array}{l}\text { Geomembrane } \\
\text { Placement Quality }\end{array}$} & \multicolumn{2}{|c|}{$\begin{array}{l}\text { Geotextile } \\
\text { Transmissivity } \\
\left(\mathrm{cm}^{2} / \mathrm{sec}\right)\end{array}$} \\
\hline 1 & 1 & & & & & & & & \\
\hline 2 & 1 & & & & & & & & \\
\hline 3 & 1 & & & & & & & & \\
\hline 4 & 1 & & & & & & & & \\
\hline 5 & 2 & & & & & & & & \\
\hline 6 & 3 & & & & & & & & \\
\hline 7 & 1 & & & & & & & & \\
\hline 8 & 2 & & & & & & & & \\
\hline 9 & 3 & & & & & & & & \\
\hline
\end{tabular}

The lack of values in the table for particular parameters in particular layers denotes that no HELP model input was required for that parameter in that layer. No data are missing from the table.

* The HELP model output often produces an increased number of significant digits for the Effective Saturated Hydraulic Conductivity over that of the actual input 


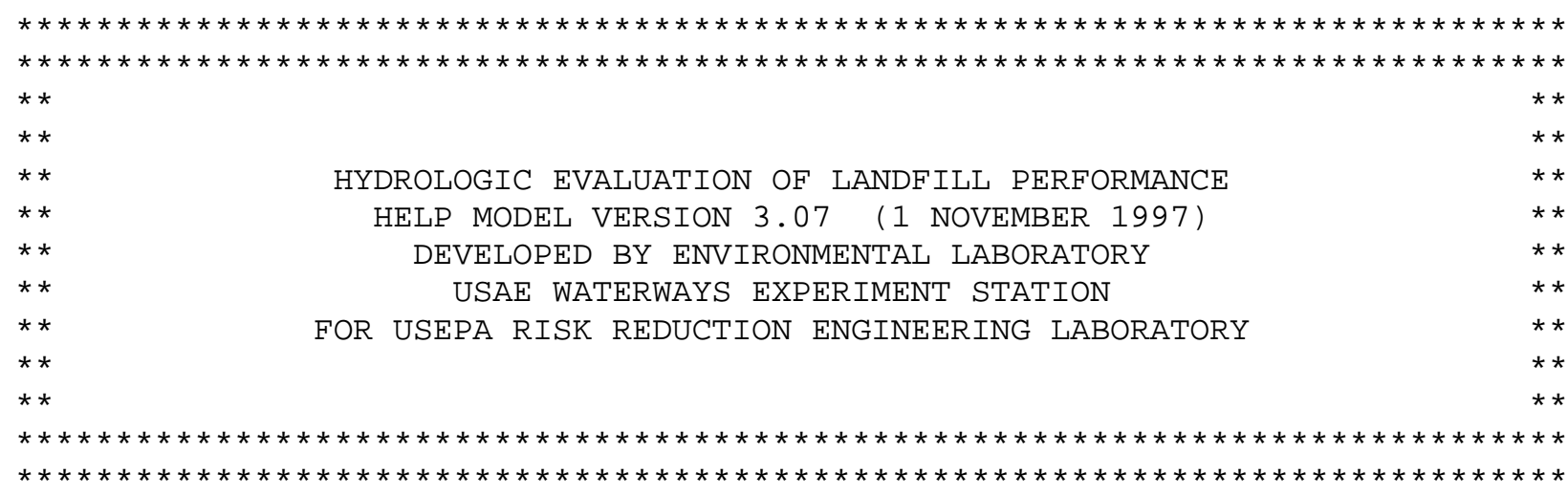
PRECIPITATION DATA FILE:
D: \HELP 3 \Hweather $\backslash$ ZPREC.D4
TEMPERATURE DATA FILE:
D: \HELP $3 \backslash$ Hweather $\backslash$ ZTEMP.D7
SOLAR RADIATION DATA FILE: D: \HELP3\Hweather $\backslash$ ZSOLAR.D13
EVAPOTRANSPIRATION DATA: D: \HELP3\Hweather $\backslash$ ZEVAP.D11
SOIL AND DESIGN DATA FILE: D: \HELP3\Hsdfmse \ZLBS6.D10
OUTPUT DATA FILE:
D: \HELP $3 \backslash$ Hsdfmse $\backslash Z L B S 6$ out.OUT

TIME: 15:0 DATE: $12 / 11 / 2003$

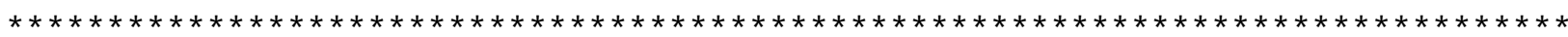

TITLE: LBS Degraded MSE Vault Closure Cap - 3,400 Years

NOTE: INITIAL MOISTURE CONTENT OF THE LAYERS AND SNOW WATER WERE SPECIFIED BY THE USER.

\begin{tabular}{|c|c|c|c|c|}
\hline \multicolumn{5}{|c|}{$\begin{array}{c}\text { TYPE } 1 \text { - VERTICAL PERCOLATION LAYER } \\
\text { MATERIAL TEXTURE NUMBER }\end{array}$} \\
\hline THICKNESS & $=$ & 5.32 & INCHES & \\
\hline POROSITY & $=$ & 0.4000 & VOL/VOI & \\
\hline FIELD CAPACITY & $=$ & 0.1100 & VOL/VOI & \\
\hline WILTING POINT & $=$ & 0.0580 & VOL/VOI & \\
\hline INITIAL SOIL WATER CONTENT & $=$ & 0.1100 & VOL/VOI & \\
\hline EFFECTIVE SAT. HYD. COND. & $=$ & 0.100000005 & $5000 \mathrm{E}-02$ & $\mathrm{CM} / \mathrm{SEC}$ \\
\hline \multicolumn{5}{|c|}{ LAYER 2} \\
\hline $\begin{array}{r}\text { TYPE } 1 \text { - VERTICAI } \\
\text { MATERIAL TEXT }\end{array}$ & & $\begin{array}{ll}\text { RCOLATION LA } \\
\text { NUMBER } & 0\end{array}$ & AYER & \\
\hline THICKNESS & $=$ & 30.00 & INCHES & \\
\hline POROSITY & $=$ & 0.3700 & VOL/VOI & \\
\hline FIELD CAPACITY & $=$ & 0.2400 & VOL/VOI & \\
\hline WILTING POINT & $=$ & 0.1360 & VOL/VOI & \\
\hline INITIAL SOIL WATER CONTENT & $=$ & 0.2400 & VOL/VOI & \\
\hline EFFECTIVE SAT. HYD. COND. & $=$ & 0.999999975 & $5000 \mathrm{E}-04$ & $\mathrm{C}$ \\
\hline
\end{tabular}

Rev. 0 
LAYER 3

--------

TYPE 1 - VERTICAL PERCOLATION LAYER

MATERIAL TEXTURE NUMBER 0

$\begin{array}{llrl}\text { THICKNESS } & = & 12.00 \mathrm{INCHES} \\ \text { POROSITY } & = & 0.0600 \mathrm{VOL} / \mathrm{VOL} \\ \text { FIELD CAPACITY } & = & 0.0560 \mathrm{VOL} / \mathrm{VOL} \\ \text { WILTING POINT } & = & 0.0520 \mathrm{VOL} / \mathrm{VOL} \\ \text { INITIAL SOIL WATER CONTENT } & = & 0.0560 \mathrm{VOL} / \mathrm{VOL} \\ \text { EFFECTIVE SAT. HYD. COND. } & =0.396999996000 \mathrm{E}-03 \mathrm{CM} / \mathrm{SEC}\end{array}$

LAYER 4

TYPE 1 - VERTICAL PERCOLATION LAYER MATERIAL TEXTURE NUMBER 0

$\begin{array}{llrl}\text { THICKNESS } & = & 12.00 & \text { INCHES } \\ \text { POROSITY } & = & 0.3750 \mathrm{VOL} / \mathrm{VOL} \\ \text { FIELD CAPACITY } & = & 0.1600 \mathrm{VOL} / \mathrm{VOL} \\ \text { WILTING POINT } & = & 0.0745 \mathrm{VOL} / \mathrm{VOL} \\ \text { INITIAL SOIL WATER CONTENT } & = & 0.1600 \mathrm{VOL} / \mathrm{VOL} \\ \text { EFFECTIVE SAT. HYD. COND. } & =0.319999992000 \mathrm{E}-02 \mathrm{CM} / \mathrm{SEC} \\ & \\ \text { LAYER } & 5 & \\ & \end{array}$

TYPE 2 - LATERAL DRAINAGE LAYER MATERIAL TEXTURE NUMBER 0

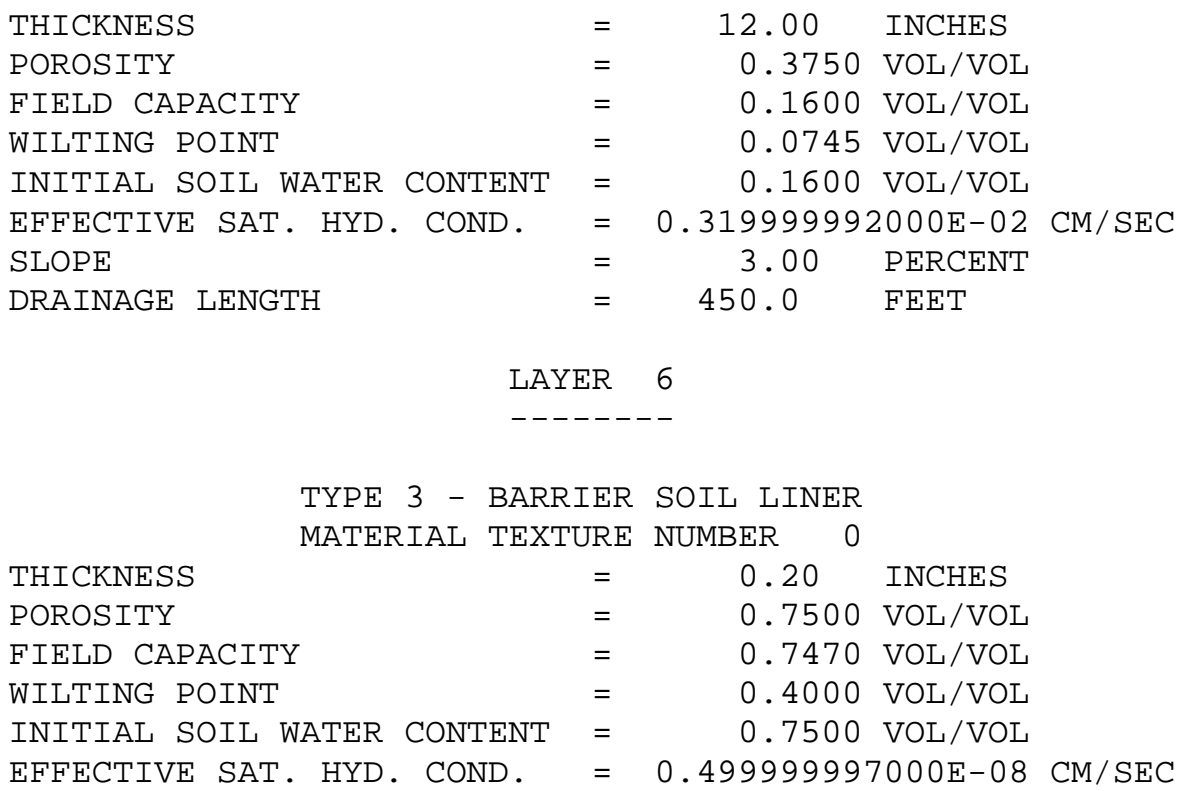


LAYER 7

$--------$

TYPE 1 - VERTICAL PERCOLATION LAYER

MATERIAL TEXTURE NUMBER 0

$\begin{array}{llrl}\text { THICKNESS } & = & 58.57 & \text { INCHES } \\ \text { POROSITY } & = & 0.3700 \mathrm{VOL} / \mathrm{VOL} \\ \text { FIELD CAPACITY } & = & 0.2400 \mathrm{VOL} / \mathrm{VOL} \\ \text { WILTING POINT } & = & 0.1360 \mathrm{VOL} / \mathrm{VOL} \\ \text { INITIAL SOIL WATER CONTENT } & = & 0.2400 \mathrm{VOL} / \mathrm{VOL} \\ \text { EFFECTIVE SAT. HYD. COND. } & =0.999999975000 \mathrm{E}-04 \mathrm{CM} / \mathrm{SEC}\end{array}$

LAYER 8

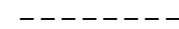

TYPE 2 - LATERAL DRAINAGE LAYER

$\begin{array}{llrl}\text { THICKNESS } & = & 24.00 & \text { INCHES } \\ \text { POROSITY } & = & 0.3670 \mathrm{VOL} / \mathrm{VOL} \\ \text { FIELD CAPACITY } & = & 0.0904 \mathrm{VOL} / \mathrm{VOL} \\ \text { WILTING POINT } & = & 0.0280 \mathrm{VOL} / \mathrm{VOL} \\ \text { INITIAL SOIL WATER CONTENT } & = & 0.0904 \mathrm{VOL} / \mathrm{VOL} \\ \text { EFFECTIVE SAT. HYD. COND. } & = & 0.92000002000 \mathrm{E}-01 \mathrm{CM} / \mathrm{SEC} \\ \text { SLOPE } & = & 11.40 \mathrm{PERCENT} \\ \text { DRAINAGE LENGTH } & = & 150.0 \mathrm{FEET}\end{array}$

LAYER 9

$--------$

TYPE 3 - BARRIER SOIL LINER

MATERIAL TEXTURE NUMBER 0

$\begin{array}{llll}\text { THICKNESS } & = & 0.20 & \text { INCHES } \\ \text { POROSITY } & = & 0.7500 \mathrm{VOL} / \mathrm{VOL} \\ \text { FIELD CAPACITY } & = & 0.7470 \mathrm{VOL} / \mathrm{VOL} \\ \text { WILTING POINT } & = & 0.4000 \mathrm{VOL} / \mathrm{VOL} \\ \text { INITIAL SOIL WATER CONTENT } & = & 0.7500 \mathrm{VOL} / \mathrm{VOL} \\ \text { EFFECTIVE SAT. HYD. COND. } & =0.499999997000 \mathrm{E}-08 \mathrm{CM} / \mathrm{SEC}\end{array}$

GENERAL DESIGN AND EVAPORATIVE ZONE DATA

NOTE: SCS RUNOFF CURVE NUMBER WAS COMPUTED FROM DEFAULT SOIL DATA BASE USING SOIL TEXTURE \# 5 WITH A GOOD STAND OF GRASS, A SURFACE SLOPE OF 3.\% AND A SLOPE LENGTH OF 450. FEET.

SCS RUNOFF CURVE NUMBER

FRACTION OF AREA ALLOWING RUNOFF

AREA PROJECTED ON HORIZONTAL PLANE

EVAPORATIVE ZONE DEPTH

INITIAL WATER IN EVAPORATIVE ZONE

UPPER LIMIT OF EVAPORATIVE STORAGE

LOWER LIMIT OF EVAPORATIVE STORAGE

INITIAL SNOW WATER

INITIAL WATER IN LAYER MATERIALS

TOTAL INITIAL WATER

TOTAL SUBSURFACE INFLOW

$\begin{array}{lcl}= & 54.40 & \\ = & 100.0 & \text { PERCENT } \\ = & 19.630 & \text { ACRES } \\ = & 22.0 & \text { INCHES } \\ = & 4.588 & \text { INCHES } \\ = & 8.300 & \text { INCHES } \\ = & 2.577 & \text { INCHES } \\ = & 0.000 & \text { INCHES } \\ = & 28.824 & \text { INCHES } \\ = & 28.824 & \text { INCHES } \\ = & 0.00 & \text { INCHES /YEAR }\end{array}$

Rev. 0 


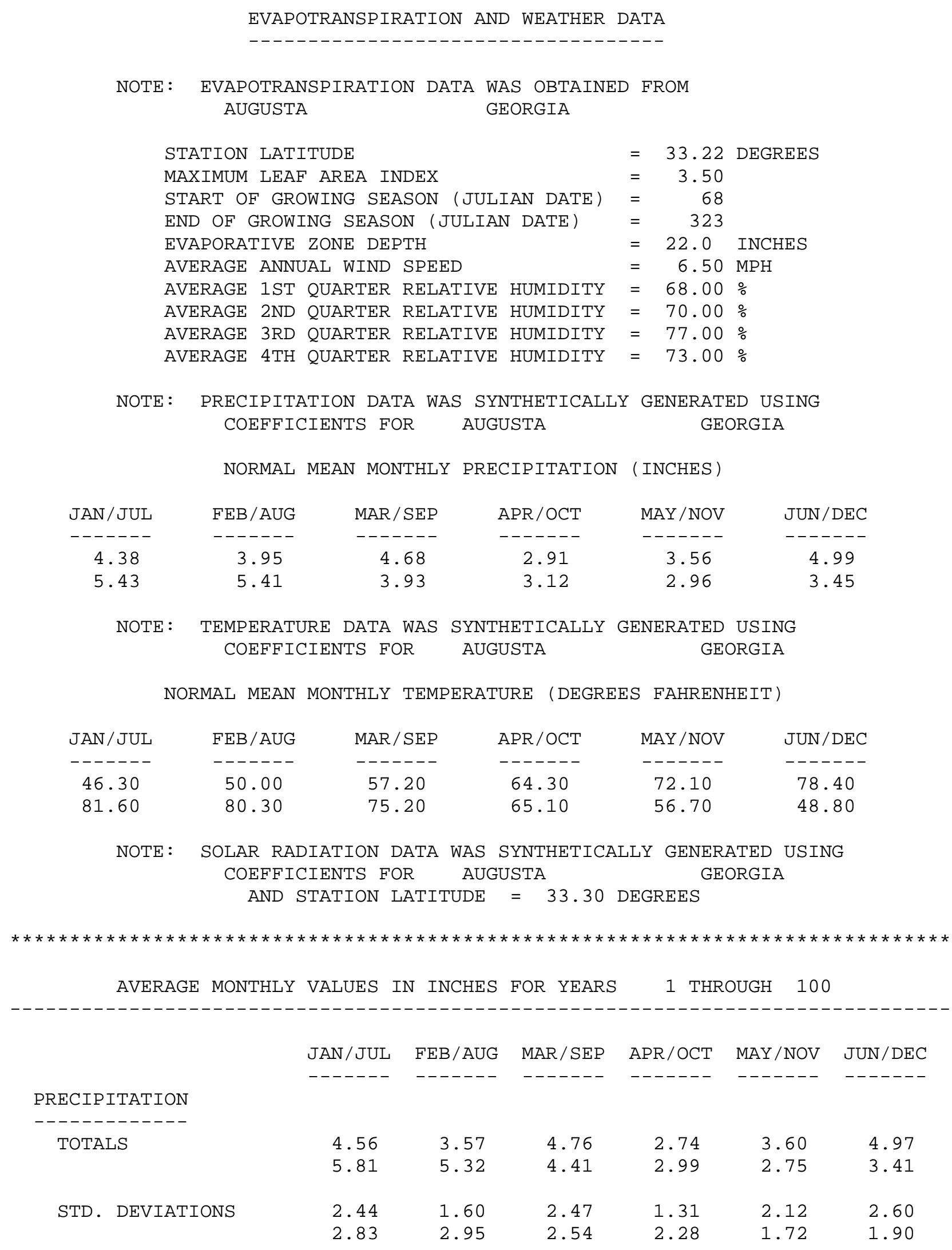

Rev. 0 
RUNOFF

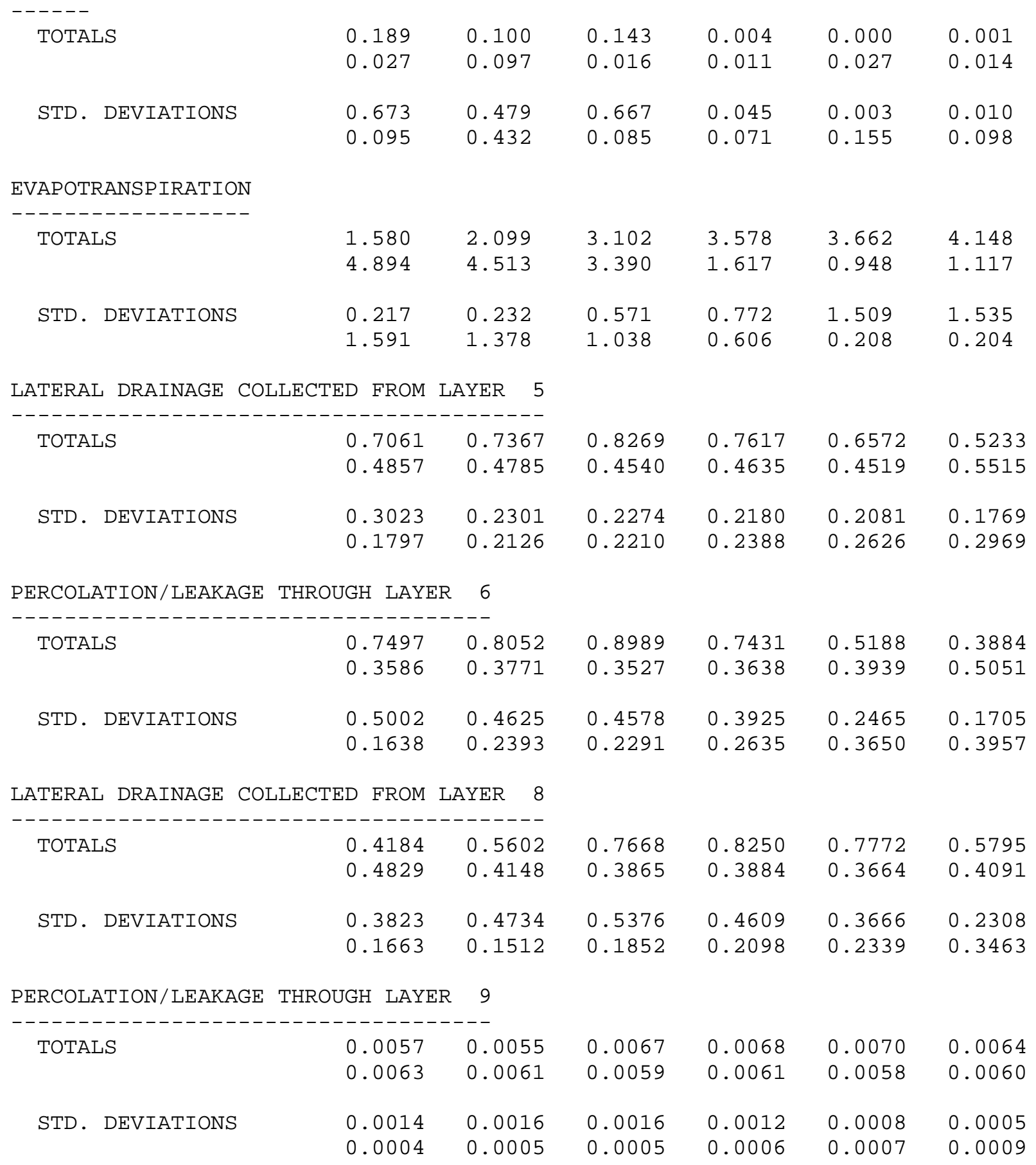


AVERAGES OF MONTHLY AVERAGED DAILY HEADS (INCHES)

DAILY AVERAGE HEAD ON TOP OF LAYER 6

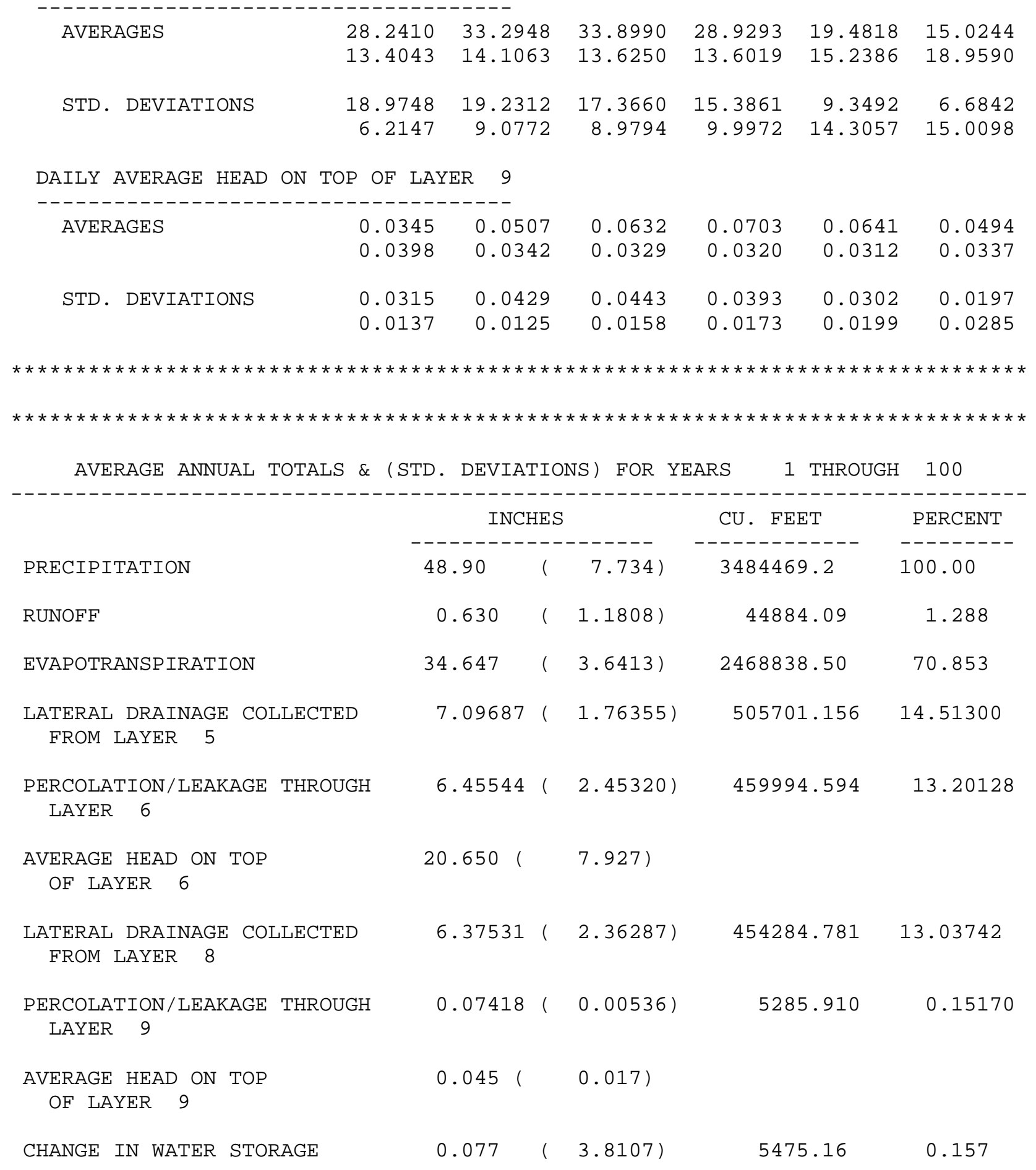




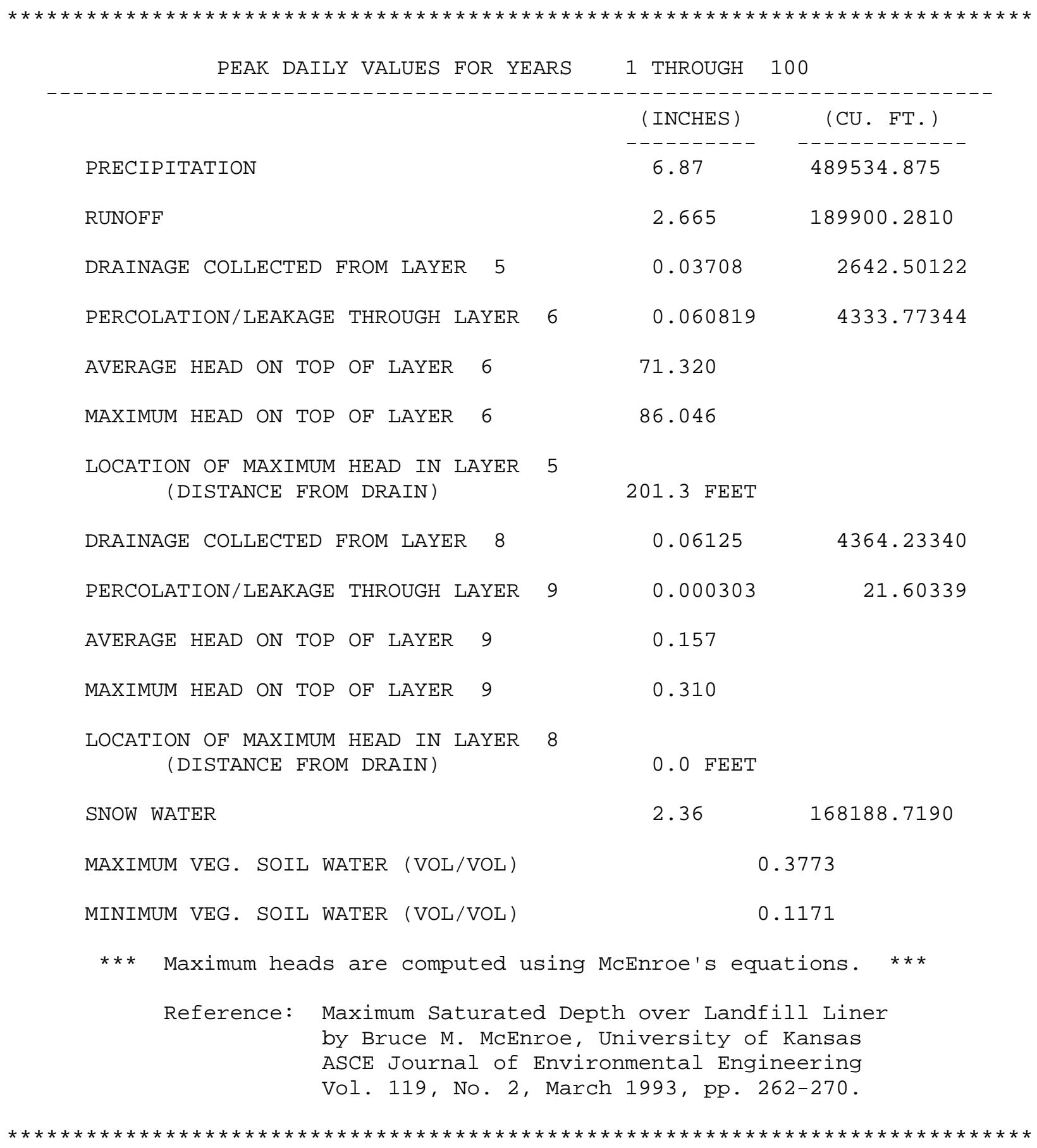

Rev. 0 


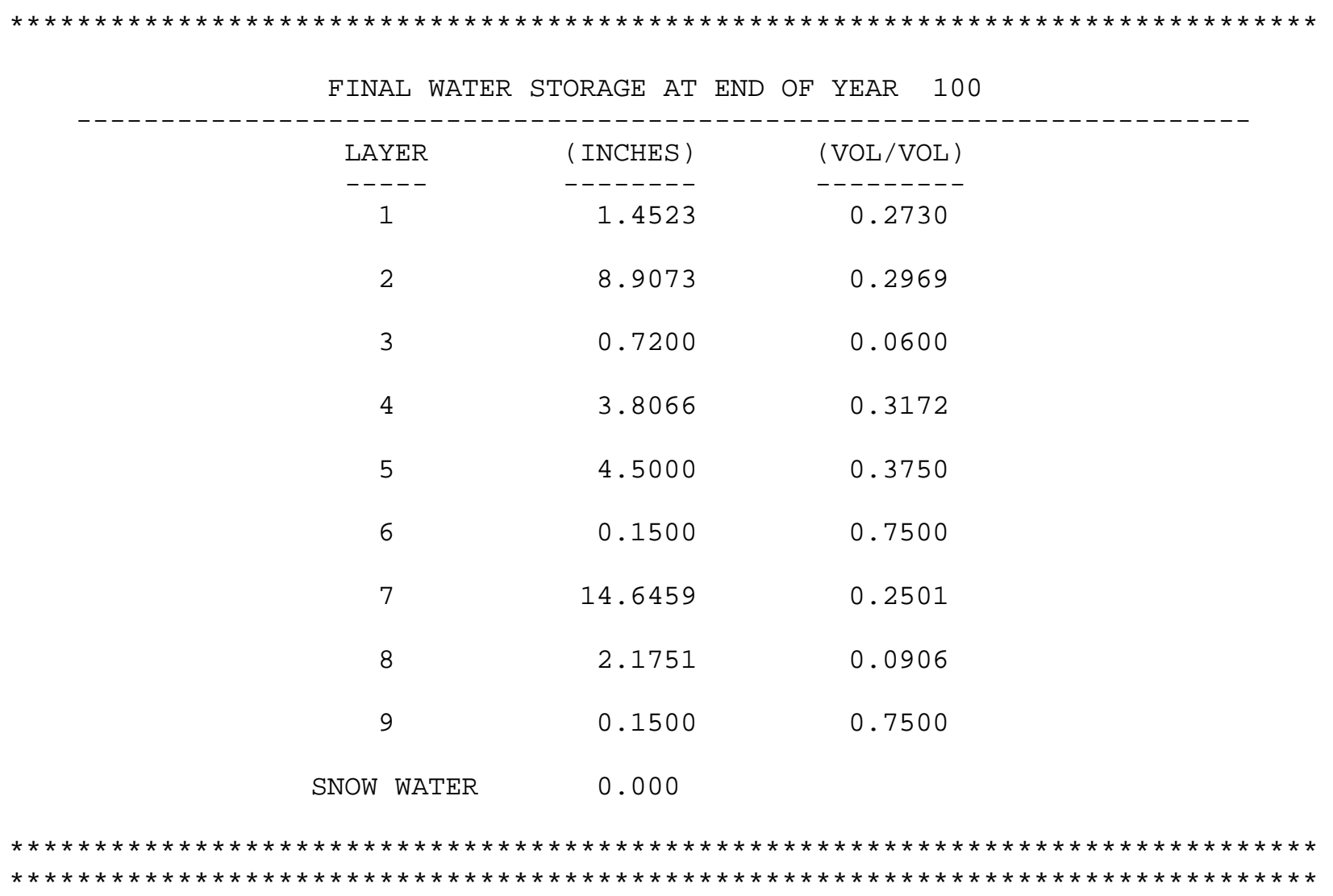


Appendix M, Lower Bounding Scenario Degraded SDF MSE Vault Closure Cap (5,600 Years): HELP Model Input Data and Output File (output file name: ZLBS7out.OUT)

Input Data:

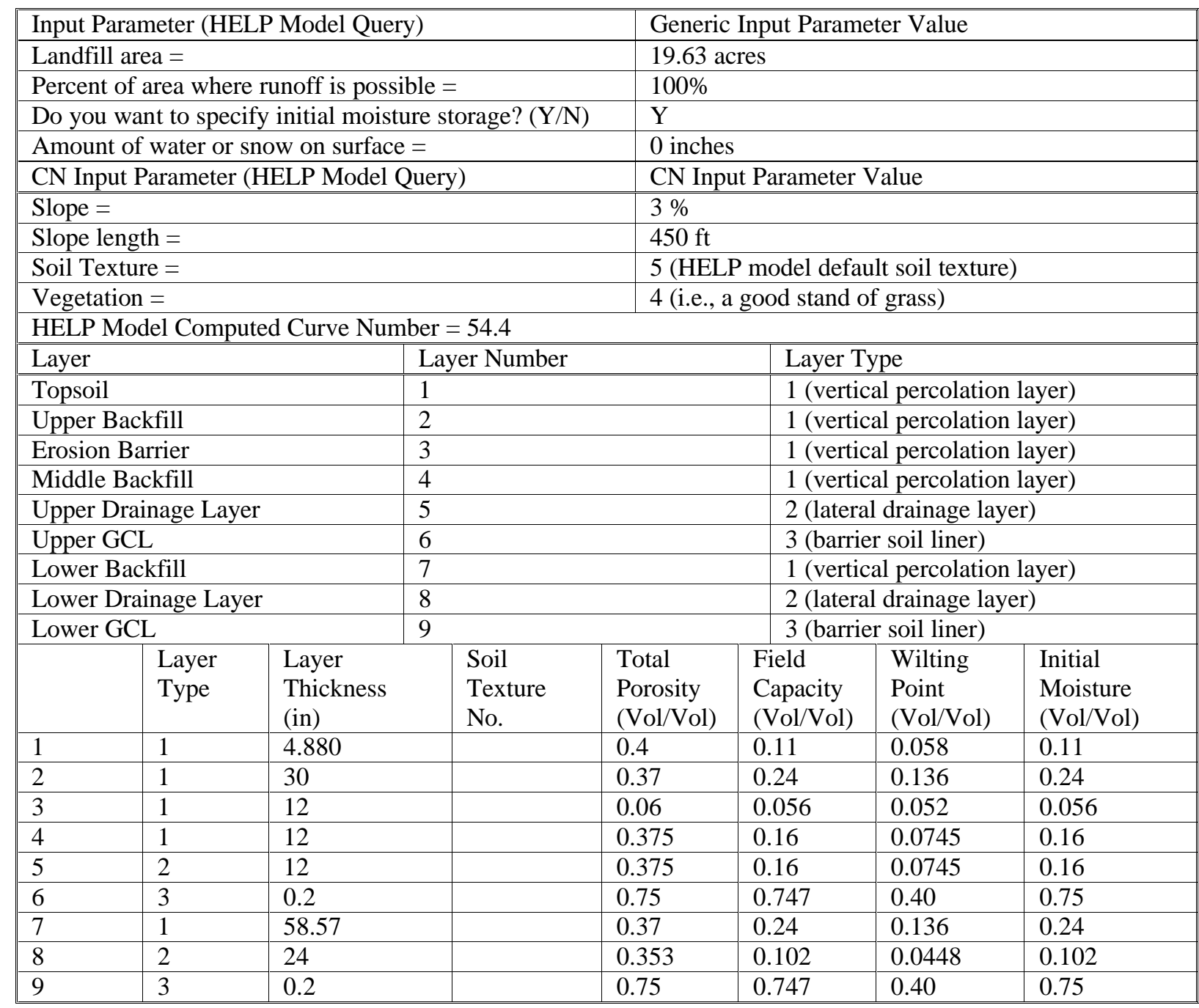

The lack of values in the table for particular parameters in particular layers denotes that no HELP model input was required for that parameter in that layer. No data are missing from the table. 
Input Data (continued):

\begin{tabular}{|c|c|c|c|c|c|c|c|c|c|}
\hline & $\begin{array}{l}\text { Layer } \\
\text { Type }\end{array}$ & $\begin{array}{l}\text { Sat. Hyd. } \\
\text { Conductivity } \\
(\mathrm{cm} / \mathrm{sec}) \\
\end{array}$ & \multicolumn{2}{|c|}{$\begin{array}{l}\text { Drainage } \\
\text { Length } \\
(\mathrm{ft}) \\
\end{array}$} & $\begin{array}{l}\text { Drain } \\
\text { Slope } \\
(\%)\end{array}$ & $\begin{array}{l}\text { Leachate } \\
\text { Recirc. } \\
(\%) \\
\end{array}$ & \multicolumn{2}{|c|}{$\begin{array}{l}\text { Recirc. to } \\
\text { Layer } \\
(\#)\end{array}$} & $\begin{array}{l}\text { Subsurface } \\
\text { Inflow } \\
\text { (in/yr) }\end{array}$ \\
\hline 1 & 1 & $1.00 \mathrm{E}-03$ & & & & & & & \\
\hline 2 & 1 & $1.00 \mathrm{E}-04$ & & & & & & & \\
\hline 3 & 1 & $3.97 \mathrm{E}-04$ & & & & & & & \\
\hline 4 & 1 & $3.20 \mathrm{E}-03$ & & & & & & & \\
\hline 5 & 2 & $3.20 \mathrm{E}-03$ & 450 & & 3 & & & & \\
\hline 6 & 3 & $5.00 \mathrm{E}-09$ & & & & & & & \\
\hline 7 & 1 & $1.00 \mathrm{E}-04$ & & & & & & & \\
\hline 8 & 2 & $8.30 \mathrm{E}-02$ & 150 & & 11.4 & & & & \\
\hline \multirow[t]{2}{*}{9} & 3 & $5.00 \mathrm{E}-09$ & & & & & & \\
\hline & $\begin{array}{l}\text { Layer } \\
\text { Type }\end{array}$ & \multicolumn{2}{|l|}{$\begin{array}{l}\text { Geomembrane } \\
\text { Pinhole Density } \\
\text { (\#/acre) }\end{array}$} & \multicolumn{2}{|c|}{$\begin{array}{l}\text { Geomembrane } \\
\text { Instal. Defects } \\
(\# / \text { acre })\end{array}$} & \multicolumn{2}{|c|}{$\begin{array}{l}\text { Geomembrane } \\
\text { Placement Quality }\end{array}$} & \multicolumn{2}{|c|}{$\begin{array}{l}\text { Geotextile } \\
\text { Transmissivity } \\
\left(\mathrm{cm}^{2} / \mathrm{sec}\right)\end{array}$} \\
\hline 1 & 1 & & & & & & & & \\
\hline 2 & 1 & & & & & & & & \\
\hline 3 & 1 & & & & & & & & \\
\hline 4 & 1 & & & & & & & & \\
\hline 5 & 2 & & & & & & & & \\
\hline 6 & 3 & & & & & & & & \\
\hline 7 & 1 & & & & & & & & \\
\hline 8 & 2 & & & & & & & & \\
\hline 9 & 3 & & & & & & & & \\
\hline
\end{tabular}

The lack of values in the table for particular parameters in particular layers denotes that no HELP model input was required for that parameter in that layer. No data are missing from the table.

* The HELP model output often produces an increased number of significant digits for the Effective Saturated Hydraulic Conductivity over that of the actual input 


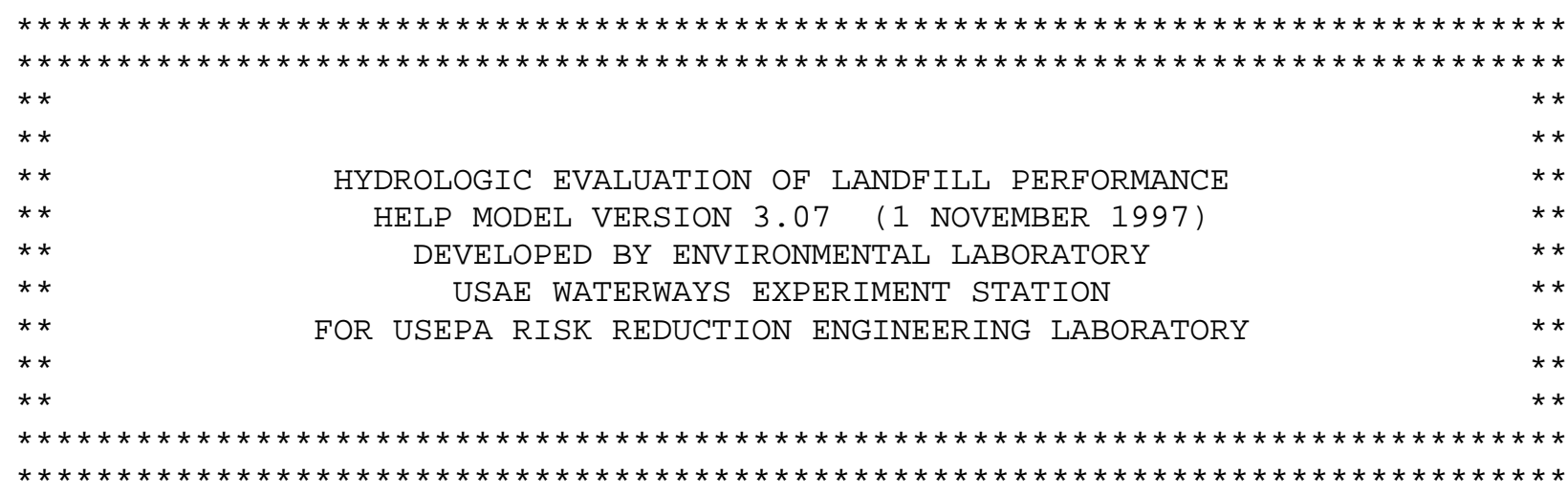

\begin{tabular}{|c|c|}
\hline PRECIPITATION DATA & $\mathrm{D}: \backslash \operatorname{HELP} 3$ \\
\hline TEMPERATURE DATA FILE: & $\mathrm{D}: \backslash$ HELP $3 \backslash$ Hweather $\backslash \mathrm{ZTEMP} . \mathrm{D} 7$ \\
\hline RADIATION DA & D $: \backslash$ HELP $3 \backslash$ Hweather $\backslash$ ZSOLAR.D13 \\
\hline OTRANSP IRATION & D: \HELP $3 \backslash$ Hweather $\backslash$ ZEVAP.D11 \\
\hline AND DESIGN DA & D: \HELP $3 \backslash$ Hsdfmse $\backslash$ ZLBS 7.D10 \\
\hline & 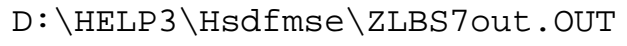 \\
\hline
\end{tabular}

TIME $: \quad 15: 8$ DATE: 12/11/2003

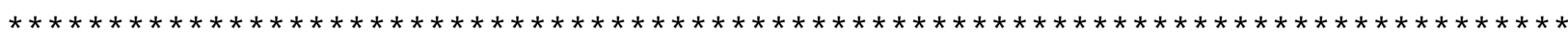
TITLE: LBS Degraded MSE Vault Closure Cap - 5,600 Years

NOTE: INITIAL MOISTURE CONTENT OF THE LAYERS AND SNOW WATER WERE SPECIFIED BY THE USER.

\begin{tabular}{|c|c|c|c|c|}
\hline \multicolumn{5}{|c|}{ LAYER 1} \\
\hline \multicolumn{5}{|c|}{ TYPE 1 - VERTICAL PERCOLATION LAYER } \\
\hline THICKNESS & $=$ & 4.88 & INCHES & \\
\hline POROSITY & $=$ & 0.4000 & VOL/VOI & \\
\hline FIELD CAPACITY & $=$ & 0.1100 & VOL/VOI & \\
\hline WILTING POINT & $=$ & 0.0580 & VOL/VOI & \\
\hline INITIAL SOIL WATER CONTENT & $=$ & 0.1100 & VOL/VOI & \\
\hline EFFECTIVE SAT. HYD. COND. & $=$ & 0.100000005 & $5000 \mathrm{E}-02$ & $\mathrm{CM} / \mathrm{SEC}$ \\
\hline \multicolumn{5}{|c|}{ LAYER 2} \\
\hline $\begin{array}{r}\text { TYPE } 1 \text { - VERTICAI } \\
\text { MATERIAL TEX? }\end{array}$ & $\begin{aligned} & P E \\
& U R E\end{aligned}$ & $\begin{array}{cl}\text { RCOLATION } & \text { LA } \\
\text { NUMBER } & 0\end{array}$ & AYER & \\
\hline THICKNESS & $=$ & 30.00 & INCHES & \\
\hline POROSITY & $=$ & 0.3700 & VOL/VOI & \\
\hline FIELD CAPACITY & $=$ & 0.2400 & VOL/VOI & \\
\hline WILTING POINT & $=$ & 0.1360 & VOL/VOI & \\
\hline INITIAL SOIL WATER CONTENT & $=$ & 0.2400 & VOL/VOI & \\
\hline EFFECTIVE SAT. HYD. COND. & $=$ & 0.999999975 & $5000 \mathrm{E}-04$ & $\mathrm{CM} / \mathrm{SEC}$ \\
\hline
\end{tabular}

Rev. 0 
LAYER 3

$--------$

TYPE 1 - VERTICAL PERCOLATION LAYER

MATERIAL TEXTURE NUMBER 0

$\begin{array}{llrl}\text { THICKNESS } & = & 12.00 \mathrm{INCHES} \\ \text { POROSITY } & = & 0.0600 \mathrm{VOL} / \mathrm{VOL} \\ \text { FIELD CAPACITY } & = & 0.0560 \mathrm{VOL} / \mathrm{VOL} \\ \text { WILTING POINT } & = & 0.0520 \mathrm{VOL} / \mathrm{VOL} \\ \text { INITIAL SOIL WATER CONTENT } & = & 0.0560 \mathrm{VOL} / \mathrm{VOL} \\ \text { EFFECTIVE SAT. HYD. COND. } & =0.396999996000 \mathrm{E}-03 \mathrm{CM} / \mathrm{SEC}\end{array}$

LAYER 4

TYPE 1 - VERTICAL PERCOLATION LAYER MATERIAL TEXTURE NUMBER 0

\begin{tabular}{|c|c|c|c|c|}
\hline THICKNESS & $=$ & 12.00 & INCHES & \\
\hline POROSITY & $=$ & 0.3750 & $\mathrm{VOL} / \mathrm{VOL}$ & \\
\hline FIELD CAPACITY & $=$ & 0.1600 & $\mathrm{VOL} / \mathrm{VOL}$ & \\
\hline WILTING POINT & $=$ & 0.0745 & $\mathrm{VOL} / \mathrm{VOL}$ & \\
\hline INITIAL SOIL WATER CONTENT & $=$ & 0.1600 & $\mathrm{VOL} / \mathrm{VOL}$ & \\
\hline EFFECTIVE SAT. HYD. COND. & $=$ & 0.319999992 & $000 E-02$ & $\mathrm{CM} / \mathrm{SEC}$ \\
\hline \multicolumn{2}{|c|}{ LAYER } & 5 & & \\
\hline
\end{tabular}

TYPE 2 - LATERAL DRAINAGE LAYER MATERIAL TEXTURE NUMBER 0

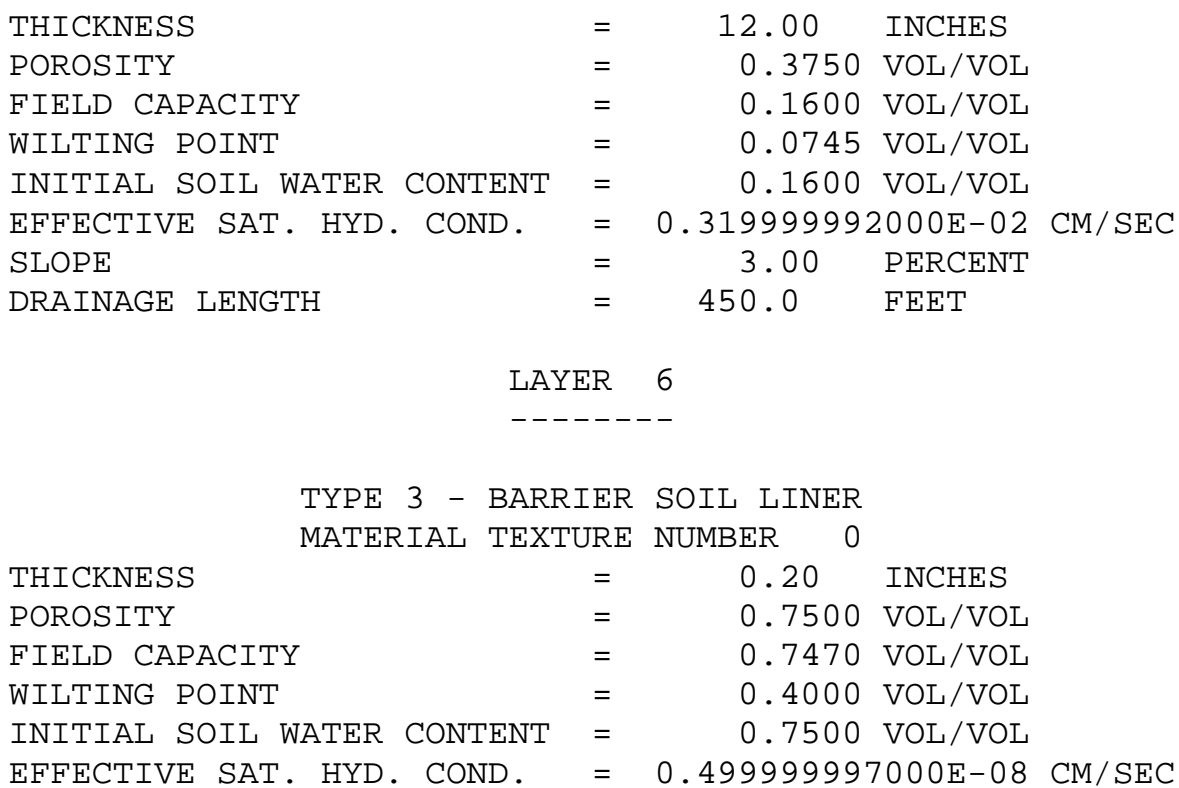

Rev. 0 
LAYER 7

$--------$

TYPE 1 - VERTICAL PERCOLATION LAYER

MATERIAL TEXTURE NUMBER 0

$\begin{array}{llrl}\text { THICKNESS } & = & 58.57 & \text { INCHES } \\ \text { POROSITY } & = & 0.3700 \mathrm{VOL} / \mathrm{VOL} \\ \text { FIELD CAPACITY } & = & 0.2400 \mathrm{VOL} / \mathrm{VOL} \\ \text { WILTING POINT } & = & 0.1360 \mathrm{VOL} / \mathrm{VOL} \\ \text { INITIAL SOIL WATER CONTENT } & = & 0.2400 \mathrm{VOL} / \mathrm{VOL} \\ \text { EFFECTIVE SAT. HYD. COND. } & =0.999999975000 \mathrm{E}-04 \mathrm{CM} / \mathrm{SEC}\end{array}$

LAYER 8

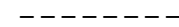

TYPE 2 - LATERAL DRAINAGE LAYER

$\begin{array}{llrl}\text { THICKNESS } & = & 24.00 & \text { INCHES } \\ \text { POROSITY } & = & 0.3530 \mathrm{VOL} / \mathrm{VOL} \\ \text { FIELD CAPACITY } & = & 0.1020 \mathrm{VOL} / \mathrm{VOL} \\ \text { WILTING POINT } & = & 0.0448 \mathrm{VOL} / \mathrm{VOL} \\ \text { INITIAL SOIL WATER CONTENT } & = & 0.1020 \mathrm{VOL} / \mathrm{VOL} \\ \text { EFFECTIVE SAT. HYD. COND. } & = & 0.82999996800 \mathrm{E}-01 \mathrm{CM} / \mathrm{SEC} \\ \text { SLOPE } & = & 11.40 \mathrm{PERCENT} \\ \text { DRAINAGE LENGTH } & = & 150.0 \mathrm{FEET}\end{array}$

LAYER 9

--------

TYPE 3 - BARRIER SOIL LINER

MATERIAL TEXTURE NUMBER 0

$\begin{array}{llrl}\text { THICKNESS } & = & 0.20 & \text { INCHES } \\ \text { POROSITY } & = & 0.7500 \mathrm{VOL} / \mathrm{VOL} \\ \text { FIELD CAPACITY } & = & 0.7470 \mathrm{VOL} / \mathrm{VOL} \\ \text { WILTING POINT } & = & 0.4000 \mathrm{VOL} / \mathrm{VOL} \\ \text { INITIAL SOIL WATER CONTENT } & = & 0.7500 \mathrm{VOL} / \mathrm{VOL} \\ \text { EFFECTIVE SAT. HYD. COND. } & =0.499999997000 \mathrm{E}-08 \mathrm{CM} / \mathrm{SEC}\end{array}$

GENERAL DESIGN AND EVAPORATIVE ZONE DATA

NOTE: SCS RUNOFF CURVE NUMBER WAS COMPUTED FROM DEFAULT SOIL DATA BASE USING SOIL TEXTURE \# 5 WITH A GOOD STAND OF GRASS, A SURFACE SLOPE OF 3.\% AND A SLOPE LENGTH OF 450. FEET.

SCS RUNOFF CURVE NUMBER

FRACTION OF AREA ALLOWING RUNOFF

AREA PROJECTED ON HORIZONTAL PLANE

EVAPORATIVE ZONE DEPTH

INITIAL WATER IN EVAPORATIVE ZONE

UPPER LIMIT OF EVAPORATIVE STORAGE

LOWER LIMIT OF EVAPORATIVE STORAGE

INITIAL SNOW WATER

INITIAL WATER IN LAYER MATERIALS

TOTAL INITIAL WATER

TOTAL SUBSURFACE INFLOW

$\begin{array}{lcl}= & 54.40 & \\ = & 100.0 & \text { PERCENT } \\ = & 19.630 & \text { ACRES } \\ = & 22.0 & \text { INCHES } \\ = & 4.646 & \text { INCHES } \\ = & 8.286 & \text { INCHES } \\ = & 2.611 & \text { INCHES } \\ = & 0.000 & \text { INCHES } \\ = & 29.054 & \text { INCHES } \\ = & 29.054 & \text { INCHES } \\ = & 0.00 & \text { INCHES /YEAR }\end{array}$

Rev. 0 
EVAPOTRANSPIRATION AND WEATHER DATA

NOTE: EVAPOTRANSPIRATION DATA WAS OBTAINED FROM AUGUSTA

GEORGIA

$\begin{array}{ll}\text { STATION LATITUDE } & =33.22 \text { DEGREES } \\ \text { MAXIMUM LEAF AREA INDEX } & =3.50 \\ \text { START OF GROWING SEASON (JULIAN DATE) } & = \\ \text { END OF GROWING SEASON (JULIAN DATE) } & =38 \\ \text { EVAPORATIVE ZONE DEPTH } & =22.0 \text { INCHES } \\ \text { AVERAGE ANNUAL WIND SPEED } & =6.50 \mathrm{MPH} \\ \text { AVERAGE 1ST QUARTER RELATIVE HUMIDITY } & =68.00 \% \\ \text { AVERAGE 2ND QUARTER RELATIVE HUMIDITY } & =70.00 \% \\ \text { AVERAGE 3RD QUARTER RELATIVE HUMIDITY } & =77.00 \% \\ \text { AVERAGE 4TH QUARTER RELATIVE HUMIDITY } & =73.00 \%\end{array}$

NOTE: PRECIPITATION DATA WAS SYNTHETICALLY GENERATED USING COEFFICIENTS FOR AUGUSTA GEORGIA

NORMAL MEAN MONTHLY PRECIPITATION (INCHES)

$\begin{array}{cccccc}\text { JAN / JUL } & \text { FEB/AUG } & \text { MAR/SEP } & \text { APR/OCT } & \text { MAY/NOV } & \text { JUN/DEC } \\ ------- & ------- & ------ & ------- & ------- & ------- \\ 4.38 & 3.95 & 4.68 & 2.91 & 3.56 & 4.99 \\ 5.43 & 5.41 & 3.93 & 3.12 & 2.96 & 3.45\end{array}$

NOTE: TEMPERATURE DATA WAS SYNTHETICALLY GENERATED USING COEFFICIENTS FOR AUGUSTA GEORGIA

NORMAL MEAN MONTHLY TEMPERATURE (DEGREES FAHRENHEIT)

$\begin{array}{cccccc}\text { JAN/JUL } & \text { FEB/AUG } & \text { MAR/SEP } & \text { APR/OCT } & \text { MAY/NOV } & \text { JUN/DEC } \\ ------ & ------ & ------- & ------ & ------ & ------ \\ 46.30 & 50.00 & 57.20 & 64.30 & 72.10 & 78.40 \\ 81.60 & 80.30 & 75.20 & 65.10 & 56.70 & 48.80\end{array}$

NOTE: SOLAR RADIATION DATA WAS SYNTHETICALLY GENERATED USING COEFFICIENTS FOR AUGUSTA GEORGIA AND STATION LATITUDE $=33.30$ DEGREES

\begin{tabular}{|c|c|c|c|c|c|c|}
\hline AVERAGE MONTHLY & VALUES I & IN INCHES & FOR YEARS & $1 \mathrm{THR}$ & OUGH & \\
\hline & JAN / JUL & $\mathrm{FEB} / \mathrm{AUG}$ & $\mathrm{MAR} / \mathrm{SEP}$ & $\mathrm{APR} / \mathrm{OCT}$ & $\mathrm{MAY} / \mathrm{NOV}$ & JUN / DEC \\
\hline & ------- & ------- & -------- & ------- & ------- & ------- \\
\hline \multicolumn{7}{|l|}{ PRECIPITATION } \\
\hline \multirow[t]{2}{*}{ TOTALS } & 4.56 & 3.57 & 4.76 & 2.74 & 3.60 & 4.97 \\
\hline & 5.81 & 5.32 & 4.41 & 2.99 & 2.75 & 3.41 \\
\hline \multirow[t]{2}{*}{ STD. DEVIATIONS } & 2.44 & 1.60 & 2.47 & 1.31 & 2.12 & 2.60 \\
\hline & 2.83 & 2.95 & 2.54 & 2.28 & 1.72 & 1.90 \\
\hline
\end{tabular}

Rev. 0 
RUNOFF

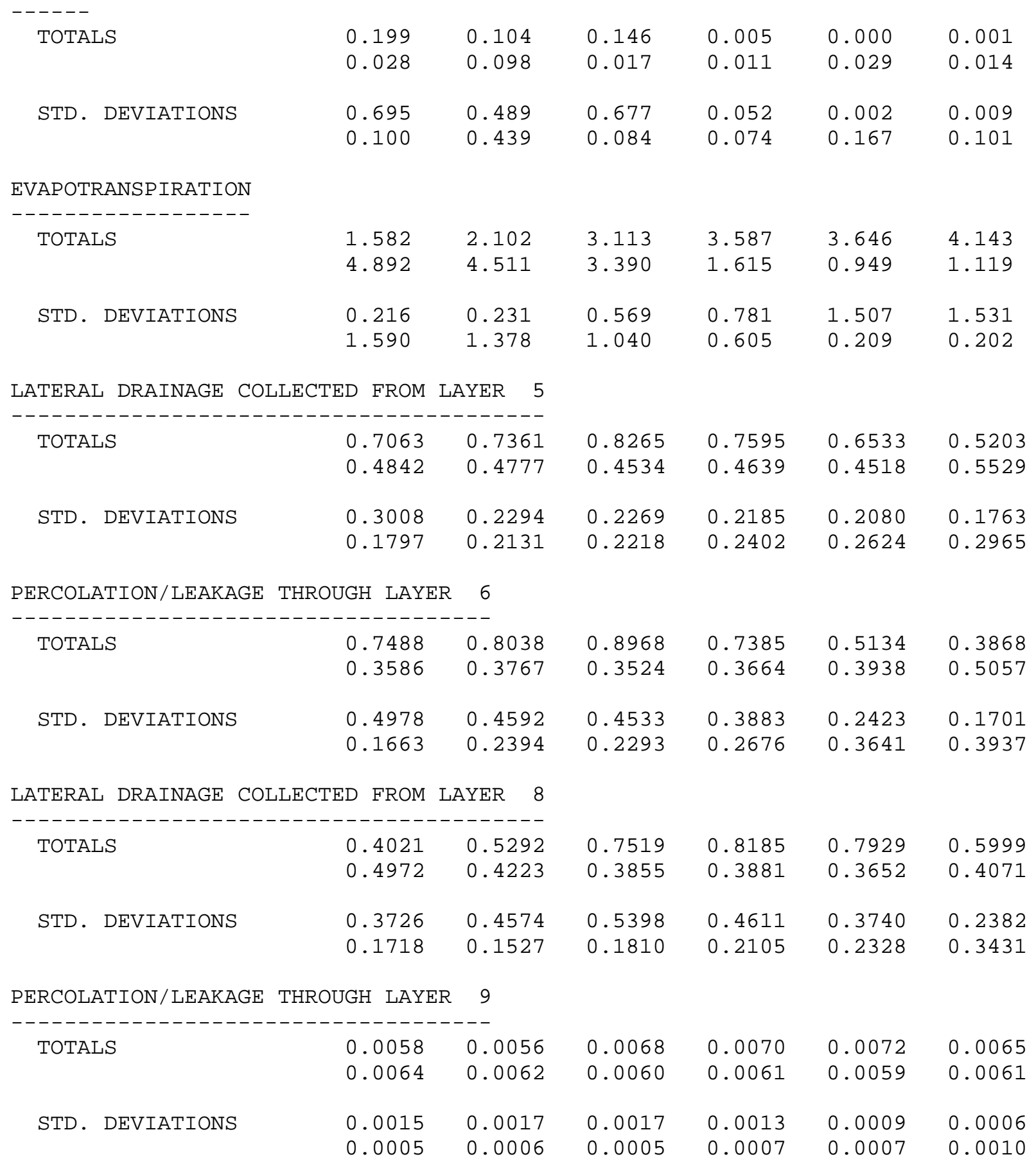


AVERAGES OF MONTHLY AVERAGED DAILY HEADS (INCHES)

DAILY AVERAGE HEAD ON TOP OF LAYER 6

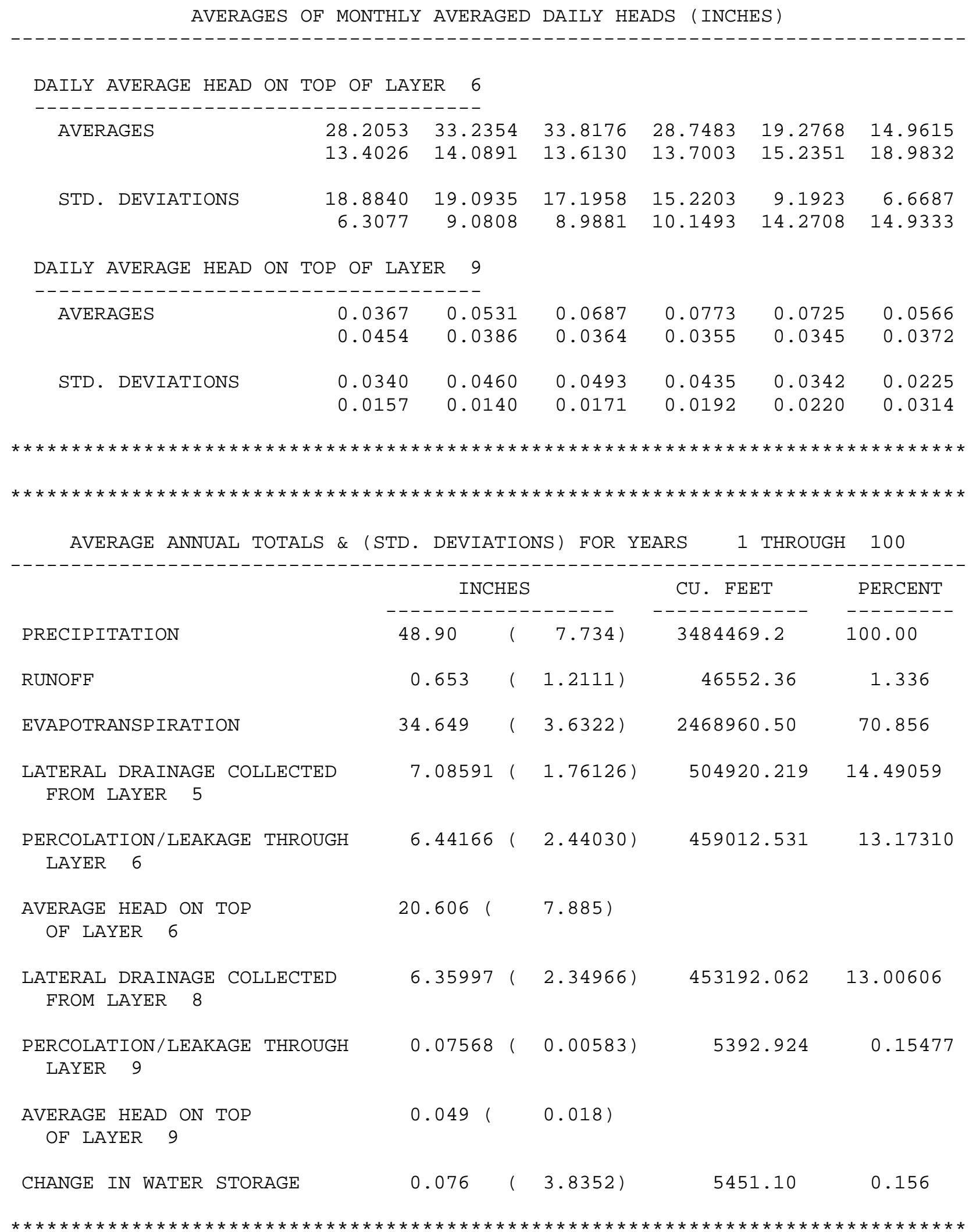

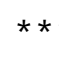




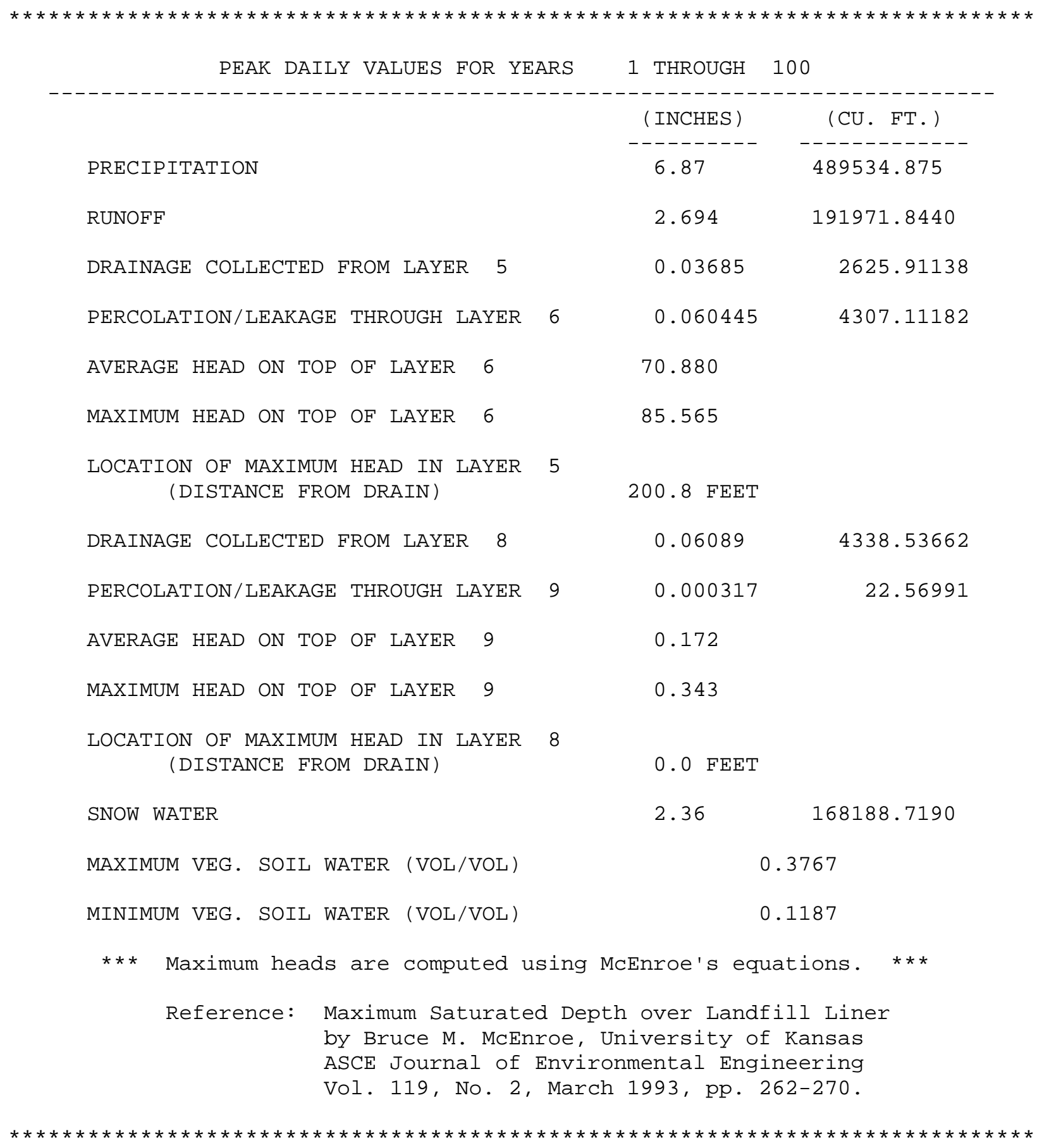

Rev. 0 


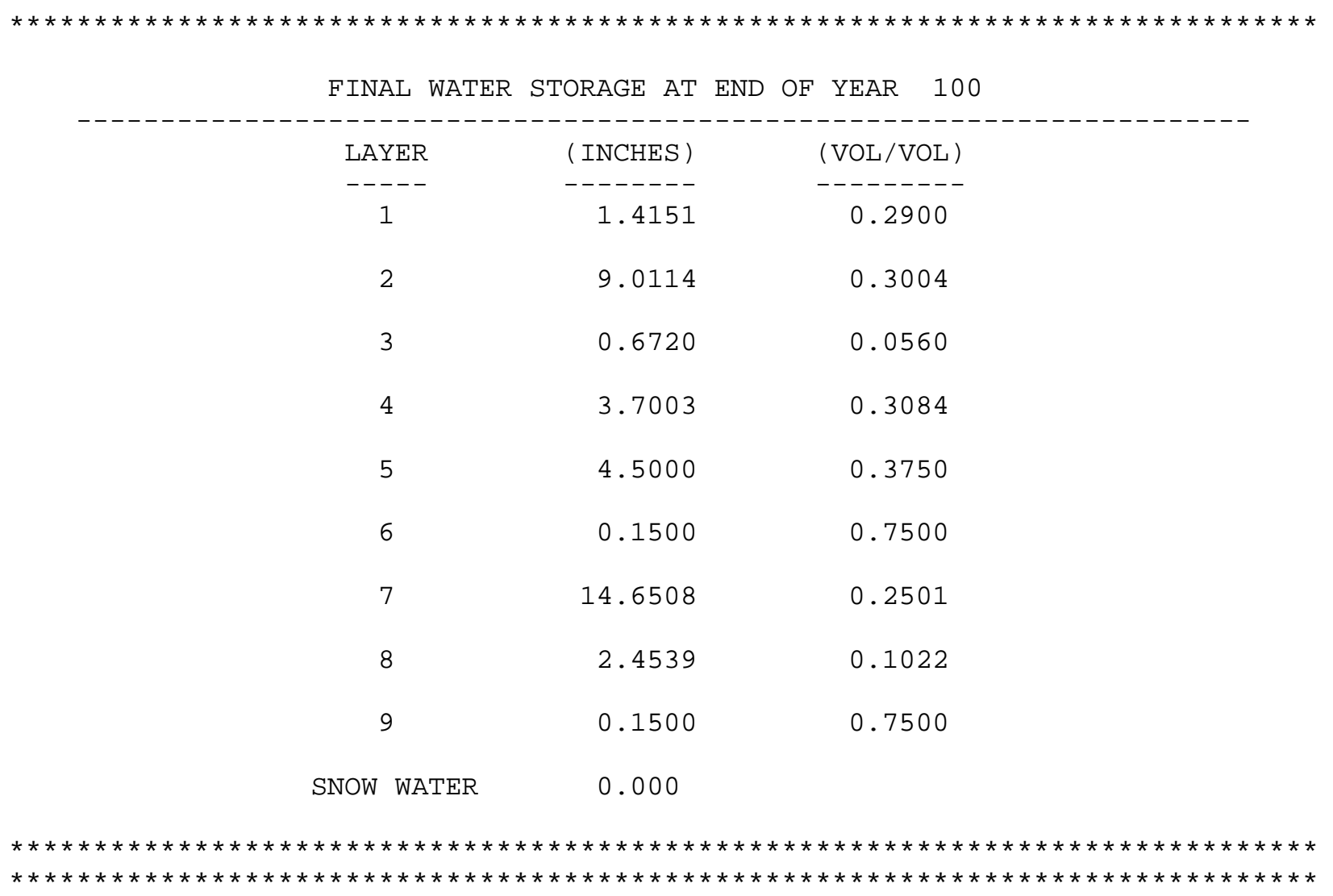


Appendix N, Lower Bounding Scenario Degraded SDF MSE Vault Closure Cap (10,000 Years): HELP Model Input Data and Output File (output file name: ZLBS8out.OUT)

\section{Input Data:}

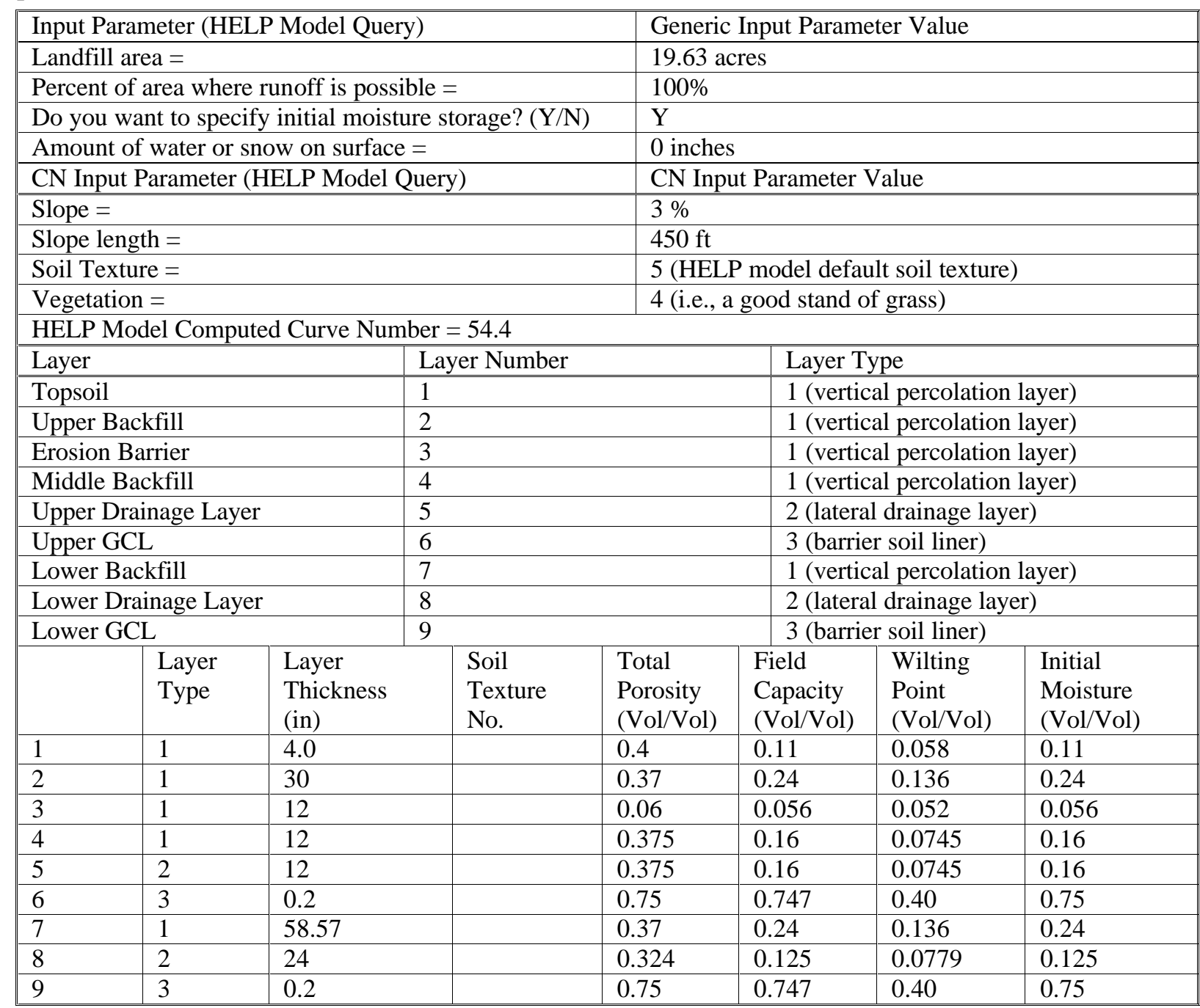

The lack of values in the table for particular parameters in particular layers denotes that no HELP model input was required for that parameter in that layer. No data are missing from the table. 
Input Data (continued):

\begin{tabular}{|c|c|c|c|c|c|c|c|c|c|}
\hline & $\begin{array}{l}\text { Layer } \\
\text { Type }\end{array}$ & $\begin{array}{l}\text { Sat. Hyd. } \\
\text { Conductivity * } \\
(\mathrm{cm} / \mathrm{sec})\end{array}$ & \multicolumn{2}{|c|}{$\begin{array}{l}\text { Drainage } \\
\text { Length } \\
\text { (ft) }\end{array}$} & $\begin{array}{l}\text { Drain } \\
\text { Slope } \\
(\%)\end{array}$ & $\begin{array}{l}\text { Leachate } \\
\text { Recirc. } \\
(\%) \\
\end{array}$ & \multicolumn{2}{|c|}{$\begin{array}{l}\text { Recirc. to } \\
\text { Layer } \\
(\#)\end{array}$} & $\begin{array}{l}\text { Subsurface } \\
\text { Inflow } \\
\text { (in/yr) }\end{array}$ \\
\hline 1 & 1 & $1.00 \mathrm{E}-03$ & & & & & & & \\
\hline 2 & 1 & $1.00 \mathrm{E}-04$ & & & & & & & \\
\hline 3 & 1 & $3.97 \mathrm{E}-04$ & & & & & & & \\
\hline 4 & 1 & $3.20 \mathrm{E}-03$ & & & & & & & \\
\hline 5 & 2 & $3.20 \mathrm{E}-03$ & 450 & & 3 & & & & \\
\hline 6 & 3 & $5.00 \mathrm{E}-09$ & & & & & & & \\
\hline 7 & 1 & $1.00 \mathrm{E}-04$ & & & & & & & \\
\hline 8 & 2 & $6.53 \mathrm{E}-02$ & 150 & & 11.4 & & & & \\
\hline \multirow[t]{2}{*}{9} & 3 & $5.00 \mathrm{E}-09$ & & & & & & \\
\hline & $\begin{array}{l}\text { Layer } \\
\text { Type }\end{array}$ & \multicolumn{2}{|l|}{$\begin{array}{l}\text { Geomembrane } \\
\text { Pinhole Density } \\
\text { (\#/acre) }\end{array}$} & \multicolumn{2}{|c|}{$\begin{array}{l}\text { Geomembrane } \\
\text { Instal. Defects } \\
(\# / \text { acre })\end{array}$} & \multicolumn{2}{|c|}{$\begin{array}{l}\text { Geomembrane } \\
\text { Placement Quality }\end{array}$} & \multicolumn{2}{|c|}{$\begin{array}{l}\text { Geotextile } \\
\text { Transmissivity } \\
\left(\mathrm{cm}^{2} / \mathrm{sec}\right)\end{array}$} \\
\hline 1 & 1 & & & & & & & & \\
\hline 2 & 1 & & & & & & & & \\
\hline 3 & 1 & & & & & & & & \\
\hline 4 & 1 & & & & & & & & \\
\hline 5 & 2 & & & & & & & & \\
\hline 6 & 3 & & & & & & & & \\
\hline 7 & 1 & & & & & & & & \\
\hline 8 & 2 & & & & & & & & \\
\hline 9 & 3 & & & & & & & & \\
\hline
\end{tabular}

The lack of values in the table for particular parameters in particular layers denotes that no HELP model input was required for that parameter in that layer. No data are missing from the table.

* The HELP model output often produces an increased number of significant digits for the Effective Saturated Hydraulic Conductivity over that of the actual input 


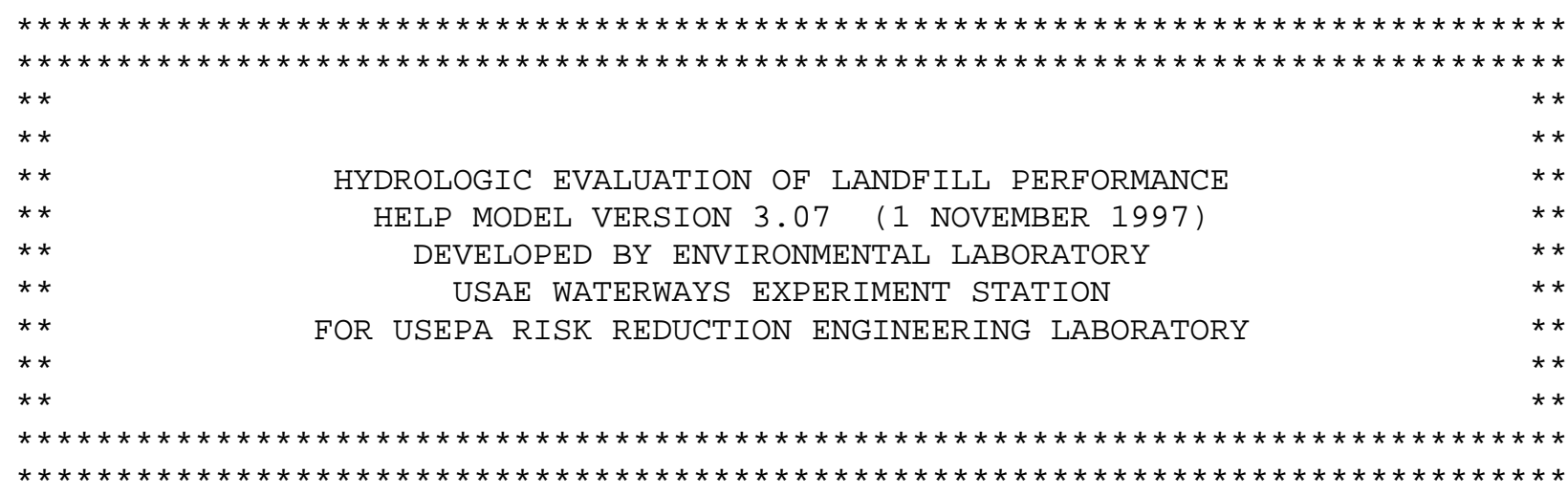
PRECIPITATION DATA FILE:
D: \HELP 3 \Hweather $\backslash$ ZPREC.D4
TEMPERATURE DATA FILE:
D: \HELP $3 \backslash$ Hweather $\backslash$ ZTEMP.D7
SOLAR RADIATION DATA FILE: D: \HELP3\Hweather $\backslash$ ZSOLAR.D13
EVAPOTRANSPIRATION DATA: D: \HELP3\Hweather $\backslash$ ZEVAP.D11
SOIL AND DESIGN DATA FILE: D: \HELP3\Hsdfmse \ZLBS8.D10
OUTPUT DATA FILE:
D: \HELP $3 \backslash$ Hsdfmse $\backslash Z L B S 8$ out.OUT

TIME: $\quad 15: 12 \quad$ DATE: $12 / 11 / 2003$

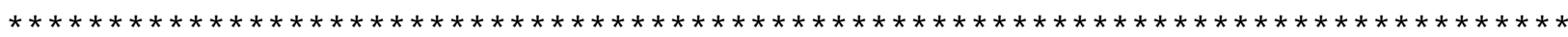

TITLE: LBS Degraded MSE Vault Closure Cap - 10,000 Years

NOTE: INITIAL MOISTURE CONTENT OF THE LAYERS AND SNOW WATER WERE SPECIFIED BY THE USER.

\begin{tabular}{|c|c|c|c|c|}
\hline \multicolumn{5}{|c|}{$\begin{array}{c}\text { TYPE } 1 \text { - VERTICAL PERCOLATION LAYER } \\
\text { MATERIAL TEXTURE NUMBER }\end{array}$} \\
\hline THICKNESS & $=$ & 4.00 & INCHES & \\
\hline POROSITY & $=$ & 0.4000 & VOL/VOI & \\
\hline FIELD CAPACITY & $=$ & 0.1100 & VOL/VOI & \\
\hline WILTING POINT & $=$ & 0.0580 & VOL/VOI & \\
\hline INITIAL SOIL WATER CONTENT & $=$ & 0.1100 & VOL/VOI & \\
\hline EFFECTIVE SAT. HYD. COND. & $=$ & 0.100000005 & $5000 \mathrm{E}-02$ & $\mathrm{CM} / \mathrm{SEC}$ \\
\hline \multicolumn{5}{|c|}{ LAYER 2} \\
\hline $\begin{array}{r}\text { TYPE } 1 \text { - VERTICAI } \\
\text { MATERIAL TEXT }\end{array}$ & & $\begin{array}{cl}\text { RCOLATION } & \text { LA } \\
\text { NUMBER } & 0\end{array}$ & AYER & \\
\hline THICKNESS & $=$ & 30.00 & INCHES & \\
\hline POROSITY & $=$ & 0.3700 & VOL/VOI & \\
\hline FIELD CAPACITY & $=$ & 0.2400 & VOL/VOI & \\
\hline WILTING POINT & $=$ & 0.1360 & VOL/VOI & \\
\hline INITIAL SOIL WATER CONTENT & $=$ & 0.2400 & VOL/VOI & \\
\hline EFFECTIVE SAT. HYD. COND. & $=$ & 0.999999975 & $5000 \mathrm{E}-04$ & $\mathrm{CC}$ \\
\hline
\end{tabular}

Rev. 0 
LAYER 3

$--------$

TYPE 1 - VERTICAL PERCOLATION LAYER

MATERIAL TEXTURE NUMBER 0

$\begin{array}{llrl}\text { THICKNESS } & = & 12.00 \mathrm{INCHES} \\ \text { POROSITY } & = & 0.0600 \mathrm{VOL} / \mathrm{VOL} \\ \text { FIELD CAPACITY } & = & 0.0560 \mathrm{VOL} / \mathrm{VOL} \\ \text { WILTING POINT } & = & 0.0520 \mathrm{VOL} / \mathrm{VOL} \\ \text { INITIAL SOIL WATER CONTENT } & = & 0.0560 \mathrm{VOL} / \mathrm{VOL} \\ \text { EFFECTIVE SAT. HYD. COND. } & =0.396999996000 \mathrm{E}-03 \mathrm{CM} / \mathrm{SEC}\end{array}$

LAYER 4

TYPE 1 - VERTICAL PERCOLATION LAYER MATERIAL TEXTURE NUMBER 0

$\begin{array}{llrl}\text { THICKNESS } & = & 12.00 & \text { INCHES } \\ \text { POROSITY } & = & 0.3750 \mathrm{VOL} / \mathrm{VOL} \\ \text { FIELD CAPACITY } & = & 0.1600 \mathrm{VOL} / \mathrm{VOL} \\ \text { WILTING POINT } & = & 0.0745 \mathrm{VOL} / \mathrm{VOL} \\ \text { INITIAL SOIL WATER CONTENT } & = & 0.1600 \mathrm{VOL} / \mathrm{VOL} \\ \text { EFFECTIVE SAT. HYD. COND. } & =0.319999992000 \mathrm{E}-02 \mathrm{CM} / \mathrm{SEC} \\ & \\ \text { LAYER } & 5 & \\ & \end{array}$

TYPE 2 - LATERAL DRAINAGE LAYER MATERIAL TEXTURE NUMBER 0

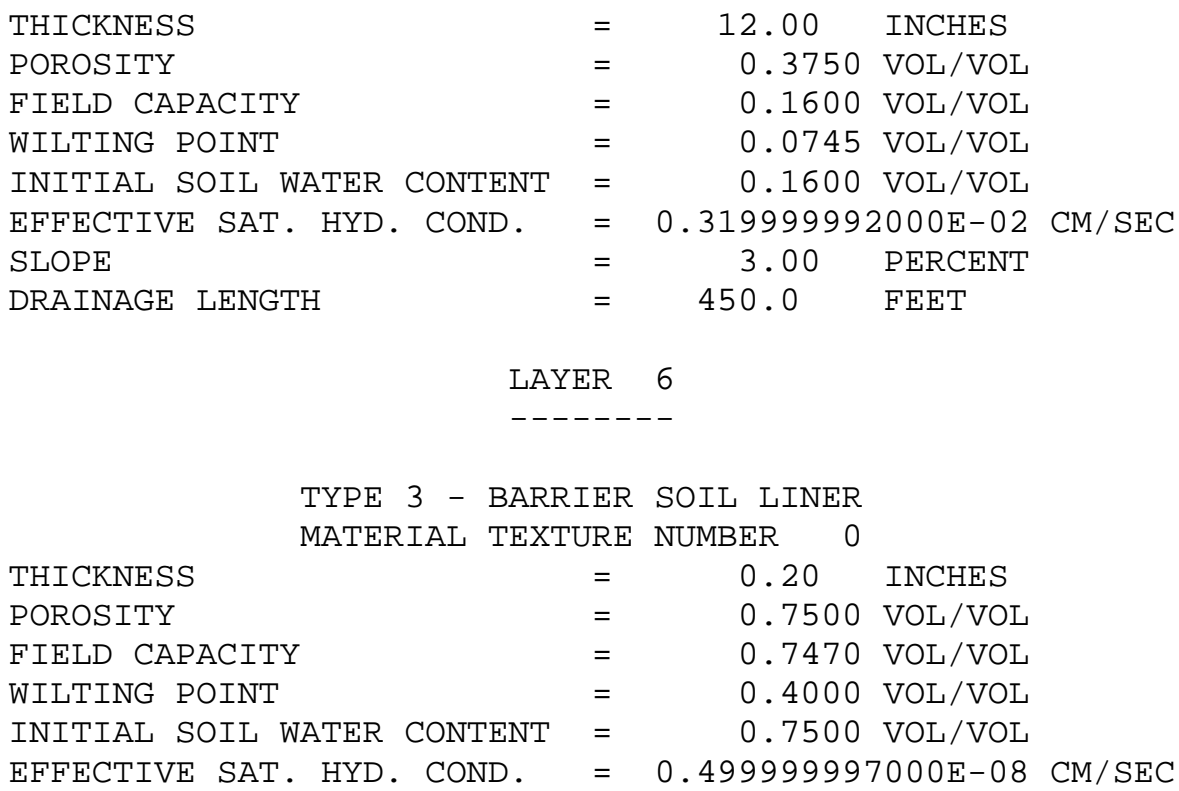


LAYER 7

$--------$

TYPE 1 - VERTICAL PERCOLATION LAYER

MATERIAL TEXTURE NUMBER 0

$\begin{array}{llrl}\text { THICKNESS } & = & 58.57 & \text { INCHES } \\ \text { POROSITY } & = & 0.3700 \mathrm{VOL} / \mathrm{VOL} \\ \text { FIELD CAPACITY } & = & 0.2400 \mathrm{VOL} / \mathrm{VOL} \\ \text { WILTING POINT } & = & 0.1360 \mathrm{VOL} / \mathrm{VOL} \\ \text { INITIAL SOIL WATER CONTENT } & = & 0.2400 \mathrm{VOL} / \mathrm{VOL} \\ \text { EFFECTIVE SAT. HYD. COND. } & =0.999999975000 \mathrm{E}-04 \mathrm{CM} / \mathrm{SEC}\end{array}$

LAYER 8

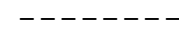

TYPE 2 - LATERAL DRAINAGE LAYER

$\begin{array}{llrl}\text { THICKNESS } & = & 24.00 & \text { INCHES } \\ \text { POROSITY } & = & 0.3240 \mathrm{VOL} / \mathrm{VOL} \\ \text { FIELD CAPACITY } & = & 0.1250 \mathrm{VOL} / \mathrm{VOL} \\ \text { WILTING POINT } & = & 0.0779 \mathrm{VOL} / \mathrm{VOL} \\ \text { INITIAL SOIL WATER CONTENT } & = & 0.1250 \mathrm{VOL} / \mathrm{VOL} \\ \text { EFFECTIVE SAT. HYD. COND. } & = & 0.65300027000 \mathrm{E}-01 \mathrm{CM} / \mathrm{SEC} \\ \text { SLOPE } & = & 11.40 \mathrm{PERCENT} \\ \text { DRAINAGE LENGTH } & = & 150.0 \mathrm{FEET}\end{array}$

LAYER 9

TYPE 3 - BARRIER SOIL LINER

MATERIAL TEXTURE NUMBER 0

$\begin{array}{llll}\text { THICKNESS } & = & 0.20 & \text { INCHES } \\ \text { POROSITY } & = & 0.7500 \mathrm{VOL} / \mathrm{VOL} \\ \text { FIELD CAPACITY } & = & 0.7470 \mathrm{VOL} / \mathrm{VOL} \\ \text { WILTING POINT } & = & 0.4000 \mathrm{VOL} / \mathrm{VOL} \\ \text { INITIAL SOIL WATER CONTENT } & = & 0.7500 \mathrm{VOL} / \mathrm{VOL} \\ \text { EFFECTIVE SAT. HYD. COND. } & =0.499999997000 \mathrm{E}-08 \mathrm{CM} / \mathrm{SEC}\end{array}$

GENERAL DESIGN AND EVAPORATIVE ZONE DATA

NOTE: SCS RUNOFF CURVE NUMBER WAS COMPUTED FROM DEFAULT SOIL DATA BASE USING SOIL TEXTURE \# 5 WITH A GOOD STAND OF GRASS, A SURFACE SLOPE OF 3.\% AND A SLOPE LENGTH OF 450. FEET.

SCS RUNOFF CURVE NUMBER

FRACTION OF AREA ALLOWING RUNOFF

AREA PROJECTED ON HORIZONTAL PLANE

EVAPORATIVE ZONE DEPTH

INITIAL WATER IN EVAPORATIVE ZONE

UPPER LIMIT OF EVAPORATIVE STORAGE

LOWER LIMIT OF EVAPORATIVE STORAGE

INITIAL SNOW WATER

INITIAL WATER IN LAYER MATERIALS

TOTAL INITIAL WATER

TOTAL SUBSURFACE INFLOW

$\begin{array}{lcl}= & 54.40 & \\ = & 100.0 & \text { PERCENT } \\ = & 19.630 & \text { ACRES } \\ = & 22.0 & \text { INCHES } \\ = & 4.760 & \text { INCHES } \\ = & 8.260 & \text { INCHES } \\ = & 2.680 & \text { INCHES } \\ = & 0.000 & \text { INCHES } \\ = & 29.509 & \text { INCHES } \\ = & 29.509 & \text { INCHES } \\ = & 0.00 & \text { INCHES /YEAR }\end{array}$

Rev. 0 


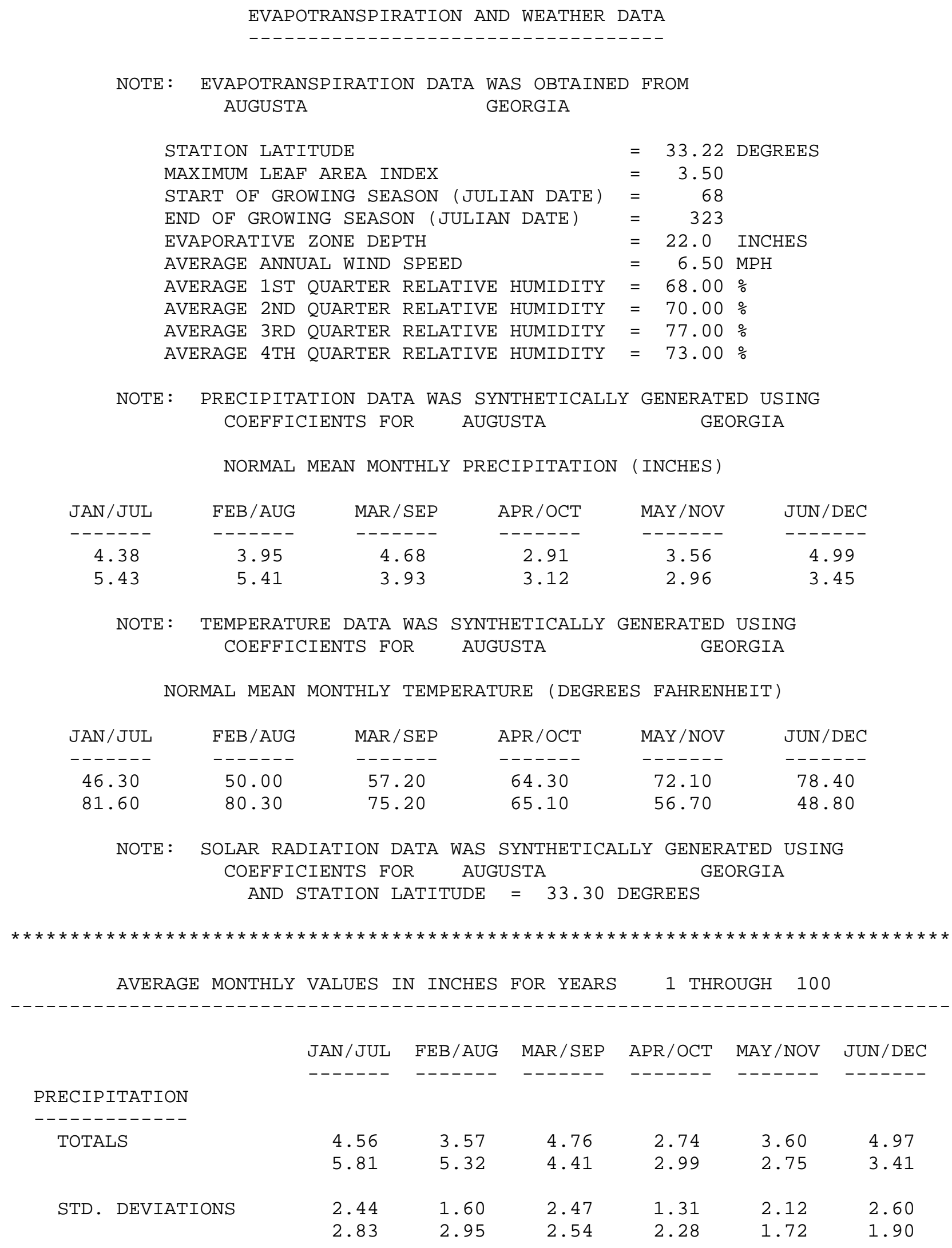

Rev. 0 
RUNOFF

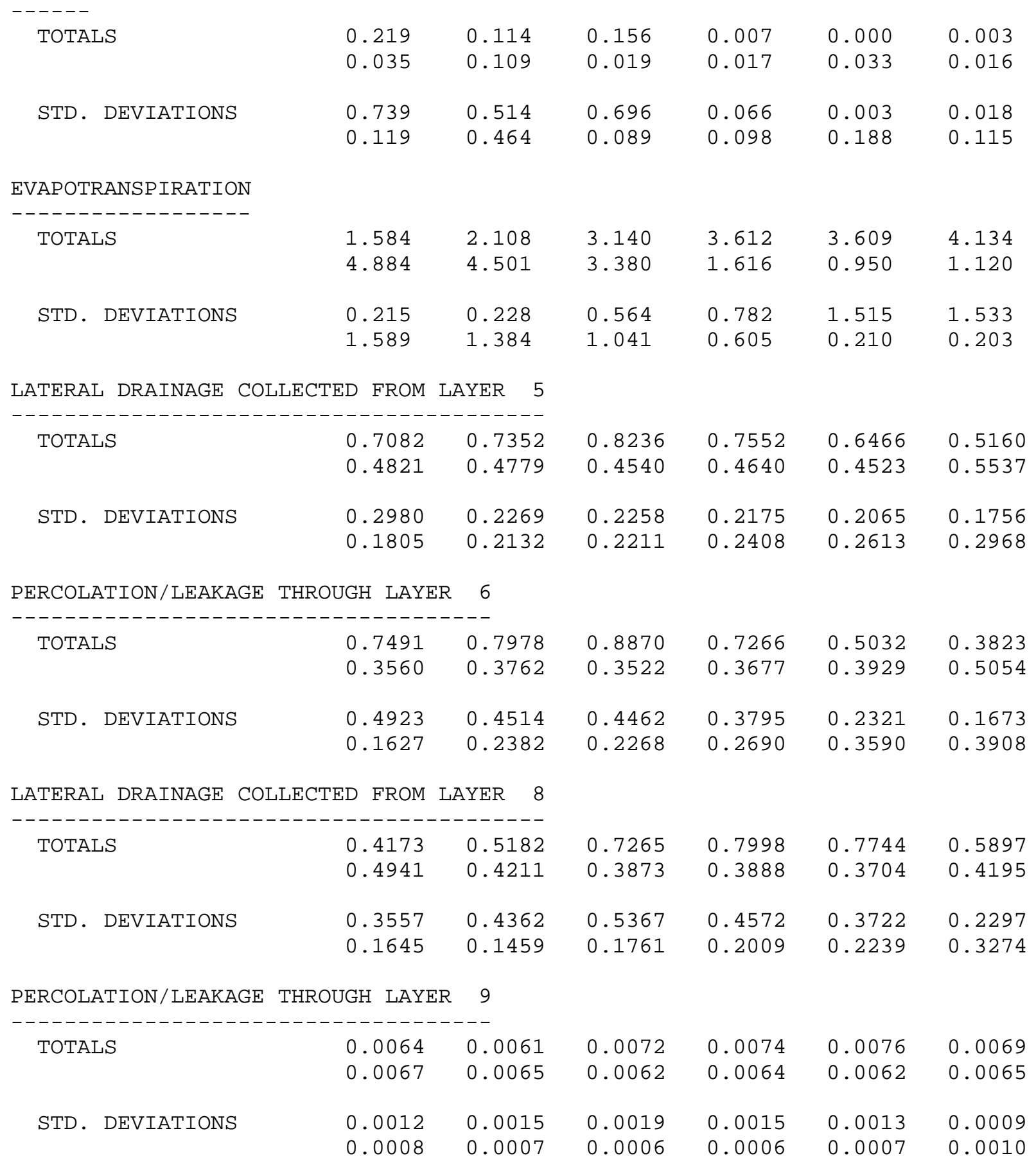


AVERAGES OF MONTHLY AVERAGED DAILY HEADS (INCHES)

DAILY AVERAGE HEAD ON TOP OF LAYER 6

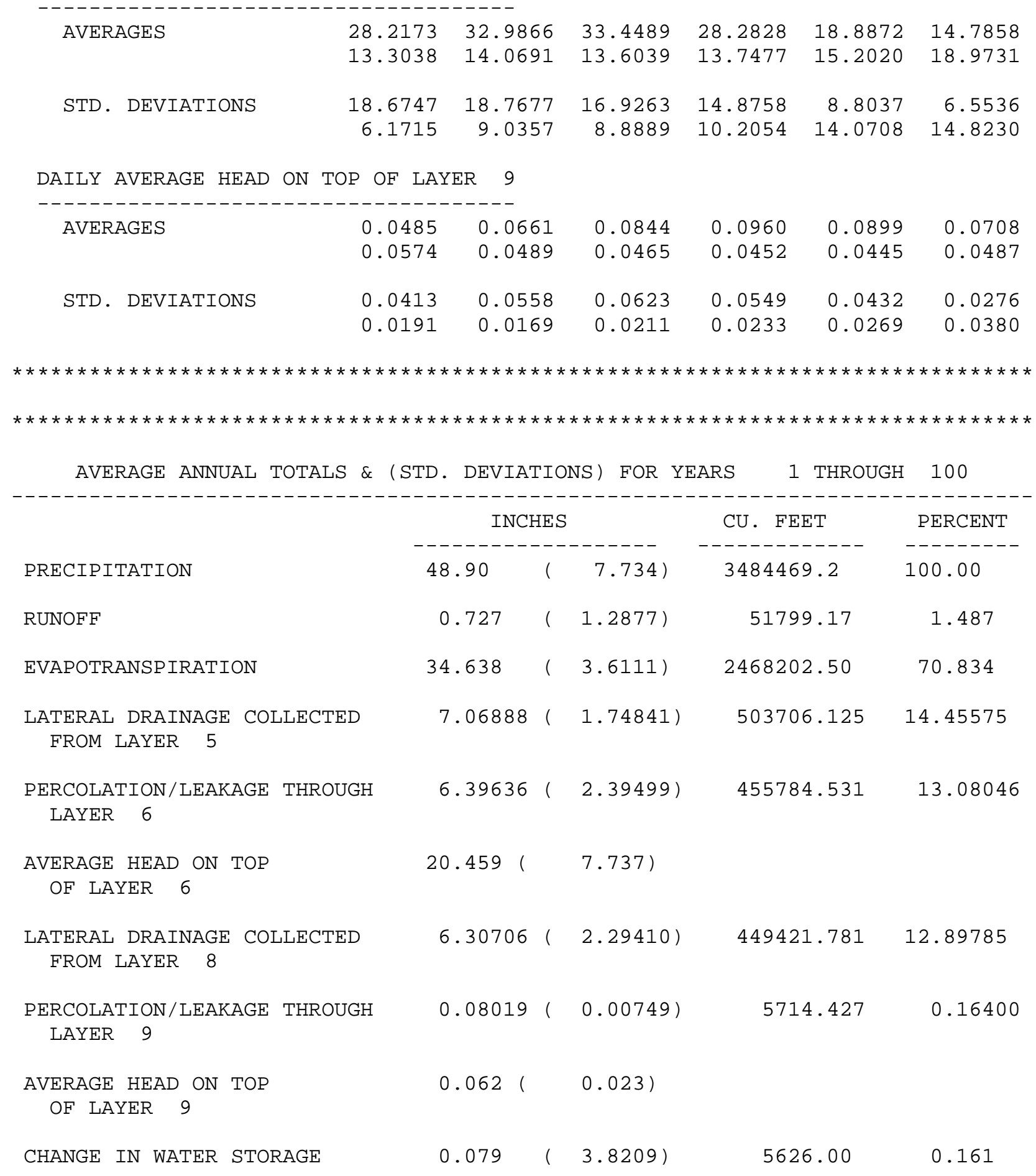




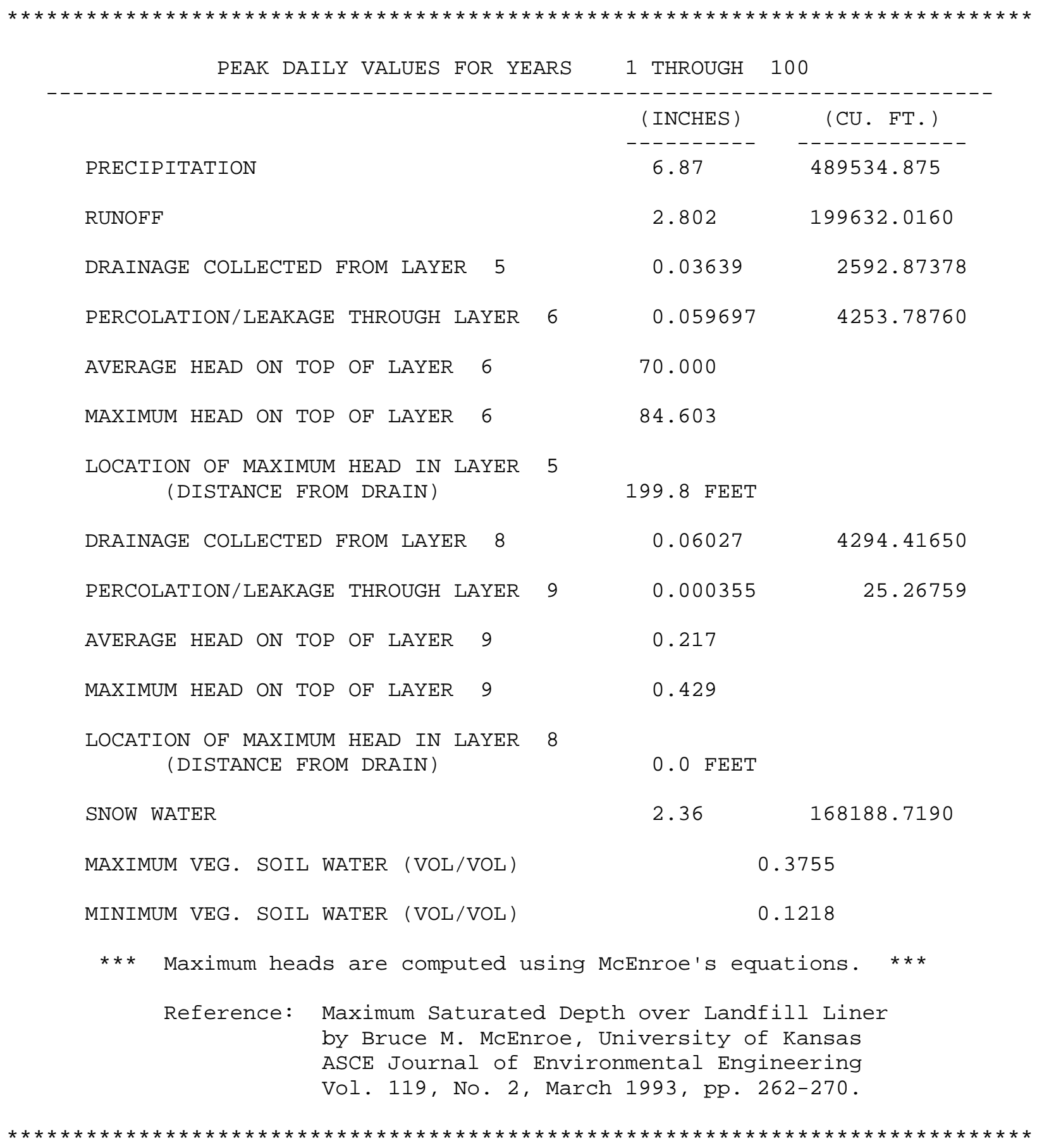

Rev. 0 


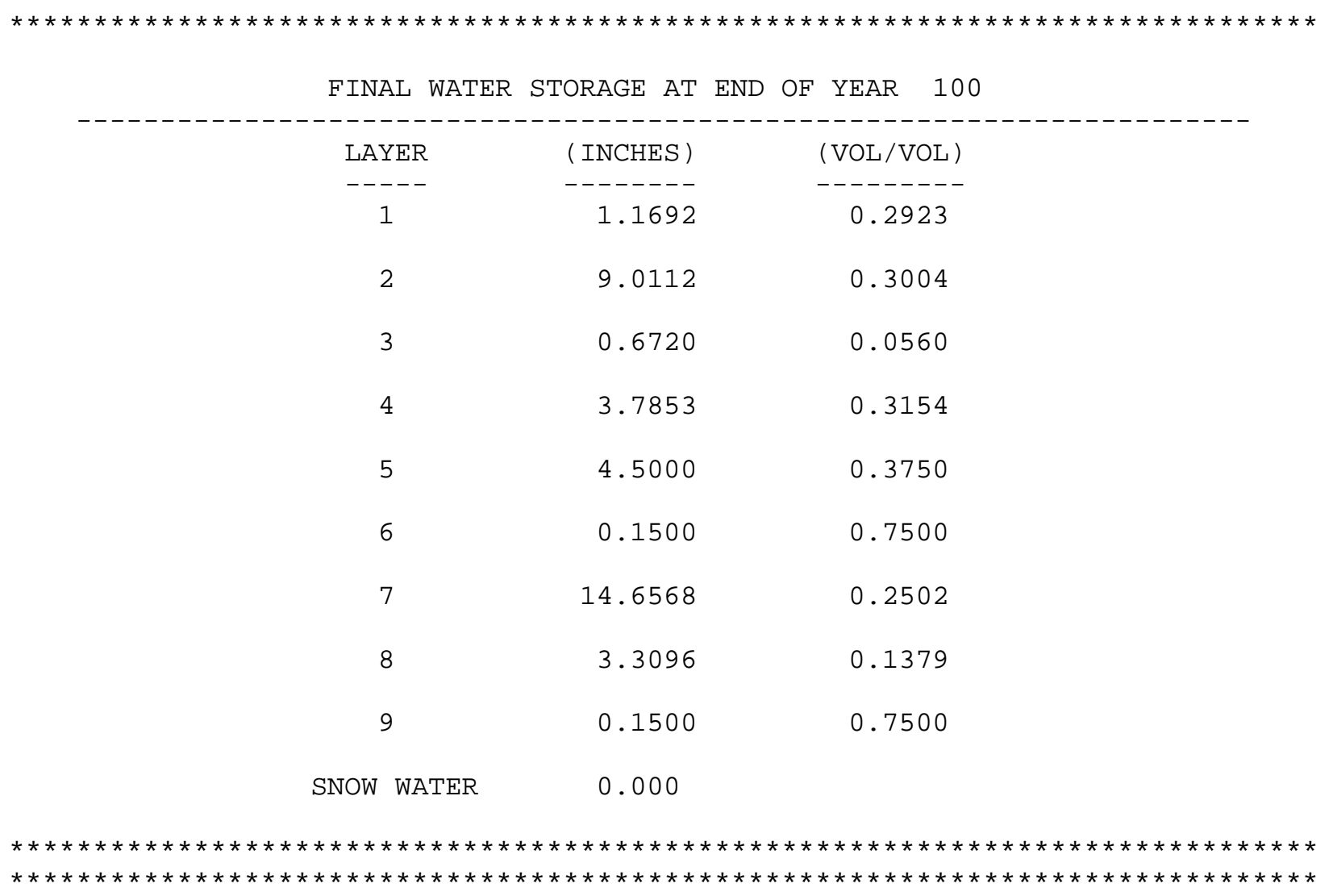


Appendix O, SDF MSE Vault Closure Cap Degraded Property Value Calculations for Upper Bounding Scenario (i.e. Institutional Control to Farm to Pine Forest)

The MSE vault closure cap initial (0 year) layer thickness and hydraulic property values from top to bottom are provided in Table 3.1-1. The degradation scenarios for each layer are provided in Table 4.4-2. Based upon the Table 4.4-2 degradation scenarios, the Table 3.1-1 initial SDF closure cap layer thickness and hydraulic property values have been modified to account for degradation at 100, 154, 300, 550, 602, 802, $1,000,1,800,3,400,5,600$ and 10,000 years after closure of the SDF.

\section{Topsoil and Upper Backfill Layer Thickness:}

From Section 4.2 the soil loss in terms of depth of loss per year for the topsoil was estimated to be $2.0 \mathrm{E}-04$ inches/year with bamboo and 0.11 inches/year with corn. For the backfill it was estimated to be 1.2E-04 inches/year with bamboo and 0.067 inches/year with corn.

Topsoil / Upper Backfill Thickness Over Time Calculation:

\begin{tabular}{|c|c|c|}
\hline Year & Vegetation & Topsoil / Upper Backfill Thickness \\
\hline 0 & bamboo & $6 "-(0$ years $\times 2.0 \mathrm{E}-04$ inches/year $)=6 " / 30 "$ \\
\hline 100 & bamboo & $6 "-(100$ years $\times 2.0 \mathrm{E}-04$ inches/year $)=5.980 " / 30 "$ \\
\hline \multicolumn{3}{|c|}{$\begin{array}{l}\text { How long does it take for the topsoil to be completely eroded away with corn which is assumed to be planted } \\
\text { immediately after the } 100 \text { year institutional control period has ended: } \\
5.980 " \div 0.11 \text { inches } / \text { year }=54 \text { years } \\
100 \text { years }+54 \text { years }=154 \text { years }\end{array}$} \\
\hline 154 & corn & $0 " / 30 "$ \\
\hline \multicolumn{3}{|c|}{$\begin{array}{l}\text { How long does it take for the upper backfill to be completely eroded away with corn which is assumed to be planted } \\
\text { immediately after the } 100 \text { year institutional control period has ended: } \\
30 " \div 0.067 \text { inches/year }=448 \text { years } \\
154 \text { years }+448 \text { years }=602 \text { years }\end{array}$} \\
\hline 300 & corn & $0 " / 30 "-((300$ years -154 years $) \times 0.067$ inches $/$ year $)=20.218 "$ \\
\hline 550 & corn & $0 " / 30 "-((550$ years -154 years $) \times 0.067$ inches $/$ year $)=3.468 "$ \\
\hline 602 & corn & $0 " / 0 "$ \\
\hline 802 & pine trees & $0 " / 0 "$ \\
\hline 1,000 & pine trees & $0 " / 0 "$ \\
\hline 1,800 & pine trees & $0 " / 0 "$ \\
\hline 3,400 & pine trees & $0 " / 0 "$ \\
\hline 5,600 & pine trees & $0 " / 0 "$ \\
\hline 10,000 & pine trees & $0 " / 0 "$ \\
\hline
\end{tabular}

\section{Erosion Barrier Hydraulic Properties:}

As outlined in Phifer and Nelson 2003, the erosion barrier is assumed to consist of a one foot thick layer of 2-inch to 6-inch granite stone whose voids are filled with a Controlled Low Strength Material (CLSM) or flowable fill. Maintenance during the institutional control period and farming practices during corn farming prevent degradation of the erosion control barrier. Subsequent to the institutional control period and corn farming, pine forest succession will result in root penetration through the erosion control barrier. This does not impact its ability to function as an erosion barrier. For this scenario pine forest succession occurs after all of the topsoil and upper backfill have been completely eroded, therefore the upper backfill is not available to fill holes in the erosion barrier after the roots decompose. However it will be assumed that root penetration breaks up the flowable fill and separates it from the granite stone. After the root decomposes it will be assumed that segregation of the granite stone and broken up flowable fill occurs, resulting in the flowable fill at the bottom of the hole and the granite stone at the top. For the purposes of this calculation the properties of the broken up flowable fill will be ignored. Therefore will assume that the degraded barrier consists of intact erosion barrier with holes filled with the granite stone. 
The following are the assumed properties of the intact erosion barrier and granite stone:

\begin{tabular}{|l|l|l|l|l|}
\hline Material & K & N & FC & WP \\
\hline Intact erosion barrier $^{1}$ & $3.97 \mathrm{E}-04$ & 0.06 & 0.056 & 0.052 \\
\hline Granite stone $^{2}$ & $3.0 \mathrm{E}-01$ & 0.397 & 0.032 & 0.013 \\
\hline
\end{tabular}

${ }^{1}$ Phifer and Nelson 2003

${ }^{2}$ USEPA 1994a and USEPA 1994b

From Section 4.1 the following assumptions relative to pine forest succession that impact the erosion barrier hydraulic properties were made:

- 200 years after the end of farming it is assumed that the entire cap is dominated by pine (i.e. 400 mature trees per acre).

- Complete turnover of the 400 mature trees per acre occurs every 100 years (in a staggered manner).

- There are 400 mature trees per acre with 4 roots to 6 feet and 1 root to 12 feet. The roots are 3 inches in diameter at a depth of 1 foot and 0.25 inches in diameter at either 6 or 12 feet, whichever is applicable.

Area of holes in erosion barrier due to root penetration:

Average Erosion Barrier Depth after topsoil and upper backfill completely eroded (see Table 3.1-1):

Average depth $=1 / 2(12 ")=6 " \approx 0.5$ '

Root Diameter for $4-6$ ' roots at $0.5^{\prime}$ ':

3 " diameter at 1 ' depth and 0.25 "' at 6'

$$
\begin{aligned}
& \left(3^{\prime \prime}-0.25^{\prime \prime}\right) /\left(6^{\prime}-1^{\prime}\right)=0.55^{\prime \prime} / \mathrm{ft} \\
& \text { Diameter }=3 "+\left(0.5^{\prime} \times 0.55^{\prime \prime} / \mathrm{ft}\right)=3.275^{\prime \prime}
\end{aligned}
$$

Area of for 4-6' roots at $0.5^{\prime}$ :

$$
\text { Area }=4 \times 1 / 4 \pi \mathrm{D}^{2}=\pi \mathrm{D}^{2}=\pi\left(3.275^{\prime \prime}\right)^{2}=33.7 \mathrm{in}^{2}
$$

Root Diameter for 1-12' root at 0.5 ':

3 " diameter at 1' depth and 0.25 " at 12 '

$$
\begin{aligned}
& \left(3^{\prime \prime}-0.25^{\prime \prime}\right) /\left(12^{\prime}-1^{\prime}\right)=0.25^{\prime \prime} / \mathrm{ft} \\
& \text { Diameter }=3 "+\left(0.5^{\prime} \times 0.25^{\prime \prime} / \mathrm{ft}\right]=3.125^{\prime \prime}
\end{aligned}
$$

Area of for 1-12' roots at $0.5^{\prime}$ '

$$
\text { Area }=1 / 4 \pi \mathrm{D}^{2}=1 / 4 \pi(3.125 ")^{2}=7.7 \mathrm{in}^{2}
$$

Total area of holes in erosion barrier per tree:

Total area $=33.7 \mathrm{in}^{2}+7.7 \mathrm{in}^{2}=41.4 \mathrm{in}^{2} \times \mathrm{ft}^{2} / 144 \mathrm{in}^{2} \approx 0.29 \mathrm{ft}^{2} /$ tree

Total area of holes per acre per 100 years:

400 trees/acre/100 years

Total area $=0.29 \mathrm{ft}^{2} /$ tree $\times 400$ trees $/$ acre $/ 100$ years $=116 \mathrm{ft}^{2} /$ acre $/ 100$ years 


\begin{tabular}{|l|l|l|}
\hline Year & Vegetation & Area of holes in erosion barrier / acre \\
\hline 0 & Bamboo & 0 \\
\hline 100 & Bamboo & 0 \\
\hline 154 & Corn & 0 \\
\hline 300 & Corn & 0 \\
\hline 550 & Corn & 0 \\
\hline 602 & Corn & 0 \\
\hline 802 & Pine trees & $116 \mathrm{ft}^{2} /$ acre \\
\hline 1,000 & Pine trees & $116 \mathrm{ft}^{2} /$ acre $+\left[(1000 \mathrm{yrs}-802 \mathrm{yrs}) \times 116 \mathrm{ft}^{2} /\right.$ acre $/ 100$ years $]=346 \mathrm{ft}^{2} /$ acre \\
\hline 1,800 & Pine trees & $116 \mathrm{ft}^{2} /$ acre $+\left[(1800 \mathrm{yrs}-802 \mathrm{yrs}) \times 116 \mathrm{ft}^{2} /\right.$ acre $/ 100$ years $]=1274 \mathrm{ft}^{2} /$ acre \\
\hline 3,400 & Pine trees & $116 \mathrm{ft}^{2} /$ acre $+\left[(3400 \mathrm{yrs}-802 \mathrm{yrs}) \times 116 \mathrm{ft}^{2} /\right.$ acre $/ 100$ years $]=3130 \mathrm{ft}^{2} /$ acre \\
\hline 5,600 & Pine trees & $116 \mathrm{ft}^{2} /$ acre $+\left[(5600 \mathrm{yrs}-802 \mathrm{yrs}) \times 116 \mathrm{ft}^{2} / \mathrm{acre} / 100\right.$ years $]=5682 \mathrm{ft}^{2} /$ acre \\
\hline 10,000 & Pine trees & $116 \mathrm{ft}^{2} /$ acre $+\left[(10000 \mathrm{yrs}-802 \mathrm{yrs}) \times 116 \mathrm{ft}^{2} /\right.$ acre $/ 100$ years $]=10786 \mathrm{ft}^{2} /$ acre \\
\hline
\end{tabular}

${ }^{1} 200$ years after corn farming ceases (i.e. at year 802) it is assumed that the entire cap is covered with pine (i.e. 400 mature trees per acre). It is assumed that each "generation" of roots becomes instantaneous voids at the 100-year turnover period.

\begin{tabular}{|l|l|l|}
\hline Year & Vegetation & Fraction $(\mathrm{f})$ of erosion barrier area comprising holes \\
\hline 0 & Bamboo & $0 \div 43560 \mathrm{ft}^{2} /$ acre $=0$ \\
\hline 100 & Bamboo & $0 \div 43560 \mathrm{ft}^{2} /$ acre $=0$ \\
\hline 154 & Corn & $0 \div 43560 \mathrm{ft}^{2} /$ acre $=0$ \\
\hline 300 & Corn & $0 \div 43560 \mathrm{ft}^{2} /$ acre $=0$ \\
\hline 550 & Corn & $0 \div 43560 \mathrm{ft}^{2} /$ acre $=0$ \\
\hline 602 & Corn & $0 \div 43560 \mathrm{ft}^{2} /$ acre $=0$ \\
\hline 802 & Pine trees & $116 \mathrm{ft}^{2} /$ acre $\div 43560 \mathrm{ft}^{2} /$ acre $=0.00266$ \\
\hline 1,000 & Pine trees & $346 \mathrm{ft}^{2} /$ acre $\div 43560 \mathrm{ft}^{2} /$ acre $=0.00794$ \\
\hline 1,800 & Pine trees & $1274 \mathrm{ft}^{2} /$ acre $\div 43560 \mathrm{ft}^{2} /$ acre $=0.0292$ \\
\hline 3,400 & Pine trees & $3130 \mathrm{ft}^{2} /$ acre $\div 43560 \mathrm{ft}^{2} /$ acre $=0.0718$ \\
\hline 5,600 & Pine trees & $5682 \mathrm{ft}^{2} /$ acre $\div 43560 \mathrm{ft}^{2} /$ acre $=0.130$ \\
\hline 10,000 & Pine trees & $10786 \mathrm{ft}^{2} /$ acre $\div 43560 \mathrm{ft}^{2} /$ acre $=0.248$ \\
\hline
\end{tabular}

The equivalent horizontal hydraulic conductivity for horizontal flow in a series of horizontal layers with different saturated hydraulic conductivities can be determined from the following equation (Freeze and Cherry 1979):

$$
K_{h}=\sum_{i=1}^{n} \frac{K_{i} d_{i}}{d} \text {, where } \mathrm{K}_{\mathrm{h}}=\text { equivalent horizontal saturated hydraulic conductivity, } \mathrm{K}_{\mathrm{i}}=\text { horizontal }
$$
saturated hydraulic conductivity of $i^{\text {th }}$ layer, $d_{i}=$ thickness of $i^{\text {th }}$ layer, $d=$ total thickness

In a similar manner the equivalent vertical hydraulic conductivity for vertical flow in a horizontal zone containing areas of materials with different saturated hydraulic conductivities can be determined based upon an area proportionality as follows:

$$
\begin{array}{r}
K_{v}=\sum_{i=1}^{n} \frac{K_{i} A_{i}}{A}, \\
\text { saturated hydraulic conductivity of } \mathrm{i}^{\text {th }} \text { layer, } \mathrm{A}_{\mathrm{v}}=\text { Area of } \mathrm{i}^{\text {th }} \text { layer, } \mathrm{A}=\text { total area }
\end{array}
$$

The following are the input saturated hydraulic conductivities (see above):

$$
\text { Intact erosion barrier }=3.97 \mathrm{E}-04 \mathrm{~cm} / \mathrm{s}
$$


Granite stone $=3.0 \mathrm{E}-01 \mathrm{~cm} / \mathrm{s}$

The fraction $(\mathrm{F})$ provided above is equivalent to $\mathrm{A}_{\mathrm{i}} / \mathrm{A}$ for the granite stone that is assumed to fill the holes in the erosion barrier and one minus the fraction $(1-F)$ is equivalent to $A_{i} / A$ for the for the intact erosion barrier, making the equation:

\begin{tabular}{|c|c|}
\hline Year & $\frac{.0 \mathrm{E}-01 \times \mathrm{F})+(3.97 \mathrm{E}-04 \times(1-\mathrm{F}))}{\mathrm{K}_{\mathrm{v}}}$ \\
\hline 0 & $(3.0 \mathrm{E}-01 \mathrm{~cm} / \mathrm{s} \times 0)+(3.97 \mathrm{E}-04 \mathrm{~cm} / \mathrm{s} \times(1-0))=3.97 \mathrm{E}-04 \mathrm{~cm} / \mathrm{s}$ \\
\hline 100 & $(3.0 \mathrm{E}-01 \mathrm{~cm} / \mathrm{s} \times 0)+(3.97 \mathrm{E}-04 \mathrm{~cm} / \mathrm{s} \times(1-0))=3.97 \mathrm{E}-04 \mathrm{~cm} / \mathrm{s}$ \\
\hline 154 & $(3.0 \mathrm{E}-01 \mathrm{~cm} / \mathrm{s} \times 0)+(3.97 \mathrm{E}-04 \mathrm{~cm} / \mathrm{s} \times(1-0))=3.97 \mathrm{E}-04 \mathrm{~cm} / \mathrm{s}$ \\
\hline 300 & $(3.0 \mathrm{E}-01 \mathrm{~cm} / \mathrm{s} \times 0)+(3.97 \mathrm{E}-04 \mathrm{~cm} / \mathrm{s} \times(1-0))=3.97 \mathrm{E}-04 \mathrm{~cm} / \mathrm{s}$ \\
\hline 550 & $(3.0 \mathrm{E}-01 \mathrm{~cm} / \mathrm{s} \times 0)+(3.97 \mathrm{E}-04 \mathrm{~cm} / \mathrm{s} \times(1-0))=3.97 \mathrm{E}-04 \mathrm{~cm} / \mathrm{s}$ \\
\hline 602 & $(3.0 \mathrm{E}-01 \mathrm{~cm} / \mathrm{s} \times 0)+(3.97 \mathrm{E}-04 \mathrm{~cm} / \mathrm{s} \times(1-0))=3.97 \mathrm{E}-04 \mathrm{~cm} / \mathrm{s}$ \\
\hline 802 & $(3.0 \mathrm{E}-01 \mathrm{~cm} / \mathrm{s} \times 0.00266)+(3.97 \mathrm{E}-04 \mathrm{~cm} / \mathrm{s} \times(1-0.00266))=1.2 \mathrm{E}-03 \mathrm{~cm} / \mathrm{s}$ \\
\hline 1,000 & $(3.0 \mathrm{E}-01 \mathrm{~cm} / \mathrm{s} \times 0.00794)+(3.97 \mathrm{E}-04 \mathrm{~cm} / \mathrm{s} \times(1-0.00794))=2.8 \mathrm{E}-03 \mathrm{~cm} / \mathrm{s}$ \\
\hline 1,800 & $(3.0 \mathrm{E}-01 \mathrm{~cm} / \mathrm{s} \times 0.0292)+(3.97 \mathrm{E}-04 \mathrm{~cm} / \mathrm{s} \times(1-0.0292))=9.1 \mathrm{E}-03 \mathrm{~cm} / \mathrm{s}$ \\
\hline 3,400 & $(3.0 \mathrm{E}-01 \mathrm{~cm} / \mathrm{s} \times 0.0718)+(3.97 \mathrm{E}-04 \mathrm{~cm} / \mathrm{s} \times(1-0.0718))=2.2 \mathrm{E}-02 \mathrm{~cm} / \mathrm{s}$ \\
\hline 5,600 & $(3.0 \mathrm{E}-01 \mathrm{~cm} / \mathrm{s} \times 0.130)+(3.97 \mathrm{E}-04 \mathrm{~cm} / \mathrm{s} \times(1-0.130))=3.9 \mathrm{E}-02 \mathrm{~cm} / \mathrm{s}$ \\
\hline 10,000 & $(3.0 \mathrm{E}-01 \mathrm{~cm} / \mathrm{s} \times 0.248)+(3.97 \mathrm{E}-04 \mathrm{~cm} / \mathrm{s} \times(1-0.248))=7.5 \mathrm{E}-02 \mathrm{~cm} / \mathrm{s}$ \\
\hline
\end{tabular}

In an analogous manner the equivalent porosity (n), field capacity (FC), and wilting point (WP) can be determined based upon an area proportionality as follows:

$$
\begin{aligned}
& n=\sum_{i=1}^{n} n_{i} A_{i} \\
& F C=\sum_{i=1}^{n} F C_{i} A_{i} \\
& W P=\sum_{i=1}^{n} W P_{i} A_{i}
\end{aligned}
$$

The following are the input properties (see above):

\begin{tabular}{|l|l|l|l|}
\hline Material & Porosity & Field Capacity & Wilting Point \\
\hline Erosion Barrier & 0.06 & 0.056 & 0.052 \\
\hline Granite Stone & 0.397 & 0.032 & 0.013 \\
\hline
\end{tabular}




\begin{tabular}{|l|l|}
\hline Year & $\mathrm{n}$ \\
\hline 0 & $(0.397 \times 0)+(0.06 \times(1-0))=0.06$ \\
\hline 100 & $(0.397 \times 0)+(0.06 \times(1-0))=0.06$ \\
\hline 154 & $(0.397 \times 0)+(0.06 \times(1-0))=0.06$ \\
\hline 300 & $(0.397 \times 0)+(0.06 \times(1-0))=0.06$ \\
\hline 550 & $(0.397 \times 0)+(0.06 \times(1-0))=0.06$ \\
\hline 602 & $(0.397 \times 0)+(0.06 \times(1-0))=0.06$ \\
\hline 802 & $(0.397 \times 0.00266)+(0.06 \times(1-0.00266))=0.061$ \\
\hline 1,000 & $(0.397 \times 0.0292)+(0.06 \times(1-0.0292))=0.070$ \\
\hline 1,800 & $(0.397 \times 0.0718)+(0.06 \times(1-0.0718))=0.084$ \\
\hline 3,400 & $(0.397 \times 0.130)+(0.06 \times(1-0.130))=0.104$ \\
\hline 5,600 & $(0.397 \times 0.248)+(0.06 \times(1-0.248))=0.144$ \\
\hline 10,000 &
\end{tabular}

\begin{tabular}{|l|l|}
\hline Year & FC \\
\hline 0 & $(0.032 \times 0)+(0.056 \times(1-0))=0.056$ \\
\hline 100 & $(0.032 \times 0)+(0.056 \times(1-0))=0.056$ \\
\hline 154 & $(0.032 \times 0)+(0.056 \times(1-0))=0.056$ \\
\hline 300 & $(0.032 \times 0)+(0.056 \times(1-0))=0.056$ \\
\hline 550 & $(0.032 \times 0)+(0.056 \times(1-0))=0.056$ \\
\hline 602 & $(0.032 \times 0)+(0.056 \times(1-0))=0.056$ \\
\hline 802 & $(0.032 \times 0.00266)+(0.056 \times(1-0.00266))=0.0559$ \\
\hline 1,000 & $(0.032 \times 0.00794)+(0.056 \times(1-0.00794))=0.0558$ \\
\hline 1,800 & $(0.032 \times 0.0292)+(0.056 \times(1-0.0292))=0.0553$ \\
\hline 3,400 & $(0.032 \times 0.0718)+(0.056 \times(1-0.0718))=0.0543$ \\
\hline 5,600 & $(0.032 \times 0.130)+(0.056 \times(1-0.130))=0.0529$ \\
\hline 10,000 & $(0.032 \times 0.248)+(0.056 \times(1-0.248))=0.050$ \\
\hline
\end{tabular}

\begin{tabular}{|l|l|}
\hline Year & WP \\
\hline 0 & $(0.013 \times 0)+(0.052 \times(1-0))=0.052$ \\
\hline 100 & $(0.013 \times 0)+(0.052 \times(1-0))=0.052$ \\
\hline 154 & $(0.013 \times 0)+(0.052 \times(1-0))=0.052$ \\
\hline 300 & $(0.013 \times 0)+(0.052 \times(1-0))=0.052$ \\
\hline 550 & $(0.013 \times 0)+(0.052 \times(1-0))=0.052$ \\
\hline 602 & $(0.013 \times 0)+(0.052 \times(1-0))=0.052$ \\
\hline 802 & $(0.013 \times 0.00266)+(0.052 \times(1-0.00266))=0.0519$ \\
\hline 1,000 & $(0.013 \times 0.00794)+(0.052 \times(1-0.00794))=0.0517$ \\
\hline 1,800 & $(0.013 \times 0.0292)+(0.052 \times(1-0.0292))=0.0509$ \\
\hline 3,400 & $(0.013 \times 0.0718)+(0.052 \times(1-0.0718))=0.0492$ \\
\hline 5,600 & $(0.013 \times 0.130)+(0.052 \times(1-0.130))=0.0469$ \\
\hline 10,000 & $(0.013 \times 0.248)+(0.052 \times(1-0.248))=0.0423$ \\
\hline
\end{tabular}


Summary Erosion Barrier Hydraulic Properties with Time:

\begin{tabular}{|l|l|l|l|l|}
\hline Year & $\mathrm{K}_{\mathrm{v}}$ & $\mathrm{n}$ & $\mathrm{FC}$ & WP \\
\hline 0 & $3.97 \mathrm{E}-04 \mathrm{~cm} / \mathrm{s}$ & 0.06 & 0.056 & 0.052 \\
\hline 100 & $3.97 \mathrm{E}-04 \mathrm{~cm} / \mathrm{s}$ & 0.06 & 0.056 & 0.052 \\
\hline 154 & $3.97 \mathrm{E}-04 \mathrm{~cm} / \mathrm{s}$ & 0.06 & 0.056 & 0.052 \\
\hline 300 & $3.97 \mathrm{E}-04 \mathrm{~cm} / \mathrm{s}$ & 0.06 & 0.056 & 0.052 \\
\hline 550 & $3.97 \mathrm{E}-04 \mathrm{~cm} / \mathrm{s}$ & 0.06 & 0.056 & 0.052 \\
\hline 602 & $3.97 \mathrm{E}-04 \mathrm{~cm} / \mathrm{s}$ & 0.06 & 0.056 & 0.052 \\
\hline 802 & $1.2 \mathrm{E}-03 \mathrm{~cm} / \mathrm{s}$ & 0.061 & 0.0559 & 0.0519 \\
\hline 1,000 & $2.8 \mathrm{E}-03 \mathrm{~cm} / \mathrm{s}$ & 0.063 & 0.0558 & 0.0517 \\
\hline 1,800 & $9.1 \mathrm{E}-03 \mathrm{~cm} / \mathrm{s}$ & 0.070 & 0.0553 & 0.0509 \\
\hline 3,400 & $2.2 \mathrm{E}-02 \mathrm{~cm} / \mathrm{s}$ & 0.084 & 0.0543 & 0.0492 \\
\hline 5,600 & $3.9 \mathrm{E}-02 \mathrm{~cm} / \mathrm{s}$ & 0.104 & 0.0529 & 0.0469 \\
\hline 10,000 & $7.5 \mathrm{E}-02 \mathrm{~cm} / \mathrm{s}$ & 0.144 & 0.050 & 0.0423 \\
\hline
\end{tabular}

\section{Ground Surface Soil Texture:}

The soil texture of the ground surface will change over time due to erosion of the topsoil and upper backfill layers and the degradation of the erosion barrier. Soil texture is utilized in the HELP model to determine the SCS Curve Number $(\mathrm{CN})$ and subsequent runoff from the closure cap. The default HELP model ground surface soil textures will be assigned based upon an equivalence between the saturated hydraulic conductivity of the material assumed to be at the ground surface and that of the default HELP model ground surface soil textures.

Default HELP Model Ground Surface Soil Textures:

\begin{tabular}{|l|l|l|l|l|}
\hline Year & $\begin{array}{l}\text { Ground Surface } \\
\text { Material }\end{array}$ & $\begin{array}{l}\text { Ground Surface } \\
\text { Material K }(\mathrm{cm} / \mathrm{s})\end{array}$ & HELP Soil Texture & $\begin{array}{l}\text { HELP Soil Texture K } \\
(\mathrm{cm} / \mathrm{s})\end{array}$ \\
\hline 0 & Topsoil & $1.0 \mathrm{E}-3$ & 5 & $1.0 \mathrm{E}-3$ \\
\hline 100 & Topsoil & $1.0 \mathrm{E}-3$ & 5 & $1.0 \mathrm{E}-3$ \\
\hline 154 & Backfill & $1.0 \mathrm{E}-4$ & 10 & $1.2 \mathrm{E}-4$ \\
\hline 300 & Backfill & $1.0 \mathrm{E}-4$ & 10 & $1.2 \mathrm{E}-4$ \\
\hline 550 & Backfill & $1.0 \mathrm{E}-4$ & 10 & $1.2 \mathrm{E}-4$ \\
\hline 602 & Erosion Barrier & $3.97 \mathrm{E}-4$ & 8 & $3.7 \mathrm{E}-4$ \\
\hline 802 & Erosion Barrier & $1.2 \mathrm{E}-3$ & 5 & $1.0 \mathrm{E}-3$ \\
\hline 1000 & Erosion Barrier & $2.8 \mathrm{E}-3$ & 3 & $3.1 \mathrm{E}-3$ \\
\hline 1800 & Erosion Barrier & $9.1 \mathrm{E}-3$ & 1 & $1.0 \mathrm{E}-2$ \\
\hline 3400 & Erosion Barrier & $2.2 \mathrm{E}-2$ & 1 & $1.0 \mathrm{E}-2$ \\
\hline 5600 & Erosion Barrier & $3.9 \mathrm{E}-2$ & 1 & $1.0 \mathrm{E}-2$ \\
\hline 10000 & Erosion Barrier & $7.5 \mathrm{E}-2$ & 1 & $1.0 \mathrm{E}-2$ \\
\hline
\end{tabular}

\section{Upper GCL Holes:}

Maintenance during the institutional control period and farming practices during corn farming prevent degradation of the upper GCL. Subsequent to the institutional control period and corn farming after all of the topsoil and upper backfill have been completely eroded, pine forest succession will result in root penetration through the GCL. This allows the overlying drainage layer to fill the holes after the roots decompose. The holes in the GCL essentially act as direct conduits from the upper drainage layer to the lower backfill layer. When saturated conditions occur in the drainage layer after major precipitation events, cones of depression are created around the holes in the GCL with a radius of influence much greater than the radius of the hole. This means that a small area of GCL holes can greatly reduce the lateral flow of water in the drainage layer and increase the vertical flow into the lower backfill.

From Section 4.1 the following assumptions were made relative to the succession of bamboo by a pine forest that result in root penetration into the upper GCL: 
- 200 years after the end of farming it is assumed that the entire cap is dominated by pine (i.e. 400 mature trees per acre).

- Complete turnover of the 400 mature trees per acre occurs every 100 years (in a staggered manner).

- There are 400 mature trees per acre with 4 roots to 6 feet and 1 root to 12 feet. The roots are 3 inches in diameter at a depth of 1 foot and 0.25 inches in diameter at either 6 or 12 feet, whichever is applicable.

Area of holes in upper GCL due to root penetration:

Upper GCL Depth $($ see Table 3.1-1) = 12" + 12" + 12" = 36" = 3'

Root Diameter for 4-6' roots at 3':

3" diameter at 1' depth and 0.25 " at 6'

$$
\begin{aligned}
& \left(3^{\prime \prime}-0.25^{\prime \prime}\right) /\left(6^{\prime}-1^{\prime}\right)=0.55^{\prime \prime} / f t \\
& \text { Diameter }=0.25^{\prime \prime}+\left[\left(6^{\prime}-3^{\prime}\right) \times 0.55^{\prime \prime} / \mathrm{ft}\right]=1.9^{\prime \prime}
\end{aligned}
$$

Area of for 4-6' roots at 3':

$$
\text { Area }=4 \times 1 / 4 \pi \mathrm{D}^{2}=\pi \mathrm{D}^{2}=\pi\left(1.9^{\prime \prime}\right)^{2}=11.3 \mathrm{in}^{2}
$$

Root Diameter for 1-12' root at 3':

3 " diameter at 1 ' depth and 0.25 " at 12 '

$$
\begin{aligned}
& \left(3^{\prime \prime}-0.25^{\prime \prime}\right) /\left(12^{\prime}-1^{\prime}\right)=0.25^{\prime \prime} / \mathrm{ft} \\
& \text { Diameter }=0.25^{\prime \prime}+\left[\left(12^{\prime}-3^{\prime}\right) \times 0.25^{\prime \prime} / \mathrm{ft}\right]=2.5^{\prime \prime}
\end{aligned}
$$

Area of for 1-12' root at 3':

$$
\text { Area }=1 / 4 \pi \mathrm{D}^{2}=1 / 4 \pi\left(2.5^{\prime \prime}\right)^{2}=4.91 \mathrm{in}^{2}
$$

Total area of holes in erosion barrier per tree:

Total area $=11.3 \mathrm{in}^{2}+4.91 \mathrm{in}^{2}=16.21 \mathrm{in}^{2} \times \mathrm{ft}^{2} / 144 \mathrm{in}^{2} \approx 0.11 \mathrm{ft}^{2} /$ tree

Total area of holes per acre per 100 years:

400 trees/acre/100 years

Total area $=0.11 \mathrm{ft}^{2} /$ tree $\times 400$ trees/acre $/ 100$ years $=44 \mathrm{ft}^{2} /$ acre $/ 100$ years

\begin{tabular}{|l|l|l|}
\hline Year & Vegetation & Area of holes in upper GCL / acre due to root penetration \\
\hline 0 & Bamboo & 0 \\
\hline 100 & Bamboo & 0 \\
\hline 154 & Corn & 0 \\
\hline 300 & Corn & 0 \\
\hline 550 & Corn & 0 \\
\hline 602 & Corn & 0 \\
\hline 802 & Pine trees & $44 \mathrm{ft}^{2} /$ acre \\
\hline 1,000 & Pine trees & $44 \mathrm{ft}^{2} /$ acre $+\left[(1000 \mathrm{yrs}-802 \mathrm{yrs}) \times 44 \mathrm{ft}^{2} /\right.$ acre $/ 100$ years $=131 \mathrm{ft}^{2} /$ acre \\
\hline 1,800 & Pine trees & $44 \mathrm{ft}^{2} /$ acre $+\left[(1800 \mathrm{yrs}-802 \mathrm{yrs}) \times 44 \mathrm{ft}^{2} /\right.$ acre $/ 100$ years $=483 \mathrm{ft}^{2} / \mathrm{acre}$ \\
\hline 3,400 & Pine trees & $44 \mathrm{ft}^{2} /$ acre $+\left[(3400 \mathrm{yrs}-802 \mathrm{yrs}) \times 44 \mathrm{ft}^{2} /\right.$ acre $/ 100$ years $=1187 \mathrm{ft}^{2} /$ acre \\
\hline 5,600 & Pine trees & $44 \mathrm{ft}^{2} /$ acre $+\left[(5600 \mathrm{yrs}-802 \mathrm{yrs}) \times 44 \mathrm{ft}^{2} /\right.$ acre $/ 100$ years $=2155 \mathrm{ft}^{2} / \mathrm{acre}$ \\
\hline 10,000 & Pine trees & $44 \mathrm{ft}^{2} /$ acre $+\left[(10000 \mathrm{yrs}-802 \mathrm{yrs}) \times 44 \mathrm{ft}^{2} /\right.$ acre $/ 100$ years $=4091 \mathrm{ft}^{2} /$ acre \\
\hline
\end{tabular}

${ }^{1} 200$ years after corn farming ceases (i.e. at year 802) it is assumed that the entire cap is covered with pine (i.e. 400 mature trees per acre) 
Number of one-square-centimeter holes in upper GCL per acre due to root penetration (each HELP model installation defect for a flexible membrane liner (FML) is assumed to be one square centimeter):

$1 \mathrm{~cm}^{2}=0.001076391 \mathrm{ft}^{2}$ so $0.001076391 \mathrm{ft}^{2} /$ installation defect

\begin{tabular}{|l|l|}
\hline Year & Percent of GCL area degraded due to root penetration \\
\hline 0 & 0 \\
\hline 100 & 0 \\
\hline 154 & 0 \\
\hline 300 & 0 \\
\hline 550 & 0 \\
\hline 602 & 0 \\
\hline 802 & $\left(44 \mathrm{ft}^{2} /\right.$ acre $\div 43560 \mathrm{ft}^{2} /$ acre $) \times 100=0.10$ \\
\hline 1,000 & $\left(131 \mathrm{ft}^{2} /\right.$ acre $\div 43560 \mathrm{ft}^{2} /$ acre $) \times 100=0.30$ \\
\hline 1,800 & $\left(483 \mathrm{ft}^{2} /\right.$ acre $\div 43560 \mathrm{ft}^{2} /$ acre $) \times 100=1.11$ \\
\hline 3,400 & $\left(1187 \mathrm{ft}^{2} /\right.$ acre $\div 43560 \mathrm{ft}^{2} /$ acre $) \times 100=2.72$ \\
\hline 5,600 & $\left(2155 \mathrm{ft}^{2} /\right.$ acre $\div 43560 \mathrm{ft}^{2} /$ acre $) \times 100=4.95$ \\
\hline 10,000 & $\left(4091 \mathrm{ft}^{2} /\right.$ acre $\div 43560 \mathrm{ft}^{2} /$ acre $) \times 100=9.39$ \\
\hline
\end{tabular}

\begin{tabular}{|l|l|}
\hline Year & \# of installation defects in upper GCL / acre due to root penetration \\
\hline 0 & 0 \\
\hline 100 & 0 \\
\hline 154 & 0 \\
\hline 300 & 0 \\
\hline 550 & 0 \\
\hline 602 & 0 \\
\hline 802 & $44 \mathrm{ft}^{2} /$ acre $\div 0.001076391 \mathrm{ft}^{2} /$ installation defect $=40,877$ \\
\hline 1,000 & $131 \mathrm{ft}^{2} /$ acre $\div 0.001076391 \mathrm{ft}^{2} /$ installation defect $=121,703$ \\
\hline 1,800 & $483 \mathrm{ft}^{2} /$ acre $\div 0.001076391 \mathrm{ft}^{2} /$ installation defect $=448,722$ \\
\hline 3,400 & $1187 \mathrm{ft}^{2} /$ acre $\div 0.001076391 \mathrm{ft}^{2} /$ installation defect $=1,102,759$ \\
\hline 5,600 & $2155 \mathrm{ft}^{2} /$ acre $\div 0.001076391 \mathrm{ft}^{2} /$ installation defect $=2,002,060$ \\
\hline 10,000 & $4091 \mathrm{ft}^{2} /$ acre $\div 0.001076391 \mathrm{ft}^{2} /$ installation defect $=3,800,664$ \\
\hline
\end{tabular}

The number of installation defects that can entered into the HELP model is limited to a maximum of 999,999. Therefore the number of installation defects calculated above for years 3,400, 5,600, and 10,000 can not be entered. As outlined in Phifer 2003 the upper GCL becomes ineffective as a barrier layer when holes comprise 0.29 percent of the layer's area. Therefore for determination of the flux at years 3,400, 5,600, and 10,000, the GCL will be assigned as a barrier soil liner with the same material properties as the overlying upper drainage layer.

\begin{tabular}{|l|l|l|}
\hline Year & HELP Model Layer Type & \# of installation defects \\
\hline 0 & 3 & NA \\
\hline 100 & 3 & NA \\
\hline 154 & 3 & NA \\
\hline 300 & 3 & NA \\
\hline 550 & 3 & NA \\
\hline 602 & 3 & NA \\
\hline 802 & 4 & 40,877 \\
\hline 1,000 & 4 & 121,703 \\
\hline 1,800 & 4 & 448,722 \\
\hline 3,400 & 3 & NA \\
\hline 5,600 & 3 & NA \\
\hline 10,000 & 3 & NA \\
\hline & & \\
\hline
\end{tabular}




\section{Middle Backfill Layer and Upper Drainage Layer Hydraulic Properties:}

It is assumed that colloidal clay migration from the 1-foot-thick middle backfill to the underlying 1-footthick upper drainage layer causes the middle backfill saturated hydraulic conductivity to increase over time and that of the upper drainage layer to decrease over time.

Determine mass of clay to fill upper drainage layer void volume $(0.38)$ :

Assume clay bulk density is $1.1 \mathrm{~g} / \mathrm{cm}^{3}$

Look at a $1-\mathrm{ft}^{2}$ area of the 1 -foot-thick upper drainage layer (i.e. $1 \mathrm{ft}^{3}$ )

Void volume $=0.38 \times 1 \mathrm{ft}^{3}=0.38 \mathrm{ft}^{3}$

Clay mass per $\mathrm{ft}^{3}=1.1 \mathrm{~g} / \mathrm{cm}^{3} \times 0.38 \mathrm{ft}^{3} \times 2.831685 \mathrm{E}-02 \mathrm{~m}^{3} / \mathrm{ft}^{3} \times 1,000,000 \mathrm{~cm}^{3} / \mathrm{m}^{3}=11,836.3 \mathrm{~g}$

Determine available clay mass in the middle backfill layer:

Assume that the middle backfill layer consists of $20 \%$ clay and $80 \%$ sand with a dry bulk density of 104-lbs/ $\mathrm{ft}^{3}$.

Clay mass $=104 \mathrm{lbs} / \mathrm{ft}^{3} \times 0.20 \times 453.59 \mathrm{~g} / \mathrm{lbs}=9,434.7 \mathrm{~g} / \mathrm{ft}^{3}$

There is not enough clay in the middle backfill layer to fill the upper drainage layer. Therefore it will be assumed that half the clay content of the middle backfill migrates into the upper drainage layer, at which point the two layers essentially become the same material and material property changes cease. Based upon this it will be assumed that the endpoint saturated hydraulic conductivity of the layers will become that of the $\log$ mid-point between the initial backfill and upper drainage layer conditions. It will also be assumed that the endpoint porosity, field capacity, and wilting point will become the arithmetic average of the backfill and upper drainage layer.

Endpoint hydraulic properties:

Intact hydraulic properties:

\begin{tabular}{|l|l|l|}
\hline Hydraulic Parameter & Middle Backfill & Upper Drainage Layer \\
\hline K & $1.0 \mathrm{E}-04 \mathrm{~cm} / \mathrm{s}$ & $1.0 \mathrm{E}-01 \mathrm{~cm} / \mathrm{s}$ \\
\hline $\mathrm{n}$ & 0.37 & 0.38 \\
\hline FC & 0.24 & 0.08 \\
\hline WP & 0.136 & 0.013 \\
\hline
\end{tabular}

Endpoint saturated hydraulic conductivity:

Middle backfill: $\mathrm{K}_{\mathrm{MB}}=0.0001 ; \log \mathrm{K}_{\mathrm{MB}}=-4$

Upper drainage layer: $\mathrm{K}_{\mathrm{UDL}}=0.1 ; \log \mathrm{K}_{\mathrm{UDL}}=-1$

Log mid-point: $\quad \frac{\log K_{M B}+\log K_{U D L}}{2}=\frac{-1+(-4)}{2}=-2.5$

$\mathrm{K}_{\mathrm{E}}=10^{-2.5}=3.2 \mathrm{E}-03 \mathrm{~cm} / \mathrm{s}$

Endpoint n, FC, and WP:

$$
\begin{aligned}
& \mathrm{n}=(0.37+0.38) / 2=0.375 \\
& \mathrm{FC}=(0.24+0.08) / 2=0.16 \\
& \mathrm{WP}=(0.136+0.013) / 2=0.0745
\end{aligned}
$$

It will be assumed that the clay migrates out of the middle backfill into the upper drainage layer with the water flux containing $63 \mathrm{mg} / \mathrm{L}$ of colloidal clay. It will also be assumed that the time to achieve the endpoint 
conditions will be based upon the estimated water flux into the upper drainage layer and migration of half the clay content of the middle backfill layer (i.e. $9,434.7 \mathrm{~g} / \mathrm{ft}^{3} \div 2=4717.4 \mathrm{~g} / \mathrm{ft}^{3}$ ).

Determine flux of water into the upper drainage layer:

Section 3.4 intact SDF closure cap Modeling determined the following average annual flux of water into the upper drainage layer (see Appendix E):

Precipitation $=48.90$ inches $/$ year

Runoff $=0.154$ inches/year

Evapotranspiration $=34.582$ inches/year

Flux of water into upper drainage layer $=$ Precipitation $-($ Runoff + Evapotranspiration $)$

Flux of water into upper drainage layer $=48.90 \mathrm{in} / \mathrm{yr}-(0.154 \mathrm{in} / \mathrm{yr}+34.582 \mathrm{in} / \mathrm{yr})$

Flux of water into upper drainage layer $=14.164 \mathrm{in} / \mathrm{yr}$

The above flux is based upon the best-case cap conditions. Therefore, a water flux into the upper drainage layer that is calculated close to the anticipated time when the endpoint properties are reached is needed. Within Phifer 2003 the endpoint properties were reached in year 2246 based upon a water flux into the upper drainage layer of $\sim 14.2 \mathrm{in} / \mathrm{yr}$. Higher water fluxes into the upper drainage layer are anticipated for this scenario for latter times, which should result the endpoint being reached sooner. Therefore will determine the flux based upon the preliminary 1,800 year conditions as follows:

- The topsoil and upper backfill are completely eroded away at year 1,800 year (see above).

- $\quad 1,800$ year erosion barrier conditions with $\mathrm{K}=9.1 \mathrm{E}-03 \mathrm{~cm} / \mathrm{s} ; \mathrm{n}=0.070 ; \mathrm{FC}=0.0553 ; \mathrm{WP}=0.0509$ (see above).

- $\quad$ 1,800 HELP model soil texture class of 1 (see above).

- $\quad$ Middle backfill and upper drainage layer at end state conditions with $\mathrm{K}=3.2 \mathrm{E}-03 \mathrm{~cm} / \mathrm{s} ; \mathrm{n}=0.375$; $\mathrm{FC}=0.16$; WP $=0.0745$ (see above). In Phifer 2003 for the base case scenario the end state conditions were determined to occur at year 2246, therefore end state conditions at year 1,800 should be a reasonable assumption for this scenario.

- Upper GCL as a flexible membrane liner (layer type \#4) 448,722 installation defects (see above).

- Lower drainage layer with intact backfill properties (used since 1,800 year conditions not yet determined).

- The detailed HELP model input data and output file associated with the preliminary 1,800-year conditions is provided at the end of this appendix. The following are the pertinent values extracted from the output file:

Precipitation $=48.90$ inches/year

Runoff $=0.000$ inches/year

Evapotranspiration $=27.492$ inches/year

Flux of water into upper drainage layer $=$ Precipitation $-($ Runoff + Evapotranspiration $)$

Flux of water into upper drainage layer $=48.90 \mathrm{in} / \mathrm{yr}-(0.000 \mathrm{in} / \mathrm{yr}+27.492 \mathrm{in} / \mathrm{yr})$

Flux of water into upper drainage layer $=21.408 \mathrm{in} / \mathrm{yr}$

Will take the average of the initial and 1,800 years fluxes as the water flux into the upper drainage layer for determination of the middle backfill and upper drainage layer properties over time: 
Average flux into upper drainage layer $=(14.164 \mathrm{in} / \mathrm{yr}+21.408 \mathrm{in} / \mathrm{yr}) / 2=17.786 \mathrm{in} / \mathrm{yr}$

Determine yearly clay migration into the upper drainage layer:

Flux into upper drainage layer $\approx 17.8 \mathrm{in} / \mathrm{yr}$

Colloidal clay concentration $=63 \mathrm{mg} / \mathrm{L}$

Flux through a $1 \mathrm{ft}^{2}$ area $=17.8 \mathrm{in} / \mathrm{yr} \times \mathrm{ft} / 12$ in $\times 1 \mathrm{ft}^{2}=1.48 \mathrm{ft}^{2} / \mathrm{yr}$

Clay flux $=1.48 \mathrm{ft}^{2} / \mathrm{yr} \times 63 \mathrm{mg} / \mathrm{L} \times 2.831685 \mathrm{E}-02 \mathrm{~m}^{3} / \mathrm{ft}^{3} \times 1000 \mathrm{~L} / \mathrm{m}^{3}=2,640 \mathrm{mg} / \mathrm{yr}=2.64 \mathrm{~g} / \mathrm{yr}$

Determine time it takes for the $4717.4 \mathrm{~g}$ of clay to migrate from the middle backfill layer to the upper drainage layer:

Time $=4717.4 \mathrm{~g} \div 2.64 \mathrm{~g} / \mathrm{yr}=1,787$ years

Determine middle backfill and upper drainage layer hydraulic property variation with time:

It will be assumed that the $\mathrm{K}$ of the middle backfill layer is increasing log linearly with time from $1.0 \mathrm{E}-04$ $\mathrm{cm} / \mathrm{s}$ to $3.2 \mathrm{E}-03 \mathrm{~cm} / \mathrm{s}$, until year 1,787 at which time the $\mathrm{K}$ becomes static. Conversely it will be assumed that the $\mathrm{K}$ of the upper drainage layer is decreasing log linearly with time from $1.0 \mathrm{E}-01 \mathrm{~cm} / \mathrm{s}$ to $3.2 \mathrm{E}-03 \mathrm{~cm} / \mathrm{s}$, until year 1,787 at which time the K becomes static. Porosity (n), FC, and WP will be assumed to behave similarly but in an arithmetic linear manner.

Initial and End State hydraulic properties:

\begin{tabular}{|l|l|l|l|}
\hline Hydraulic Parameter & Initial Middle Backfill & $\begin{array}{l}\text { Initial Upper Drainage } \\
\text { Layer }\end{array}$ & End State at 1,787 years \\
\hline $\mathrm{K}$ & $1.0 \mathrm{E}-04 \mathrm{~cm} / \mathrm{s}$ & $1.0 \mathrm{E}-01 \mathrm{~cm} / \mathrm{s}$ & $3.2 \mathrm{E}-03 \mathrm{~cm} / \mathrm{s}$ \\
\hline $\mathrm{n}$ & 0.37 & 0.38 & 0.375 \\
\hline FC & 0.24 & 0.08 & 0.16 \\
\hline WP & 0.136 & 0.013 & 0.0745 \\
\hline
\end{tabular}

Determine fraction change for each year:

\begin{tabular}{|l|l|}
\hline Year & Fraction \\
\hline 0 & $0 \div 1787=0$ \\
\hline 100 & $100 \div 1787=0.056$ \\
\hline 154 & $154 \div 1787=0.0862$ \\
\hline 300 & $300 \div 1787=0.168$ \\
\hline 550 & $550 \div 1787=0.308$ \\
\hline 602 & $602 \div 1787=0.337$ \\
\hline 802 & $802 \div 1787=0.449$ \\
\hline 1,000 & $1000 \div 1787=0.560$ \\
\hline 1,800 & 1.0 \\
\hline 3,400 & 1.0 \\
\hline 5,600 & 1.0 \\
\hline 10,000 & 1.0 \\
\hline
\end{tabular}


Determine variation in $\mathrm{K}, \mathrm{n}, \mathrm{FC}$, and WP with time in the middle backfill:

\begin{tabular}{|l|l|l|l|l|l|}
\hline Year & Fraction, $\mathrm{F}$ & $\mathrm{K}^{1}(\mathrm{~cm} / \mathrm{s})$ & $\mathrm{n}^{2}$ & $\mathrm{FC}^{3}$ & $\mathrm{WP}^{4}$ \\
\hline 0 & 0 & 0.0001 & 0.37 & 0.24 & 0.136 \\
\hline 100 & 0.056 & 0.00012 & 0.37 & 0.236 & 0.132 \\
\hline 154 & 0.0862 & 0.00014 & 0.37 & 0.233 & 0.131 \\
\hline 300 & 0.168 & 0.00018 & 0.371 & 0.226 & 0.126 \\
\hline 550 & 0.308 & 0.00029 & 0.372 & 0.215 & 0.117 \\
\hline 602 & 0.337 & 0.00032 & 0.372 & 0.213 & 0.115 \\
\hline 802 & 0.449 & 0.00047 & 0.372 & 0.204 & 0.108 \\
\hline 1,000 & 0.560 & 0.00069 & 0.373 & 0.195 & 0.102 \\
\hline 1,800 & 1.0 & 0.0032 & 0.375 & 0.16 & 0.0745 \\
\hline 3,400 & 1.0 & 0.0032 & 0.375 & 0.16 & 0.0745 \\
\hline 5,600 & 1.0 & 0.0032 & 0.375 & 0.16 & 0.0745 \\
\hline 10,000 & 1.0 & 0.0032 & 0.375 & 0.16 & 0.0745 \\
\hline
\end{tabular}

${ }^{1} K=10^{[-4+((-2.5-(-4)) F)]}=10^{(-4+1.5 F)}$

${ }^{2} \mathrm{n}=0.37+(0.375-0.37) \mathrm{F}$

${ }^{3} \mathrm{FC}=0.24-(0.24-0.16) \mathrm{F}$

${ }^{4} \mathrm{WP}=0.136-(0.136-0.0745) \mathrm{F}$

Determine variation in $\mathrm{K}, \mathrm{n}, \mathrm{FC}$, and WP with time in the upper drainage layer:

\begin{tabular}{|l|l|l|l|l|l|}
\hline Year & Fraction, $\mathrm{F}$ & $\mathrm{K}^{1}(\mathrm{~cm} / \mathrm{s})$ & $\mathrm{n}^{2}$ & $\mathrm{FC}^{3}$ & $\mathrm{WP}^{4}$ \\
\hline 0 & 0 & 0.1 & 0.38 & 0.08 & 0.013 \\
\hline 100 & 0.056 & 0.082 & 0.38 & 0.084 & 0.0164 \\
\hline 154 & 0.0862 & 0.074 & 0.38 & 0.087 & 0.0183 \\
\hline 300 & 0.168 & 0.056 & 0.379 & 0.093 & 0.0233 \\
\hline 550 & 0.308 & 0.034 & 0.378 & 0.105 & 0.0319 \\
\hline 602 & 0.337 & 0.031 & 0.378 & 0.107 & 0.0337 \\
\hline 802 & 0.449 & 0.021 & 0.378 & 0.116 & 0.0406 \\
\hline 1,000 & 0.560 & 0.014 & 0.377 & 0.125 & 0.0474 \\
\hline 1,800 & 1.0 & 0.0032 & 0.375 & 0.16 & 0.0745 \\
\hline 3,400 & 1.0 & 0.0032 & 0.375 & 0.16 & 0.0745 \\
\hline 5,600 & 1.0 & 0.0032 & 0.375 & 0.16 & 0.0745 \\
\hline 10,000 & 1.0 & 0.0032 & 0.375 & 0.16 & 0.0745 \\
\hline
\end{tabular}

${ }^{1} K=10^{[-1+((-2.5-(-1)) F)]}=10^{(-1-1.5 F)}$

${ }^{2} \mathrm{n}=0.38-(0.38-0.375) \mathrm{F}$

${ }^{3} \mathrm{FC}=0.08+(0.16-0.08) \mathrm{F}$

${ }^{4} \mathrm{WP}=0.013+(0.0745-0.013) \mathrm{F}$

\section{Lower Drainage Layer Hydraulic Properties:}

It is assumed that colloidal clay migration from the minimum 5-foot-thick overlying backfill into the 2-footthick lower drainage layer is driven by the water flux through the upper GCL. This water flux driven clay migration enters into the lower drainage layer and fills the lower drainage layer from the bottom up. This reduces the saturated hydraulic conductivity of the clay-filled portion from $1.0 \mathrm{E}-01$ to $1.0 \mathrm{E}-04 \mathrm{~cm} / \mathrm{s}$ (i.e. to the saturated hydraulic conductivity of the overlying backfill), while the conductivity of the clean portion remains at $1.0 \mathrm{E}-01 \mathrm{~cm} / \mathrm{s}$. As the thickness of the lower drainage layer filled with clay increases, the equivalent hydraulic conductivity of the entire layer decreases. This is different from that assumed for the upper drainage layer since the lower drainage layer has significantly more backfill overlying it. The HELP model was run for each year with all of the previously degraded properties (see above) without degradation 
of the lower drainage layer in order to determine the infiltration through the upper GCL. The results are as follows:

\begin{tabular}{|l|l|}
\hline Year & Infiltration through upper GCL (inches/year) \\
\hline 0 & 0.36170 \\
\hline 100 & 0.43127 \\
\hline 154 & 0.42058 \\
\hline 300 & 0.56138 \\
\hline 550 & 1.21999 \\
\hline 602 & 1.37415 \\
\hline 802 & 16.11727 \\
\hline 1,000 & 19.46389 \\
\hline 1,800 & 21.31867 \\
\hline 3,400 & 21.42358 \\
\hline 5,600 & 21.13124 \\
\hline 10,000 & 20.05366 \\
\hline
\end{tabular}

It is assumed that there is a linear change in the infiltration over time between data points.

Determine cumulative volume of water through the lower drainage layer over time:

\begin{tabular}{|c|c|c|c|c|}
\hline Year & $\begin{array}{l}\text { Infiltration through } \\
\text { upper GCL } \\
\text { (inches/year) }\end{array}$ & $\begin{array}{l}\text { Time Step } \\
\text { Infiltration }{ }^{1} \\
\text { (inches) }\end{array}$ & $\begin{array}{l}\text { Cumulative } \\
\text { Infiltration } \\
\text { (inches) }\end{array}$ & $\begin{array}{l}\text { Cumulative Volume } \\
\text { over one } \mathrm{ft}^{2} \text { area } \\
\left(\mathrm{ft}^{3}\right)\end{array}$ \\
\hline 0 & 0.36170 & 0 & 0 & 0 \\
\hline 100 & 0.43127 & 39.648 & 39.648 & 3.304 \\
\hline 154 & 0.42058 & 23.000 & 62.648 & 5.221 \\
\hline 300 & 0.56138 & 71.683 & 134.331 & 11.194 \\
\hline 550 & 1.21999 & 222.671 & 357.002 & 29.750 \\
\hline 602 & 1.37415 & 67.448 & 424.450 & 35.371 \\
\hline 802 & 16.11727 & $1,749.142$ & $2,173.592$ & 181.133 \\
\hline 1,000 & 19.46389 & $3,522.535$ & $5,696.127$ & 474.677 \\
\hline 1,800 & 21.31867 & $16,313.024$ & $22,009.151$ & $1,834.096$ \\
\hline 3,400 & 21.42358 & $34,193.800$ & $56,202.951$ & $4,683.579$ \\
\hline 5,600 & 21.13124 & $46,810.302$ & $103,013.253$ & $8,584.438$ \\
\hline 10,000 & 20.05366 & $90,606.780$ & $193,620.033$ & $16,135.003$ \\
\hline
\end{tabular}

${ }^{1}$ Time Step Infiltration $=\left[I_{1} \times\left(T_{2}-T_{1}\right)\right]+\left[1 / 2 \times\left(I_{2}-I_{1}\right)\left(T_{2}-T_{1}\right)\right]$, where $\mathrm{I}=$ infiltration at time 1 or 2 ; $\mathrm{T}=$ time at time 1 or 2

${ }^{2}$ Cumulative Infiltration $=$ Previous cumulative Infiltration + Time Step Infiltration at current time step

${ }^{3}$ Cumulative Volume over one $\mathrm{ft}^{2}$ area $=($ Cumulative Infiltration $\div 12 \mathrm{in} / \mathrm{ft}) \times 1 \mathrm{ft}^{2}$

Determine mass of clay to fill lower drainage layer void volume (0.38):

Assume clay bulk density is $1.1 \mathrm{~g} / \mathrm{cm}^{3}$

Look at a $1-\mathrm{ft}^{2}$ area of the 2 -foot-thick upper drainage layer (i.e. $2 \mathrm{ft}^{3}$ )

Void volume $=0.38 \times 2 \mathrm{ft}^{3}=0.76 \mathrm{ft}^{3}$

Clay mass per $\mathrm{ft}^{3}=1.1 \mathrm{~g} / \mathrm{cm}^{3} \times 0.76 \mathrm{ft}^{3} \times 2.831685 \mathrm{E}-02 \mathrm{~m}^{3} / \mathrm{ft}^{3} \times 1,000,000 \mathrm{~cm}^{3} / \mathrm{m}^{3}=23,672.9 \mathrm{~g}$

Determine total flux of water into the lower drainage layer required to completely fill it with clay:

It will be assumed that the clay migrates out of the lower backfill into the lower drainage layer with the water flux containing $63 \mathrm{mg} / \mathrm{L}$ of colloidal clay. 


$$
V=\frac{23,672.9 \mathrm{~g} \times 1000 \mathrm{mg} / \mathrm{g}}{63 \mathrm{mg} / \mathrm{L} \times 28.31685 \mathrm{~L} / \mathrm{ft}^{3}}=13,269.8 \mathrm{ft}^{3}
$$

Determine the mass of clay that has migrated into the lower drainage layer at the end of each time step:

\begin{tabular}{|l|l|}
\hline Year & Mass of clay into lower drainage layer \\
\hline 0 & 0 \\
\hline 100 & $3.3 \mathrm{ft}^{3} \times 63 \mathrm{mg} / \mathrm{L} \times 28.31685 \mathrm{~L} / \mathrm{ft}^{3} \times \mathrm{g} / 1000 \mathrm{mg}=5.9 \mathrm{~g}$ \\
\hline 154 & $5.2 \mathrm{ft}^{3} \times 63 \mathrm{mg} / \mathrm{L} \times 28.31685 \mathrm{~L} / \mathrm{ft}^{3} \times \mathrm{g} / 1000 \mathrm{mg}=9.3 \mathrm{~g}$ \\
\hline 300 & $11.2 \mathrm{ft}^{3} \times 63 \mathrm{mg} / \mathrm{L} \times 28.31685 \mathrm{~L} / \mathrm{ft}^{3} \times \mathrm{g} / 1000 \mathrm{mg}=20.0 \mathrm{~g}$ \\
\hline 550 & $29.75 \mathrm{ft}^{3} \times 63 \mathrm{mg} / \mathrm{L} \times 28.31685 \mathrm{~L} / \mathrm{ft}^{3} \times \mathrm{g} / 1000 \mathrm{mg}=53.1 \mathrm{~g}$ \\
\hline 602 & $35.4 \mathrm{ft}^{3} \times 63 \mathrm{mg} / \mathrm{L} \times 28.31685 \mathrm{~L} / \mathrm{ft}^{3} \times \mathrm{g} / 1000 \mathrm{mg}=63.2 \mathrm{~g}$ \\
\hline 802 & $181.1 \mathrm{ft}^{3} \times 63 \mathrm{mg} / \mathrm{L} \times 28.31685 \mathrm{~L} / \mathrm{ft}^{3} \times \mathrm{g} / 1000 \mathrm{mg}=323.1 \mathrm{~g}$ \\
\hline 1,000 & $474.7 \mathrm{ft}^{3} \times 63 \mathrm{mg} / \mathrm{L} \times 28.31685 \mathrm{~L} / \mathrm{ft}^{3} \times \mathrm{g} / 1000 \mathrm{mg}=846.8 \mathrm{~g}$ \\
\hline 1,800 & $1,834.1 \mathrm{ft}^{3} \times 63 \mathrm{mg} / \mathrm{L} \times 28.31685 \mathrm{~L} / \mathrm{ft}^{3} \times \mathrm{g} / 1000 \mathrm{mg}=3,272.0 \mathrm{~g}$ \\
\hline 3,400 & $4,683.6 \mathrm{ft}^{3} \times 63 \mathrm{mg} / \mathrm{L} \times 28.31685 \mathrm{~L} / \mathrm{ft}^{3} \times \mathrm{g} / 1000 \mathrm{mg}=8,355.4 \mathrm{~g}$ \\
\hline 5,600 & $8,584.4 \mathrm{ft}^{3} \times 63 \mathrm{mg} / \mathrm{L} \times 28.31685 \mathrm{~L} / \mathrm{ft}^{3} \times \mathrm{g} / 1000 \mathrm{mg}=15,314.3 \mathrm{~g}$ \\
\hline 10,000 & $16,135.0 \mathrm{ft}^{3} \times 63 \mathrm{mg} / \mathrm{L} \times 28.31685 \mathrm{~L} / \mathrm{ft}^{3} \times \mathrm{g} / 1000 \mathrm{mg}=28,784.2 \mathrm{~g}$ \\
\hline
\end{tabular}

Determine the fraction of the lower drainage layer filled at the end of each time step:

\begin{tabular}{|l|l|}
\hline Year & Fraction of the lower drainage layer filled \\
\hline 0 & 0 \\
\hline 100 & $5.9 \mathrm{~g} \div 23,672.9 \mathrm{~g}=0.000249$ \\
\hline 154 & $9.3 \mathrm{~g} \div 23,672.9 \mathrm{~g}=0.000393$ \\
\hline 300 & $20.0 \mathrm{~g} \div 23,672.9 \mathrm{~g}=0.000845$ \\
\hline 550 & $53.1 \mathrm{~g} \div 23,672.9 \mathrm{~g}=0.00224$ \\
\hline 602 & $63.2 \mathrm{~g} \div 23,672.9 \mathrm{~g}=0.00267$ \\
\hline 802 & $323.1 \mathrm{~g} \div 23,672.9 \mathrm{~g}=0.0136$ \\
\hline 1,000 & $846.8 \mathrm{~g} \div 23,672.9 \mathrm{~g}=0.0358$ \\
\hline 1,800 & $3,272.0 \mathrm{~g} \div 23,672.9 \mathrm{~g}=0.138$ \\
\hline 3,400 & $8,355.4 \mathrm{~g} \div 23,672.9 \mathrm{~g}=0.353$ \\
\hline 5,600 & $15,314.3 \mathrm{~g} \div 23,672.9 \mathrm{~g}=0.647$ \\
\hline 10,000 & $\begin{array}{l}28,784.2 \mathrm{~g} \div 23,672.9 \mathrm{~g}=1.216 \text { (the fraction can not be greater than } 1.0 ; \text { this indicates that the lower } \\
\text { drainage layer is completely fill prior to year 10,000) }\end{array}$ \\
\hline
\end{tabular}

The following are the hydraulic properties of the clean and clay filled portion of the lower drainage layer:

\begin{tabular}{|l|l|l|l|l|}
\hline Material & $\begin{array}{l}\text { Saturated Hydraulic } \\
\text { Conductivity }(\mathrm{cm} / \mathrm{s})\end{array}$ & Porosity & Field Capacity & Wilting Point \\
\hline Clean & $1.0 \mathrm{E}-01$ & 0.38 & 0.08 & 0.013 \\
\hline Clay filled & $1.0 \mathrm{E}-04$ & 0.22 (see below) & 0.21 (see below) & 0.20 (see below) \\
\hline
\end{tabular}

Determine the porosity of the clay filled portion of the lower drainage layer:

Porosity of the clay:

Assumed clay bulk density, $\rho_{\mathrm{b}}=1.1 \mathrm{~g} / \mathrm{cm}^{2}$

Assumed clay particle density, $\rho_{\mathrm{p}}=2.6 \mathrm{~g} / \mathrm{cm}^{2}$

Resulting clay porosity, $n=1-\frac{\rho_{b}}{\rho_{p}}=1-\frac{1.1 \mathrm{~g} / \mathrm{cm}^{2}}{2.6 \mathrm{~g} / \mathrm{cm}^{2}}=0.58$

Porosity of the clay filled portion $=$ Porosity of clean portion $\times$ porosity of clay

Porosity of the clay filled portion $=0.38 \times 0.58=0.22$ 
Determine the field capacity and wilting point of the clay filled portion of the lower drainage layer:

Will assume that the field capacity and wilting point of the clay fill portion has the same ratio versus its porosity of 0.22 as the equivalent ratio for kaolin clay.

From WSRC 2002 the following kaolin properties are found: $\mathrm{n}=0.56 ; \mathrm{FC}=0.55 ; \mathrm{WP}=0.50$

$$
\begin{aligned}
& \mathrm{FC}=0.22 \times(0.55 \div 0.56) \approx 0.21 \\
& \mathrm{WP}=0.22 \times(0.50 \div 0.56) \approx 0.20
\end{aligned}
$$

Determine the equivalent horizontal hydraulic conductivity of the lower drainage layer over time:

The equivalent horizontal hydraulic conductivity for horizontal flow in a series of horizontal layers with different saturated hydraulic conductivities can be determined from the following equation (Freeze and Cherry 1979):

$$
K_{h}=\sum_{i=1}^{n} \frac{K_{i} d_{i}}{d}, \begin{aligned}
& \text { where } \mathrm{K}_{\mathrm{h}}=\text { equivalent horizontal saturated hydraulic conductivity, } \mathrm{K}_{\mathrm{i}}=\text { horizontal } \\
& \begin{array}{l}
\text { saturated hydraulic conductivity of } \mathrm{i}^{\text {th }} \text { layer, } \mathrm{d}_{\mathrm{i}}=\text { thickness of } \mathrm{i}^{\text {th }} \text { layer, } \mathrm{d}=\text { total } \\
\text { thickness }
\end{array}
\end{aligned}
$$

The fraction, $\mathrm{F}$, equals $d_{i} / d$ for the clay filled portion and $d_{i} / d$ for the clean drainage layer material equals $(1-\mathrm{F})$, making the equation:

$$
K_{h}=\left(K_{\text {filled }} \times F\right)+\left[K_{\text {clean }} \times(1-F)\right]
$$

\begin{tabular}{|l|l|}
\hline Year & Equivalent K $(\mathrm{cm} / \mathrm{s})$ \\
\hline 0 & 0.1 \\
\hline 100 & $(0.0001 \times 0.000249)+[0.1 \times(1-0.000249)]=0.1$ \\
\hline 154 & $(0.0001 \times 0.000393)+[0.1 \times(1-0.000393)]=0.1$ \\
\hline 300 & $(0.0001 \times 0.000845)+[0.1 \times(1-0.000845)]=0.0999$ \\
\hline 550 & $(0.0001 \times 0.00224)+[0.1 \times(1-0.00224)]=0.0998$ \\
\hline 602 & $(0.0001 \times 0.00267)+[0.1 \times(1-0.00267)]=0.0997$ \\
\hline 802 & $(0.0001 \times 0.0136)+[0.1 \times(1-0.0136)]=0.986$ \\
\hline 1,000 & $(0.0001 \times 0.138)+[0.1 \times(1-0.138)]=0.0862$ \\
\hline 1,800 & $(0.0001 \times 0.353)+[0.1 \times(1-0.353)]=0.0647$ \\
\hline 3,400 & $(0.0001 \times 0.647)+[0.1 \times(1-0.647)]=0.0354$ \\
\hline 5,600 & $(0.0001 \times 1.0)+[0.1 \times(1-1.0)]=0.0001$ \\
\hline 10,000 & \\
\hline
\end{tabular}

Determine the equivalent $\mathrm{n}, \mathrm{FC}$, and WP for the lower drainage layer over time:

In an analogous manner to that for $\mathrm{K}$, the equivalent $\mathrm{n}, \mathrm{FC}$, and $\mathrm{WP}$ can be determined based upon the fraction filled as follows:

$$
\begin{aligned}
& n=\left(n_{\text {filled }} \times F\right)+\left[n_{\text {clean }} \times(1-F)\right] \\
& F C=\left(F C_{\text {filled }} \times F\right)+\left[F C_{\text {clean }} \times(1-F)\right] \\
& W P=\left(W P_{\text {filled }} \times F\right)+\left[W P_{\text {clean }} \times(1-F)\right]
\end{aligned}
$$




\begin{tabular}{|l|l|}
\hline Year & Equivalent $\mathrm{n}$ \\
\hline 0 & $(0.22 \times 0)+[0.38 \times(1-0)]=0.38$ \\
\hline 100 & $(0.22 \times 0.000249)+[0.38 \times(1-0.000249)]=0.38$ \\
\hline 154 & $(0.22 \times 0.000393)+[0.38 \times(1-0.000393)]=0.38$ \\
\hline 300 & $(0.22 \times 0.000845)+[0.38 \times(1-0.000845)]=0.38$ \\
\hline 550 & $(0.22 \times 0.00224)+[0.38 \times(1-0.00224)]=0.38$ \\
\hline 602 & $(0.22 \times 0.00267)+[0.38 \times(1-0.00267)]=0.38$ \\
\hline 802 & $(0.22 \times 0.0358)+[0.38 \times(1-0.0358)]=0.374$ \\
\hline 1,000 & $(0.22 \times 0.138)+[0.38 \times(1-0.138)]=0.358$ \\
\hline 1,800 & $(0.22 \times 0.353)+[0.38 \times(1-0.353)]=0.324$ \\
\hline 3,400 & $(0.22 \times 1.0)+[0.38 \times(1-1.0)]=0.22$ \\
\hline 5,600 &
\end{tabular}

\begin{tabular}{|l|l|}
\hline Year & Equivalent FC \\
\hline 0 & $(0.21 \times 0)+[0.08 \times(1-0)]=0.08$ \\
\hline 100 & $(0.21 \times 0.000249)+[0.08 \times(1-0.000249)]=0.08$ \\
\hline 154 & $(0.21 \times 0.000393)+[0.08 \times(1-0.000393)]=0.08$ \\
\hline 300 & $(0.21 \times 0.000845)+[0.08 \times(1-0.000845)]=0.08$ \\
\hline 550 & $(0.21 \times 0.00224)+[0.08 \times(1-0.00224)]=0.0803$ \\
\hline 602 & $(0.21 \times 0.00267)+[0.08 \times(1-0.00267)]=0.0803$ \\
\hline 802 & $(0.21 \times 0.0136)+[0.08 \times(1-0.0136)]=0.0818$ \\
\hline 1,000 & $(0.21 \times 0.0358)+[0.08 \times(1-0.0358)]=0.0846$ \\
\hline 1,800 & $(0.21 \times 0.138)+[0.08 \times(1-0.138)]=0.0979$ \\
\hline 3,400 & $(0.21 \times 0.353)+[0.08 \times(1-0.353)]=0.126$ \\
\hline 5,600 & $(0.21 \times 1.0)+[0.08 \times(1-1.0)]=0.21$ \\
\hline 10,000 &
\end{tabular}

\begin{tabular}{|l|l|}
\hline Year & Equivalent WP \\
\hline 0 & $(0.20 \times 0)+[0.013 \times(1-0)]=0.013$ \\
\hline 100 & $(0.20 \times 0.000249)+[0.013 \times(1-0.000249)]=0.013$ \\
\hline 154 & $(0.20 \times 0.000393)+[0.013 \times(1-0.000393)]=0.0131$ \\
\hline 300 & $(0.20 \times 0.000845)+[0.013 \times(1-0.000845)]=0.0132$ \\
\hline 550 & $(0.20 \times 0.00224)+[0.013 \times(1-0.00224)]=0.0134$ \\
\hline 602 & $(0.20 \times 0.00267)+[0.013 \times(1-0.00267)]=0.0135$ \\
\hline 802 & $(0.20 \times 0.0136)+[0.013 \times(1-0.0136)]=0.0155$ \\
\hline 1,000 & $(0.20 \times 0.0358)+[0.013 \times(1-0.0358)]=0.0197$ \\
\hline 1,800 & $(0.20 \times 0.353)+[0.013 \times(1-0.353)]=0.0790$ \\
\hline 3,400 & $(0.20 \times 0.647)+[0.013 \times(1-0.647)]=0.134$ \\
\hline 5,600 & $(0.20 \times 0)+.[0.013 \times(1-0)]=0.20$. \\
\hline 10,000 & \\
\hline
\end{tabular}


Summary Lower Drainage Layer Hydraulic Properties with Time:

\begin{tabular}{|l|l|l|l|l|}
\hline Year & $\mathrm{K}(\mathrm{cm} / \mathrm{s})$ & $\mathrm{n}$ & $\mathrm{FC}$ & WP \\
\hline 0 & 0.1 & 0.38 & 0.08 & 0.013 \\
\hline 100 & 0.1 & 0.38 & 0.08 & 0.013 \\
\hline 154 & 0.1 & 0.38 & 0.08 & 0.0131 \\
\hline 300 & 0.0999 & 0.38 & 0.08 & 0.0132 \\
\hline 550 & 0.0998 & 0.38 & 0.0803 & 0.0134 \\
\hline 602 & 0.0997 & 0.38 & 0.0803 & 0.0135 \\
\hline 802 & 0.0986 & 0.378 & 0.0818 & 0.0155 \\
\hline 1,000 & 0.0964 & 0.374 & 0.0846 & 0.0197 \\
\hline 1,800 & 0.0862 & 0.358 & 0.0979 & 0.0388 \\
\hline 3,400 & 0.0647 & 0.324 & 0.126 & 0.0790 \\
\hline 5,600 & 0.0354 & 0.276 & 0.164 & 0.134 \\
\hline 10,000 & 0.0001 & 0.22 & 0.21 & 0.20 \\
\hline
\end{tabular}

The HELP model was rerun for each time step with all of the degraded properties (see above) including that of the lower drainage layer. Infiltration through the upper GCL did not change with the addition of the degraded lower drainage layer properties. Therefore the above estimated lower drainage layer hydraulic properties over time are verified.

\section{Infiltration through the Upper GCL at Complete Degradation}

The infiltration through the upper GCL at complete degradation and the associated time of occurrence have been determined based upon the following:

- As outlined above at year 10,000 all layers except the erosion barrier have reached their assumed degradation endpoint. Therefore the properties of all layers except the erosion barrier will be assigned their year 10,000 values.

- As outlined in Table 4.4-2 complete degradation of the erosion barrier is assumed to result in separation and segregation of the granite stone and flowable fill with the granite stone located on top of the broken up flowable fill. As previous done for the purposes of this calculation the properties of the broken up flowable fill will be ignored. Therefore the properties of the completely degraded erosion barrier are those of the granite stone as shown below:

\begin{tabular}{|l|l|l|l|l|}
\hline Material & $\begin{array}{l}\text { Saturated Hydraulic } \\
\text { Conductivity }(\mathrm{cm} / \mathrm{s})\end{array}$ & Porosity & Field Capacity & Wilting Point \\
\hline $\begin{array}{l}\text { Completely } \\
\text { Degraded Erosion } \\
\text { Barrier (i.e. Granite } \\
\text { Stone) }\end{array}$ & $3.0 \mathrm{E}-01$ & 0.397 & 0.032 & 0.013 \\
\hline
\end{tabular}

The above parameter values for the completely degraded erosion barrier (i.e. granite stone) replaced the previous year 10,000 HELP run to determine infiltration at complete degradation. The detailed HELP model input data and output file associated with this completely degraded case are provided at the end of this appendix. The infiltration through the upper GCL at complete degradation was determined to be 18.59674 inches/year.

Determine time required for complete degradation of the erosion barrier:

Complete degradation of the erosion barrier will occur after pine trees have completely penetrated the entire area.

From previous erosion barrier calculations:

$$
\begin{aligned}
& 116 \mathrm{ft}^{2} / \text { acre }+\left[(\mathrm{X}-802 \mathrm{yrs}) \times 116 \mathrm{ft}^{2} / \text { acre } / 100 \text { years }\right]=43,560 \mathrm{ft}^{2} / \text { acre } \\
& (\mathrm{X}-802 \mathrm{yrs}) \times 116 \mathrm{ft}^{2} / \text { acre } / 100 \text { years }=43,444 \mathrm{ft}^{2} / \text { acre }
\end{aligned}
$$




$$
\begin{aligned}
& X-802 \text { yrs }=37,452 \text { yrs } \\
& X=38,254 \text { yrs }
\end{aligned}
$$

\section{Year that Lower Drainage Layer Completely Silts In}

From previous calculations above the following were determined:

- It takes a total of $13,269.8 \mathrm{ft}^{3}$ of infiltrating water to completely silt in the lower drainage layer.

- The lower drainage layer completely silts in between year 5,600 and 10,000.

- Through year 5,600 the infiltrating water volume was $8,584.438 \mathrm{ft}^{3}$.

- At year 5,600 the infiltration through the upper GCL was 21.13124 inches/year, and at year 10,000 it was 20.05366 inches/year.

- It is assumed that infiltration varies linearly between year 5,600 and year 10,000.

Determine water volume remaining after year 5,600 to completely silt in the lower drainage layer:

$$
\mathrm{V}=13,269.8 \mathrm{ft}^{3}-8,584.438 \mathrm{ft}^{3}=4,685.362 \mathrm{ft}^{3}
$$

Determine time to completely silt in the lower drainage layer:

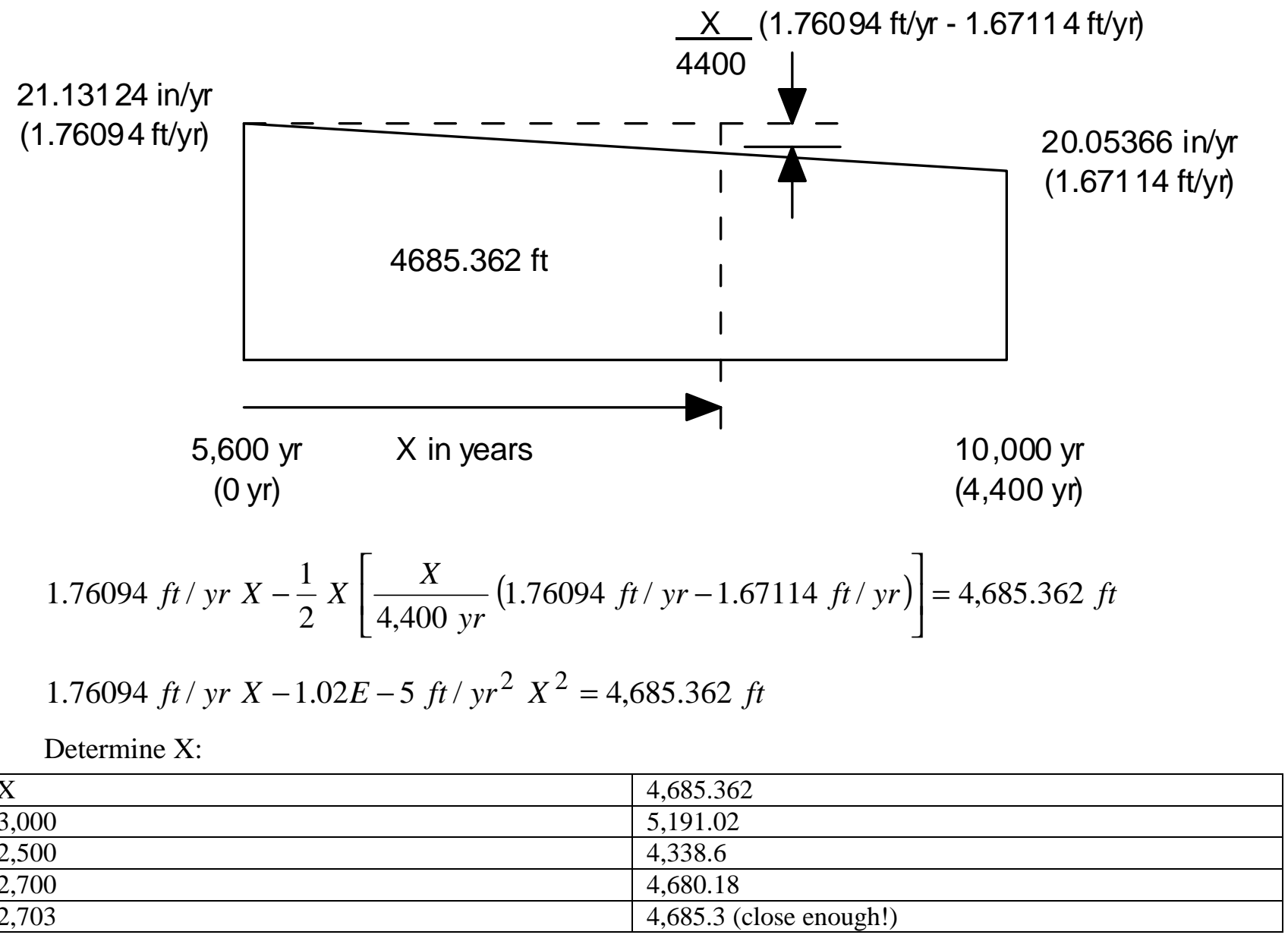

Year lower drainage layer completely silts in:

$$
\text { Year }=5,600+2,703=8,303
$$


At year 8,803 the lower drainage layer completely silts in and has the following properties: saturated hydraulic conductivity $=1.0 \mathrm{E}-04 \mathrm{~cm} / \mathrm{s}$; porosity $=0.22$; field capacity $=0.21$; wilting point $=0.20$. 
Upper Bounding Scenario Degraded SDF MSE Vault Closure Cap (Preliminary 1,800 Years): HELP Model Input Data and Output Files (output file name: ZUBSP18o.OUT)

Input Data:

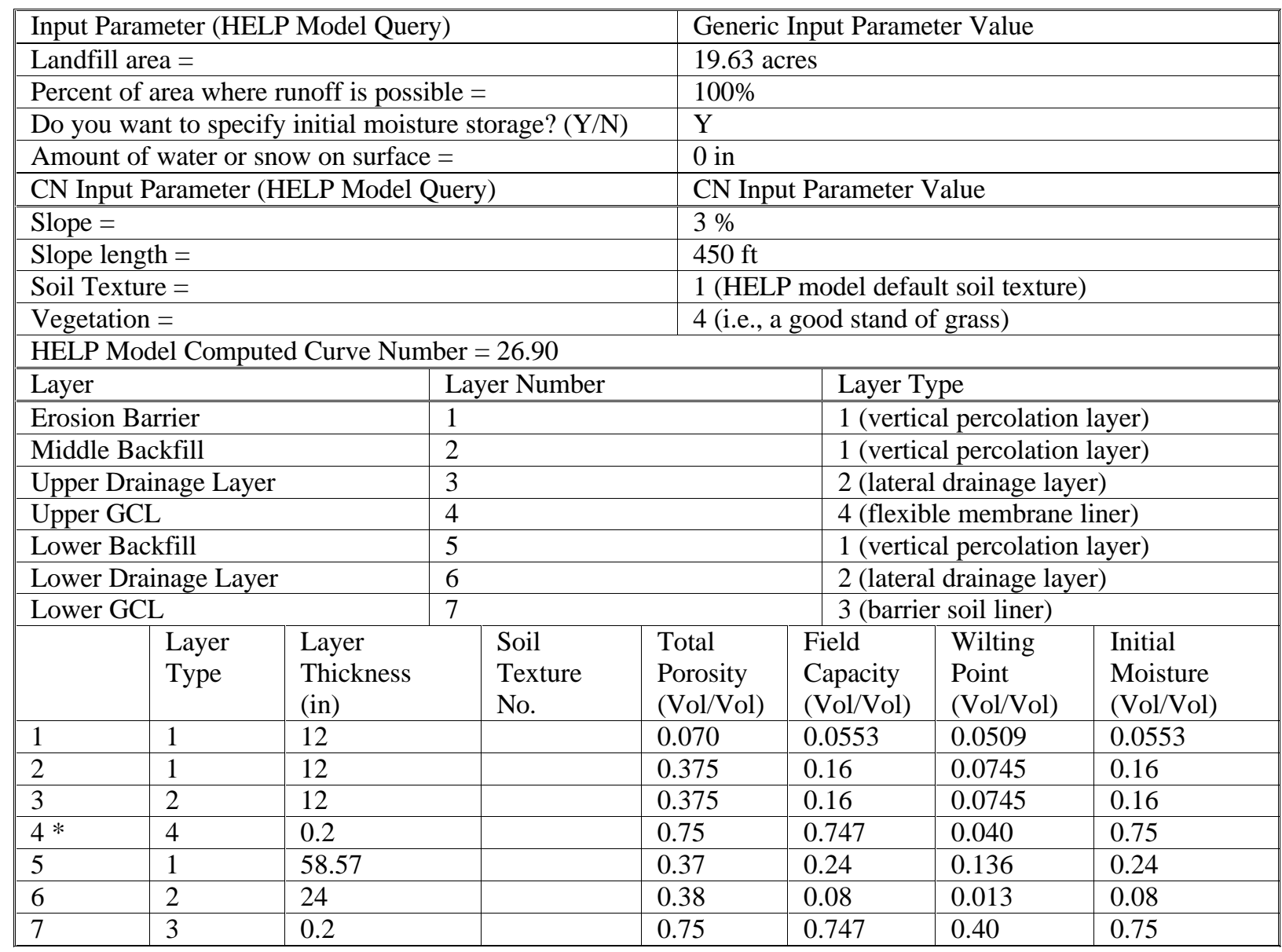

The lack of values in the table for particular parameters in particular layers denotes that no HELP model input was required for that parameter in that layer. No data is missing from the table.

* The input porosity, field capacity, and wilting point values of the upper GCL are ignored by the HELP model, since the upper GCL is designated as an geomembrane in order for the HELP model to take into account the holes produced by root penetration. 
Input Data (continued):

\begin{tabular}{|c|c|c|c|c|c|c|c|c|c|}
\hline & $\begin{array}{l}\text { Layer } \\
\text { Type }\end{array}$ & $\begin{array}{l}\text { Sat. Hyd. } \\
\text { Conductivity * } \\
(\mathrm{cm} / \mathrm{sec})\end{array}$ & \multicolumn{2}{|c|}{$\begin{array}{l}\text { Drainage } \\
\text { Length } \\
(\mathrm{ft}) \\
\end{array}$} & $\begin{array}{l}\text { Drain } \\
\text { Slope } \\
(\%)\end{array}$ & $\begin{array}{l}\text { Leachate } \\
\text { Recirc. } \\
(\%) \\
\end{array}$ & \multicolumn{2}{|c|}{$\begin{array}{l}\text { Recirc. to } \\
\text { Layer } \\
(\#)\end{array}$} & $\begin{array}{l}\text { Subsurface } \\
\text { Inflow } \\
\text { (in/yr) }\end{array}$ \\
\hline 1 & 1 & 9.1E-03 & & & & & & & \\
\hline 2 & 1 & $3.20 \mathrm{E}-03$ & & & & & & & \\
\hline 3 & 2 & $3.20 \mathrm{E}-03$ & 450 & & 3 & & & & \\
\hline 4 & 4 & $5.00 \mathrm{E}-09$ & & & & & & & \\
\hline 5 & 1 & $1.00 \mathrm{E}-04$ & & & & & & & \\
\hline 6 & 2 & $1.00 \mathrm{E}-01$ & 150 & & 11.4 & & & & \\
\hline 7 & 3 & $5.00 \mathrm{E}-09$ & & & & & & & \\
\hline & $\begin{array}{l}\text { Layer } \\
\text { Type }\end{array}$ & \multicolumn{2}{|l|}{$\begin{array}{l}\text { Geomembrane } \\
\text { Pinhole Density } \\
\text { (\#/acre) }\end{array}$} & $\begin{array}{l}\mathrm{Ge} \\
\mathrm{Ins} \\
(\# / \mathrm{c}\end{array}$ & $\begin{array}{l}\text { mbrane } \\
\text { Defects }\end{array}$ & \multicolumn{2}{|c|}{$\begin{array}{l}\text { Geomembrane } \\
\text { Placement Quality }\end{array}$} & \multicolumn{2}{|c|}{$\begin{array}{l}\text { Geotextile } \\
\text { Transmissivity } \\
\left(\mathrm{cm}^{2} / \mathrm{sec}\right)\end{array}$} \\
\hline 1 & 1 & & & & & & & & \\
\hline 2 & 1 & & & & & & & & \\
\hline 3 & 2 & & & & & & & & \\
\hline 4 & 4 & 0 & & 448 & & 1 & & & \\
\hline 5 & 1 & & & & & & & & \\
\hline 6 & 2 & & & & & & & & \\
\hline 7 & 3 & & & & & & & & \\
\hline
\end{tabular}

The lack of values in the table for particular parameters in particular layers denotes that no HELP model input was required for that parameter in that layer. No data is missing from the table.

* The HELP model output often produces an increased number of significant digits for the Effective Saturated Hydraulic Conductivity over that of the actual input 


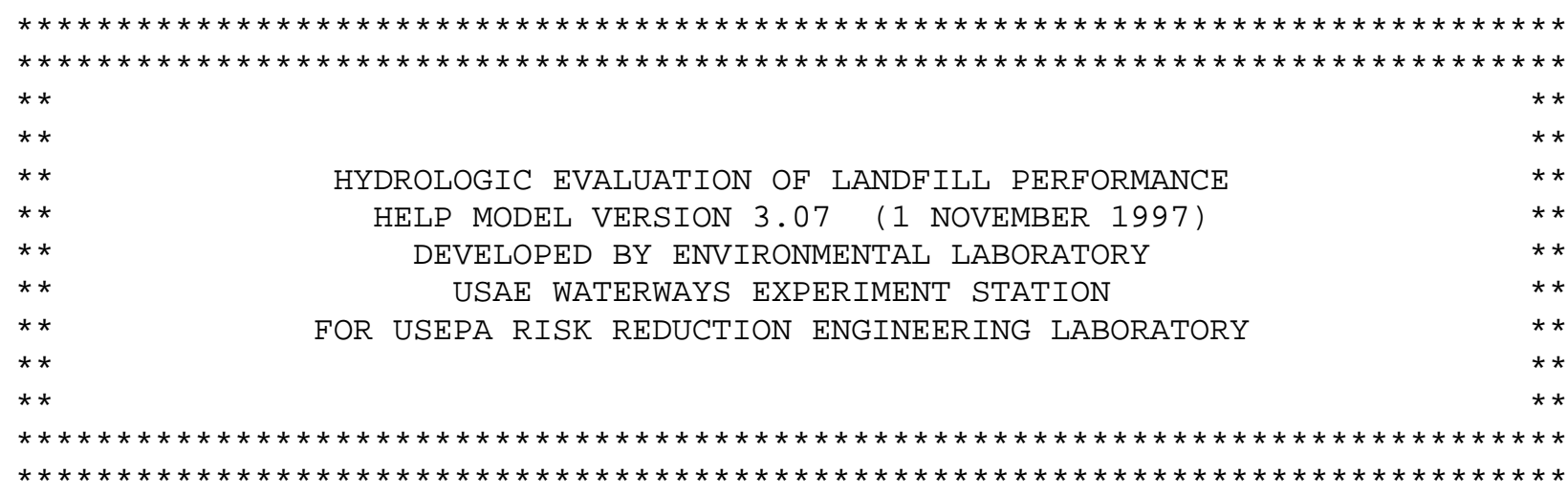

\begin{tabular}{|c|c|}
\hline PRECIPITATION DATA FILE: & $\mathrm{D}: \backslash$ HELP $3 \backslash$ Hweather $\backslash \mathrm{Z} \backslash$ \\
\hline TEMPERATURE DATA FILE: & $\mathrm{D}: \backslash$ HELP $3 \backslash$ Hweather $\backslash \mathrm{ZTEMP}$. D 7 \\
\hline SOLAR RADIATION DATA FILE: & D : \HELP $3 \backslash$ Hweather $\backslash Z$ SOLAR.D13 \\
\hline EVAPOTRANSPIRATION DATA: & $\mathrm{D}: \backslash$ HELP $3 \backslash$ Hweather $\backslash$ ZEVAP . D11 \\
\hline SOIL AND DESIGN DATA FILE: & D : \HELP $3 \backslash$ Hsdfmse $\backslash Z U B S P 18 . D 10$ \\
\hline OUTPUT DATA FILE: & $\backslash$ ZUBSP 18 \\
\hline
\end{tabular}

TIME : $10: 57 \quad$ DATE : $1 / 9 / 2004$

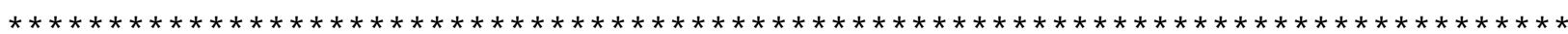
TITLE: UBS Degraded MSE Vault Closure Cap - Preliminary 1,800 yrs

NOTE: INITIAL MOISTURE CONTENT OF THE LAYERS AND SNOW WATER WERE SPECIFIED BY THE USER.

\begin{tabular}{|c|c|c|c|c|}
\hline \multicolumn{5}{|c|}{ LAYER 1} \\
\hline \multicolumn{5}{|c|}{ TYPE 1 - VERTICAL PERCOLATION LAYER } \\
\hline THICKNESS & $=$ & 12.00 & INCHES & \\
\hline POROSITY & $=$ & 0.0700 & VOL/VOL & \\
\hline FIELD CAPACITY & $=$ & 0.0553 & $\mathrm{VOL} / \mathrm{VOL}$ & \\
\hline WILTING POINT & $=$ & 0.0509 & $\mathrm{VOL} / \mathrm{VOL}$ & \\
\hline INITIAL SOIL WATER CONTENT & $=$ & 0.0553 & $\mathrm{VOL} / \mathrm{VOL}$ & \\
\hline EFFECTIVE SAT. HYD. COND. & $=$ & 0.910000037 & $7000 E-02$ & $\mathrm{CM} / \mathrm{SEC}$ \\
\hline \multicolumn{5}{|c|}{ LAYER 2} \\
\hline \multicolumn{5}{|c|}{ TYPE 1 - VERTICAL PERCOLATION LAYER } \\
\hline THICKNESS & $=$ & 12.00 & INCHES & \\
\hline POROSITY & $=$ & 0.3750 & VOL/VOL & \\
\hline FIELD CAPACITY & $=$ & 0.1600 & VOL/VOL & \\
\hline WILTING POINT & $=$ & 0.0745 & $\mathrm{VOL} / \mathrm{VOL}$ & \\
\hline INITIAL SOIL WATER CONTENT & $=$ & 0.1600 & VOL/VOL & \\
\hline EFFECTIVE SAT. HYD. COND. & $=$ & 0.319999992 & $2000 E-02$ & $\left(\mathbb{N}_{1}\right)$ \\
\hline
\end{tabular}

Rev. 0 
LAYER 3

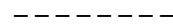

TYPE 2 - LATERAL DRAINAGE LAYER MATERIAL TEXTURE NUMBER 0

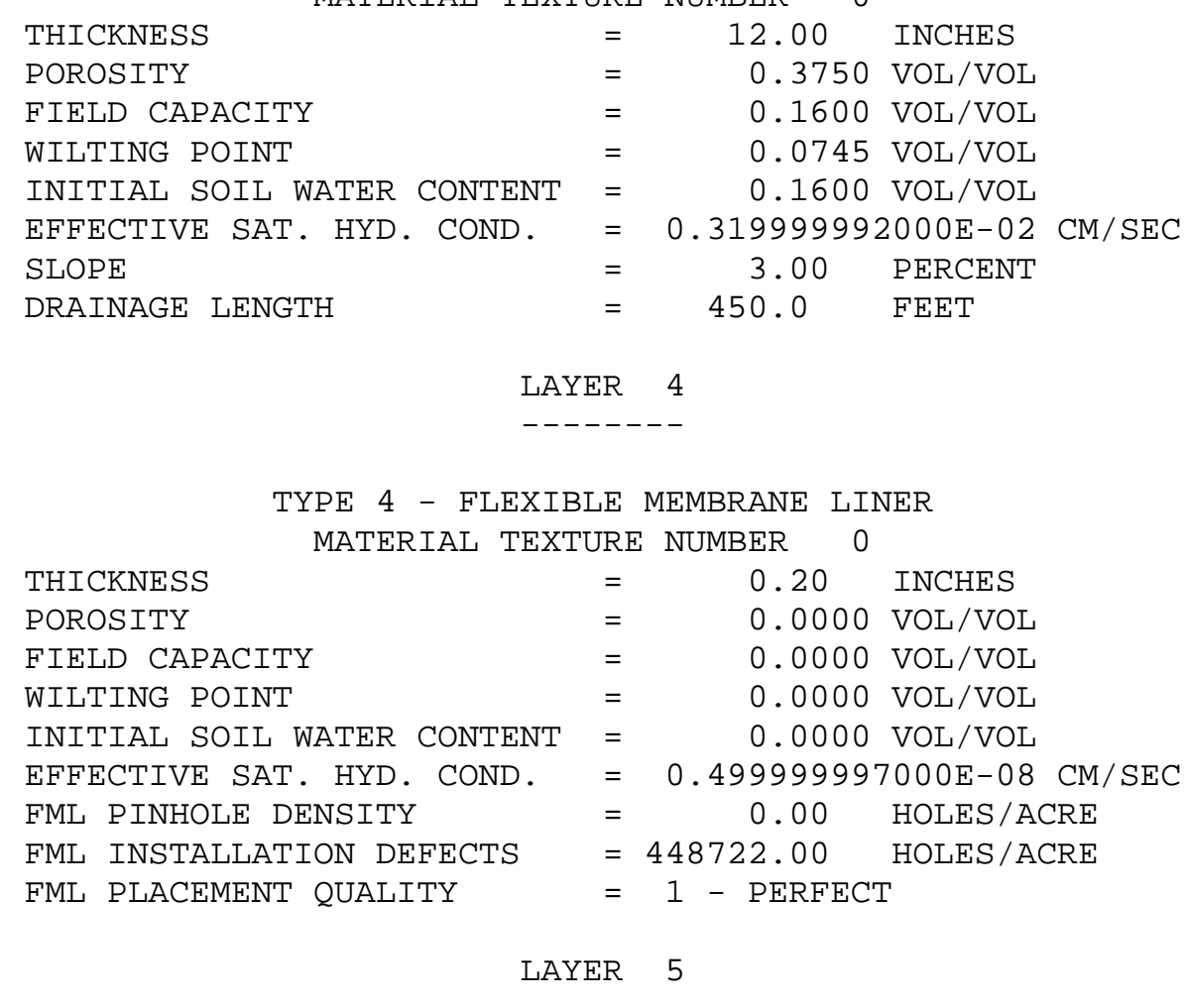

TYPE 1 - VERTICAL PERCOLATION LAYER MATERIAL TEXTURE NUMBER 0

$\begin{array}{llcc}\text { THICKNESS } & = & 58.57 & \text { INCHES } \\ \text { POROSITY } & = & 0.3700 \mathrm{VOL} / \mathrm{VOL} \\ \text { FIELD CAPACITY } & = & 0.2400 \mathrm{VOL} / \mathrm{VOL} \\ \text { WILTING POINT } & = & 0.1360 \mathrm{VOL} / \mathrm{VOL} \\ \text { INITIAL SOIL WATER CONTENT } & = & 0.2400 \mathrm{VOL} / \mathrm{VOL} \\ \text { EFEECTIVE SAT. HYD. COND. } & =0.999999975000 \mathrm{E}-04 \mathrm{CM} / \mathrm{SEC}\end{array}$

\section{LAYER 6}

TYPE 2 - LATERAL DRAINAGE LAYER

\begin{tabular}{|c|c|c|c|c|}
\hline MATERIAL TEX & JRE & NUMBER & & \\
\hline THICKNESS & $=$ & 24.00 & INCHES & \\
\hline POROSITY & $=$ & 0.3800 & $\mathrm{VOL} / \mathrm{VOL}$ & \\
\hline FIELD CAPACITY & $=$ & 0.0800 & VOL/VOL & \\
\hline WILTING POINT & $=$ & 0.0130 & VOL/VOL & \\
\hline INITIAL SOIL WATER CONTENT & $=$ & 0.0800 & VOL/VOL & \\
\hline EFFECTIVE SAT. HYD. COND. & $=$ & 0.100000001 & 1000 & $\mathrm{CM} / \mathrm{SEC}$ \\
\hline SLOPE & $=$ & 11.40 & PERCENT & \\
\hline DRAINAGE LENGTH & $=$ & 150.0 & FEET & \\
\hline
\end{tabular}

Rev. 0 
LAYER 7

$--------$

TYPE 3 - BARRIER SOIL LINER

MATERIAL TEXTURE NUMBER 0

$\begin{array}{llrl}\text { THICKNESS } & = & 0.20 \mathrm{INCHES} \\ \text { POROSITY } & = & 0.7500 \mathrm{VOL} / \mathrm{VOL} \\ \text { FIELD CAPACITY } & = & 0.7470 \mathrm{VOL} / \mathrm{VOL} \\ \text { WILTING POINT } & = & 0.4000 \mathrm{VOL} / \mathrm{VOL} \\ \text { INITIAL SOIL WATER CONTENT } & = & 0.7500 \mathrm{VOL} / \mathrm{VOL} \\ \text { EFFECTIVE SAT. HYD. COND. } & =0.499999997000 \mathrm{E}-08 \mathrm{CM} / \mathrm{SEC}\end{array}$

GENERAL DESIGN AND EVAPORATIVE ZONE DATA

NOTE: SCS RUNOFF CURVE NUMBER WAS COMPUTED FROM DEFAULT SOIL DATA BASE USING SOIL TEXTURE \# 1 WITH A GOOD STAND OF GRASS, A SURFACE SLOPE OF 3.\% AND A SLOPE LENGTH OF 450. FEET.

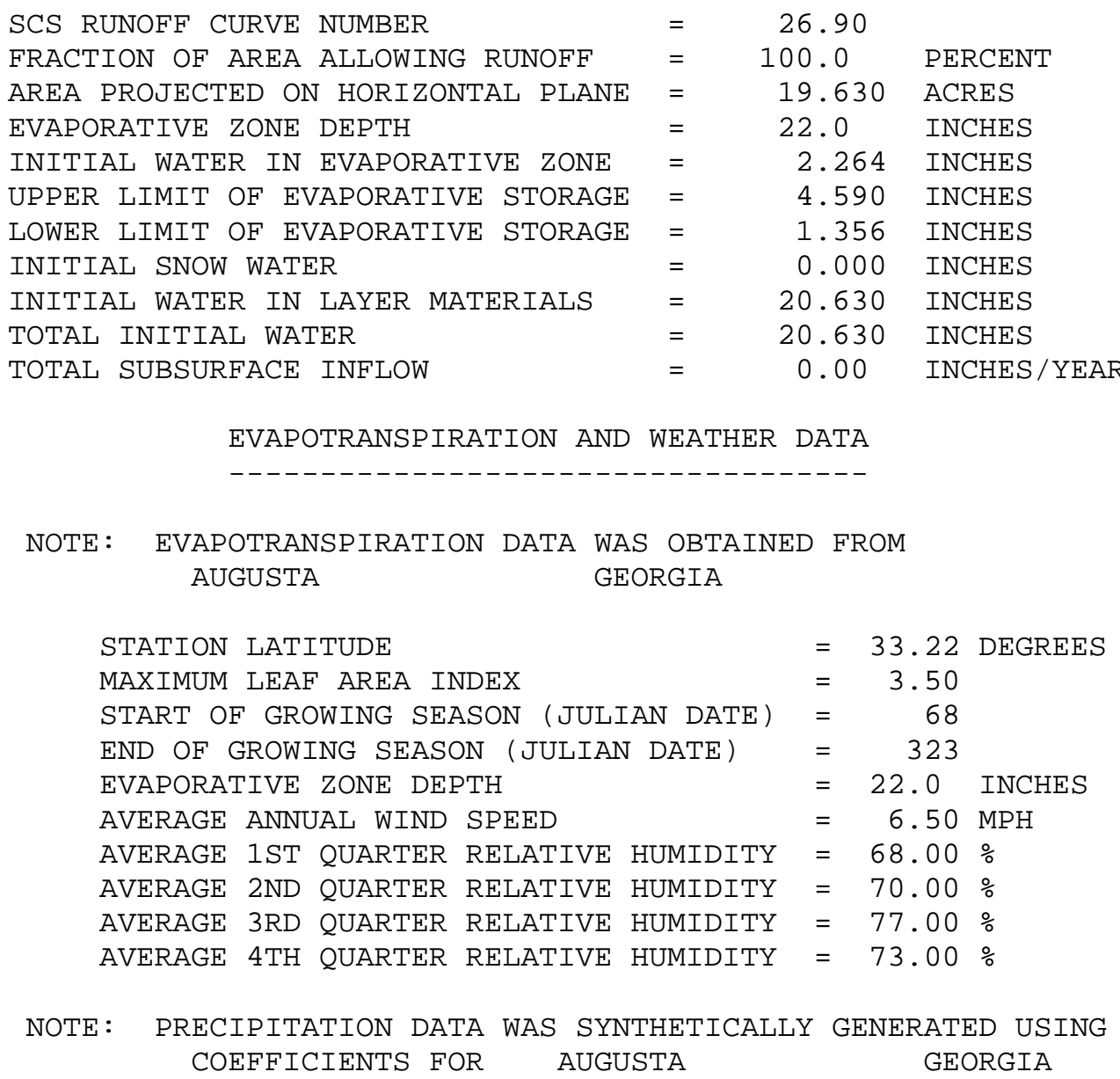


NORMAL MEAN MONTHLY PRECIPITATION (INCHES)

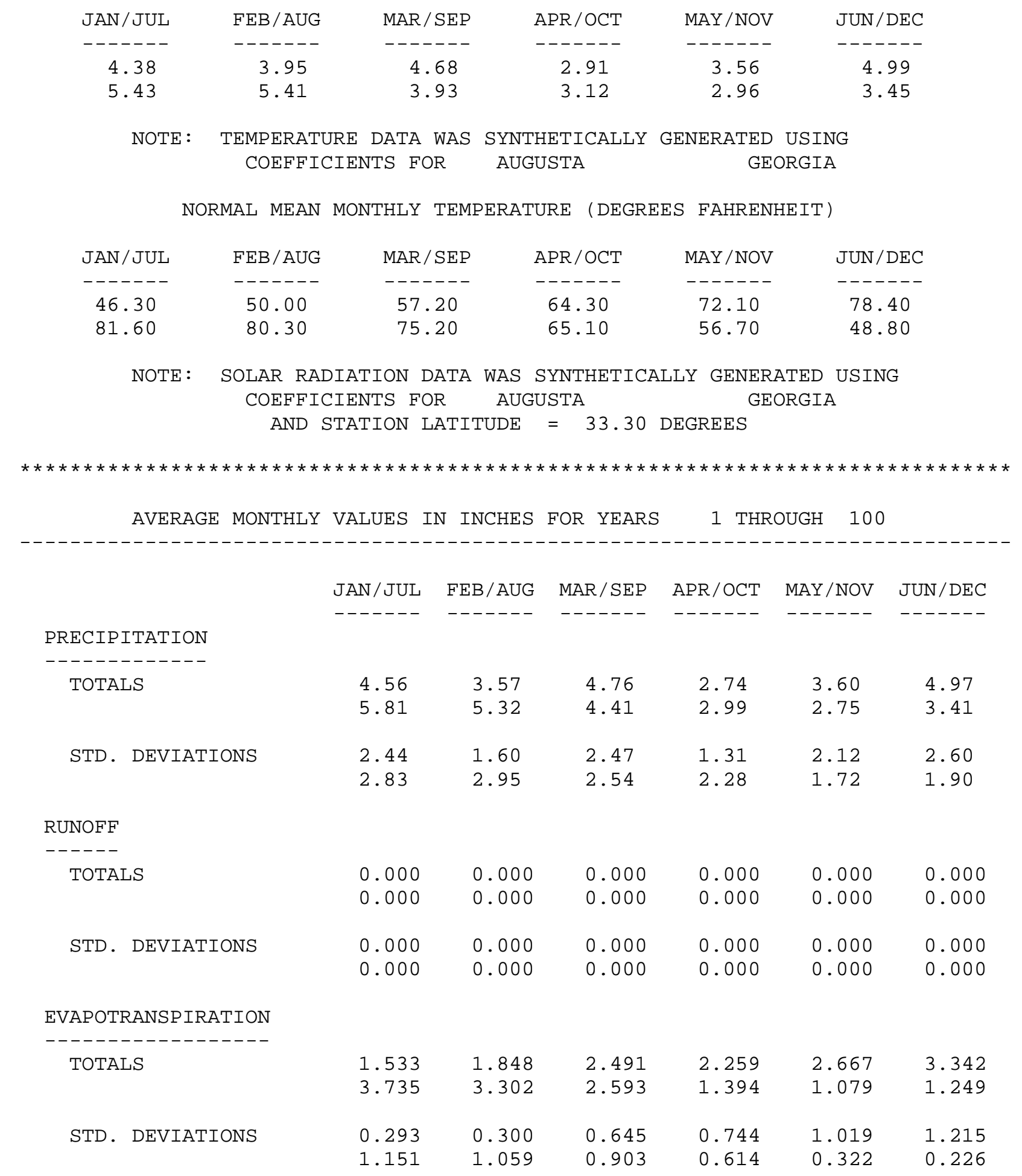




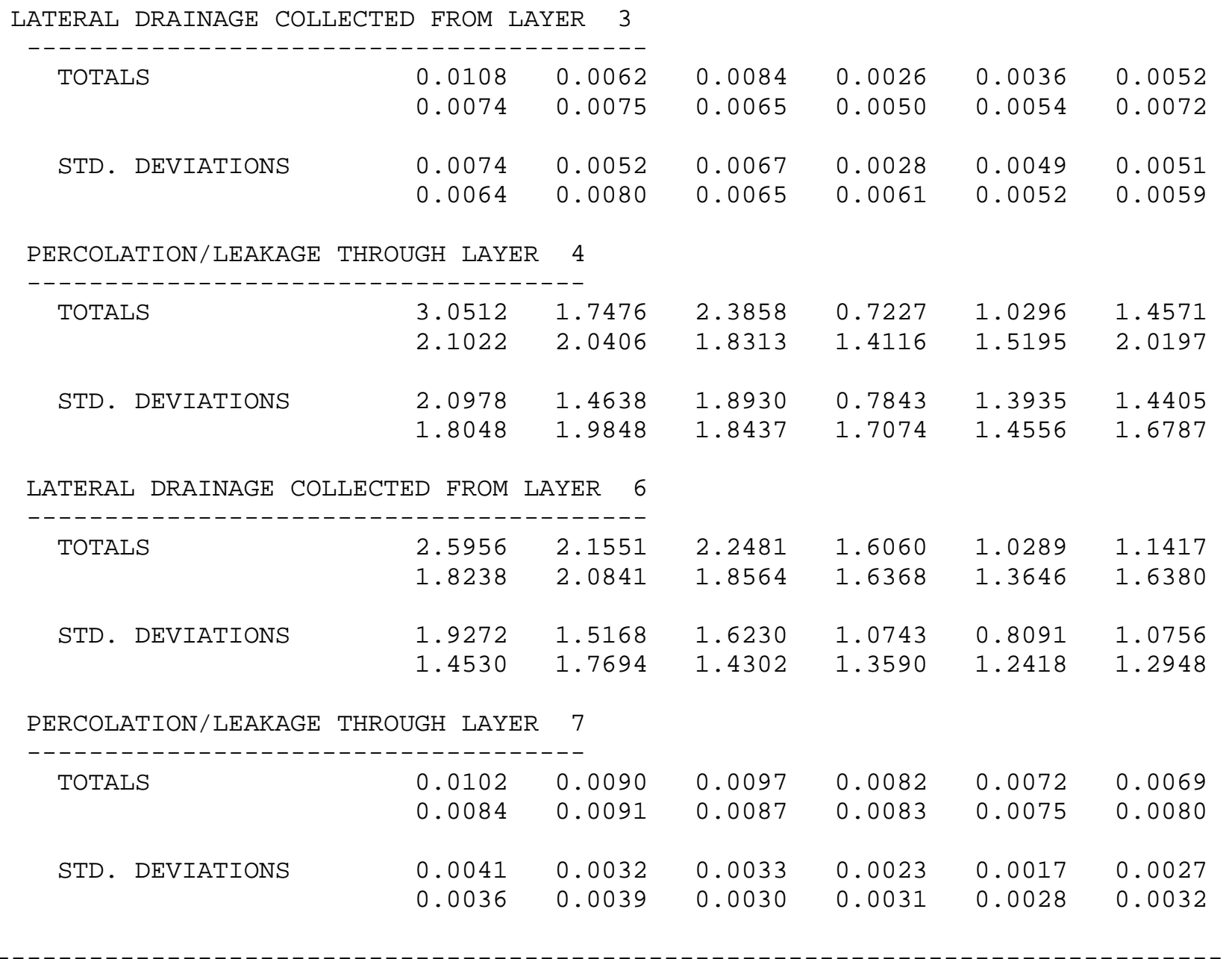

AVERAGES OF MONTHLY AVERAGED DAILY HEADS (INCHES)

DAILY AVERAGE HEAD ON TOP OF LAYER 4

$\begin{array}{lllllll}\text { AVERAGES } & 0.2885 & 0.1810 & 0.2256 & 0.0705 & 0.0973 & 0.1424 \\ & 0.1988 & 0.2001 & 0.1790 & 0.1336 & 0.1484 & 0.1909 \\ \text { STD. DEVIATIONS } & 0.1985 & 0.1519 & 0.1791 & 0.0766 & 0.1318 & 0.1408 \\ & 0.1708 & 0.2119 & 0.1803 & 0.1619 & 0.1423 & 0.1588\end{array}$

DAILY AVERAGE HEAD ON TOP OF LAYER 7

$\begin{array}{lllllll}\text { AVERAGES } & 0.1969 & 0.1792 & 0.1705 & 0.1259 & 0.0780 & 0.0895 \\ & 0.1383 & 0.1581 & 0.1455 & 0.1241 & 0.1069 & 0.1242 \\ \text { STD. DEVIATIONS } & 0.1462 & 0.1263 & 0.1231 & 0.0842 & 0.0614 & 0.0843 \\ & 0.1102 & 0.1342 & 0.1121 & 0.1031 & 0.0973 & 0.0982\end{array}$




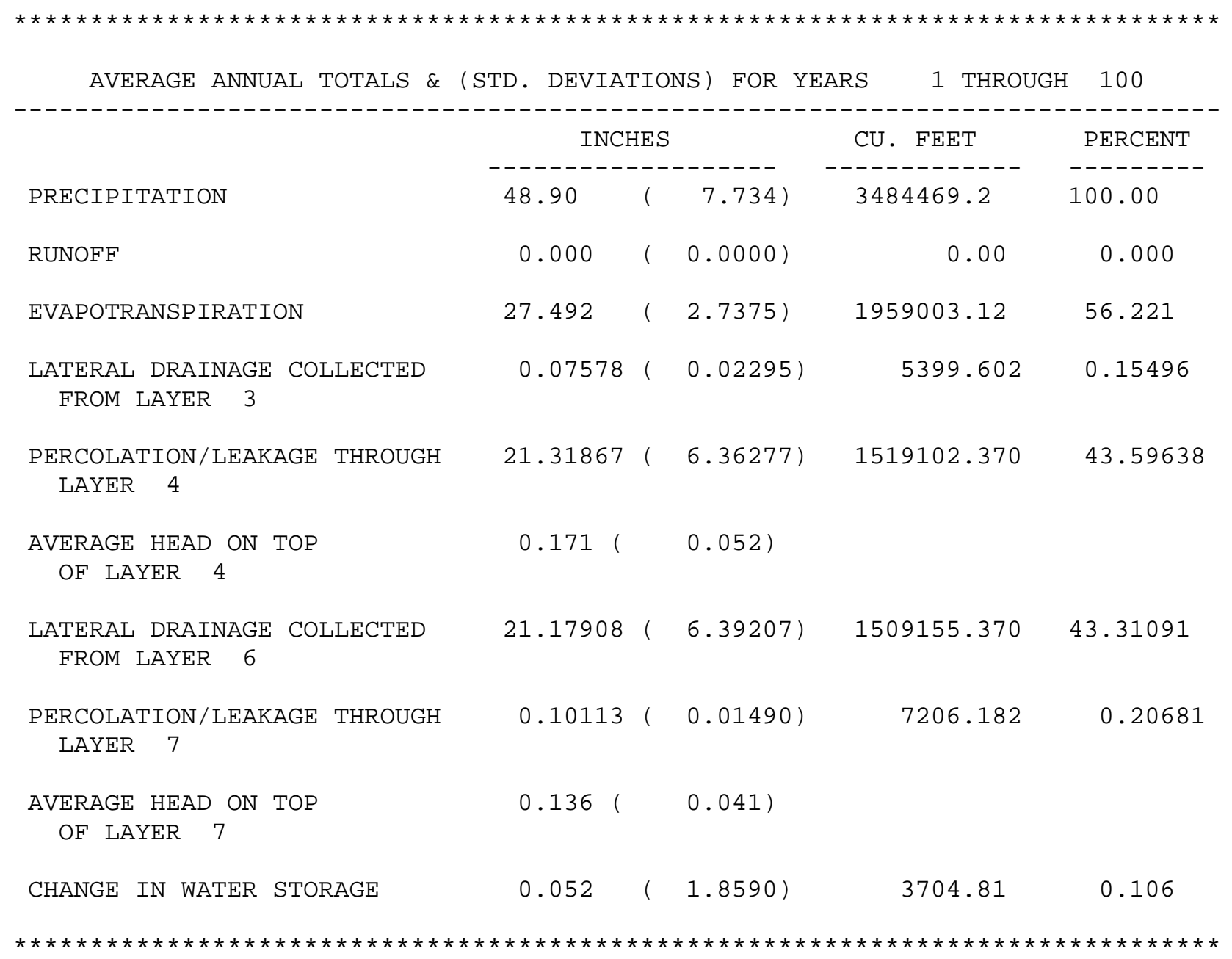




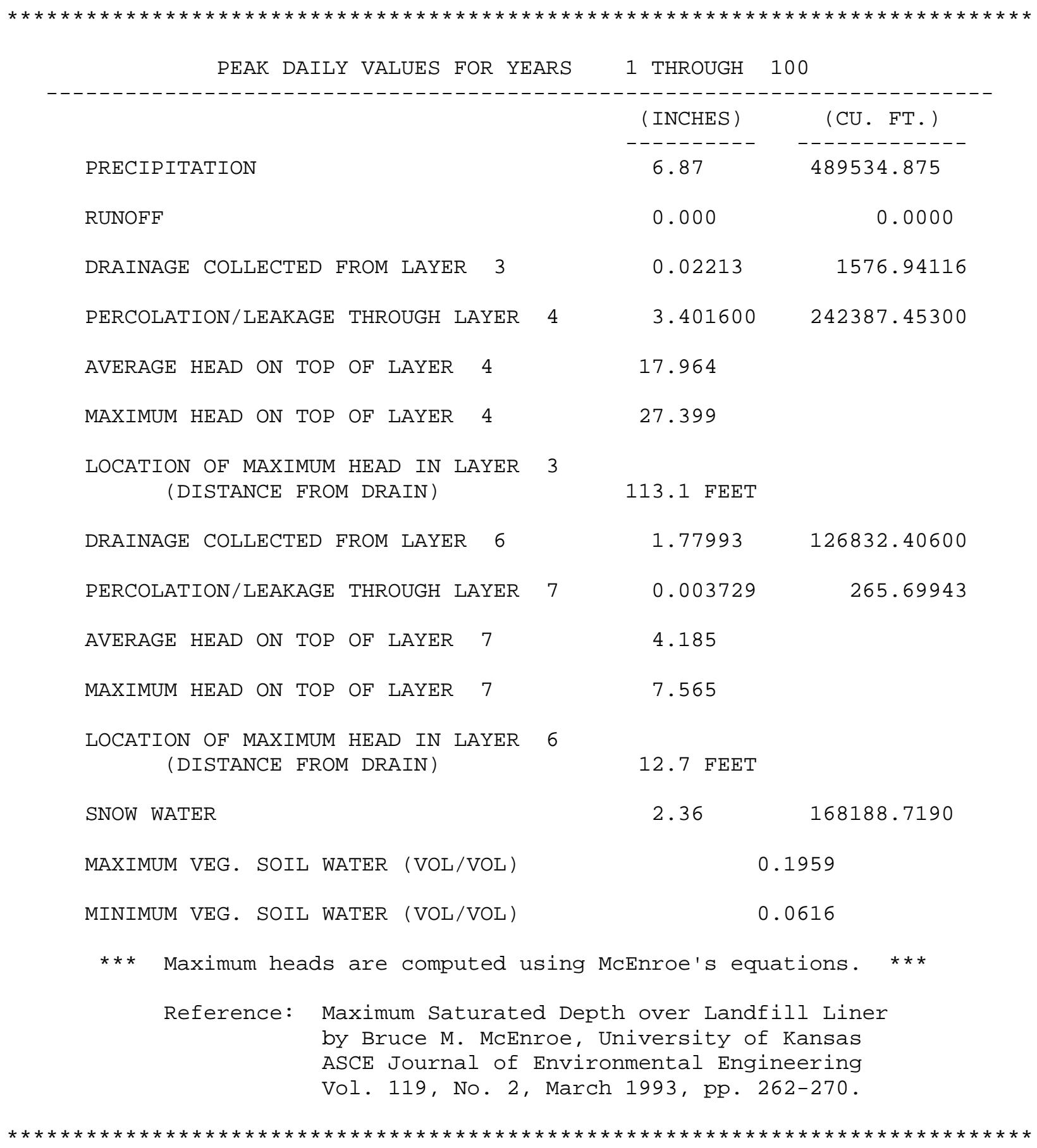

Rev. 0 


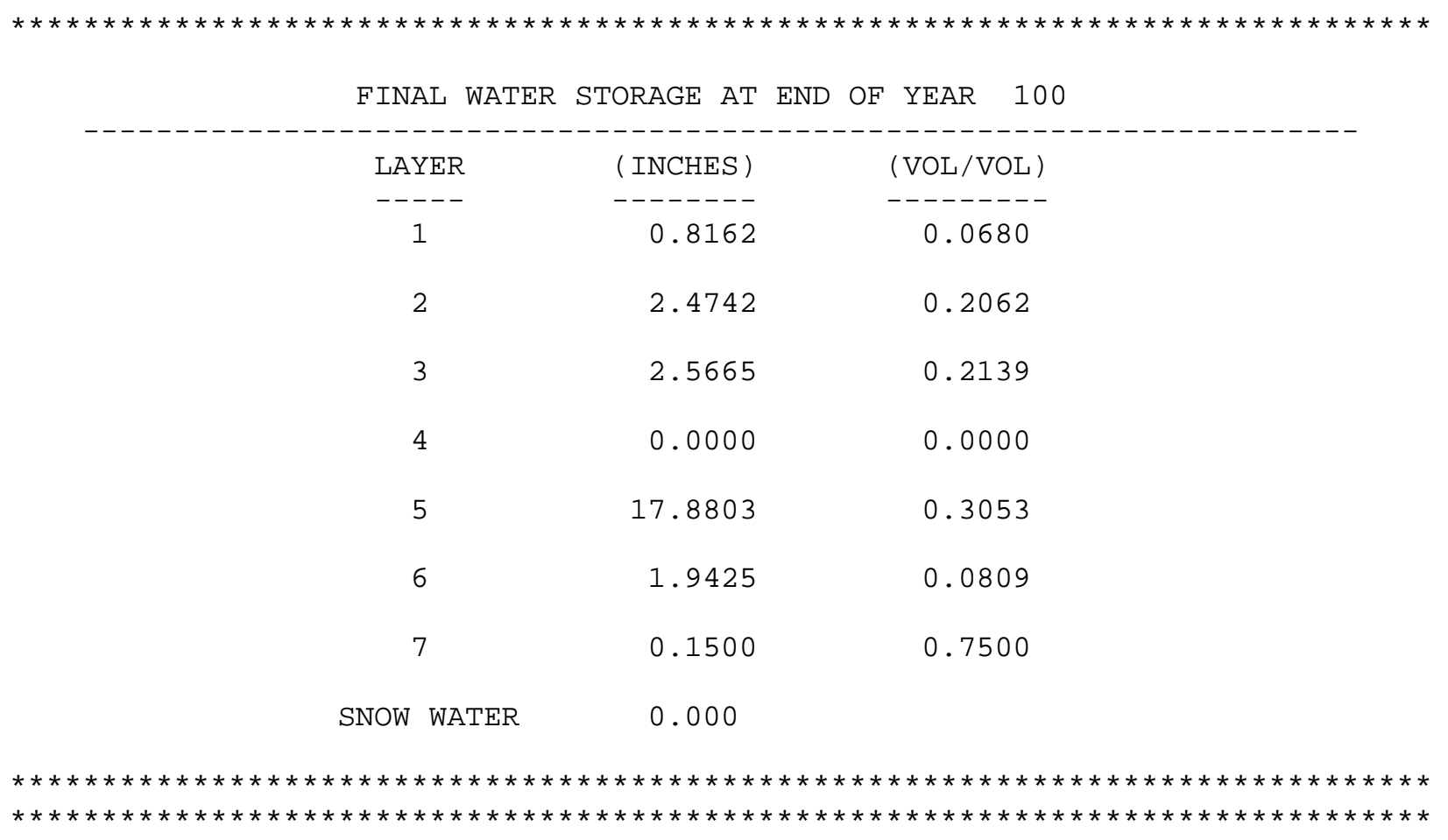


Upper Bounding Scenario Degraded SDF MSE Vault Closure Cap (38,254 Years): HELP Model Input Data and Output File (output file name: ZUBSD12o.OUT)

\section{Input Data:}

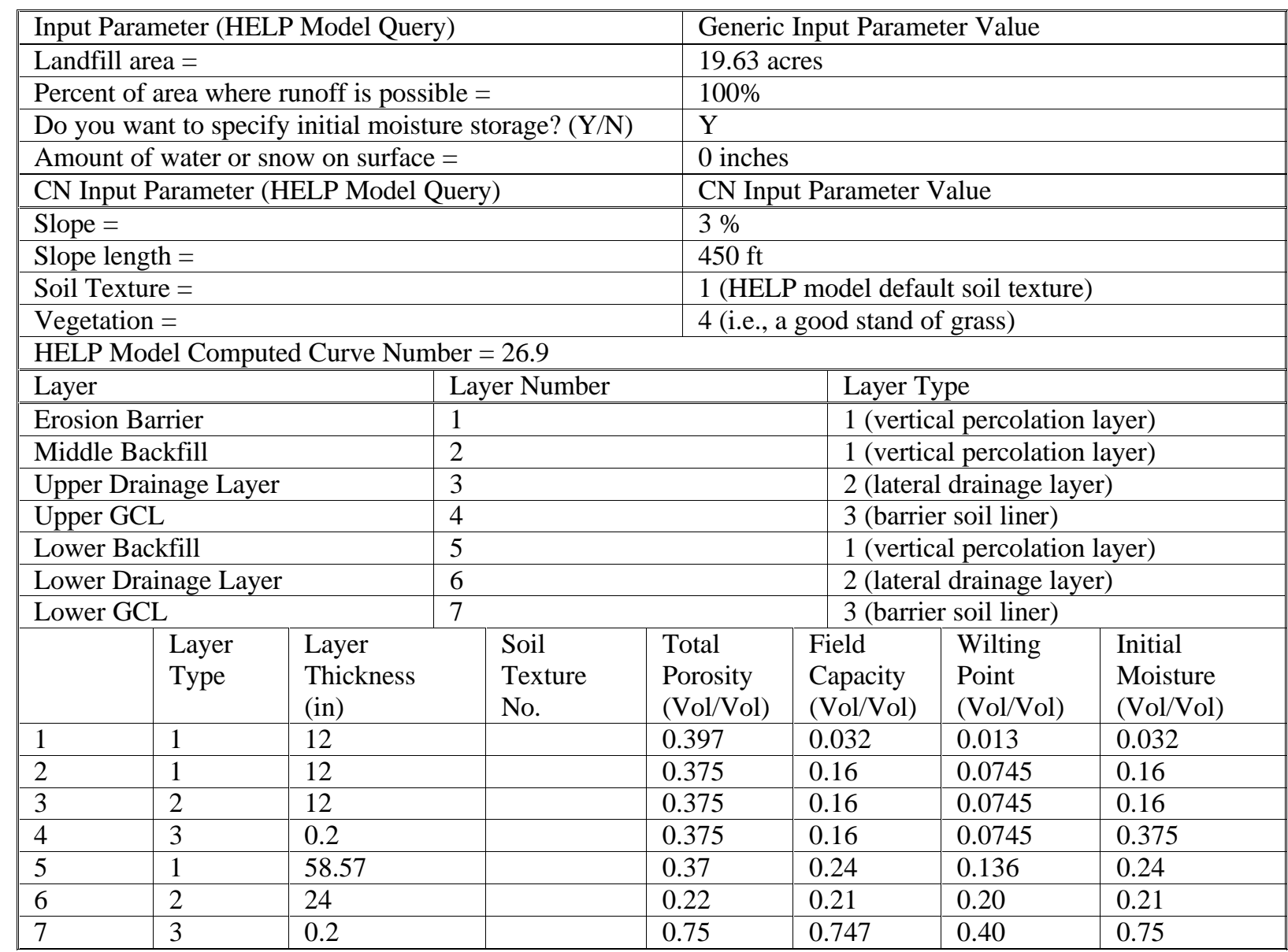

The lack of values in the table for particular parameters in particular layers denotes that no HELP model input was required for that parameter in that layer. No data are missing from the table. 
Input Data (continued):

\begin{tabular}{|c|c|c|c|c|c|c|c|c|c|}
\hline & $\begin{array}{l}\text { Layer } \\
\text { Type }\end{array}$ & $\begin{array}{l}\text { Sat. Hyd. } \\
\text { Conductivity * } \\
(\mathrm{cm} / \mathrm{sec})\end{array}$ & \multicolumn{2}{|c|}{$\begin{array}{l}\text { Drainage } \\
\text { Length } \\
(\mathrm{ft}) \\
\end{array}$} & $\begin{array}{l}\text { Drain } \\
\text { Slope } \\
(\%)\end{array}$ & $\begin{array}{l}\text { Leachate } \\
\text { Recirc. } \\
(\%)\end{array}$ & \multicolumn{2}{|c|}{$\begin{array}{l}\text { Recirc. to } \\
\text { Layer } \\
(\#)\end{array}$} & $\begin{array}{l}\text { Subsurface } \\
\text { Inflow } \\
\text { (in/yr) }\end{array}$ \\
\hline 1 & 1 & 3.00E-01 & & & & & & & \\
\hline 2 & 1 & $3.20 \mathrm{E}-03$ & & & & & & & \\
\hline 3 & 2 & $3.20 \mathrm{E}-03$ & 450 & & 3 & & & & \\
\hline 4 & 3 & $3.20 \mathrm{E}-03$ & & & & & & & \\
\hline 5 & 1 & $1.00 \mathrm{E}-04$ & & & & & & & \\
\hline 6 & 2 & $1.00 \mathrm{E}-04$ & 150 & & 11.4 & & & & \\
\hline 7 & 3 & $5.00 \mathrm{E}-09$ & & & & & & & \\
\hline & $\begin{array}{l}\text { Layer } \\
\text { Type }\end{array}$ & \multicolumn{2}{|l|}{$\begin{array}{l}\text { Geomembrane } \\
\text { Pinhole Density } \\
\text { (\#/acre) }\end{array}$} & $\begin{array}{l}\mathrm{Ge} \\
\mathrm{Ins} \\
(\# / \mathrm{c}\end{array}$ & $\begin{array}{l}\text { mbrane } \\
\text { Defects }\end{array}$ & \multicolumn{2}{|c|}{$\begin{array}{l}\text { Geomembrane } \\
\text { Placement Quality }\end{array}$} & \multicolumn{2}{|c|}{$\begin{array}{l}\text { Geotextile } \\
\text { Transmissivity } \\
\left(\mathrm{cm}^{2} / \mathrm{sec}\right)\end{array}$} \\
\hline 1 & 1 & & & & & & & & \\
\hline 2 & 1 & & & & & & & & \\
\hline 3 & 2 & & & & & & & & \\
\hline 4 & 3 & & & & & & & & \\
\hline 5 & 1 & & & & & & & & \\
\hline 6 & 2 & & & & & & & & \\
\hline 7 & 3 & & & & & & & & \\
\hline
\end{tabular}

The lack of values in the table for particular parameters in particular layers denotes that no HELP model input was required for that parameter in that layer. No data are missing from the table.

* The HELP model output often produces an increased number of significant digits for the Effective Saturated Hydraulic Conductivity over that of the actual input 


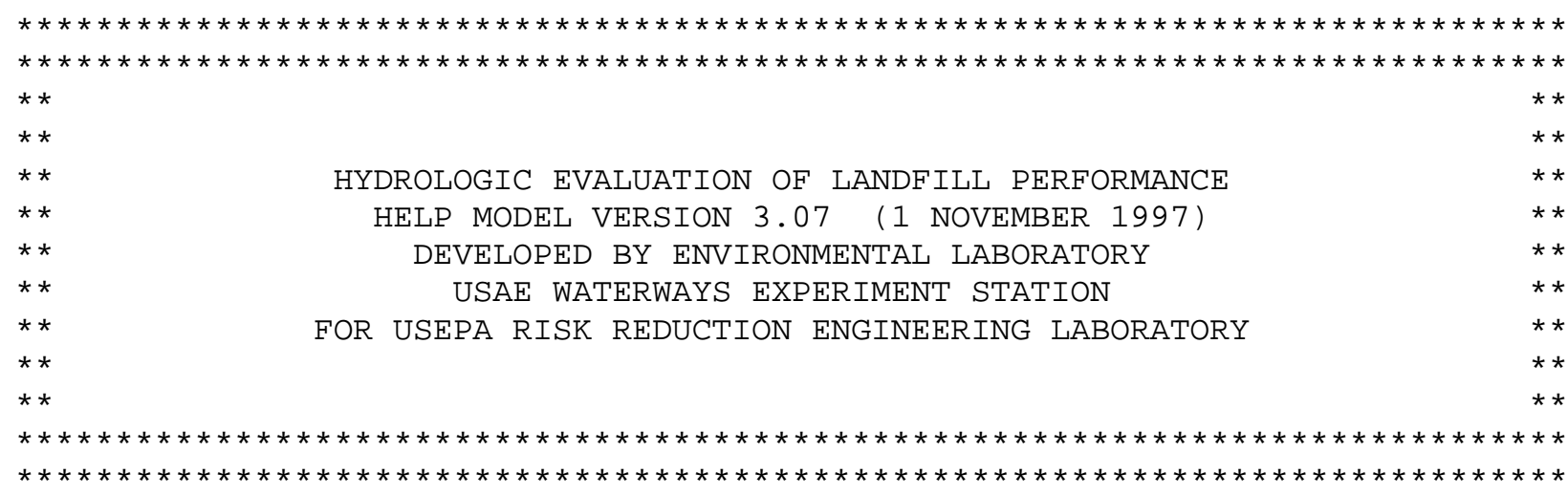

\begin{tabular}{|c|c|}
\hline PRECIPITATION DATA FILE: & $\mathrm{D}: \backslash$ HELP $3 \backslash$ Hweather $\backslash \mathrm{ZP}$ \\
\hline TEMPERATURE DATA FILE: & D : \HELP 3 \Hweather ZTEMP.D7 \\
\hline SOLAR RADIATION DATA FILE: & D : \HELP $3 \backslash$ Hweather \ZSOLAR.D13 \\
\hline EVAPOTRANSPIRATION DATA: & D : \HELP $3 \backslash$ Hweather \ZEVAP . D11 \\
\hline SOIL AND DESIGN DATA FILE: & $\mathrm{D}: \backslash$ HELP $3 \backslash$ Hsdfmse $\backslash$ ZUBSD12.D10 \\
\hline OUTPUT DATA FILE: & sdfmse $\backslash$ ZUBSD 12 \\
\hline
\end{tabular}

TIME: $16: 8 \quad$ DATE: $2 / 9 / 2004$

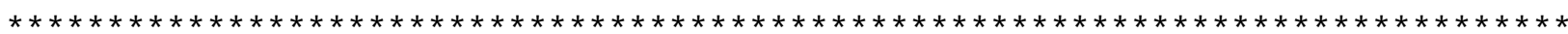
TITLE: UBS Degraded MSE Vault Closure Cap - 38,254 years

NOTE: INITIAL MOISTURE CONTENT OF THE LAYERS AND SNOW WATER WERE SPECIFIED BY THE USER.

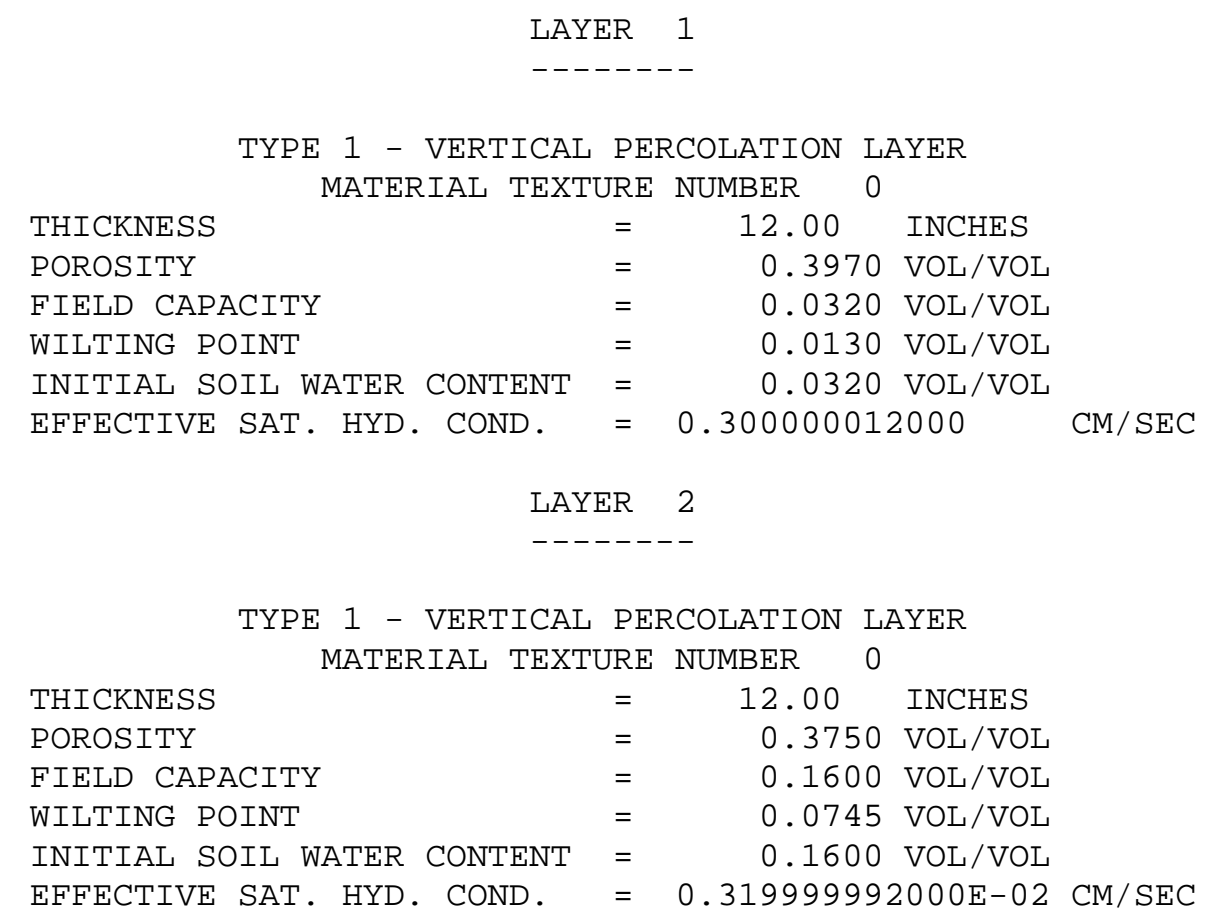

Rev. 0 
LAYER 3

$--------$

TYPE 2 - LATERAL DRAINAGE LAYER

MATERIAL TEXTURE NUMBER 0

\begin{tabular}{|c|c|c|c|c|}
\hline & & & & \\
\hline THICKNESS & $=$ & 12.00 & INCHES & \\
\hline POROSITY & $=$ & 0.3750 & VOL/VOL & \\
\hline FIELD CAPACITY & $=$ & 0.1600 & $\mathrm{VOL} / \mathrm{VOL}$ & \\
\hline WILTING POINT & $=$ & 0.0745 & $\mathrm{VOL} / \mathrm{VOL}$ & \\
\hline INITIAL SOIL WATER CONTENT & $=$ & 0.1600 & $\mathrm{VOL} / \mathrm{VOL}$ & \\
\hline EFFECTIVE SAT. HYD. COND. & $=$ & 0.319999992 & $2000 E-02$ & $\mathrm{CM} / \mathrm{SEC}$ \\
\hline SLOPE & $=$ & 3.00 & PERCENT & \\
\hline DRAINAGE LENGTH & $=$ & 450.0 & FEET & \\
\hline LAY & & 4 & & \\
\hline--- & & & & \\
\hline TYPE 3 - BARR & IER & SOIL LINER & & \\
\hline THICKNESS MATERIAL TEXI & $\begin{array}{l}\text { URE } \\
=\end{array}$ & $\begin{array}{l}\text { NUMBER } \\
0.20\end{array}$ & INCHES & \\
\hline POROSITY & $=$ & 0.3750 & $\mathrm{VOL} / \mathrm{VOL}$ & \\
\hline FIELD CAPACITY & $=$ & 0.1600 & $\mathrm{VOL} / \mathrm{VOL}$ & \\
\hline WILTING POINT & $=$ & 0.0745 & $\mathrm{VOL} / \mathrm{VOL}$ & \\
\hline INITIAL SOIL WATER CONTENT & $=$ & 0.3750 & $\mathrm{VOL} / \mathrm{VOL}$ & \\
\hline EFFECTIVE SAT. HYD. COND. & $=$ & 0.319999992 & $2000 \mathrm{E}-02$ & $\mathrm{CM} / \mathrm{SEC}$ \\
\hline LAY & & 5 & & \\
\hline
\end{tabular}

TYPE 1 - VERTICAL PERCOLATION LAYER MATERIAL TEXTURE NUMBER 0

$\begin{array}{llrl}\text { THICKNESS } & = & 58.57 \mathrm{INCHES} \\ \text { POROSITY } & = & 0.3700 \mathrm{VOL} / \mathrm{VOL} \\ \text { FIELD CAPACITY } & = & 0.2400 \mathrm{VOL} / \mathrm{VOL} \\ \text { WILTING POINT } & = & 0.1360 \mathrm{VOL} / \mathrm{VOL} \\ \text { INITIAL SOIL WATER CONTENT } & = & 0.2400 \mathrm{VOL} / \mathrm{VOL} \\ \text { EFEECTIVE SAT. HYD. COND. } & =0.999999975000 \mathrm{E}-04 \mathrm{CM} / \mathrm{SEC}\end{array}$

LAYER 6

--------

TYPE 2 - LATERAL DRAINAGE LAYER

THICKNESS

MATERIAL TEXTURE NUMBER 0

POROSITY

$=24.00 \quad$ INCHES

FIELD CAPACITY $=0.2100 \mathrm{VOL} / \mathrm{VOL}$

WILTING POINT $=0.2000 \mathrm{VOL} / \mathrm{VOL}$

INITIAL SOIL WATER CONTENT $=0.2100 \mathrm{VOL} / \mathrm{VOL}$

EFFECTIVE SAT. HYD. COND. $=0.999999975000 \mathrm{E}-04 \mathrm{CM} / \mathrm{SEC}$

SLOPE

DRAINAGE LENGTH

$=11.40 \quad$ PERCENT

$=150.0 \quad \mathrm{FEET}$

Rev. 0 
LAYER 7

$--------$

TYPE 3 - BARRIER SOIL LINER

MATERIAL TEXTURE NUMBER 0

$\begin{array}{llll}\text { THICKNESS } & = & 0.20 \mathrm{INCHES} \\ \text { POROSITY } & = & 0.7500 \mathrm{VOL} / \mathrm{VOL} \\ \text { FIELD CAPACITY } & = & 0.7470 \mathrm{VOL} / \mathrm{VOL} \\ \text { WILTING POINT } & = & 0.4000 \mathrm{VOL} / \mathrm{VOL} \\ \text { INITIAL SOIL WATER CONTENT } & = & 0.7500 \mathrm{VOL} / \mathrm{VOL} \\ \text { EFFECTIVE SAT. HYD. COND. } & =0.499999997000 \mathrm{E}-08 \mathrm{CM} / \mathrm{SEC}\end{array}$

GENERAL DESIGN AND EVAPORATIVE ZONE DATA

NOTE: SCS RUNOFF CURVE NUMBER WAS COMPUTED FROM DEFAULT SOIL DATA BASE USING SOIL TEXTURE \# 1 WITH A GOOD STAND OF GRASS, A SURFACE SLOPE OF 3.\% AND A SLOPE LENGTH OF 450. FEET.

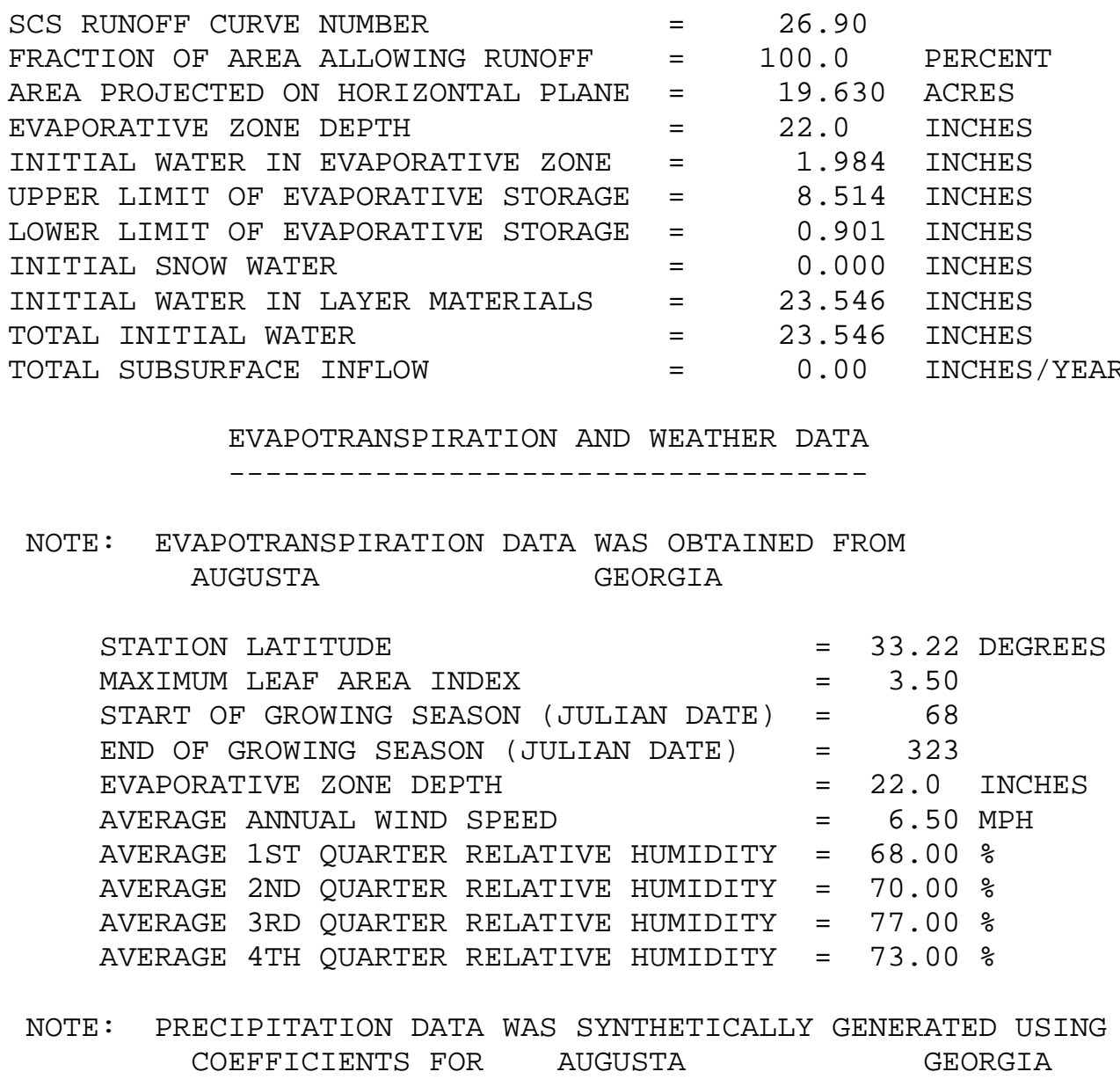


NORMAL MEAN MONTHLY PRECIPITATION (INCHES)

$\begin{array}{cccccc}\text { JAN / JUL } & \text { FEB/AUG } & \text { MAR/SEP } & \text { APR/OCT } & \text { MAY/NOV } & \text { JUN/DEC } \\ ------ & ------ & ------- & ------- & ------- & ------- \\ 4.38 & 3.95 & 4.68 & 2.91 & 3.56 & 4.99 \\ 5.43 & 5.41 & 3.93 & 3.12 & 2.96 & 3.45\end{array}$

NOTE: TEMPERATURE DATA WAS SYNTHETICALLY GENERATED USING COEFFICIENTS FOR AUGUSTA GEORGIA

NORMAL MEAN MONTHLY TEMPERATURE (DEGREES FAHRENHEIT)

$\begin{array}{cccccc}\text { JAN/JUL } & \text { FEB/AUG } & \text { MAR/SEP } & \text { APR/OCT } & \text { MAY/NOV } & \text { JUN/DEC } \\ ------- & ------ & ------ & ------ & ------ & ------- \\ 46.30 & 50.00 & 57.20 & 64.30 & 72.10 & 78.40 \\ 81.60 & 80.30 & 75.20 & 65.10 & 56.70 & 48.80\end{array}$

NOTE: SOLAR RADIATION DATA WAS SYNTHETICALLY GENERATED USING COEFFICIENTS FOR AUGUSTA GEORGIA AND STATION LATITUDE $=33.30$ DEGREES

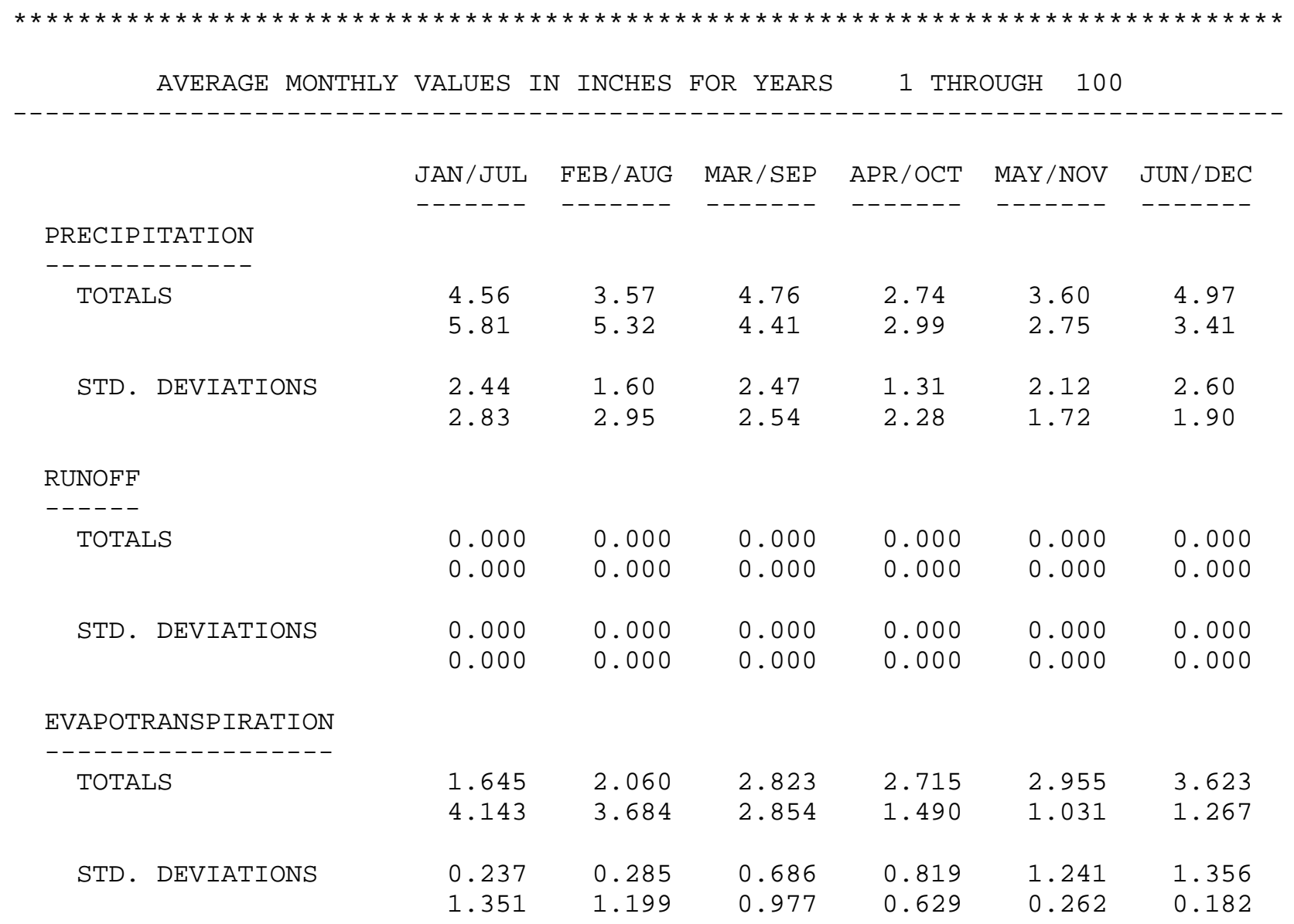




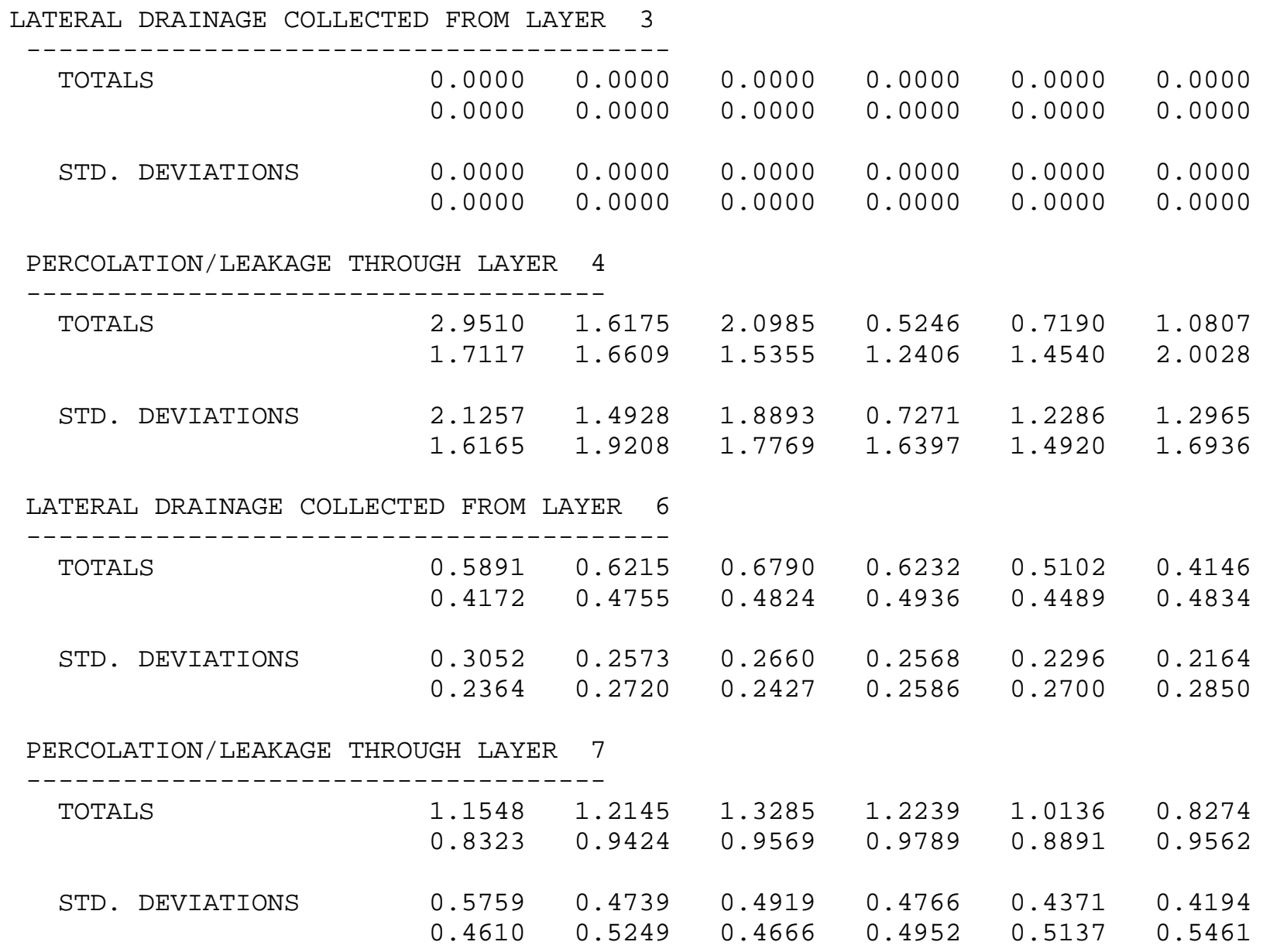

AVERAGES OF MONTHLY AVERAGED DAILY HEADS (INCHES)

DAILY AVERAGE HEAD ON TOP OF LAYER 4

$\begin{array}{lllllll}\text { AVERAGES } & 0.0452 & 0.0249 & 0.0296 & 0.0081 & 0.0096 & 0.0159 \\ & 0.0240 & 0.0221 & 0.0186 & 0.0181 & 0.0223 & 0.0274 \\ \text { STD. DEVIATIONS } & 0.0382 & 0.0251 & 0.0316 & 0.0129 & 0.0177 & 0.0213 \\ & 0.0261 & 0.0270 & 0.0233 & 0.0297 & 0.0278 & 0.0265\end{array}$

DAILY AVERAGE HEAD ON TOP OF LAYER 7

\begin{tabular}{|c|c|c|c|c|c|c|}
\hline AVERAGES & $\begin{array}{l}43.6097 \\
31.3769\end{array}$ & $\begin{array}{l}50.3192 \\
35.5542\end{array}$ & $\begin{array}{l}50.1942 \\
37.3121\end{array}$ & $\begin{array}{l}47.7751 \\
36.9337\end{array}$ & $\begin{array}{l}38.2504 \\
34.6518\end{array}$ & $\begin{array}{l}32.2369 \\
36.0772\end{array}$ \\
\hline STD. DEVIATIONS & $\begin{array}{l}21.8427 \\
17.4825\end{array}$ & $\begin{array}{l}19.6512 \\
19.9018\end{array}$ & $\begin{array}{l}18.6593 \\
18.2875\end{array}$ & $\begin{array}{l}18.6803 \\
18.7808\end{array}$ & $\begin{array}{l}16.5818 \\
20.1343\end{array}$ & $\begin{array}{l}16.4323 \\
20.7074\end{array}$ \\
\hline
\end{tabular}




\begin{tabular}{|c|c|c|c|c|c|c|}
\hline AVERAGE ANNUAL TOTALS \& & \multicolumn{2}{|c|}{ (STD. DEVIATIONS) } & \multicolumn{2}{|c|}{ ) FOR YEARS } & 1 THROUGH & \multirow{2}{*}{$\begin{array}{l}100 \\
\text { PERCENT }\end{array}$} \\
\hline & INCH & HES & & & U. FEET & \\
\hline PRECIPITATION & 48.90 & ( & $7.734)$ & & 484469.2 & 100.00 \\
\hline RUNOFF & 0.000 & $(0$ & $.0000)$ & & 0.00 & 0.000 \\
\hline EVAPOTRANSPIRATION & 30.290 & $(3$ & $3.0661)$ & & 158378.25 & 61.943 \\
\hline $\begin{array}{l}\text { LATERAL DRAINAGE COLLECTED } \\
\text { FROM LAYER } 3\end{array}$ & 0.00002 & $(0$ & $.00001)$ & & 1.422 & 0.00004 \\
\hline $\begin{array}{l}\text { PERCOLATION/LEAKAGE THROUGH } \\
\text { LAYER } 4\end{array}$ & 18.59674 & $(6$ & $.32641)$ & & 325146.250 & 38.03008 \\
\hline $\begin{array}{l}\text { AVERAGE HEAD ON TOP } \\
\text { OF LAYER } 4\end{array}$ & $0.022 \quad($ & & $.008)$ & & & \\
\hline $\begin{array}{l}\text { LATERAL DRAINAGE COLLECTED } \\
\text { FROM LAYER } 6\end{array}$ & 6.23846 & $(1$ & $.96206)$ & & 444533.625 & 12.75757 \\
\hline $\begin{array}{l}\text { PERCOLATION/LEAKAGE THROUGH } \\
\text { LAYER } 7\end{array}$ & 12.31864 & $(3$ & $.71703)$ & & 877787.937 & 25.19144 \\
\hline $\begin{array}{l}\text { AVERAGE HEAD ON TOP } \\
\text { OF LAYER } 7\end{array}$ & $39.524 \quad($ & & $.963)$ & & & \\
\hline CHANGE IN WATER STORAGE & 0.053 & $(3$ & $.0163)$ & & 3768.12 & 0.108 \\
\hline
\end{tabular}




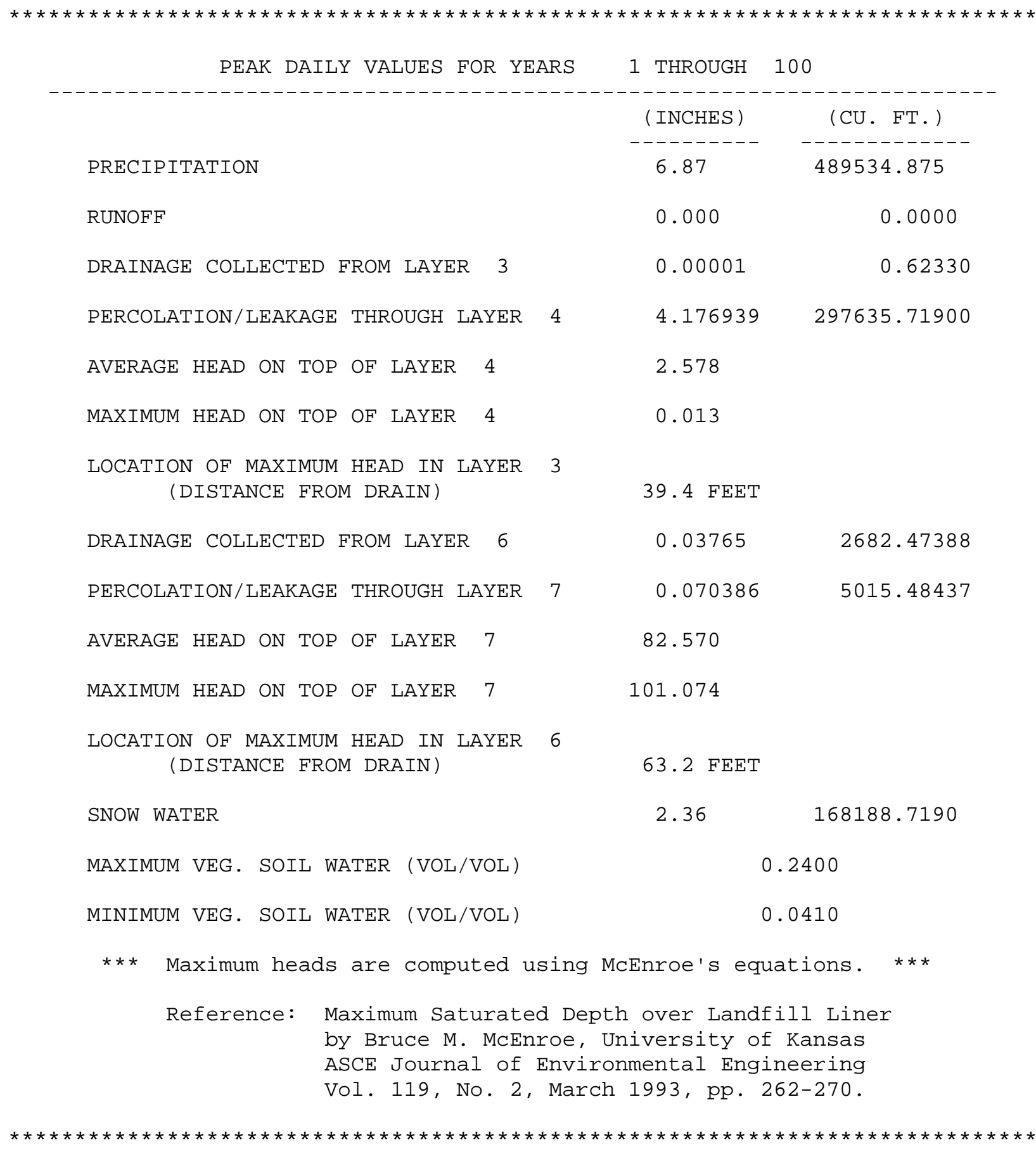

Rev. 0 


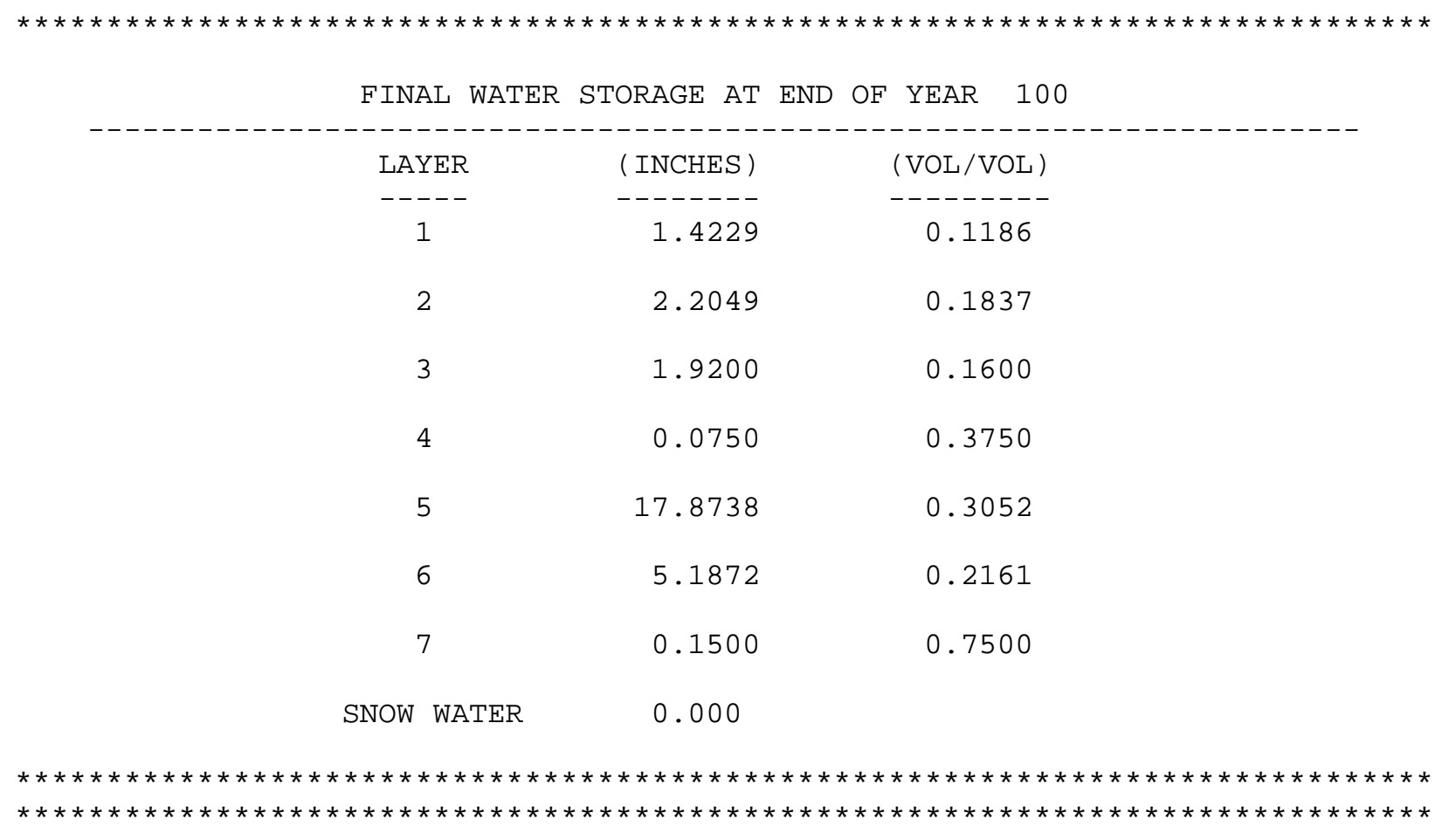


THIS PAGE INTENTIONALLY LEFT BLANK 
Appendix P, Upper Bounding Scenario Degraded SDF MSE Vault Closure Cap (100 Years): HELP Model Input Data and Output File (output file name: ZUBSD1ou.OUT)

\section{Input Data:}

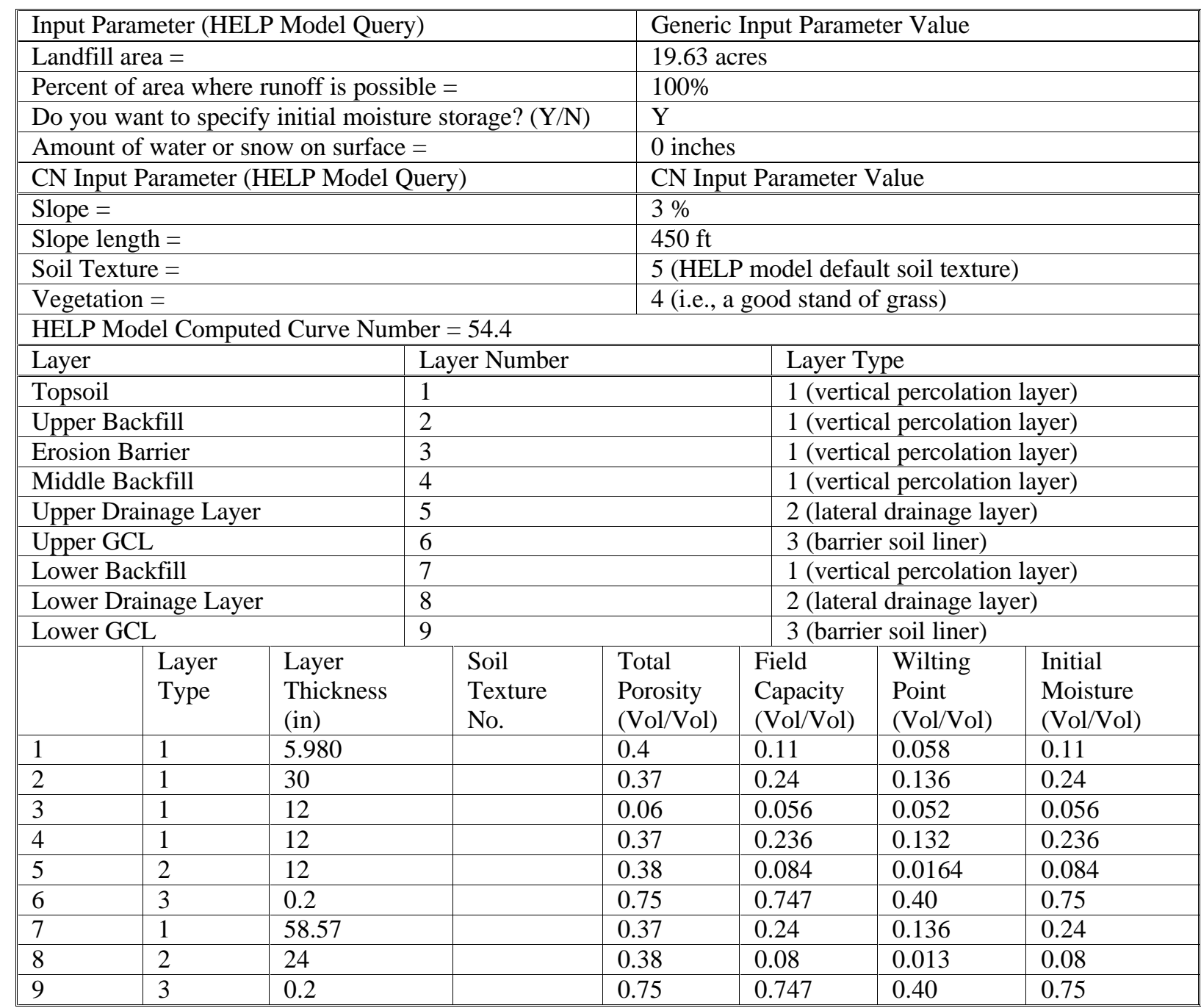

The lack of values in the table for particular parameters in particular layers denotes that no HELP model input was required for that parameter in that layer. No data are missing from the table. 
Input Data (continued):

\begin{tabular}{|c|c|c|c|c|c|c|c|c|c|}
\hline & $\begin{array}{l}\text { Layer } \\
\text { Type }\end{array}$ & $\begin{array}{l}\text { Sat. Hyd. } \\
\text { Conductivity * } \\
(\mathrm{cm} / \mathrm{sec})\end{array}$ & \multicolumn{2}{|c|}{$\begin{array}{l}\text { Drainage } \\
\text { Length } \\
(\mathrm{ft}) \\
\end{array}$} & $\begin{array}{l}\text { Drain } \\
\text { Slope } \\
(\%)\end{array}$ & $\begin{array}{l}\text { Leachate } \\
\text { Recirc. } \\
(\%) \\
\end{array}$ & \multicolumn{2}{|c|}{$\begin{array}{l}\text { Recirc. to } \\
\text { Layer } \\
(\#)\end{array}$} & $\begin{array}{l}\text { Subsurface } \\
\text { Inflow } \\
\text { (in/yr) }\end{array}$ \\
\hline 1 & 1 & $1.00 \mathrm{E}-03$ & & & & & & & \\
\hline 2 & 1 & $1.00 \mathrm{E}-04$ & & & & & & & \\
\hline 3 & 1 & $3.97 \mathrm{E}-04$ & & & & & & & \\
\hline 4 & 1 & $1.20 \mathrm{E}-04$ & & & & & & & \\
\hline 5 & 2 & $8.20 \mathrm{E}-02$ & 450 & & 3 & & & & \\
\hline 6 & 3 & $5.00 \mathrm{E}-09$ & & & & & & & \\
\hline 7 & 1 & $1.00 \mathrm{E}-04$ & & & & & & & \\
\hline 8 & 2 & $1.00 \mathrm{E}-01$ & 150 & & 11.4 & & & & \\
\hline \multirow[t]{2}{*}{9} & 3 & $5.00 \mathrm{E}-09$ & & & & & & \\
\hline & $\begin{array}{l}\text { Layer } \\
\text { Type }\end{array}$ & \multicolumn{2}{|l|}{$\begin{array}{l}\text { Geomembrane } \\
\text { Pinhole Density } \\
\text { (\#/acre) }\end{array}$} & \multicolumn{2}{|c|}{$\begin{array}{l}\text { Geomembrane } \\
\text { Instal. Defects } \\
(\# / \text { acre })\end{array}$} & \multicolumn{2}{|c|}{$\begin{array}{l}\text { Geomembrane } \\
\text { Placement Quality }\end{array}$} & \multicolumn{2}{|c|}{$\begin{array}{l}\text { Geotextile } \\
\text { Transmissivity } \\
\left(\mathrm{cm}^{2} / \mathrm{sec}\right)\end{array}$} \\
\hline 1 & 1 & & & & & & & & \\
\hline 2 & 1 & & & & & & & & \\
\hline 3 & 1 & & & & & & & & \\
\hline 4 & 1 & & & & & & & & \\
\hline 5 & 2 & & & & & & & & \\
\hline 6 & 3 & & & & & & & & \\
\hline 7 & 1 & & & & & & & & \\
\hline 8 & 2 & & & & & & & & \\
\hline 9 & 3 & & & & & & & & \\
\hline
\end{tabular}

The lack of values in the table for particular parameters in particular layers denotes that no HELP model input was required for that parameter in that layer. No data are missing from the table.

* The HELP model output often produces an increased number of significant digits for the Effective Saturated Hydraulic Conductivity over that of the actual input 


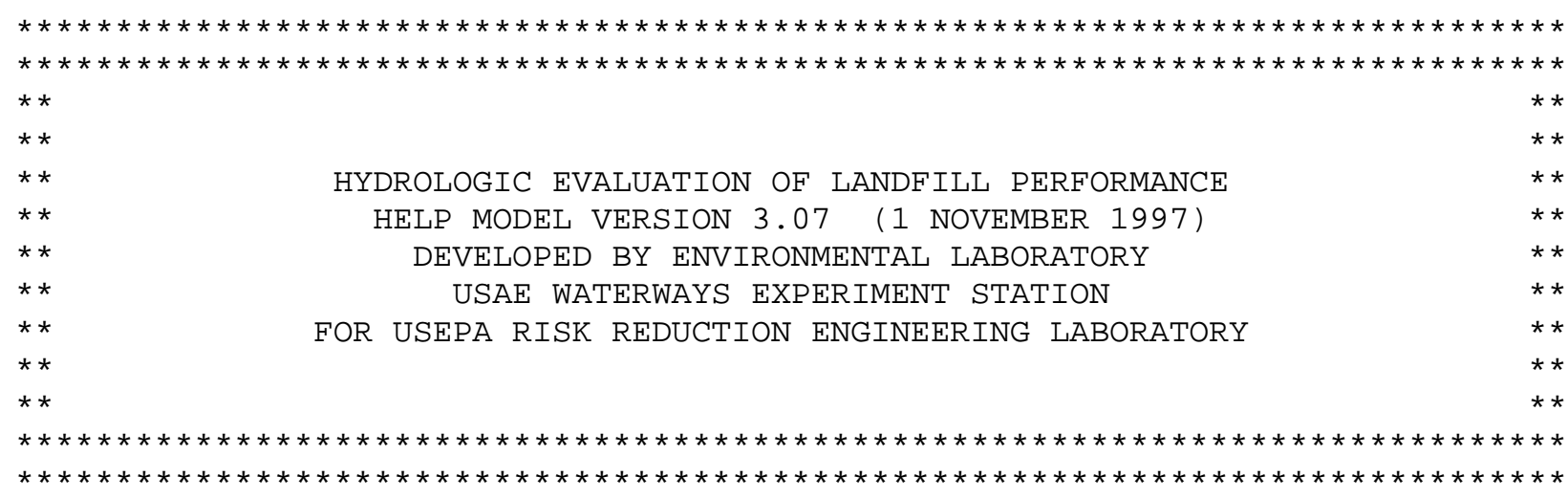

\begin{tabular}{|c|c|}
\hline PRECIPITATION DATA FILE: & $\mathrm{D}: \backslash$ HELP $3 \backslash$ Hweather $\backslash 2$ \\
\hline TEMPERATURE DATA FILE: & D : \HELP $3 \backslash$ Hweather $\backslash \mathrm{ZTEMP}$. D 7 \\
\hline SOLAR RADIATION DATA FILE: & D : \HELP $3 \backslash$ Hweather $\backslash$ ZSOLAR.D13 \\
\hline EVAPOTRANSPIRATION DATA: & D : \HELP $3 \backslash$ Hweat her $\backslash$ ZEVAP . D11 \\
\hline SOIL AND DESIGN DATA FILE: & 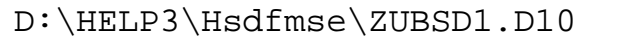 \\
\hline UTPUT DATA FILE: & $\mathrm{D}: \backslash \mathrm{HELP} 3 \backslash$ Hsdfmse $\backslash$ ZUBSD 101 \\
\hline
\end{tabular}

TIME : $14: 10 \quad$ DATE : $1 / 12 / 2004$

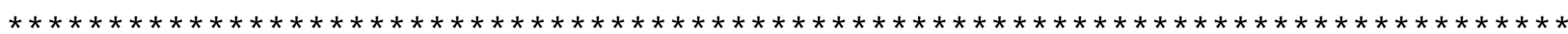
TITLE: UBS Degraded MSE Vault Closure Cap - 100 years

NOTE: INITIAL MOISTURE CONTENT OF THE LAYERS AND SNOW WATER WERE SPECIFIED BY THE USER.

\begin{tabular}{|c|c|c|c|c|}
\hline \multicolumn{5}{|c|}{$\begin{array}{ll}\text { LAYER } & 1 \\
-------\end{array}$} \\
\hline \multicolumn{4}{|c|}{ TYPE 1 - VERTICAL PERCOLATION LAYER } & \\
\hline THICKNESS & $=$ & 5.98 & INCHES & \\
\hline POROSITY & $=$ & 0.4000 & VOL/VOL & \\
\hline FIELD CAPACITY & $=$ & 0.1100 & $\mathrm{VOL} / \mathrm{VOL}$ & \\
\hline WILTING POINT & $=$ & 0.0580 & VOL/VOL & \\
\hline INITIAL SOIL WATER CONTENT & $=$ & 0.1100 & VOL/VOL & \\
\hline EFFECTIVE SAT. HYD. COND. & $=$ & 0.100000005 & $5000 E-02$ & $\mathrm{CM} / \mathrm{SEC}$ \\
\hline \multicolumn{5}{|c|}{ LAYER 2} \\
\hline \multicolumn{5}{|c|}{ TYPE 1 - VERTICAL PERCOLATION LAYER } \\
\hline THICKNESS & $=$ & 30.00 & INCHES & \\
\hline POROSITY & $=$ & 0.3700 & VOL/VOL & \\
\hline FIELD CAPACITY & $=$ & 0.2400 & VOL/VOL & \\
\hline WILTING POINT & $=$ & 0.1360 & VOL/VOL & \\
\hline INITIAL SOIL WATER CONTENT & $=$ & 0.2400 & VOL/VOL & \\
\hline EFFECTIVE SAT. HYD. COND. & $=$ & 0.999999975 & $5000 E-04$ & $\mathrm{Cl}$ \\
\hline
\end{tabular}

Rev. 0 
LAYER 3

--------

TYPE 1 - VERTICAL PERCOLATION LAYER

MATERIAL TEXTURE NUMBER 0

$\begin{array}{llrl}\text { THICKNESS } & = & 12.00 \mathrm{INCHES} \\ \text { POROSITY } & = & 0.0600 \mathrm{VOL} / \mathrm{VOL} \\ \text { FIELD CAPACITY } & = & 0.0560 \mathrm{VOL} / \mathrm{VOL} \\ \text { WILTING POINT } & = & 0.0520 \mathrm{VOL} / \mathrm{VOL} \\ \text { INITIAL SOIL WATER CONTENT } & = & 0.0560 \mathrm{VOL} / \mathrm{VOL} \\ \text { EFFECTIVE SAT. HYD. COND. } & =0.396999996000 \mathrm{E}-03 \mathrm{CM} / \mathrm{SEC}\end{array}$

LAYER 4

TYPE 1 - VERTICAL PERCOLATION LAYER MATERIAL TEXTURE NUMBER 0

$\begin{array}{llrl}\text { THICKNESS } & = & 12.00 \mathrm{INCHES} \\ \text { POROSITY } & = & 0.3700 \mathrm{VOL} / \mathrm{VOL} \\ \text { FIELD CAPACITY } & = & 0.2360 \mathrm{VOL} / \mathrm{VOL} \\ \text { WILTING POINT } & = & 0.1320 \mathrm{VOL} / \mathrm{VOL} \\ \text { INITIAL SOIL WATER CONTENT } & = & 0.2360 \mathrm{VOL} / \mathrm{VOL} \\ \text { EFFECTIVE SAT. HYD. COND. } & =0.11999999000 \mathrm{E}-03 \mathrm{CM} / \mathrm{SEC}\end{array}$

LAYER 5

$--------$

TYPE 2 - LATERAL DRAINAGE LAYER MATERIAL TEXTURE NUMBER 0

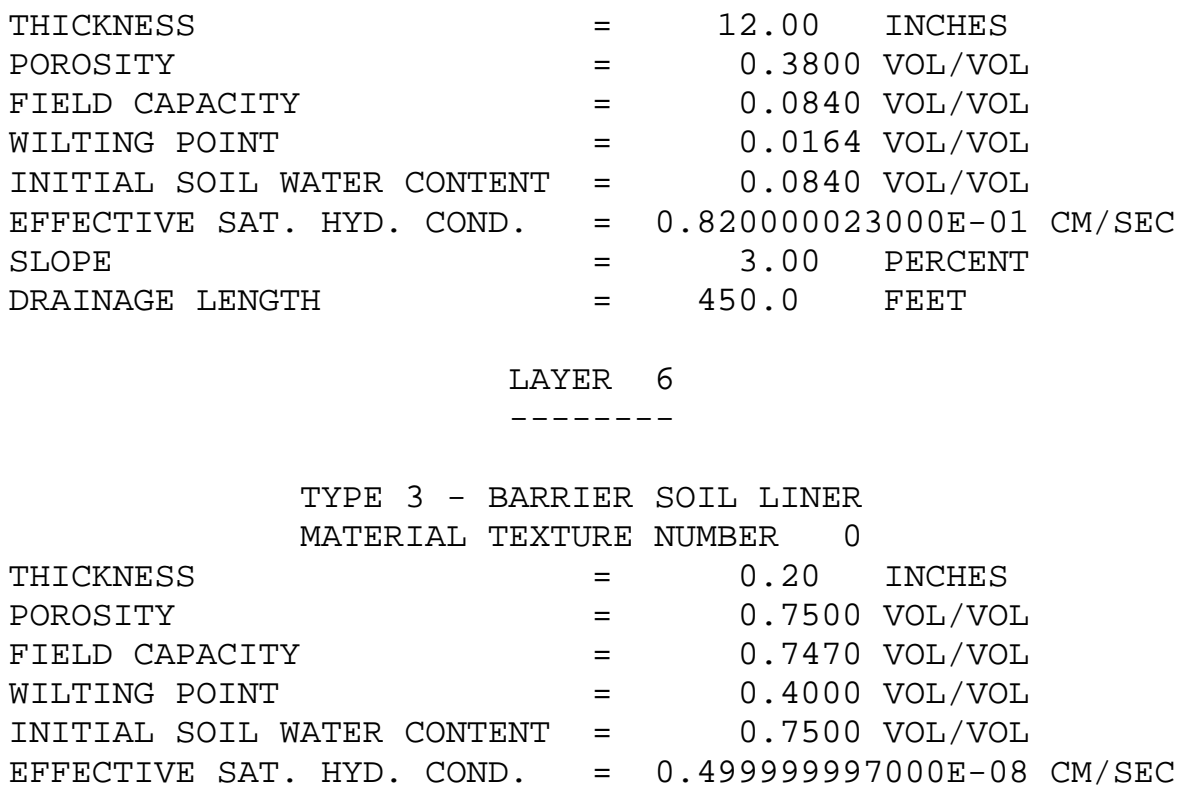

Rev. 0 
LAYER 7

$--------$

TYPE 1 - VERTICAL PERCOLATION LAYER

MATERIAL TEXTURE NUMBER 0

$\begin{array}{llrl}\text { THICKNESS } & = & 58.57 & \text { INCHES } \\ \text { POROSITY } & = & 0.3700 \mathrm{VOL} / \mathrm{VOL} \\ \text { FIELD CAPACITY } & = & 0.2400 \mathrm{VOL} / \mathrm{VOL} \\ \text { WILTING POINT } & = & 0.1360 \mathrm{VOL} / \mathrm{VOL} \\ \text { INITIAL SOIL WATER CONTENT } & = & 0.2400 \mathrm{VOL} / \mathrm{VOL} \\ \text { EFFECTIVE SAT. HYD. COND. } & =0.999999975000 \mathrm{E}-04 \mathrm{CM} / \mathrm{SEC}\end{array}$

LAYER 8

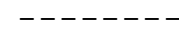

TYPE 2 - LATERAL DRAINAGE LAYER

$\begin{array}{llrl}\text { THICKNESS } & = & 24.00 & \text { INCHES } \\ \text { POROSITY } & = & 0.3800 \mathrm{VOL} / \mathrm{VOL} \\ \text { FIELD CAPACITY } & = & 0.0800 \mathrm{VOL} / \mathrm{VOL} \\ \text { WILTING POINT } & = & 0.0130 \mathrm{VOL} / \mathrm{VOL} \\ \text { INITIAL SOIL WATER CONTENT } & = & 0.0800 \mathrm{VOL} / \mathrm{VOL} \\ \text { EFFECTIVE SAT. HYD. COND. } & = & 0.10000001000 & \mathrm{CM} / \mathrm{SEC} \\ \text { SLOPE } & = & 11.40 \mathrm{PERCENT} & \\ \text { DRAINAGE LENGTH } & = & 150.0 & \mathrm{FEET}\end{array}$

LAYER 9

TYPE 3 - BARRIER SOIL LINER

MATERIAL TEXTURE NUMBER 0

$\begin{array}{llll}\text { THICKNESS } & = & 0.20 & \text { INCHES } \\ \text { POROSITY } & = & 0.7500 \mathrm{VOL} / \mathrm{VOL} \\ \text { FIELD CAPACITY } & = & 0.7470 \mathrm{VOL} / \mathrm{VOL} \\ \text { WILTING POINT } & = & 0.4000 \mathrm{VOL} / \mathrm{VOL} \\ \text { INITIAL SOIL WATER CONTENT } & = & 0.7500 \mathrm{VOL} / \mathrm{VOL} \\ \text { EFFECTIVE SAT. HYD. COND. } & =0.499999997000 \mathrm{E}-08 \mathrm{CM} / \mathrm{SEC}\end{array}$

GENERAL DESIGN AND EVAPORATIVE ZONE DATA

NOTE: SCS RUNOFF CURVE NUMBER WAS COMPUTED FROM DEFAULT SOIL DATA BASE USING SOIL TEXTURE \# 5 WITH A GOOD STAND OF GRASS, A SURFACE SLOPE OF 3.\% AND A SLOPE LENGTH OF 450. FEET.

SCS RUNOFF CURVE NUMBER

FRACTION OF AREA ALLOWING RUNOFF

AREA PROJECTED ON HORIZONTAL PLANE

EVAPORATIVE ZONE DEPTH

INITIAL WATER IN EVAPORATIVE ZONE

UPPER LIMIT OF EVAPORATIVE STORAGE

LOWER LIMIT OF EVAPORATIVE STORAGE

INITIAL SNOW WATER

INITIAL WATER IN LAYER MATERIALS

TOTAL INITIAL WATER

TOTAL SUBSURFACE INFLOW

$\begin{array}{lcl}= & 54.40 & \\ = & 100.0 & \text { PERCENT } \\ = & 19.630 & \text { ACRES } \\ = & 22.0 & \text { INCHES } \\ = & 4.503 & \text { INCHES } \\ = & 8.319 & \text { INCHES } \\ = & 2.526 & \text { INCHES } \\ = & 0.000 & \text { INCHES } \\ = & 28.647 & \text { INCHES } \\ = & 28.647 & \text { INCHES } \\ = & 0.00 & \text { INCHES /YEAR }\end{array}$

Rev. 0 


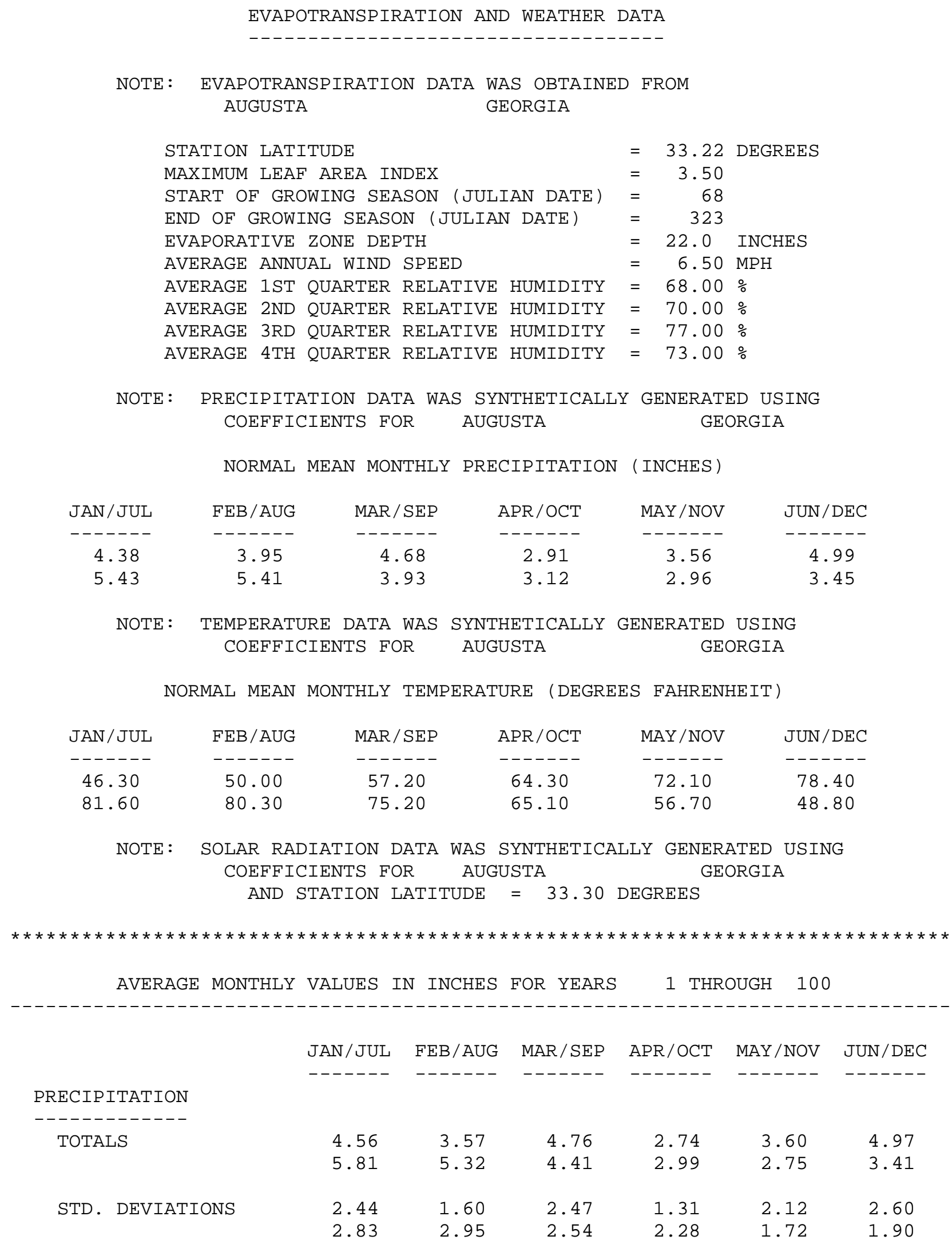

Rev. 0 
RUNOFF

\begin{tabular}{|c|c|c|c|c|c|c|}
\hline TOTALS & $\begin{array}{l}0.004 \\
0.027\end{array}$ & $\begin{array}{l}0.000 \\
0.091\end{array}$ & $\begin{array}{l}0.004 \\
0.016\end{array}$ & $\begin{array}{l}0.000 \\
0.006\end{array}$ & $\begin{array}{l}0.000 \\
0.002\end{array}$ & $\begin{array}{l}0.002 \\
0.001\end{array}$ \\
\hline STD. DEVIATIONS & $\begin{array}{l}0.020 \\
0.093\end{array}$ & $\begin{array}{l}0.000 \\
0.404\end{array}$ & $\begin{array}{l}0.027 \\
0.086\end{array}$ & $\begin{array}{l}0.000 \\
0.058\end{array}$ & $\begin{array}{l}0.002 \\
0.015\end{array}$ & $\begin{array}{l}0.015 \\
0.004\end{array}$ \\
\hline \multicolumn{7}{|l|}{ EVAPOTRANSP IRATION } \\
\hline TOTALS & $\begin{array}{l}1.577 \\
4.898\end{array}$ & $\begin{array}{l}2.093 \\
4.520\end{array}$ & $\begin{array}{l}3.072 \\
3.385\end{array}$ & $\begin{array}{l}3.553 \\
1.619\end{array}$ & $\begin{array}{l}3.657 \\
0.948\end{array}$ & $\begin{array}{l}4.141 \\
1.115\end{array}$ \\
\hline STD. DEVIATIONS & $\begin{array}{l}0.221 \\
1.589\end{array}$ & $\begin{array}{l}0.236 \\
1.377\end{array}$ & $\begin{array}{l}0.582 \\
1.040\end{array}$ & $\begin{array}{l}0.761 \\
0.606\end{array}$ & $\begin{array}{l}1.521 \\
0.207\end{array}$ & $\begin{array}{l}1.545 \\
0.205\end{array}$ \\
\hline \multicolumn{7}{|c|}{ LATERAL DRAINAGE COLLECTED FROM LAYER 5} \\
\hline TOTALS & $\begin{array}{l}2.4473 \\
0.5422\end{array}$ & $\begin{array}{l}2.0838 \\
0.8056\end{array}$ & $\begin{array}{l}1.9296 \\
0.7456\end{array}$ & $\begin{array}{l}1.2481 \\
0.7750\end{array}$ & $\begin{array}{l}0.4364 \\
0.8928\end{array}$ & $\begin{array}{l}0.3120 \\
1.4653\end{array}$ \\
\hline STD. DEVIATIONS & $\begin{array}{l}1.7695 \\
0.7744\end{array}$ & $\begin{array}{l}1.4993 \\
1.0088\end{array}$ & $\begin{array}{l}1.4379 \\
0.9990\end{array}$ & $\begin{array}{l}1.0556 \\
1.0513\end{array}$ & $\begin{array}{l}0.4450 \\
1.1885\end{array}$ & $\begin{array}{l}0.5670 \\
1.2857\end{array}$ \\
\hline \multicolumn{7}{|c|}{ PERCOLATION/LEAKAGE THROUGH LAYER 6} \\
\hline TOTALS & $\begin{array}{l}0.0736 \\
0.0186\end{array}$ & $\begin{array}{l}0.0626 \\
0.0262\end{array}$ & $\begin{array}{l}0.0583 \\
0.0247\end{array}$ & $\begin{array}{l}0.0397 \\
0.0253\end{array}$ & $\begin{array}{l}0.0170 \\
0.0282\end{array}$ & $\begin{array}{l}0.0126 \\
0.0445\end{array}$ \\
\hline STD. DEVIATIONS & $\begin{array}{l}0.0531 \\
0.0222\end{array}$ & $\begin{array}{l}0.0439 \\
0.0286\end{array}$ & $\begin{array}{l}0.0397 \\
0.0288\end{array}$ & $\begin{array}{l}0.0307 \\
0.0301\end{array}$ & $\begin{array}{l}0.0125 \\
0.0336\end{array}$ & $\begin{array}{l}0.0162 \\
0.0364\end{array}$ \\
\hline \multicolumn{7}{|c|}{ LATERAL DRAINAGE COLLECTED FROM LAYER 8} \\
\hline TOTALS & $\begin{array}{l}0.0588 \\
0.0146\end{array}$ & $\begin{array}{l}0.0548 \\
0.0214\end{array}$ & $\begin{array}{l}0.0579 \\
0.0195\end{array}$ & $\begin{array}{l}0.0421 \\
0.0213\end{array}$ & $\begin{array}{l}0.0155 \\
0.0242\end{array}$ & $\begin{array}{l}0.0085 \\
0.0394\end{array}$ \\
\hline STD. DEVIATIONS & $\begin{array}{l}0.0362 \\
0.0206\end{array}$ & $\begin{array}{l}0.0336 \\
0.0261\end{array}$ & $\begin{array}{l}0.0426 \\
0.0248\end{array}$ & $\begin{array}{l}0.0421 \\
0.0274\end{array}$ & $\begin{array}{l}0.0247 \\
0.0312\end{array}$ & $\begin{array}{l}0.0155 \\
0.0332\end{array}$ \\
\hline $\begin{array}{l}\text { PERCOLATION/LEAKAGE } \\
-----------------1\end{array}$ & UGH LAYER & $\begin{array}{r}9 \\
---\end{array}$ & & & & \\
\hline TOTALS & $\begin{array}{l}0.0051 \\
0.0038\end{array}$ & $\begin{array}{l}0.0049 \\
0.0041\end{array}$ & $\begin{array}{l}0.0054 \\
0.0040\end{array}$ & $\begin{array}{l}0.0051 \\
0.0040\end{array}$ & $\begin{array}{l}0.0050 \\
0.0038\end{array}$ & $\begin{array}{l}0.0040 \\
0.0043\end{array}$ \\
\hline STD. DEVIAI & $\begin{array}{l}0.0009 \\
0.0020\end{array}$ & $\begin{array}{l}0.0002 \\
0.0020\end{array}$ & $\begin{array}{l}0.0003 \\
0.0019\end{array}$ & $\begin{array}{l}0.0005 \\
0.0020\end{array}$ & $\begin{array}{l}0.0009 \\
0.0021\end{array}$ & $\begin{array}{l}0.0017 \\
0.0019\end{array}$ \\
\hline
\end{tabular}




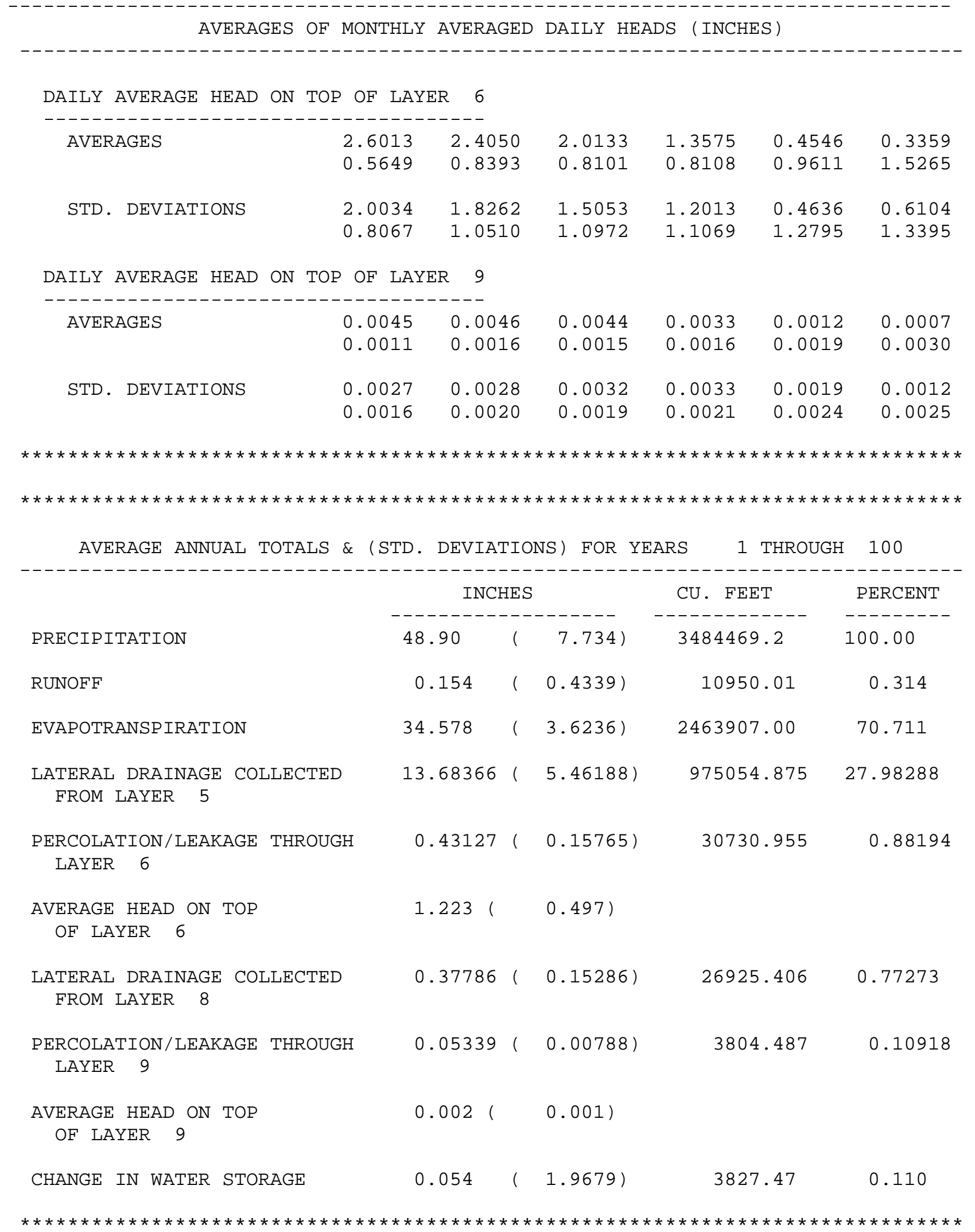




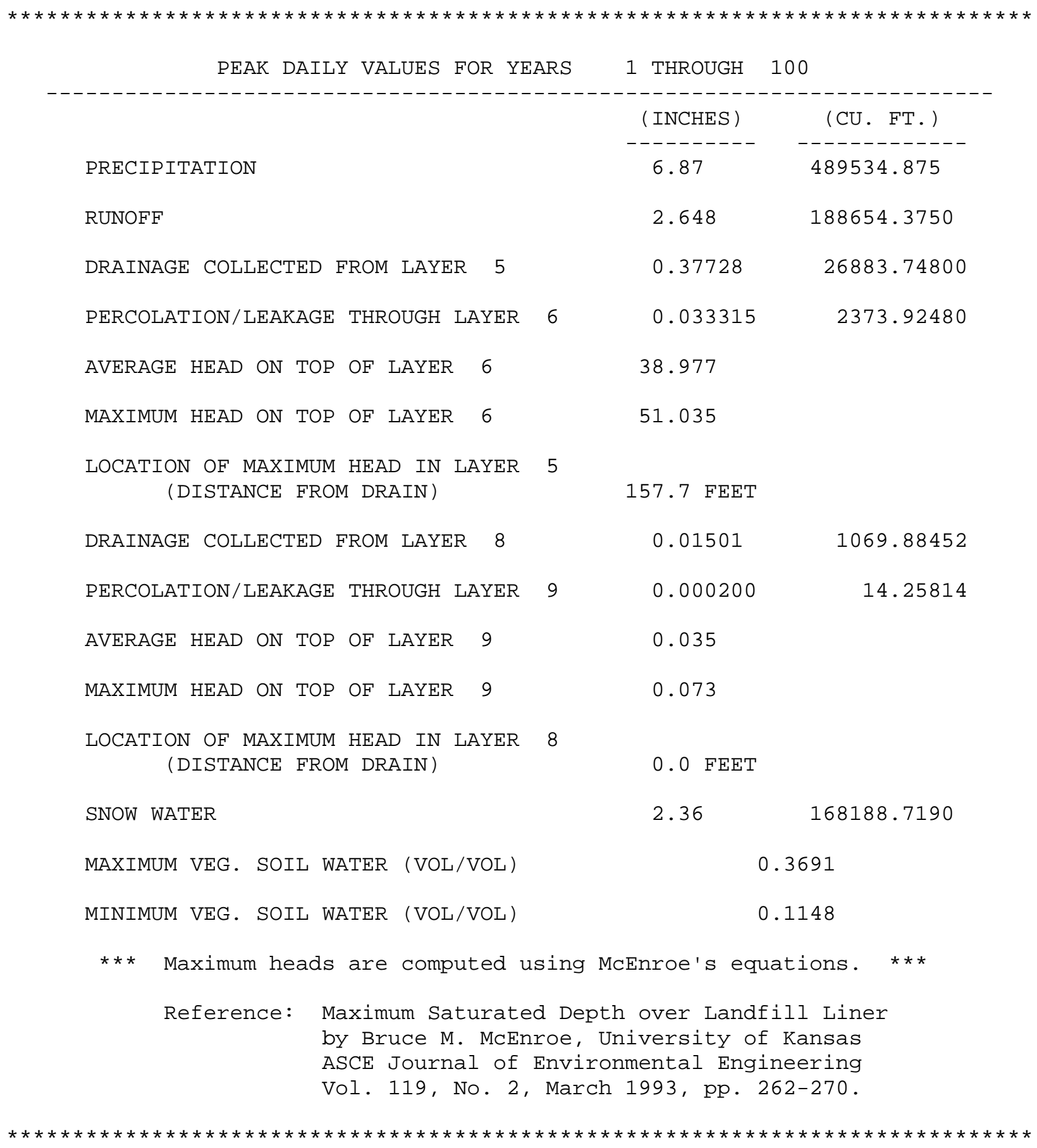

Rev. 0 


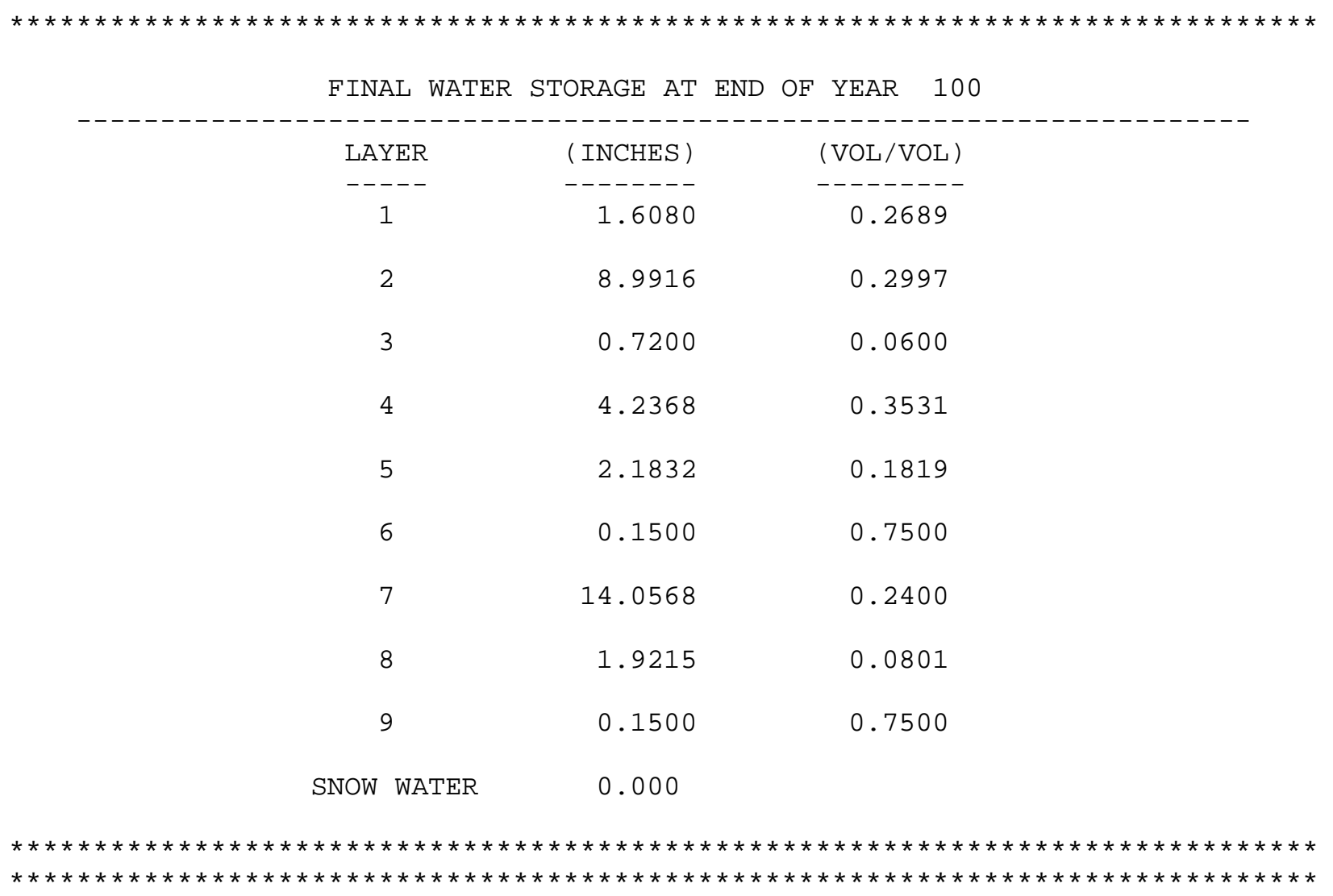


Appendix Q, Upper Bounding Scenario Degraded SDF MSE Vault Closure Cap (154 Years): HELP Model Input Data and Output File (output file name: ZUBSD2ou.OUT)

\section{Input Data:}

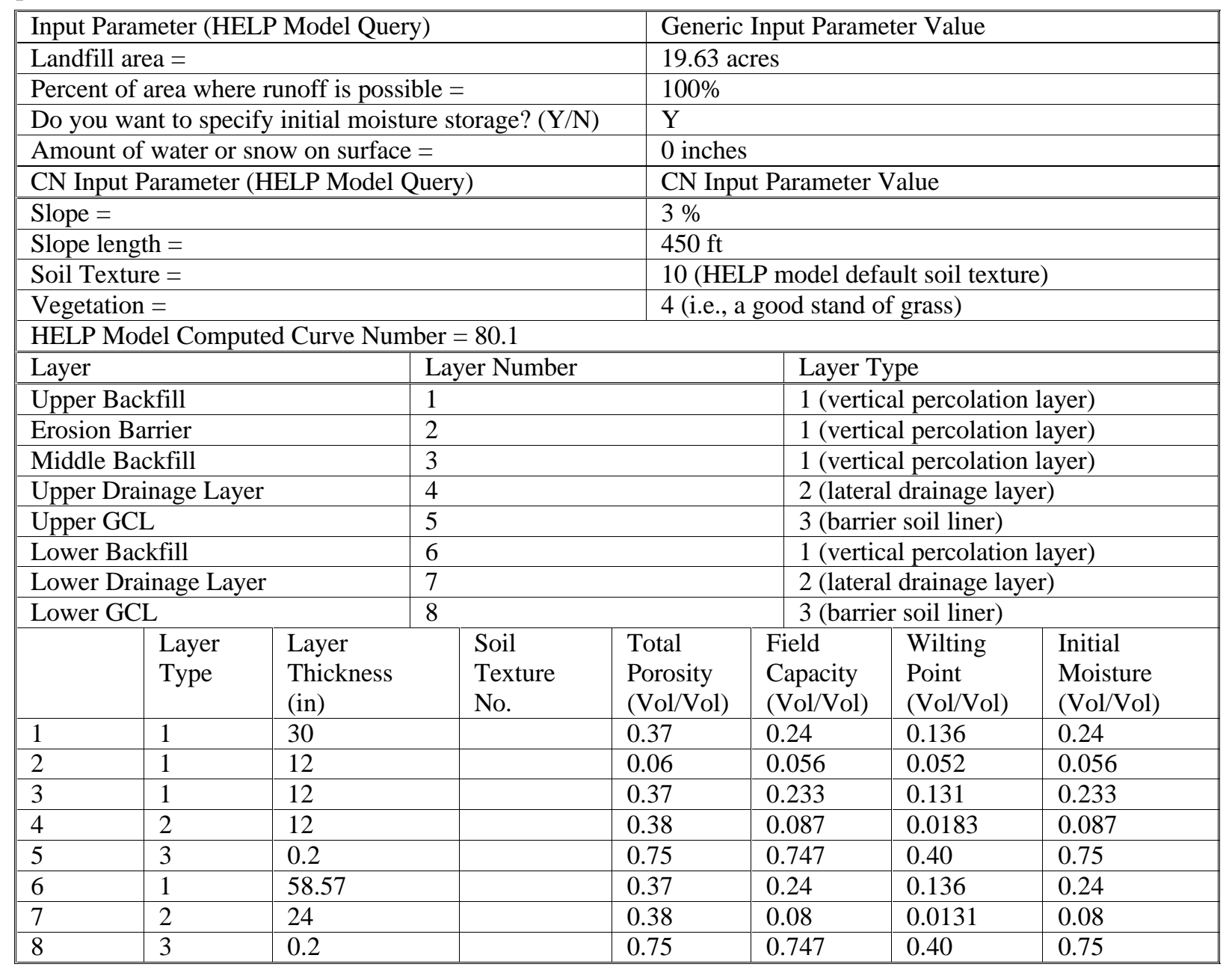

The lack of values in the table for particular parameters in particular layers denotes that no HELP model input was required for that parameter in that layer. No data are missing from the table. 
Input Data (continued):

\begin{tabular}{|c|c|c|c|c|c|c|c|c|c|}
\hline & $\begin{array}{l}\text { Layer } \\
\text { Type }\end{array}$ & \multirow{2}{*}{$\begin{array}{l}\text { Sat. Hyd. } \\
\text { Conductivity * } \\
(\mathrm{cm} / \mathrm{sec})\end{array}$} & \multicolumn{2}{|c|}{$\begin{array}{l}\text { Drainage } \\
\text { Length } \\
\text { (ft) }\end{array}$} & \multirow[t]{2}{*}{$\begin{array}{l}\text { Drain } \\
\text { Slope } \\
(\%) \\
\end{array}$} & \multirow[t]{2}{*}{$\begin{array}{l}\text { Leachate } \\
\text { Recirc. } \\
(\%) \\
\end{array}$} & \multicolumn{2}{|c|}{$\begin{array}{l}\text { Recirc. to } \\
\text { Layer } \\
(\#)\end{array}$} & \multirow[t]{2}{*}{$\begin{array}{l}\text { Subsurface } \\
\text { Inflow } \\
\text { (in/yr) }\end{array}$} \\
\hline 1 & 1 & & & & & & & \\
\hline 2 & 1 & $3.97 \mathrm{E}-04$ & & & & & & \\
\hline 3 & 1 & $1.40 \mathrm{E}-04$ & & & & & \multicolumn{2}{|c|}{ 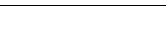 } & \\
\hline 4 & 2 & $7.40 \mathrm{E}-02$ & 450 & & 3 & & \multicolumn{2}{|c|}{ 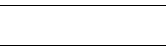 } & \\
\hline 5 & 3 & $5.00 \mathrm{E}-09$ & & & & & \multicolumn{2}{|c|}{ 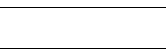 } & \\
\hline 6 & 1 & $1.00 \mathrm{E}-04$ & & & & & & & \\
\hline 7 & 2 & $1.00 \mathrm{E}-01$ & 150 & & 11.4 & & & & \\
\hline 8 & 3 & $5.00 \mathrm{E}-09$ & & & & & & & \\
\hline & $\begin{array}{l}\text { Layer } \\
\text { Type }\end{array}$ & \multicolumn{2}{|l|}{$\begin{array}{l}\text { Geomembrane } \\
\text { Pinhole Density } \\
\text { (\#/acre) }\end{array}$} & $\begin{array}{l}\mathrm{Ge} \\
\mathrm{Ins} \\
(\# / \mathrm{c}\end{array}$ & $\begin{array}{l}\text { mbrane } \\
\text { Defects }\end{array}$ & \multicolumn{2}{|c|}{$\begin{array}{l}\text { Geomembrane } \\
\text { Placement Quality }\end{array}$} & \multicolumn{2}{|c|}{$\begin{array}{l}\text { Geotextile } \\
\text { Transmissivity } \\
\left(\mathrm{cm}^{2} / \mathrm{sec}\right)\end{array}$} \\
\hline 1 & 1 & & & & & & & & \\
\hline 2 & 1 & & & & & & & & \\
\hline 3 & 1 & & & & & & & & \\
\hline 4 & 2 & & & & & & & & \\
\hline 5 & 3 & & & & & & & & \\
\hline 6 & 1 & & & & & & & & \\
\hline 7 & 2 & & & & & & & & \\
\hline 8 & 3 & & & & & & & & \\
\hline
\end{tabular}

The lack of values in the table for particular parameters in particular layers denotes that no HELP model input was required for that parameter in that layer. No data are missing from the table.

* The HELP model output often produces an increased number of significant digits for the Effective Saturated Hydraulic Conductivity over that of the actual input 


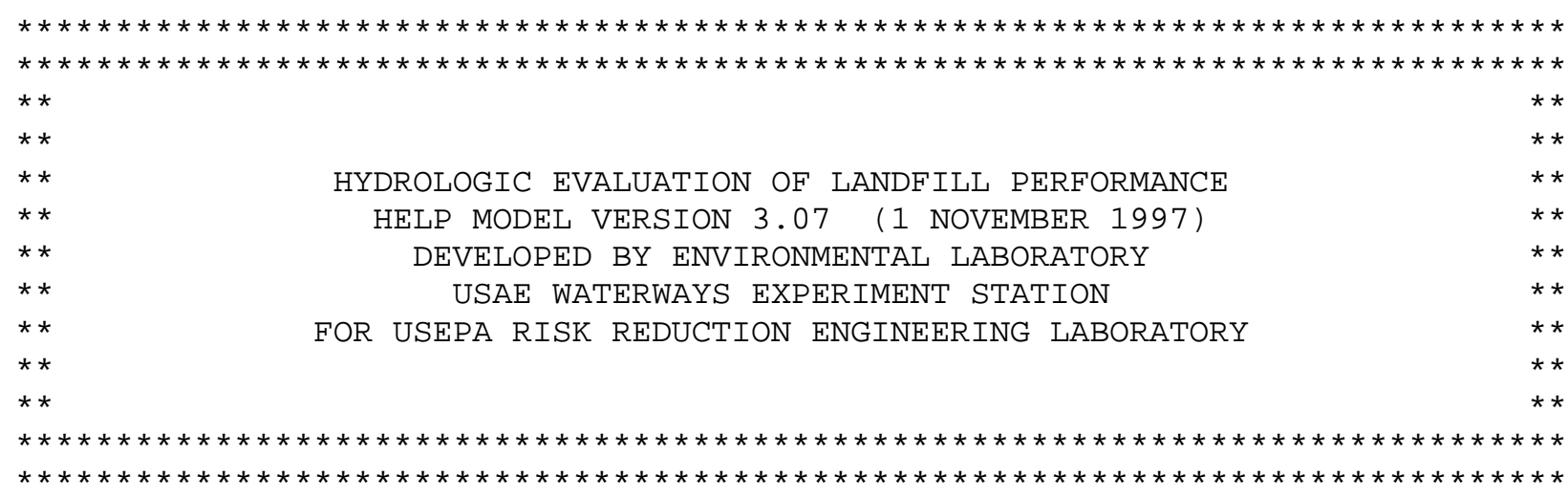

\begin{tabular}{|c|c|}
\hline PRECIPITATION DATA FILE: & $\mathrm{D}: \backslash$ HELP $3 \backslash$ Hweather $\backslash 2$ \\
\hline TEMPERATURE DATA FILE: & D : \HELP $3 \backslash$ Hweather $\backslash \mathrm{ZTEMP}$. D 7 \\
\hline SOLAR RADIATION DATA FILE: & D : \HELP $3 \backslash$ Hweather $\backslash$ ZSOLAR.D13 \\
\hline EVAPOTRANSPIRATION DATA: & D : \HELP $3 \backslash$ Hweat her $\backslash$ ZEVAP . D11 \\
\hline SOIL AND DESIGN DATA FILE: & 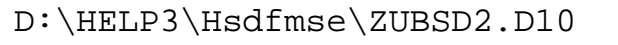 \\
\hline UTPUT DATA FILE: & $\mathrm{D}: \backslash \mathrm{HELP} 3 \backslash \mathrm{Hsdfmse \backslash ZUBSD2O}$ \\
\hline
\end{tabular}

TIME : $13: 38 \quad$ DATE $: \quad 1 / 13 / 2004$

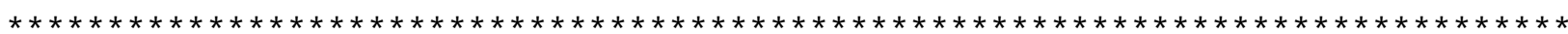
TITLE: UBS Degraded MSE Vault Closure Cap - 154 years

NOTE: INITIAL MOISTURE CONTENT OF THE LAYERS AND SNOW WATER WERE SPECIFIED BY THE USER.

\begin{tabular}{|c|c|c|c|c|}
\hline \multicolumn{5}{|c|}{ LAYER 1} \\
\hline \multicolumn{5}{|c|}{ TYPE 1 - VERTICAL PERCOLATION LAYER } \\
\hline THICKNESS & $=$ & 30.00 & INCHES & \\
\hline POROSITY & $=$ & 0.3700 & VOL/VOL & \\
\hline FIELD CAPACITY & $=$ & 0.2400 & $\mathrm{VOL} / \mathrm{VOL}$ & \\
\hline WILTING POINT & $=$ & 0.1360 & VOL/VOL & \\
\hline INITIAL SOIL WATER CONTENT & $=$ & 0.2400 & VOL/VOL & \\
\hline EFFECTIVE SAT. HYD. COND. & $=$ & 0.999999975 & $5000 \mathrm{E}-04$ & $\mathrm{CM} / \mathrm{SEC}$ \\
\hline \multicolumn{5}{|c|}{ LAYER 2} \\
\hline \multicolumn{5}{|c|}{ TYPE 1 - VERTICAL PERCOLATION LAYER } \\
\hline THICKNESS & $=$ & 12.00 & INCHES & \\
\hline POROSITY & $=$ & 0.0600 & VOL/VOL & \\
\hline FIELD CAPACITY & $=$ & 0.0560 & VOL/VOL & \\
\hline WILTING POINT & $=$ & 0.0520 & VOL/VOL & \\
\hline INITIAL SOIL WATER CONTENT & $=$ & 0.0560 & VOL/VOL & \\
\hline EFFECTIVE SAT. HYD. COND. & $=$ & 0.396999996 & $6000 E-03$ & $\left(\mathbb{N}_{1}\right)$ \\
\hline
\end{tabular}

Rev. 0 
LAYER 3

$--------$

TYPE 1 - VERTICAL PERCOLATION LAYER

MATERIAL TEXTURE NUMBER 0

\begin{tabular}{|c|c|c|c|c|}
\hline THICKNESS & $=$ & 12.00 & INCHES & \\
\hline POROSITY & $=$ & 0.3700 & $\mathrm{VOL} / \mathrm{VOL}$ & \\
\hline FIELD CAPACITY & $=$ & 0.2330 & $\mathrm{VOL} / \mathrm{VOL}$ & \\
\hline WILTING POINT & $=$ & 0.1310 & $\mathrm{VOL} / \mathrm{VOL}$ & \\
\hline INITIAL SOIL WATER CONTENT & $=$ & 0.2330 & $\mathrm{VOL} / \mathrm{VOL}$ & \\
\hline EFFECTIVE SAT. HYD. COND. & $=$ & 0.140000004 & $4000 \mathrm{E}-03$ & $\mathrm{CM} / \mathrm{SEC}$ \\
\hline LAY & $\mathrm{ER}$ & 4 & & \\
\hline--- & --- & & & \\
\hline TYPE 2 - LATERA & $L \mathrm{DR}$ & RAINAGE LAYE & & \\
\hline MATERIAL TEXT & URE & NUMBER & & \\
\hline THICKNESS & $=$ & 12.00 & INCHES & \\
\hline POROSITY & $=$ & 0.3800 & $\mathrm{VOL} / \mathrm{VOL}$ & \\
\hline FIELD CAPACITY & $=$ & 0.0870 & $\mathrm{VOL} / \mathrm{VOL}$ & \\
\hline WILTING POINT & $=$ & 0.0183 & $\mathrm{VOL} / \mathrm{VOL}$ & \\
\hline INITIAL SOIL WATER CONTENT & $=$ & 0.0870 & $\mathrm{VOL} / \mathrm{VOL}$ & \\
\hline EFFECTIVE SAT. HYD. COND. & $=$ & 0.740000010 & $0000 \mathrm{E}-01$ & $\mathrm{CM} / \mathrm{SEC}$ \\
\hline SLOPE & $=$ & 3.00 & PERCENT & \\
\hline DRAINAGE LENGTH & $=$ & 450.0 & FEET & \\
\hline
\end{tabular}

LAYER 5

TYPE 3 - BARRIER SOIL LINER

MATERIAL TEXTURE NUMBER 0

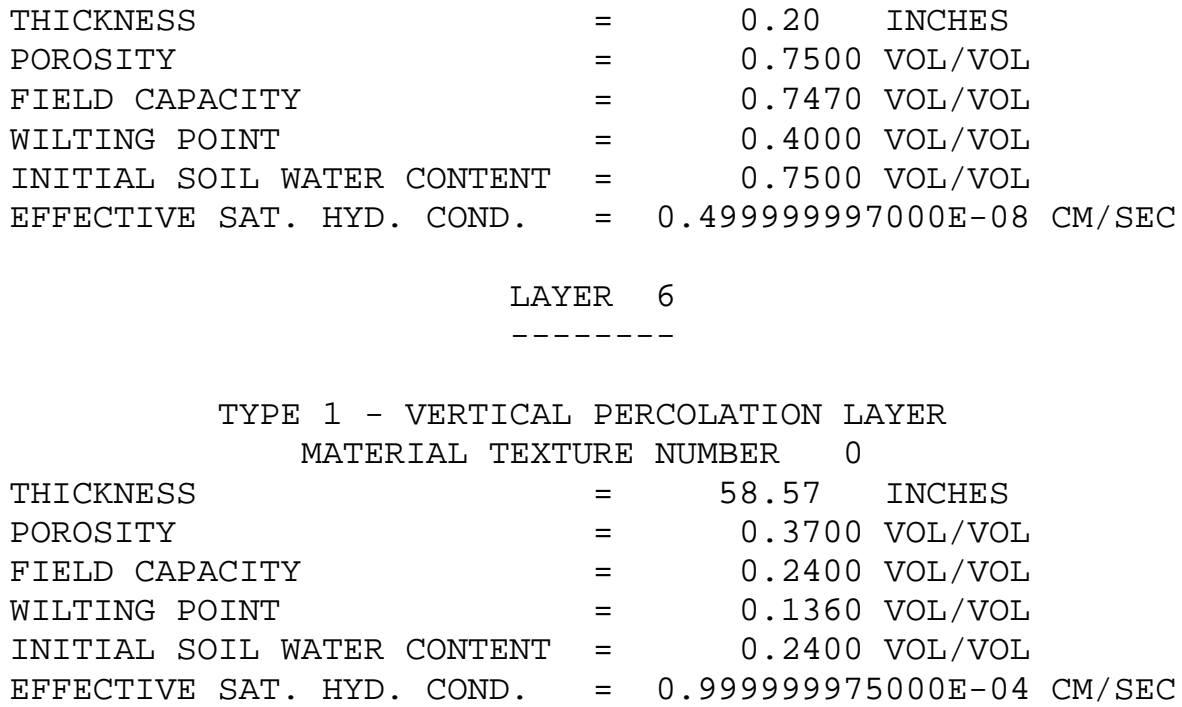

Rev. 0 
LAYER 7

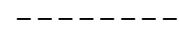

TYPE 2 - LATERAL DRAINAGE LAYER MATERIAL TEXTURE NUMBER 0

\begin{tabular}{|c|c|c|c|c|}
\hline \\
\hline THICKNESS & $=$ & 24.00 & INCHES & \\
\hline POROSITY & $=$ & 0.3800 & VOL/VOL & \\
\hline FIELD CAPACITY & $=$ & 0.0800 & $\mathrm{VOL} / \mathrm{VOL}$ & \\
\hline WILTING POINT & $=$ & 0.0131 & $\mathrm{VOL} / \mathrm{VOL}$ & \\
\hline INITIAL SOIL WATER CONTENT & $=$ & 0.0800 & $\mathrm{VOL} / \mathrm{VOL}$ & \\
\hline EFFECTIVE SAT. HYD. COND. & $=$ & .100000001 & 1000 & $\mathrm{CM} / \mathrm{SEC}$ \\
\hline SLOPE & $=$ & 11.40 & PERCENT & \\
\hline DRAINAGE LENGTH & $=$ & 150.0 & FEET & \\
\hline
\end{tabular}

LAYER 8

TYPE 3 - BARRIER SOIL LINER MATERIAL TEXTURE NUMBER 0

$\begin{array}{llll}\text { THICKNESS } & = & 0.20 & \text { INCHES } \\ \text { POROSITY } & = & 0.7500 \mathrm{VOL} / \mathrm{VOL} \\ \text { FIELD CAPACITY } & = & 0.7470 \mathrm{VOL} / \mathrm{VOL} \\ \text { WILTING POINT } & = & 0.4000 \mathrm{VOL} / \mathrm{VOL} \\ \text { INITIAL SOIL WATER CONTENT } & = & 0.7500 \mathrm{VOL} / \mathrm{VOL} \\ \text { EFEECTIVE SAT. HYD. COND. } & =0.499999997000 \mathrm{E}-08 \mathrm{CM} / \mathrm{SEC}\end{array}$

GENERAL DESIGN AND EVAPORATIVE ZONE DATA

NOTE: SCS RUNOFF CURVE NUMBER WAS COMPUTED FROM DEFAULT SOIL DATA BASE USING SOIL TEXTURE \#10 WITH A GOOD STAND OF GRASS, A SURFACE SLOPE OF 3.\% AND A SLOPE LENGTH OF 450. FEET.

SCS RUNOFF CURVE NUMBER FRACTION OF AREA ALLOWING RUNOFF AREA PROJECTED ON HORIZONTAL PLANE EVAPORATIVE ZONE DEPTH INITIAL WATER IN EVAPORATIVE ZONE UPPER LIMIT OF EVAPORATIVE STORAGE LOWER LIMIT OF EVAPORATIVE STORAGE INITIAL SNOW WATER INITIAL WATER IN LAYER MATERIALS TOTAL INITIAL WATER TOTAL SUBSURFACE INFLOW

$\begin{array}{lcl}= & 80.10 & \\ = & 100.0 & \text { PERCENT } \\ = & 19.630 & \text { ACRES } \\ = & 22.0 & \text { INCHES } \\ = & 5.280 & \text { INCHES } \\ = & 8.140 & \text { INCHES } \\ = & 2.992 & \text { INCHES } \\ = & 0.000 & \text { INCHES } \\ = & 27.989 & \text { INCHES } \\ = & 27.989 & \text { INCHES } \\ = & 0.00 & \text { INCHES /YEAR }\end{array}$


NOTE: EVAPOTRANSPIRATION DATA WAS OBTAINED FROM AUGUSTA GEORGIA

STATION LATITUDE

MAXIMUM LEAF AREA INDEX

START OF GROWING SEASON (JULIAN DATE)

END OF GROWING SEASON (JULIAN DATE)

EVAPORATIVE ZONE DEPTH

AVERAGE ANNUAL WIND SPEED

AVERAGE 1ST QUARTER RELATIVE HUMIDITY

AVERAGE 2ND QUARTER RELATIVE HUMIDITY

AVERAGE 3RD QUARTER RELATIVE HUMIDITY

AVERAGE 4TH QUARTER RELATIVE HUMIDITY
$=33.22$ DEGREES

$=3.50$

$=68$

$=323$

$=22.0$ INCHES

$=6.50 \mathrm{MPH}$

$=68.00 \%$

$=70.00 \%$

$=77.00 \%$

$=73.00 \%$

$\begin{array}{cccc}\text { NOTE: } & \text { PRECIPITATION DATA } & \text { WAS SYNTHETICALLY GENERATED USING } \\ \text { COEFFICIENTS FOR } & \text { AUGUSTA } & \text { GEORGIA }\end{array}$ NORMAL MEAN MONTHLY PRECIPITATION (INCHES)

\begin{tabular}{|c|c|c|c|c|c|c|c|c|}
\hline JAN / JUL & FEB/AUG & \multicolumn{3}{|c|}{ MAR/SEP APR/OCT } & MAY / NOV & \multicolumn{3}{|c|}{ JUN / DEC } \\
\hline------- & ------- & \multirow{2}{*}{\multicolumn{2}{|c|}{$\begin{array}{c}------ \\
4.68\end{array}$}} & -------- & ------- & \multicolumn{3}{|c|}{-------} \\
\hline 4.38 & 3.95 & & & 2.91 & 3.56 & \multicolumn{3}{|c|}{4.99} \\
\hline 5.43 & 5.41 & \multicolumn{2}{|c|}{3.93} & 3.12 & 2.96 & \multicolumn{3}{|c|}{3.45} \\
\hline NOTE : & \multicolumn{2}{|c|}{$\begin{array}{l}\text { TEMPERATURE DATA WAS } \\
\text { COEFFICIENTS FOR }\end{array}$} & $\begin{array}{lr}\text { VAS } & \text { SYNT } \\
2 & \text { AUG }\end{array}$ & $\begin{array}{l}\text { HET ICALLY } \\
\text { USTA }\end{array}$ & \multicolumn{3}{|c|}{$\begin{array}{c}\text { GENERATED USING } \\
\text { GEORGIA }\end{array}$} & \\
\hline \multicolumn{2}{|c|}{ NORMAL MEAN } & \multicolumn{6}{|c|}{ MONTHLY TEMPERATURE (DEGREES FAHRENHEIT) } & \\
\hline JAN / JUL & FEB/AUG & \multicolumn{2}{|c|}{$\mathrm{MAR} / \mathrm{SEP}$} & $\mathrm{APR} / \mathrm{OCT}$ & MAY / NOV & \multicolumn{3}{|c|}{ JUN/DEC } \\
\hline------- & ------- & ------- & -- & -------- & ------- & \multicolumn{3}{|c|}{-------} \\
\hline 46.30 & 50.00 & 57.20 & & 64.30 & 72.10 & \multicolumn{3}{|c|}{78.40} \\
\hline 81.60 & 80.30 & 75.20 & & 65.10 & 56.70 & \multicolumn{3}{|c|}{48.80} \\
\hline \multirow[t]{2}{*}{ NOTE : } & \multicolumn{2}{|c|}{$\begin{array}{c}\text { SOLAR RADIATION DAT } \\
\text { COEFFICIENTS FOR }\end{array}$} & $\begin{array}{l}\text { TA } \text { WAS } \\
\text { AUG }\end{array}$ & $\begin{array}{l}\text { SYNTHETICA } \\
\text { USTA }\end{array}$ & \multicolumn{2}{|c|}{$\begin{array}{r}\text { SLY GENERATED } \\
\text { GEORGIA }\end{array}$} & USING & \\
\hline & \multicolumn{3}{|c|}{ AND STATION LATITUDE } & $=33.30$ & DEGREES & & & \\
\hline AVERAGE & MONTHLY & VALUES IN & INCHES & FOR YEARS & 1 THR & OUGH & 100 & \\
\hline & & JAN / JUL & $\mathrm{FEB} / \mathrm{AUG}$ & MAR/SEP & $\mathrm{APR} / \mathrm{OCT}$ & $\mathrm{MAY} /$ & NOV & JUN/DEC \\
\hline & & $-------\quad-$ & ------- & ------- & ------- & ---- & ---- & ------- \\
\hline $\begin{array}{l}\text { PRECIPITATION } \\
-------------\end{array}$ & & & & & & & & \\
\hline TOTALS & & 4.56 & 3.57 & 4.76 & 2.74 & & 60 & 4.97 \\
\hline & & 5.81 & 5.32 & 4.41 & 2.99 & & & 3.41 \\
\hline STD. DEVIATI & CONS & 2.44 & 1.60 & 2.47 & 1.31 & & 12 & 2.60 \\
\hline & & 2.83 & 2.95 & 2.54 & 2.28 & & .72 & 1.90 \\
\hline
\end{tabular}

Rev. 0 
RUNOFF

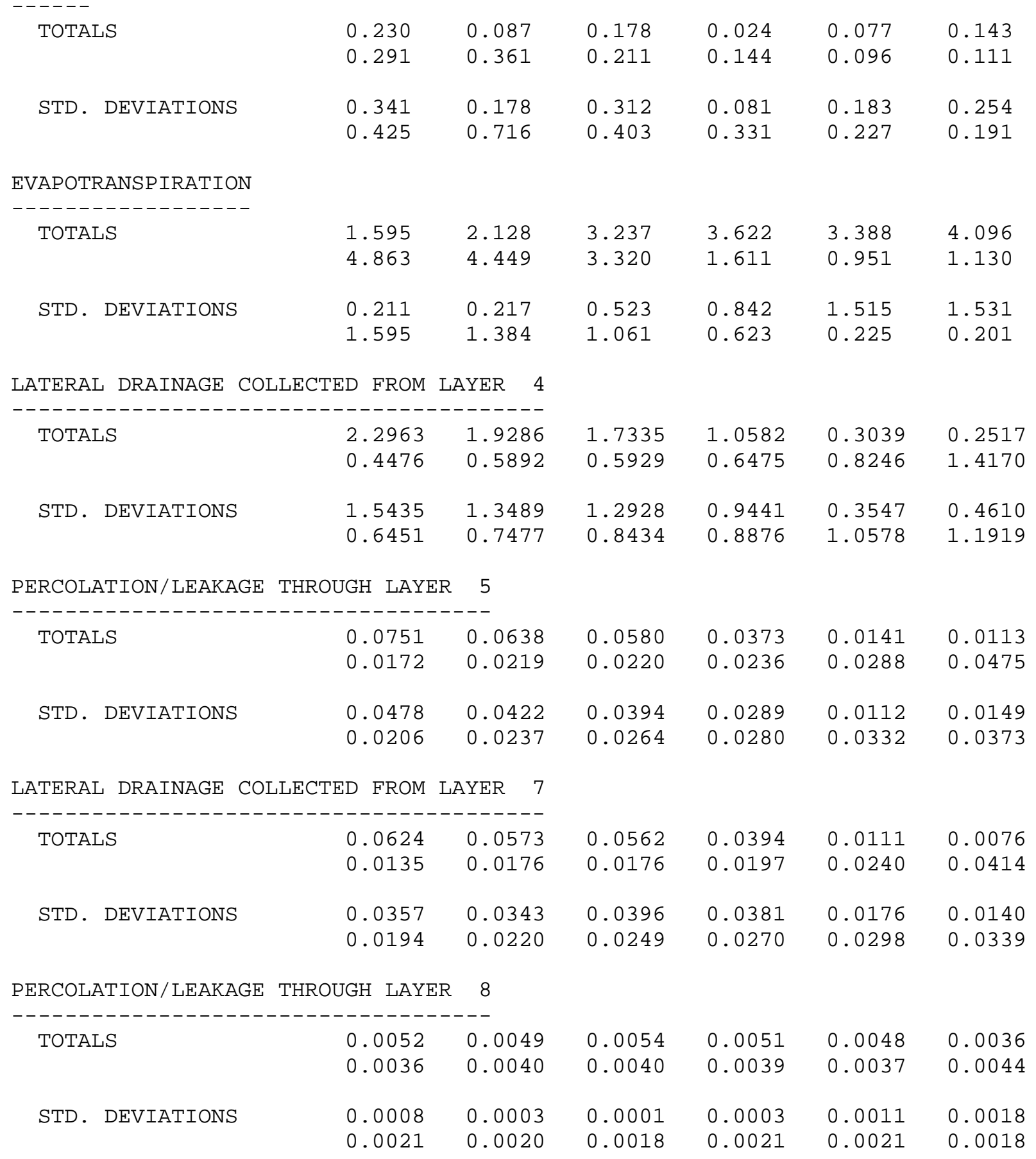




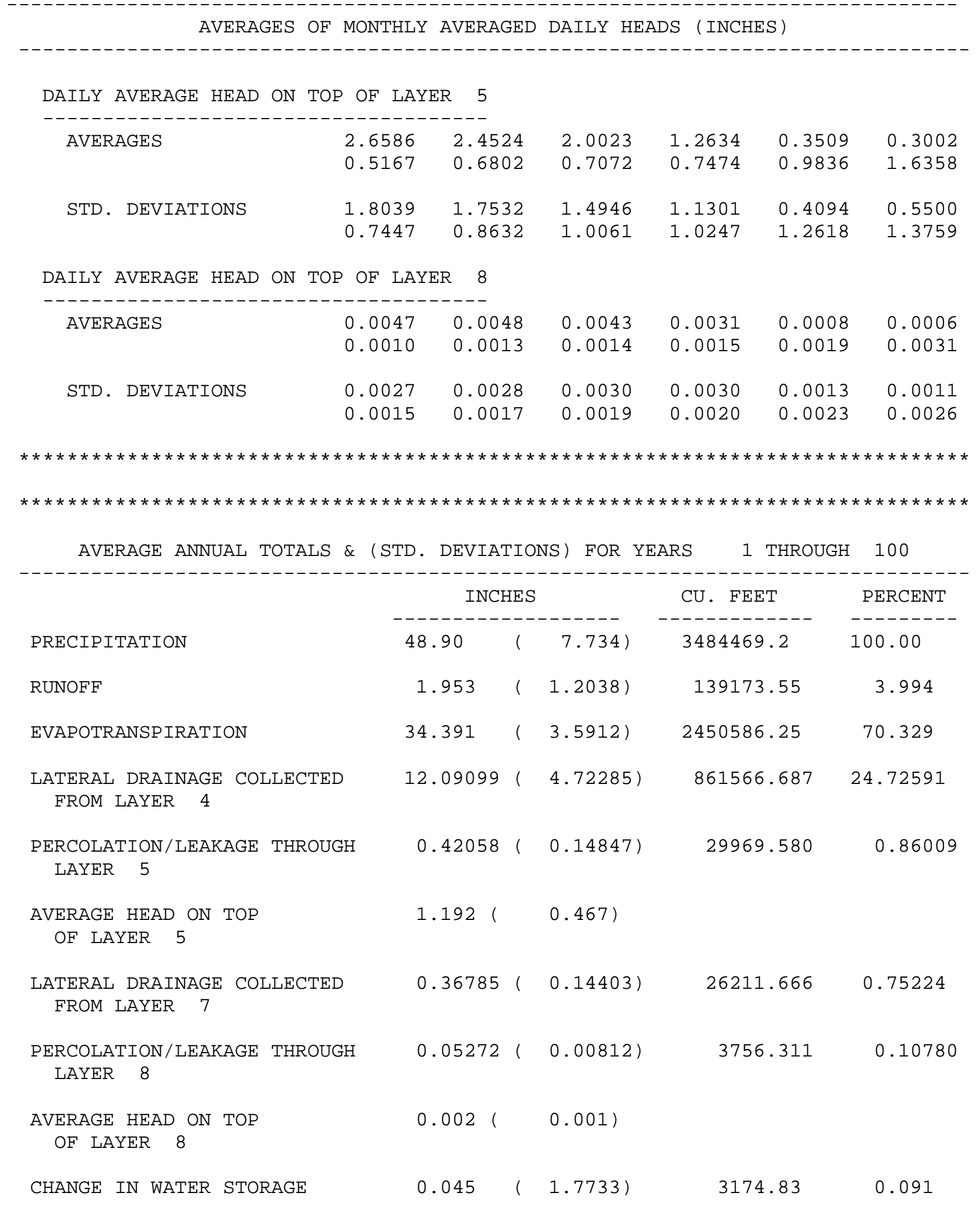

Rev. 0 


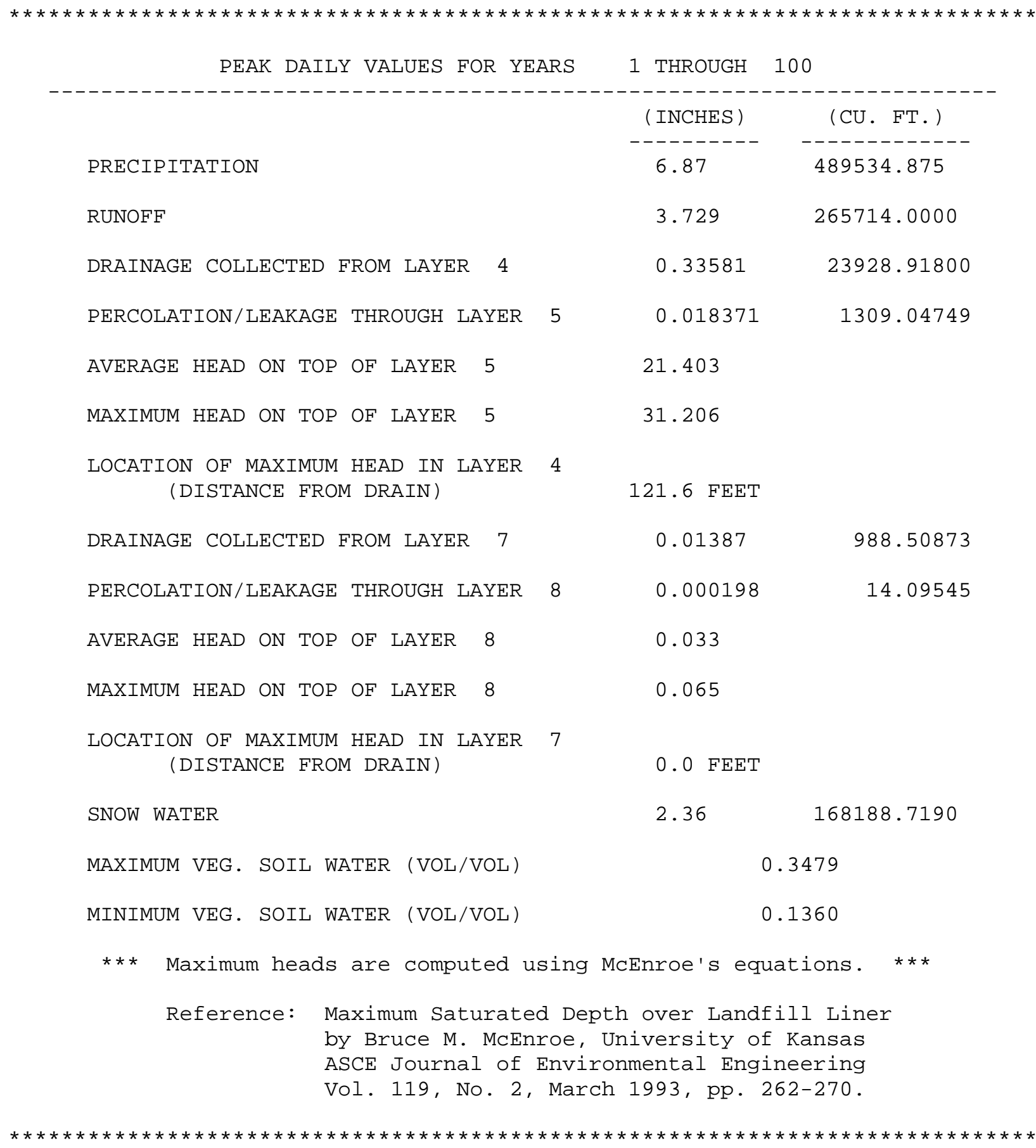

Rev. 0 


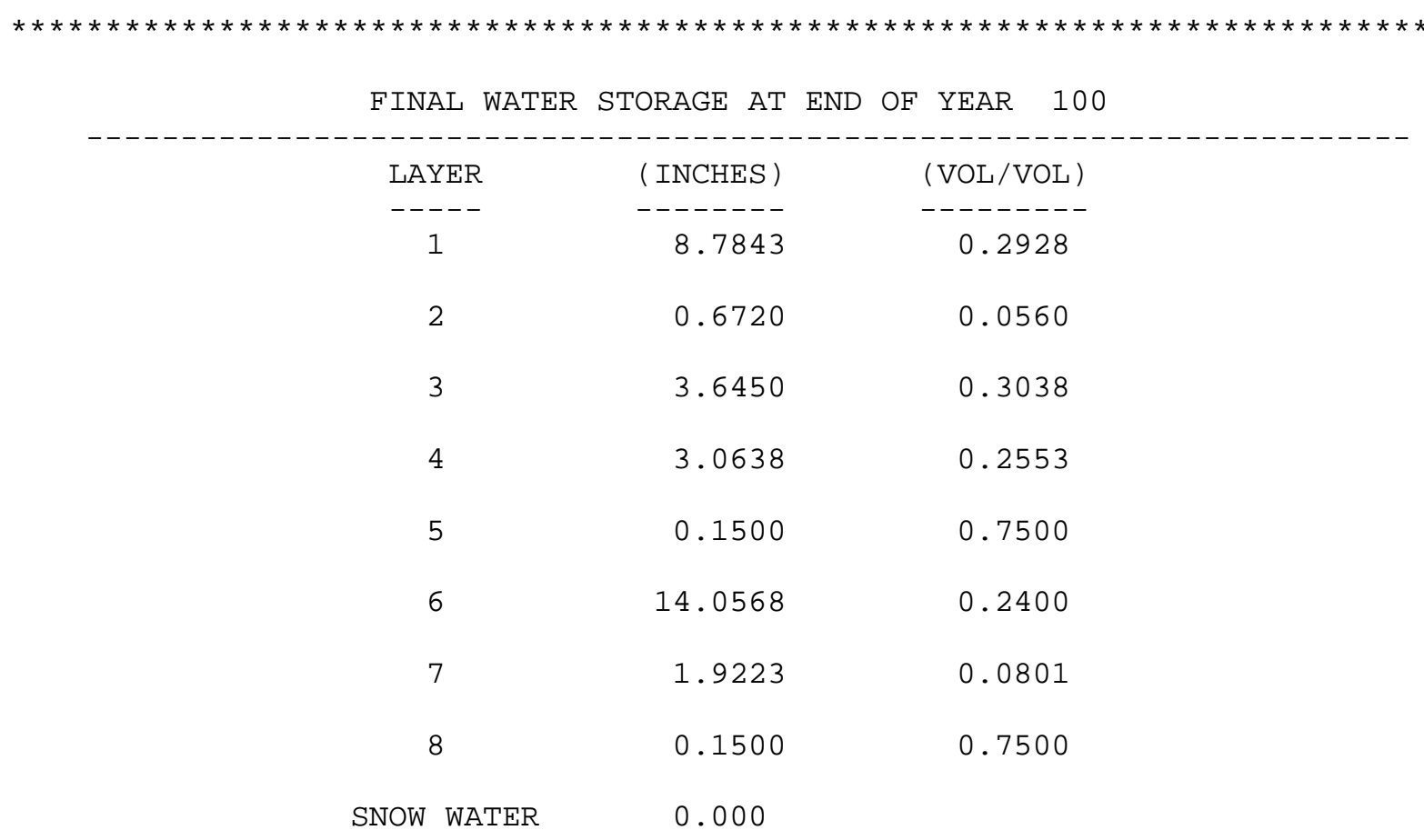


Appendix R, Upper Bounding Scenario Degraded SDF MSE Vault Closure Cap (300 Years): HELP Model Input Data and Output File (output file name: ZUBSD3ou.OUT)

\section{Input Data:}

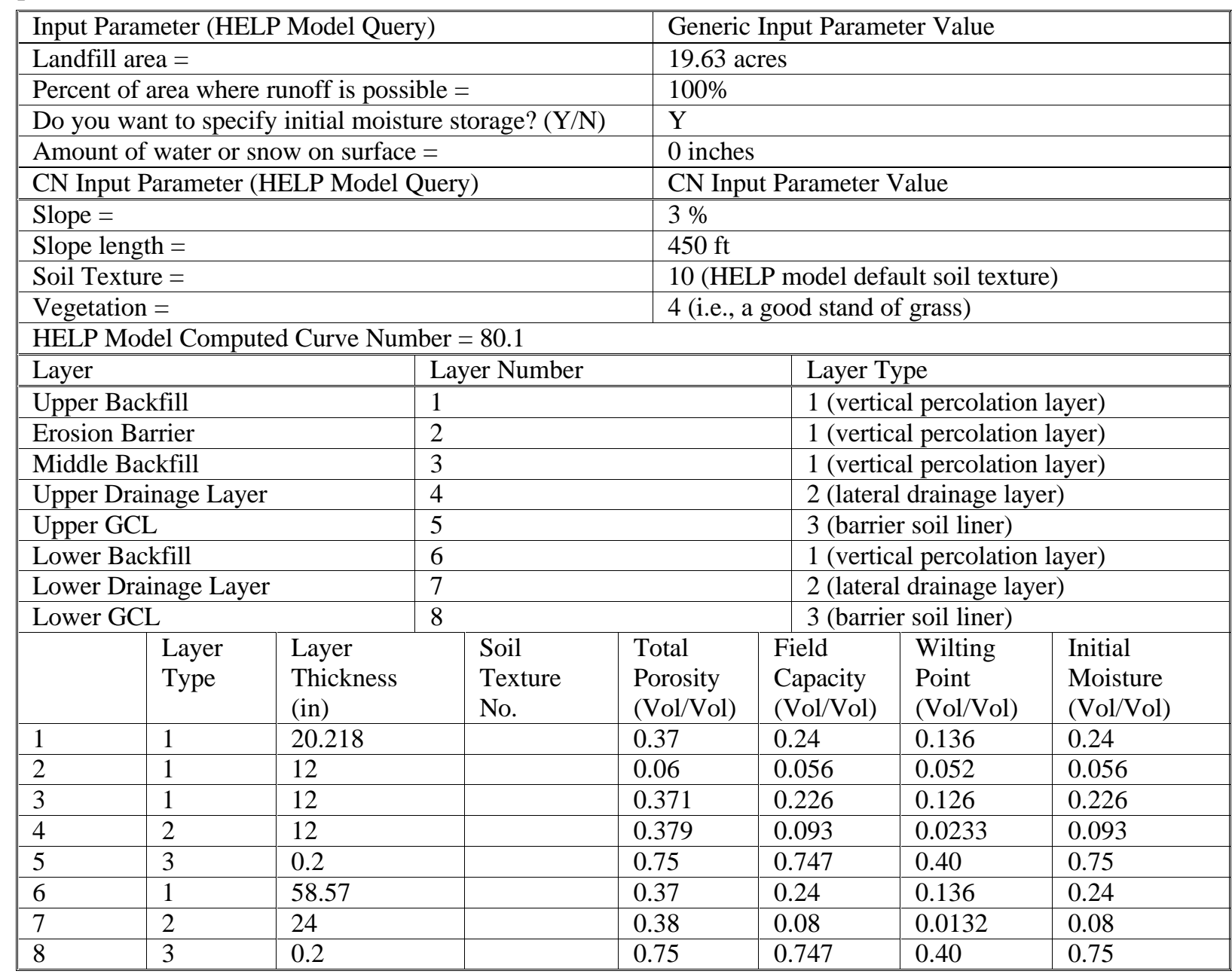

The lack of values in the table for particular parameters in particular layers denotes that no HELP model input was required for that parameter in that layer. No data are missing from the table. 
Input Data (continued):

\begin{tabular}{|c|c|c|c|c|c|c|c|c|c|}
\hline & $\begin{array}{l}\text { Layer } \\
\text { Type }\end{array}$ & \multirow{2}{*}{$\begin{array}{l}\text { Sat. Hyd. } \\
\text { Conductivity * } \\
(\mathrm{cm} / \mathrm{sec})\end{array}$} & \multicolumn{2}{|c|}{$\begin{array}{l}\text { Drainage } \\
\text { Length } \\
\text { (ft) }\end{array}$} & \multirow[t]{2}{*}{$\begin{array}{l}\text { Drain } \\
\text { Slope } \\
(\%) \\
\end{array}$} & \multirow[t]{2}{*}{$\begin{array}{l}\text { Leachate } \\
\text { Recirc. } \\
(\%) \\
\end{array}$} & \multicolumn{2}{|c|}{$\begin{array}{l}\text { Recirc. to } \\
\text { Layer } \\
(\#)\end{array}$} & \multirow[t]{2}{*}{$\begin{array}{l}\text { Subsurface } \\
\text { Inflow } \\
\text { (in/yr) }\end{array}$} \\
\hline 1 & 1 & & & & & & & \\
\hline 2 & 1 & $3.97 \mathrm{E}-04$ & & & & & & \\
\hline 3 & 1 & $1.80 \mathrm{E}-04$ & & & & & \multicolumn{2}{|c|}{ 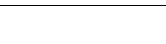 } & \\
\hline 4 & 2 & $5.60 \mathrm{E}-02$ & 450 & & 3 & & \multicolumn{2}{|c|}{+2} & \\
\hline 5 & 3 & $5.00 \mathrm{E}-09$ & & & & & \multicolumn{2}{|c|}{ 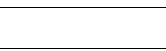 } & \\
\hline 6 & 1 & $1.00 \mathrm{E}-04$ & & & & & & & \\
\hline 7 & 2 & 9.99E-02 & 150 & & 11.4 & & & & \\
\hline 8 & 3 & $5.00 \mathrm{E}-09$ & & & & & & & \\
\hline & $\begin{array}{l}\text { Layer } \\
\text { Type }\end{array}$ & \multicolumn{2}{|l|}{$\begin{array}{l}\text { Geomembrane } \\
\text { Pinhole Density } \\
\text { (\#/acre) }\end{array}$} & $\begin{array}{l}\mathrm{Ge} \\
\mathrm{Ins} \\
(\# / \mathrm{c}\end{array}$ & $\begin{array}{l}\text { mbrane } \\
\text { Defects }\end{array}$ & \multicolumn{2}{|c|}{$\begin{array}{l}\text { Geomembrane } \\
\text { Placement Quality }\end{array}$} & \multicolumn{2}{|c|}{$\begin{array}{l}\text { Geotextile } \\
\text { Transmissivity } \\
\left(\mathrm{cm}^{2} / \mathrm{sec}\right)\end{array}$} \\
\hline 1 & 1 & & & & & & & & \\
\hline 2 & 1 & & & & & & & & \\
\hline 3 & 1 & & & & & & & & \\
\hline 4 & 2 & & & & & & & & \\
\hline 5 & 3 & & & & & & & & \\
\hline 6 & 1 & & & & & & & & \\
\hline 7 & 2 & & & & & & & & \\
\hline 8 & 3 & & & & & & & & \\
\hline
\end{tabular}

The lack of values in the table for particular parameters in particular layers denotes that no HELP model input was required for that parameter in that layer. No data are missing from the table.

* The HELP model output often produces an increased number of significant digits for the Effective Saturated Hydraulic Conductivity over that of the actual input 


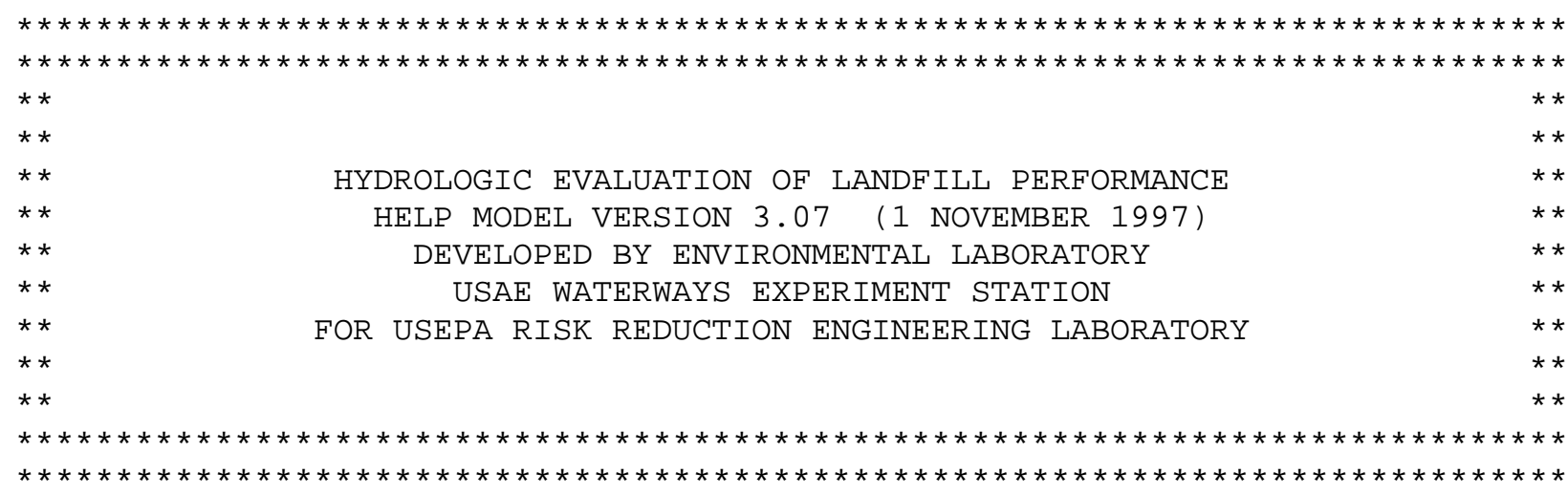

\begin{tabular}{|c|c|}
\hline PRECIPITATION DATA FILE: & $\mathrm{D}: \backslash$ HELP $3 \backslash$ Hweather $\backslash \mathrm{ZPREC} . \mathrm{D} 4$ \\
\hline TEMPERATURE DATA FILE: & D : \HELP 3 \Hweather ZTEMP.D7 \\
\hline SOLAR RADIATION DATA FILE: & D: \HELP $3 \backslash$ Hweather \ZSOLAR.D13 \\
\hline EVAPOTRANSPIRATION DATA: & D : \HELP $3 \backslash$ Hweather \ZEVAP . D11 \\
\hline SOIL AND DESIGN DATA FILE: & D : \HELP $3 \backslash$ Hsdfmse \ZUBSD3 . D10 \\
\hline OUTPUT DATA FILE: & D : \HELP $3 \backslash$ Hsdfmse \ZUBSD 3ou. OUT \\
\hline
\end{tabular}

TIME : 13:42 DATE: 1/13/2004

TITLE: UBS Degraded MSE Vault Closure Cap - 300 years

NOTE: INITIAL MOISTURE CONTENT OF THE LAYERS AND SNOW WATER WERE SPECIFIED BY THE USER.

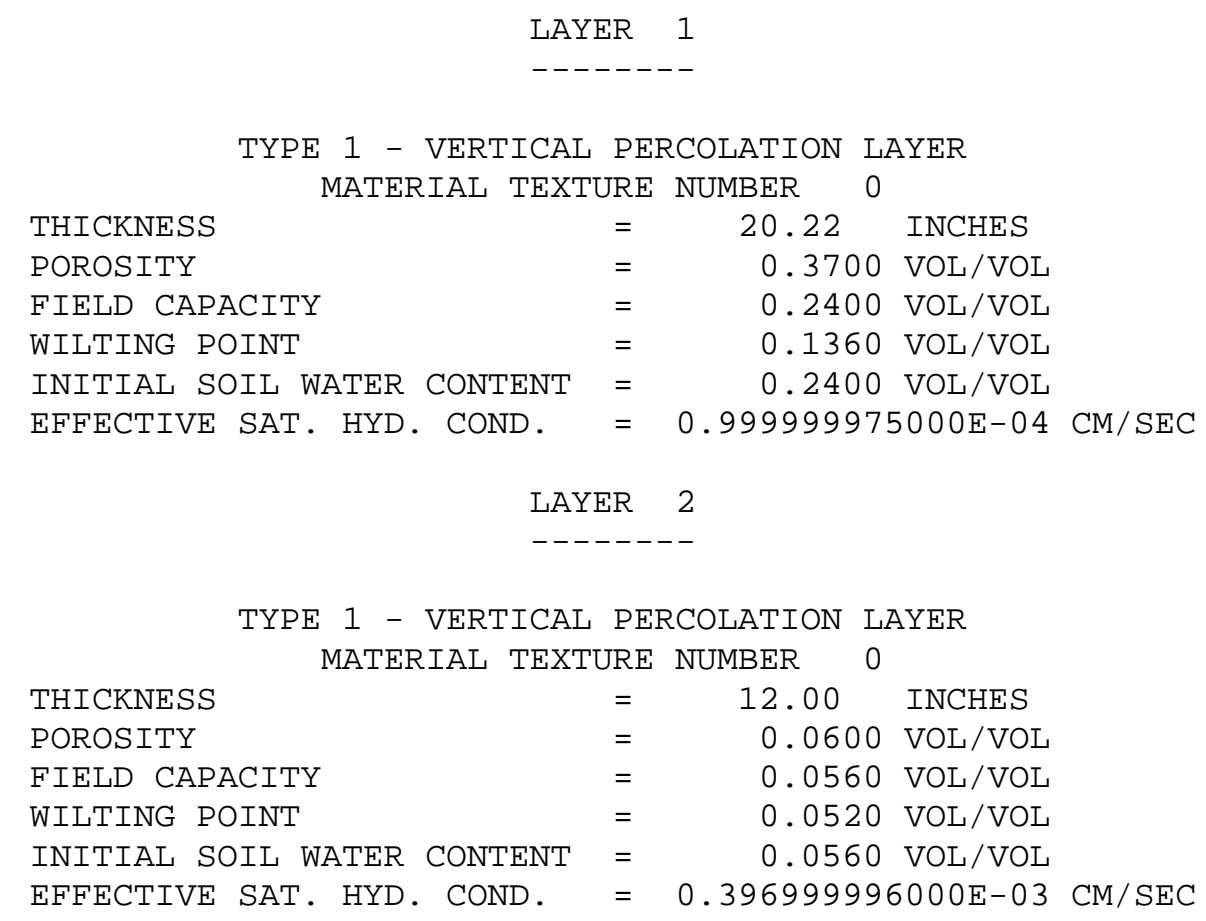

Rev. 0 
LAYER 3

-------

TYPE 1 - VERTICAL PERCOLATION LAYER

MATERIAL TEXTURE NUMBER 0

\begin{tabular}{|c|c|c|c|c|}
\hline THICKNESS & $=$ & 12.00 & INCHES & \\
\hline POROSITY & $=$ & 0.3710 & $\mathrm{VOL} / \mathrm{VOL}$ & \\
\hline FIELD CAPACITY & $=$ & 0.2260 & $\mathrm{VOL} / \mathrm{VOL}$ & \\
\hline WILTING POINT & $=$ & 0.1260 & VOL/VOL & \\
\hline INITIAL SOIL WATER CONTENT & $=$ & 0.2260 & $\mathrm{VOL} / \mathrm{VOL}$ & \\
\hline EFFECTIVE SAT. HYD. COND. & $=$ & 0.180000003 & $3000 \mathrm{E}-03$ & $\mathrm{CM} / \mathrm{SEC}$ \\
\hline LAY & $\Xi R$ & 4 & & \\
\hline--- & ---- & & & \\
\hline TYPE 2 - LATERI & {$[\mathrm{DR}$} & RAINAGE LAYE & & \\
\hline MATERIAL TEXT & $\mathrm{JRE}$ & NUMBER & & \\
\hline THICKNESS & $=$ & 12.00 & INCHES & \\
\hline POROSITY & $=$ & 0.3790 & $\mathrm{VOL} / \mathrm{VOL}$ & \\
\hline FIELD CAPACITY & $=$ & 0.0930 & $\mathrm{VOL} / \mathrm{VOL}$ & \\
\hline WILTING POINT & $=$ & 0.0233 & $\mathrm{VOL} / \mathrm{VOL}$ & \\
\hline INITIAL SOIL WATER CONTENT & $=$ & 0.0930 & $\mathrm{VOL} / \mathrm{VOL}$ & \\
\hline EFFECTIVE SAT. HYD. COND. & $=$ & 0.560000017 & $7000 \mathrm{E}-01$ & $\mathrm{CM} / \mathrm{SEC}$ \\
\hline SLOPE & $=$ & 3.00 & PERCENT & \\
\hline DRAINAGE LENGTH & $=$ & 450.0 & FEET & \\
\hline
\end{tabular}

LAYER 5

TYPE 3 - BARRIER SOIL LINER

MATERIAL TEXTURE NUMBER 0

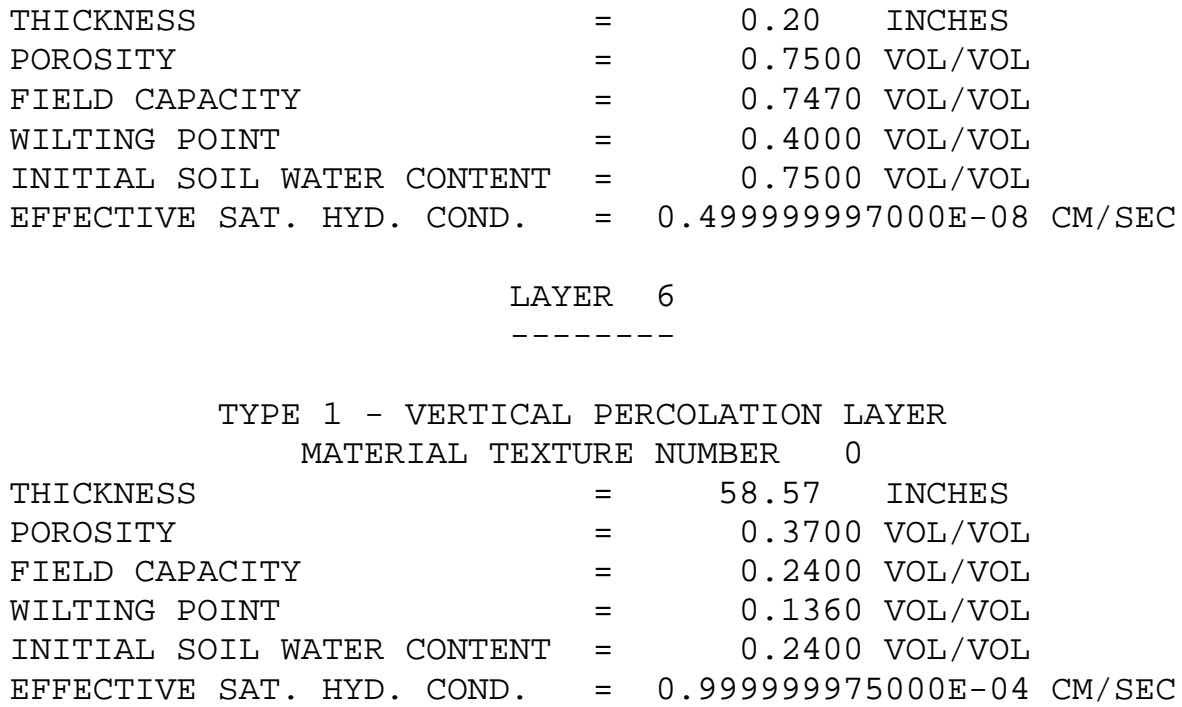

Rev. 0 
LAYER 7

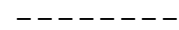

TYPE 2 - LATERAL DRAINAGE LAYER MATERIAL TEXTURE NUMBER 0

$\begin{array}{llcc}\text { THICKNESS } & = & 24.00 & \text { INCHES } \\ \text { POROSITY } & = & 0.3800 \mathrm{VOL} / \mathrm{VOL} \\ \text { FIELD CAPACITY } & = & 0.0800 \mathrm{VOL} / \mathrm{VOL} \\ \text { WILTING POINT } & = & 0.0132 \mathrm{VOL} / \mathrm{VOL} \\ \text { INITIAL SOIL WATER CONTENT } & = & 0.0800 \mathrm{VOL} / \mathrm{VOL} \\ \text { EFFECTIVE SAT. HYD. COND. } & =0.998999998000 \mathrm{E}-01 \mathrm{CM} / \mathrm{SEC} \\ \text { SLOPE } & = & 11.40 \mathrm{PERCENT} \\ \text { DRAINAGE LENGTH } & = & 150.0 & \mathrm{FEET}\end{array}$

LAYER 8

TYPE 3 - BARRIER SOIL LINER MATERIAL TEXTURE NUMBER 0

$\begin{array}{llrl}\text { THICKNESS } & = & 0.20 \mathrm{INCHES} \\ \text { POROSITY } & = & 0.7500 \mathrm{VOL} / \mathrm{VOL} \\ \text { FIELD CAPACITY } & = & 0.7470 \mathrm{VOL} / \mathrm{VOL} \\ \text { WILTING POINT } & = & 0.4000 \mathrm{VOL} / \mathrm{VOL} \\ \text { INITIAL SOIL WATER CONTENT } & = & 0.7500 \mathrm{VOL} / \mathrm{VOL} \\ \text { EFEECTIVE SAT. HYD. COND. } & =0.499999997000 \mathrm{E}-08 \mathrm{CM} / \mathrm{SEC}\end{array}$

GENERAL DESIGN AND EVAPORATIVE ZONE DATA

NOTE: SCS RUNOFF CURVE NUMBER WAS COMPUTED FROM DEFAULT SOIL DATA BASE USING SOIL TEXTURE \#10 WITH A GOOD STAND OF GRASS, A SURFACE SLOPE OF 3.\% AND A SLOPE LENGTH OF 450. FEET.

SCS RUNOFF CURVE NUMBER FRACTION OF AREA ALLOWING RUNOFF AREA PROJECTED ON HORIZONTAL PLANE EVAPORATIVE ZONE DEPTH INITIAL WATER IN EVAPORATIVE ZONE UPPER LIMIT OF EVAPORATIVE STORAGE LOWER LIMIT OF EVAPORATIVE STORAGE INITIAL SNOW WATER INITIAL WATER IN LAYER MATERIALS TOTAL INITIAL WATER TOTAL SUBSURFACE INFLOW

$\begin{array}{lcl}= & 80.10 & \\ = & 100.0 & \text { PERCENT } \\ = & 19.630 & \text { ACRES } \\ = & 22.0 & \text { INCHES } \\ = & 4.952 & \text { INCHES } \\ = & 7.588 & \text { INCHES } \\ = & 2.842 & \text { INCHES } \\ = & 0.000 & \text { INCHES } \\ = & 25.629 & \text { INCHES } \\ = & 25.629 & \text { INCHES } \\ = & 0.00 & \text { INCHES /YEAR }\end{array}$


NOTE: EVAPOTRANSPIRATION DATA WAS OBTAINED FROM AUGUSTA GEORGIA

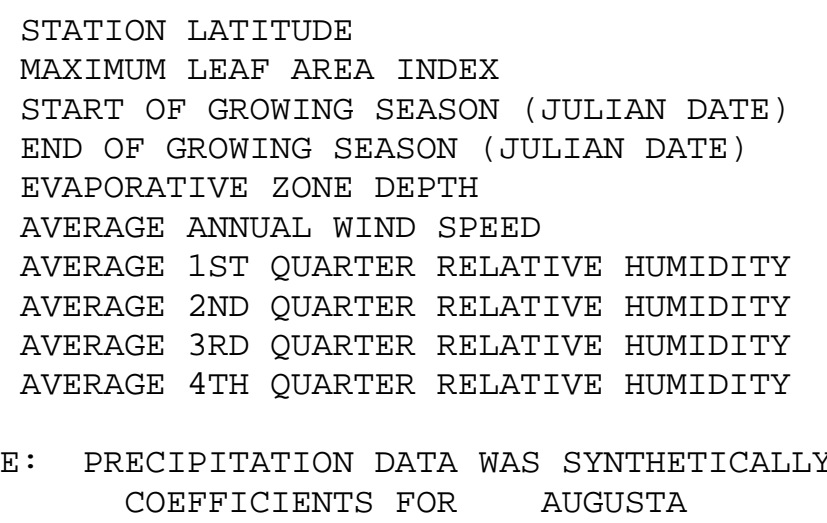
NORMAL MEAN MONTHLY PRECIPITATION (INCHES)
$=33.22$ DEGREES

$=\quad 3.50$

$=68$

$=323$

$=22.0$ INCHES

$=6.50 \mathrm{MPH}$

$=68.00 \%$

$=70.00 \%$

$=77.00 \%$

$=73.00 \%$

\section{NOTE: PRECIPITATION DATA WAS SYNTHETICALLY GENERATED USING COEFFICIENTS FOR AUGUSTA GEORGIA}

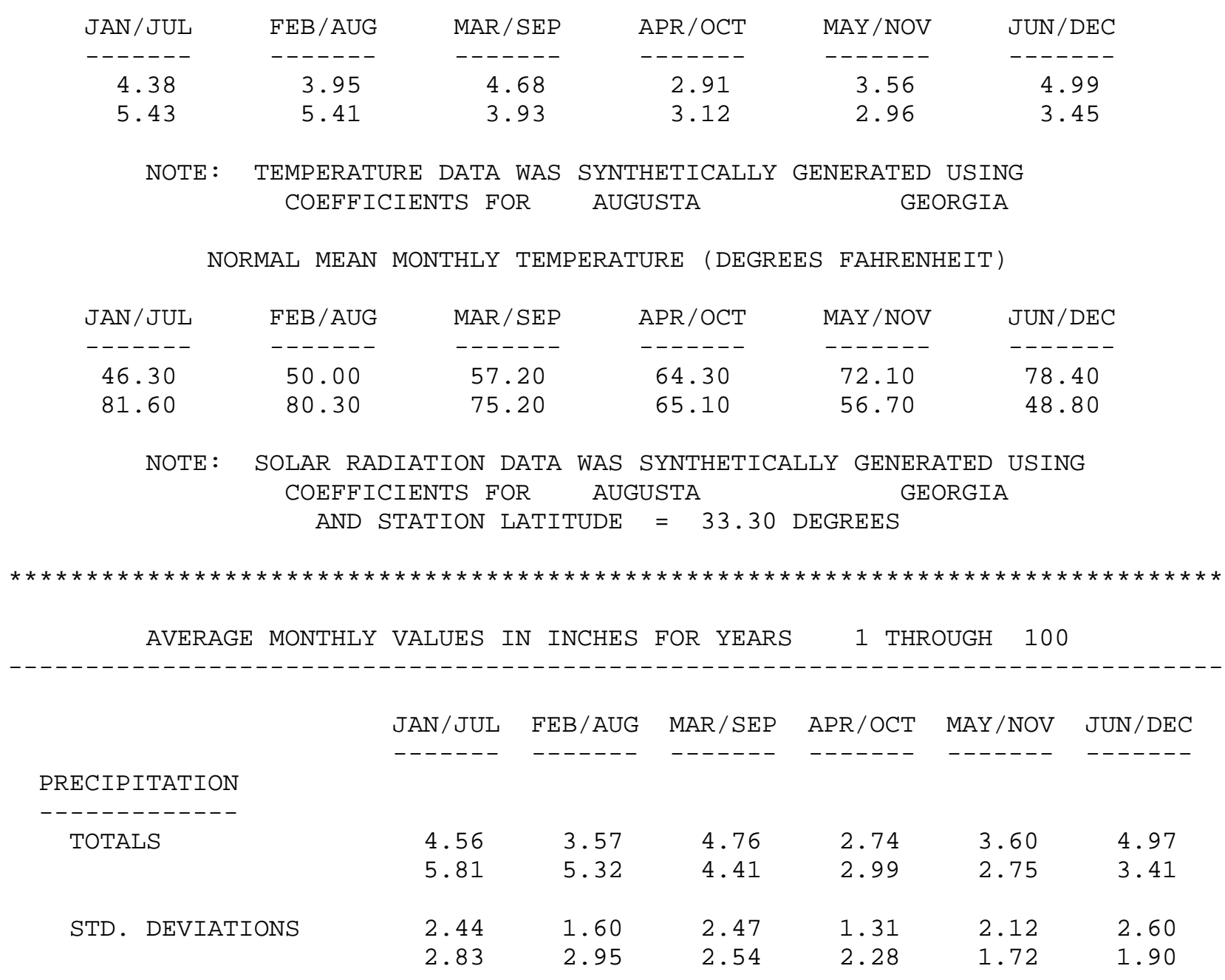




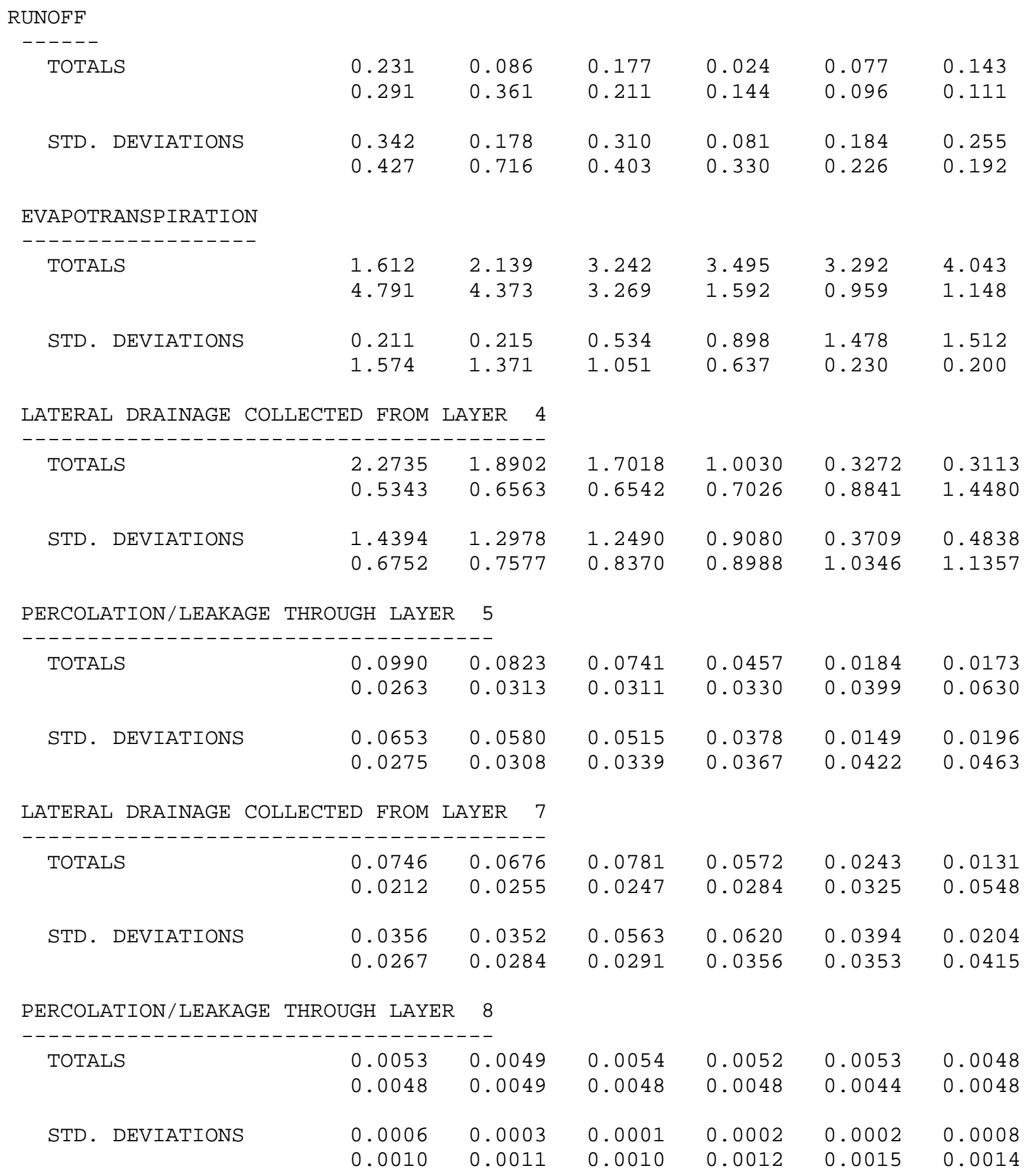


AVERAGES OF MONTHLY AVERAGED DAILY HEADS (INCHES)

DAILY AVERAGE HEAD ON TOP OF LAYER 5

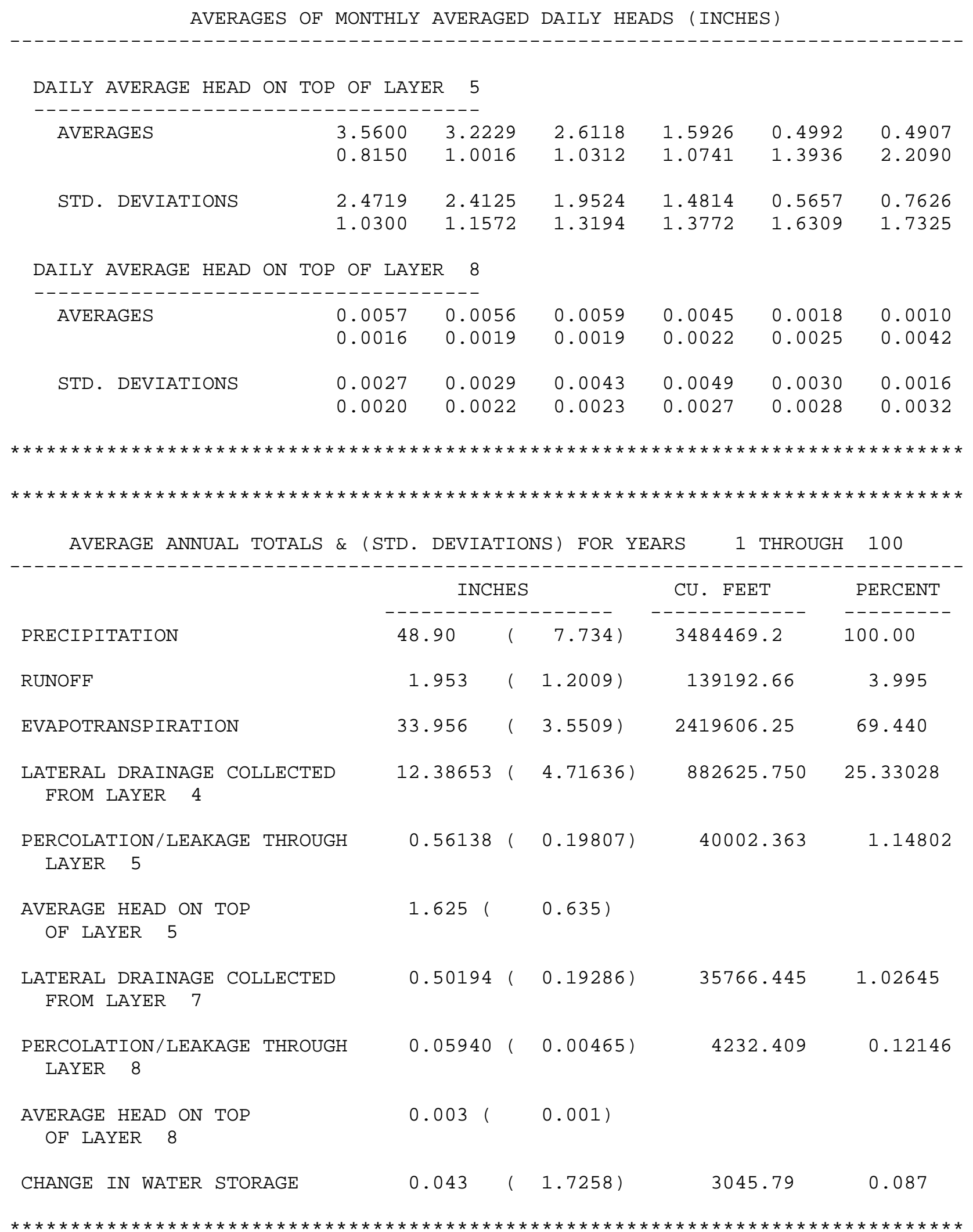$$
\star \star *
$$ 


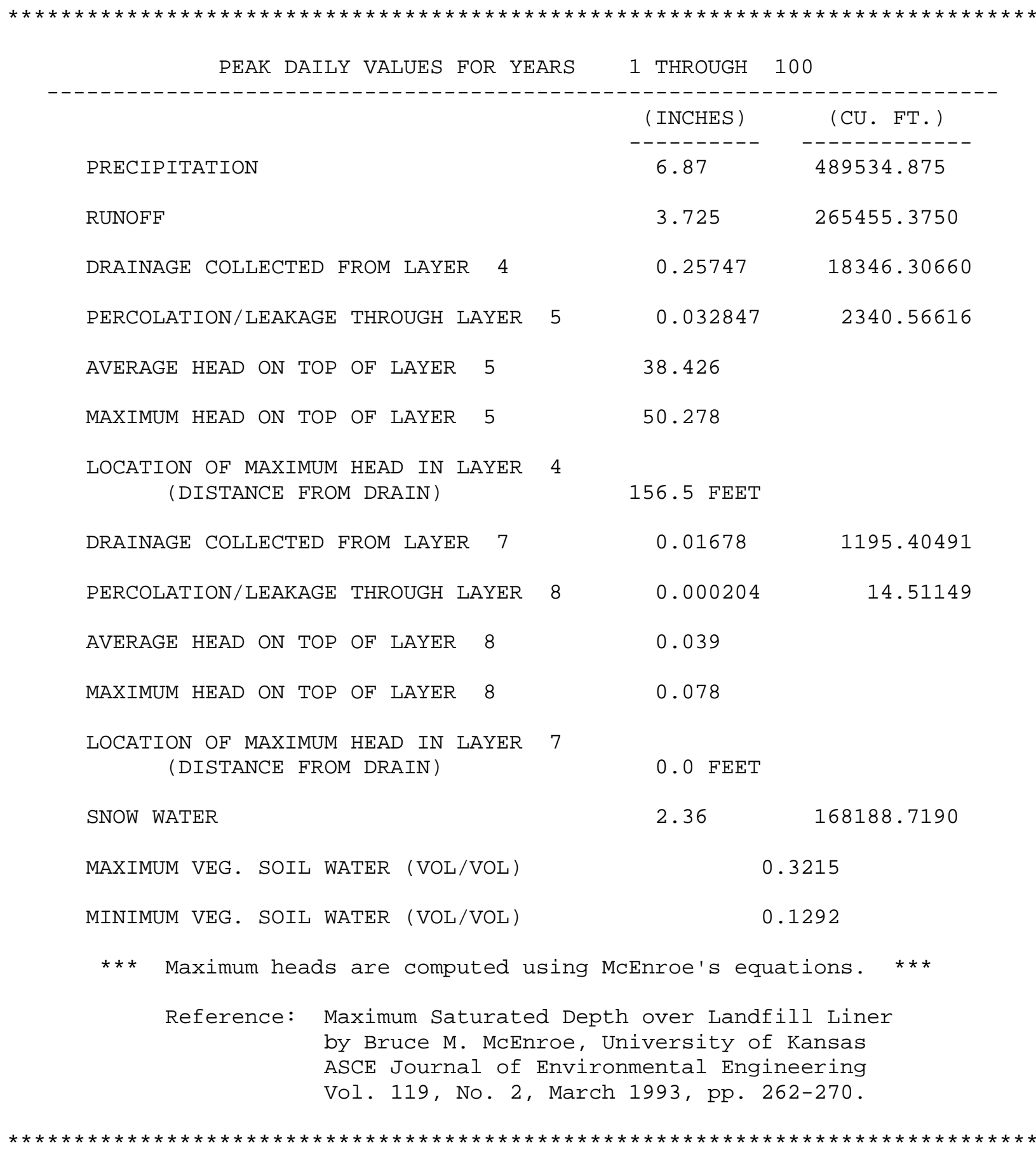

Rev. 0 


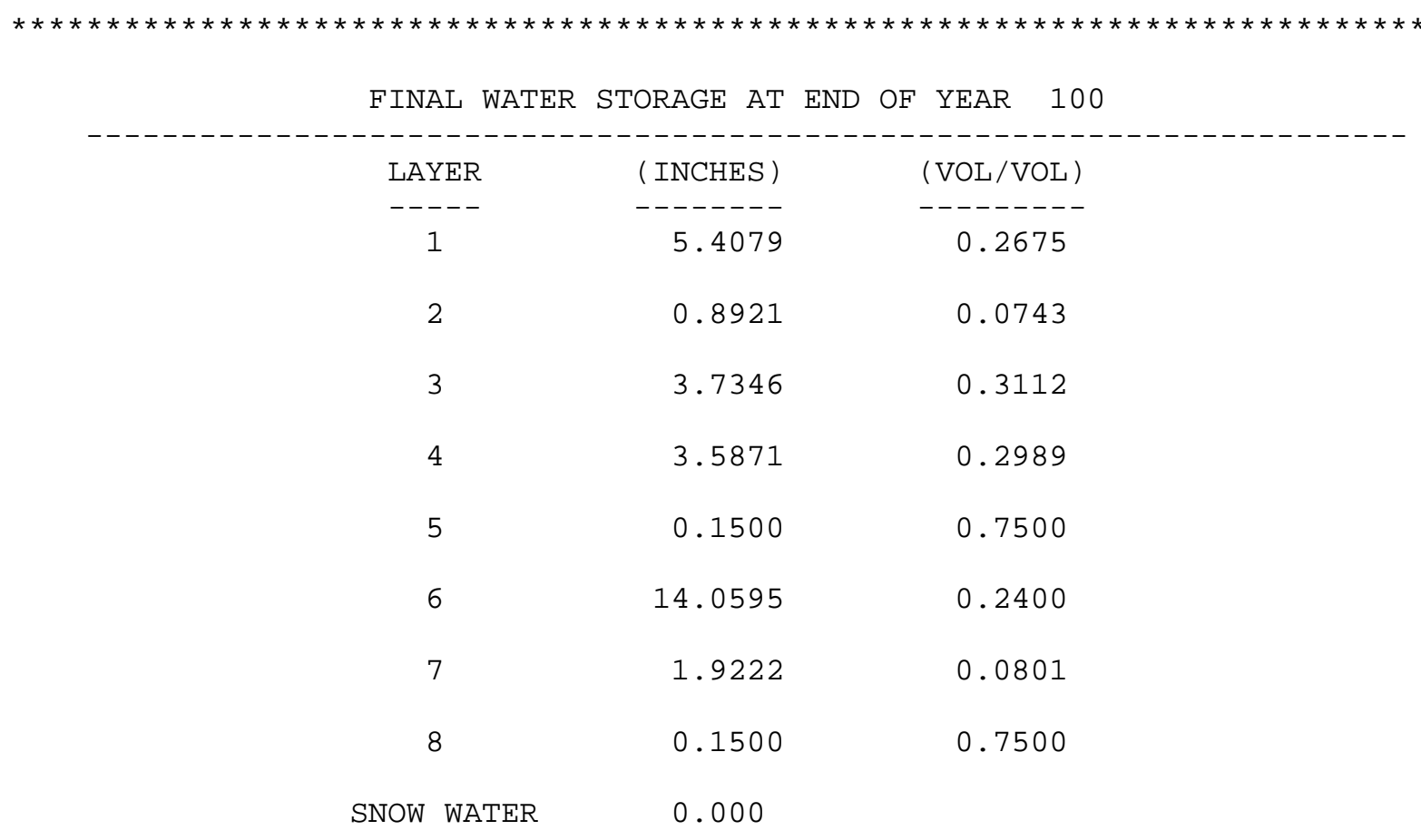


Appendix S, Upper Bounding Scenario Degraded SDF MSE Vault Closure Cap (550 Years): HELP Model Input Data and Output File (output file name: ZUBSD4ou.OUT)

\section{Input Data:}

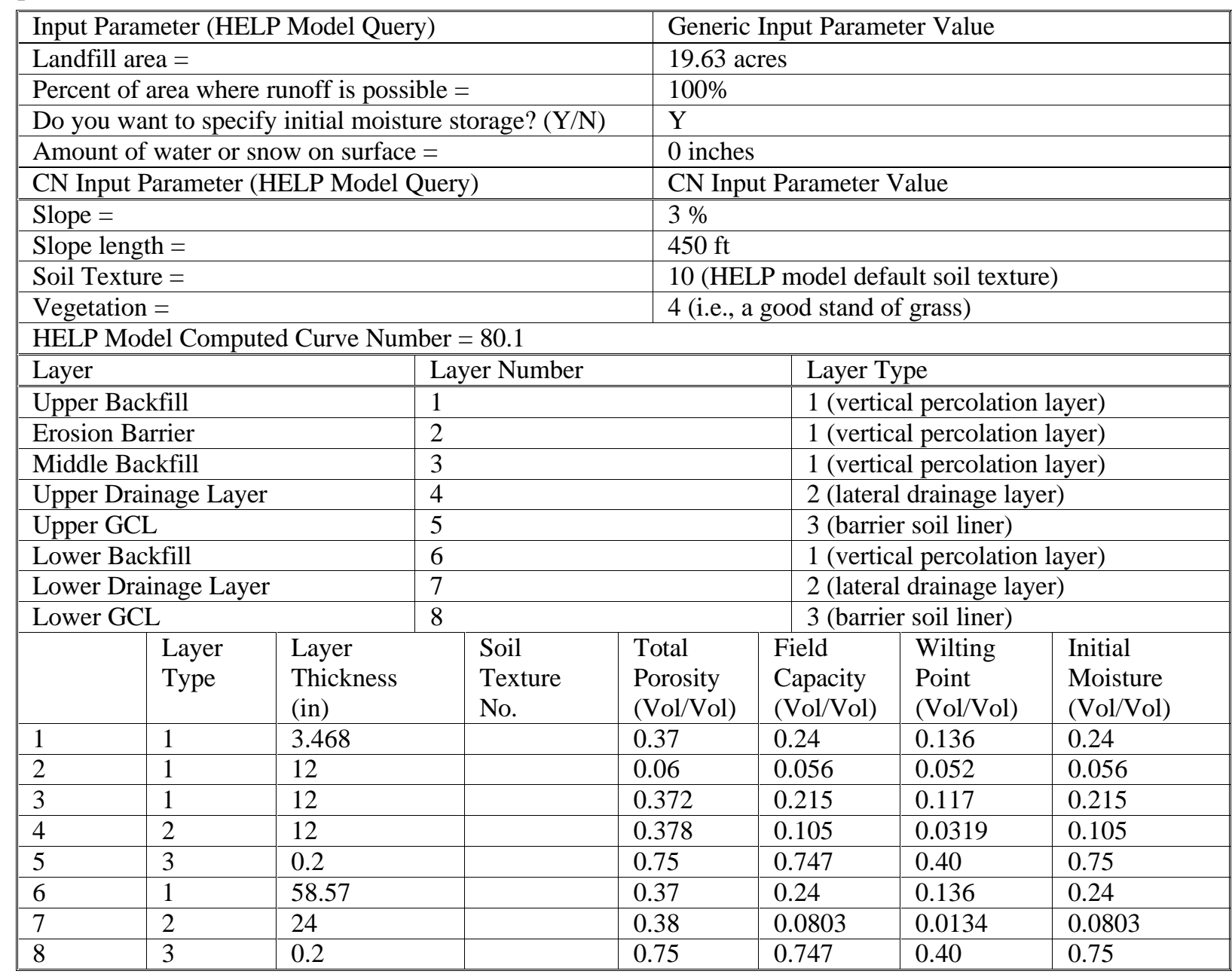

The lack of values in the table for particular parameters in particular layers denotes that no HELP model input was required for that parameter in that layer. No data are missing from the table. 
Input Data (continued):

\begin{tabular}{|c|c|c|c|c|c|c|c|c|c|}
\hline & $\begin{array}{l}\text { Layer } \\
\text { Type }\end{array}$ & \multirow{2}{*}{$\begin{array}{l}\text { Sat. Hyd. } \\
\text { Conductivity * } \\
(\mathrm{cm} / \mathrm{sec})\end{array}$} & \multicolumn{2}{|c|}{$\begin{array}{l}\text { Drainage } \\
\text { Length } \\
\text { (ft) }\end{array}$} & \multirow[t]{2}{*}{$\begin{array}{l}\text { Drain } \\
\text { Slope } \\
(\%) \\
\end{array}$} & \multirow[t]{2}{*}{$\begin{array}{l}\text { Leachate } \\
\text { Recirc. } \\
(\%) \\
\end{array}$} & \multicolumn{2}{|c|}{$\begin{array}{l}\text { Recirc. to } \\
\text { Layer } \\
(\#)\end{array}$} & \multirow[t]{2}{*}{$\begin{array}{l}\text { Subsurface } \\
\text { Inflow } \\
\text { (in/yr) }\end{array}$} \\
\hline 1 & 1 & & & & & & & \\
\hline 2 & 1 & $3.97 \mathrm{E}-04$ & & & & & & \\
\hline 3 & 1 & $2.90 \mathrm{E}-04$ & & & & & \multicolumn{2}{|c|}{ 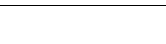 } & \\
\hline 4 & 2 & $3.40 \mathrm{E}-02$ & 450 & & 3 & & \multicolumn{2}{|c|}{+2} & \\
\hline 5 & 3 & $5.00 \mathrm{E}-09$ & & & & & \multicolumn{2}{|c|}{ 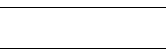 } & \\
\hline 6 & 1 & $1.00 \mathrm{E}-04$ & & & & & & & \\
\hline 7 & 2 & $9.98 \mathrm{E}-02$ & 150 & & 11.4 & & & & \\
\hline 8 & 3 & $5.00 \mathrm{E}-09$ & & & & & & & \\
\hline & $\begin{array}{l}\text { Layer } \\
\text { Type }\end{array}$ & \multicolumn{2}{|l|}{$\begin{array}{l}\text { Geomembrane } \\
\text { Pinhole Density } \\
\text { (\#/acre) }\end{array}$} & $\begin{array}{l}\mathrm{Ge} \\
\mathrm{Ins} \\
(\# / \mathrm{c}\end{array}$ & $\begin{array}{l}\text { mbrane } \\
\text { Defects }\end{array}$ & \multicolumn{2}{|c|}{$\begin{array}{l}\text { Geomembrane } \\
\text { Placement Quality }\end{array}$} & \multicolumn{2}{|c|}{$\begin{array}{l}\text { Geotextile } \\
\text { Transmissivity } \\
\left(\mathrm{cm}^{2} / \mathrm{sec}\right)\end{array}$} \\
\hline 1 & 1 & & & & & & & & \\
\hline 2 & 1 & & & & & & & & \\
\hline 3 & 1 & & & & & & & & \\
\hline 4 & 2 & & & & & & & & \\
\hline 5 & 3 & & & & & & & & \\
\hline 6 & 1 & & & & & & & & \\
\hline 7 & 2 & & & & & & & & \\
\hline 8 & 3 & & & & & & & & \\
\hline
\end{tabular}

The lack of values in the table for particular parameters in particular layers denotes that no HELP model input was required for that parameter in that layer. No data are missing from the table.

* The HELP model output often produces an increased number of significant digits for the Effective Saturated Hydraulic Conductivity over that of the actual input 


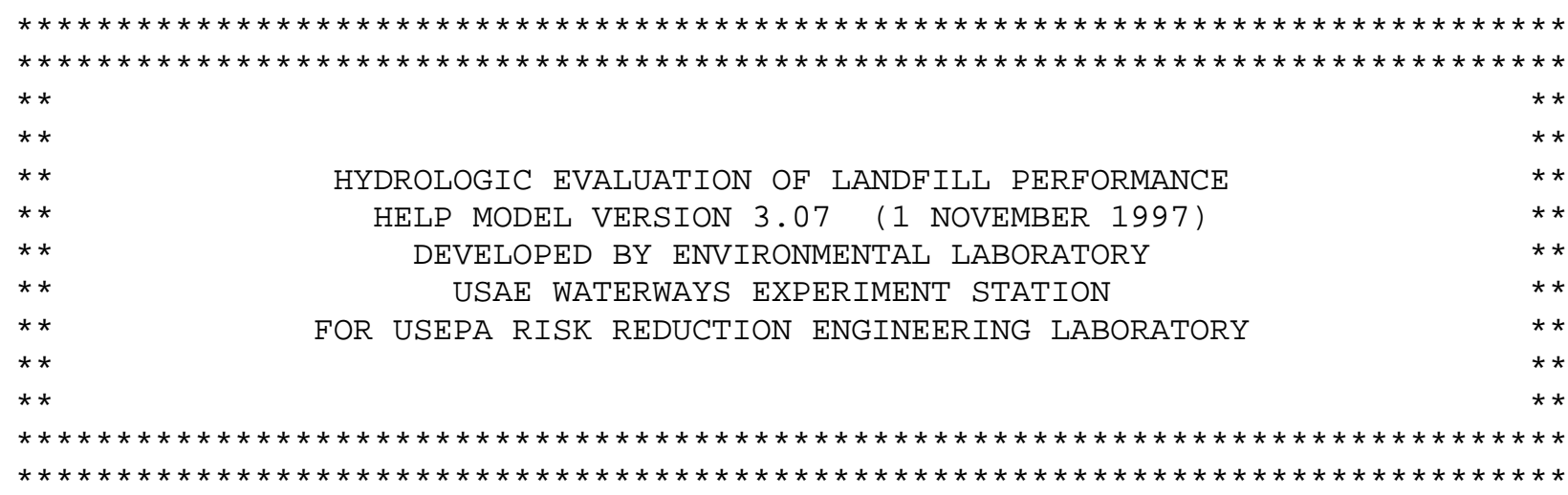

\begin{tabular}{|c|c|}
\hline PRECIPITATION DATA FILE: & $\mathrm{D}: \backslash$ HELP $3 \backslash$ Hweather $\backslash 2$ \\
\hline TEMPERATURE DATA FILE: & D : \HELP $3 \backslash$ Hweather $\backslash \mathrm{ZTEMP}$. D 7 \\
\hline SOLAR RADIATION DATA FILE: & D : \HELP $3 \backslash$ Hweather $\backslash$ ZSOLAR.D13 \\
\hline EVAPOTRANSPIRATION DATA: & D : \HELP $3 \backslash$ Hweat her $\backslash$ ZEVAP . D11 \\
\hline SOIL AND DESIGN DATA FILE: & 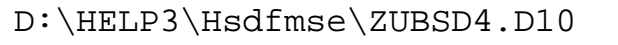 \\
\hline UTPUT DATA FILE: & 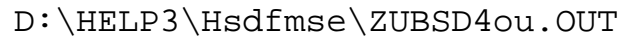 \\
\hline
\end{tabular}

TIME : $13: 53 \quad$ DATE $: \quad 1 / 13 / 2004$

TITLE: UBS Degraded MSE Vault Closure Cap - 550 years

NOTE: INITIAL MOISTURE CONTENT OF THE LAYERS AND SNOW WATER WERE SPECIFIED BY THE USER.

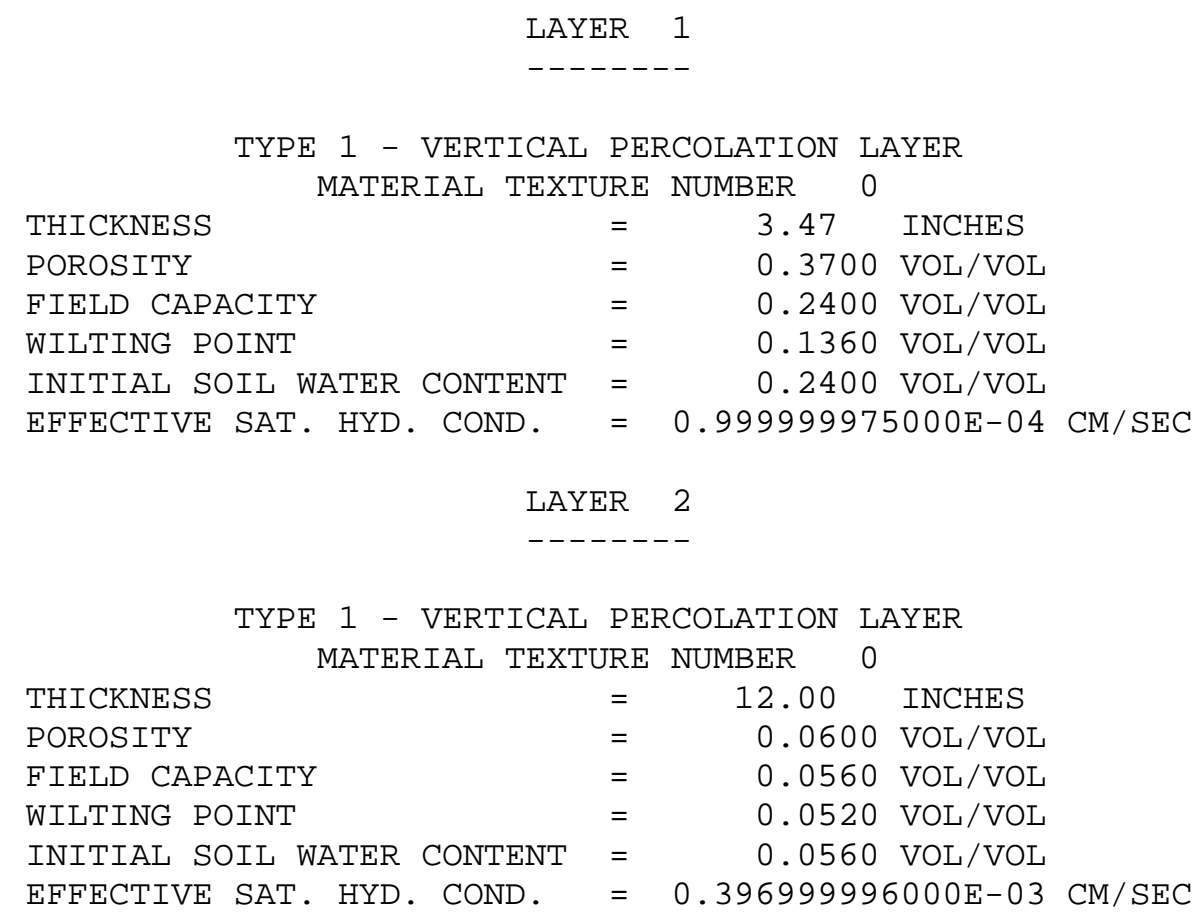

Rev. 0 
LAYER 3

--------

TYPE 1 - VERTICAL PERCOLATION LAYER

MATERIAL TEXTURE NUMBER 0

$\begin{array}{llrl}\text { THICKNESS } & = & 12.00 & \text { INCHES } \\ \text { POROSITY } & = & 0.3720 \mathrm{VOL} / \mathrm{VOL} \\ \text { FIELD CAPACITY } & = & 0.2150 \mathrm{VOL} / \mathrm{VOL} \\ \text { WILTING POINT } & = & 0.1170 \mathrm{VOL} / \mathrm{VOL} \\ \text { INITIAL SOIL WATER CONTENT } & = & 0.2150 \mathrm{VOL} / \mathrm{VOL} \\ \text { EFFECTIVE SAT. HYD. COND. } & =0.28999996000 \mathrm{E}-03 \mathrm{CM} / \mathrm{SEC}\end{array}$

LAYER 4

$-$

TYPE 2 - LATERAL DRAINAGE LAYER

THICKNESS

MATERIAL TEXTURE NUMBER 0

POROSITY

$=\quad 12.00 \quad$ INCHES

FIELD CAPACITY

$=0.3780 \mathrm{VOL} / \mathrm{VOL}$

WILTING POINT $\quad=$

$=0.1050 \mathrm{VOL} / \mathrm{VOL}$

$0.0319 \mathrm{VOL} / \mathrm{VOL}$

INITIAL SOIL WATER CONTENT

$0.1050 \mathrm{VOL} / \mathrm{VOL}$

SLOPE

$=$

$0.340000018000 \mathrm{E}-01 \mathrm{CM} / \mathrm{SEC}$

DRAINAGE LENGTH

$=3.00 \quad$ PERCENT

$=450.0 \quad \mathrm{FEET}$

LAYER 5

TYPE 3 - BARRIER SOIL LINER

MATERIAL TEXTURE NUMBER 0

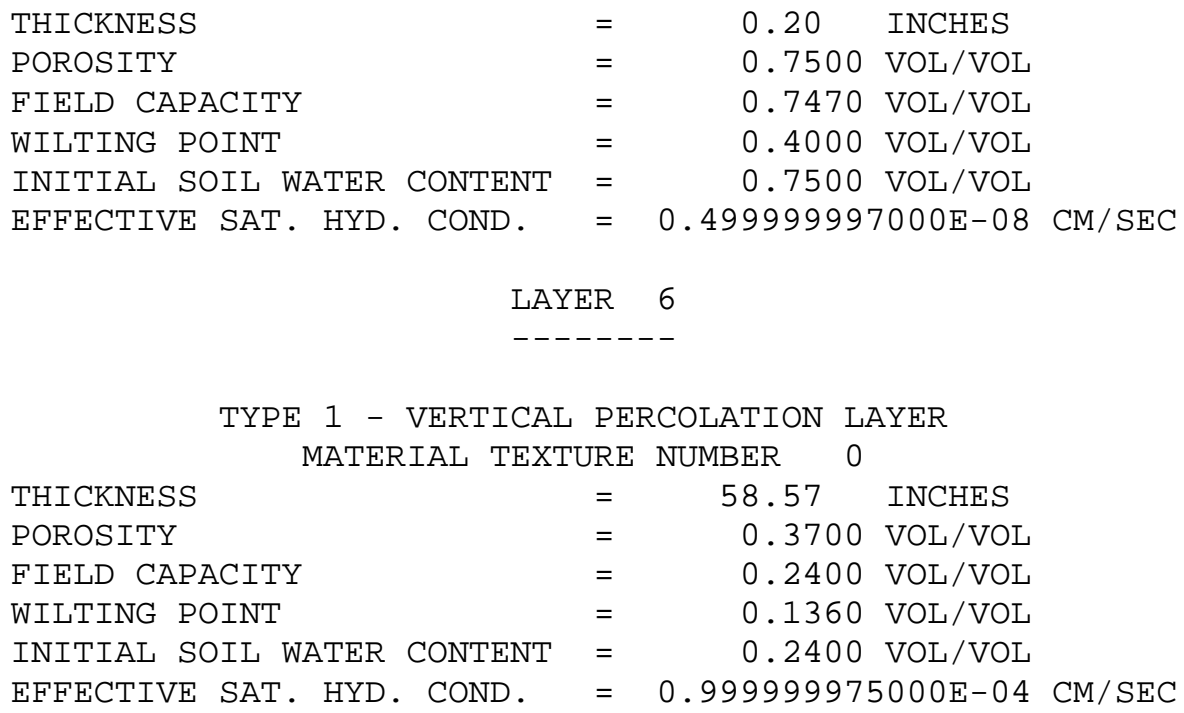

Rev. 0 
LAYER 7

$--------$

TYPE 2 - LATERAL DRAINAGE LAYER

MATERIAL TEXTURE NUMBER 0

$\begin{array}{llcl}\text { THICKNESS } & = & 24.00 & \text { INCHES } \\ \text { POROSITY } & = & 0.3800 \mathrm{VOL} / \mathrm{VOL} \\ \text { FIELD CAPACITY } & = & 0.0803 \mathrm{VOL} / \mathrm{VOL} \\ \text { WILTING POINT } & = & 0.0134 \mathrm{VOL} / \mathrm{VOL} \\ \text { INITIAL SOIL WATER CONTENT } & = & 0.0803 \mathrm{VOL} / \mathrm{VOL} \\ \text { EFFECTIVE SAT. HYD. COND. } & =0.997999981000 \mathrm{E}-01 \mathrm{CM} / \mathrm{SEC} \\ \text { SLOPE } & = & 11.40 \mathrm{PERCENT} \\ \text { DRAINAGE LENGTH } & = & 150.0 \mathrm{FEET}\end{array}$

LAYER 8

TYPE 3 - BARRIER SOIL LINER

MATERIAL TEXTURE NUMBER 0

THICKNESS

POROSITY

FIELD CAPACITY

WILTING POINT

INITIAL SOIL WATER CONTENT =

EFFECTIVE SAT. HYD. COND.

$$
\begin{array}{rrr}
= & 0.20 & \text { INCHES } \\
= & 0.7500 & \mathrm{VOL} / \mathrm{VOL} \\
= & 0.7470 \mathrm{VOL} / \mathrm{VOL} \\
= & 0.4000 \mathrm{VOL} / \mathrm{VOL} \\
= & 0.7500 \mathrm{VOL} / \mathrm{VOL} \\
= & 0.499999997000 \mathrm{E}-08 \mathrm{CM} / \mathrm{SEC}
\end{array}
$$

GENERAL DESIGN AND EVAPORATIVE ZONE DATA

NOTE: SCS RUNOFF CURVE NUMBER WAS COMPUTED FROM DEFAULT SOIL DATA BASE USING SOIL TEXTURE \#10 WITH A GOOD STAND OF GRASS, A SURFACE SLOPE OF 3.\% AND A SLOPE LENGTH OF 450. FEET.

SCS RUNOFF CURVE NUMBER

FRACTION OF AREA ALLOWING RUNOFF

AREA PROJECTED ON HORIZONTAL PLANE

EVAPORATIVE ZONE DEPTH

INITIAL WATER IN EVAPORATIVE ZONE

UPPER LIMIT OF EVAPORATIVE STORAGE LOWER LIMIT OF EVAPORATIVE STORAGE INITIAL SNOW WATER

INITIAL WATER IN LAYER MATERIALS

TOTAL INITIAL WATER

TOTAL SUBSURFACE INFLOW

$\begin{array}{lcl}= & 80.10 & \\ = & 100.0 & \text { PERCENT } \\ = & 19.630 & \text { ACRES } \\ = & 22.0 & \text { INCHES } \\ = & 2.909 & \text { INCHES } \\ = & 4.433 & \text { INCHES } \\ = & 1.860 & \text { INCHES } \\ = & 0.000 & \text { INCHES } \\ = & 21.628 & \text { INCHES } \\ = & 21.628 & \text { INCHES } \\ = & 0.00 & \text { INCHES /YEAR }\end{array}$


NOTE: EVAPOTRANSPIRATION DATA WAS OBTAINED FROM AUGUSTA GEORGIA

STATION LATITUDE

MAXIMUM LEAF AREA INDEX

START OF GROWING SEASON (JULIAN DATE)

END OF GROWING SEASON (JULIAN DATE)

EVAPORATIVE ZONE DEPTH

AVERAGE ANNUAL WIND SPEED

AVERAGE 1ST QUARTER RELATIVE HUMIDITY

AVERAGE 2ND QUARTER RELATIVE HUMIDITY

AVERAGE 3RD QUARTER RELATIVE HUMIDITY

AVERAGE 4TH QUARTER RELATIVE HUMIDITY
$=33.22$ DEGREES

$=3.50$

$=68$

$=323$

$=22.0$ INCHES

$=6.50 \mathrm{MPH}$

$=68.00 \%$

$=70.00 \%$

$=77.00 \%$

$=73.00 \%$

$\begin{array}{cccc}\text { NOTE: } & \text { PRECIPITATION DATA } & \text { WAS SYNTHETICALLY GENERATED USING } \\ \text { COEFFICIENTS FOR } & \text { AUGUSTA } & \text { GEORGIA }\end{array}$ NORMAL MEAN MONTHLY PRECIPITATION (INCHES)

\begin{tabular}{|c|c|c|c|c|c|c|c|c|}
\hline JAN / JUL & FEB/AUG & \multicolumn{3}{|c|}{ MAR/SEP APR/OCT } & MAY / NOV & \multicolumn{3}{|c|}{ JUN / DEC } \\
\hline------- & ------- & \multirow{2}{*}{\multicolumn{2}{|c|}{$\begin{array}{c}------ \\
4.68\end{array}$}} & -------- & ------- & \multicolumn{3}{|c|}{-------} \\
\hline 4.38 & 3.95 & & & 2.91 & 3.56 & \multicolumn{3}{|c|}{4.99} \\
\hline 5.43 & 5.41 & \multicolumn{2}{|c|}{3.93} & 3.12 & 2.96 & \multicolumn{3}{|c|}{3.45} \\
\hline NOTE : & \multicolumn{2}{|c|}{$\begin{array}{l}\text { TEMPERATURE DATA WAS } \\
\text { COEFFICIENTS FOR }\end{array}$} & $\begin{array}{lr}\text { VAS } & \text { SYNT } \\
2 & \text { AUG }\end{array}$ & $\begin{array}{l}\text { HET ICALLY } \\
\text { USTA }\end{array}$ & \multicolumn{3}{|c|}{$\begin{array}{c}\text { GENERATED USING } \\
\text { GEORGIA }\end{array}$} & \\
\hline \multicolumn{2}{|c|}{ NORMAL MEAN } & \multicolumn{6}{|c|}{ MONTHLY TEMPERATURE (DEGREES FAHRENHEIT) } & \\
\hline JAN / JUL & FEB/AUG & \multicolumn{2}{|c|}{$\mathrm{MAR} / \mathrm{SEP}$} & $\mathrm{APR} / \mathrm{OCT}$ & MAY / NOV & \multicolumn{3}{|c|}{ JUN/DEC } \\
\hline------- & ------- & ------- & -- & -------- & ------- & \multicolumn{3}{|c|}{-------} \\
\hline 46.30 & 50.00 & 57.20 & & 64.30 & 72.10 & \multicolumn{3}{|c|}{78.40} \\
\hline 81.60 & 80.30 & 75.20 & & 65.10 & 56.70 & \multicolumn{3}{|c|}{48.80} \\
\hline \multirow[t]{2}{*}{ NOTE : } & \multicolumn{2}{|c|}{$\begin{array}{c}\text { SOLAR RADIATION DAT } \\
\text { COEFFICIENTS FOR }\end{array}$} & $\begin{array}{l}\text { TA } \text { WAS } \\
\text { AUG }\end{array}$ & $\begin{array}{l}\text { SYNTHETICA } \\
\text { USTA }\end{array}$ & \multicolumn{2}{|c|}{$\begin{array}{r}\text { SLY GENERATED } \\
\text { GEORGIA }\end{array}$} & USING & \\
\hline & \multicolumn{3}{|c|}{ AND STATION LATITUDE } & $=33.30$ & DEGREES & & & \\
\hline AVERAGE & MONTHLY & VALUES IN & INCHES & FOR YEARS & 1 THR & OUGH & 100 & \\
\hline & & JAN / JUL & $\mathrm{FEB} / \mathrm{AUG}$ & MAR/SEP & $\mathrm{APR} / \mathrm{OCT}$ & $\mathrm{MAY} /$ & NOV & JUN/DEC \\
\hline & & $-------\quad-$ & ------- & ------- & ------- & ---- & ---- & ------- \\
\hline $\begin{array}{l}\text { PRECIPITATION } \\
-------------\end{array}$ & & & & & & & & \\
\hline TOTALS & & 4.56 & 3.57 & 4.76 & 2.74 & & 60 & 4.97 \\
\hline & & 5.81 & 5.32 & 4.41 & 2.99 & & & 3.41 \\
\hline STD. DEVIATI & CONS & 2.44 & 1.60 & 2.47 & 1.31 & & 12 & 2.60 \\
\hline & & 2.83 & 2.95 & 2.54 & 2.28 & & .72 & 1.90 \\
\hline
\end{tabular}

Rev. 0 


\begin{tabular}{|c|c|c|c|c|c|c|}
\hline \multicolumn{7}{|l|}{ RUNOFF } \\
\hline \multirow[t]{2}{*}{ TOTALS } & 0.192 & 0.084 & 0.144 & 0.021 & 0.072 & 0.125 \\
\hline & 0.267 & 0.333 & 0.181 & 0.123 & 0.063 & 0.068 \\
\hline \multirow{2}{*}{ STD. DEVIATIONS } & 0.429 & 0.246 & 0.311 & 0.072 & 0.162 & 0.219 \\
\hline & 0.378 & 0.670 & 0.362 & 0.316 & 0.162 & 0.138 \\
\hline \multicolumn{7}{|l|}{ EVAPOTRANSP IRATION } \\
\hline \multirow{2}{*}{ TOTALS } & 1.681 & 2.097 & 2.865 & 2.406 & 2.802 & 3.438 \\
\hline & 3.898 & 3.454 & 2.698 & 1.466 & 1.068 & 1.298 \\
\hline \multirow[t]{2}{*}{ STD. DEVIATIONS } & 0.228 & 0.294 & 0.738 & 0.909 & 1.126 & 1.312 \\
\hline & 1.269 & 1.166 & 0.950 & 0.679 & 0.282 & 0.203 \\
\hline \multicolumn{7}{|c|}{ LATERAL DRAINAGE COLLECTED FROM LAYER 4} \\
\hline \multirow[t]{2}{*}{ TOTALS } & 2.1202 & 1.8138 & 1.7760 & 1.2001 & 0.7499 & 0.9084 \\
\hline & 1.3365 & 1.4961 & 1.3923 & 1.2466 & 1.2125 & 1.5414 \\
\hline \multirow[t]{2}{*}{ STD. DEVIATIONS } & 1.1708 & 1.1039 & 1.0639 & 0.8652 & 0.6453 & 0.7220 \\
\hline & 0.9105 & 0.9416 & 0.8999 & 1.0017 & 0.9693 & 0.9844 \\
\hline \multicolumn{7}{|c|}{ PERCOLATION/LEAKAGE THROUGH LAYER 5} \\
\hline \multirow{2}{*}{ TOTALS } & -----1 & 01349 & 01310 & & & \\
\hline & $\begin{array}{l}0.1595 \\
0.0942\end{array}$ & $\begin{array}{l}0.1349 \\
0.1066\end{array}$ & $\begin{array}{l}0.1310 \\
0.0999\end{array}$ & $\begin{array}{l}0.0858 \\
0.0904\end{array}$ & $\begin{array}{l}0.0550 \\
0.0883\end{array}$ & 0.1090 \\
\hline \multirow[t]{2}{*}{ STD. DEVIATIONS } & 0.1091 & 0.0999 & 0.0905 & 0.0605 & 0.0429 & 0.0483 \\
\hline & 0.0611 & 0.0677 & 0.0659 & 0.0729 & 0.0725 & 0.0684 \\
\hline \multicolumn{7}{|c|}{ LATERAL DRAINAGE COLLECTED FROM LAYER 7} \\
\hline \multirow{2}{*}{ TOTALS } & 0.1088 & 0.0975 & 0.1294 & 0.1274 & 0.1065 & 0.0765 \\
\hline & 0.0763 & 0.0852 & 0.0864 & 0.0878 & 0.0821 & 0.0924 \\
\hline \multirow{2}{*}{ STD. DEVIATIONS } & 0.0636 & 0.0553 & 0.0790 & 0.1025 & 0.1050 & 0.0774 \\
\hline & 0.0490 & 0.0434 & 0.0495 & 0.0607 & 0.0612 & 0.0632 \\
\hline \multicolumn{7}{|c|}{ PERCOLATION/LEAKAGE THROUGH LAYER 8} \\
\hline \multirow{2}{*}{ TOTALS } & 0.0053 & 0.0048 & 0.0055 & 0.0053 & 0.0055 & 0.0053 \\
\hline & 0.0054 & 0.0054 & 0.0052 & 0.0054 & 0.0052 & 0.0054 \\
\hline \multirow[t]{2}{*}{ STD. DEVIATIONS } & 0.0006 & 0.0006 & 0.0004 & 0.0003 & 0.0002 & 0.0002 \\
\hline & 0.0002 & 0.0003 & 0.0004 & 0.0005 & 0.0003 & 0.0002 \\
\hline
\end{tabular}




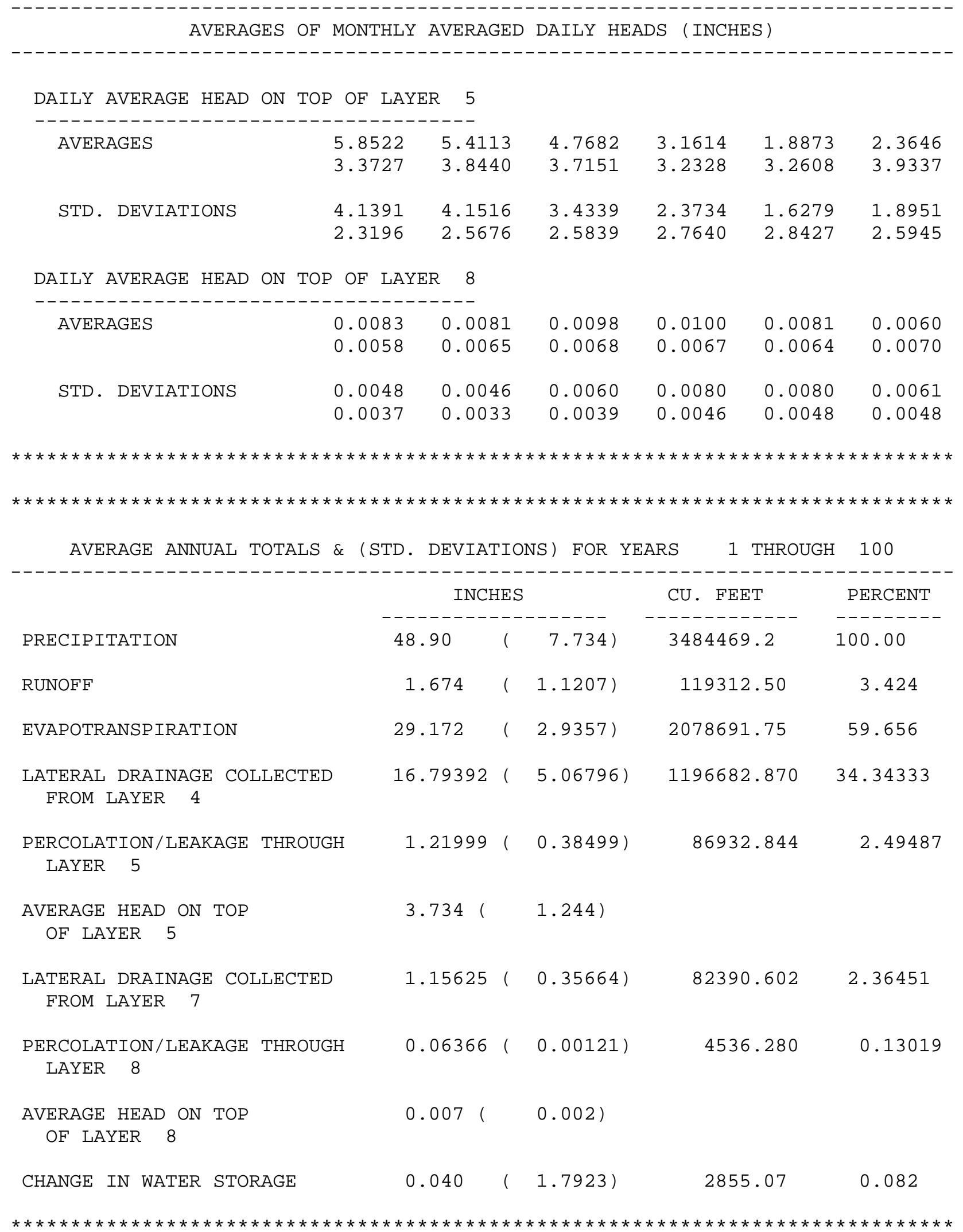

Rev. 0 


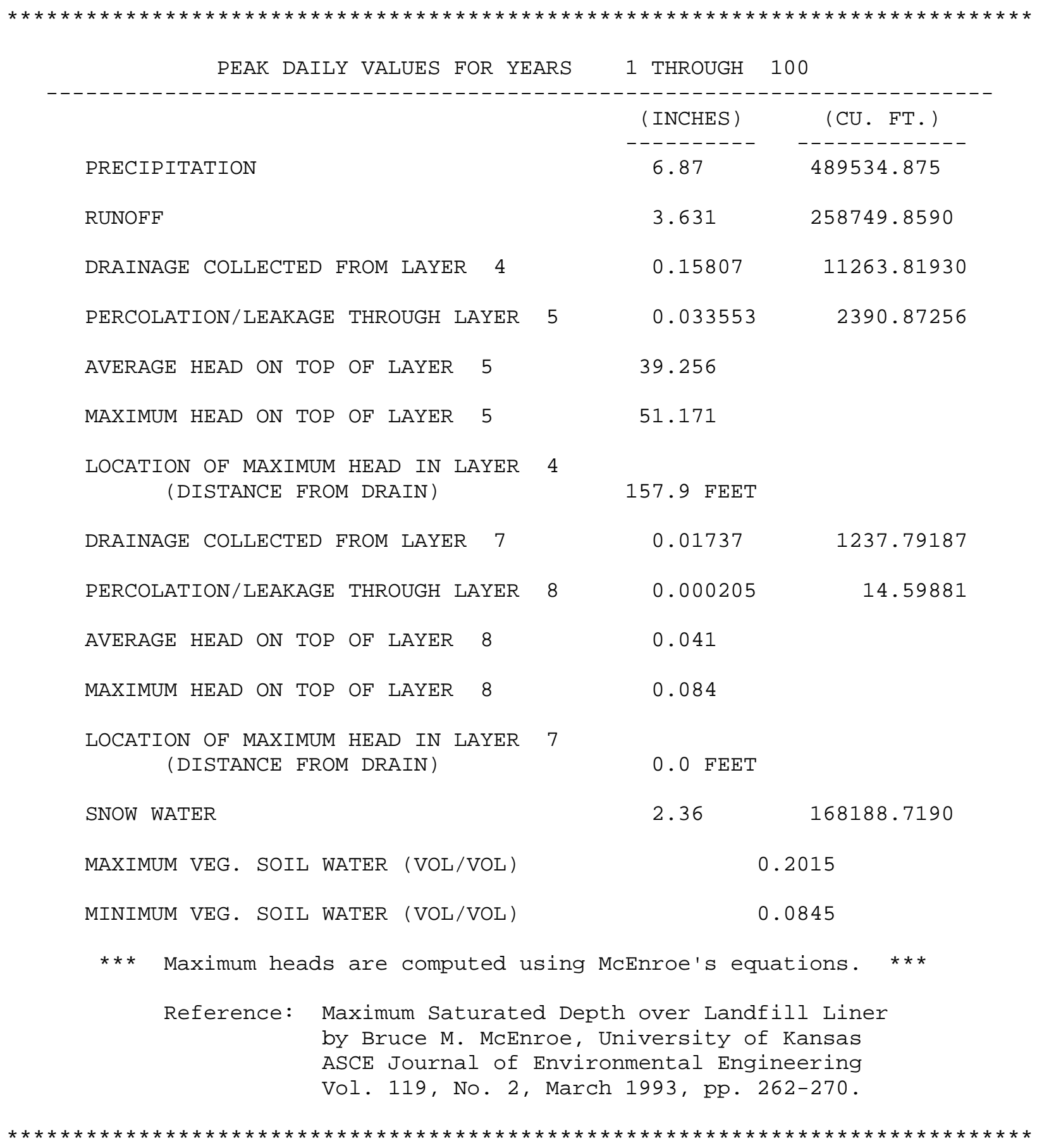

Rev. 0 


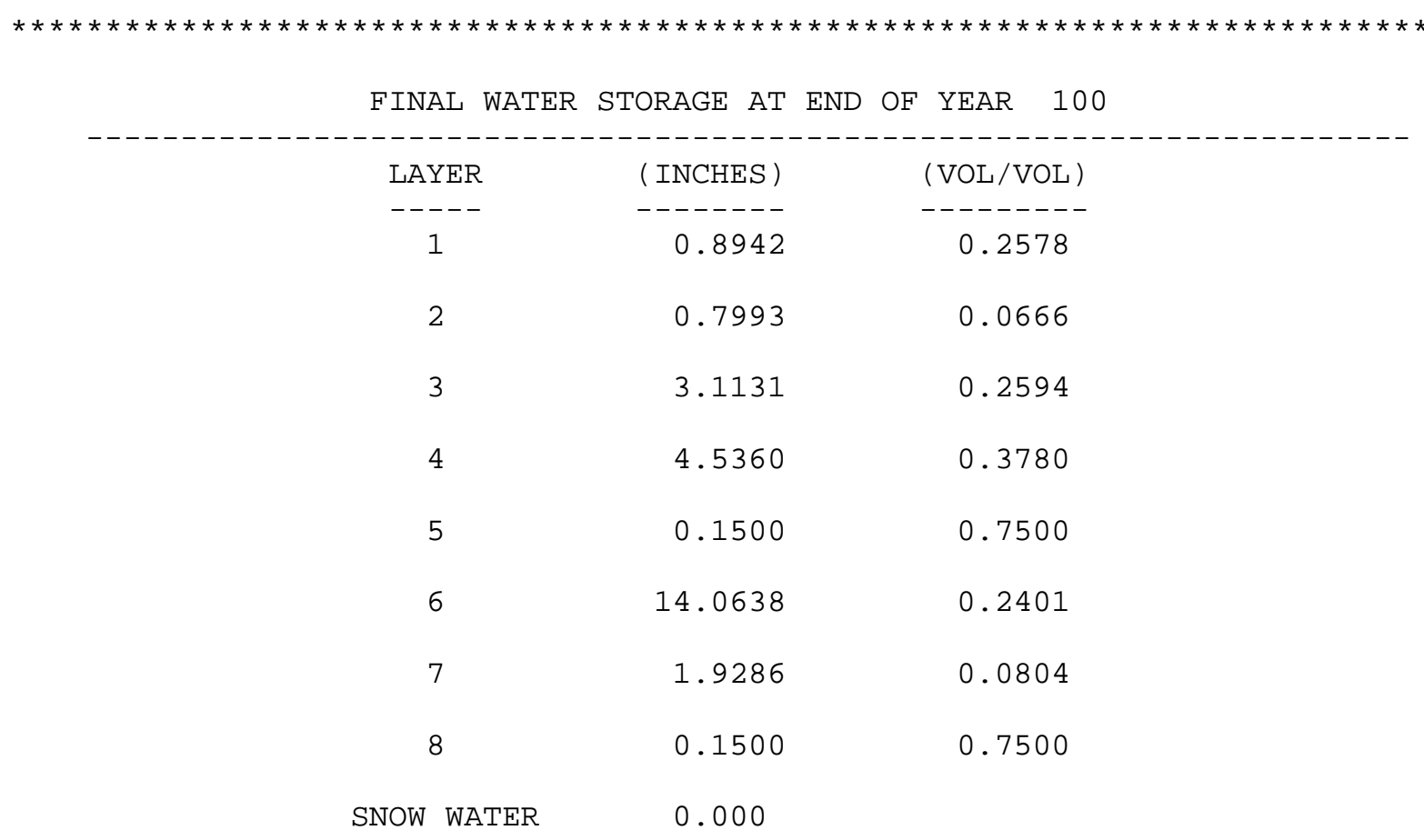


Appendix T, Upper Bounding Scenario Degraded SDF MSE Vault Closure Cap (602 Years): HELP Model Input Data and Output File (output file name: ZUBSD5ou.OUT)

\section{Input Data:}

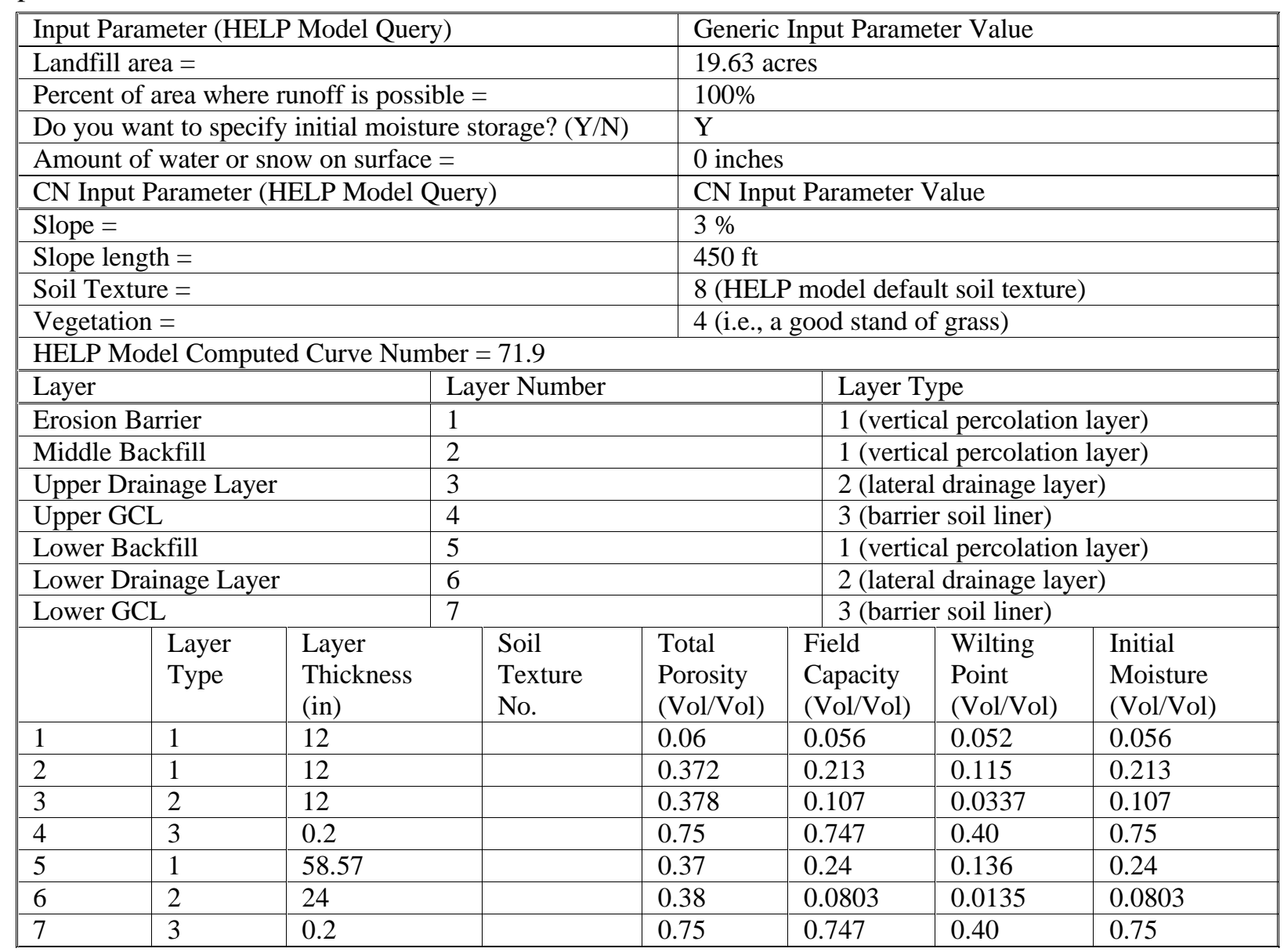

The lack of values in the table for particular parameters in particular layers denotes that no HELP model input was required for that parameter in that layer. No data are missing from the table. 
Input Data (continued):

\begin{tabular}{|c|c|c|c|c|c|c|c|c|c|}
\hline & $\begin{array}{l}\text { Layer } \\
\text { Type }\end{array}$ & $\begin{array}{l}\text { Sat. Hyd. } \\
\text { Conductivity * } \\
(\mathrm{cm} / \mathrm{sec})\end{array}$ & \multicolumn{2}{|c|}{$\begin{array}{l}\text { Drainage } \\
\text { Length } \\
(\mathrm{ft}) \\
\end{array}$} & $\begin{array}{l}\text { Drain } \\
\text { Slope } \\
(\%) \\
\end{array}$ & $\begin{array}{l}\text { Leachate } \\
\text { Recirc. } \\
(\%) \\
\end{array}$ & \multicolumn{2}{|c|}{$\begin{array}{l}\text { Recirc. to } \\
\text { Layer } \\
(\#)\end{array}$} & $\begin{array}{l}\text { Subsurface } \\
\text { Inflow } \\
\text { (in/yr) }\end{array}$ \\
\hline 1 & 1 & 3.97E-04 & & & & & & & \\
\hline 2 & 1 & $3.20 \mathrm{E}-04$ & & & & & & & \\
\hline 3 & 2 & $3.10 \mathrm{E}-02$ & 450 & & 3 & & & & \\
\hline 4 & 3 & $5.00 \mathrm{E}-09$ & & & & & & & \\
\hline 5 & 1 & $1.00 \mathrm{E}-04$ & & & & & & & \\
\hline 6 & 2 & $9.97 \mathrm{E}-02$ & 150 & & 11.4 & & & & \\
\hline 7 & 3 & $5.00 \mathrm{E}-09$ & & & & & & \\
\hline & $\begin{array}{l}\text { Layer } \\
\text { Type }\end{array}$ & \multicolumn{2}{|l|}{$\begin{array}{l}\text { Geomembrane } \\
\text { Pinhole Density } \\
\text { (\#/acre) }\end{array}$} & \multicolumn{2}{|c|}{$\begin{array}{l}\text { Geomembrane } \\
\text { Instal. Defects } \\
(\# / \text { acre })\end{array}$} & \multicolumn{2}{|c|}{$\begin{array}{l}\text { Geomembrane } \\
\text { Placement Quality }\end{array}$} & \multicolumn{2}{|c|}{$\begin{array}{l}\text { Geotextile } \\
\text { Transmissivity } \\
\left(\mathrm{cm}^{2} / \mathrm{sec}\right)\end{array}$} \\
\hline 1 & 1 & & & & & & & & \\
\hline 2 & 1 & & & & & & & & \\
\hline 3 & 2 & & & & & & & & \\
\hline 4 & 3 & & & & & & & & \\
\hline 5 & 1 & & & & & & & & \\
\hline 6 & 2 & & & & & & & & \\
\hline 7 & 3 & & & & & & & & \\
\hline
\end{tabular}

The lack of values in the table for particular parameters in particular layers denotes that no HELP model input was required for that parameter in that layer. No data are missing from the table.

* The HELP model output often produces an increased number of significant digits for the Effective Saturated Hydraulic Conductivity over that of the actual input 


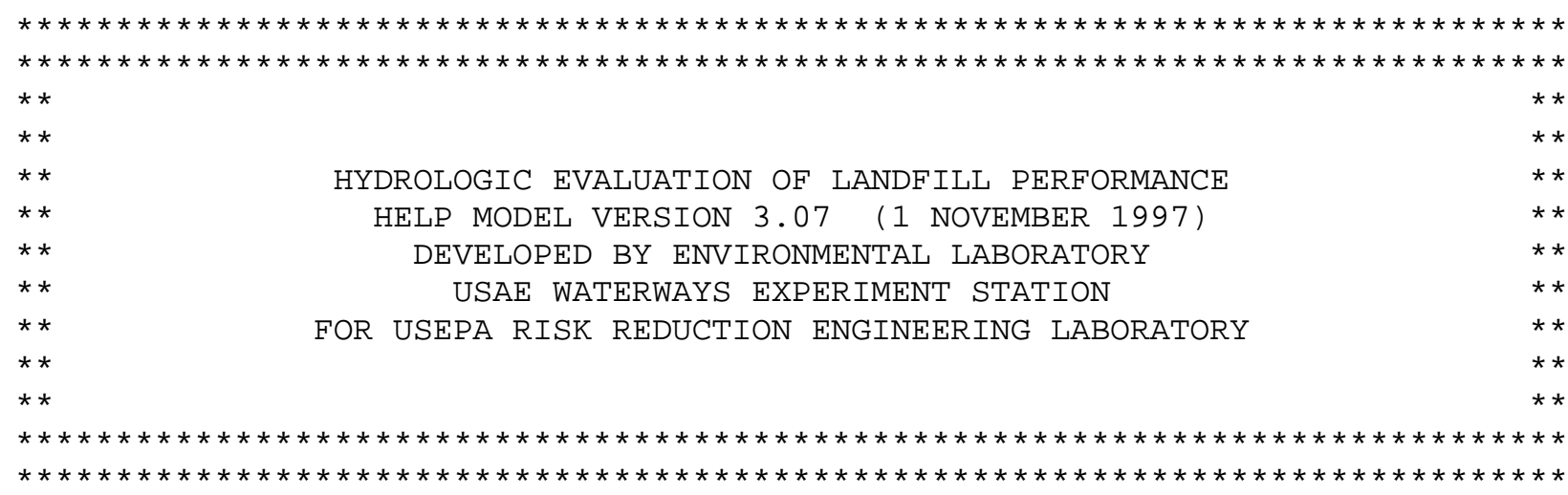

\begin{tabular}{|c|c|}
\hline PRECIPITATION DATA & $\mathrm{D}: \backslash \mathrm{HE}$ \\
\hline TEMPERATURE DATA FILE: & D : \HELP $3 \backslash$ Hweather $\backslash$ ZTEMP . D 7 \\
\hline ATION DA & D: \HELP $3 \backslash$ Hweather $\backslash$ ZSOLAR.D13 \\
\hline TRANSP IRATION DATA: & D: \HELP $3 \backslash$ Hweather $\backslash$ ZEVAP.D11 \\
\hline DESIGN D & $\mathrm{D}: \backslash$ HELP $3 \backslash$ Hsdfmse $\backslash$ ZUBSD 5.D10 \\
\hline & UB \\
\hline
\end{tabular}

TIME: 14:0 DATE: 1/13/2004

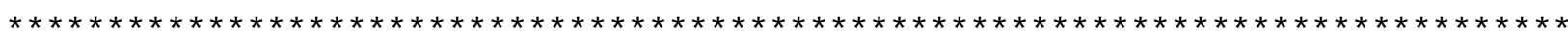
TITLE: UBS Degraded MSE Vault Closure Cap - 602 years

NOTE: INITIAL MOISTURE CONTENT OF THE LAYERS AND SNOW WATER WERE SPECIFIED BY THE USER.

\begin{tabular}{|c|c|c|c|c|}
\hline \multicolumn{5}{|c|}{ LAYER 1} \\
\hline \multicolumn{5}{|c|}{ TYPE 1 - VERTICAL PERCOLATION LAYER } \\
\hline THICKNESS & $=$ & 12.00 & INCHES & \\
\hline POROSITY & $=$ & 0.0600 & $\mathrm{VOL} / \mathrm{VOL}$ & \\
\hline FIELD CAPACITY & $=$ & 0.0560 & VOL/VOL & \\
\hline WILTING POINT & $=$ & 0.0520 & VOL/VOL & \\
\hline INITIAL SOIL WATER CONTENT & $=$ & 0.0560 & VOL/VOL & \\
\hline EFFECTIVE SAT. HYD. COND. & $=$ & 0.396999996 & $6000 \mathrm{E}-03$ & $\mathrm{CM} / \mathrm{SEC}$ \\
\hline \multicolumn{5}{|c|}{ LAYER 2} \\
\hline $\begin{array}{r}\text { TYPE } 1 \text { - VERTICAI } \\
\text { MATERIAL TEX? }\end{array}$ & $\begin{aligned} & P E \\
& U R E\end{aligned}$ & $\begin{array}{cl}\text { RCOLATION } & \text { LA } \\
\text { NUMBER } & 0\end{array}$ & AYER & \\
\hline THICKNESS & $=$ & 12.00 & INCHES & \\
\hline POROSITY & $=$ & 0.3720 & VOL/VOL & \\
\hline FIELD CAPACITY & $=$ & 0.2130 & $\mathrm{VOL} / \mathrm{VOL}$ & \\
\hline WILTING POINT & $=$ & 0.1150 & $\mathrm{VOL} / \mathrm{VOL}$ & \\
\hline INITIAL SOIL WATER CONTENT & $=$ & 0.2130 & VOL/VOL & \\
\hline EFFECTIVE SAT. HYD. COND. & $=$ & 0.319999992 & $2000 E-03$ & $\mathrm{CM} / \mathrm{SEC}$ \\
\hline
\end{tabular}

Rev. 0 
LAYER 3

$--------$

TYPE 2 - LATERAL DRAINAGE LAYER

MATERIAL TEXTURE NUMBER 0

\begin{tabular}{|c|c|c|c|c|}
\hline & & & & \\
\hline THICKNESS & $=$ & 12.00 & INCHES & \\
\hline POROSITY & $=$ & 0.3780 & VOL/VOL & \\
\hline FIELD CAPACITY & $=$ & 0.1070 & VOL/VOL & \\
\hline WILTING POINT & $=$ & 0.0337 & VOL/VOL & \\
\hline INITIAL SOIL WATER CONTENT & $=$ & 0.1070 & VOL/VOL & \\
\hline EFFECTIVE SAT. HYD. COND. & $=$ & 0.309999995 & $5000 E-01$ & $\mathrm{CM} / \mathrm{SEC}$ \\
\hline SLOPE & $=$ & 3.00 & PERCENT & \\
\hline DRAINAGE LENGTH & $=$ & 450.0 & FEET & \\
\hline LAY & ER & 4 & & \\
\hline--- & & & & \\
\hline TYPE $3-$ BARR & IER & SOIL LINER & & \\
\hline MATERIAL TEXT & URE & NUMBER 0 & & \\
\hline THICKNESS & $=$ & 0.20 & INCHES & \\
\hline POROSITY & $=$ & 0.7500 & VOL/VOL & \\
\hline FIELD CAPACITY & $=$ & 0.7470 & VOL/VOL & \\
\hline WILTING POINT & $=$ & 0.4000 & VOL/VOL & \\
\hline INITIAL SOIL WATER CONTENT & $=$ & 0.7500 & VOL/VOL & \\
\hline EFFECTIVE SAT. HYD. COND. & $=$ & 0.499999997 & $7000 \mathrm{E}-08$ & $\mathrm{CM} / \mathrm{SEC}$ \\
\hline LAY & & 5 & & \\
\hline
\end{tabular}

TYPE 1 - VERTICAL PERCOLATION LAYER MATERIAL TEXTURE NUMBER 0

$\begin{array}{llrl}\text { THICKNESS } & = & 58.57 \mathrm{INCHES} \\ \text { POROSITY } & = & 0.3700 \mathrm{VOL} / \mathrm{VOL} \\ \text { FIELD CAPACITY } & = & 0.2400 \mathrm{VOL} / \mathrm{VOL} \\ \text { WILTING POINT } & = & 0.1360 \mathrm{VOL} / \mathrm{VOL} \\ \text { INITIAL SOIL WATER CONTENT } & = & 0.2400 \mathrm{VOL} / \mathrm{VOL} \\ \text { EFFECTIVE SAT. HYD. COND. } & =0.999999975000 \mathrm{E}-04 \mathrm{CM} / \mathrm{SEC}\end{array}$

LAYER 6

$--------$

TYPE 2 - LATERAL DRAINAGE LAYER

MATERIAL TEXTURE NUMBER 0

THICKNESS

POROSITY

$=\quad 24.00 \quad$ INCHES

FIELD CAPACITY

$=0.3800 \mathrm{VOL} / \mathrm{VOL}$

$0.0135 \mathrm{VOL} / \mathrm{VOL}$

INITIAL SOIL WATER CONTENT $=0.0803 \mathrm{VOL} / \mathrm{VOL}$

EFFECTIVE SAT. HYD. COND. $=0.996999964000 \mathrm{E}-01 \mathrm{CM} / \mathrm{SEC}$

SLOPE

DRAINAGE LENGTH

$=11.40$ PERCENT

$=\quad 150.0 \quad \mathrm{FEET}$

Rev. 0 
LAYER 7

$--------$

TYPE 3 - BARRIER SOIL LINER

MATERIAL TEXTURE NUMBER 0

$\begin{array}{llrl}\text { THICKNESS } & = & 0.20 \mathrm{INCHES} \\ \text { POROSITY } & = & 0.7500 \mathrm{VOL} / \mathrm{VOL} \\ \text { FIELD CAPACITY } & = & 0.7470 \mathrm{VOL} / \mathrm{VOL} \\ \text { WILTING POINT } & = & 0.4000 \mathrm{VOL} / \mathrm{VOL} \\ \text { INITIAL SOIL WATER CONTENT } & = & 0.7500 \mathrm{VOL} / \mathrm{VOL} \\ \text { EFFECTIVE SAT. HYD. COND. } & =0.499999997000 \mathrm{E}-08 \mathrm{CM} / \mathrm{SEC}\end{array}$

GENERAL DESIGN AND EVAPORATIVE ZONE DATA

NOTE: SCS RUNOFF CURVE NUMBER WAS COMPUTED FROM DEFAULT SOIL DATA BASE USING SOIL TEXTURE \# 8 WITH A GOOD STAND OF GRASS, A SURFACE SLOPE OF 3.\% AND A SLOPE LENGTH OF 450. FEET.

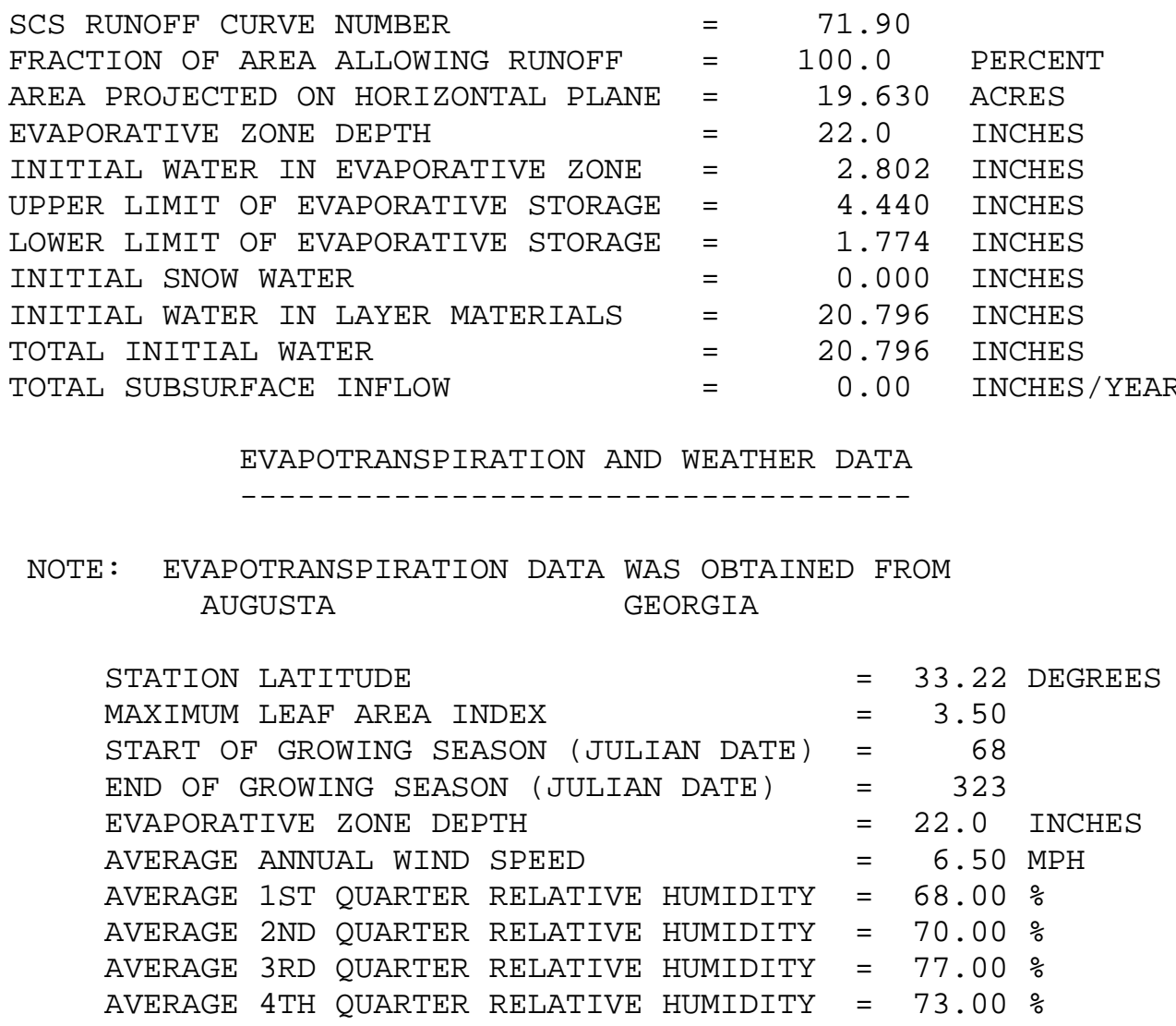




$$
\begin{aligned}
& \text { NOTE: PRECIPITATION DATA WAS SYNTHETICALLY GENERATED USING } \\
& \text { COEFFICIENTS FOR AUGUSTA GEORGIA } \\
& \text { NORMAL MEAN MONTHLY PRECIPITATION (INCHES) } \\
& \begin{array}{cccccc}
\text { JAN/JUL } & \text { FEB/AUG } & \text { MAR/SEP } & \text { APR/OCT } & \text { MAY/NOV } & \text { JUN/DEC } \\
------ & ------ & ------ & ------ & ------ & ------ \\
4.38 & 3.95 & 4.68 & 2.91 & 3.56 & 4.99 \\
5.43 & 5.41 & 3.93 & 3.12 & 2.96 & 3.45
\end{array}
\end{aligned}
$$

\begin{tabular}{|c|c|c|c|c|c|c|}
\hline AVERAGE MONTHLY & VALUES IN & N INCHES & FOR YEARS & \multicolumn{2}{|c|}{1 THROUGH } & 100 \\
\hline & JAN/JUL & $\mathrm{FEB} / \mathrm{AUG}$ & $\mathrm{MAR} / \mathrm{SEP}$ & $\mathrm{APR} / \mathrm{OCT}$ & $\mathrm{MAY} / \mathrm{NOV}$ & JUN/DEC \\
\hline \multicolumn{7}{|l|}{ PRECIPITATION } \\
\hline \multirow[t]{2}{*}{ TOTALS } & 4.56 & 3.57 & 4.76 & 2.74 & 3.60 & 4.97 \\
\hline & 5.81 & 5.32 & 4.41 & 2.99 & 2.75 & 3.41 \\
\hline \multirow[t]{2}{*}{ STD. DEVIATIONS } & 2.44 & 1.60 & 2.47 & 1.31 & 2.12 & 2.60 \\
\hline & 2.83 & 2.95 & 2.54 & 2.28 & 1.72 & 1.90 \\
\hline \multicolumn{7}{|l|}{ RUNOFF } \\
\hline \multirow{2}{*}{ TOTALS } & 0.161 & 0.069 & 0.092 & 0.003 & 0.011 & 0.022 \\
\hline & 0.078 & 0.154 & 0.082 & 0.049 & 0.032 & 0.010 \\
\hline \multirow[t]{2}{*}{ STD. DEVIATIONS } & 0.562 & 0.347 & 0.377 & 0.017 & 0.042 & 0.061 \\
\hline & 0.182 & 0.517 & 0.351 & 0.301 & 0.148 & 0.046 \\
\hline \multicolumn{7}{|l|}{ EVAPOTRANSP IRATION } \\
\hline \multirow[t]{2}{*}{ TOTALS } & 1.652 & 2.095 & 2.878 & 2.482 & 2.872 & 3.546 \\
\hline & 3.979 & 3.557 & 2.740 & 1.472 & 1.052 & 1.274 \\
\hline \multirow[t]{2}{*}{ STD. DEVIATIONS } & 0.223 & 0.279 & 0.718 & 0.929 & 1.184 & 1.353 \\
\hline & 1.295 & 1.189 & 0.961 & 0.674 & 0.274 & 0.193 \\
\hline
\end{tabular}

NORMAL MEAN MONTHLY TEMPERATURE (DEGREES FAHRENHEIT)

$\begin{array}{cccccc}\text { JAN/JUL } & \text { FEB/AUG } & \text { MAR/SEP } & \text { APR/OCT } & \text { MAY/NOV } & \text { JUN/DEC } \\ ------ & ------ & ------ & ------ & ------ & ------ \\ 46.30 & 50.00 & 57.20 & 64.30 & 72.10 & 78.40 \\ 81.60 & 80.30 & 75.20 & 65.10 & 56.70 & 48.80\end{array}$

NOTE: SOLAR RADIATION DATA WAS SYNTHETICALLY GENERATED USING COEFFICIENTS FOR AUGUSTA GEORGIA AND STATION LATITUDE $=33.30$ DEGREES 


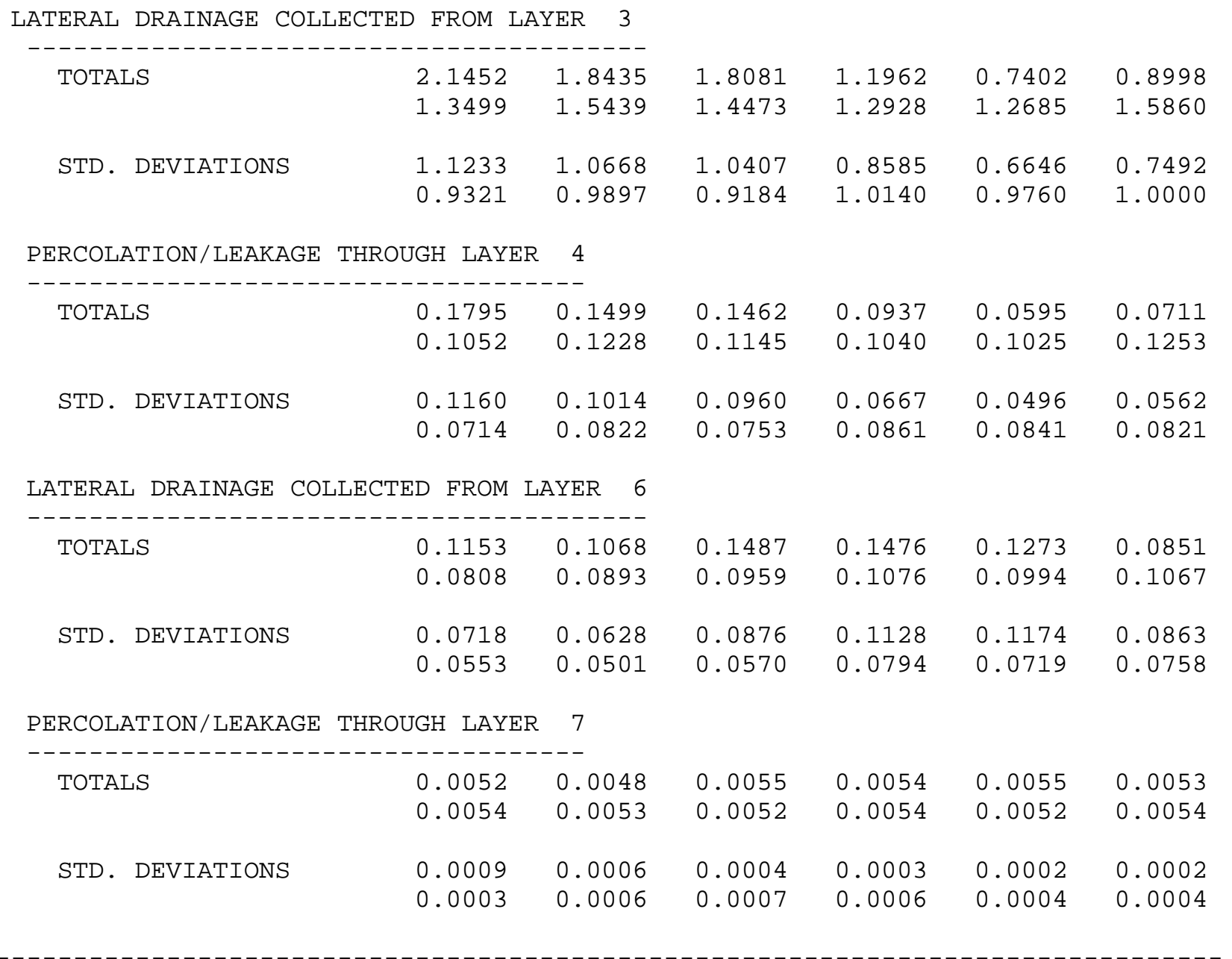

AVERAGES OF MONTHLY AVERAGED DAILY HEADS (INCHES)

DAILY AVERAGE HEAD ON TOP OF LAYER 4

$\begin{array}{lllllll}\text { AVERAGES } & 6.6097 & 6.0338 & 5.3468 & 3.4717 & 2.0567 & 2.5883 \\ & 3.7906 & 4.4596 & 4.2917 & 3.7471 & 3.8162 & 4.5531 \\ \text { STD. DEVIATIONS } & & & & & & \\ & 4.3961 & 4.2118 & 3.6413 & 2.6149 & 1.8810 & 2.2030 \\ & 2.7065 & 3.1156 & 2.9477 & 3.2623 & 3.2952 & 3.1154\end{array}$

DAILY AVERAGE HEAD ON TOP OF LAYER 7

$\begin{array}{lllllll}\text { AVERAGES } & 0.0088 & 0.0089 & 0.0113 & 0.0116 & 0.0097 & 0.0067 \\ & 0.0061 & 0.0068 & 0.0075 & 0.0082 & 0.0078 & 0.0081 \\ \text { STD. DEVIATIONS } & 0.0055 & 0.0053 & 0.0067 & 0.0089 & 0.0089 & 0.0068 \\ & 0.0042 & 0.0038 & 0.0045 & 0.0060 & 0.0057 & 0.0058\end{array}$




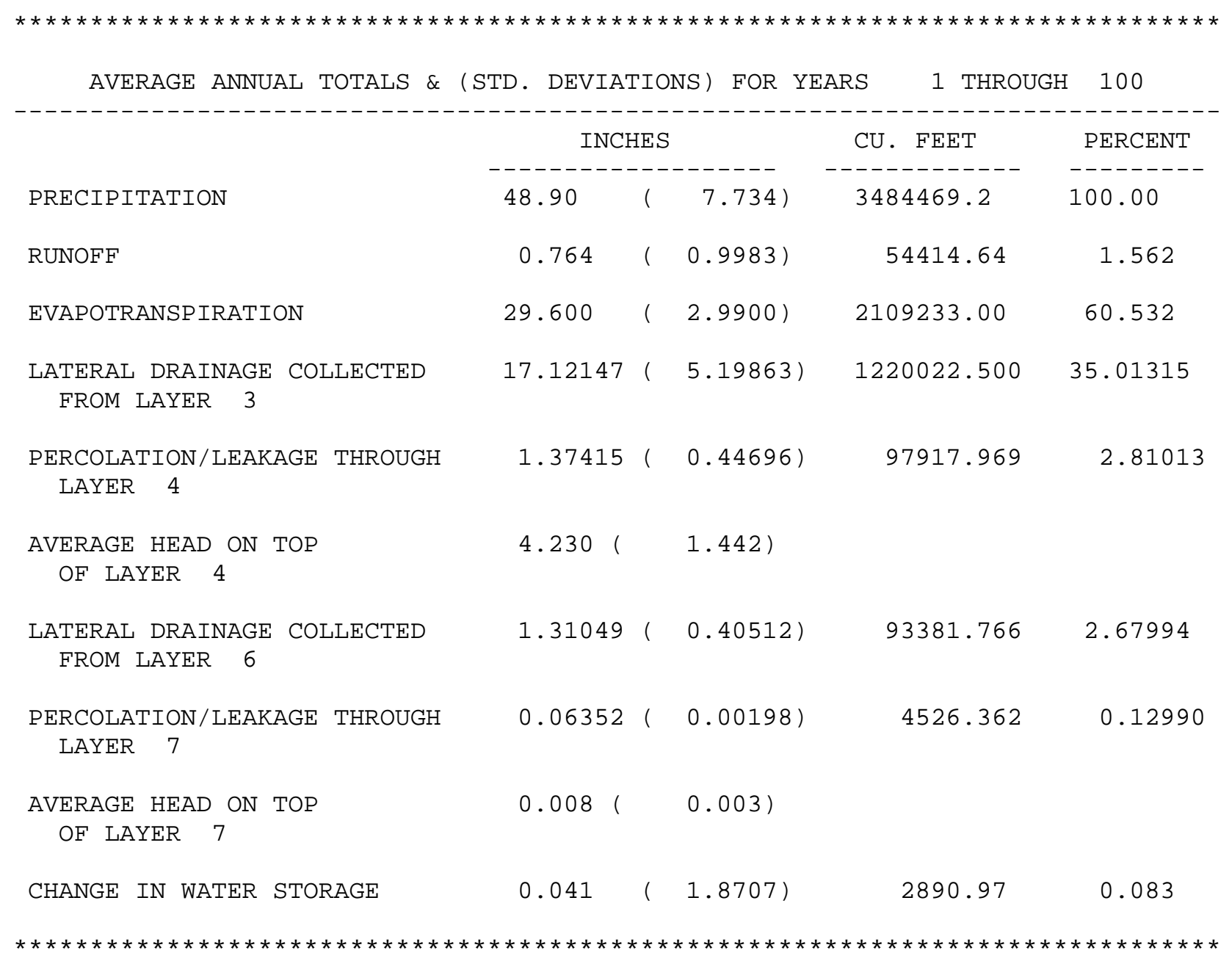




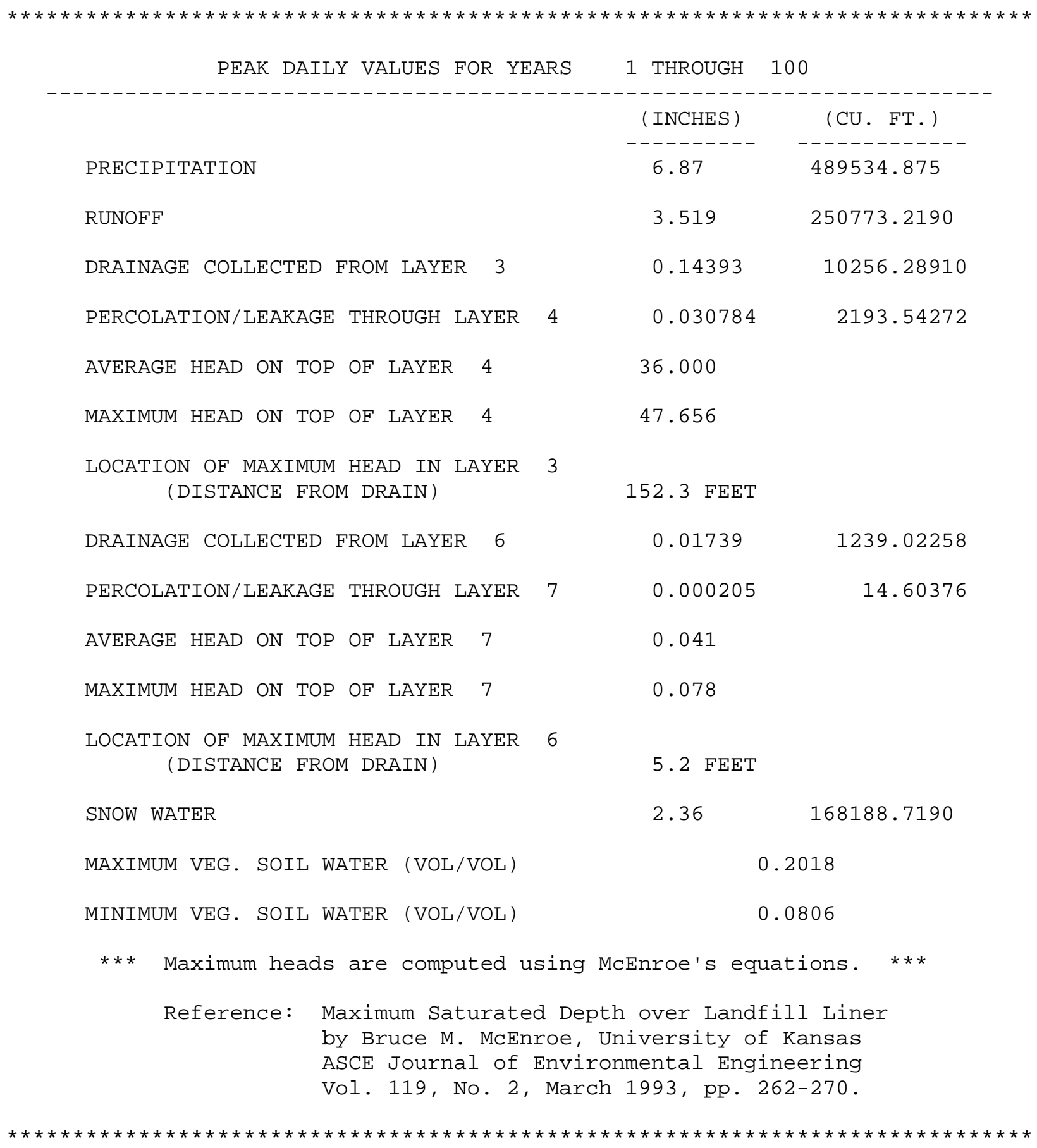

Rev. 0 


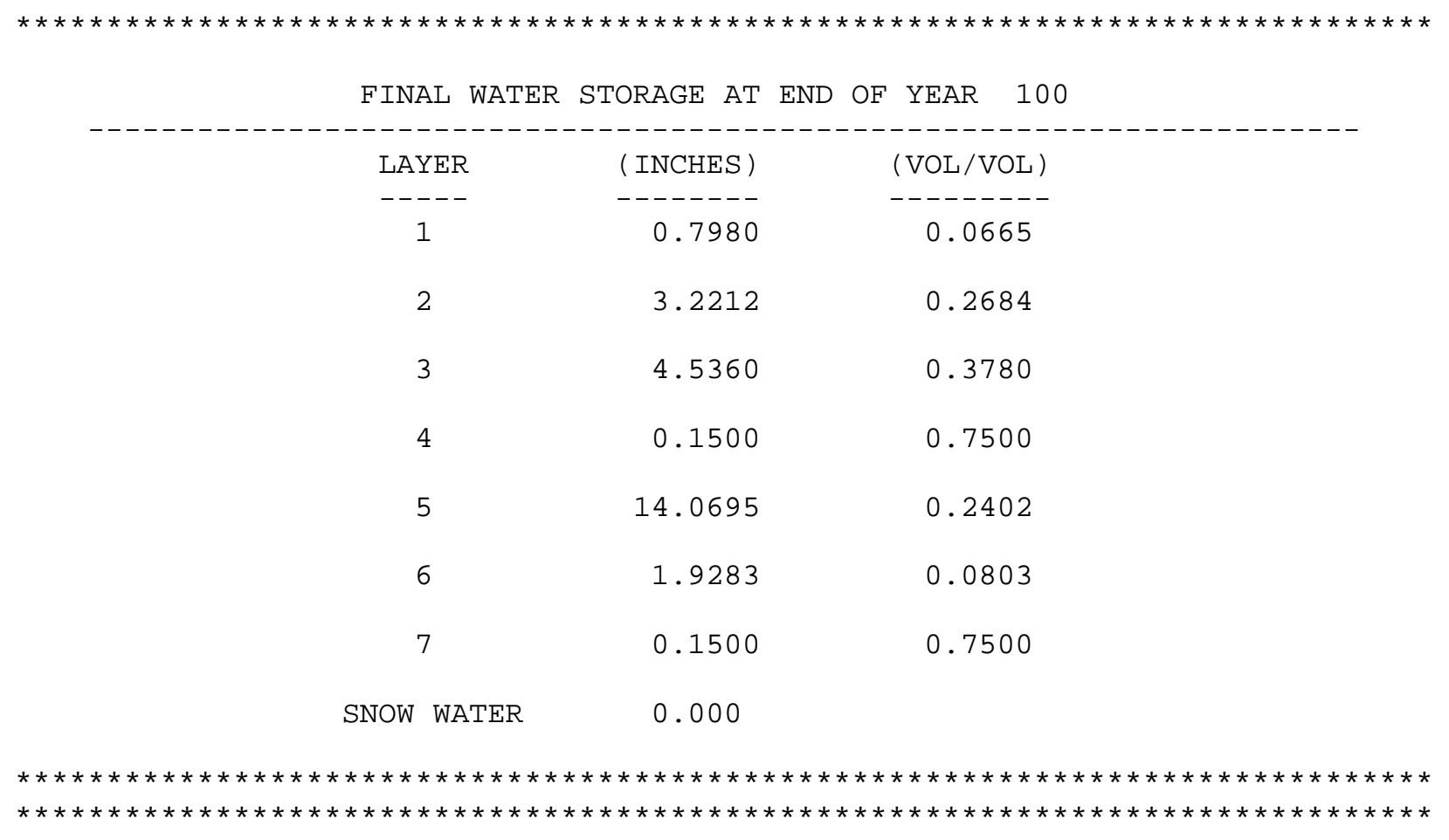


Appendix U, Upper Bounding Scenario Degraded SDF MSE Vault Closure Cap (802 Years): HELP Model Input Data and Output File (output file name: ZUBSD6ou.OUT)

\section{Input Data:}

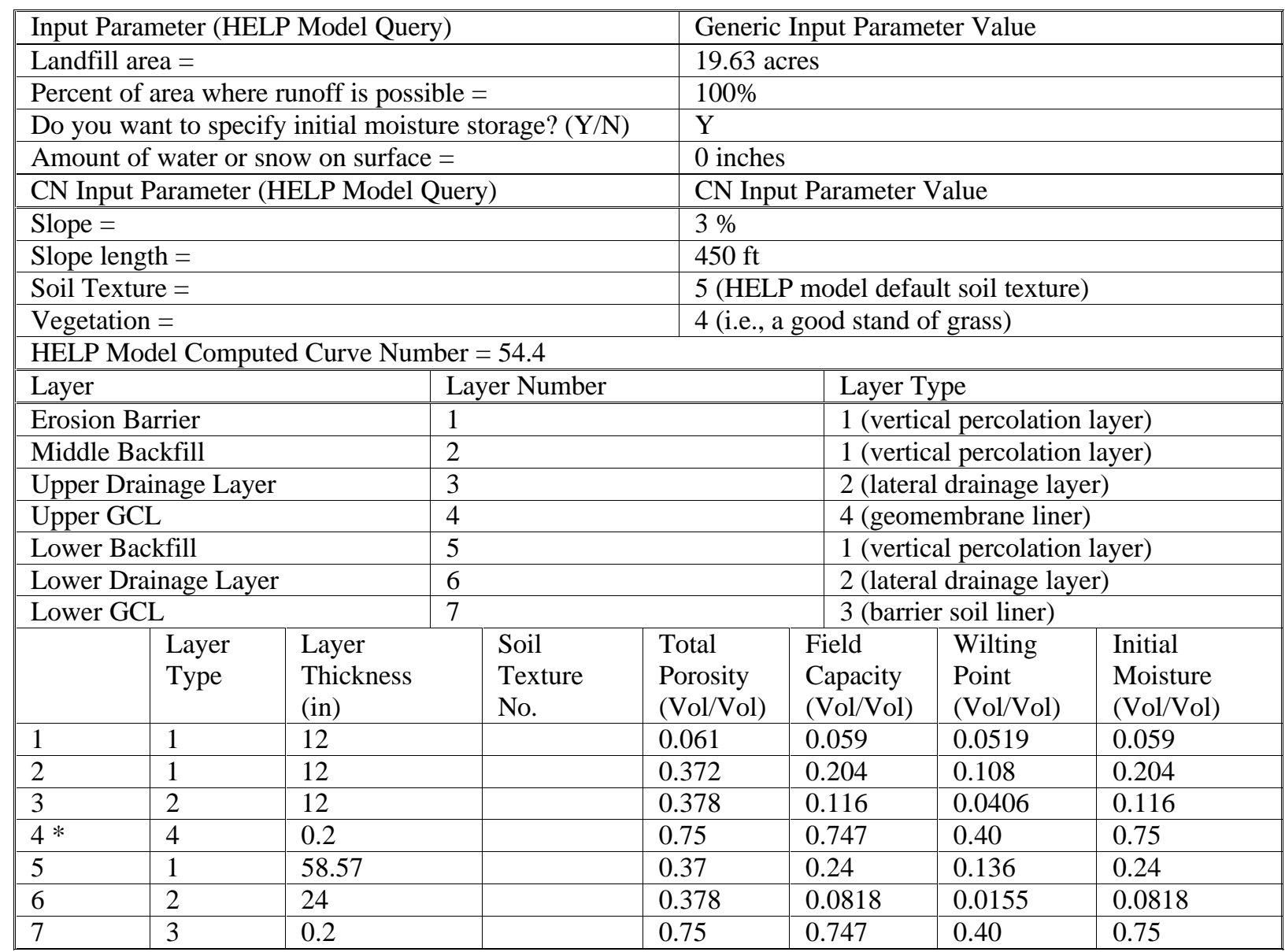

The lack of values in the table for particular parameters in particular layers denotes that no HELP model input was required for that parameter in that layer. No data are missing from the table.

* The input porosity, field capacity, and wilting point values of the upper GCL are ignored by the HELP model, since the upper GCL is designated as an geomembrane in order for the HELP model to take into account the holes produced by root penetration. 
Input Data (continued):

\begin{tabular}{|c|c|c|c|c|c|c|c|c|c|}
\hline & $\begin{array}{l}\text { Layer } \\
\text { Type }\end{array}$ & $\begin{array}{l}\text { Sat. Hyd. } \\
\text { Conductivity * } \\
(\mathrm{cm} / \mathrm{sec})\end{array}$ & \multicolumn{2}{|c|}{$\begin{array}{l}\text { Drainage } \\
\text { Length } \\
(\mathrm{ft}) \\
\end{array}$} & $\begin{array}{l}\text { Drain } \\
\text { Slope } \\
(\%)\end{array}$ & $\begin{array}{l}\text { Leachate } \\
\text { Recirc. } \\
(\%)\end{array}$ & \multicolumn{2}{|c|}{$\begin{array}{l}\text { Recirc. to } \\
\text { Layer } \\
(\#)\end{array}$} & $\begin{array}{l}\text { Subsurface } \\
\text { Inflow } \\
\text { (in/yr) }\end{array}$ \\
\hline 1 & 1 & $1.20 \mathrm{E}-03$ & & & & & & & \\
\hline 2 & 1 & $4.70 \mathrm{E}-04$ & & & & & & & \\
\hline 3 & 2 & $2.10 \mathrm{E}-02$ & 450 & & 3 & & & & \\
\hline 4 & 4 & $5.00 \mathrm{E}-09$ & & & & & & & \\
\hline 5 & 1 & $1.00 \mathrm{E}-04$ & & & & & & & \\
\hline 6 & 2 & $9.86 \mathrm{E}-02$ & 150 & & 11.4 & & & & \\
\hline 7 & 3 & $5.00 \mathrm{E}-09$ & & & & & & & \\
\hline & $\begin{array}{l}\text { Layer } \\
\text { Type }\end{array}$ & \multicolumn{2}{|l|}{$\begin{array}{l}\text { Geomembrane } \\
\text { Pinhole Density } \\
\text { (\#/acre) }\end{array}$} & \multicolumn{2}{|c|}{$\begin{array}{l}\text { Geomembrane } \\
\text { Instal. Defects } \\
\text { (\#/acre) }\end{array}$} & \multicolumn{2}{|c|}{$\begin{array}{l}\text { Geomembrane } \\
\text { Placement Quality }\end{array}$} & \multicolumn{2}{|c|}{$\begin{array}{l}\text { Geotextile } \\
\text { Transmissivity } \\
\left(\mathrm{cm}^{2} / \mathrm{sec}\right)\end{array}$} \\
\hline 1 & 1 & & & & & & & & \\
\hline 2 & 1 & & & & & & & & \\
\hline 3 & 2 & & & & & & & & \\
\hline 4 & 4 & 0 & & 40 & & 1 & & & \\
\hline 5 & 1 & & & & & & & & \\
\hline 6 & 2 & & & & & & & & \\
\hline 7 & 3 & & & & & & & & \\
\hline
\end{tabular}

The lack of values in the table for particular parameters in particular layers denotes that no HELP model input was required for that parameter in that layer. No data are missing from the table.

* The HELP model output often produces an increased number of significant digits for the Effective Saturated Hydraulic Conductivity over that of the actual input 


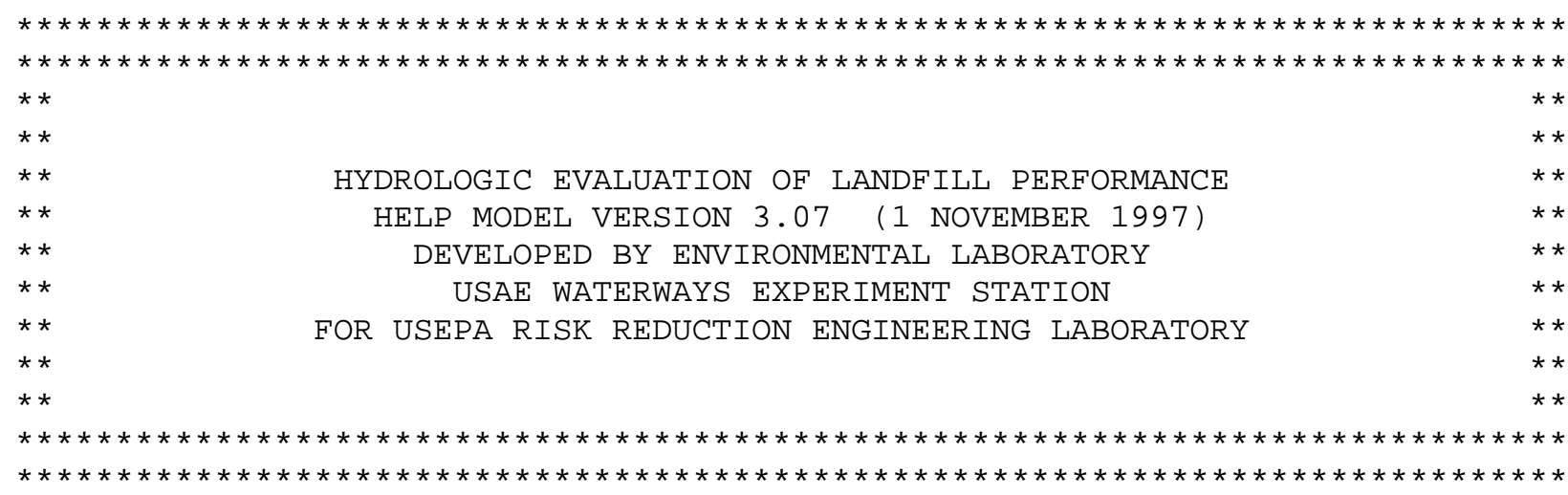

\begin{tabular}{|c|c|}
\hline PRECIPITATION DATA & $\mathrm{D}: \backslash \mathrm{HE}$ \\
\hline TEMPERATURE DATA FILE: & D : \HELP $3 \backslash$ Hweather $\backslash$ ZTEMP . D 7 \\
\hline ATION DA & D: \HELP $3 \backslash$ Hweather $\backslash$ ZSOLAR.D13 \\
\hline OTRANSPIRATION DATA: & D: \HELP $3 \backslash$ Hweather $\backslash$ ZEVAP.D11 \\
\hline DESIGN D & $\mathrm{D}: \backslash$ HELP $3 \backslash$ Hsdfmse $\backslash$ ZUBSD $6 . D 10$ \\
\hline & UB \\
\hline
\end{tabular}

TIME: $14: 2$ DATE: $1 / 13 / 2004$

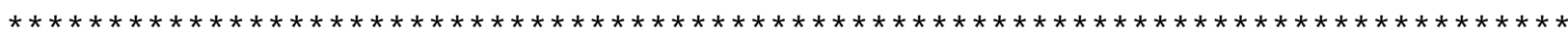
TITLE: UBS Degraded MSE Vault Closure Cap - 802 years

NOTE: INITIAL MOISTURE CONTENT OF THE LAYERS AND SNOW WATER WERE SPECIFIED BY THE USER.

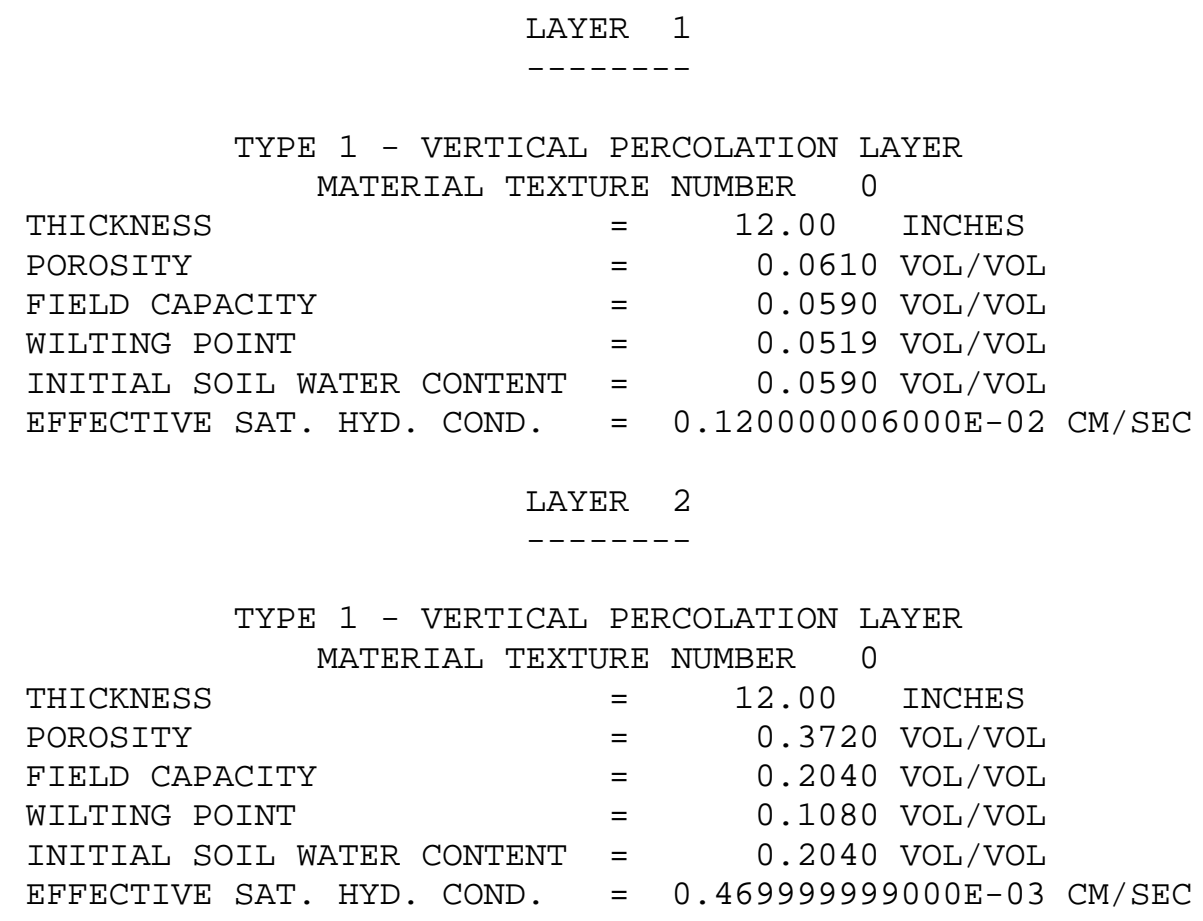

Rev. 0 
LAYER 3

$--------$

TYPE 2 - LATERAL DRAINAGE LAYER

MATERIAL TEXTURE NUMBER 0

\begin{tabular}{|c|c|c|c|}
\hline & & & \\
\hline THICKNESS & $=$ & 12.00 & INCHES \\
\hline POROSITY & $=$ & 0.3780 & VOL/VOL \\
\hline FIELD CAPACITY & $=$ & 0.1160 & VOL/VOL \\
\hline WILTING POINT & $=$ & 0.0406 & VOL/VOL \\
\hline INITIAL SOIL WATER CONTENT & $=$ & 0.1160 & VOL/VOL \\
\hline EFFECTIVE SAT. HYD. COND. & $=$ & 0.209999997 & $7000 \mathrm{E}-01 \mathrm{CM} / \mathrm{SEC}$ \\
\hline SLOPE & $=$ & 3.00 & PERCENT \\
\hline DRAINAGE LENGTH & $=$ & 450.0 & FEET \\
\hline LAY & & 4 & \\
\hline-- & & & \\
\hline $\begin{array}{r}\text { TYPE } 4 \text { - FLEXIB } \\
\text { MATERIAL TEXT }\end{array}$ & $\begin{array}{l}\text { LE } \\
\text { URE }\end{array}$ & $\begin{array}{cc}\text { MEMBRANE } & \text { LIN } \\
\text { NUMBER } & 0\end{array}$ & NER \\
\hline THICKNESS & $=$ & 0.20 & INCHES \\
\hline POROSITY & $=$ & 0.0000 & VOL/VOL \\
\hline FIELD CAPACITY & $=$ & 0.0000 & VOL/VOL \\
\hline WILTING POINT & $=$ & 0.0000 & VOL/VOL \\
\hline INITIAL SOIL WATER CONTENT & $=$ & 0.0000 & VOL/VOL \\
\hline EFFECTIVE SAT. HYD. COND. & $=$ & 0.499999997 & $7000 \mathrm{E}-08 \mathrm{CM} / \mathrm{SEC}$ \\
\hline FML PINHOLE DENSITY & $=$ & 0.00 & HOLES / ACRE \\
\hline FML INSTALLATION DEFECTS & $=$ & 40877.00 & HOLES / ACRE \\
\hline FML PLACEMENT QUALITY & $=$ & 1 - PERFECT & \\
\hline LA & & 5 & \\
\hline
\end{tabular}

TYPE 1 - VERTICAL PERCOLATION LAYER MATERIAL TEXTURE NUMBER 0

$\begin{array}{llrl}\text { THICKNESS } & = & 58.57 \mathrm{INCHES} \\ \text { POROSITY } & = & 0.3700 \mathrm{VOL} / \mathrm{VOL} \\ \text { FIELD CAPACITY } & = & 0.2400 \mathrm{VOL} / \mathrm{VOL} \\ \text { WILTING POINT } & = & 0.1360 \mathrm{VOL} / \mathrm{VOL} \\ \text { INITIAL SOIL WATER CONTENT } & = & 0.2400 \mathrm{VOL} / \mathrm{VOL} \\ \text { EFEECTIVE SAT. HYD. COND. } & =0.999999975000 \mathrm{E}-04 \mathrm{CM} / \mathrm{SEC}\end{array}$

LAYER 6

TYPE 2 - LATERAL DRAINAGE LAYER MATERIAL TEXTURE NUMBER 0

$\begin{array}{llcl}\text { THICKNESS } & = & 24.00 & \text { INCHES } \\ \text { POROSITY } & = & 0.3780 \mathrm{VOL} / \mathrm{VOL} \\ \text { FIELD CAPACITY } & = & 0.0818 \mathrm{VOL} / \mathrm{VOL} \\ \text { WILTING POINT } & = & 0.0155 \mathrm{VOL} / \mathrm{VOL} \\ \text { INITIAL SOIL WATER CONTENT } & = & 0.0818 \mathrm{VOL} / \mathrm{VOL} \\ \text { EFEECTIVE SAT. HYD. COND. } & =0.986000001000 \mathrm{E}-01 \mathrm{CM} / \mathrm{SEC} \\ \text { SLOPE } & = & 11.40 \mathrm{PERCENT} \\ \text { DRAINAGE LENGTH } & =150.0 & \mathrm{FEET}\end{array}$

Rev. 0 
LAYER 7

$--------$

TYPE 3 - BARRIER SOIL LINER

MATERIAL TEXTURE NUMBER 0

$\begin{array}{llrl}\text { THICKNESS } & = & 0.20 \mathrm{INCHES} \\ \text { POROSITY } & = & 0.7500 \mathrm{VOL} / \mathrm{VOL} \\ \text { FIELD CAPACITY } & = & 0.7470 \mathrm{VOL} / \mathrm{VOL} \\ \text { WILTING POINT } & = & 0.4000 \mathrm{VOL} / \mathrm{VOL} \\ \text { INITIAL SOIL WATER CONTENT } & = & 0.7500 \mathrm{VOL} / \mathrm{VOL} \\ \text { EFFECTIVE SAT. HYD. COND. } & =0.499999997000 \mathrm{E}-08 \mathrm{CM} / \mathrm{SEC}\end{array}$

GENERAL DESIGN AND EVAPORATIVE ZONE DATA

NOTE: SCS RUNOFF CURVE NUMBER WAS COMPUTED FROM DEFAULT SOIL DATA BASE USING SOIL TEXTURE \# 5 WITH A GOOD STAND OF GRASS, A SURFACE SLOPE OF 3.\% AND A SLOPE LENGTH OF 450. FEET.

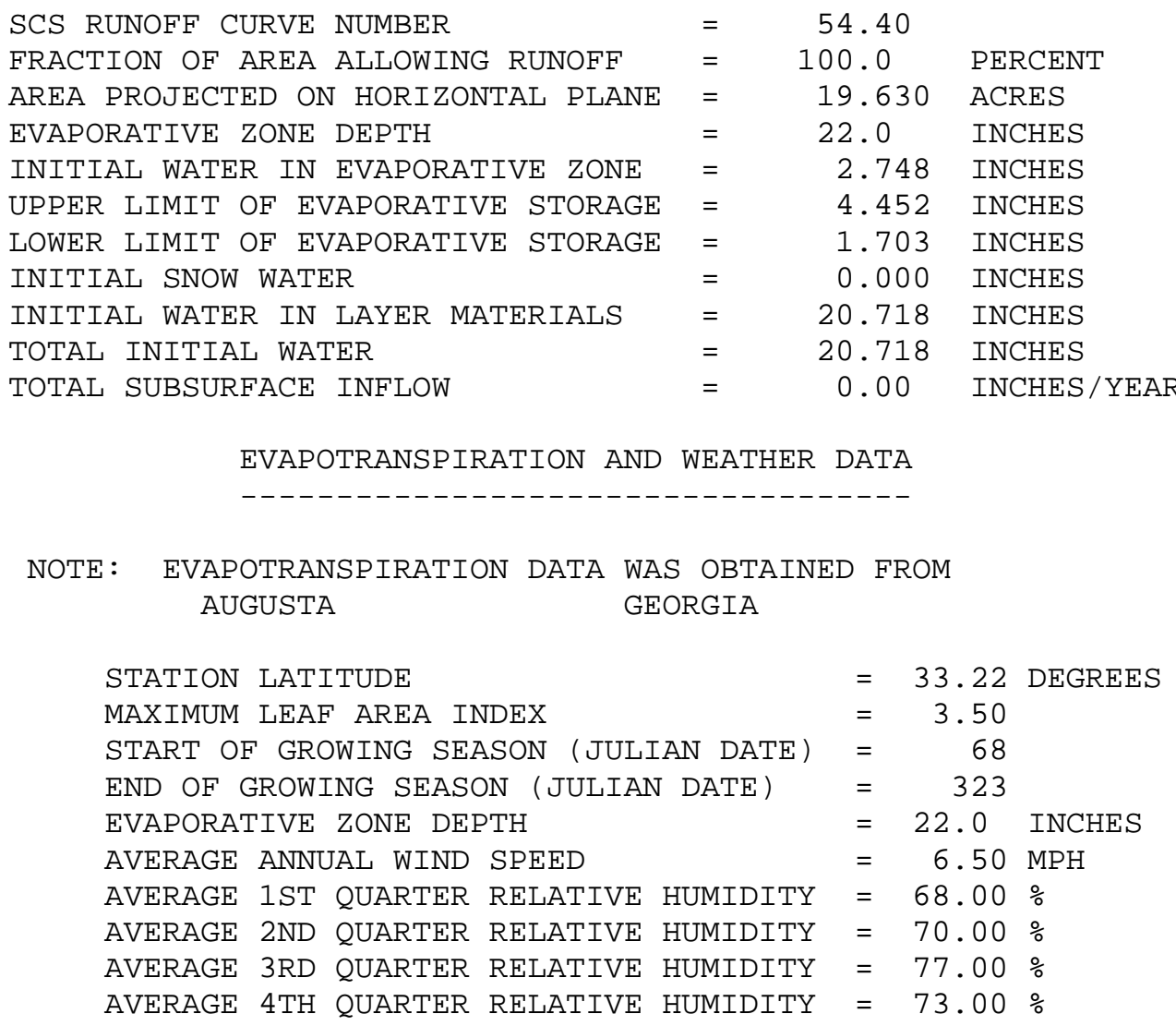




$$
\begin{aligned}
& \text { NOTE: PRECIPITATION DATA WAS SYNTHETICALLY GENERATED USING } \\
& \text { COEFFICIENTS FOR AUGUSTA GEORGIA } \\
& \text { NORMAL MEAN MONTHLY PRECIPITATION (INCHES) } \\
& \begin{array}{cccccc}
\text { JAN/JUL } & \text { FEB/AUG } & \text { MAR/SEP } & \text { APR/OCT } & \text { MAY/NOV } & \text { JUN/DEC } \\
------ & ------ & ------ & ------ & ------ & ------ \\
4.38 & 3.95 & 4.68 & 2.91 & 3.56 & 4.99 \\
5.43 & 5.41 & 3.93 & 3.12 & 2.96 & 3.45
\end{array}
\end{aligned}
$$

\begin{tabular}{|c|c|c|c|c|c|c|}
\hline AVERAGE MONTHLY & VALUES IN & N INCHES & FOR YEARS & $1 \mathrm{THF}$ & OUGH 100 & \\
\hline & JAN / JUL & FEB / AUG & MAR/SEP & APR/OCT & MAY / NOV & JUN/DEC \\
\hline \multicolumn{7}{|l|}{ PRECIPITATION } \\
\hline TOTALS & $\begin{array}{l}4.56 \\
5.81\end{array}$ & $\begin{array}{l}3.57 \\
5.32\end{array}$ & $\begin{array}{l}4.76 \\
4.41\end{array}$ & $\begin{array}{l}2.74 \\
2.99\end{array}$ & $\begin{array}{l}3.60 \\
2.75\end{array}$ & $\begin{array}{l}4.97 \\
3.41\end{array}$ \\
\hline \multirow[t]{2}{*}{ STD. DEVIATIONS } & 2.44 & 1.60 & 2.47 & 1.31 & 2.12 & 2.60 \\
\hline & 2.83 & 2.95 & 2.54 & 2.28 & 1.72 & 1.90 \\
\hline \multicolumn{7}{|l|}{ RUNOFF } \\
\hline TOTALS & $\begin{array}{l}0.000 \\
0.000\end{array}$ & $\begin{array}{l}0.000 \\
0.031\end{array}$ & $\begin{array}{l}0.000 \\
0.002\end{array}$ & $\begin{array}{l}0.000 \\
0.006\end{array}$ & $\begin{array}{l}0.000 \\
0.000\end{array}$ & $\begin{array}{l}0.000 \\
0.000\end{array}$ \\
\hline STD. DEVIATIONS & $\begin{array}{l}0.000 \\
0.002\end{array}$ & $\begin{array}{l}0.000 \\
0.189\end{array}$ & $\begin{array}{l}0.000 \\
0.017\end{array}$ & $\begin{array}{l}0.000 \\
0.055\end{array}$ & $\begin{array}{l}0.000 \\
0.000\end{array}$ & $\begin{array}{l}0.000 \\
0.000\end{array}$ \\
\hline \multicolumn{7}{|l|}{ EVAPOTRANSP IRATION } \\
\hline TOTALS & $\begin{array}{l}1.584 \\
3.865\end{array}$ & $\begin{array}{l}1.951 \\
3.464\end{array}$ & $\begin{array}{l}2.649 \\
2.702\end{array}$ & $\begin{array}{l}2.426 \\
1.454\end{array}$ & $\begin{array}{l}2.784 \\
1.105\end{array}$ & $\begin{array}{l}3.457 \\
1.281\end{array}$ \\
\hline STD. DEVIATIONS & $\begin{array}{l}0.270 \\
1.205\end{array}$ & $\begin{array}{l}0.294 \\
1.125\end{array}$ & $\begin{array}{l}0.649 \\
0.934\end{array}$ & $\begin{array}{l}0.774 \\
0.637\end{array}$ & $\begin{array}{l}1.083 \\
0.316\end{array}$ & $\begin{array}{l}1.279 \\
0.205\end{array}$ \\
\hline
\end{tabular}

NORMAL MEAN MONTHLY TEMPERATURE (DEGREES FAHRENHEIT)

$\begin{array}{cccccc}\text { JAN/JUL } & \text { FEB/AUG } & \text { MAR/SEP } & \text { APR/OCT } & \text { MAY/NOV } & \text { JUN/DEC } \\ ------ & ------ & ------ & ------ & ------ & ------ \\ 46.30 & 50.00 & 57.20 & 64.30 & 72.10 & 78.40 \\ 81.60 & 80.30 & 75.20 & 65.10 & 56.70 & 48.80\end{array}$

NOTE: SOLAR RADIATION DATA WAS SYNTHETICALLY GENERATED USING COEFFICIENTS FOR AUGUSTA GEORGIA AND STATION LATITUDE $=33.30$ DEGREES 


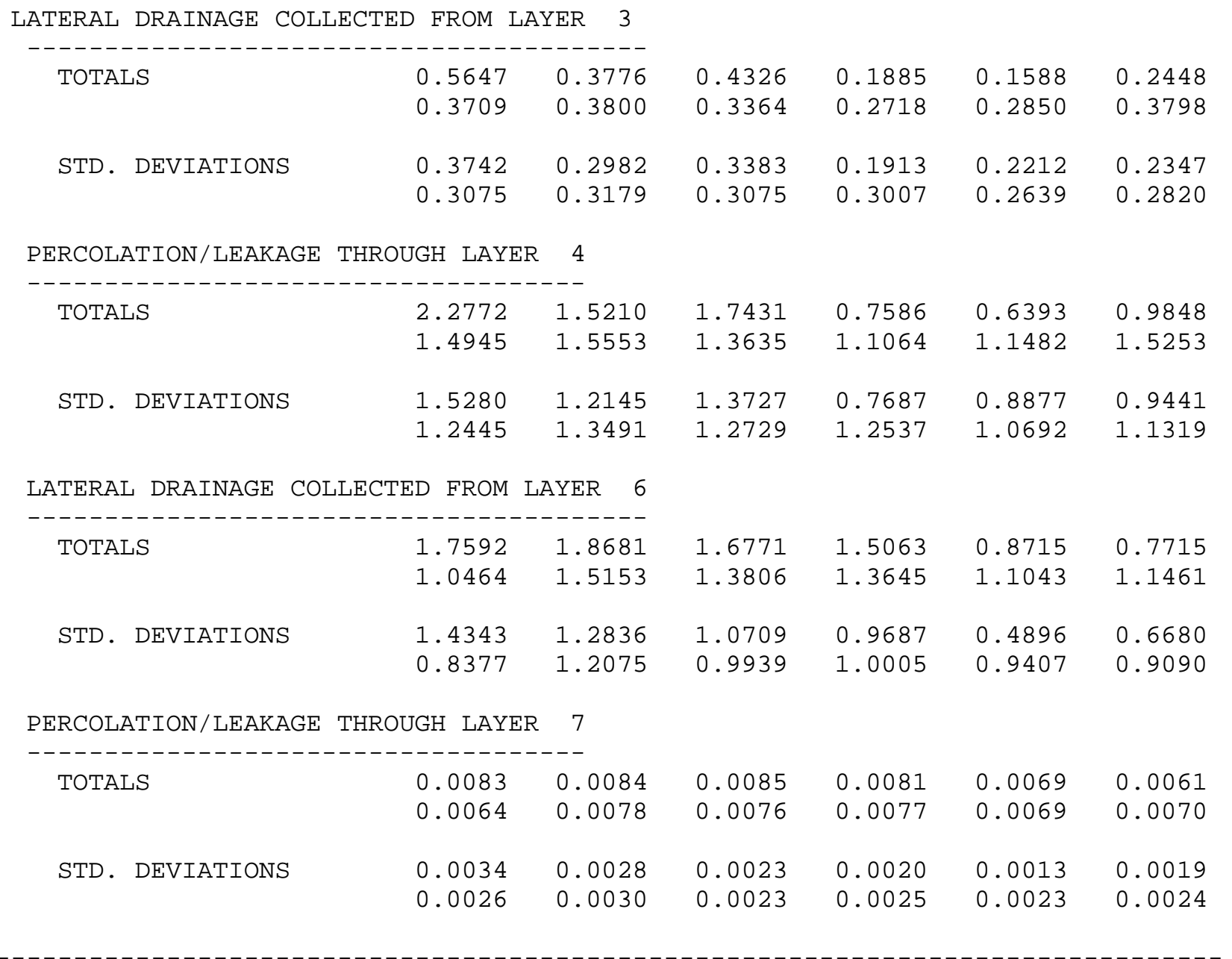

AVERAGES OF MONTHLY AVERAGED DAILY HEADS (INCHES)

DAILY AVERAGE HEAD ON TOP OF LAYER 4

$\begin{array}{lllllll}\text { AVERAGES } & 2.3071 & 1.6893 & 1.7657 & 0.7931 & 0.6461 & 1.0302 \\ & 1.5134 & 1.5752 & 1.4268 & 1.1199 & 1.2015 & 1.5450 \\ \text { STD. DEVIATIONS } & & & & & & \\ & 1.5487 & 1.3497 & 1.3914 & 0.8057 & 0.9001 & 0.9890 \\ & 1.2617 & 1.3675 & 1.3333 & 1.2710 & 1.1200 & 1.1474\end{array}$

DAILY AVERAGE HEAD ON TOP OF LAYER 7

$\begin{array}{lllllll}\text { AVERAGES } & 0.1353 & 0.1576 & 0.1290 & 0.1197 & 0.0670 & 0.0613 \\ & 0.0805 & 0.1166 & 0.1097 & 0.1050 & 0.0878 & 0.0882 \\ \text { STD. DEVIATIONS } & 0.1103 & 0.1084 & 0.0824 & 0.0770 & 0.0377 & 0.0531 \\ & 0.0644 & 0.0929 & 0.0790 & 0.0770 & 0.0748 & 0.0699\end{array}$




\begin{tabular}{|c|c|c|c|c|c|c|}
\hline AVERAGE ANNUAL TOTALS \& & \multicolumn{2}{|c|}{ (STD. DEVIATIONS) } & \multicolumn{2}{|c|}{ ) FOR YEARS } & 1 THROUGH & \multirow{2}{*}{$\begin{array}{l}100 \\
\text { PERCENT }\end{array}$} \\
\hline & INCH & IES & & & U. FEET & \\
\hline PRECIPITATION & 48.90 & ( & $7.734)$ & & 484469.2 & 100.00 \\
\hline RUNOFF & 0.038 & $(0$ & $0.1965)$ & & 2740.38 & 0.079 \\
\hline EVAPOTRANSPIRATION & 28.723 & $(2$ & $2.8346)$ & & 046702.00 & 58.738 \\
\hline $\begin{array}{l}\text { LATERAL DRAINAGE COLLECTED } \\
\text { FROM LAYER } 3\end{array}$ & 3.99102 & $(1$ & $1.25187)$ & & 284387.844 & 8.16158 \\
\hline $\begin{array}{l}\text { PERCOLATION/LEAKAGE THROUGH } \\
\text { LAYER } 4\end{array}$ & 16.11727 & $(5$ & $5.09535)$ & & 148466.750 & 32.95959 \\
\hline $\begin{array}{l}\text { AVERAGE HEAD ON TOP } \\
\text { OF LAYER } 4\end{array}$ & 1.384( & & $0.438)$ & & & \\
\hline $\begin{array}{l}\text { LATERAL DRAINAGE COLLECTED } \\
\text { FROM LAYER } 6\end{array}$ & 16.01076 & $(4$ & $4.97200)$ & & 140877.120 & 32.74178 \\
\hline $\begin{array}{l}\text { PERCOLATION/LEAKAGE THROUGH } \\
\text { LAYER } 7\end{array}$ & 0.08980 & $(0$ & $0.01248)$ & & 6399.206 & 0.18365 \\
\hline $\begin{array}{l}\text { AVERAGE HEAD ON TOP } \\
\text { OF LAYER } 7\end{array}$ & 0.1051 & & $0.033)$ & & & \\
\hline CHANGE IN WATER STORAGE & 0.047 & $(2$ & $2.1262)$ & & 3362.64 & 0.097 \\
\hline
\end{tabular}




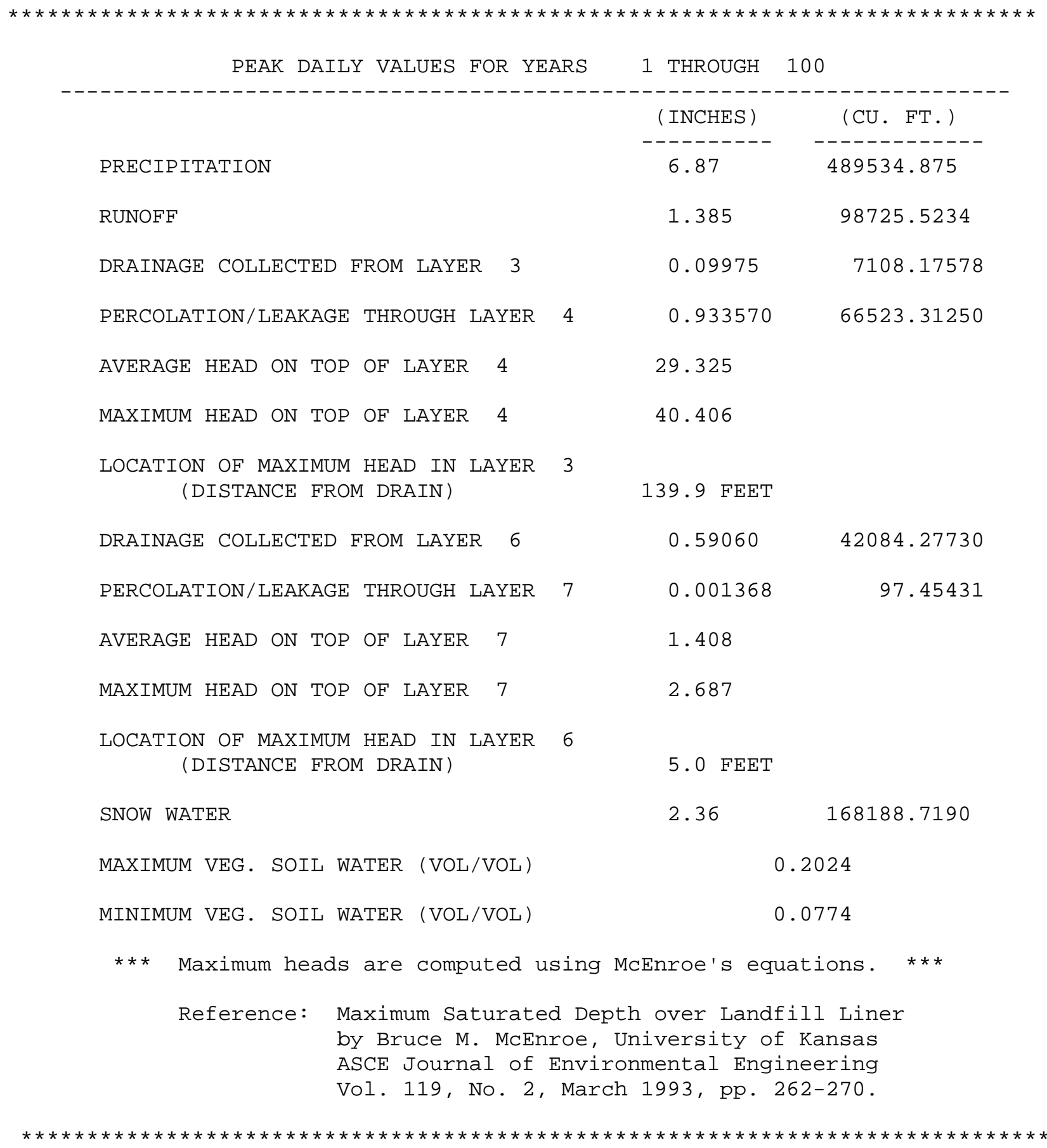

Rev. 0 


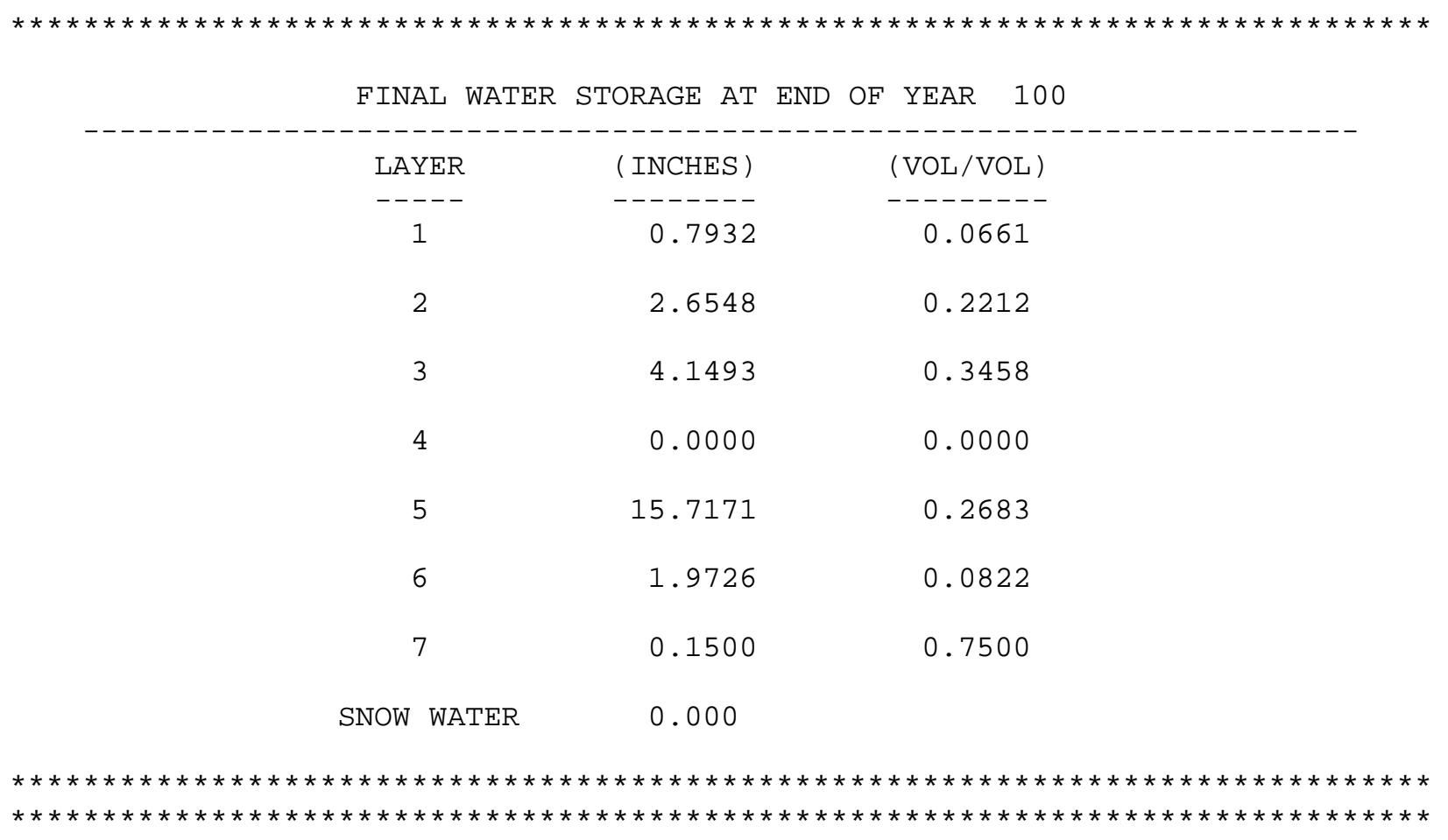


Appendix V, Upper Bounding Scenario Degraded SDF MSE Vault Closure Cap (1,000 Years): HELP Model Input Data and Output File (output file name: ZUBSD7ou.OUT)

\section{Input Data:}

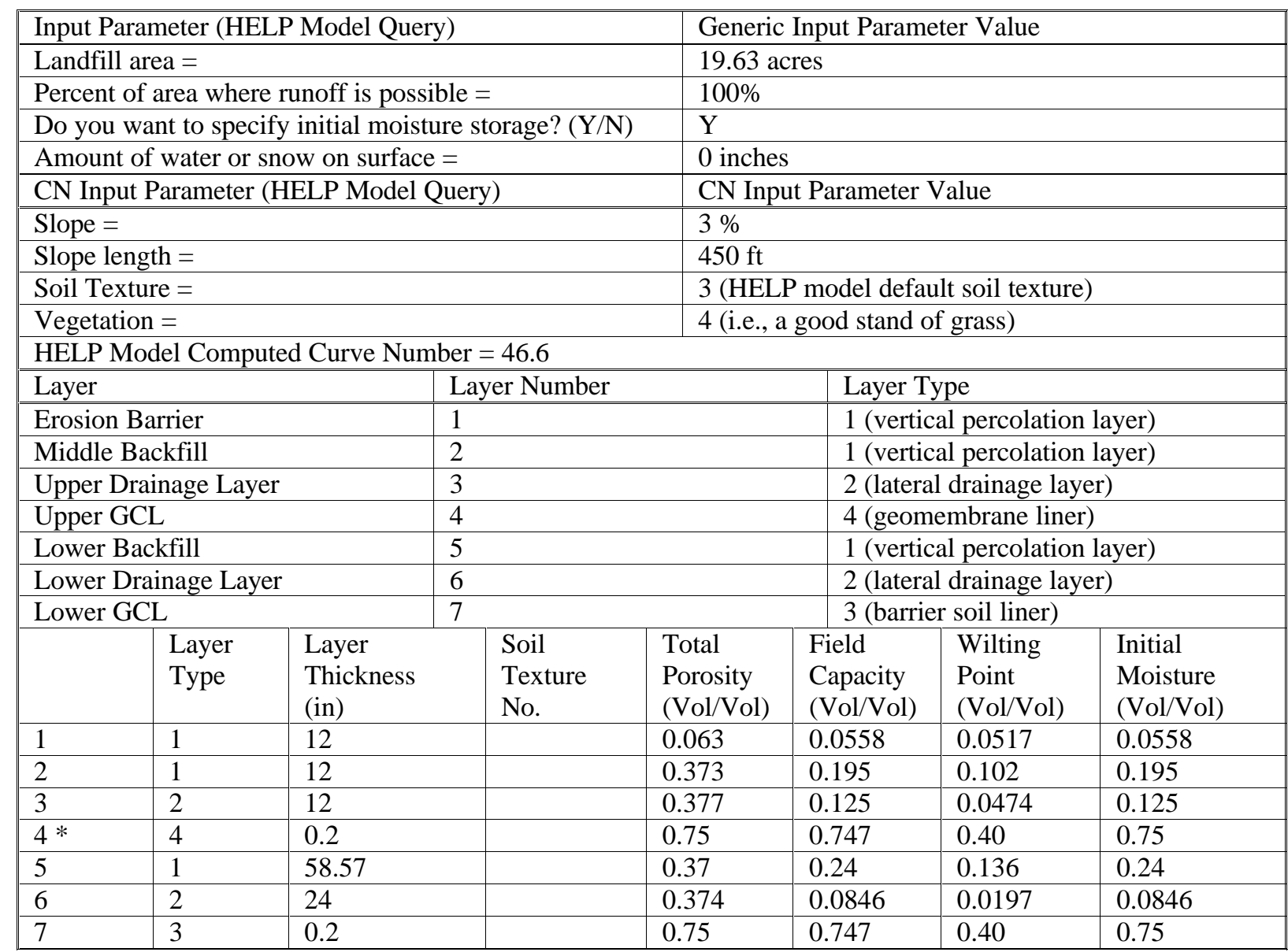

The lack of values in the table for particular parameters in particular layers denotes that no HELP model input was required for that parameter in that layer. No data are missing from the table.

* The input porosity, field capacity, and wilting point values of the upper GCL are ignored by the HELP model, since the upper GCL is designated as an geomembrane in order for the HELP model to take into account the holes produced by root penetration. 
Input Data (continued):

\begin{tabular}{|c|c|c|c|c|c|c|c|c|c|}
\hline & $\begin{array}{l}\text { Layer } \\
\text { Type }\end{array}$ & $\begin{array}{l}\text { Sat. Hyd. } \\
\text { Conductivity * } \\
(\mathrm{cm} / \mathrm{sec})\end{array}$ & \multicolumn{2}{|c|}{$\begin{array}{l}\text { Drainage } \\
\text { Length } \\
(\mathrm{ft}) \\
\end{array}$} & $\begin{array}{l}\text { Drain } \\
\text { Slope } \\
(\%) \\
\end{array}$ & $\begin{array}{l}\text { Leachate } \\
\text { Recirc. } \\
(\%)\end{array}$ & \multicolumn{2}{|c|}{$\begin{array}{l}\text { Recirc. to } \\
\text { Layer } \\
(\#)\end{array}$} & $\begin{array}{l}\text { Subsurface } \\
\text { Inflow } \\
\text { (in/yr) }\end{array}$ \\
\hline 1 & 1 & $2.80 \mathrm{E}-03$ & & & & & & & \\
\hline 2 & 1 & $6.90 \mathrm{E}-04$ & & & & & & & \\
\hline 3 & 2 & $1.40 \mathrm{E}-02$ & 450 & & 3 & & & & \\
\hline 4 & 4 & $5.00 \mathrm{E}-09$ & & & & & & & \\
\hline 5 & 1 & $1.00 \mathrm{E}-04$ & & & & & & & \\
\hline 6 & 2 & $9.64 \mathrm{E}-02$ & 150 & & 11.4 & & & & \\
\hline 7 & 3 & $5.00 \mathrm{E}-09$ & & & & & & \\
\hline & $\begin{array}{l}\text { Layer } \\
\text { Type }\end{array}$ & \multicolumn{2}{|l|}{$\begin{array}{l}\text { Geomembrane } \\
\text { Pinhole Density } \\
\text { (\#/acre) }\end{array}$} & \multicolumn{2}{|c|}{$\begin{array}{l}\text { Geomembrane } \\
\text { Instal. Defects } \\
\text { (\#/acre) }\end{array}$} & \multicolumn{2}{|c|}{$\begin{array}{l}\text { Geomembrane } \\
\text { Placement Quality }\end{array}$} & \multicolumn{2}{|c|}{$\begin{array}{l}\text { Geotextile } \\
\text { Transmissivity } \\
\left(\mathrm{cm}^{2} / \mathrm{sec}\right)\end{array}$} \\
\hline 1 & 1 & & & & & & & & \\
\hline 2 & 1 & & & & & & & & \\
\hline 3 & 2 & & & & & & & & \\
\hline 4 & 4 & 0 & & 121 & & 1 & & & \\
\hline 5 & 1 & & & & & & & & \\
\hline 6 & 2 & & & & & & & & \\
\hline 7 & 3 & & & & & & & & \\
\hline
\end{tabular}

The lack of values in the table for particular parameters in particular layers denotes that no HELP model input was required for that parameter in that layer. No data are missing from the table.

* The HELP model output often produces an increased number of significant digits for the Effective Saturated Hydraulic Conductivity over that of the actual input 


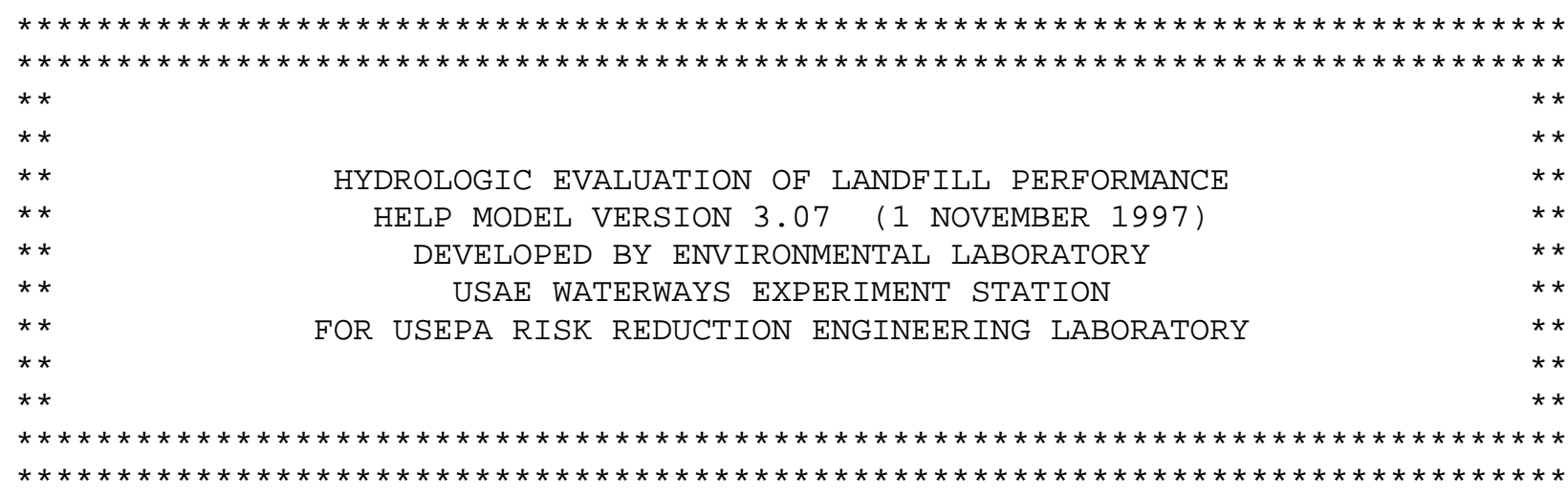

\begin{tabular}{|c|c|}
\hline PRECIPITATION DATA & $\mathrm{D}: \backslash \mathrm{HE}$ \\
\hline TEMPERATURE DATA FILE: & D : \HELP $3 \backslash$ Hweather $\backslash$ ZTEMP . D 7 \\
\hline ATION DA & D: \HELP $3 \backslash$ Hweather $\backslash$ ZSOLAR.D13 \\
\hline TRANSP IRATION DATA: & D: \HELP $3 \backslash$ Hweather $\backslash$ ZEVAP.D11 \\
\hline DESIGN D & $\mathrm{D}: \backslash$ HELP $3 \backslash$ Hsdfmse $\backslash$ ZUBSD 7 .D10 \\
\hline & UBS \\
\hline
\end{tabular}

TIME $: 14: 7 \quad$ DATE $: \quad 1 / 13 / 2004$

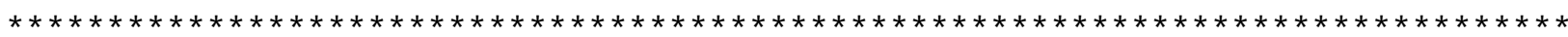
TITLE: UBS Degraded MSE Vault Closure Cap - 1,000 years

NOTE: INITIAL MOISTURE CONTENT OF THE LAYERS AND SNOW WATER WERE SPECIFIED BY THE USER.

\begin{tabular}{|c|c|c|c|c|}
\hline \multicolumn{5}{|c|}{ LAYER 1} \\
\hline \multicolumn{5}{|c|}{ TYPE 1 - VERTICAL PERCOLATION LAYER } \\
\hline THICKNESS & $=$ & 12.00 & INCHES & \\
\hline POROSITY & $=$ & 0.0630 & VOL/VOI & \\
\hline FIELD CAPACITY & $=$ & 0.0558 & VOL/VOI & \\
\hline WILTING POINT & $=$ & 0.0517 & VOL/VOI & \\
\hline INITIAL SOIL WATER CONTENT & $=$ & 0.0558 & VOL/VOI & \\
\hline EFFECTIVE SAT. HYD. COND. & $=$ & 0.279999990 & $0000 E-02$ & $\mathrm{CM} / \mathrm{SEC}$ \\
\hline \multicolumn{5}{|c|}{ LAYER 2} \\
\hline $\begin{array}{r}\text { TYPE } 1 \text { - VERTICAI } \\
\text { MATERIAL TEX? }\end{array}$ & $\begin{aligned} & P E \\
& U R E\end{aligned}$ & $\begin{array}{ll}\text { RCOLATION } & \text { LA } \\
\text { NUMBER } & 0\end{array}$ & AYER & \\
\hline THICKNESS & $=$ & 12.00 & INCHES & \\
\hline POROSITY & $=$ & 0.3730 & VOL/VOI & \\
\hline FIELD CAPACITY & $=$ & 0.1950 & $\mathrm{VOL} / \mathrm{VOI}$ & \\
\hline WILTING POINT & $=$ & 0.1020 & VOL/VOI & \\
\hline INITIAL SOIL WATER CONTENT & $=$ & 0.1950 & VOL/VOI & \\
\hline EFFECTIVE SAT. HYD. COND. & $=$ & 0.690000015 & $5000 \mathrm{E}-03$ & ( \\
\hline
\end{tabular}

Rev. 0 
LAYER 3

$--------$

TYPE 2 - LATERAL DRAINAGE LAYER

MATERIAL TEXTURE NUMBER 0

$\begin{array}{llcc}\text { THICKNESS } & = & 12.00 & \text { INCHES } \\ \text { POROSITY } & = & 0.3770 \mathrm{VOL} / \mathrm{VOL} \\ \text { FIELD CAPACITY } & = & 0.1250 \mathrm{VOL} / \mathrm{VOL} \\ \text { WILTING POINT } & = & 0.0474 \mathrm{VOL} / \mathrm{VOL} \\ \text { INITIAL SOIL WATER CONTENT } & = & 0.1250 \mathrm{VOL} / \mathrm{VOL} \\ \text { EFEECTIVE SAT. HYD. COND. } & = & 0.140000004000 \mathrm{E}-01 \mathrm{CM} / \mathrm{SEC} \\ \text { SLOPE } & = & 3.00 \mathrm{PERCENT} \\ \text { DRAINAGE LENGTH } & = & 450.0 & \mathrm{FEET}\end{array}$

LAYER 4

TYPE 4 - FLEXIBLE MEMBRANE LINER MATERIAL TEXTURE NUMBER 0

$\begin{array}{llcl}\text { THICKNESS } & = & 0.20 & \text { INCHES } \\ \text { POROSITY } & = & 0.0000 \mathrm{VOL} / \mathrm{VOL} \\ \text { FIELD CAPACITY } & = & 0.0000 \mathrm{VOL} / \mathrm{VOL} \\ \text { WILTING POINT } & = & 0.0000 \mathrm{VOL} / \mathrm{VOL} \\ \text { INITIAL SOIL WATER CONTENT } & = & 0.0000 \mathrm{VOL} / \mathrm{VOL} \\ \text { EFFECTIVE SAT. HYD. COND. } & =0.499999997000 \mathrm{E}-08 \mathrm{CM} / \mathrm{SEC} \\ \text { FML PINHOLE DENSITY } & = & 0.00 \mathrm{HOLES} / \mathrm{ACRE} \\ \text { FML INSTALLATION DEFECTS } & =121703.00 \mathrm{HOLES} / \mathrm{ACRE} \\ \text { FML PLACEMENT QUALITY } & =1-\mathrm{PERFECT}\end{array}$

TYPE 1 - VERTICAL PERCOLATION LAYER MATERIAL TEXTURE NUMBER 0

$\begin{array}{llcl}\text { THICKNESS } & = & 58.57 & \text { INCHES } \\ \text { POROSITY } & = & 0.3700 \mathrm{VOL} / \mathrm{VOL} \\ \text { FIELD CAPACITY } & = & 0.2400 \mathrm{VOL} / \mathrm{VOL} \\ \text { WILTING POINT } & = & 0.1360 \mathrm{VOL} / \mathrm{VOL} \\ \text { INITIAL SOIL WATER CONTENT } & = & 0.2400 \mathrm{VOL} / \mathrm{VOL} \\ \text { EFEECTIVE SAT. HYD. COND. } & =0.999999975000 \mathrm{E}-04 \mathrm{CM} / \mathrm{SEC}\end{array}$
EFFECTIVE SAT. HYD. COND. $=0.999999975000 \mathrm{E}-04 \mathrm{CM} / \mathrm{SEC}$

LAYER 6

$--------$

TYPE 2 - LATERAL DRAINAGE LAYER MATERIAL TEXTURE NUMBER 0

$\begin{array}{llcc}\text { THICKNESS } & = & 24.00 & \text { INCHES } \\ \text { POROSITY } & = & 0.3740 \mathrm{VOL} / \mathrm{VOL} \\ \text { FIELD CAPACITY } & = & 0.0846 \mathrm{VOL} / \mathrm{VOL} \\ \text { WILTING POINT } & = & 0.0197 \mathrm{VOL} / \mathrm{VOL} \\ \text { INITIAL SOIL WATER CONTENT } & = & 0.0846 \mathrm{VOL} / \mathrm{VOL} \\ \text { EFFECTIVE SAT. HYD. COND. } & =0.964000002000 \mathrm{E}-01 \mathrm{CM} / \mathrm{SEC} \\ \text { SLOPE } & = & 11.40 \mathrm{PERCENT} \\ \text { DRAINAGE LENGTH } & = & 150.0 & \mathrm{FEET}\end{array}$

Rev. 0 
LAYER 7

$--------$

TYPE 3 - BARRIER SOIL LINER

MATERIAL TEXTURE NUMBER 0

$\begin{array}{llrl}\text { THICKNESS } & = & 0.20 \mathrm{INCHES} \\ \text { POROSITY } & = & 0.7500 \mathrm{VOL} / \mathrm{VOL} \\ \text { FIELD CAPACITY } & = & 0.7470 \mathrm{VOL} / \mathrm{VOL} \\ \text { WILTING POINT } & = & 0.4000 \mathrm{VOL} / \mathrm{VOL} \\ \text { INITIAL SOIL WATER CONTENT } & = & 0.7500 \mathrm{VOL} / \mathrm{VOL} \\ \text { EFFECTIVE SAT. HYD. COND. } & =0.499999997000 \mathrm{E}-08 \mathrm{CM} / \mathrm{SEC}\end{array}$

GENERAL DESIGN AND EVAPORATIVE ZONE DATA

NOTE: SCS RUNOFF CURVE NUMBER WAS COMPUTED FROM DEFAULT SOIL DATA BASE USING SOIL TEXTURE \# 3 WITH A GOOD STAND OF GRASS, A SURFACE SLOPE OF 3.\% AND A SLOPE LENGTH OF 450. FEET.

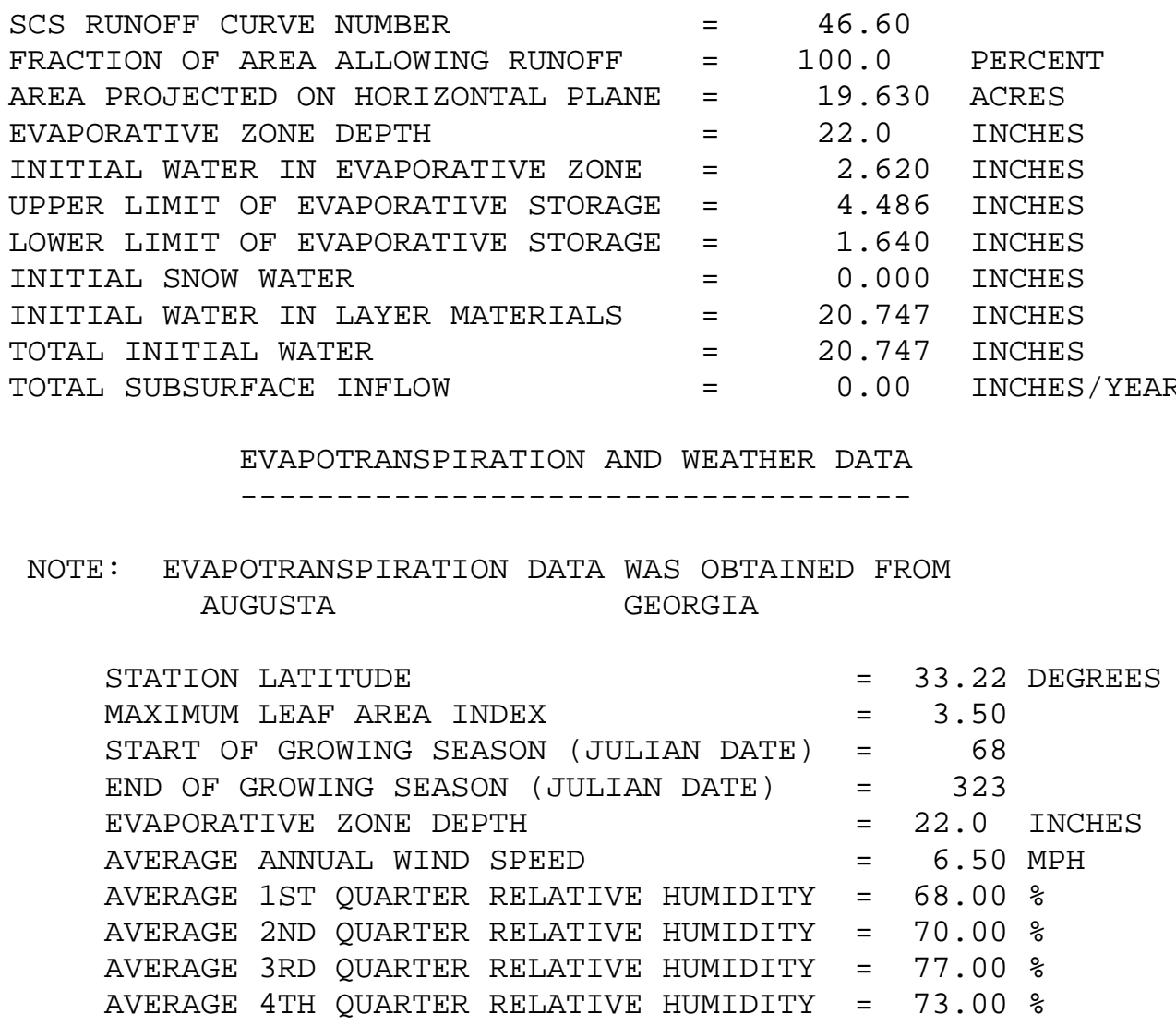




$$
\begin{aligned}
& \text { NOTE: PRECIPITATION DATA WAS SYNTHETICALLY GENERATED USING } \\
& \text { COEFFICIENTS FOR AUGUSTA GEORGIA } \\
& \text { NORMAL MEAN MONTHLY PRECIPITATION (INCHES) } \\
& \begin{array}{cccccc}
\text { JAN/JUL } & \text { FEB/AUG } & \text { MAR/SEP } & \text { APR/OCT } & \text { MAY/NOV } & \text { JUN/DEC } \\
------ & ------ & ------ & ------ & ------ & ------ \\
4.38 & 3.95 & 4.68 & 2.91 & 3.56 & 4.99 \\
5.43 & 5.41 & 3.93 & 3.12 & 2.96 & 3.45
\end{array}
\end{aligned}
$$

\begin{tabular}{|c|c|c|c|c|c|c|}
\hline AVERAGE MONTHLY & VALUES IN & N INCHES & FOR YEARS & $1 \mathrm{THF}$ & OUGH $\quad 100$ & \\
\hline & JAN / JUL & $\mathrm{FEB} / \mathrm{AUG}$ & $\mathrm{MAR} / \mathrm{SEP}$ & $\mathrm{APR} / \mathrm{OCT}$ & $\mathrm{MAY} / \mathrm{NOV}$ & JUN / DEC \\
\hline \multicolumn{7}{|l|}{ PRECIPITATION } \\
\hline \multirow[t]{2}{*}{ TOTALS } & 4.56 & 3.57 & 4.76 & 2.74 & 3.60 & 4.97 \\
\hline & 5.81 & 5.32 & 4.41 & 2.99 & 2.75 & 3.41 \\
\hline \multirow[t]{2}{*}{ STD. DEVIATIONS } & 2.44 & 1.60 & 2.47 & 1.31 & 2.12 & 2.60 \\
\hline & 2.83 & 2.95 & 2.54 & 2.28 & 1.72 & 1.90 \\
\hline \multicolumn{7}{|l|}{ RUNOFF } \\
\hline \multirow{2}{*}{ TOTALS } & 0.000 & 0.000 & 0.000 & 0.000 & 0.000 & 0.000 \\
\hline & 0.000 & 0.016 & 0.000 & 0.000 & 0.000 & 0.000 \\
\hline \multirow[t]{2}{*}{ STD. DEVIATIONS } & 0.000 & 0.000 & 0.000 & 0.000 & 0.000 & 0.000 \\
\hline & 0.000 & 0.108 & 0.000 & 0.000 & 0.000 & 0.000 \\
\hline \multicolumn{7}{|l|}{ EVAPOTRANSPIRATION } \\
\hline \multirow{2}{*}{ TOTALS } & 1.560 & 1.908 & 2.564 & 2.331 & 2.752 & 3.435 \\
\hline & 3.843 & 3.445 & 2.680 & 1.432 & 1.085 & 1.261 \\
\hline \multirow[t]{2}{*}{ STD. DEVIATIONS } & 0.284 & 0.306 & 0.679 & 0.776 & 1.048 & 1.266 \\
\hline & 1.190 & 1.111 & 0.921 & 0.628 & 0.321 & 0.215 \\
\hline
\end{tabular}

NORMAL MEAN MONTHLY TEMPERATURE (DEGREES FAHRENHEIT)

$\begin{array}{cccccc}\text { JAN/JUL } & \text { FEB/AUG } & \text { MAR/SEP } & \text { APR/OCT } & \text { MAY/NOV } & \text { JUN/DEC } \\ ------ & ------ & ------ & ------ & ------ & ------ \\ 46.30 & 50.00 & 57.20 & 64.30 & 72.10 & 78.40 \\ 81.60 & 80.30 & 75.20 & 65.10 & 56.70 & 48.80\end{array}$

NOTE: SOLAR RADIATION DATA WAS SYNTHETICALLY GENERATED USING COEFFICIENTS FOR AUGUSTA GEORGIA AND STATION LATITUDE $=33.30$ DEGREES 


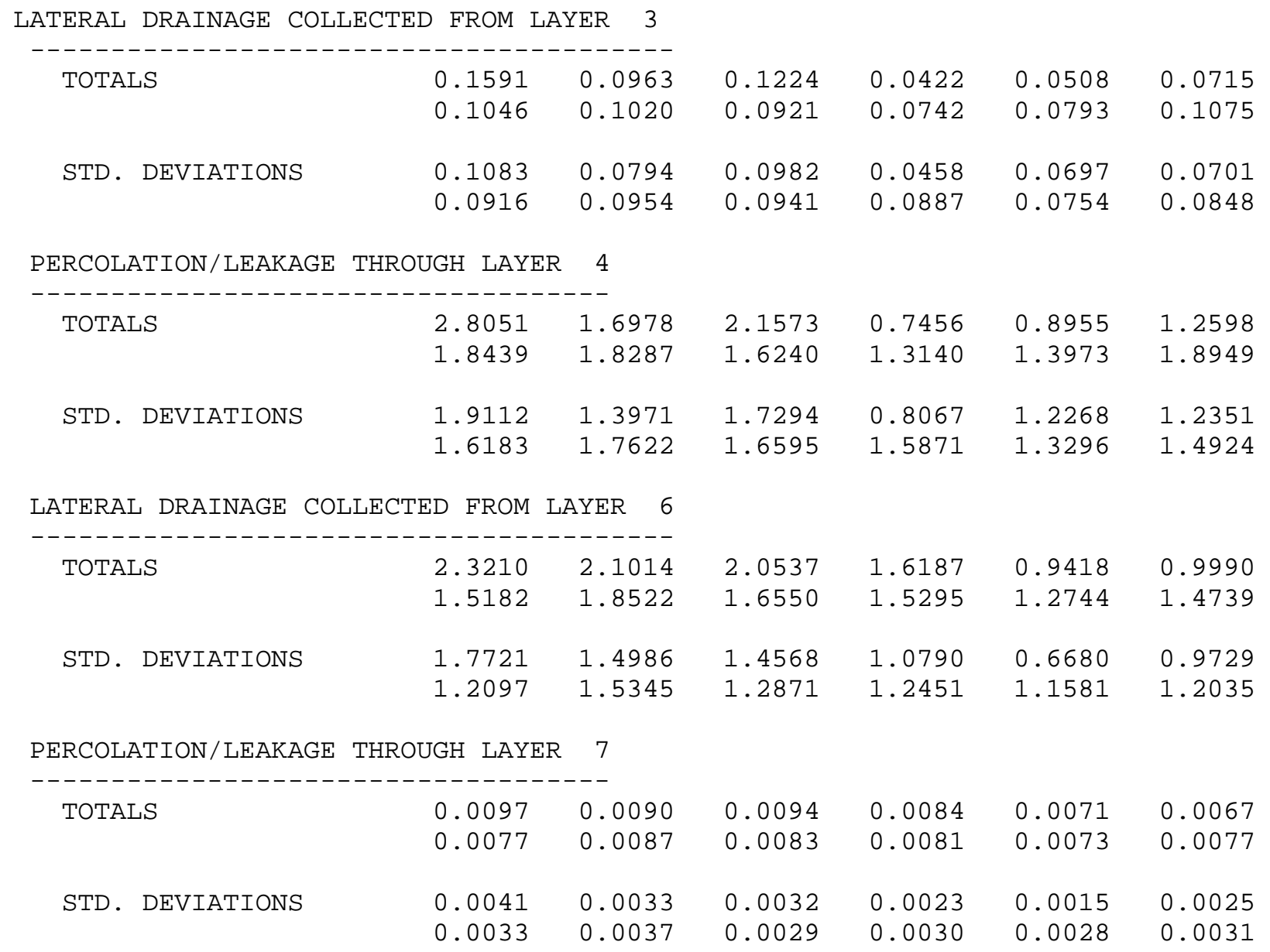

AVERAGES OF MONTHLY AVERAGED DAILY HEADS (INCHES)

DAILY AVERAGE HEAD ON TOP OF LAYER 4

$\begin{array}{lllllll}\text { AVERAGES } & 0.9716 & 0.6445 & 0.7471 & 0.2663 & 0.3099 & 0.4506 \\ & 0.6385 & 0.6331 & 0.5809 & 0.4549 & 0.5000 & 0.6562 \\ \text { STD. DEVIATIONS } & 0.6624 & 0.5308 & 0.5994 & 0.2889 & 0.4250 & 0.4423 \\ & 0.5608 & 0.6107 & 0.5943 & 0.5499 & 0.4761 & 0.5173\end{array}$

DAILY AVERAGE HEAD ON TOP OF LAYER 7

$\begin{array}{lllllll}\text { AVERAGES } & 0.1826 & 0.1813 & 0.1616 & 0.1316 & 0.0741 & 0.0812 \\ & 0.1194 & 0.1457 & 0.1345 & 0.1203 & 0.1036 & 0.1160 \\ & & & & & & \\ \text { STD. DEVIATIONS } & 0.1394 & 0.1294 & 0.1146 & 0.0877 & 0.0526 & 0.0791 \\ & 0.0952 & 0.1207 & 0.1046 & 0.0980 & 0.0941 & 0.0947\end{array}$




\begin{tabular}{|c|c|c|c|c|c|c|}
\hline AVERAGE ANNUAL TOTALS \& & \multicolumn{2}{|c|}{ (STD. DEVIATIONS) } & \multicolumn{2}{|c|}{ ) FOR YEARS } & 1 THROUGH & \multirow{2}{*}{$\begin{array}{l}100 \\
\text { PERCENT }\end{array}$} \\
\hline & INCH & IES & & & U. FEET & \\
\hline PRECIPITATION & 48.90 & ( & $7.734)$ & & 484469.2 & 100.00 \\
\hline RUNOFF & 0.016 & $(0$ & $0.1078)$ & & 1143.22 & 0.033 \\
\hline EVAPOTRANSPIRATION & 28.295 & $(2$ & $2.7952)$ & & 016190.25 & 57.862 \\
\hline $\begin{array}{l}\text { LATERAL DRAINAGE COLLECTED } \\
\text { FROM LAYER } 3\end{array}$ & 1.10213 & $(0$ & $0.33837)$ & & 78534.008 & 2.25383 \\
\hline $\begin{array}{l}\text { PERCOLATION/LEAKAGE THROUGH } \\
\text { LAYER } 4\end{array}$ & 19.46389 & $(5$ & $5.99995)$ & & 386936.620 & 39.80339 \\
\hline $\begin{array}{l}\text { AVERAGE HEAD ON TOP } \\
\text { OF LAYER } 4\end{array}$ & 0.571( & & $0.176)$ & & & \\
\hline $\begin{array}{l}\text { LATERAL DRAINAGE COLLECTED } \\
\text { FROM LAYER } 6\end{array}$ & 19.33876 & $(5$ & $5.95606)$ & & 378019.750 & 39.54748 \\
\hline $\begin{array}{l}\text { PERCOLATION/LEAKAGE THROUGH } \\
\text { LAYER } 7\end{array}$ & 0.09811 & $(0$ & $0.01463)$ & & 6991.046 & 0.20063 \\
\hline $\begin{array}{l}\text { AVERAGE HEAD ON TOP } \\
\text { OF LAYER } 7\end{array}$ & 0.129( & & $0.040)$ & & & \\
\hline CHANGE IN WATER STORAGE & 0.050 & $(2$ & $2.0018)$ & & 3591.10 & 0.103 \\
\hline
\end{tabular}




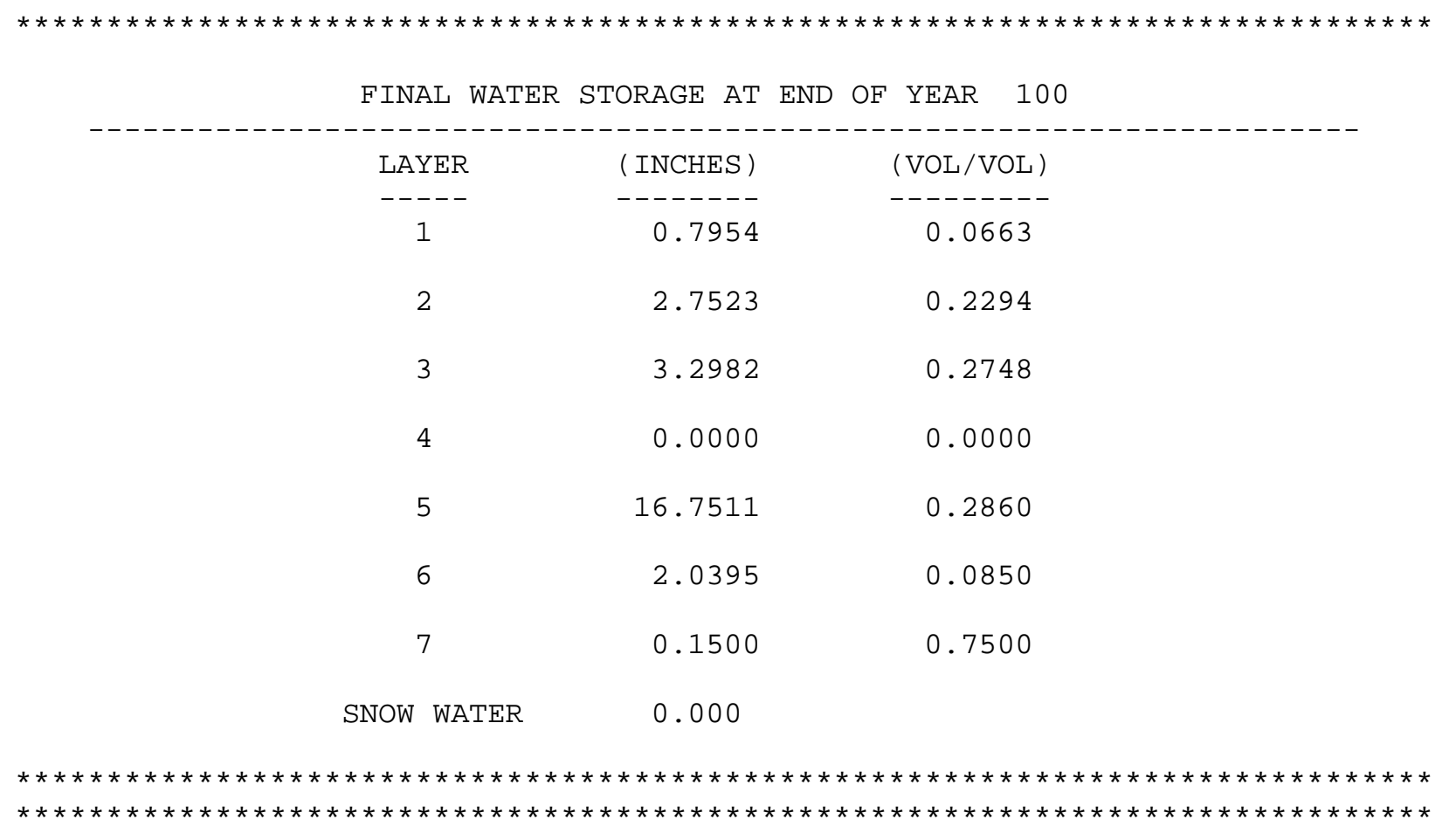


Appendix W, Upper Bounding Scenario Degraded SDF MSE Vault Closure Cap (1,800 Years): HELP Model Input Data and Output File (output file name: ZUBSD8ou.OUT)

Input Data:

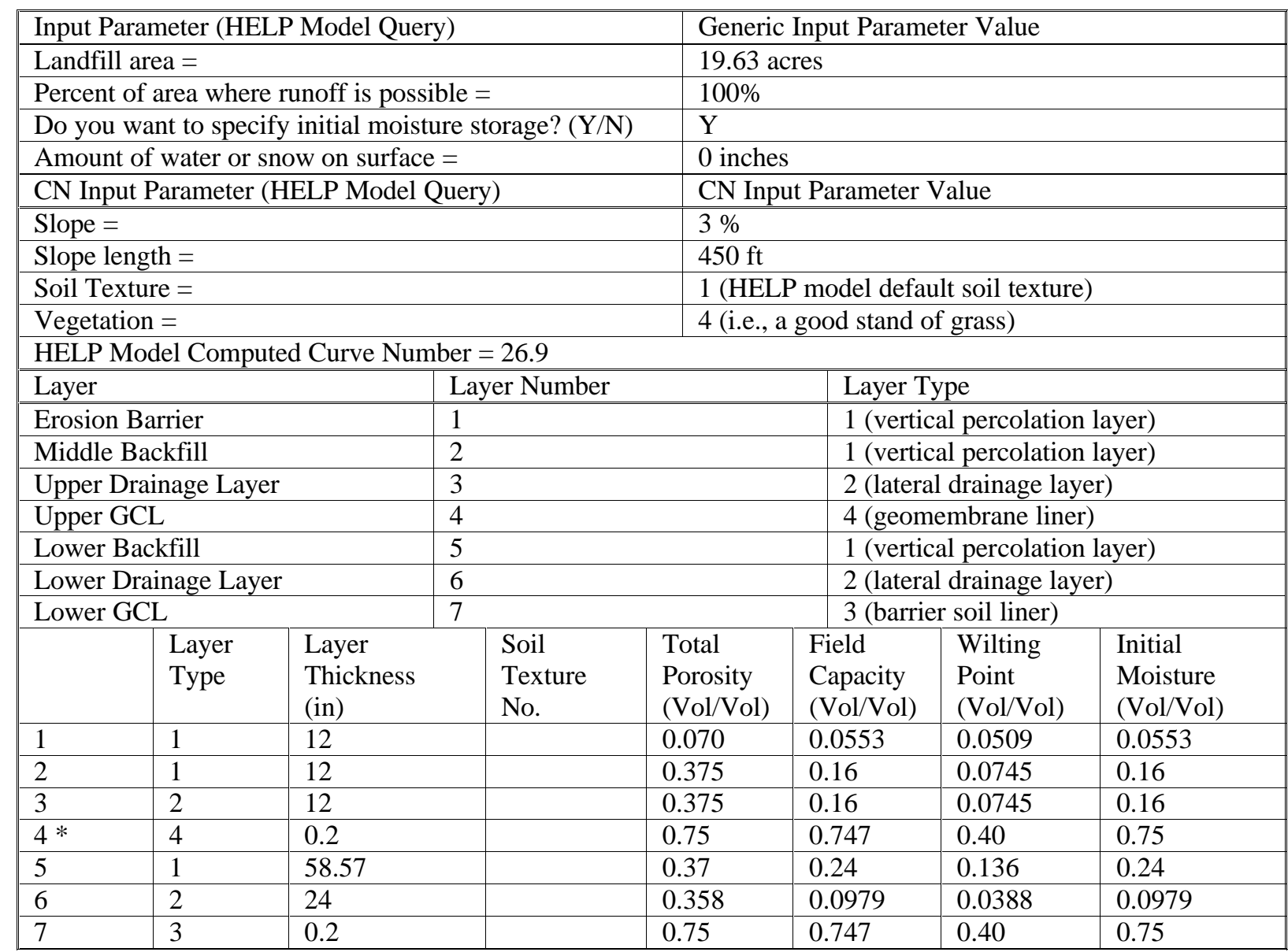

The lack of values in the table for particular parameters in particular layers denotes that no HELP model input was required for that parameter in that layer. No data are missing from the table.

* The input porosity, field capacity, and wilting point values of the upper GCL are ignored by the HELP model, since the upper GCL is designated as an geomembrane in order for the HELP model to take into account the holes produced by root penetration. 
Input Data (continued):

\begin{tabular}{|c|c|c|c|c|c|c|c|c|c|}
\hline & $\begin{array}{l}\text { Layer } \\
\text { Type }\end{array}$ & $\begin{array}{l}\text { Sat. Hyd. } \\
\text { Conductivity * } \\
(\mathrm{cm} / \mathrm{sec})\end{array}$ & \multicolumn{2}{|c|}{$\begin{array}{l}\text { Drainage } \\
\text { Length } \\
(\mathrm{ft}) \\
\end{array}$} & $\begin{array}{l}\text { Drain } \\
\text { Slope } \\
(\%)\end{array}$ & $\begin{array}{l}\text { Leachate } \\
\text { Recirc. } \\
(\%)\end{array}$ & \multicolumn{2}{|c|}{$\begin{array}{l}\text { Recirc. to } \\
\text { Layer } \\
(\#)\end{array}$} & $\begin{array}{l}\text { Subsurface } \\
\text { Inflow } \\
\text { (in/yr) }\end{array}$ \\
\hline 1 & 1 & 9.10E-03 & & & & & & & \\
\hline 2 & 1 & $3.20 \mathrm{E}-03$ & & & & & & & \\
\hline 3 & 2 & $3.20 \mathrm{E}-03$ & 450 & & 3 & & & & \\
\hline 4 & 4 & $5.00 \mathrm{E}-09$ & & & & & & & \\
\hline 5 & 1 & $1.00 \mathrm{E}-04$ & & & & & & & \\
\hline 6 & 2 & $8.62 \mathrm{E}-02$ & 150 & & 11.4 & & & & \\
\hline 7 & 3 & $5.00 \mathrm{E}-09$ & & & & & & & \\
\hline & $\begin{array}{l}\text { Layer } \\
\text { Type }\end{array}$ & \multicolumn{2}{|l|}{$\begin{array}{l}\text { Geomembrane } \\
\text { Pinhole Density } \\
\text { (\#/acre) }\end{array}$} & $\begin{array}{l}\text { Gec } \\
\text { Inst } \\
(\# / a\end{array}$ & $\begin{array}{l}\text { Defects } \\
\text { Derane }\end{array}$ & \multicolumn{2}{|c|}{$\begin{array}{l}\text { Geomembrane } \\
\text { Placement Quality }\end{array}$} & \multicolumn{2}{|c|}{$\begin{array}{l}\text { Geotextile } \\
\text { Transmissivity } \\
\left(\mathrm{cm}^{2} / \mathrm{sec}\right)\end{array}$} \\
\hline 1 & 1 & & & & & & & & \\
\hline 2 & 1 & & & & & & & & \\
\hline 3 & 2 & & & & & & & & \\
\hline 4 & 4 & 0 & & 448 & & 1 & & & \\
\hline 5 & 1 & & & & & & & & \\
\hline 6 & 2 & & & & & & & & \\
\hline 7 & 3 & & & & & & & & \\
\hline
\end{tabular}

The lack of values in the table for particular parameters in particular layers denotes that no HELP model input was required for that parameter in that layer. No data are missing from the table.

* The HELP model output often produces an increased number of significant digits for the Effective Saturated Hydraulic Conductivity over that of the actual input 


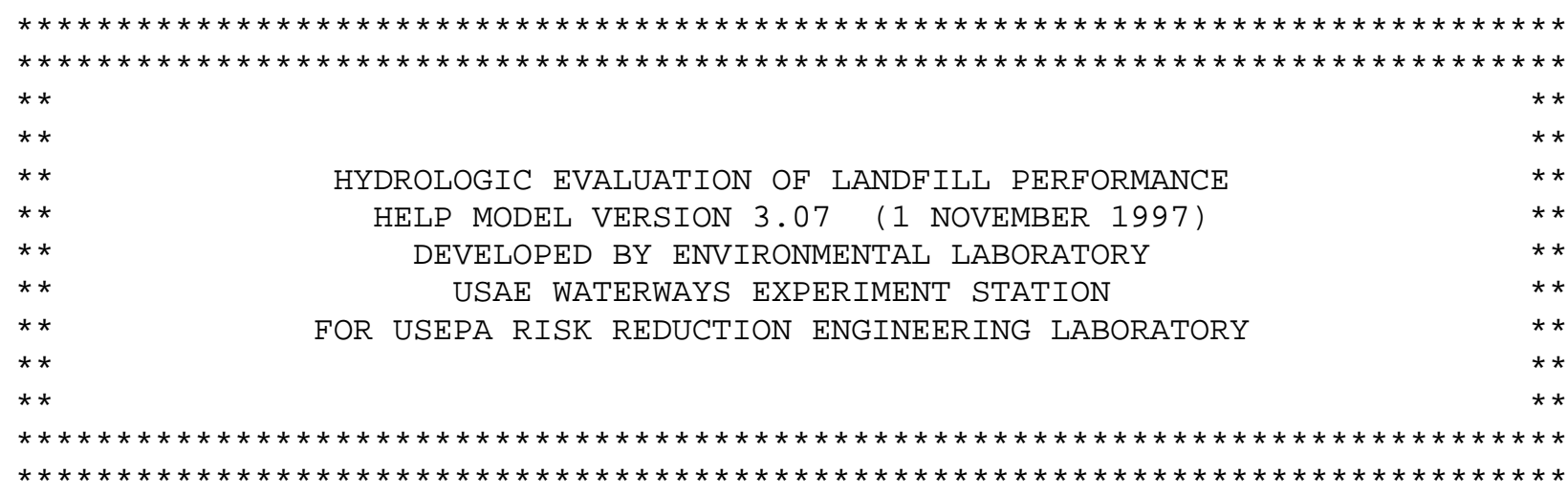

\begin{tabular}{|c|c|}
\hline RECIPITATION DATA & $: \backslash$ HELP $3 \backslash$ Hweather $\backslash$ \\
\hline TEMPERATURE DATA FILE: & D: \HELP $3 \backslash$ Hweather $\backslash$ ZTEMP.D7 \\
\hline FILE: & D: \HELP $3 \backslash$ Hweather $\backslash$ ZSOLAR.D13 \\
\hline IRATION & D: \HELP $3 \backslash$ Hweather $\backslash$ ZEVAP.D11 \\
\hline AND DESIC & $\mathrm{D}: \backslash \mathrm{HELP} 3 \backslash \mathrm{Hsdfmse \backslash ZUBSD8.D10}$ \\
\hline & - $\backslash$ HELP $3 \backslash$ Hsdfmse $\backslash$ ZUBSD $80 u$ \\
\hline
\end{tabular}

TIME: $14: 10 \quad$ DATE: $1 / 13 / 2004$

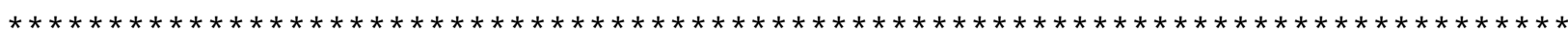
TITLE: UBS Degraded MSE Vault Closure Cap - 1,800 years

NOTE: INITIAL MOISTURE CONTENT OF THE LAYERS AND SNOW WATER WERE SPECIFIED BY THE USER.

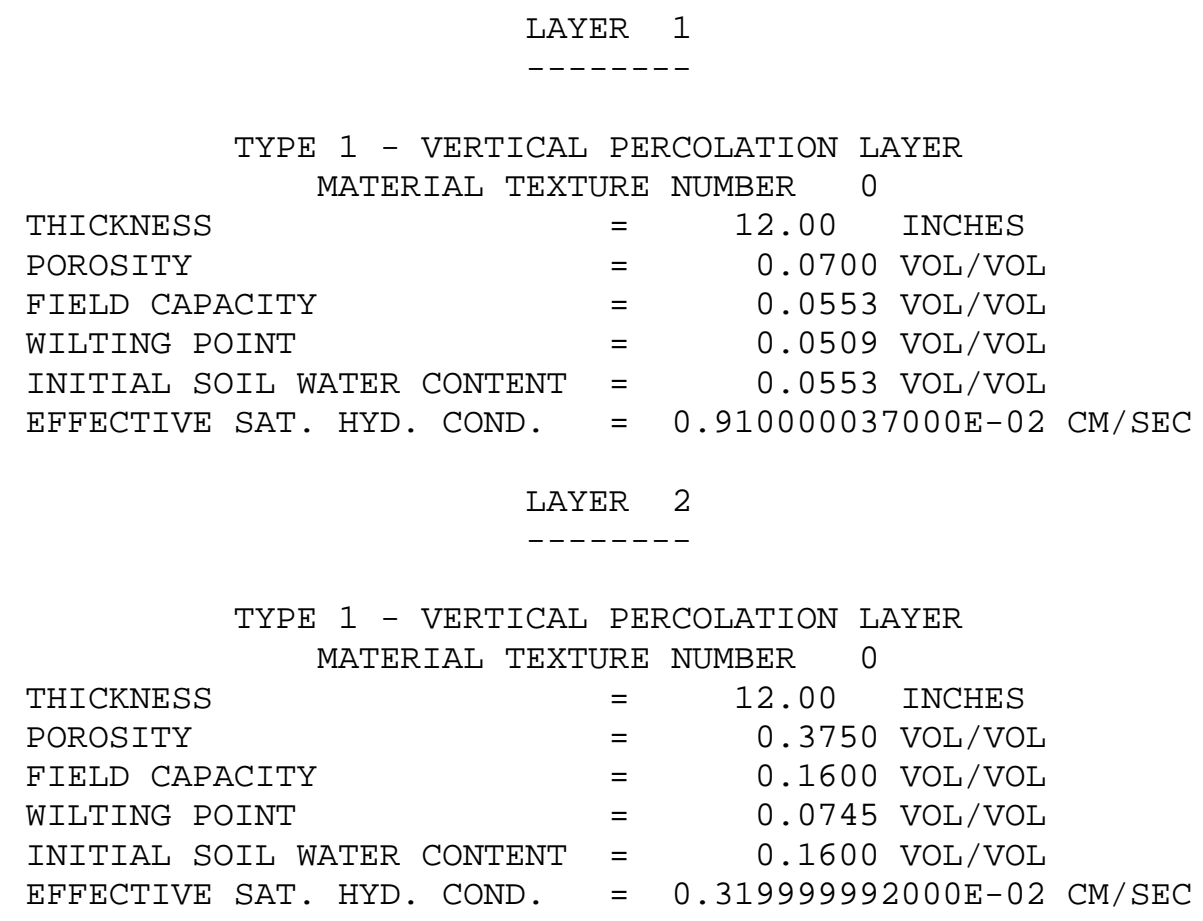

Rev. 0 
LAYER 3

$--------$

TYPE 2 - LATERAL DRAINAGE LAYER

MATERIAL TEXTURE NUMBER 0

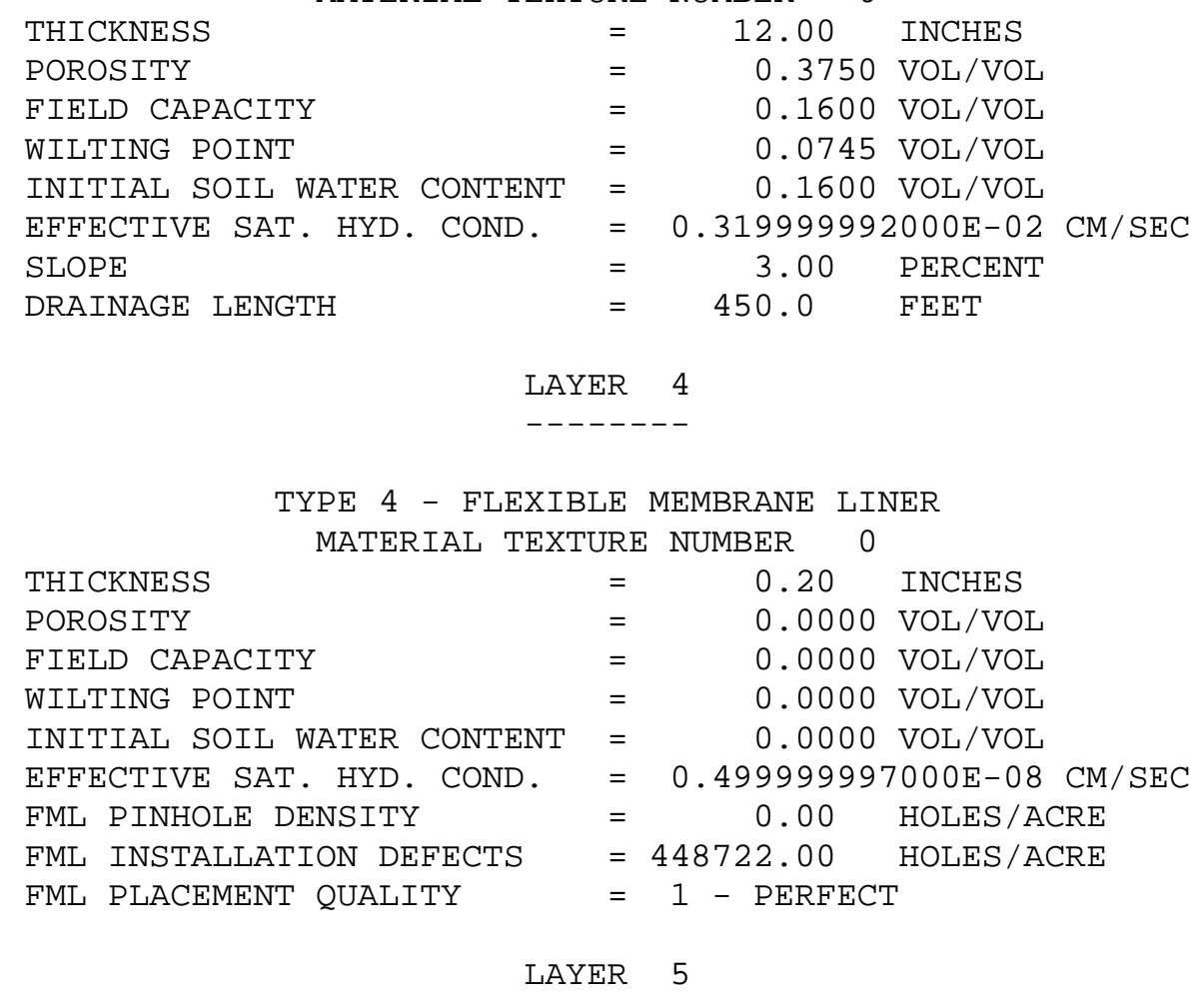

TYPE 1 - VERTICAL PERCOLATION LAYER MATERIAL TEXTURE NUMBER 0

$\begin{array}{llrl}\text { THICKNESS } & = & 58.57 \mathrm{INCHES} \\ \text { POROSITY } & = & 0.3700 \mathrm{VOL} / \mathrm{VOL} \\ \text { FIELD CAPACITY } & = & 0.2400 \mathrm{VOL} / \mathrm{VOL} \\ \text { WILTING POINT } & = & 0.1360 \mathrm{VOL} / \mathrm{VOL} \\ \text { INITIAL SOIL WATER CONTENT } & = & 0.2400 \mathrm{VOL} / \mathrm{VOL} \\ \text { EFEECTIVE SAT. HYD. COND. } & =0.999999975000 \mathrm{E}-04 \mathrm{CM} / \mathrm{SEC}\end{array}$

LAYER 6

TYPE 2 - LATERAL DRAINAGE LAYER MATERIAL TEXTURE NUMBER 0

$\begin{array}{llcl}\text { THICKNESS } & = & 24.00 & \text { INCHES } \\ \text { POROSITY } & = & 0.3580 \mathrm{VOL} / \mathrm{VOL} \\ \text { FIELD CAPACITY } & = & 0.0979 \mathrm{VOL} / \mathrm{VOL} \\ \text { WILTING POINT } & = & 0.0388 \mathrm{VOL} / \mathrm{VOL} \\ \text { INITIAL SOIL WATER CONTENT } & = & 0.0979 \mathrm{VOL} / \mathrm{VOL} \\ \text { EFEECTIVE SAT. HYD. COND. } & =0.861999989000 \mathrm{E}-01 \mathrm{CM} / \mathrm{SEC} \\ \text { SLOPE } & = & 11.40 \mathrm{PERCENT} \\ \text { DRAINAGE LENGTH } & =150.0 & \mathrm{FEET}\end{array}$

Rev. 0 
LAYER 7

$--------$

TYPE 3 - BARRIER SOIL LINER

MATERIAL TEXTURE NUMBER 0

$\begin{array}{llrl}\text { THICKNESS } & = & 0.20 \mathrm{INCHES} \\ \text { POROSITY } & = & 0.7500 \mathrm{VOL} / \mathrm{VOL} \\ \text { FIELD CAPACITY } & = & 0.7470 \mathrm{VOL} / \mathrm{VOL} \\ \text { WILTING POINT } & = & 0.4000 \mathrm{VOL} / \mathrm{VOL} \\ \text { INITIAL SOIL WATER CONTENT } & = & 0.7500 \mathrm{VOL} / \mathrm{VOL} \\ \text { EFFECTIVE SAT. HYD. COND. } & =0.499999997000 \mathrm{E}-08 \mathrm{CM} / \mathrm{SEC}\end{array}$

GENERAL DESIGN AND EVAPORATIVE ZONE DATA

NOTE: SCS RUNOFF CURVE NUMBER WAS COMPUTED FROM DEFAULT SOIL DATA BASE USING SOIL TEXTURE \# 1 WITH A GOOD STAND OF GRASS, A SURFACE SLOPE OF 3.\% AND A SLOPE LENGTH OF 450. FEET.

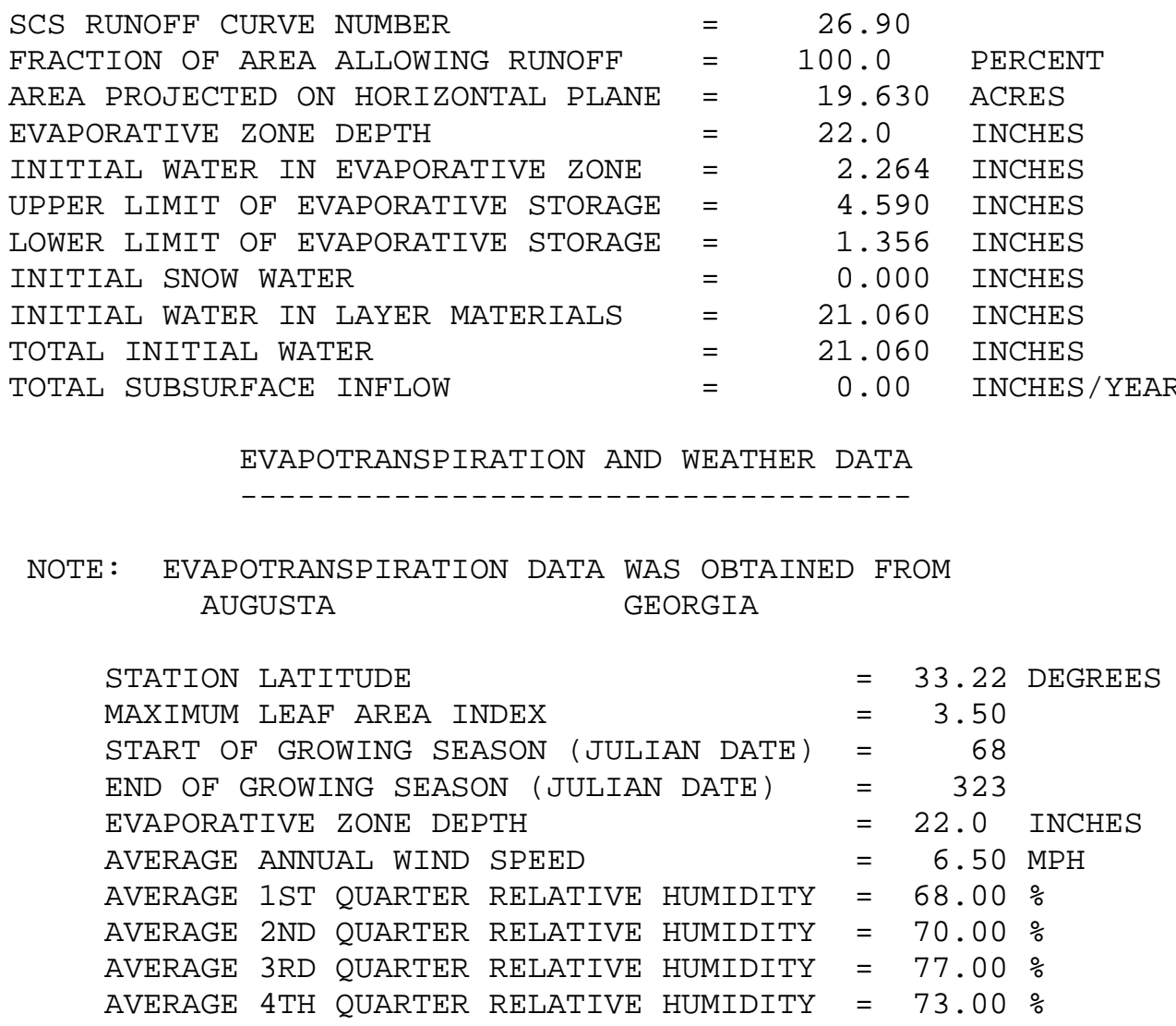




$$
\begin{aligned}
& \text { NOTE: PRECIPITATION DATA WAS SYNTHETICALLY GENERATED USING } \\
& \text { COEFFICIENTS FOR AUGUSTA GEORGIA } \\
& \text { NORMAL MEAN MONTHLY PRECIPITATION (INCHES) } \\
& \begin{array}{cccccc}
\text { JAN/JUL } & \text { FEB/AUG } & \text { MAR/SEP } & \text { APR/OCT } & \text { MAY/NOV } & \text { JUN/DEC } \\
------ & ------ & ------ & ------ & ------ & ------ \\
4.38 & 3.95 & 4.68 & 2.91 & 3.56 & 4.99 \\
5.43 & 5.41 & 3.93 & 3.12 & 2.96 & 3.45
\end{array}
\end{aligned}
$$

\begin{tabular}{|c|c|c|c|c|c|c|}
\hline AVERAGE MONTHLY & VALUES & IN INCHES & FOR YEARS & $1 \mathrm{THR}$ & OUGH 100 & \\
\hline & JAN / JUL & FEB/AUG & $\mathrm{MAR} / \mathrm{SEP}$ & $\mathrm{APR} / \mathrm{OCT}$ & $\mathrm{MAY} / \mathrm{NOV}$ & JUN/DEC \\
\hline \multicolumn{7}{|l|}{ PRECIPITATION } \\
\hline \multirow{2}{*}{ TOTALS } & 4.56 & 3.57 & 4.76 & 2.74 & 3.60 & 4.97 \\
\hline & 5.81 & 5.32 & 4.41 & 2.99 & 2.75 & 3.41 \\
\hline \multirow[t]{2}{*}{ STD. DEVIATIONS } & 2.44 & 1.60 & 2.47 & 1.31 & 2.12 & 2.60 \\
\hline & 2.83 & 2.95 & 2.54 & 2.28 & 1.72 & 1.90 \\
\hline \multicolumn{7}{|l|}{ RUNOFF } \\
\hline \multirow{2}{*}{ TOTALS } & 0.000 & 0.000 & 0.000 & 0.000 & 0.000 & 0.000 \\
\hline & 0.000 & 0.000 & 0.000 & 0.000 & 0.000 & 0.000 \\
\hline \multirow[t]{2}{*}{ STD. DEVIATIONS } & 0.000 & 0.000 & 0.000 & 0.000 & 0.000 & 0.000 \\
\hline & 0.000 & 0.000 & 0.000 & 0.000 & 0.000 & 0.000 \\
\hline \multicolumn{7}{|l|}{ EVAPOTRANSPIRATION } \\
\hline \multirow{2}{*}{ TOTALS } & 1.533 & 1.848 & 2.491 & 2.259 & 2.667 & 3.342 \\
\hline & 3.735 & 3.302 & 2.593 & 1.394 & 1.079 & 1.249 \\
\hline \multirow[t]{2}{*}{ STD. DEVIATIONS } & 0.293 & 0.300 & 0.645 & 0.744 & 1.019 & 1.215 \\
\hline & 1.151 & 1.059 & 0.903 & 0.614 & 0.322 & 0.226 \\
\hline
\end{tabular}

NORMAL MEAN MONTHLY TEMPERATURE (DEGREES FAHRENHEIT)

$\begin{array}{cccccc}\text { JAN/JUL } & \text { FEB/AUG } & \text { MAR/SEP } & \text { APR/OCT } & \text { MAY/NOV } & \text { JUN/DEC } \\ ------ & ------ & ------ & ------ & ------ & ------ \\ 46.30 & 50.00 & 57.20 & 64.30 & 72.10 & 78.40 \\ 81.60 & 80.30 & 75.20 & 65.10 & 56.70 & 48.80\end{array}$

NOTE: SOLAR RADIATION DATA WAS SYNTHETICALLY GENERATED USING COEFFICIENTS FOR AUGUSTA GEORGIA AND STATION LATITUDE $=33.30$ DEGREES 
LATERAL DRAINAGE COLLECTED FROM LAYER 3

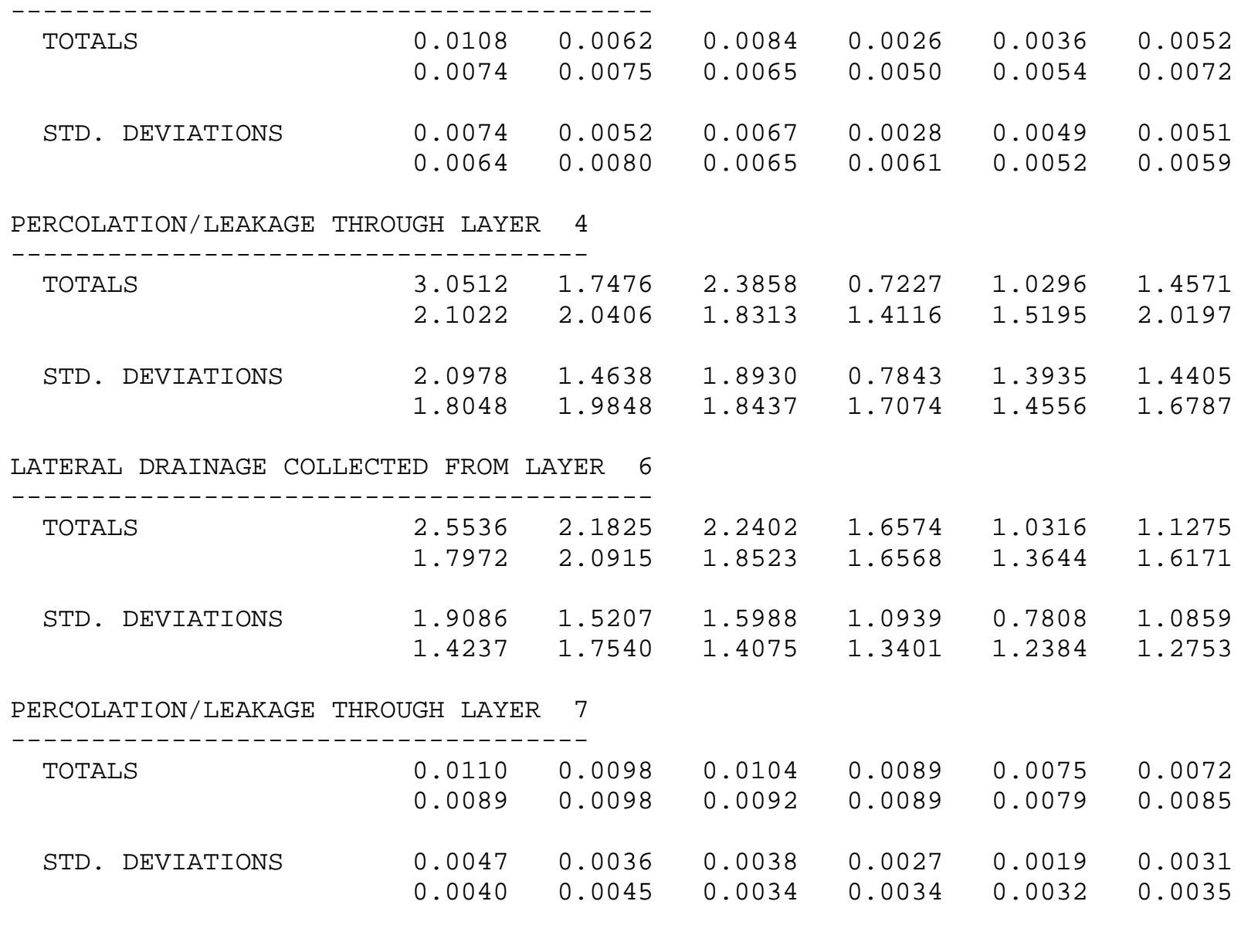

DAILY AVERAGE HEAD ON TOP OF LAYER 4

$\begin{array}{lllllll}\text { AVERAGES } & 0.2885 & 0.1810 & 0.2256 & 0.0705 & 0.0973 & 0.1424 \\ & 0.1988 & 0.2001 & 0.1790 & 0.1336 & 0.1484 & 0.1909 \\ \text { STD. DEVIATIONS } & 0.1985 & 0.1519 & 0.1791 & 0.0766 & 0.1318 & 0.1408 \\ & 0.1708 & 0.2119 & 0.1803 & 0.1619 & 0.1423 & 0.1588\end{array}$

DAILY AVERAGE HEAD ON TOP OF LAYER 7

$\begin{array}{lllllll}\text { AVERAGES } & 0.2247 & 0.2106 & 0.1971 & 0.1507 & 0.0908 & 0.1025 \\ & 0.1581 & 0.1840 & 0.1684 & 0.1458 & 0.1241 & 0.1423 \\ \text { STD. DEVIATIONS } & 0.1679 & 0.1469 & 0.1407 & 0.0995 & 0.0687 & 0.0987 \\ & 0.1253 & 0.1543 & 0.1280 & 0.1179 & 0.1126 & 0.1122\end{array}$




\begin{tabular}{|c|c|c|c|c|c|c|}
\hline AVERAGE ANNUAL TOTALS \& & \multicolumn{2}{|c|}{ (STD. DEVIATIONS) } & \multicolumn{2}{|c|}{ ) FOR YEARS } & 1 THROUGH & \multirow{2}{*}{$\begin{array}{l}100 \\
\text { PERCENT }\end{array}$} \\
\hline & INCH & IES & & & U. FEET & \\
\hline PRECIPITATION & 48.90 & ( & $7.734)$ & & 484469.2 & 100.00 \\
\hline RUNOFF & 0.000 & $(0$ & $0.0000)$ & & 0.00 & 0.000 \\
\hline EVAPOTRANSPIRATION & 27.492 & $(2$ & $2.7375)$ & & 959003.12 & 56.221 \\
\hline $\begin{array}{l}\text { LATERAL DRAINAGE COLLECTED } \\
\text { FROM LAYER } 3\end{array}$ & 0.07578 & $(0$ & $0.02295)$ & & 5399.602 & 0.15496 \\
\hline $\begin{array}{l}\text { PERCOLATION/LEAKAGE THROUGH } \\
\text { LAYER } 4\end{array}$ & 21.31867 & $(6$ & $6.36277)$ & & 519102.370 & 43.59638 \\
\hline $\begin{array}{l}\text { AVERAGE HEAD ON TOP } \\
\text { OF LAYER } 4\end{array}$ & 0.171( & & $0.052)$ & & & \\
\hline $\begin{array}{l}\text { LATERAL DRAINAGE COLLECTED } \\
\text { FROM LAYER } 6\end{array}$ & 21.17214 & $(6$ & $6.37298)$ & & 508660.870 & 43.29672 \\
\hline $\begin{array}{l}\text { PERCOLATION/LEAKAGE THROUGH } \\
\text { LAYER } 7\end{array}$ & 0.10798 & $(0$ & $0.01688)$ & & 7694.309 & 0.22082 \\
\hline $\begin{array}{l}\text { AVERAGE HEAD ON TOP } \\
\text { OF LAYER } 7\end{array}$ & $0.158 \quad($ & & $0.048)$ & & & \\
\hline CHANGE IN WATER STORAGE & 0.052 & $(1$ & (.9127) & & 3711.20 & 0.107 \\
\hline
\end{tabular}




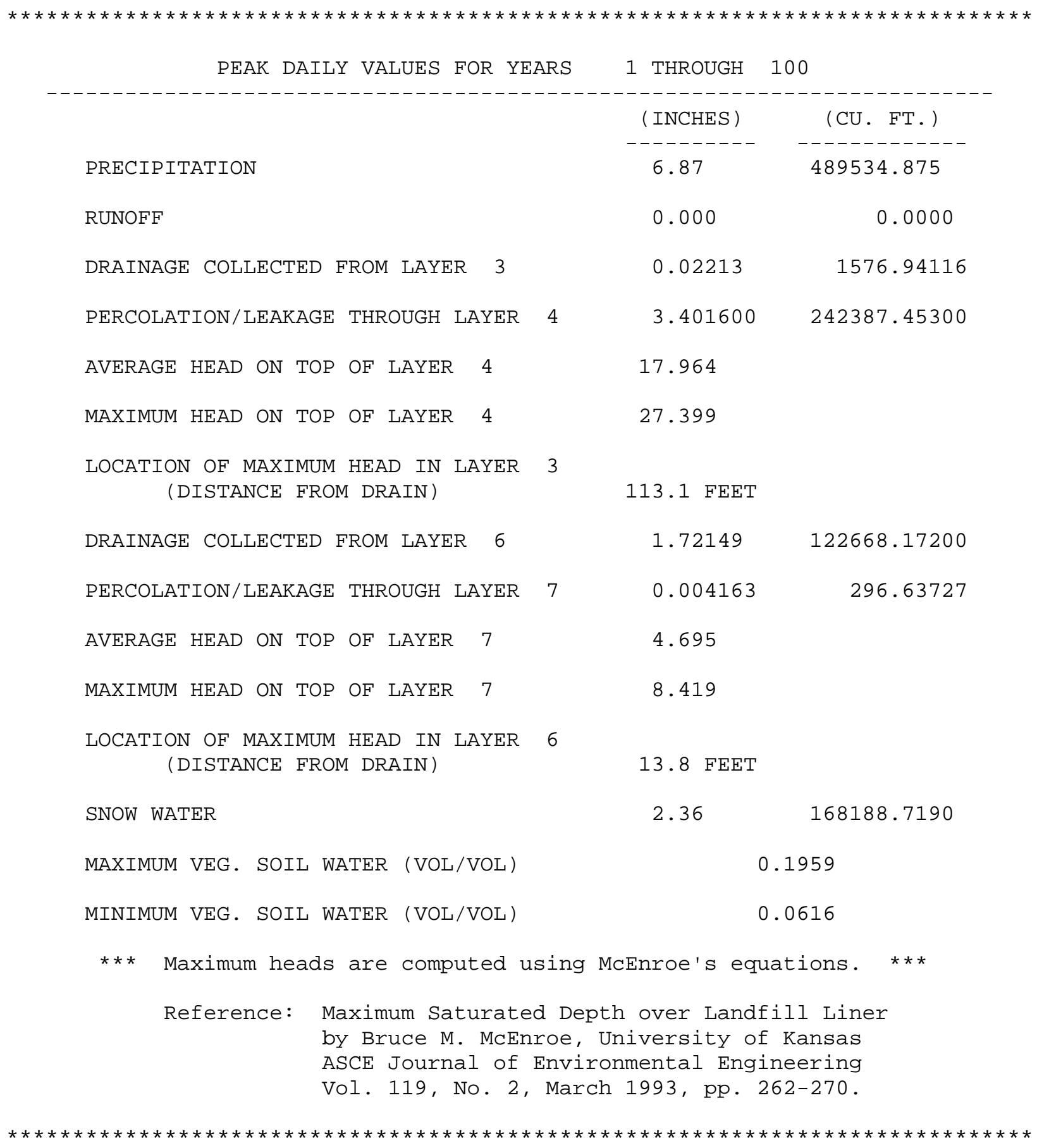

Rev. 0 


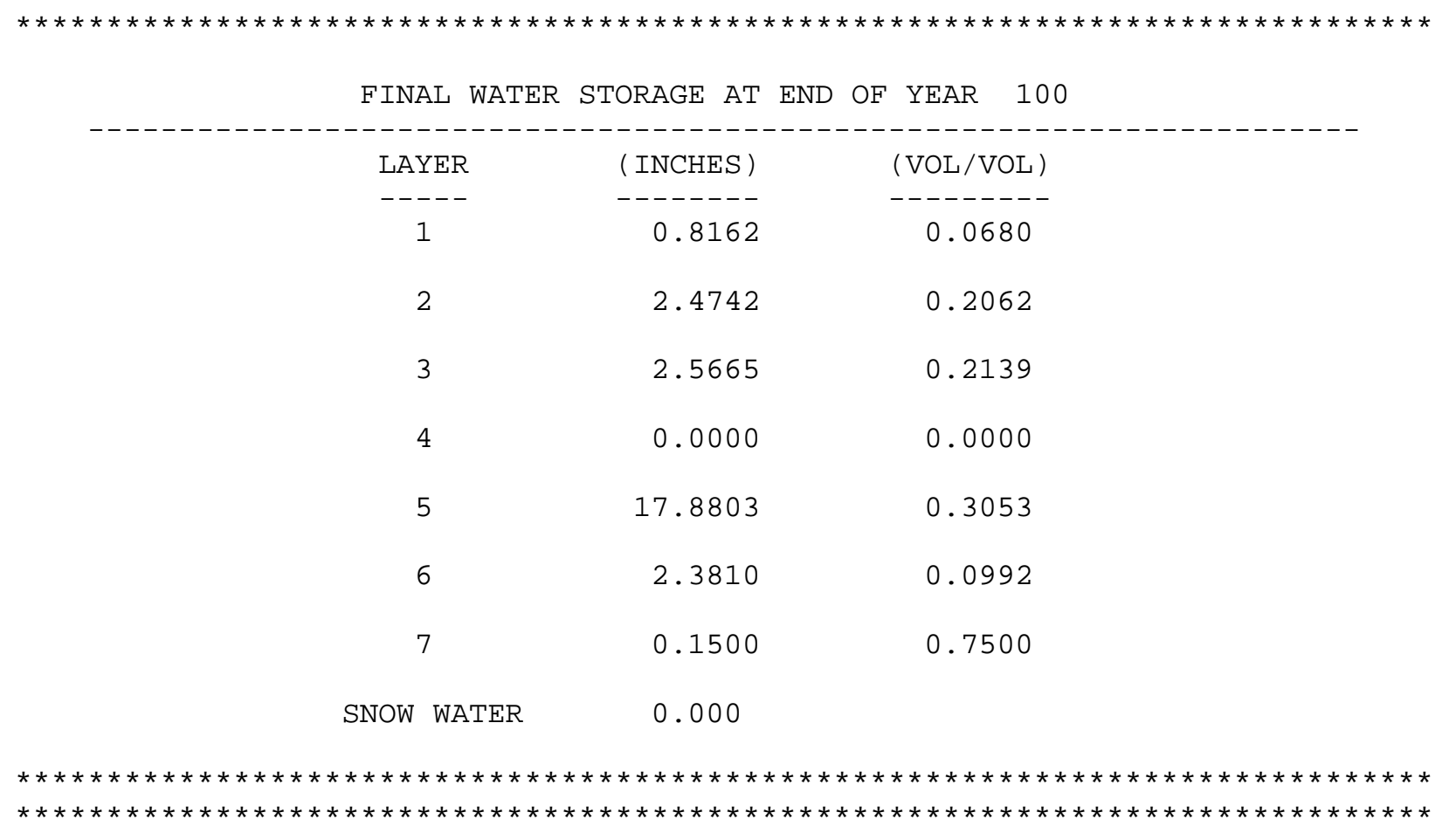


Appendix X, Upper Bounding Scenario Degraded SDF MSE Vault Closure Cap (3,400 Years): HELP Model Input Data and Output File (output file name: ZUBSD9ou.OUT)

\section{Input Data:}

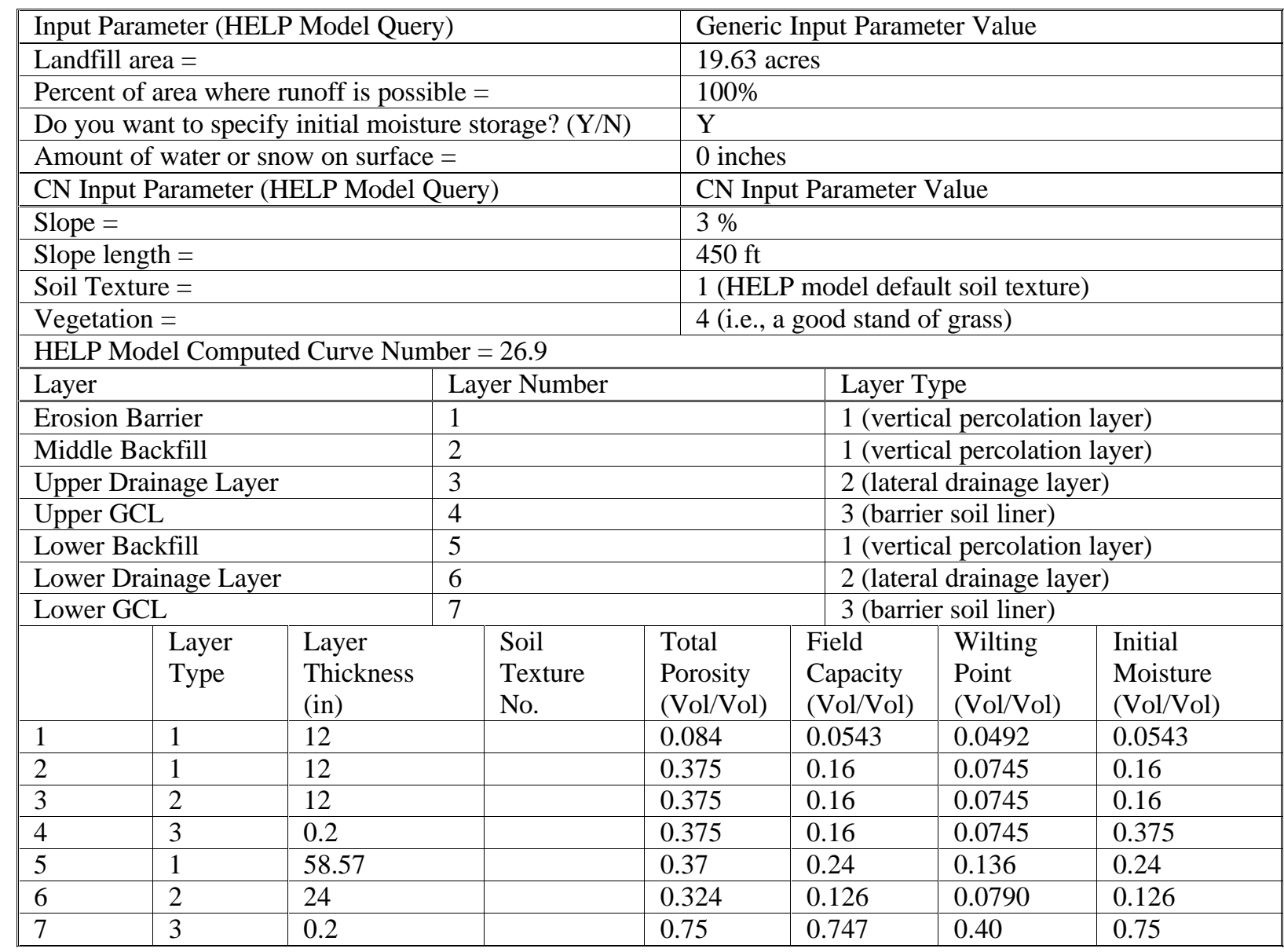

The lack of values in the table for particular parameters in particular layers denotes that no HELP model input was required for that parameter in that layer. No data are missing from the table. 
Input Data (continued):

\begin{tabular}{|c|c|c|c|c|c|c|c|c|c|}
\hline & $\begin{array}{l}\text { Layer } \\
\text { Type }\end{array}$ & $\begin{array}{l}\text { Sat. Hyd. } \\
\text { Conductivity * } \\
(\mathrm{cm} / \mathrm{sec})\end{array}$ & \multicolumn{2}{|c|}{$\begin{array}{l}\text { Drainage } \\
\text { Length } \\
(\mathrm{ft}) \\
\end{array}$} & $\begin{array}{l}\text { Drain } \\
\text { Slope } \\
(\%) \\
\end{array}$ & $\begin{array}{l}\text { Leachate } \\
\text { Recirc. } \\
(\%) \\
\end{array}$ & \multicolumn{2}{|c|}{$\begin{array}{l}\text { Recirc. to } \\
\text { Layer } \\
(\#)\end{array}$} & $\begin{array}{l}\text { Subsurface } \\
\text { Inflow } \\
\text { (in/yr) }\end{array}$ \\
\hline 1 & 1 & $2.20 \mathrm{E}-02$ & & & & & & & \\
\hline 2 & 1 & $3.20 \mathrm{E}-03$ & & & & & & & \\
\hline 3 & 2 & $3.20 \mathrm{E}-03$ & 450 & & 3 & & & & \\
\hline 4 & 3 & $3.20 \mathrm{E}-03$ & & & & & & & \\
\hline 5 & 1 & $1.00 \mathrm{E}-04$ & & & & & & & \\
\hline 6 & 2 & $6.47 \mathrm{E}-02$ & 150 & & 11.4 & & & & \\
\hline 7 & 3 & $5.00 \mathrm{E}-09$ & & & & & & \\
\hline & $\begin{array}{l}\text { Layer } \\
\text { Type }\end{array}$ & \multicolumn{2}{|l|}{$\begin{array}{l}\text { Geomembrane } \\
\text { Pinhole Density } \\
\text { (\#/acre) }\end{array}$} & \multicolumn{2}{|c|}{$\begin{array}{l}\text { Geomembrane } \\
\text { Instal. Defects } \\
(\# / \text { acre })\end{array}$} & \multicolumn{2}{|c|}{$\begin{array}{l}\text { Geomembrane } \\
\text { Placement Quality }\end{array}$} & \multicolumn{2}{|c|}{$\begin{array}{l}\text { Geotextile } \\
\text { Transmissivity } \\
\left(\mathrm{cm}^{2} / \mathrm{sec}\right)\end{array}$} \\
\hline 1 & 1 & & & & & & & & \\
\hline 2 & 1 & & & & & & & & \\
\hline 3 & 2 & & & & & & & & \\
\hline 4 & 3 & & & & & & & & \\
\hline 5 & 1 & & & & & & & & \\
\hline 6 & 2 & & & & & & & & \\
\hline 7 & 3 & & & & & & & & \\
\hline
\end{tabular}

The lack of values in the table for particular parameters in particular layers denotes that no HELP model input was required for that parameter in that layer. No data are missing from the table.

* The HELP model output often produces an increased number of significant digits for the Effective Saturated Hydraulic Conductivity over that of the actual input 

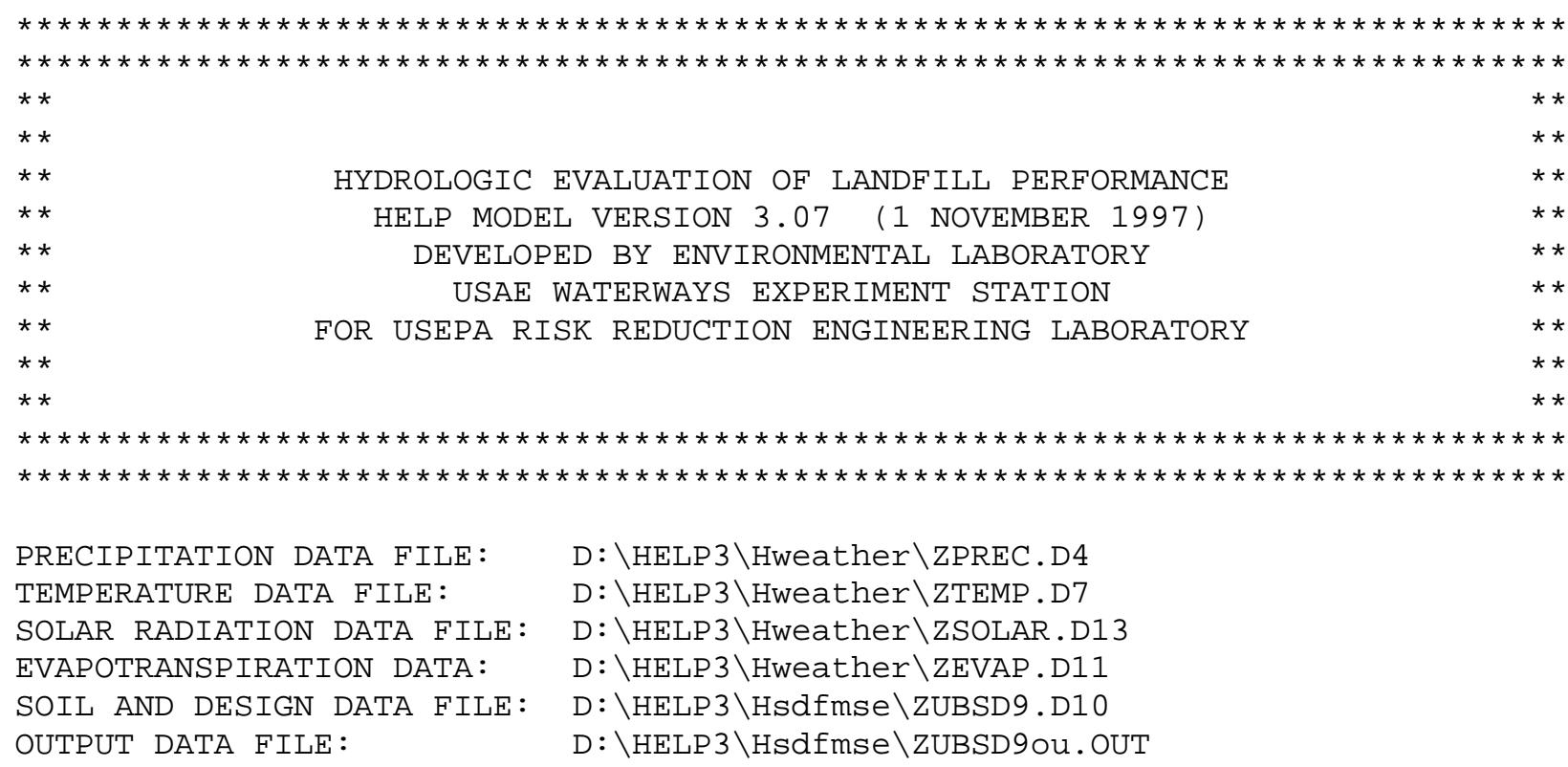

NOTE: INITIAL MOISTURE CONTENT OF THE LAYERS AND SNOW WATER WERE SPECIFIED BY THE USER.

\begin{tabular}{|c|c|c|c|c|}
\hline \multicolumn{5}{|c|}{ LAYER 1} \\
\hline \multicolumn{5}{|c|}{ TYPE 1 - VERTICAL PERCOLATION LAYER } \\
\hline THICKNESS & $=$ & 12.00 & INCHES & \\
\hline POROSITY & $=$ & 0.0840 & VOL/VOI & \\
\hline FIELD CAPACITY & $=$ & 0.0543 & VOL/VOI & \\
\hline WILTING POINT & $=$ & 0.0492 & VOL/VOI & \\
\hline INITIAL SOIL WATER CONTENT & $=$ & 0.0543 & VOL/VOI & \\
\hline EFFECTIVE SAT. HYD. COND. & $=$ & 0.219999999 & $9000 \mathrm{E}-01$ & $\mathrm{CM} / \mathrm{SEC}$ \\
\hline \multicolumn{5}{|c|}{ LAYER 2} \\
\hline $\begin{array}{r}\text { TYPE } 1 \text { - VERTICAI } \\
\text { MATERIAL TEX? }\end{array}$ & $\begin{aligned} & P E \\
& U R E\end{aligned}$ & $\begin{array}{cl}\text { RCOLATION } & \text { LA } \\
\text { NUMBER } & 0\end{array}$ & AYER & \\
\hline THICKNESS & $=$ & 12.00 & INCHES & \\
\hline POROSITY & $=$ & 0.3750 & VOL/VOI & \\
\hline FIELD CAPACITY & $=$ & 0.1600 & VOL/VOI & \\
\hline WILTING POINT & $=$ & 0.0745 & VOL/VOI & \\
\hline INITIAL SOIL WATER CONTENT & $=$ & 0.1600 & $\mathrm{VOL} / \mathrm{VOI}$ & \\
\hline EFFECTIVE SAT. HYD. COND. & $=$ & 0.319999992 & $2000 \mathrm{E}-02$ & $\mathrm{CM} / \mathrm{SEC}$ \\
\hline
\end{tabular}

Rev. 0 
LAYER 3

$--------$

TYPE 2 - LATERAL DRAINAGE LAYER

MATERIAL TEXTURE NUMBER 0

\begin{tabular}{|c|c|c|c|c|}
\hline & & & & \\
\hline THICKNESS & $=$ & 12.00 & INCHES & \\
\hline POROSITY & $=$ & 0.3750 & $\mathrm{VOL} / \mathrm{VOL}$ & \\
\hline FIELD CAPACITY & $=$ & 0.1600 & $\mathrm{VOL} / \mathrm{VOL}$ & \\
\hline WILTING POINT & $=$ & 0.0745 & $\mathrm{VOL} / \mathrm{VOL}$ & \\
\hline INITIAL SOIL WATER CONTENT & $=$ & 0.1600 & $\mathrm{VOL} / \mathrm{VOL}$ & \\
\hline EFFECTIVE SAT. HYD. COND. & $=$ & 0.319999992 & $2000 E-02$ & $\mathrm{CM} / \mathrm{SEC}$ \\
\hline SLOPE & $=$ & 3.00 & PERCENT & \\
\hline DRAINAGE LENGTH & $=$ & 450.0 & FEET & \\
\hline LAY & ER & 4 & & \\
\hline--- & --- & - & & \\
\hline TYPE $3-$ BARR & IER & SOIL LINER & & \\
\hline MAIERIAL IEXI & $\begin{array}{l}\text { URE } \\
=\end{array}$ & $\begin{array}{l}\text { NUMBER } \\
0.20\end{array}$ & INCHES & \\
\hline POROSITY & $=$ & 0.3750 & VOL/VOL & \\
\hline FIELD CAPACITY & $=$ & 0.1600 & $\mathrm{VOL} / \mathrm{VOL}$ & \\
\hline WILTING POINT & $=$ & 0.0745 & $\mathrm{VOL} / \mathrm{VOL}$ & \\
\hline INITIAL SOIL WATER CONTENT & $=$ & 0.3750 & $\mathrm{VOL} / \mathrm{VOL}$ & \\
\hline EFFECTIVE SAT. HYD. COND. & $=$ & 0.319999992 & $2000 E-02$ & $\mathrm{CM} / \mathrm{SEC}$ \\
\hline LAY & $E R$ & 5 & & \\
\hline
\end{tabular}

TYPE 1 - VERTICAL PERCOLATION LAYER MATERIAL TEXTURE NUMBER 0

$\begin{array}{llrl}\text { THICKNESS } & = & 58.57 \mathrm{INCHES} \\ \text { POROSITY } & = & 0.3700 \mathrm{VOL} / \mathrm{VOL} \\ \text { FIELD CAPACITY } & = & 0.2400 \mathrm{VOL} / \mathrm{VOL} \\ \text { WILTING POINT } & = & 0.1360 \mathrm{VOL} / \mathrm{VOL} \\ \text { INITIAL SOIL WATER CONTENT } & = & 0.2400 \mathrm{VOL} / \mathrm{VOL} \\ \text { EFFECTIVE SAT. HYD. COND. } & =0.999999975000 \mathrm{E}-04 \mathrm{CM} / \mathrm{SEC}\end{array}$

LAYER 6

$--------$

TYPE 2 - LATERAL DRAINAGE LAYER

MATERIAL TEXTURE NUMBER 0

THICKNESS

POROSITY

$=24.00 \quad$ INCHES

FIELD CAPACITY

$=0.3240 \mathrm{VOL} / \mathrm{VOL}$

WILTING POINT $=0.0790 \mathrm{VOL} / \mathrm{VOL}$

INITIAL SOIL WATER CONTENT $=0.1260 \mathrm{VOL} / \mathrm{VOL}$

EFFECTIVE SAT. HYD. COND. $=0.647000000000 \mathrm{E}-01 \mathrm{CM} / \mathrm{SEC}$

SLOPE

DRAINAGE LENGTH

$=11.40 \quad$ PERCENT

$=150.0 \quad \mathrm{FEET}$ 
LAYER 7

$--------$

TYPE 3 - BARRIER SOIL LINER

MATERIAL TEXTURE NUMBER 0

$\begin{array}{llll}\text { THICKNESS } & = & 0.20 \mathrm{INCHES} \\ \text { POROSITY } & = & 0.7500 \mathrm{VOL} / \mathrm{VOL} \\ \text { FIELD CAPACITY } & = & 0.7470 \mathrm{VOL} / \mathrm{VOL} \\ \text { WILTING POINT } & = & 0.4000 \mathrm{VOL} / \mathrm{VOL} \\ \text { INITIAL SOIL WATER CONTENT } & = & 0.7500 \mathrm{VOL} / \mathrm{VOL} \\ \text { EFFECTIVE SAT. HYD. COND. } & =0.499999997000 \mathrm{E}-08 \mathrm{CM} / \mathrm{SEC}\end{array}$

GENERAL DESIGN AND EVAPORATIVE ZONE DATA

NOTE: SCS RUNOFF CURVE NUMBER WAS COMPUTED FROM DEFAULT SOIL DATA BASE USING SOIL TEXTURE \# 1 WITH A GOOD STAND OF GRASS, A SURFACE SLOPE OF 3.\% AND A SLOPE LENGTH OF 450. FEET.

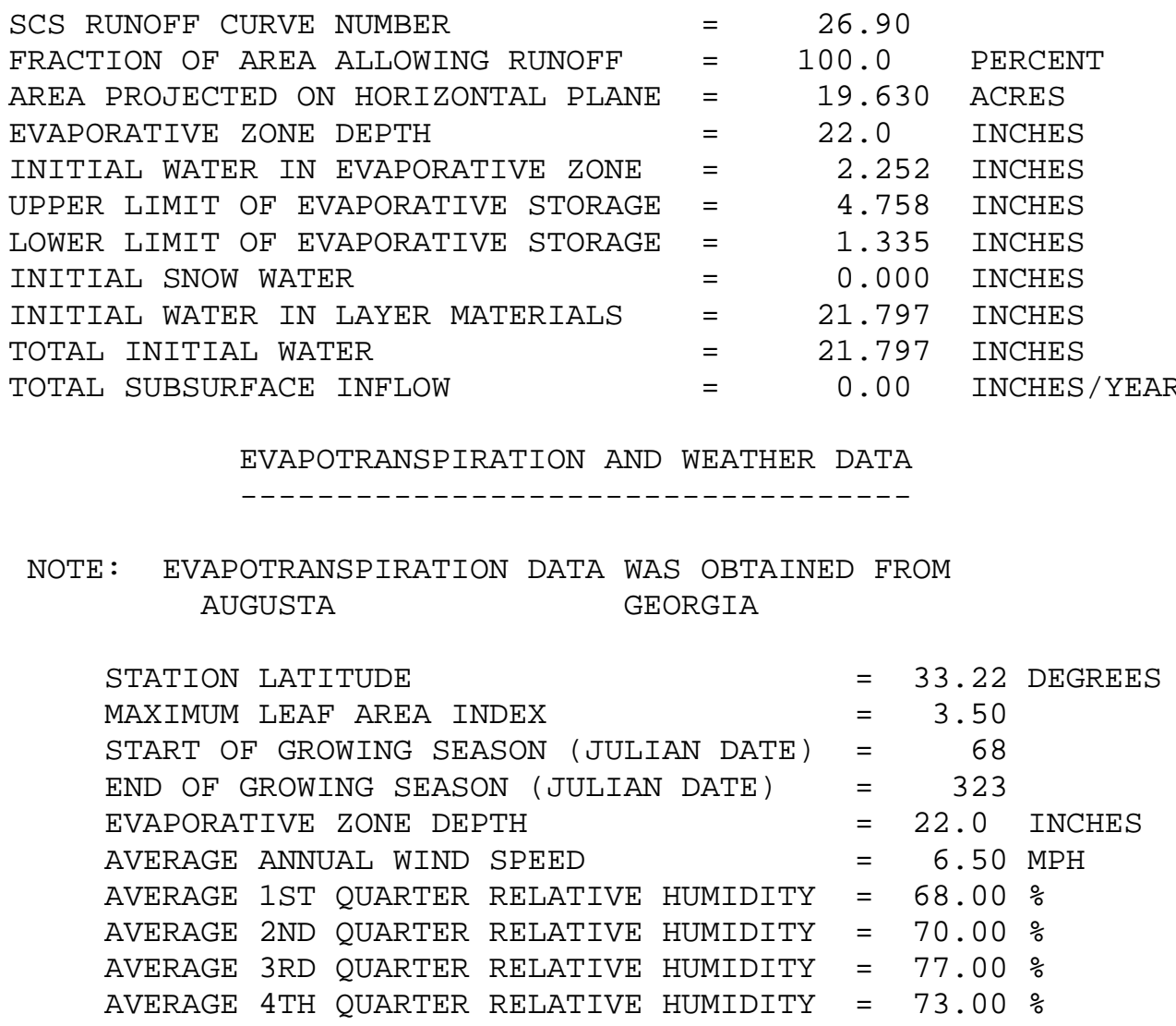




$$
\begin{aligned}
& \text { NOTE: PRECIPITATION DATA WAS SYNTHETICALLY GENERATED USING } \\
& \text { COEFFICIENTS FOR AUGUSTA GEORGIA } \\
& \text { NORMAL MEAN MONTHLY PRECIPITATION (INCHES) } \\
& \begin{array}{cccccc}
\text { JAN/JUL } & \text { FEB/AUG } & \text { MAR/SEP } & \text { APR/OCT } & \text { MAY/NOV } & \text { JUN/DEC } \\
------ & ------ & ------ & ------ & ------ & ------ \\
4.38 & 3.95 & 4.68 & 2.91 & 3.56 & 4.99 \\
5.43 & 5.41 & 3.93 & 3.12 & 2.96 & 3.45
\end{array}
\end{aligned}
$$

\begin{tabular}{|c|c|c|c|c|c|c|}
\hline AVERAGE MONTHLY & VALUES IN & N INCHES & FOR YEARS & $1 \mathrm{THR}$ & DUGH & \\
\hline & JAN/JUL & $\mathrm{FEB} / \mathrm{AUG}$ & $\mathrm{MAR} / \mathrm{SEP}$ & $\mathrm{APR} / \mathrm{OCT}$ & $\mathrm{MAY} / \mathrm{NOV}$ & JUN/DEC \\
\hline \multicolumn{7}{|l|}{ PRECIPITATION } \\
\hline \multirow[t]{2}{*}{ TOTALS } & 4.56 & 3.57 & 4.76 & 2.74 & 3.60 & 4.97 \\
\hline & 5.81 & 5.32 & 4.41 & 2.99 & 2.75 & 3.41 \\
\hline \multirow[t]{2}{*}{ STD. DEVIATIONS } & 2.44 & 1.60 & 2.47 & 1.31 & 2.12 & 2.60 \\
\hline & 2.83 & 2.95 & 2.54 & 2.28 & 1.72 & 1.90 \\
\hline \multicolumn{7}{|l|}{ RUNOFF } \\
\hline \multirow{2}{*}{ TOTALS } & 0.000 & 0.000 & 0.000 & 0.000 & 0.000 & 0.000 \\
\hline & 0.000 & 0.000 & 0.000 & 0.000 & 0.000 & 0.000 \\
\hline \multirow[t]{2}{*}{ STD. DEVIATIONS } & 0.000 & 0.000 & 0.000 & 0.000 & 0.000 & 0.000 \\
\hline & 0.000 & 0.000 & 0.000 & 0.000 & 0.000 & 0.000 \\
\hline \multicolumn{7}{|l|}{ EVAPOTRANSP IRATION } \\
\hline \multirow[t]{2}{*}{ TOTALS } & 1.526 & 1.853 & 2.479 & 2.282 & 2.698 & 3.334 \\
\hline & 3.739 & 3.292 & 2.580 & 1.386 & 1.055 & 1.247 \\
\hline \multirow[t]{2}{*}{ STD. DEVIATIONS } & 0.281 & 0.305 & 0.637 & 0.734 & 1.051 & 1.207 \\
\hline & 1.165 & 1.054 & 0.894 & 0.606 & 0.311 & 0.218 \\
\hline
\end{tabular}

NORMAL MEAN MONTHLY TEMPERATURE (DEGREES FAHRENHEIT)

$\begin{array}{cccccc}\text { JAN/JUL } & \text { FEB/AUG } & \text { MAR/SEP } & \text { APR/OCT } & \text { MAY/NOV } & \text { JUN/DEC } \\ ------ & ------ & ------ & ------ & ------ & ------ \\ 46.30 & 50.00 & 57.20 & 64.30 & 72.10 & 78.40 \\ 81.60 & 80.30 & 75.20 & 65.10 & 56.70 & 48.80\end{array}$

NOTE: SOLAR RADIATION DATA WAS SYNTHETICALLY GENERATED USING COEFFICIENTS FOR AUGUSTA GEORGIA AND STATION LATITUDE $=33.30$ DEGREES 
LATERAL DRAINAGE COLLECTED FROM LAYER 3

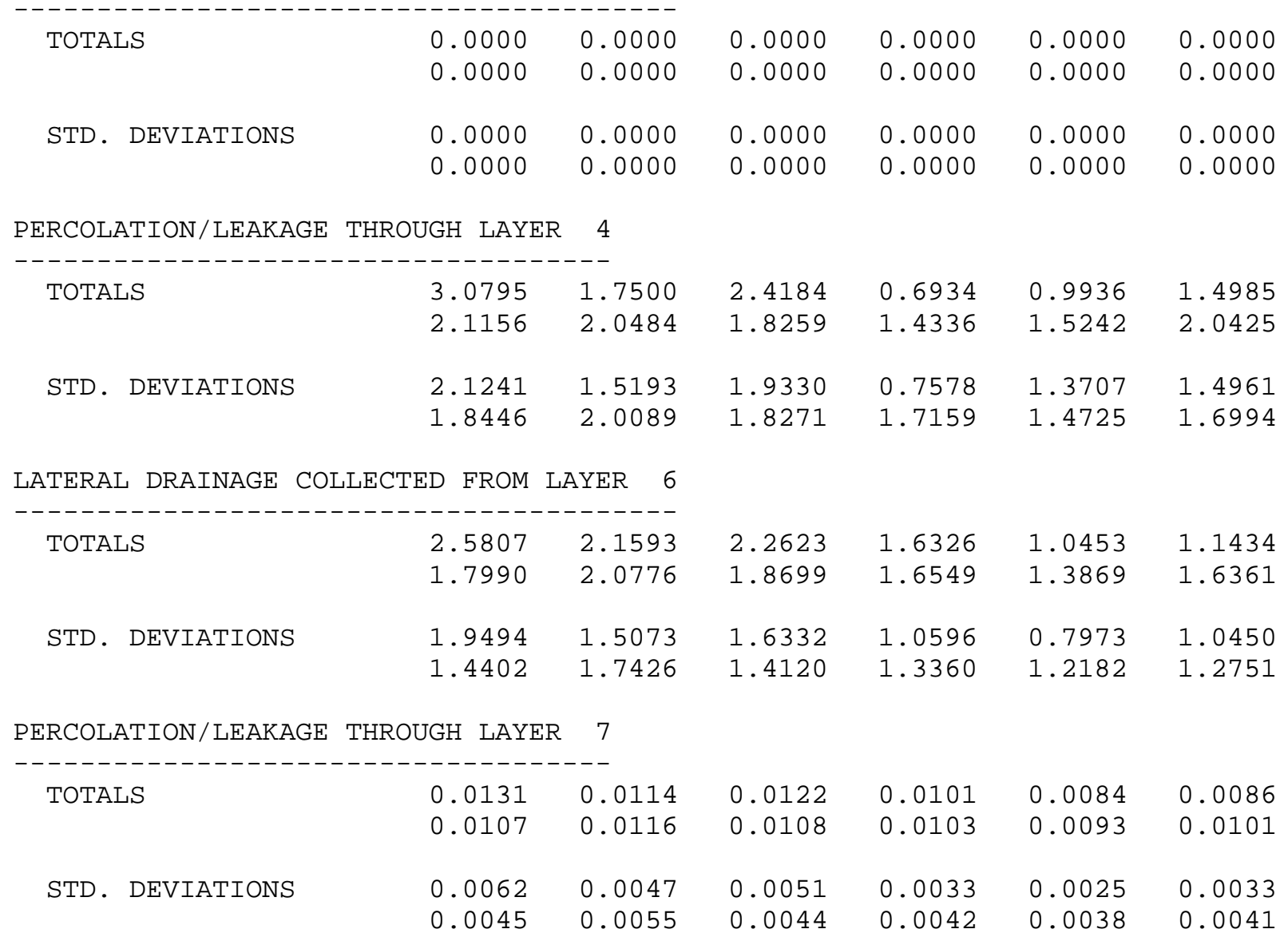

DAILY AVERAGE HEAD ON TOP OF LAYER 4

\begin{tabular}{|c|c|c|c|c|c|c|}
\hline AVERAGES & $\begin{array}{l}0.0446 \\
0.0263\end{array}$ & $\begin{array}{l}0.0272 \\
0.0287\end{array}$ & $\begin{array}{l}0.0334 \\
0.0270\end{array}$ & $\begin{array}{l}0.0101 \\
0.0185\end{array}$ & $\begin{array}{l}0.0125 \\
0.0226\end{array}$ & $\begin{array}{l}0.0224 \\
0.0284\end{array}$ \\
\hline STD. DEVIATIONS & $\begin{array}{l}0.0359 \\
0.0284\end{array}$ & $\begin{array}{l}0.0283 \\
0.0355\end{array}$ & $\begin{array}{l}0.0320 \\
0.0308\end{array}$ & $\begin{array}{l}0.0132 \\
0.0229\end{array}$ & $\begin{array}{l}0.0192 \\
0.0261\end{array}$ & $\begin{array}{l}0.0249 \\
0.0256\end{array}$ \\
\hline
\end{tabular}

DAILY AVERAGE HEAD ON TOP OF LAYER 7

$\begin{array}{lllllll}\text { AVERAGES } & 0.3025 & 0.2775 & 0.2652 & 0.1977 & 0.1225 & 0.1385 \\ & 0.2109 & 0.2435 & 0.2265 & 0.1940 & 0.1680 & 0.1918 \\ \text { STD. DEVIATIONS } & 0.2285 & 0.1939 & 0.1914 & 0.1284 & 0.0935 & 0.1266 \\ & 0.1688 & 0.2043 & 0.1710 & 0.1566 & 0.1476 & 0.1495\end{array}$




\begin{tabular}{|c|c|c|c|c|c|c|}
\hline AVERAGE ANNUAL TOTALS \& & \multicolumn{2}{|c|}{ (STD. DEVIATIONS) } & \multicolumn{2}{|c|}{ ) FOR YEARS } & 1 THROUGH & \multirow{2}{*}{$\begin{array}{l}100 \\
\text { PERCENT }\end{array}$} \\
\hline & INCH & IES & & & U. FEET & \\
\hline PRECIPITATION & 48.90 & ( & $7.734)$ & & 484469.2 & 100.00 \\
\hline RUNOFF & 0.000 & $(0$ & $0.0000)$ & & 0.00 & 0.000 \\
\hline EVAPOTRANSPIRATION & 27.471 & $(2$ & $2.7402)$ & & 957474.75 & 56.177 \\
\hline $\begin{array}{l}\text { LATERAL DRAINAGE COLLECTED } \\
\text { FROM LAYER } 3\end{array}$ & 0.00002 & $(0$ & $0.00001)$ & & 1.677 & 0.00005 \\
\hline $\begin{array}{l}\text { PERCOLATION/LEAKAGE THROUGH } \\
\text { LAYER } 4\end{array}$ & 21.42358 & $(6$ & $6.40759)$ & & 526578.120 & 43.81092 \\
\hline $\begin{array}{l}\text { AVERAGE HEAD ON TOP } \\
\text { OF LAYER } 4\end{array}$ & $0.025 \quad($ & & $0.008)$ & & & \\
\hline $\begin{array}{l}\text { LATERAL DRAINAGE COLLECTED } \\
\text { FROM LAYER } 6\end{array}$ & 21.24801 & $(6$ & $6.40753)$ & & 514067.250 & 43.45188 \\
\hline $\begin{array}{l}\text { PERCOLATION/LEAKAGE THROUGH } \\
\text { LAYER } 7\end{array}$ & 0.12671 & $(0$ & $0.02043)$ & & 9028.894 & 0.25912 \\
\hline $\begin{array}{l}\text { AVERAGE HEAD ON TOP } \\
\text { OF LAYER } 7\end{array}$ & 0.212( & & $0.064)$ & & & \\
\hline CHANGE IN WATER STORAGE & 0.055 & $(1$ & $1.9035)$ & & 3896.46 & 0.112 \\
\hline
\end{tabular}




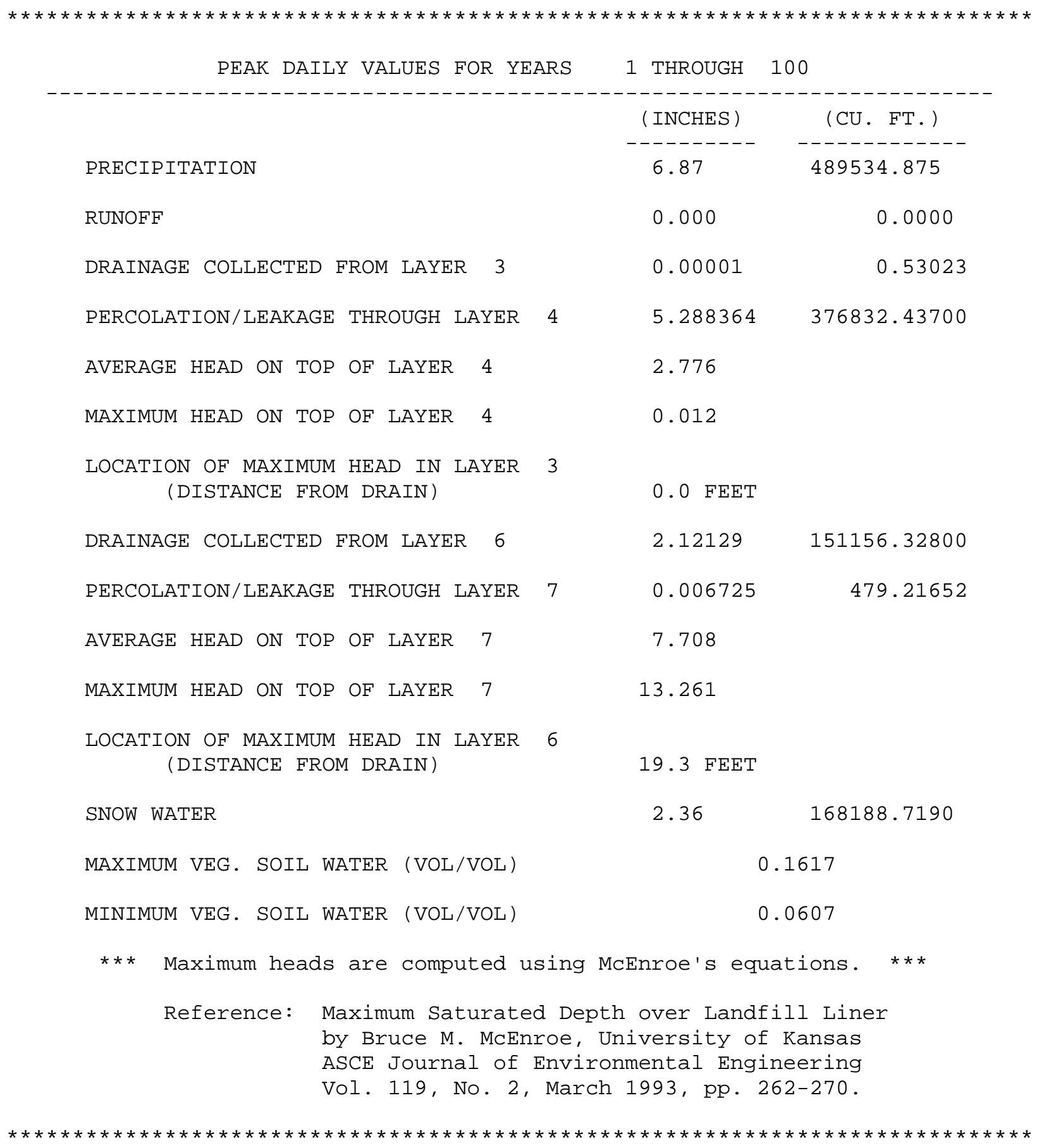

Rev. 0 


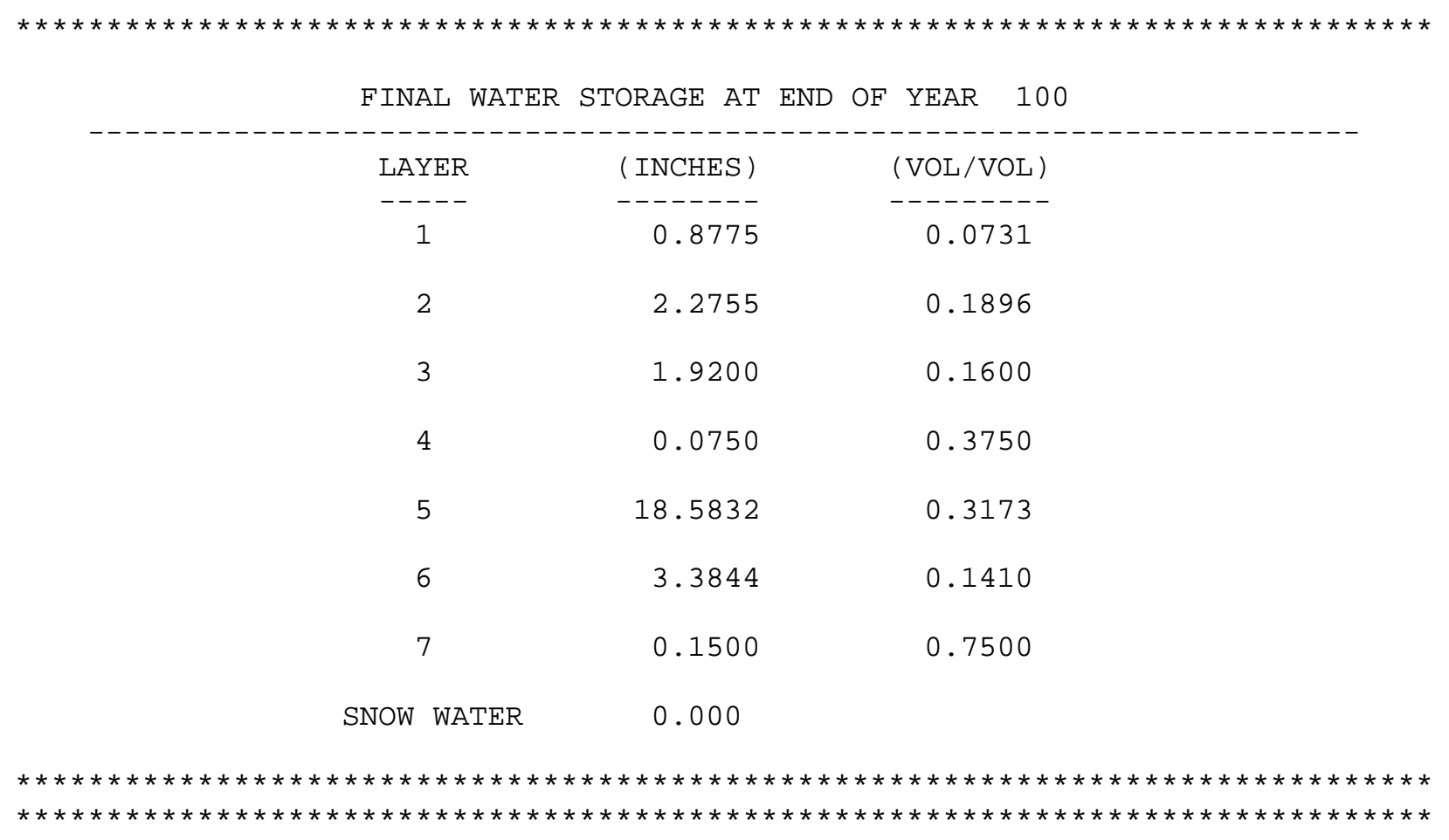


Appendix Y, Upper Bounding Scenario Degraded SDF MSE Vault Closure Cap (5,600 Years): HELP Model Input Data and Output File (output file name: ZUBSD10o.OUT)

\section{Input Data:}

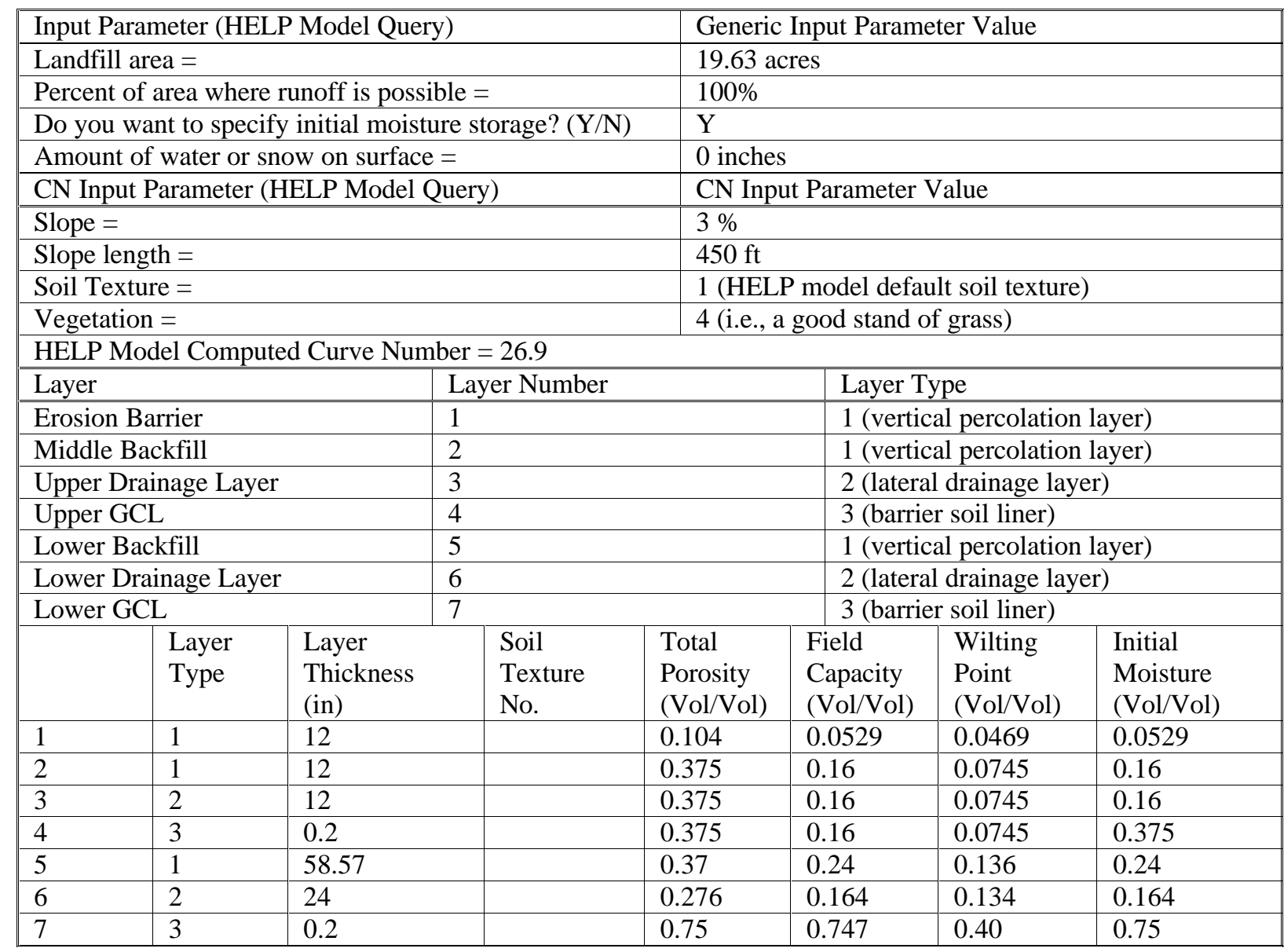

The lack of values in the table for particular parameters in particular layers denotes that no HELP model input was required for that parameter in that layer. No data are missing from the table. 
Input Data (continued):

\begin{tabular}{|c|c|c|c|c|c|c|c|c|c|}
\hline & $\begin{array}{l}\text { Layer } \\
\text { Type }\end{array}$ & $\begin{array}{l}\text { Sat. Hyd. } \\
\text { Conductivity * } \\
(\mathrm{cm} / \mathrm{sec})\end{array}$ & \multicolumn{2}{|c|}{$\begin{array}{l}\text { Drainage } \\
\text { Length } \\
(\mathrm{ft}) \\
\end{array}$} & $\begin{array}{l}\text { Drain } \\
\text { Slope } \\
(\%) \\
\end{array}$ & $\begin{array}{l}\text { Leachate } \\
\text { Recirc. } \\
(\%) \\
\end{array}$ & \multicolumn{2}{|c|}{$\begin{array}{l}\text { Recirc. to } \\
\text { Layer } \\
(\#)\end{array}$} & $\begin{array}{l}\text { Subsurface } \\
\text { Inflow } \\
\text { (in/yr) }\end{array}$ \\
\hline 1 & 1 & $3.90 \mathrm{E}-02$ & & & & & & & \\
\hline 2 & 1 & $3.20 \mathrm{E}-03$ & & & & & & & \\
\hline 3 & 2 & $3.20 \mathrm{E}-03$ & 450 & & 3 & & & & \\
\hline 4 & 3 & $3.20 \mathrm{E}-03$ & & & & & & & \\
\hline 5 & 1 & $1.00 \mathrm{E}-04$ & & & & & & & \\
\hline 6 & 2 & $3.54 \mathrm{E}-02$ & 150 & & 11.4 & & & & \\
\hline 7 & 3 & $5.00 \mathrm{E}-09$ & & & & & & \\
\hline & $\begin{array}{l}\text { Layer } \\
\text { Type }\end{array}$ & \multicolumn{2}{|l|}{$\begin{array}{l}\text { Geomembrane } \\
\text { Pinhole Density } \\
\text { (\#/acre) }\end{array}$} & \multicolumn{2}{|c|}{$\begin{array}{l}\text { Geomembrane } \\
\text { Instal. Defects } \\
\text { (\#/acre) }\end{array}$} & \multicolumn{2}{|c|}{$\begin{array}{l}\text { Geomembrane } \\
\text { Placement Quality }\end{array}$} & \multicolumn{2}{|c|}{$\begin{array}{l}\text { Geotextile } \\
\text { Transmissivity } \\
\left(\mathrm{cm}^{2} / \mathrm{sec}\right)\end{array}$} \\
\hline 1 & 1 & & & & & & & & \\
\hline 2 & 1 & & & & & & & & \\
\hline 3 & 2 & & & & & & & & \\
\hline 4 & 3 & & & & & & & & \\
\hline 5 & 1 & & & & & & & & \\
\hline 6 & 2 & & & & & & & & \\
\hline 7 & 3 & & & & & & & & \\
\hline
\end{tabular}

The lack of values in the table for particular parameters in particular layers denotes that no HELP model input was required for that parameter in that layer. No data are missing from the table.

* The HELP model output often produces an increased number of significant digits for the Effective Saturated Hydraulic Conductivity over that of the actual input 


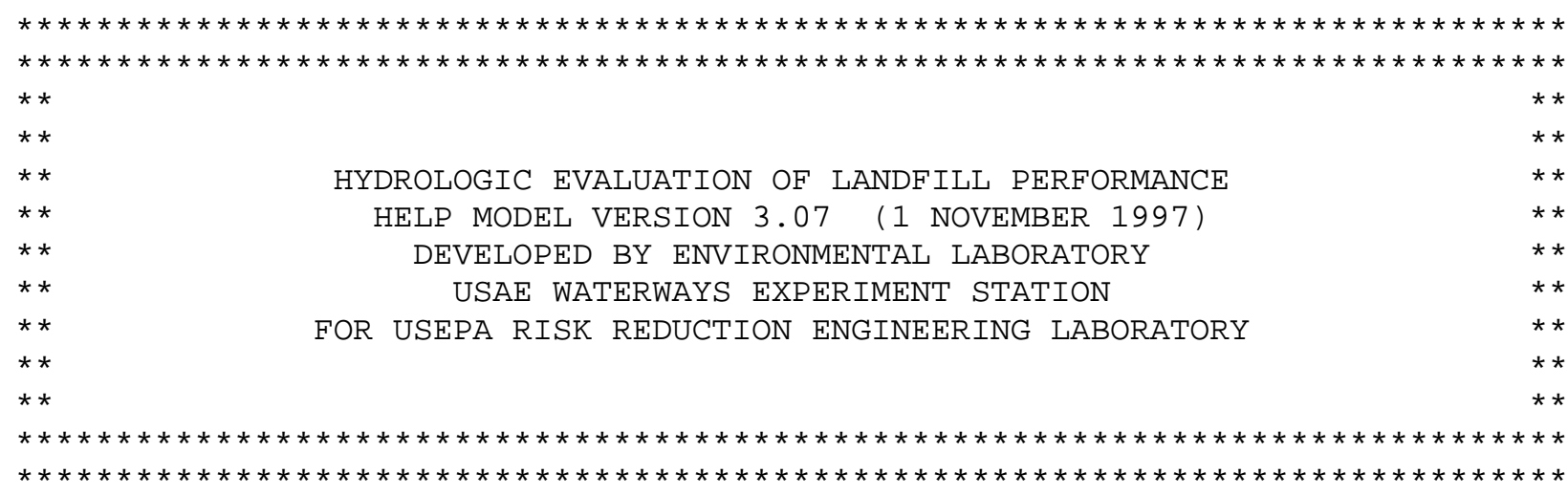

\begin{tabular}{|c|c|}
\hline Ol & D: \HELP $3 \backslash$ Hweather $\backslash$ \\
\hline TEMPERATURE DATA FILE: & D: \HELP $3 \backslash$ Hweather $\backslash Z T E M P . D 7$ \\
\hline ATION DATA FILE: & AR.D13 \\
\hline VAPOTRANSPIRATION DATA: & D: \HELP $3 \backslash$ Hweather $\backslash$ ZEVAP.D11 \\
\hline ND DESIGN DATE & $\mathrm{D}: \backslash$ HELP $3 \backslash$ Hsdfmse \ZUBSD $10 . \mathrm{D} 10$ \\
\hline & ZUBSD \\
\hline
\end{tabular}

TIME: 9:53 DATE: 2/11/2004

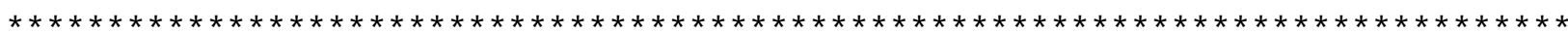
TITLE: UBS Degraded MSE Vault Closure Cap - 5,600 years

NOTE: INITIAL MOISTURE CONTENT OF THE LAYERS AND SNOW WATER WERE SPECIFIED BY THE USER.

\begin{tabular}{|c|c|c|c|c|}
\hline \multicolumn{5}{|c|}{ LAYER 1} \\
\hline \multicolumn{5}{|c|}{ TYPE 1 - VERTICAL PERCOLATION LAYER } \\
\hline THICKNESS & $=$ & 12.00 & INCHES & \\
\hline POROSITY & $=$ & 0.1040 & $\mathrm{VOL} / \mathrm{VOL}$ & \\
\hline FIELD CAPACITY & $=$ & 0.0529 & VOL/VOL & \\
\hline WILTING POINT & $=$ & 0.0469 & VOL/VOL & \\
\hline INITIAL SOIL WATER CONTENT & $=$ & 0.0529 & VOL/VOL & \\
\hline EFFECTIVE SAT. HYD. COND. & $=$ & 0.390000008 & $8000 \mathrm{E}-01$ & $\mathrm{CM} / \mathrm{SEC}$ \\
\hline \multicolumn{5}{|c|}{ LAYER 2} \\
\hline $\begin{array}{r}\text { TYPE } 1 \text { - VERTICAI } \\
\text { MATERIAL TEX? }\end{array}$ & & $\begin{array}{ll}\text { RCOLATION } & \text { LA } \\
\text { NUMBER } & 0\end{array}$ & AYER & \\
\hline THICKNESS & $=$ & 12.00 & INCHES & \\
\hline POROSITY & $=$ & 0.3750 & VOL/VOL & \\
\hline FIELD CAPACITY & $=$ & 0.1600 & VOL/VOL & \\
\hline WILTING POINT & $=$ & 0.0745 & $\mathrm{VOL} / \mathrm{VOL}$ & \\
\hline INITIAL SOIL WATER CONTENT & $=$ & 0.1600 & $\mathrm{VOL} / \mathrm{VOL}$ & \\
\hline EFFECTIVE SAT. HYD. COND. & $=$ & 0.319999992 & $2000 E-02$ & $C M$ \\
\hline
\end{tabular}

Rev. 0 
LAYER 3

$--------$

TYPE 2 - LATERAL DRAINAGE LAYER MATERIAL TEXTURE NUMBER 0

\begin{tabular}{|c|c|c|c|c|}
\hline & & & & \\
\hline THICKNESS & $=$ & 12.00 & INCHES & \\
\hline POROSITY & $=$ & 0.3750 & $\mathrm{VOL} / \mathrm{VOL}$ & \\
\hline FIELD CAPACITY & $=$ & 0.1600 & $\mathrm{VOL} / \mathrm{VOL}$ & \\
\hline WILTING POINT & $=$ & 0.0745 & $\mathrm{VOL} / \mathrm{VOL}$ & \\
\hline INITIAL SOIL WATER CONTENT & $=$ & 0.1600 & $\mathrm{VOL} / \mathrm{VOL}$ & \\
\hline EFFECTIVE SAT. HYD. COND. & $=$ & 0.319999992 & $2000 E-02$ & $\mathrm{CM} / \mathrm{SEC}$ \\
\hline SLOPE & $=$ & 3.00 & PERCENT & \\
\hline DRAINAGE LENGTH & $=$ & 450.0 & FEET & \\
\hline LAY & ER & 4 & & \\
\hline--- & --- & - & & \\
\hline TYPE $3-$ BARR & IER & SOIL LINER & & \\
\hline MAIERIAL IEXI & $\begin{array}{l}\text { URE } \\
=\end{array}$ & $\begin{array}{l}\text { NUMBER } \\
0.20\end{array}$ & INCHES & \\
\hline POROSITY & $=$ & 0.3750 & VOL/VOL & \\
\hline FIELD CAPACITY & $=$ & 0.1600 & $\mathrm{VOL} / \mathrm{VOL}$ & \\
\hline WILTING POINT & $=$ & 0.0745 & $\mathrm{VOL} / \mathrm{VOL}$ & \\
\hline INITIAL SOIL WATER CONTENT & $=$ & 0.3750 & $\mathrm{VOL} / \mathrm{VOL}$ & \\
\hline EFFECTIVE SAT. HYD. COND. & $=$ & 0.319999992 & $2000 E-02$ & $\mathrm{CM} / \mathrm{SEC}$ \\
\hline LAY & $E R$ & 5 & & \\
\hline
\end{tabular}

TYPE 1 - VERTICAL PERCOLATION LAYER MATERIAL TEXTURE NUMBER 0

$\begin{array}{llrl}\text { THICKNESS } & = & 58.57 & \text { INCHES } \\ \text { POROSITY } & = & 0.3700 \mathrm{VOL} / \mathrm{VOL} \\ \text { FIELD CAPACITY } & = & 0.2400 \mathrm{VOL} / \mathrm{VOL} \\ \text { WILTING POINT } & = & 0.1360 \mathrm{VOL} / \mathrm{VOL} \\ \text { INITIAL SOIL WATER CONTENT } & = & 0.2400 \mathrm{VOL} / \mathrm{VOL} \\ \text { EFEECTIVE SAT. HYD. COND. } & =0.999999975000 \mathrm{E}-04 \mathrm{CM} / \mathrm{SEC}\end{array}$

LAYER 6

$--------$

TYPE 2 - LATERAL DRAINAGE LAYER MATERIAL TEXTURE NUMBER 0

THICKNESS

POROSITY

$=\quad 24.00$ INCHES

FIELD CAPACITY

$=0.2760 \mathrm{VOL} / \mathrm{VOL}$

WILTING POINT

$=0.1640 \mathrm{VOL} / \mathrm{VOL}$

INITIAL SOIL WATER CONTENT $=0.1640 \mathrm{VOL} / \mathrm{VOL}$

EFFECTIVE SAT. HYD. COND. $=0.353999995000 \mathrm{E}-01 \mathrm{CM} / \mathrm{SEC}$

SLOPE

DRAINAGE LENGTH

$=11.40 \quad$ PERCENT

$=\quad 150.0 \quad \mathrm{FEET}$ 
LAYER 7

$--------$

TYPE 3 - BARRIER SOIL LINER

MATERIAL TEXTURE NUMBER 0

$\begin{array}{llrl}\text { THICKNESS } & = & 0.20 \mathrm{INCHES} \\ \text { POROSITY } & = & 0.7500 \mathrm{VOL} / \mathrm{VOL} \\ \text { FIELD CAPACITY } & = & 0.7470 \mathrm{VOL} / \mathrm{VOL} \\ \text { WILTING POINT } & = & 0.4000 \mathrm{VOL} / \mathrm{VOL} \\ \text { INITIAL SOIL WATER CONTENT } & = & 0.7500 \mathrm{VOL} / \mathrm{VOL} \\ \text { EFFECTIVE SAT. HYD. COND. } & =0.499999997000 \mathrm{E}-08 \mathrm{CM} / \mathrm{SEC}\end{array}$

GENERAL DESIGN AND EVAPORATIVE ZONE DATA

NOTE: SCS RUNOFF CURVE NUMBER WAS COMPUTED FROM DEFAULT SOIL DATA BASE USING SOIL TEXTURE \# 1 WITH A GOOD STAND OF GRASS, A SURFACE SLOPE OF 3.\% AND A SLOPE LENGTH OF 450. FEET.

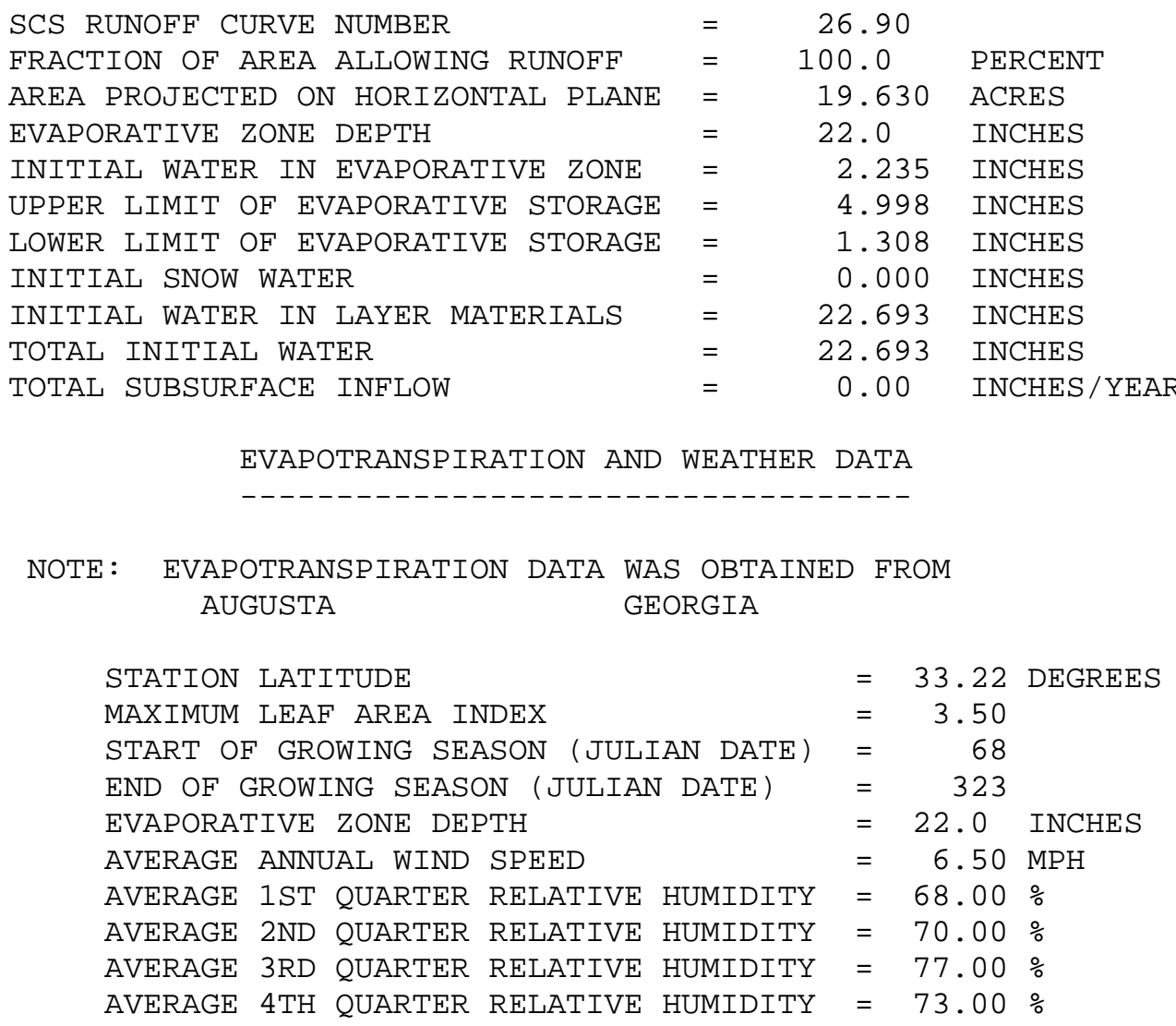




$$
\begin{aligned}
& \text { NOTE: PRECIPITATION DATA WAS SYNTHETICALLY GENERATED USING } \\
& \text { COEFFICIENTS FOR AUGUSTA GEORGIA } \\
& \text { NORMAL MEAN MONTHLY PRECIPITATION (INCHES) } \\
& \begin{array}{cccccc}
\text { JAN/JUL } & \text { FEB/AUG } & \text { MAR/SEP } & \text { APR/OCT } & \text { MAY/NOV } & \text { JUN/DEC } \\
------ & ------ & ------ & ------ & ------ & ------ \\
4.38 & 3.95 & 4.68 & 2.91 & 3.56 & 4.99 \\
5.43 & 5.41 & 3.93 & 3.12 & 2.96 & 3.45
\end{array}
\end{aligned}
$$

\begin{tabular}{|c|c|c|c|c|c|c|}
\hline AVERAGE MONTHLY & VALUES IN & N INCHES & FOR YEARS & \multicolumn{2}{|c|}{1 THROUGH } & 100 \\
\hline & JAN/JUL & $\mathrm{FEB} / \mathrm{AUG}$ & $\mathrm{MAR} / \mathrm{SEP}$ & $\mathrm{APR} / \mathrm{OCT}$ & $\mathrm{MAY} / \mathrm{NOV}$ & JUN / DEC \\
\hline \multicolumn{7}{|l|}{ PRECIPITATION } \\
\hline \multirow[t]{2}{*}{ TOTALS } & 4.56 & 3.57 & 4.76 & 2.74 & 3.60 & 4.97 \\
\hline & 5.81 & 5.32 & 4.41 & 2.99 & 2.75 & 3.41 \\
\hline \multirow[t]{2}{*}{ STD. DEVIATIONS } & 2.44 & 1.60 & 2.47 & 1.31 & 2.12 & 2.60 \\
\hline & 2.83 & 2.95 & 2.54 & 2.28 & 1.72 & 1.90 \\
\hline \multicolumn{7}{|l|}{ RUNOFF } \\
\hline \multirow{2}{*}{ TOTALS } & 0.000 & 0.000 & 0.000 & 0.000 & 0.000 & 0.000 \\
\hline & 0.000 & 0.000 & 0.000 & 0.000 & 0.000 & 0.000 \\
\hline \multirow[t]{2}{*}{ STD. DEVIATIONS } & 0.000 & 0.000 & 0.000 & 0.000 & 0.000 & 0.000 \\
\hline & 0.000 & 0.000 & 0.000 & 0.000 & 0.000 & 0.000 \\
\hline \multicolumn{7}{|l|}{ EVAPOTRANSP IRATION } \\
\hline \multirow[t]{2}{*}{ TOTALS } & 1.552 & 1.901 & 2.514 & 2.338 & 2.740 & 3.354 \\
\hline & 3.756 & 3.305 & 2.609 & 1.399 & 1.041 & 1.249 \\
\hline \multirow[t]{2}{*}{ STD. DEVIATIONS } & 0.282 & 0.299 & 0.633 & 0.757 & 1.082 & 1.229 \\
\hline & 1.170 & 1.081 & 0.894 & 0.604 & 0.291 & 0.210 \\
\hline
\end{tabular}

NORMAL MEAN MONTHLY TEMPERATURE (DEGREES FAHRENHEIT)

$\begin{array}{cccccc}\text { JAN/JUL } & \text { FEB/AUG } & \text { MAR/SEP } & \text { APR/OCT } & \text { MAY/NOV } & \text { JUN/DEC } \\ ------ & ------ & ------ & ------ & ------ & ------ \\ 46.30 & 50.00 & 57.20 & 64.30 & 72.10 & 78.40 \\ 81.60 & 80.30 & 75.20 & 65.10 & 56.70 & 48.80\end{array}$

NOTE: SOLAR RADIATION DATA WAS SYNTHETICALLY GENERATED USING COEFFICIENTS FOR AUGUSTA GEORGIA AND STATION LATITUDE $=33.30$ DEGREES 
LATERAL DRAINAGE COLLECTED FROM LAYER 3

$\begin{array}{lllllll}\text { TOTALS } & 0.0000 & 0.0000 & 0.0000 & 0.0000 & 0.0000 & 0.0000 \\ & 0.0000 & 0.0000 & 0.0000 & 0.0000 & 0.0000 & 0.0000 \\ \text { STD. DEVIATIONS } & 0.0000 & 0.0000 & 0.0000 & 0.0000 & 0.0000 & 0.0000 \\ & 0.0000 & 0.0000 & 0.0000 & 0.0000 & 0.0000 & 0.0000\end{array}$

PERCOLATION/LEAKAGE THROUGH LAYER 4

\begin{tabular}{|c|c|c|c|c|c|c|}
\hline TOTALS & $\begin{array}{l}3.0476 \\
2.0996\end{array}$ & $\begin{array}{l}1.7224 \\
2.0526\end{array}$ & $\begin{array}{l}2.3844 \\
1.7938\end{array}$ & $\begin{array}{l}0.6803 \\
1.4017\end{array}$ & $\begin{array}{l}0.9666 \\
1.5138\end{array}$ & $\begin{array}{l}1.4297 \\
2.0388\end{array}$ \\
\hline STD. DEVIATIONS & $\begin{array}{l}2.1362 \\
1.8388\end{array}$ & $\begin{array}{l}1.4842 \\
2.0183\end{array}$ & $\begin{array}{l}1.9591 \\
1.8568\end{array}$ & $\begin{array}{l}0.7621 \\
1.6957\end{array}$ & $\begin{array}{l}1.3798 \\
1.4708\end{array}$ & $\begin{array}{l}1.4819 \\
1.6996\end{array}$ \\
\hline LATERAL DRAINAGE & ED FROM & $\begin{array}{ll}\text { LAYER } & 6 \\
--------\end{array}$ & & & & \\
\hline TOTALS & $\begin{array}{l}2.5804 \\
1.7592\end{array}$ & $\begin{array}{l}2.1134 \\
2.0828\end{array}$ & $\begin{array}{l}2.2429 \\
1.8197\end{array}$ & $\begin{array}{l}1.5738 \\
1.6138\end{array}$ & $\begin{array}{l}1.0200 \\
1.3541\end{array}$ & $\begin{array}{l}1.1036 \\
1.6445\end{array}$ \\
\hline STD. DEVIATIONS & $\begin{array}{l}1.9666 \\
1.4611\end{array}$ & $\begin{array}{l}1.5155 \\
1.7751\end{array}$ & $\begin{array}{l}1.6294 \\
1.3895\end{array}$ & $\begin{array}{l}1.0640 \\
1.3488\end{array}$ & $\begin{array}{l}0.7936 \\
1.2126\end{array}$ & $\begin{array}{l}1.0363 \\
1.3003\end{array}$ \\
\hline
\end{tabular}

PERCOLATION/LEAKAGE THROUGH LAYER 7

$\begin{array}{llllllll}\text { TOTALS } & 0.0197 & 0.0167 & 0.0179 & 0.0139 & 0.0110 & 0.0113 \\ & 0.0151 & 0.0169 & 0.0153 & 0.0143 & 0.0127 & 0.0144 \\ \text { STD. DEVIATIONS } & 0.0113 & 0.0087 & 0.0093 & 0.0061 & 0.0045 & 0.0059 \\ & 0.0083 & 0.0101 & 0.0079 & 0.0077 & 0.0069 & 0.0075\end{array}$

AVERAGES OF MONTHLY AVERAGED DAILY HEADS (INCHES)

DAILY AVERAGE HEAD ON TOP OF LAYER 4

$\begin{array}{lllllll}\text { AVERAGES } & 0.0440 & 0.0288 & 0.0330 & 0.0095 & 0.0144 & 0.0184 \\ & 0.0275 & 0.0249 & 0.0261 & 0.0183 & 0.0213 & 0.0306 \\ \text { STD. DEVIATIONS } & 0.0353 & 0.0261 & 0.0359 & 0.0107 & 0.0226 & 0.0211 \\ & 0.0298 & 0.0287 & 0.0341 & 0.0256 & 0.0230 & 0.0295\end{array}$

DAILY AVERAGE HEAD ON TOP OF LAYER 7

$\begin{array}{lllllll}\text { AVERAGES } & 0.5528 & 0.4965 & 0.4805 & 0.3484 & 0.2185 & 0.2443 \\ & 0.3769 & 0.4462 & 0.4028 & 0.3458 & 0.2998 & 0.3523 \\ \text { STD. DEVIATIONS } & 0.4213 & 0.3566 & 0.3491 & 0.2356 & 0.1700 & 0.2294 \\ & 0.3130 & 0.3803 & 0.3076 & 0.2890 & 0.2684 & 0.2786\end{array}$




\begin{tabular}{|c|c|c|c|c|c|c|}
\hline AVERAGE ANNUAL TOTALS \& & \multicolumn{2}{|c|}{ (STD. DEVIATIONS) } & \multicolumn{2}{|c|}{ ) FOR YEARS } & 1 THROUGH & \multirow{2}{*}{$\begin{array}{l}100 \\
\text { PERCENT }\end{array}$} \\
\hline & INCH & IES & & & UU. FEET & \\
\hline PRECIPITATION & 48.90 & ( & $7.734)$ & & 3484469.2 & 100.00 \\
\hline RUNOFF & 0.000 & $(0$ & $0.0000)$ & & 0.00 & 0.000 \\
\hline EVAPOTRANSPIRATION & 27.756 & $(2$ & $2.7635)$ & & 977837.50 & 56.762 \\
\hline $\begin{array}{l}\text { LATERAL DRAINAGE COLLECTED } \\
\text { FROM LAYER } 3\end{array}$ & 0.00002 & $(0$ & $0.00001)$ & & 1.710 & 0.00005 \\
\hline $\begin{array}{l}\text { PERCOLATION/LEAKAGE THROUGH } \\
\text { LAYER } 4\end{array}$ & 21.13124 & $(6$ & $6.44700)$ & & 505746.620 & 43.21309 \\
\hline $\begin{array}{l}\text { AVERAGE HEAD ON TOP } \\
\text { OF LAYER } 4\end{array}$ & $0.025 \quad($ & & $0.009)$ & & & \\
\hline $\begin{array}{l}\text { LATERAL DRAINAGE COLLECTED } \\
\text { FROM LAYER } 6\end{array}$ & 20.90792 & $(6$ & $6.42289)$ & & 489833.870 & 42.75641 \\
\hline $\begin{array}{l}\text { PERCOLATION/LEAKAGE THROUGH } \\
\text { LAYER } 7\end{array}$ & 0.17926 & $(0$ & $0.03686)$ & & 12773.592 & 0.36659 \\
\hline $\begin{array}{l}\text { AVERAGE HEAD ON TOP } \\
\text { OF LAYER } 7\end{array}$ & $0.380 \quad($ & & $0.117)$ & & & \\
\hline CHANGE IN WATER STORAGE & 0.056 & $(1$ & $1.8648)$ & & 4022.33 & 0.115 \\
\hline
\end{tabular}




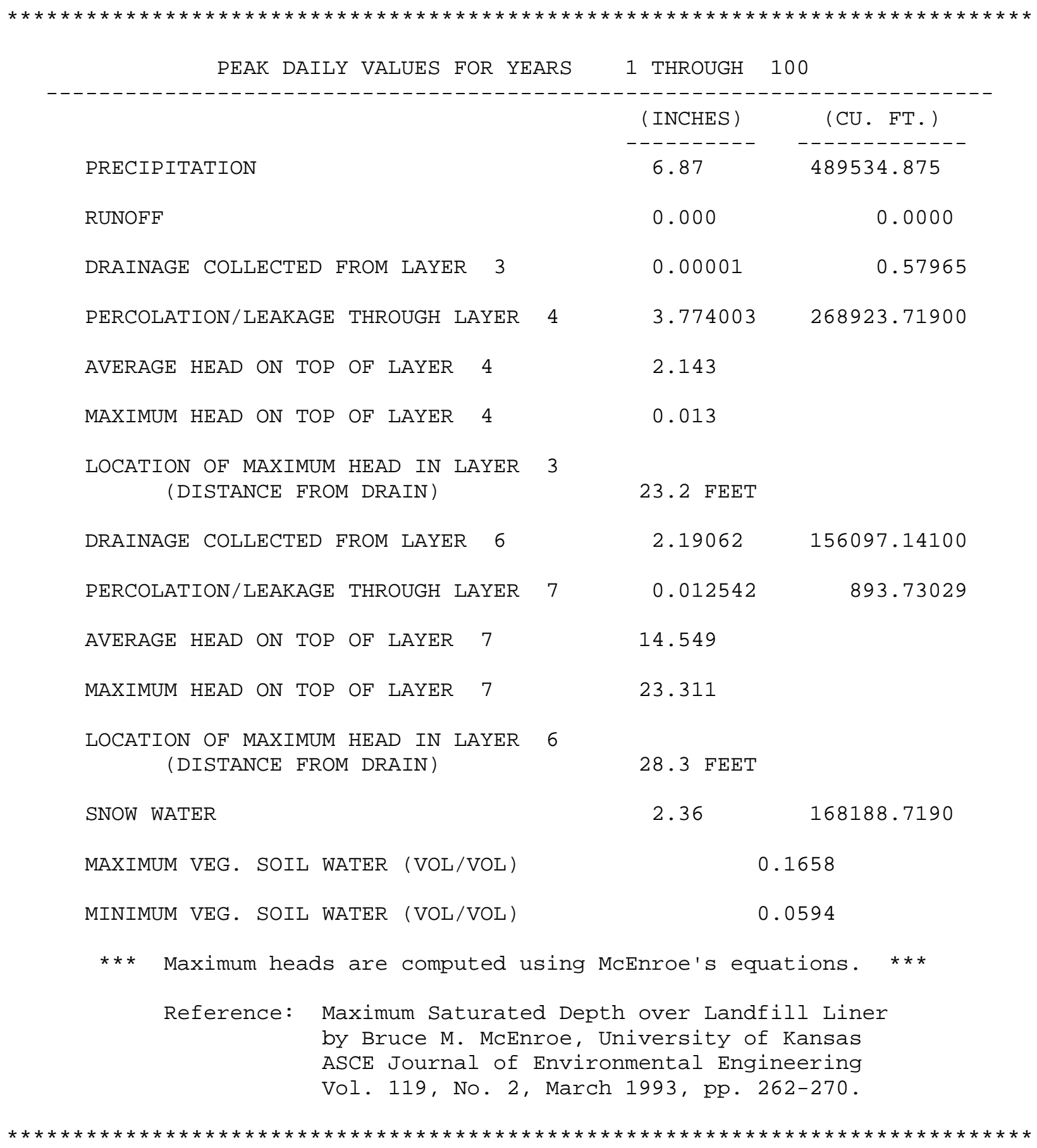

Rev. 0 


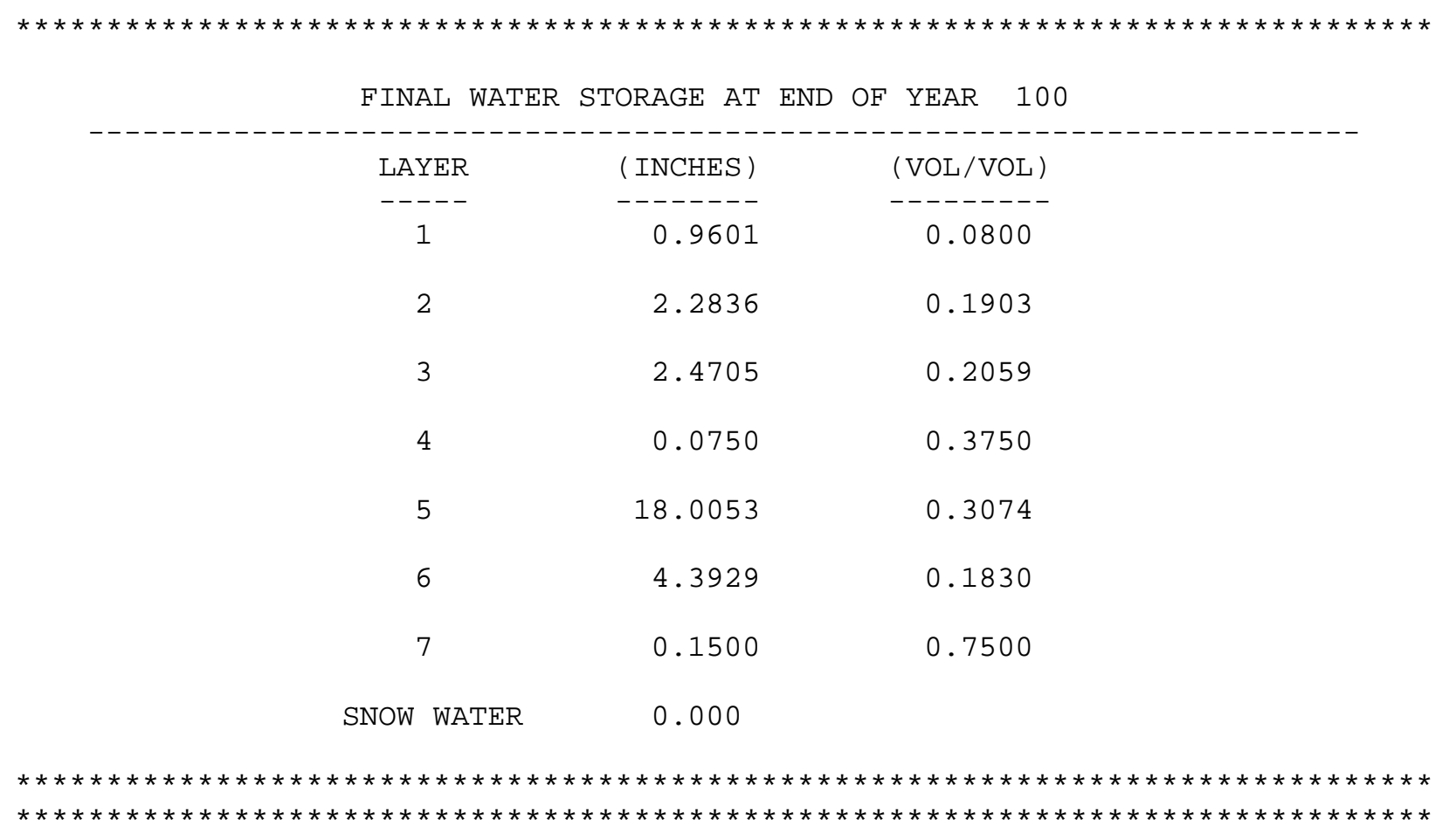


Appendix Z, Upper Bounding Scenario Degraded SDF MSE Vault Closure Cap (10,000 Years): HELP Model Input Data and Output File (output file name: ZUBSD11o.OUT)

\section{Input Data:}

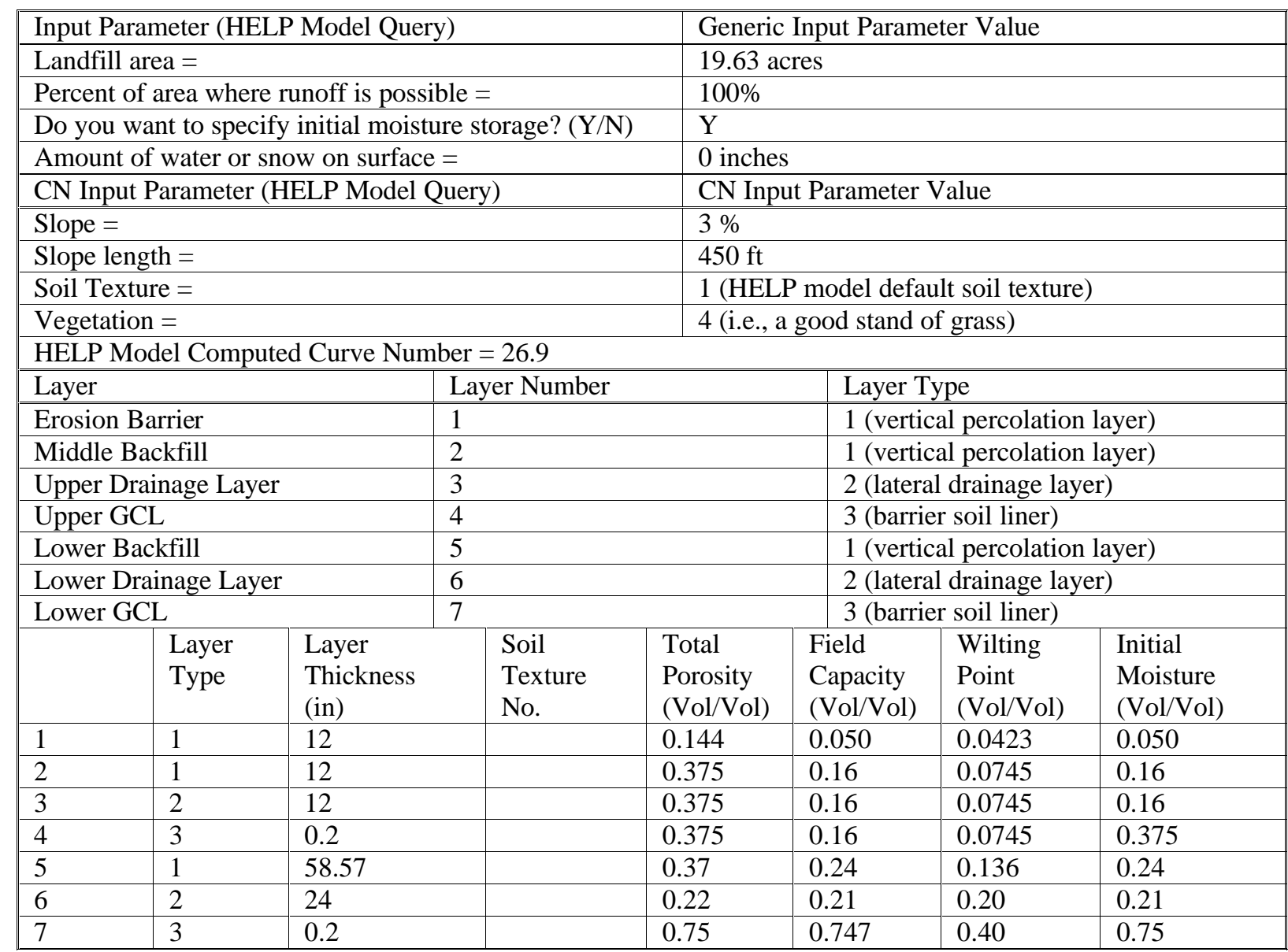

The lack of values in the table for particular parameters in particular layers denotes that no HELP model input was required for that parameter in that layer. No data are missing from the table. 
Input Data (continued):

\begin{tabular}{|c|c|c|c|c|c|c|c|c|c|}
\hline & $\begin{array}{l}\text { Layer } \\
\text { Type }\end{array}$ & $\begin{array}{l}\text { Sat. Hyd. } \\
\text { Conductivity * } \\
(\mathrm{cm} / \mathrm{sec})\end{array}$ & \multicolumn{2}{|c|}{$\begin{array}{l}\text { Drainage } \\
\text { Length } \\
(\mathrm{ft}) \\
\end{array}$} & $\begin{array}{l}\text { Drain } \\
\text { Slope } \\
(\%) \\
\end{array}$ & $\begin{array}{l}\text { Leachate } \\
\text { Recirc. } \\
(\%) \\
\end{array}$ & \multicolumn{2}{|c|}{$\begin{array}{l}\text { Recirc. to } \\
\text { Layer } \\
(\#)\end{array}$} & $\begin{array}{l}\text { Subsurface } \\
\text { Inflow } \\
\text { (in/yr) }\end{array}$ \\
\hline 1 & 1 & 7.50E-02 & & & & & & & \\
\hline 2 & 1 & $3.20 \mathrm{E}-03$ & & & & & & & \\
\hline 3 & 2 & $3.20 \mathrm{E}-03$ & 450 & & 3 & & & & \\
\hline 4 & 3 & $3.20 \mathrm{E}-03$ & & & & & & & \\
\hline 5 & 1 & $1.00 \mathrm{E}-04$ & & & & & & & \\
\hline 6 & 2 & $1.00 \mathrm{E}-04$ & 150 & & 11.4 & & & & \\
\hline 7 & 3 & $5.00 \mathrm{E}-09$ & & & & & & \\
\hline & $\begin{array}{l}\text { Layer } \\
\text { Type }\end{array}$ & \multicolumn{2}{|l|}{$\begin{array}{l}\text { Geomembrane } \\
\text { Pinhole Density } \\
\text { (\#/acre) }\end{array}$} & \multicolumn{2}{|c|}{$\begin{array}{l}\text { Geomembrane } \\
\text { Instal. Defects } \\
(\# / \text { acre })\end{array}$} & \multicolumn{2}{|c|}{$\begin{array}{l}\text { Geomembrane } \\
\text { Placement Quality }\end{array}$} & \multicolumn{2}{|c|}{$\begin{array}{l}\text { Geotextile } \\
\text { Transmissivity } \\
\left(\mathrm{cm}^{2} / \mathrm{sec}\right)\end{array}$} \\
\hline 1 & 1 & & & & & & & & \\
\hline 2 & 1 & & & & & & & & \\
\hline 3 & 2 & & & & & & & & \\
\hline 4 & 3 & & & & & & & & \\
\hline 5 & 1 & & & & & & & & \\
\hline 6 & 2 & & & & & & & & \\
\hline 7 & 3 & & & & & & & & \\
\hline
\end{tabular}

The lack of values in the table for particular parameters in particular layers denotes that no HELP model input was required for that parameter in that layer. No data are missing from the table.

* The HELP model output often produces an increased number of significant digits for the Effective Saturated Hydraulic Conductivity over that of the actual input 


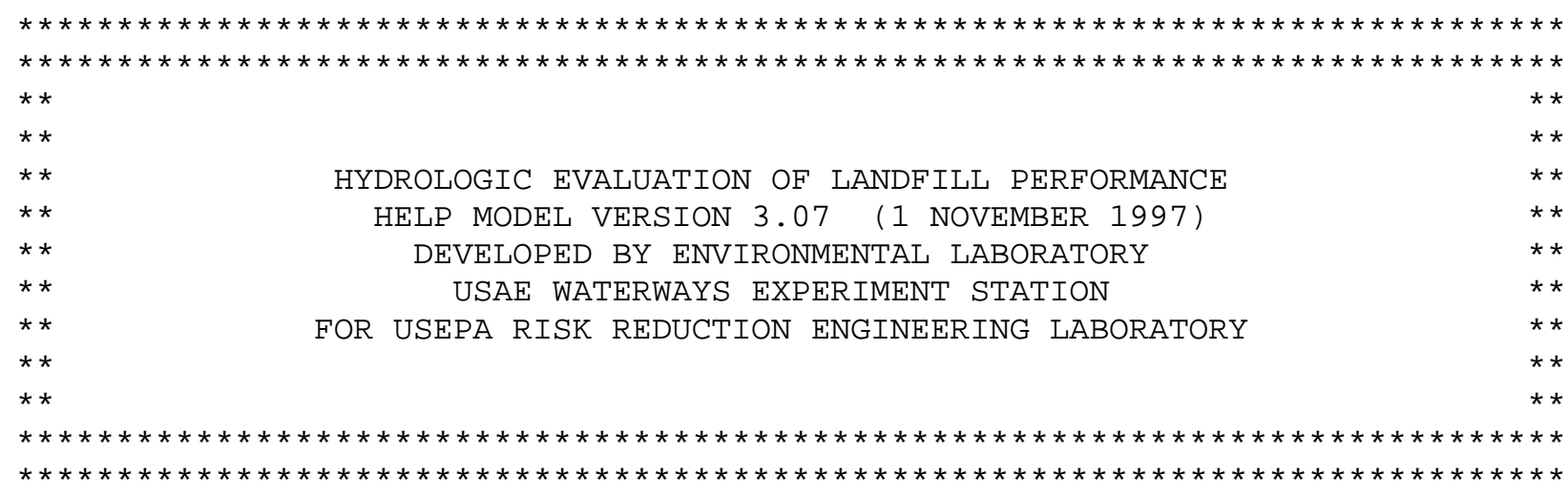

\begin{tabular}{|c|c|}
\hline PRECIPITATION DATA FILE: & $\mathrm{D}: \backslash$ HELP $3 \backslash$ Hweather $\backslash \mathrm{Z}$ \\
\hline TEMPERATURE DATA FILE: & D : \HELP 3 \Hweather ZTEMP.D7 \\
\hline SOLAR RADIATION DATA FILE: & D : \HELP $3 \backslash$ Hweather \ZSOLAR.D13 \\
\hline EVAPOTRANSPIRATION DATA: & D: \HELP $3 \backslash$ Hweather \ZEVAP . D11 \\
\hline SOIL AND DESIGN DATA FILE: & $\mathrm{D}: \backslash \mathrm{HELP} 3 \backslash \mathrm{Hsdfmse \backslash ZUBSD11.D10}$ \\
\hline OUTPUT DATA FILE: & $\mathrm{D}: \backslash$ HELP $3 \backslash$ Hsdfmse $\backslash$ ZUBSD 110. OUT \\
\hline
\end{tabular}

TIME : $\quad 9: 58 \quad$ DATE : $2 / 11 / 2004$

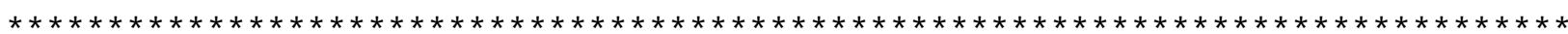
TITLE: UBS Degraded MSE Vault Closure Cap - 10,000 years

NOTE: INITIAL MOISTURE CONTENT OF THE LAYERS AND SNOW WATER WERE SPECIFIED BY THE USER.

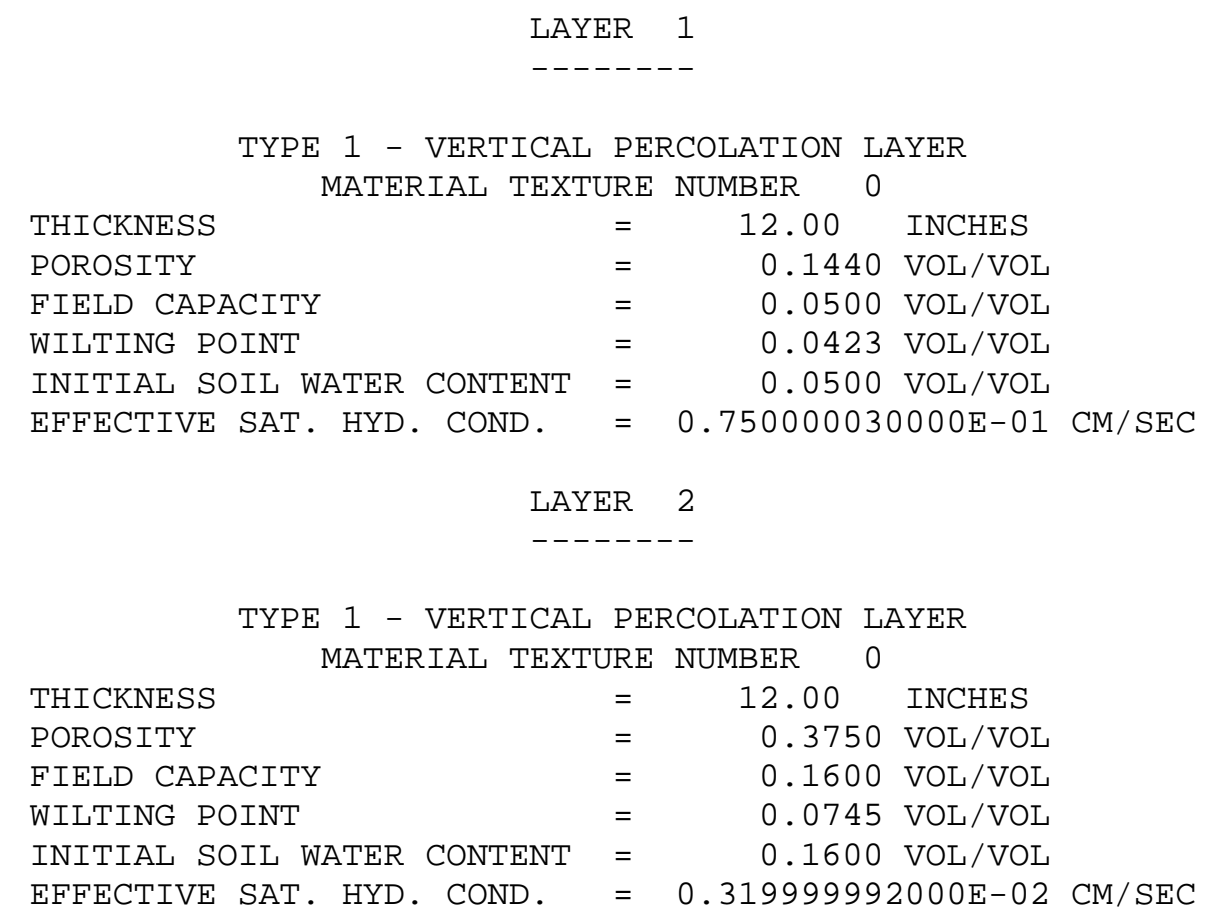

Rev. 0 
LAYER 3

$--------$

TYPE 2 - LATERAL DRAINAGE LAYER

MATERIAL TEXTURE NUMBER 0

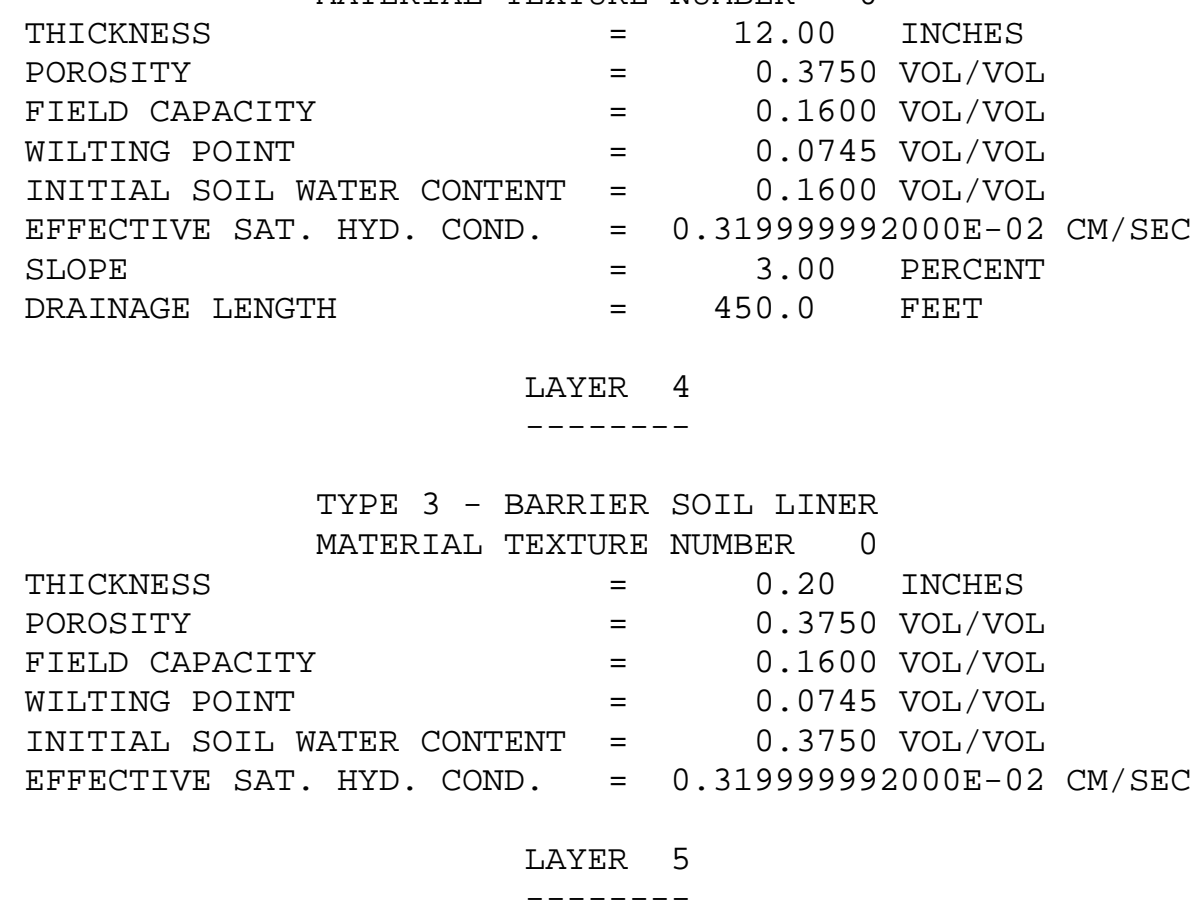

TYPE 1 - VERTICAL PERCOLATION LAYER MATERIAL TEXTURE NUMBER 0

$\begin{array}{llrl}\text { THICKNESS } & = & 58.57 \mathrm{INCHES} \\ \text { POROSITY } & = & 0.3700 \mathrm{VOL} / \mathrm{VOL} \\ \text { FIELD CAPACITY } & = & 0.2400 \mathrm{VOL} / \mathrm{VOL} \\ \text { WILTING POINT } & = & 0.1360 \mathrm{VOL} / \mathrm{VOL} \\ \text { INITIAL SOIL WATER CONTENT } & = & 0.2400 \mathrm{VOL} / \mathrm{VOL} \\ \text { EFFECTIVE SAT. HYD. COND. } & =0.999999975000 \mathrm{E}-04 \mathrm{CM} / \mathrm{SEC}\end{array}$

LAYER 6

$--------$

TYPE 2 - LATERAL DRAINAGE LAYER

MATERIAL TEXTURE NUMBER 0

THICKNESS

POROSITY

$=\quad 24.00 \quad$ INCHES

FIELD CAPACITY

$=0.2200 \mathrm{VOL} / \mathrm{VOL}$

$=0.2000 \mathrm{VOL} / \mathrm{VOL}$

INITIAL SOIL WATER CONTENT $=0.2100 \mathrm{VOL} / \mathrm{VOL}$

EFFECTIVE SAT. HYD. COND. = $0.999999975000 \mathrm{E}-04 \mathrm{CM} / \mathrm{SEC}$

SLOPE

DRAINAGE LENGTH

$=11.40 \quad$ PERCENT

$=150.0 \quad \mathrm{FEET}$

Rev. 0 
LAYER 7

$--------$

TYPE 3 - BARRIER SOIL LINER

MATERIAL TEXTURE NUMBER 0

$\begin{array}{llll}\text { THICKNESS } & = & 0.20 \mathrm{INCHES} \\ \text { POROSITY } & = & 0.7500 \mathrm{VOL} / \mathrm{VOL} \\ \text { FIELD CAPACITY } & = & 0.7470 \mathrm{VOL} / \mathrm{VOL} \\ \text { WILTING POINT } & = & 0.4000 \mathrm{VOL} / \mathrm{VOL} \\ \text { INITIAL SOIL WATER CONTENT } & = & 0.7500 \mathrm{VOL} / \mathrm{VOL} \\ \text { EFFECTIVE SAT. HYD. COND. } & =0.499999997000 \mathrm{E}-08 \mathrm{CM} / \mathrm{SEC}\end{array}$

GENERAL DESIGN AND EVAPORATIVE ZONE DATA

NOTE: SCS RUNOFF CURVE NUMBER WAS COMPUTED FROM DEFAULT SOIL DATA BASE USING SOIL TEXTURE \# 1 WITH A GOOD STAND OF GRASS, A SURFACE SLOPE OF 3.\% AND A SLOPE LENGTH OF 450. FEET.

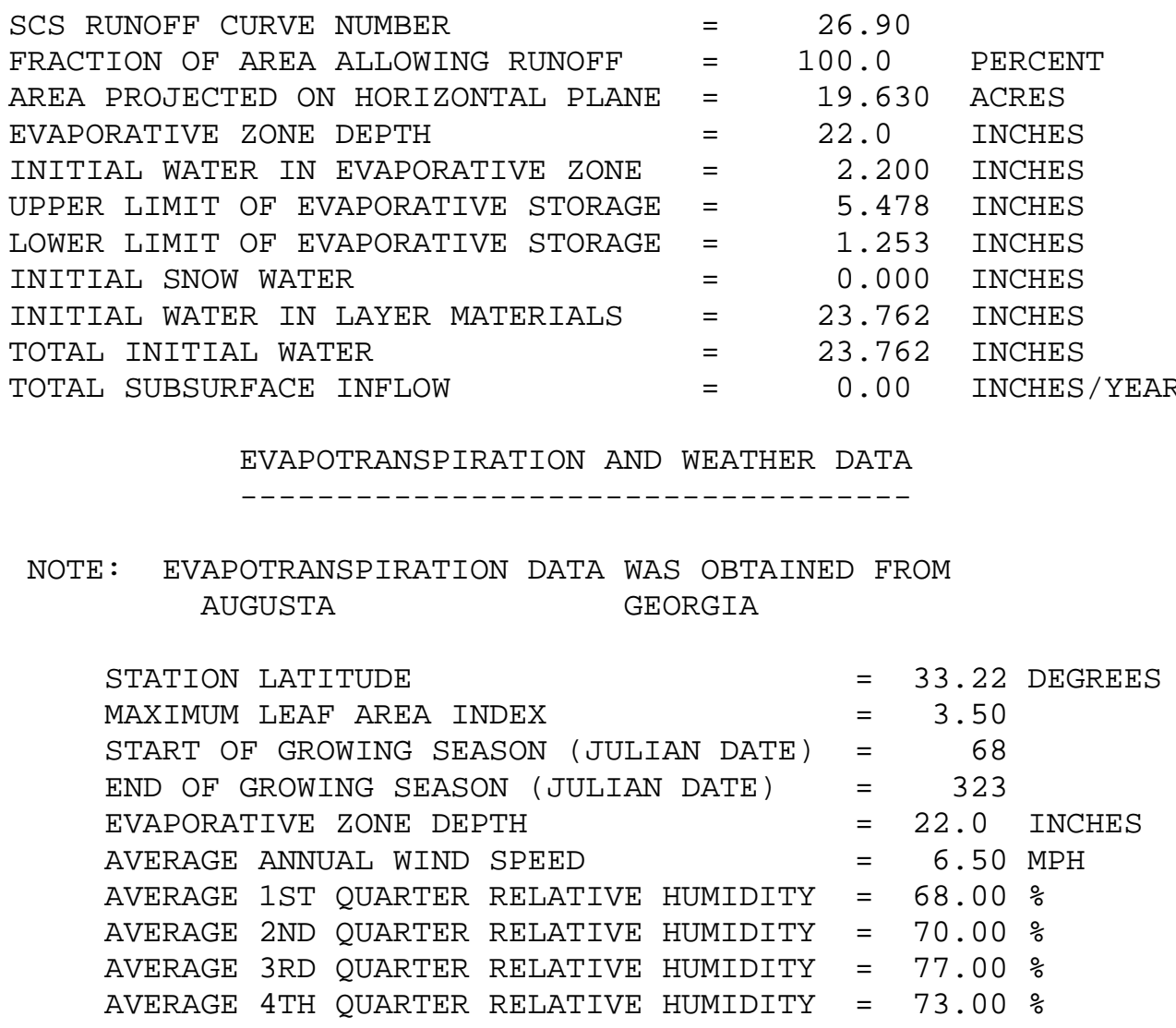




$$
\begin{aligned}
& \text { NOTE: PRECIPITATION DATA WAS SYNTHETICALLY GENERATED USING } \\
& \text { COEFFICIENTS FOR AUGUSTA GEORGIA } \\
& \text { NORMAL MEAN MONTHLY PRECIPITATION (INCHES) } \\
& \begin{array}{cccccc}
\text { JAN/JUL } & \text { FEB/AUG } & \text { MAR/SEP } & \text { APR/OCT } & \text { MAY/NOV } & \text { JUN/DEC } \\
------ & ------ & ------ & ------ & ------ & ------ \\
4.38 & 3.95 & 4.68 & 2.91 & 3.56 & 4.99 \\
5.43 & 5.41 & 3.93 & 3.12 & 2.96 & 3.45
\end{array}
\end{aligned}
$$

\begin{tabular}{|c|c|c|c|c|c|c|}
\hline AVERAGE MONTHLY & VALUES IN & N INCHES & FOR YEARS & \multicolumn{2}{|c|}{1 THROUGH } & 100 \\
\hline & JAN/JUL & $\mathrm{FEB} / \mathrm{AUG}$ & $\mathrm{MAR} / \mathrm{SEP}$ & $\mathrm{APR} / \mathrm{OCT}$ & $\mathrm{MAY} / \mathrm{NOV}$ & JUN / DEC \\
\hline \multicolumn{7}{|l|}{ PRECIPITATION } \\
\hline \multirow[t]{2}{*}{ TOTALS } & 4.56 & 3.57 & 4.76 & 2.74 & 3.60 & 4.97 \\
\hline & 5.81 & 5.32 & 4.41 & 2.99 & 2.75 & 3.41 \\
\hline \multirow[t]{2}{*}{ STD. DEVIATIONS } & 2.44 & 1.60 & 2.47 & 1.31 & 2.12 & 2.60 \\
\hline & 2.83 & 2.95 & 2.54 & 2.28 & 1.72 & 1.90 \\
\hline \multicolumn{7}{|l|}{ RUNOFF } \\
\hline \multirow{2}{*}{ TOTALS } & 0.000 & 0.000 & 0.000 & 0.000 & 0.000 & 0.000 \\
\hline & 0.000 & 0.000 & 0.000 & 0.000 & 0.000 & 0.000 \\
\hline \multirow[t]{2}{*}{ STD. DEVIATIONS } & 0.000 & 0.000 & 0.000 & 0.000 & 0.000 & 0.000 \\
\hline & 0.000 & 0.000 & 0.000 & 0.000 & 0.000 & 0.000 \\
\hline \multicolumn{7}{|l|}{ EVAPOTRANSP IRATION } \\
\hline \multirow{2}{*}{ TOTALS } & 1.603 & 1.982 & 2.647 & 2.496 & 2.850 & 3.465 \\
\hline & 3.926 & 3.444 & 2.711 & 1.427 & 1.034 & 1.248 \\
\hline \multirow[t]{2}{*}{ STD. DEVIATIONS } & 0.274 & 0.289 & 0.662 & 0.780 & 1.172 & 1.282 \\
\hline & 1.271 & 1.131 & 0.938 & 0.621 & 0.283 & 0.207 \\
\hline
\end{tabular}

NORMAL MEAN MONTHLY TEMPERATURE (DEGREES FAHRENHEIT)

$\begin{array}{cccccc}\text { JAN/JUL } & \text { FEB/AUG } & \text { MAR/SEP } & \text { APR/OCT } & \text { MAY/NOV } & \text { JUN/DEC } \\ ------ & ------ & ------ & ------ & ------ & ------ \\ 46.30 & 50.00 & 57.20 & 64.30 & 72.10 & 78.40 \\ 81.60 & 80.30 & 75.20 & 65.10 & 56.70 & 48.80\end{array}$

NOTE: SOLAR RADIATION DATA WAS SYNTHETICALLY GENERATED USING COEFFICIENTS FOR AUGUSTA GEORGIA AND STATION LATITUDE $=33.30$ DEGREES 
LATERAL DRAINAGE COLLECTED FROM LAYER 3

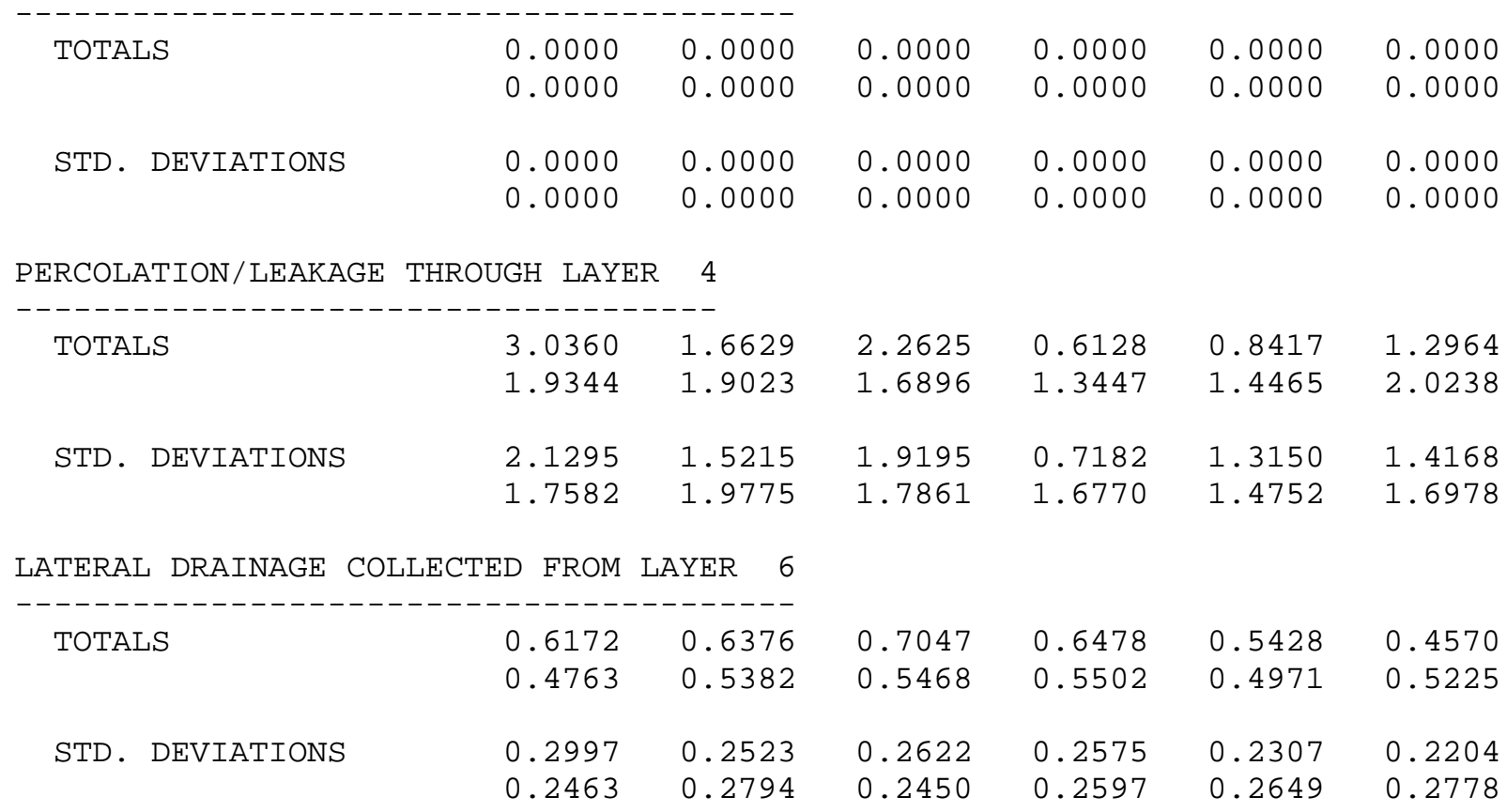

PERCOLATION/LEAKAGE THROUGH LAYER 7

$\begin{array}{lllllll}\text { TOTALS } & 1.2083 & 1.2448 & 1.3764 & 1.2694 & 1.0765 & 0.9097 \\ & 0.9467 & 1.0622 & 1.0801 & 1.0874 & 0.9831 & 1.0320 \\ \text { STD. DEVIATIONS } & 0.5623 & 0.4635 & 0.4824 & 0.4756 & 0.4364 & 0.4234 \\ & 0.4758 & 0.5336 & 0.4657 & 0.4923 & 0.5018 & 0.5288\end{array}$

AVERAGES OF MONTHLY AVERAGED DAILY HEADS (INCHES)

DAILY AVERAGE HEAD ON TOP OF LAYER 4

$\begin{array}{lllllll}\text { AVERAGES } & 0.0454 & 0.0246 & 0.0299 & 0.0085 & 0.0104 & 0.0188 \\ & 0.0239 & 0.0242 & 0.0234 & 0.0183 & 0.0193 & 0.0327 \\ \text { STD. DEVIATIONS } & 0.0366 & 0.0252 & 0.0338 & 0.0128 & 0.0198 & 0.0230 \\ & 0.0226 & 0.0295 & 0.0287 & 0.0263 & 0.0235 & 0.0311\end{array}$

DAILY AVERAGE HEAD ON TOP OF LAYER 7

\begin{tabular}{|c|c|c|c|c|c|c|}
\hline AVERAGES & $\begin{array}{l}45.6372 \\
35.7117\end{array}$ & $\begin{array}{l}51.5823 \\
40.0956\end{array}$ & $\begin{array}{l}52.0127 \\
42.1399\end{array}$ & $\begin{array}{l}49.5576 \\
41.0525\end{array}$ & $\begin{array}{l}40.6339 \\
38.3359\end{array}$ & $\begin{array}{l}35.4604 \\
38.9516\end{array}$ \\
\hline STD. DEVIATIONS & $\begin{array}{l}21.3258 \\
18.0489\end{array}$ & $\begin{array}{l}19.2214 \\
20.2354\end{array}$ & $\begin{array}{l}18.2994 \\
18.2515\end{array}$ & $\begin{array}{l}18.6430 \\
18.6704\end{array}$ & $\begin{array}{l}16.5548 \\
19.6669\end{array}$ & $\begin{array}{l}16.5915 \\
20.0545\end{array}$ \\
\hline
\end{tabular}




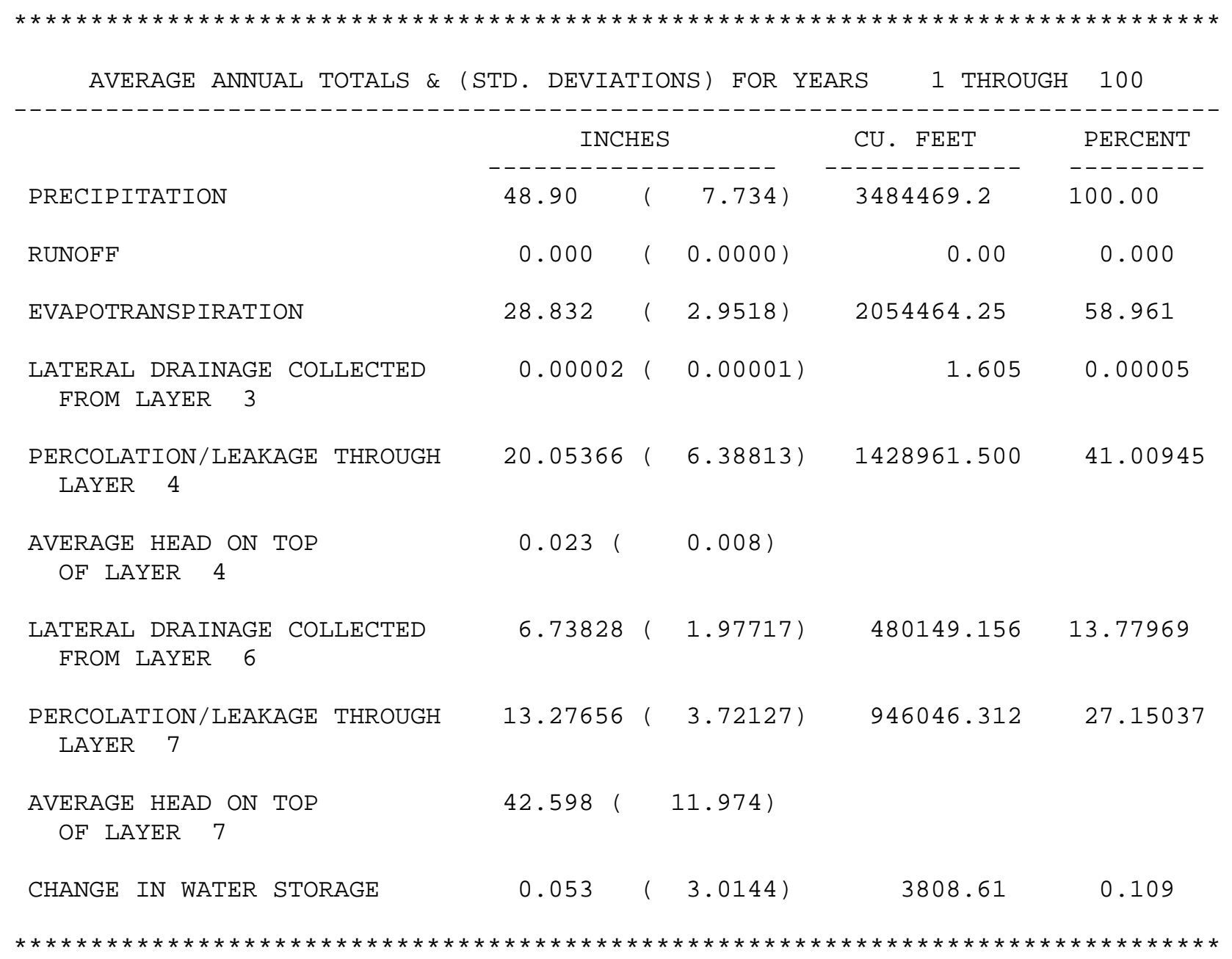




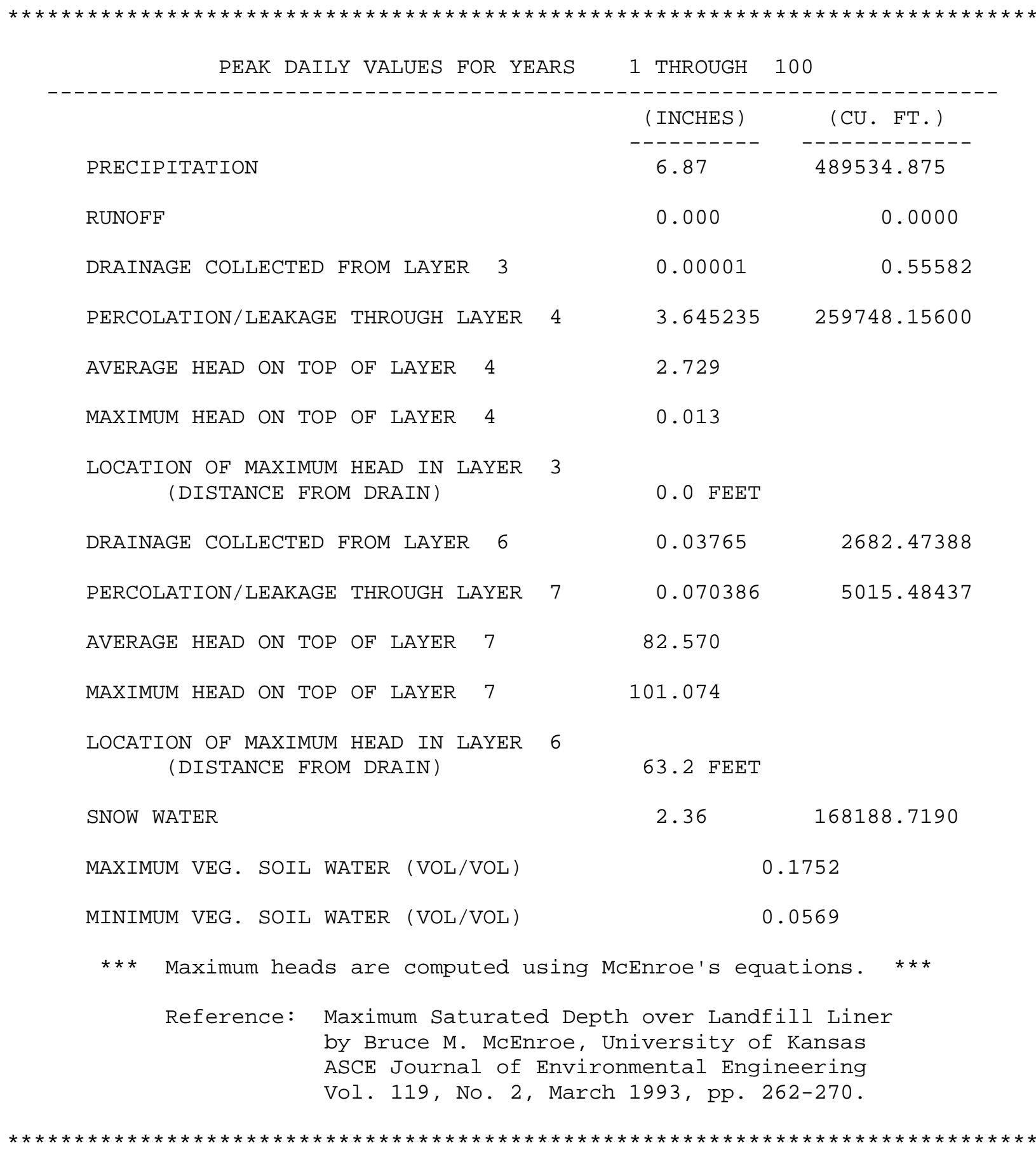

Rev. 0 


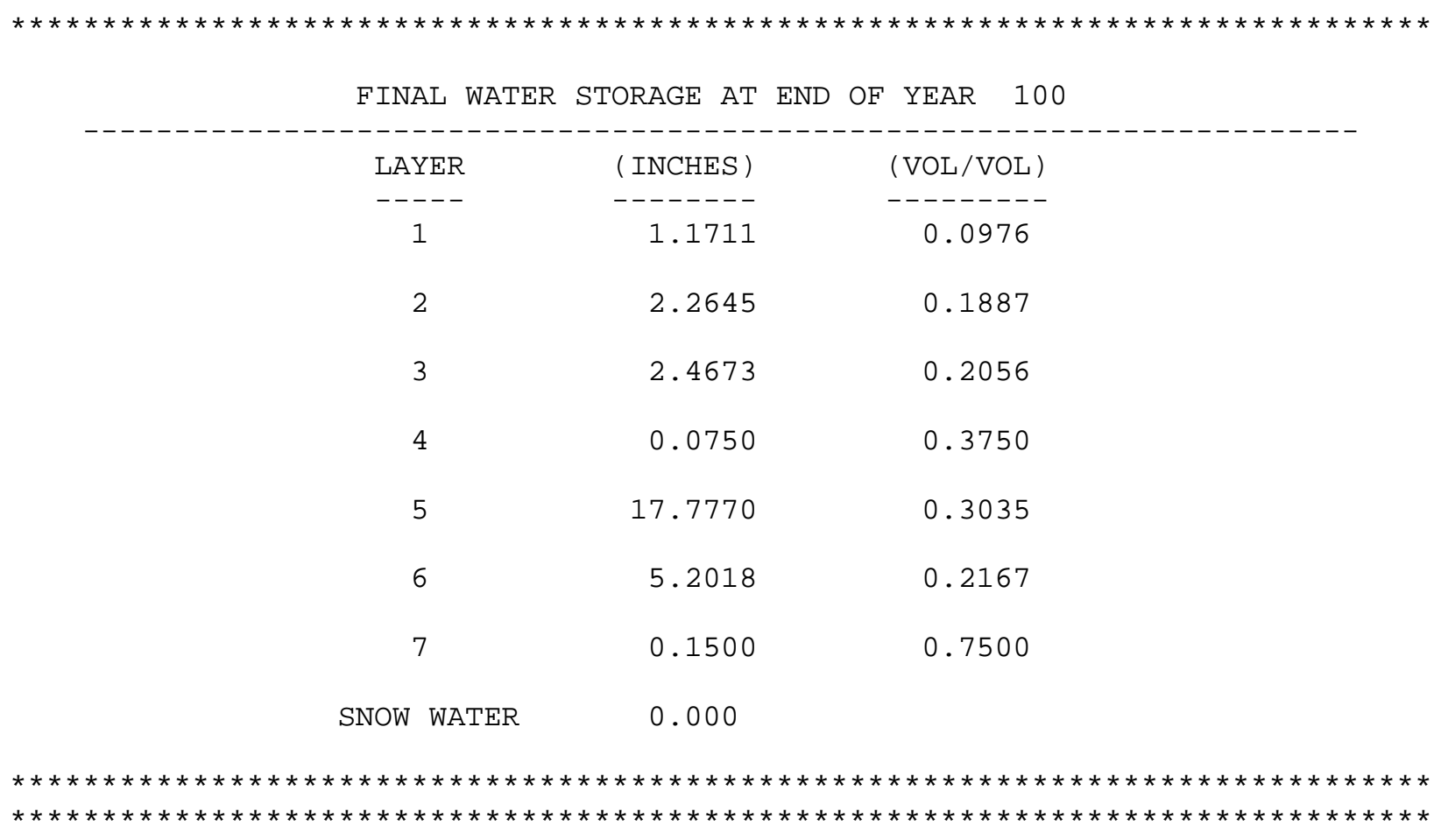


THIS PAGE INTENTIONALLY LEFT BLANK 